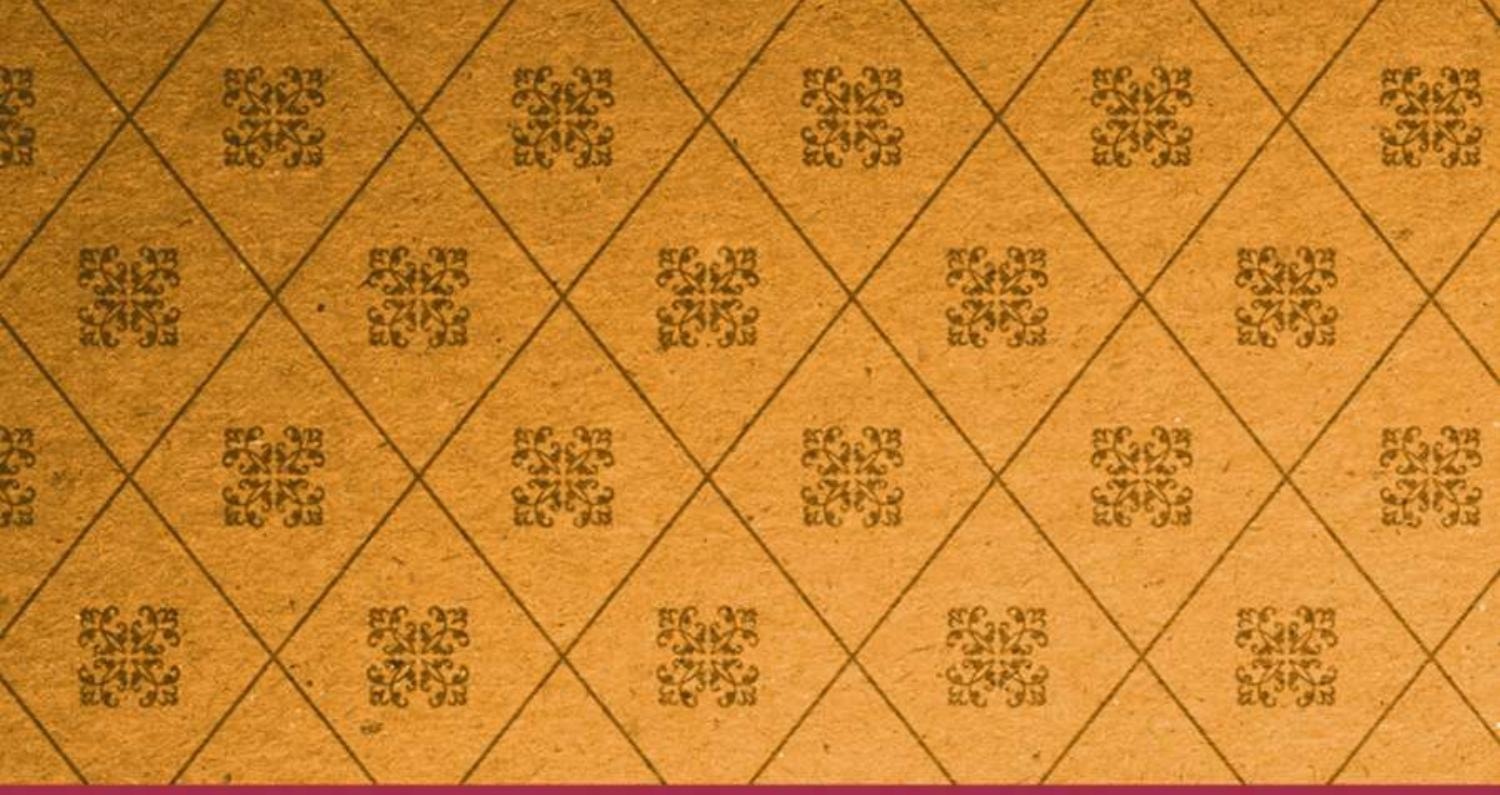

Routledge Monographs in Classical Studies

\title{
MEMORIES OF UTOPIA
}

\section{THE REVISION OF HISTORIES AND LANDSCAPES IN LATE ANTIQUITY}

Edited by

Bronwen Neil and Kosta Simic

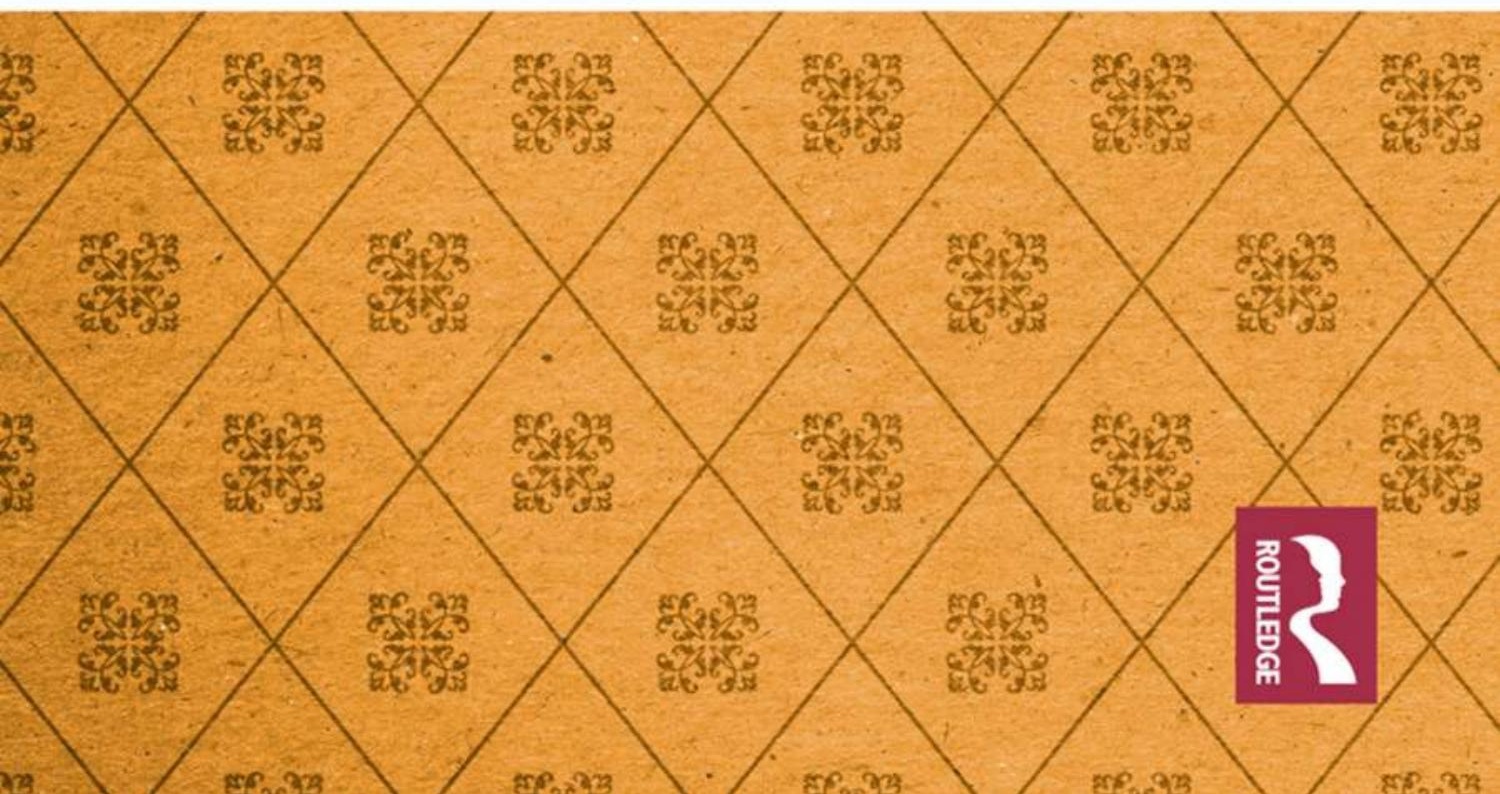




\section{Memories of Utopia}

These essays examine how various communities remembered and commemorated their shared past through the lens of utopia and its corollary, dystopia, providing a framework for the reinterpretation of rapidly changing religious, cultural, and political realities of the turbulent period from 300 to $750 \mathrm{CE}$.

The common theme of the chapters is the utopian ideals of religious groups, whether these are inscribed on the body, on the landscape, in texts, or on other cultural objects. The volume is the first to apply this conceptual framework to Late Antiquity, when historically significant conflicts arose between the adherents of four major religious identities: Graeco-Roman 'pagans'; newly dominant Christians; diaspora Jews, who were more or less persecuted, depending on the current regime; and the emerging religion and power of Islam. Late Antiquity was thus a period when dystopian realities competed with memories of a mythical Golden Age, variously conceived according to the religious identity of the group. The contributors come from a range of disciplines, including cultural studies, religious studies, ancient history, and art history, and employ both theoretical and empirical approaches. This volume is unique in the range of evidence it draws upon, both visual and textual, to support the basic argument that utopia in Late Antiquity, whether conceived spiritually, artistically, or politically, was a place of the past but also of the future, even of the afterlife.

Memories of Utopia will be of interest to historians, archaeologists, and art historians of the later Roman Empire and those working on religion in Late Antiquity and Byzantium.

Bronwen Neil, FAHA, is Professor of Ancient History at Macquarie University, Australia, and Research Associate of the Department of Biblical and Ancient Studies at the University of South Africa. She is director of the Centre for Ancient Cultural Heritage and Environment (CACHE) at Macquarie University. Her publications on Late Antiquity include studies of letter-writing, gender, bishops of Rome, dream interpretation, and hagiography.

Kosta Simic (PhD Australian Catholic University, 2018) is a sessional lecturer and postdoctoral researcher in the School of Theology at the Australian Catholic University, Brisbane. He has published two books and several articles on Byzantine hymnography. 


\section{Routledge Monographs in Classical Studies}

Titles include

Fantasy in Greek and Roman Literature

Graham Anderson

Piracy, Pillage, and Plunder in Antiquity

Appropriation and the Ancient World

Edited by Richard Evans and Martine de Marre

Romans at War

Soldiers, Citizens, and Society in the Roman Republic

Edited by Jeremy Armstrong and Michael P. Fronda

The Discourse of Kingship in Classical Greece

Carol Atack

Emotional Trauma in Greece and Rome

Representations and Reactions

Edited by Andromache Karanika and Vassiliki Panoussi

The Representation of Slavery in the Greek Novel

Resistance and Appropriation

William M. Owens

Memories of Utopia

The Revision of Histories and Landscapes in Late Antiquity

Edited by Bronwen Neil and Kosta Simic

\section{The Making of Identities in Athenian Oratory}

Edited by Jakub Filonik, Brenda Griffith-Williams and Janek Kucharski

For more information on this series, visit: www.routledge.com/classicalstudies/ series/RMCS 


\section{Memories of Utopia \\ The Revision of Histories and Landscapes in Late Antiquity}

\section{Edited by Bronwen Neil and Kosta Simic}


First published 2020

by Routledge

2 Park Square, Milton Park, Abingdon, Oxon OX14 4RN

and by Routledge

52 Vanderbilt Avenue, New York, NY 10017

Routledge is an imprint of the Taylor \& Francis Group, an informa business

(C) 2020 selection and editorial matter, Bronwen Neil and Kosta Simic; individual chapters, the contributors

The right of Bronwen Neil and Kosta Simic to be identified as the authors of the editorial material, and of the authors for their individual chapters, has been asserted in accordance with sections 77 and 78 of the Copyright, Designs and Patents Act 1988.

All rights reserved. No part of this book may be reprinted or reproduced or utilised in any form or by any electronic, mechanical, or other means, now known or hereafter invented, including photocopying and recording, or in any information storage or retrieval system, without permission in writing from the publishers.

Trademark notice: Product or corporate names may be trademarks or registered trademarks, and are used only for identification and explanation without intent to infringe.

British Library Cataloguing-in-Publication Data

A catalogue record for this book is available from the British Library

Library of Congress Cataloging-in-Publication Data

Names: Neil, Bronwen, editor. | Simić, Kosta, editor.

Title: Memories of utopia : the revision of histories and landscapes in Late Antiquity / edited by Bronwen Neil and Kosta Simic.

Identifiers: LCCN 2019038122 (print) | LCCN 2019038123 (ebook) |

ISBN 9781138328679 (hardback) | ISBN 9780429448508 (ebook)

Subjects: LCSH: Utopias-Religious aspects. | Utopias-History-To

1500.| Utopias-Byzantine Empire. | Byzantine Empire-Civilization.

Classification: LCC HX807 .M46 2020 (print) | LCC HX807 (ebook) |

DDC 335/.02093709015-dc23

LC record available at https://lccn.loc.gov/2019038122

LC ebook record available at https://lccn.loc.gov/2019038123

ISBN: 978-1-138-32867-9 (hbk)

ISBN: 978-0-429-44850-8 (ebk)

Typeset in Times New Roman

by Apex CoVantage, LLC 


\section{Contents}

List of figures

List of contributors

viii

Acknowledgements

Abbreviations

Map of the Byzantine Mediterranean 500-700 CE

\section{PART I}

Writing and rewriting the history of conflicts

1 Curating the past: the retrieval of historical memories and utopian ideals

BRONWEN NEIL

2 Julian's Cynics: remembering for future purposes

3 Memories of trauma and the formation of a Christian identity JONATHAN P. CONANT

4 Augustine's memory of the 411 confrontation with Emeritus of Cherchell

GEOFFREY D. DUNN

\section{PART II}

Forging a new utopia: holy bodies and holy places

5 Purity and the rewriting of memory: revisiting Julian's disgust for the Christian worship of corpses and its consequences 
vi Contents

6 Constructing the sacred in Late Antiquity: Jerome as a guide to Christian identity

NAOKI KAMIMURA

7 Utopia, body, and pastness in John Chrysostom

CHRIS L. DE WET

\section{PART III}

Rewriting landscapes: creating new memories of the past

8 Memories of peace and violence in the late-antique West BRONWEN NEIL

9 Two foreign saints in Palestine: responses to religious conflict in the fifth to seventh centuries

PAULINE ALLEN AND KOSTA SIMIC

10 Remembering the damned: Byzantine liturgical hymns as instruments of religious polemics

KOSTA SIMIC

11 Paradise regained? Utopias of deliverance in seventh-century apocalyptic discourse

RYAN W. STRICKLER

12 Ausonius, Fortunatus, and the ruins of the Moselle

CHRIS BISHOP

\section{PART IV}

Memory and materiality

13 Spitting on statues and shaving Hercules's beard: the conflict over images (and idols) in early Christianity

ROBIN M. JENSEN

14 Athena, patroness of the marketplace: from Athens

to Constantinople 
15 Transformation of Mediterranean ritual spaces up to the early Arab conquests

LEONELA FUNDIC

Epilogue

RAJIV K. BHOLA

Scripture index

Index 


\section{Figures}

Map of the Byzantine Mediterranean 500-700 CE XV

13.1 Robert E. Lee statue, Charlottesville, Virginia, USA. 208

13.2 Jefferson Davis statue, New Orleans, Louisiana, USA. 209

13.3. Septimius Severus with Julia Domna, Caracalla and Geta (with erased face). Egypt, ca. 200 CE. 210

13.4 Colossal statue of Hercules, replica of the Farnese Hercules, found in the baths at Hippo Regius (Annaba, Algeria). 218

13.5 Silver double shekel of Carthage with obverse of Melqart and reverse of Hannibal. Issued by the Barcid family in Spain. From the Mogente Hoard, Valencia, Spain, around 230 BCE. Now in the British Museum, Inv. no. 1911,0702.1.

13.6 Marble statue of Hercules holding apples, inscribed with cross, ca. $100 \mathrm{CE}$, from Tralles (Turkey).

13.7 Bust of Germanicus with incised cross, originally made in Egypt, ca. 14-20 CE, now in the British Museum.

13.8 Four heads of the Kings of Judah, from the Gallery of Kings on the west façade of the Cathedral of Notre Dame, Paris, now in the Musée national du Moyen Age, Paris, France.

14.1 Athena steelyard weight currently held at the Metropolitan Museum of Art, Accession Number: 61.112.

14.2 A statue of Athena in front of the Austrian Parliament Building. 239

14.3 Steelyard weight currently held in the Metropolitan Museum of Art, Accession Number: 59.184.

15.1 St George in Zorava (Izraa), southwest Syria. 255

15.2 Theseion, Athens. 256

15.3 Basilica of Messene, Peloponnese, Greece. 258

15.4 Basilica of Messene, Peloponnese, Greece. 259 


\section{Contributors}

Pauline Allen, FBA, FAHA, is Professor of Early Christian Studies at the Australian Catholic University, Research Associate of the Department of Ancient and Modern Languages at the University of Pretoria, South Africa, and Honorary Research Fellow of the Sydney College of Divinity, Australia. She has published widely on early Christianity, including books on letters, homilies, Severus of Antioch, Maximus the Confessor, and the churches of Antioch.

Rajiv K. Bhola is a postdoctoral fellow on the ARC Discovery Project Memories of Utopia in Late Antiquity: Destroying the Past to Create the Future. He is a $\mathrm{PhD}$ graduate of the University of Ottawa's Department of Classics and Religious Studies. His current research project relates to Eusebius of Caesarea's reception of Plato.

Chris Bishop is a lecturer in the Centre for Classical Studies at the Australian National University where he teaches Latin, Ancient Greek, and History. Having previously edited Text and Transmission in Medieval Europe (2007), he has recently published a monograph on reception studies-Medievalist Comics and the American Century (2016) - as well as numerous articles on classical and medieval poetry.

Philip Bosman teaches ancient Greek language, literature, and history at Stellenbosch University, South Africa. He has published on the Cynic tradition; authors Euripides, Philo, Paul, Lucian, and Plutarch; the Dodona oracle; and reception of the classics in South Africa. He has edited several volumes, most recently Ancient Routes to Happiness (2017) and Intellectual and Empire in the Greco-Roman World (2019).

Jonathan P. Conant is Associate Professor of History at Brown University, USA. His research focuses on the inter-regional integration of the Mediterranean and the transition from antiquity to the middle ages. He is the author of Staying Roman: Conquest and Identity in Africa and the Mediterranean, 439-700 (2012).

Chris L. de Wet is Associate Professor of New Testament and Early Christian Studies, in the Department of Biblical and Ancient Studies at the University 
of South Africa, Pretoria, and Honorary Research Fellow at the Australian Lutheran College, University of Divinity, Adelaide. He is the author of two recent books on slavery and co-editor of Reconceiving Religious Conflict: New Views from the Formative Centuries of Christianity, Routledge Studies in the Early Christian World (2018).

Geoffrey D. Dunn is an honorary research associate at the University of Pretoria, South Africa, in the Department of Ancient and Modern Languages. Until 2015 he was a senior research fellow at Australian Catholic University in the Centre for Early Christian Studies. His areas of research are Roman North Africa and early fifth-century Roman bishops.

Leonela Fundic (PhD University of Thessaloniki, Greece) has held positions as a postdoctoral researcher in the history of Byzantine art at the Australian Catholic University, Macquarie University, and the University of Queensland. She has published articles in Byzantion and Zograf.

Robin M. Jensen is Patrick O'Brien Professor of Theology at the University of Notre Dame, USA, and concurrent professor of the history of art. Her recent projects include The Cross: History, Art, and Controversy (2017) and (coeditor) The Routledge Handbook of Early Christian Art (2018).

Naoki Kamimura is a research fellow of Tokyo Gakugei University and a lecturer in philosophy and ethics at Tokyo Metropolitan University, Japan. He is the author of Disciplines and Identities, Divine and Spiritual, in Late Antiquity (2017), and has published in Augustinian Studies, Prayer and Spirituality in the Early Church, and Studia Patristica.

Wendy Mayer, FAHA, is Professor and Associate Dean for Research at the Australian Lutheran College, University of Divinity and a research associate of the Department of Biblical and Ancient Studies at the University of South Africa. Research interests include Antioch in Late Antiquity and religious conflict. She is co-author of The Churches of Syrian Antioch (2012), and co-editor of Reconceiving Religious Conflict: New Views from the Formative Centuries of Christianity (2018) with Chris de Wet.

Bronwen Neil, FAHA, is Professor of Ancient History at Macquarie University, Australia, and Research Associate of the Department of Biblical and Ancient Studies at the University of South Africa. She is Director of the Centre for Ancient Cultural Heritage and Environment (CACHE) at Macquarie University. Her publications on Late Antiquity include studies of letter-writing, gender, bishops of Rome, dream interpretation, and hagiography.

Kosta Simic (PhD Australian Catholic University, 2018) is a sessional lecturer and postdoctoral researcher in the School of Theology at the Australian Catholic University, Brisbane. He has published two books and several articles on Byzantine hymnography. 
Ryan W. Strickler (PhD Macquarie University, 2018) is a postdoctoral researcher at Macquarie University, Australia, and Lecturer in Classics and Ancient History at the University of Queensland, Australia. He has published several articles on apocalyptic literature and forgeries in the time of Maximus the Confessor.

Janet Wade (PhD Macquarie University, 2017) was the Macquarie Gale Postdoctoral Fellow at the British School at Rome in 2018. She has published on maritime culture and rituals in Late Antiquity, with a focus on the eastern Roman Empire. Her research interests also include travel and communication networks in the Roman world. 


\section{Acknowledgements}

The editors undertook this project with the aid of a grant from the Australian Research Council for Memories of Utopia: Destroying the Past to Create the Future (300-650 CE) (Discovery Project 170104595). Chief investigators on the project were Bronwen Neil, Wendy Mayer, Pauline Allen, and Chris de Wet (partner investigator). Leonela Fundic, Ryan Strickler, and Rajiv Bhola worked on the project at Macquarie University as postdoctoral fellows and contributed chapters. We are grateful to our international collaborators Dr Naoki Kamimura and Prof Robin Jensen for their contributions.

Early drafts of several chapters were presented at various conferences. These included the Asia-Pacific Early Christian Studies Society conference on 'Early Christian Responses to Conflict' at the Australian Catholic University, Melbourne, in September 2017; the 39th Australasian Society for Classical Studies conference held in February 2018 at the University of Queensland; and the North American Patristics Society meeting held in May 2018 in Chicago.

Jonathan Conant's chapter was first delivered as a keynote address to the APECSS conference on 'Early Christian Responses to Conflict,' then to the Five College Seminar in Late Antiquity at Smith College, Northampton, MA (April 2018), and to the Cultures and Religions of the Ancient Mediterranean (CRAM) seminar, whose participants he would like to thank for their many useful comments and suggestions. Assoc Prof Conant owes a special debt of appreciation to Susan Ashbrook Harvey and to Susan Einbinder, each of whom read a draft of the chapter and offered much helpful feedback.

Each chapter was double-blind peer reviewed. The editors would like to thank the anonymous peer reviewers who read and commented on the first drafts. We are grateful to Amy Davis-Poynter for accepting the volume and bringing it to light, and to the two reviewers appointed by Routledge, who offered many helpful suggestions.

The library staff at Macquarie University, the Australian Catholic University, and the Australian Lutheran College have offered great assistance with various loans and acquisitions. For their valuable proofreading and editorial assistance, we thank Dr Phoebe Garrett from the Australian National University and Dr Sandra Sewell from Tamborine Mountain. 
Finally, the editors would like to offer heartfelt thanks to our partners and other family members at home and abroad, whose ongoing interest means everything to us, and particular thanks to Pauline Allen, the sine qua non of early Christian studies in Australia.

$B N$ and $K S$ 


\section{Abbreviations}

Abbreviations follow PLRE and Oxford Classical Dictionary, with the following additions:

CCSG Corpus Christianorum series Graeca. Turnhout: Brepols.

CCSL Corpus Christianorum series Latina. Turnhout: Brepols.

CSEL Corpus scriptorum ecclesiasticorum Latinorum. Vienna: F. Tempsky.

CTh Codex Theodosianus

DOP Dumbarton Oaks papers

GCS Die Griechischen christlichen Schriftsteller der ersten Jahrhunderte. Berlin: De Gruyter.

ESV The Holy Bible, English Standard Version

FOTC The Fathers of the Church series. Washington, DC: Catholic University of America Press.

HTR Harvard theological review

LCL Loeb Classical Library. Cambridge, MA: Harvard University Press.

LP Liber pontificalis

MGH Monumenta Germaniae historica. Hanover: Hahn.

MGH SRM MGH scriptores rerum Merovingicarum. Hanover: Hahn.

NBA Nuova biblioteca Agostiniana. Rome: Maurists.

no. number

NPNF Nicene and post-Nicene Fathers. Edinburgh: T. \& T. Clark.

PG Patrologia Graeca. Series completus, edited by J.-P. Migne. Paris.

PL Patrologia Latina. Series completus, edited by J.-P. Migne. Paris.

PLS PL Supplementa, edited by J.-P. Migne. Paris.

SC Sources chrétiennes. Paris: Éditions du Cerf.

StP Studia patristica. Leuven: Peeters.

$\mathrm{TCH}$ Transformation of the Classical heritage. Los Angeles: University of California Press.

TTH Translated texts for historians. Liverpool: Liverpool University Press.

VC Vigiliae Christianae

WUNT Wissenschaftliche Untersuchungen zum Neuen Testament 


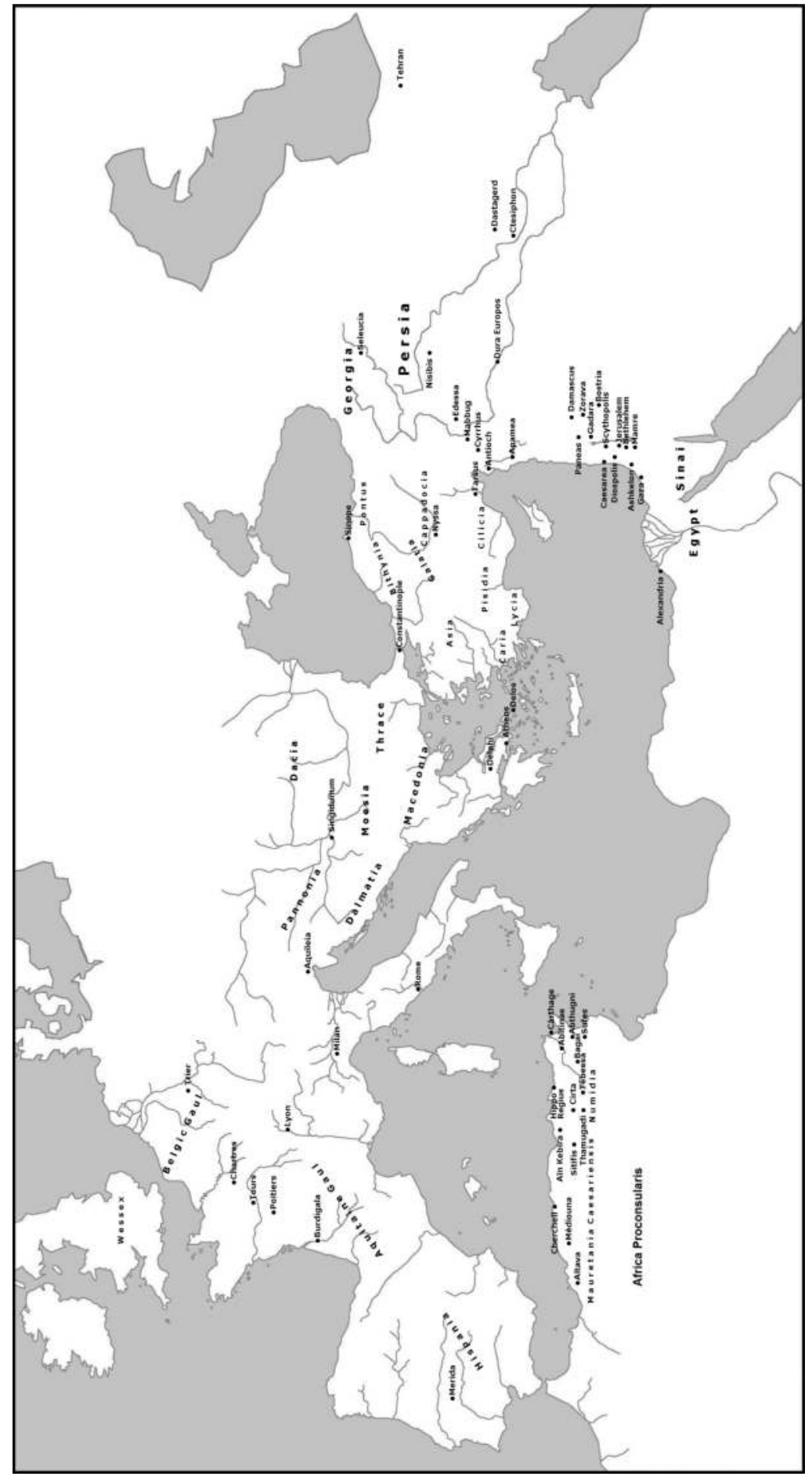

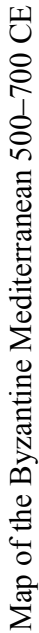


$\because$ Taylor \& Francis Taylor \& Francis Group http://taylorandfrancis.com 


\section{Part I}

Writing and rewriting the history of conflicts 
$\because$ Taylor \& Francis Taylor \& Francis Group http://taylorandfrancis.com 


\title{
1 Curating the past \\ The retrieval of historical memories and utopian ideals
}

\author{
Bronwen Neil
}

When we think of how historical memories are transmitted through generations and centuries, we may think of a wide range of artefacts, from written texts to inscriptions, art, and architecture. ${ }^{1}$ We might also think of the little things that carry memories for individuals: an ancestor's book, a watch, or a treasured piece of jewellery. Some cultural productions may seem incidental and even trivial compared with the ideas behind commemorative community practices, such as raising monuments at sacred sites, processing with holy books, or liturgically commemorating past heroes and villains. It is clear from memory studies that objects imbued with memory (souvenirs), acts of commemoration, and the associated cognitive processes all played an important role in keeping utopian ideals alive in Late Antiquity, as they do today.

By studying the history of cultural artefacts and practices from the early Christian centuries to $750 \mathrm{CE}$, we can show the operation in the past of two powerful ideas, with which we are more or less familiar in the current post-truth millennium. The first is that the destruction of common memories destroys cultural unity. The second is that such memories can be reframed by changing the cultural record, by altering the physical environment or erasing or altering the public discourses by which significant events are remembered, whether with celebration or mourning.

\section{Why study memory and utopian ideals together?}

The contributors to this volume reveal how various religious groups in Late Antiquity created new memories of the past and forged a new vision of the collective future by manipulating religious texts and by destroying and/or repurposing material objects. To this end, we have drawn upon and adduced a unique range of evidence, both visual and textual, to support the basic argument that utopia in Late Antiquity, whether conceived spiritually, artistically, or politically, was an imagined place or state of the past but also of the future, even extending to the next life. Our collective assumption is that the ways in which past and future utopian communities were envisaged and commemorated in literature and the visual arts reveal what was most important to that group's identity, whatever their religious affiliation. We apply this conceptual framework to Late Antiquity, a period when historically significant conflicts arose between the adherents of four major 


\section{Bronwen Neil}

religious identities: Christian, Zoroastrian, Jewish, and Muslim. By exploring the many ways in which the past was remembered and rewritten in Late Antiquity, we seek to discover whether the same commemorative practices can be found across time, across space, and across religions during the establishment of a new, Christian identity.

The studies within this volume span the period from the initial contact of Graeco-Roman communities with Christians of various stripes up to the ArabByzantine wars of the mid-seventh and eighth centuries. We have used various terms to describe this period, depending on the context: the early Christian centuries (first to fourth); the Later Roman Empire, which ended with the departure of the last Western emperor from Italy in 476; or Late Antiquity, a vaguely defined period that spans from the third century to the seventh or eighth century. Our common task is to show how various religious groups in Late Antiquity manipulated religious and historical texts, and destroyed or repurposed material objects, to create new idealised memories of the past and to forge a new vision of the collective future.

My task here is to highlight and explore some of the key ideas of the chapters within, and to show how the application of theory to the data provides us with new evidence and opens up new avenues for exploration. Let us start with the important question of definitions before we review some recent significant studies in the fields of memory retrieval and the construction of utopian communities, and the links between the two.

\section{Defining our terms}

In English, the term utopia has inescapable associations with Sir Thomas More's Latin work of the same name, subtitled in the English translation: 'A fruitful and pleasant work of the best State and of the public Weal, and of the new isle called Utopia' (More 1516; Robinson 1551). Since More's coinage, the term has been used in a variety of contexts, including political (especially in regard to Marxism), architectural, and science fiction discourses. Variously derived from Greek eu-topia ('well place') or ou-topia ('no place'), a utopia is often defined in terms of its opposite, dystopia.

For members of subcultures in conflict with the mainstream, utopia is a landscape of the imagination. It often has religious overtones, as we will see in the conflicts described within, between pagans and Christians, between Christian subgroups, and between Christians and other monotheists. We have consciously used the dated term pagan to identify practitioners of traditional Graeco-Roman religion and the adherents of mystery cults. The term, while unsatisfactory in that it has pejorative overtones and seems to assume a 'non-pagan' perspective, has been redeployed in recent scholarship on Late Antiquity (Rives 2009). We hope our readers will accept it in lieu of a more satisfactory term.

Utopia is an imaginary landscape of the past or future, one which is based on an ideological pursuit of purity and happiness. The idea of utopia and its opposite, dystopia, is a multi-valent topos, which has been the key to so much art and 
literature in the past that it is easy to assume we know what it means in any given context without really thinking about it.

It is often easier to articulate what is not an ideal living community than to encapsulate the ideal in precise terms. Classical utopias (in Latin, locus amoenus) were places where the weather was never inclement; where there was no shortage of food, water, or shelter; where entertainment was free; and where work was not required. A state of physical bliss is also the foundation of the Zoroastrian concept of Paradise, imagined as a garden with continuous running water, flowers in constant bloom, and trees bearing fruit all year round. This idea found a counterpart in the Christian heaven, with hell, its dystopian counterpart, being envisaged as the exact opposite: a place of fire and brimstone, where physical tortures went on forever.

In his monumental work Ideology and Utopia, German sociologist Karl Mannheim (Mannheim 1936), introduced the concept of collective utopian thinking to his sociology of knowledge. Utopia for Mannheim was a concept that predominated among oppressed groups, rather than the ruling class. Utopian thinking occurred when a group was intellectually invested in the destruction and transformation of a current feature of society to such an extent that the sole focus of its members was directed towards those aspects of the current social order that needed changing. ${ }^{2}$ Mannheim contrasted utopian thinking with ideological thinking: while utopian thinking seeks to change the current social order, ideological thinking seeks to preserve it. Both ways of thinking share the fault of being unable to diagnose society as it actually is; the reality to be comprehended is distorted and concealed by the blinders of either utopianism or ideology. This distortion is complicated by the fact that the reality we fail to comprehend may be a dynamic one (Mannheim 1997: 87). 'A state of mind is utopian when it is incongruous with the state of reality in which it occurs,' Mannheim asserted (1997: 173). It may be able to be realised in a future social order, however (1997: 177).

In respect to heavenly hopes, or what we have termed eschatological utopia, Mannheim believed that as long as medieval society could locate Paradise outside society, in a sphere which transcended history and dulled its revolutionary edge, it did not require utopian thinking to believe that such a place or state existed. Late Antiquity is an interesting time to view the change from non-utopian thinking to ideological thinking. The idea of Paradise was fully integrated into medieval society (Mannheim 1997: 174), but in the Gothic West and the early Byzantine East of the fifth to seventh centuries, the concepts of heaven and hell, with their eternal implications, were still gradually being introduced. While medievals expected that a utopian state could only be realised in a future time, after death, late-antique writers were more genuinely hopeful, even revolutionary, in their thinking about social change in the present day. Mannheim's distinction between utopian and ideological thinking thus does not apply to the earlier period. Many late-antique writers, builders, and artists were not concerned to maintain the status quo but rather to challenge existing social orders.

The focus in utopian studies has mostly been directed towards groups rather than individuals. Clint Jones and Cameron Ellis (2016) have attempted to retrieve 


\section{Bronwen Neil}

the individual in their multidisciplinary studies of collective utopias. Their volume moves away from the dominant, macro-level theorising on identity and its relationship to globalising trends, focusing instead on the individual's relationship with utopia. Theirs is a theoretical study, which does not deal with practical attempts to build a utopia in urban or rural settings.

Early memory studies have followed a similar trajectory from a focus on group memories to those of individuals. The contested term cultural memory (Das kulturelle Gedächtnis) was first adopted in ancient world studies by Egyptologist Jan Assmann (2000: 11-44; 2007) and is linked with the identity of a finite community that transmits a fixed culture. As an increasing body of scholarship on memory history (Gedächtnisgeschichte) has demonstrated, however, both remembering and forgetting are more dynamic than Assmann's theory allowed. They are social, cultural, or cognitive processes that are rarely neutral (Connerton 1989; Baxter 1999), and may be fictitious. The creation of fictive memories could also be an unconscious or accidental act. Rather than speaking of cultural memory, many historians now prefer to use the alternatives coined by Maurice Halbwachs: collective memory (Halbwachs 1950) or social memory (Halbwachs 1952). However, even these terms have been subject to compelling critiques with the boom of memory studies in the 1990s. Noa Gedi and Yigal Elam warned that the concept of collective memory occupies a sort of no-man's-land, becoming 'the predominant notion which replaces real (factual) history, on the one hand, and real (personal) memory, on the other hand' (Gedi and Elam 1996: 40).

The so-called memory boom of the $1990 \mathrm{~s}$, which affected various disciplines of the humanities and social sciences, including anthropology, history, sociology, cultural studies, and cognitive studies, has exposed the ways in which memories of the past can be manipulated to suit present political agendas or serve prevailing ideologies (Klein 2000; Berliner 2005; Thiessen 2008). In a ground-breaking study of Germany's rituals and traditions of remembering the Holocaust in memorials and counter-memorials, James Young spoke of collected memories and of their collective meaning in society (Young 1993). According to this view, our traditions and cultural forms continuously assign common meaning to our disparate memories (Young 1993: xii). Individuals cannot share another's memory any more than they can share another's cortex, even when groups share 'socially constructed assumptions and values that organise memory into roughly similar patterns' (Young 1993: xi). This position is still widely cited as authoritative, for example by Corning and Schuman (2015: 12). However, Susan Crane persuasively argued for the need to retrieve the individual from collective memory in historical studies (Crane 1997).

The applicability of social-memory theories to antiquity continues to be debated, as shown in the recent exchange between T. P. Wiseman and Karl Joachim Hölkeskamp in Memoria Romana (Galinsky 2014), where Wiseman argued that collective memory cannot be carried in monuments and literature (Wiseman 2014: 40). He favoured the term popular memory, which he found in competing, especially non-elite, forms of remembering. This is most significant, 
he argued, in oral and performative cultures, in particular the classical Roman games. Against Wiseman, Hölkeskamp (2016) defended the power of material and literary culture to emote memory. The memories invested in material objects were particularly important to those in power, until such a time as people failed to connect with the memories evoked, at which point physical symbols became objects of resistance (Alderman and Dwyer 2009).

When studying ancient societies, we need to heed Martin Bommas's warning that, when pushed too far, the concept of social memory comes to represent 'a theoretical and idealising picture of the past in the past' (Bommas 2011: viii). To avoid this idealising tendency, we need to take into account the influences of conflict and the use and abuse of power invested in one group over others. In the process, we will uncover a hidden record of religious conflicts and supremacist discourses that operated across the various religious groups of the Roman Empire from 300 to $750 \mathrm{CE}$.

Our analysis of the literary, documentary, and material evidence suggests that such discourses were often accompanied by acts of violence and the destruction of objects of religious and cultural significance. Utopian discourses exacerbated violent conflict between groups both within individual religions (especially but not only Christianity) and between adherents of different religions in this formative period, with profound effects on the later history of the Middle East. However, accounts of past violence directed against sacred sites and objects could also be exaggerated to suit a new religious agenda. Representations of the past are transmitted across generations in various ways (Corning and Shuman 2015: 1-14).

Intergenerational erasure or dishonouring of the past in the process of damnatio memoriae was a common administrative tactic across the Roman Empire in Late Antiquity (Hahn 2004; Hahn et al. 2008; Shepardson 2014). The practice of damnatio memoriae included the rewriting of decorative programmes (Hedrick 2000: 89), revision of facial features on imperial busts (Varner 2004), and the deliberate destruction of civic buildings dedicated to a prominent citizen's memory, or simply the failure to restore them. Charles Hedrick Jr's insightful study of an inscription from the fifth century $(C I L 6,1783)$ demonstrates how much can be deduced about contemporary social paradigms of religious change from a single Roman monument. The inscription commemorates the senatorial cursus honorum of Virius Nichomachus Flavianus (d. 394) and his son Nichomachus Flavianus (d. 432). The name of Flavianus the elder, an overt pagan and supporter of the unsuccessful bid for imperial power by another pagan, Eugenius, was initially suppressed when the senate was Christianised, but was restored by his grandson in 431. Hedrick argues that the exclusion of details from this lengthy inscription is equally important as the details it contains (Hedrick 2000: 86-7). 'To be manipulated, memory must be silently evoked,' as he puts it (Hedrick 2000: 230). Along with the rewriting or construction of memory on monuments of stone, deliberate forgetting or erasure could be enacted narratively through civic and ecclesiastical histories, philosophical tracts, liturgical texts, and the lives of Christian 'saints.' All these genres are studied in the chapters within. 


\section{Bronwen Neil}

\section{Structure of the volume}

The fourteen chapters that follow have been divided into four groups roughly by genre of source material. Part I, Writing and rewriting the history of conflicts, deals with the written documentation of conflict between Christians and nonChristians, between different sects within Christianity, and between those of different religious identities. The sources are late-antique histories, martyrologies, letters, council acts, and other texts by which Christians, both elites and nonelites, remembered past conflicts.

Part II, Forging a new utopia: holy bodies and holy places, focuses on hagiography and its commemoration of the ascetic lifestyle of saints and their holy places. These three chapters show that the body became a new landscape for enacting utopian (as well as dystopian) ideals. Their literary sources have a strong focus on eschatology or the End Times, which framed the way people of Late Antiquity considered their pasts. The contrast between the Graeco-Roman traditions and new, scripturally inspired traditions towards the body and its mortality is drawn here.

Part III, Rewriting landscapes: creating new memories of the past, studies how the reshaping of physical landscapes and built environments was discussed in late-antique texts, mainly those generated in ecclesiastical and monastic communities, which looked back to an imaginary and more golden past. Two chapters focus on western, Latin sources, the other three on those written in Greek and Syriac and deriving from the Byzantine East.

The authors of three chapters in Part IV, Memory and materiality, examine the material evidence for the destruction and repurposing of religious art, artefacts, and architectural monuments. They show the disconnect between the material evidence for repurposing of objects and buildings, and the written accounts, which tend to exaggerate destruction and rebuilding in line with a triumphalist Christian agenda. Rajiv Bhola's Epilogue draws out further common themes and future directions of study.

\section{Methodological approaches to textual sources}

The various methodological approaches adopted by our authors to their textual sources are unified by a common focus on how people's memories were shaped by utopian ideals, which affected their idea of the future as much as their recall of past events.

In Parts I to IV, we are mainly concerned with what happened when feudal societies looked back on their non-Christian past and tried to Christianise it in retrospect, by demolishing sacred buildings of other religious traditions, or rewriting texts, or defacing pagan monumental images. The Gospels' grand narrative of justice and equality for all human beings remained present in this utopian thinking, but the details of how that system could be worked out when the oppressed minority (Christians) had become the dominant power had yet to be worked out. The same rethinking and recasting of history had to happen again when Arabic 
Islam took power over Byzantine territories in the seventh and eighth centuries. It is important to remember that in both cases theocracy, not democracy, was the ideal. An implicit connection can be made between utopia and the paradisal hopes of early Christianity and early Islam.

We are also interested in what resulted when adherents of traditional GraecoRoman state religion like the emperor Julian (361-3) looked back wistfully on the pre-Christian past and tried to reimagine it. In that unique moment of Late Antiquity, Julian and his supporters were trying to change a past social order retrospectively, to reflect a current ideology in which they were the dominant majority, not the oppressed minority. It amounted to utopian thinking in the sense that it was equally incapable of being realised.

Marit Böker's concept of realistic utopias, those that can be partially realised, is relevant here. Utopian thinking, the classic example being Marxism, has often been criticised for being out of touch with reality and alarmingly susceptible to totalitarianism. Böker (2017) has posited a more robust concept of utopia which can meet these charges by the recognition that utopian visions are limited by various degrees of realism. She writes of realistic utopia as 'an open-ended process of utopian visioning within a democratic, pluralistic context; a conception which in fact shares much in common with the normative theory of deliberative democracy' (2017: 99). The utopian ideal of democracy, a state that is always in the future, is discussed by Chris de Wet in Chapter 7. In the case studies of Late Antiquity presented here, the clashes between the ideals of a Graeco-Roman republican limited democracy, late-Roman imperial autocracy, and those of the new theocracies of Christianity and Islam limited the potential for the realisation of any utopian vision.

Clearly there is one individual at the centre of all Christian visions of utopia, and that is Jesus Christ, but the fourth to eighth centuries were a long way from the time of the Messiah, and his message had to be mediated by fallible human beings, operating in situations of war, famine, mass migration, and other social stressors. This was an age when written records were difficult to access even for the few who were literate, and vital civic information was distributed by word of mouth, or the public reading of letters or imperial edicts. Public statuary in the late-antique city was the equivalent of film or literature in terms of cultural influence. In such times even a minor change to the written or monumental record-a name left off the diptychs or a nose knocked off a cult statue-could have huge repercussions. It is the impact of such subversive acts that we are concerned to note in this volume.

Cognitive studies have offered a way forward, especially moral foundations theory (MFT) and conceptual metaphor theory, both used by Wendy Mayer and discussed further here. Recent advances in cognitive studies have shown that construction of a new identity through revision of memories is an established practice in the modern era. The idea that communities must be strongly bound together with shared ideologies is central to the idea of a perfect society (Jones and Ellis 2016). However, the individuals that comprise a community are rarely considered central to a strong communal theory. By focusing on the utopian city and its 
citizens in the modern age, but also on the individuals and the utopian bodies that make up utopian communities as these are portrayed in modern cultural productions, especially film and literature, Jones and Ellis have made an important corrective to current trends in utopia studies. It is a lesson that can usefully be applied to our study of the ancient world, where the individual is much easier to grasp than the identity of any given community. Indeed, the voice of the elite (male) individual is hard to avoid in texts that preach unity at the expense of individual opinion, especially on matters of faith.

\section{Methodological approaches to historical archaeology}

In trying to retrieve contemporary collective memories from commemorative texts of Late Antiquity, such as the hagiographies, martyr acts, and sacred histories discussed, historians face a unique set of problems. The oral traditionin the absence of written accounts, or perhaps even if they conflict with written accounts - was taken to be reliable by its ancient audiences because of their belief that the holy reporter would not lie. The authors of works in these genres rooted the story in someone else's individual memory. In the twenty-first century we have learned to be more sceptical. Historical archaeology is often useful in furnishing harder evidence than that provided by texts. Even this field, however, has been shaped by schools of interpretation when it comes to retrieving memories of the past.

Along with the authors in Galinsky (2014), others have taken a 'cultural memory' approach to ancient archaeology. Neil Christie's collection covering the Mediterranean and Anglo-Saxon cultures from the fourth to tenth centuries showed historical archaeologists challenging traditional historical narratives of decline in these two ancient cultures by presenting new archaeological evidence (Christie 2004). This volume highlighted the range and diversity of continuity and change in rural landscapes and less frequently in cities (e.g. Corinth) of Late Antiquity across a wide geographical area. Its authors demonstrated that the fictitious vision of urban decline in Greek cities spurred by a narrative of decline and fall ought not to be applied to rural archaeology, where it was no more applicable than it had been to Greek cities (Sanders 2004: 189).

Somewhat like Galinsky (2014), a more recent collection of archaeological studies explored the dynamic relationship between the spaces, places, and monuments of ancient Rome, the stories the Romans told about them, and the uses they made of them (García Morcillo et al. 2016). Its authors focused on the monumental and epigraphical evidence from one city only-Rome, from the Republic to the Empire - tracing changes in memories and mentalities in order to shed new light on the life of the buildings and monuments of the ancient city and the memories they carried with them. They did not include the late-antique Roman built environment, and therefore did not seek to deal with the Christianisation of these monuments and inscriptions. They also ignored the question of whether classical Romans looked to the eternal duration of their city in the future, rather than fetishising the built environment of its past (Jenkyns 2014: 19). 
A third edited collection treated the evidence afforded by art and archaeology for the collective memory of the ancient Near East, especially Egypt (Nadali 2016). Its editor Davide Nadali reminds us that when individuals from the ruling class control the memories that are handed down in official records, collective memory must be understood as connected with a narrow section of the community (Nadali 2016: 4). This collection closes with Martin Bommas's comparison of the culture of memory and forgetting in Ancient Egypt and the modern Mississippi Delta (Bommas 2016). Bommas offers a methodological paradigm for my own speculations below on the ideological agenda of those who have destroyed the monuments of the ancient Near East in recent years.

Finally, Mattia Guidetti made a serious contribution to the debate on the transformation of Syria from a late-antique Christian society to a Muslim one with his study of the conversion of churches to mosques in the early medieval period of the seventh to ninth centuries (Guidetti 2016). By analysing the location of mosques and their building materials, Guidetti reveals the laborious transfer of marble from churches to mosques. Guidetti's study is not concerned with evidence for religious conflict, but only with the archaeological evidence for the changing identity of places of worship, from Christian to Muslim.

\section{Realising utopia or dystopia through revision of memory}

There have been many ideological movements in history which lay claim to a pure religion of the past, one that is unsullied by political or moral compromise. One such movement in the current day is Daesh, known in the West as ISIS or ISIL (Islamic State of Iraq and the Levant), which lays claim to a purified Islam, as lived and preached by the Prophet Muhammad (d. 632). Conflicting claims to a utopian past dominate current conflicts between Muslim supporters and opponents of Daesh in the Middle East, as well as Muslims and Christians in all parts of the world. This is evident from pleas to preserve the historical monuments of Syria which hark back to the 'birthplace of civilisation' and 'the cradle of Christianity,' just as much as in the battle call of those who seek to destroy monuments in the lands of the new Islamic State movement. Some ISIL members reportedly see themselves as wiping out idolatry and restoring a pure (Sunni) Islam. Late Antiquity and current apocalyptic movements within Christianity and Islam employ some common strategies - physical, rhetorical, and political — to reframe and erase history for utopian ends. In the pre-Islamic context, the religious struggles of Late Antiquity involved pagans, Jews, Christians, and Zoroastrians. Destruction in the name of utopian ideals, then as now, operated on various levels: the rhetorical destruction of the written past and the material destruction of the physical past, in the form of shrines and oracles, churches and temples, statues and inscriptions, and religious images. The rhetoric of religious superiority easily escalated into violence but this cannot easily be attributed to monotheism or polytheism (Dijkstra 2015; Dijkstra 2018; Mayer 2018: 6-7; Bremmer 2018: 35).

For those involved in cultural warfare, whether they be insurgents, rebels, revolutionaries, or custodians of past and current regimes, the erasure of the physical 


\section{Bronwen Neil}

and literary past is a necessary precursor to the change in worldview that will follow. In the modern context of struggles in the Middle East, this is particularly clear in the campaign to destroy cultural landmarks in the name of eradicating so-called idolatry and restoring a purified Islam to the regions of Iraq and Syria. The same impulse is evident in the destruction of books in late-antique Rome (Neil forthcoming) and in the defacing of art and statuary (see Jensen's chapter within). Both were common practices in early Christianity as it struggled against the established Graeco-Roman religious culture of Mediterranean society, and later between Christian groups such as the Nicenes and the anti-Nicene Arians, the Donatists, and North African Catholics.

\section{Emerging themes}

The value of collective or social memory for understanding history depends upon careful contextualisation, whether we are studying the ancient or recent past. The memories passed down by one section of the population, or one religious group, or one particular region, should not be taken as representative of the whole (Winter 2000). In the following chapters, we have tried to be sensitive to historical, generic, and material contexts, and to read the evidence accordingly, whether it be artefact, literary, art-historical, or architectural. Our attempt to identify an overarching Christian narrative of utopian retrieval of the past has led us to employ a number of methodological approaches, which are discussed according to three major themes that have emerged from the studies reviewed here and the chapters within.

\section{Landscape and identity}

One of the strongest themes of the volume is how modification or reconception of a landscape impacts upon the religious identity of those who inhabit it. This includes actual physical landscapes that can be destroyed and remodelled as well as idealised landscapes such as the human body (whether alive or dead, mortal or immortal) and the afterlife.

Three of our chapters deal with ideological problems arising from human mortality. The human body was undoubtedly the most intimate site of revision. For French philosopher Michel Foucault, indeed, the existence of the soul without a body is the most deep-rooted utopian longing of man (sic). ${ }^{3}$ The denial and denigration of the body became a utopian ideal of early Christian ascetics. In Chapter 7, Chris de Wet applies Derridean post-modernist deconstruction theory to the notion of 'pastness,' with a Foucauldian analysis of power relations and embodiment in relation to asceticism. This analysis is based on John Chrysostom's reading of several key passages of the New Testament on slavery and the proper relationship to the physical realm. The implications of Foucault's theory that disciplining the body is at the heart of most of what we call religious practice are found to be relevant to fourth- and fifth-century Christian reappraisals of the relationship between spirit and flesh. Can a similar impulse be identified in the deaths, whether voluntary or not, of North African martyrs in the Great 
Persecution and the vivid commemorations of their violent deaths centuries later, studied by Jonathan Conant in Chapter 3?

A similar preoccupation with bodies characterised reactions to the new Christian cult of the dead in mid-fourth-century Antioch, then the place of residence of the East's first pagan emperor since pre-Constantinian times. Wendy Mayer (Chapter 5) explores the agency of Emperor Julian's discourse in escalating antiChristian feelings of disgust towards Christians, through the application of moral foundations theory (Haidt 2012). Jonathan Haidt proposes that several innate and universally available psychological systems are the foundations of intuitive ethics. Each culture then constructs virtues, narratives, and institutions on top of these foundations, thus creating their own unique moralities. Haidt's theory offers a comprehensive tool for understanding why morality can vary so much across cultures and yet still show so many commonalities. In the later Roman Empire, we can see this overlaying occurring within one broad culture, e.g. the Christian and anti-Christian groups of the eastern and western empire. In the same chapter, Mayer applies conceptual metaphor theory to illuminate how cognition worked at the preconscious level to bring about physical destruction of Christian shrines. Both theories allow us to see the well-known texts of Julian in fresh ways.

Another physical site or landscape of utopia was the holy land of Israel. Jerome's enthusiasm for shaping a new Christian landscape of sacred sites in Palestine grew not only out of his concern for pilgrimage to the Holy Land but also out of his search for a new religious identity that was based on a putative, primitive early Christian (and by corollary, Jewish) creation of utopia. The effect on future generations of this drive for a new identity was significant, as shown by Pauline Allen and Kosta Simic in their study of non-Chalcedonians (Chapter 9). Peter the Iberian influenced the following generation of non-Chalcedonians, including Severus of Antioch, Zachariah Rhetor, and John Rufus, the author of his Life. Competition between factions within Christianity also entailed the persecution of perceived outsiders, namely, Jews and Zoroastrians.

A comparative literature study of the hagiographic memorials of Gallic, Spanish, and Italian saints' cults is made by Bronwen Neil in Chapter 8. This analysis allows us to see a similar narrative of peace accompanying the persecution of non-mainstream Christianity in Italy, Spain, and Gaul, a narrative of saintly power that is miraculous but also violent in its chastisements. Western hagiographers like Gregory of Tours, Gregory the Great, and the anonymous author of the Lives of the Méridan fathers sought to make a rift with the preChristian pasts of Gaul, Italy, and Spain by portraying them in dystopian terms. They contrasted the pagan past with the idealised recent past, in which a new order was instantiated. This new order was characterised by miraculous healings and divine mercy for the obedient, and was a prelude to the eternal afterlife, a relatively new concept to believers in these regions. However, no utopia can exist without its shadow side. A dystopian future characterised by violence was forecast for those who perpetuated the old, violent, social order and rejected the new Christian paradigm. In this paradigm the burial places and bodies of the saints were equally 'places' to be colonised by the Holy Spirit or its enemies, the Devil and his demons. 


\section{Bronwen Neil}

The comparative literature approach of Chris Bishop in Chapter 12 also affords new insights into well-known literary sources. His close reading of two GalloRoman epic poems builds on past work on the imagery of the Waste Land in early medieval poetry. Bishop's comparative-linguistic analysis of the various allegorical images of ruin and decay, familiar from contemporary Anglo-Saxon poetry, in the two Latin poems is supported by archaeological evidence for changing settlement patterns in Gaul. Bishop explores the links between the work of two Gallo-Roman poets, one non-Christian and the other a convert, and how their belief systems influenced their development of different ideologies of the constructed landscape.

\section{Cultural memory and social cohesion}

A basic feature of any utopian vision is harmony and social cohesion. In a religious context, this means that memories of difference have to be either removed from memory, reconceived, or transcended. While in the current age of multiculturalism, religious identities might be put aside in the name of tolerance and the greater good, this was not an ideal or even a possibility in the fourth to eighth centuries. Late-antique bishops wished for conformity in doctrine above all things, as the actions of Augustine in the Donatist controversy show (Chapter 4). Memory is malleable and is aided by destruction and reconstruction. Altering the physical landscape can alter the mental landscape. Destruction itself was not enough; for the late-ancient Christians there was no reverence or nostalgia in ruins of temples or synagogues: compare the accounts of Renaissance tourists of ancient Roman ruins, celebrated as memoria Romana (Galinsky 2014). New markers of harmony had to be built in their place. The triad of construction-destruction-reconstruction was a permanent feature of the restless late-antique landscape. The desire for harmony can lead to violence, just as the desire for cohesion can lead to destruction. This is the paradox that lies within any utopian dream: disruptive elements have to be coerced or removed to allow the utopia to be realised.

Altering the written record of events - even those that belong to the previous generation and thus pertain to living memory - could also alter community memory. Geoffrey Dunn (Chapter 4) gives a telling example in Augustine's recollection in 418 of events that occurred in the 390s and of how the Council of Carthage in 411 dealt with them. Augustine framed divisions within the Donatist church as an attack on the ideal of ecclesial unity. Another example is Julian's praise of the anarchic philosophical school of the Cynics. He praised Cynics of the past like Diogenes while rejecting those of the present, such as Herakleios, who were too much like his other adversaries, the Christians. Philip Bosman's study (Chapter 2) showed how an emperor and master orator sought to distort memories of the past to fulfil his own ideological agenda and create an idealised future in which Christians, not Cynics, were the outcasts.

Two chapters (5 and 10) on the seventh and early eighth centuries show Byzantines attempting to cope with the Persian and Arab conquests by reinterpreting them as part of their providential history, and the effect of these conquests on their 
use of ritual space and on their liturgical commemorations of the saints. These authors focused on orthodoxy as a marker of religious identity and on the challenges of regime change to the Byzantine sense of social cohesion.

In Chapter 10, Simic's study of the diptychs recited in the early Byzantine liturgy, we find that even liturgical texts could be effectively mobilised to communicate messages that delineated dogmatic differences and strengthened the congregation's sense of identity vis-à-vis a common foe, the heterodox. Simic argues that these hymns, addressed to a wide audience, helped to reinforce social cohesion within Orthodox communities who were facing external attacks from Muslim forces. We saw the same impulse in operation in Conant's piece (Chapter 3 ) on the creation of liturgical communities focused on the commemoration of North African martyrs. The apocalyptic sources of Byzantine Orthodox and Jewish traditions deployed by Ryan Strickler (Chapter 11) illustrate that the impulse to look forward to a utopian restoration in the future was universal in this period, at least across Byzantine and former-Byzantine territories.

\section{The cycle of construction-destruction-reconstruction}

By the end of the fourth century, official legislation authorising the removal of pagan statuary prompted local acts of desecration and destruction of images along with altars. These deeds may have been meant primarily as a repudiation of the gods' traditional cults, but aspects of social, economic, or ethnic conflict may also have instigated and sustained them. The Christian poetry of Gaul discussed in Chapter 12 was also marked by the cycles of construction and destruction. While Ausonius describes the bucolic splendour of the landscape of the Moselle valley in rapturous detail towards the end of the fourth century, the Christian poet Venantius Fortunatus lamented the signs of decay in the same landscape- the lofty villas had disappeared, the town walls were ruptured, the high places bristled with fortifications and weapons of war. Ausonius's vision idealised natural beauty and wilderness, in contrast to the rapid urbanisation of late-Roman Gaul. Two centuries later Fortunatus observed that the same rural landscape was falling into decay but endowed its decline with eschatological significance.

Weighing against the tendency to destroy all signs of previous religious traditions was the belief that each new religion improves upon and is the fulfilment of the promises of the ones preceding it. Our final two chapters look at such repurposing of material artefacts that pertained to defunct religious practices.

Janet Wade (Chapter 14) applies an archaeological contextualisation of steelweights and busts of Athena to determine what ritual objects were being preserved from the past and employed with new religious attachments, in the maritime trade between Constantinople, Athens, and the wider Mediterranean. Wade asks whether the steelyard and shipping weights in the shape of the bust of Athena or Minerva indicate the yearning for a pre-Christian past or the completion of a thorough process of Christianisation of the goddess by the sixth century.

Leonela Fundic (Chapter 15) employs a much broader set of visual evidence from archaeological sites, architecture, sculpture, and epigraphy from across the 
Mediterranean and the Balkans from the fourth to eighth centuries, to show similarly that revisionism need not entail violent destruction. Like Jensen and Wade, Fundic shows that when literary evidence is interpreted from the perspective of art history, rhetorical accounts of the destruction of statues, temples, synagogues, and shrines often contradict the more reliable material evidence for repurposing.

Such material evidence shows a desire for social cohesion in the built and material environment that transcended different religious affiliations. It challenges the dominant narrative of violent destruction of relics from the non-Christian past, but it also demands cautious interpretation. Answers to the questions posed in Part IV may change as more archaeological evidence emerges.

\section{Conclusion}

The studies in this volume suggest that cultural inertia was constantly pushing against religious innovation and reform in the later Roman Empire, because memory shapes the past and the future. The evidence of texts from this period suggests parallels between the ancient and contemporary worlds that are yet to be explored. Recently rediscovered sources such as the Book of Zerubbabel and the apocalyptic poetry of George of Pisidia demand more study as to the degree of societal instability required for their production and popular consumption. Just as the Islamic State looks back to a mythical seventh century of pure Islam, some of our ancient sources seek to regain or portray a utopian past that is mostly imaginary; others seek to depict the past in a dystopian light, to highlight the superiority of the current regime. We see this impulse at work in the writings of the emperor Julian in the mid-fourth century, just as we find it in Christian works of the same period. Parallels with contemporary apocalyptic movements could yield more insights into the impact of such literature on societal unrest and religious change.

New material evidence has been brought to bear here from recent archaeological projects in the Balkans, Greece, and Turkey. Artefacts like the fifth- to sixthcentury steelyard weights and shipping weights in the shape of Athena show how new memories of religious significance could be attached to old objects. New epigraphic evidence from the nascent Islamic lands of the seventh and eighth centuries suggests that Byzantine shrines were not always destroyed, for reasons of religious intolerance or any other reason, but were sometimes reshaped to preserve the memory of the past and to create an idealised future. The sacred places and landscapes of previous religions were sometimes, perhaps often, incorporated into the current religious regime and served the ritual narratives of the future.

We hope that these chapters contribute to reflections on our own collective futures, and the role of memory in shaping them, both in cultures which embrace religious pluralism and those that do not.

\section{Notes}

1 I am grateful to the Australian Research Council for funding Discovery Project 170104595 'Memories of Utopia: Destroying the Past to Create the Future (300-650 CE)' from 2017 to 2020 . 
2 My summary of Mannheim 1936 is indebted to lecture notes by Christina Maimone, Stanford University (Political Science 311 ).

3 Foucault 2006: 234.

\section{Bibliography}

\section{Primary sources}

More, T. (1516) De optimo reipublicae statu et de nova insula Utopia. Leuven: Thierry Martens. (1551) Utopia: A fruteful, and pleasaunt worke of the beste state of a publyque weale, and of the newe yle called Vtopia. Translated by Robinson, R. London: Abraham Vele.

\section{Secondary sources}

Alderman, D. and Dwyer, O. (2009) 'Memorials and monuments'. In Kitchin, R. and Thrift, N. (eds.), International encyclopedia of human geography, vol. 7. Amsterdam: Elsevier, 51-8.

Assmann, J. (2000) Religion und kulturelle Gedächtnis: zehn Studien. Translated by R. Livingstone. Munich: C. H. Beck. Press. (2006) Religion and cultural memory: Ten studies. Stanford: Stanford University (2007) Das kulturelle Gedächtnis: Schrift, Erinnerung und politische Identität in fruhen Hochkulturen, 6th edn. Translated by Wilson, D. H. Munich: C. H. Beck. (2011) Cultural memory and early civilization: Writing, remembrance, and political imagination. Cambridge: Cambridge University Press.

Baxter, C. (ed.) (1999) Graywolf Forum three: The business of memory: The art of remembering in an age of forgetting. Saint Paul, MN: Graywolf Press.

Berliner, D. (2005) 'Social thought and commentary: The abuses of memory: Reflections on the memory boom in anthropology'. Anthropological Quarterly, 78: 197-211.

Böker, M. (2017) 'The concept of realistic utopia: Ideal theory as critique'. Constellations, 24/1: 89-100.

Bommas, M. (ed.) (2011) Cultural memory and identity in ancient societies. London and New York: Routledge.

(2016) 'From ancient Egypt to the Mississippi delta: A comparative approach to cultural memory and forgetting'. In Nadali (ed.), 163-82.

Bremmer, J. (2018) 'Religious violence and its roots: A view from antiquity'. In Mayer and de Wet (eds.), 30-42.

Christie, N. (ed.) (2004) Landscapes of change: Rural evolutions in Late Antiquity and the early Middle Ages. London: Routledge.

Connerton, P. (1989) How societies remember. Cambridge: Cambridge University Press.

Corning, A. and Schuman, H. (2015) Generations and collective memory. Chicago: University of Chicago Press.

Crane, S. A. (1997) 'Writing the individual back into collective memory'. The American Historical Review, 102: 1372-85.

Dijkstra, J. H. E. (2015) 'Religious violence in late-antique Egypt reconsidered: The cases of Alexandria, Panopolis and Philae'. Journal of Early Christian History, 6: 24-48.

(2018) 'Religious violence in late-antique Egypt reconsidered'. In Mayer and de Wet (eds.), 211-33. 


\section{Bronwen Neil}

Foucault, M. (2006) 'The utopian body'. In Jones, C. A. (ed.), Sensorium: Embodied experience, technology, and contemporary art. Cambridge, MA: Harvard University Press, 229-34.

Galinsky, K. (ed.) (2014) Memoria romana: Memory in Rome and Rome in memory. Supplements to the memoirs of the American Academy in Rome, vol. 10. Ann Arbor: University of Michigan Press.

García Morcillo, M., Richardson, J. H., and Santangelo, F. (eds.) (2016) Ruin or renewal? Places and the transformation of memory in the city of Rome. Rome: Edizioni Qasar.

Gedi, N. and Elam, Y. (1996) 'Collective memory: What is it?' History and Memory, 8: $30-50$.

Guidetti, M. (2016) In the shadow of the church: The building of mosques in early medieval Syria. Leiden and Boston: Brill.

Halbwachs, M. (1950) La mémoire collective. Paris: Presses universitaires de France. (1952) Les cadres sociaux de la mémoire. Paris: Librairie Félix Alcan.

(1992) On collective memory. Translated by Coser, L. A. Chicago: University of Chicago Press.

Hahn, J. (2004) Gewalt und religiöser Konflikt: Studien zu den Auseinandersetzungen zwischen Christen, Heiden und Juden im Osten des Römischen Reiches. Berlin: Akademie Verlag.

Hahn, J., Emmel, S., and Gotter, U. (eds.) (2008) From temple to church, destruction and renewal of local cultic topography in Late Antiquity. Leiden and Boston: Brill.

Haidt, J. (2012) The righteous mind: Why good people are divided by politics and religion. New York: Vintage Books.

Hedrick, Jr, C. W. (2000) History and silence: Purge and rehabilitation of memory in Late Antiquity. Austin, Texas: University of Texas.

Hölkeskamp, J. K. (2016) 'In the web of (hi)stories: Memoria, monuments, and their mythhistorical interconnectedness'. In Galinksy, K. (ed.) Memory in ancient Rome and early Christianity. Oxford: Oxford University Press, 169-213.

Jenkyns, R. (2014) 'The memory of Rome in Rome'. In Galinsky (ed.), 15-26.

Jones, C. and Ellis, C. (eds.) (2016) The individual and utopia: A multidisciplinary study of humanity and perfection. London and New York: Routledge.

Klein, L. (2000) 'On the emergence of memory in historical discourse'. Representations, 69: $127-50$.

Mannheim, K. (1936) Ideology and utopia: An introduction to the sociology of knowledge. Translated by L. Wirth and E. Shils. London: Harcourt, Brace. [Repr. with introduction by Turner, B. S. (1997) Routledge: London].

Mayer, W. (2018) 'Re-theorising religious conflict: Early Christianity to Late Antiquity and beyond'. In Mayer and de Wet (eds.), 3-29.

Mayer, W. and de Wet, C. L. (eds.) (2018) Reconceiving religious conflict: New views from the formative centuries of Christianity. Routledge studies in the early Christian world. London and New York: Routledge.

Nadali, D. (ed.) (2016) Envisioning the past through memories: How memory shaped ancient Near Eastern societies. Cultural memory and history in antiquity, 3. London: Bloomsbury.

Neil, B. (forthcoming) 'Rivalries in Rome: Pope Hormisdas on what not to read in the sixth century'. In Dunn, G. D. and Shepardson, C. (eds.) Dealing with difference: Christian patterns of response to religious rivalry in Late Antiquity and beyond.

Rives, J. (2009) 'Graeco-Roman religion in the Roman empire: Old assumptions and new approaches'. Currents in Biblical Research, 8/2: 240-99. 
Sanders, G. D. R. (2004) 'Problems in interpreting rural and urban settlement in Southern Greece, AD 365-700'. In Christie (ed.), 163-93.

Shepardson, C. (2014) Controlling contested places: Late-antique Antioch and the spatial politics of religious controversy. Berkeley and Los Angeles: University of California Press.

Thiessen, M. (2008) 'Gedächtnisgeschichte: Neue Forschungen zur Entstehung und Tradierung von Erinnerungen'. Archiv für Sozialgeschichte, 48: 607-34.

Varner, E. R. (2004) Mutilation and transformation: Damnatio memoriae and Roman imperial portraiture. Leiden and Boston: Brill.

Winter, J. (2000) 'The generation of memory: Reflections on the "memory boom" in contemporary historical studies'. German Historical Institute Bulletin, 27: 69-92.

Wiseman, T. P. (2014) 'Popular memory'. In Galinsky (ed.), 42-61.

Young, J. E. (1993) The texture of memory: Holocaust memorials and meaning. New Haven: Yale University Press. 


\title{
2 Julian's Cynics \\ Remembering for future purposes
}

\author{
Philip Bosman
}

The emperor Julian managed to generate an abundance of memories like very few other figures from antiquity, as recent scholarly biographies reveal (Bringmann 2004; Rosen 2006; Teitler 2017). This was certainly not due to prolonged power or longevity: he ruled the Roman world for barely twenty months and died aged thirty-two. Furthermore, his vision of re-Hellenising ${ }^{1}$ the empire failed and not only because of the brevity of his reign: the cracks started to show soon after he came to rule, but in particular during his stay in Antioch. ${ }^{2}$ It is thus not so much his accomplishments as his position at the crossroads of history that determined Julian's singular stature. The intensity of emotions surrounding his person and what he signified gave rise to a profusion of literature written during and after his reign, by partisans like Libanius and Ammianus, as well as by detractors like Gregory of Nazianzus and John Chrysostom. ${ }^{3}$ We should also not forget that Julian was a prolific author in his own right (Baker-Brian and Tougher 2012b: 17), a fact that in equal measures facilitates and complicates our understanding of the man and his motivations. Even in the best of scholarship to this day, neutrality towards the apostate has always been hard to attain, due to both his personality and his ideology. ${ }^{4}$

In the current chapter, however, I am less concerned with memories about Julian than with Julian's own memory of Cynic philosophy. What might otherwise be considered as the reinterpretation or the misrepresentation of a tradition may for the purposes of this volume be termed an adjustment or a realignment of memory with a view to employing that memory for future use. Julian stood in a centuries-old tradition of idealising the classical Greek past, but as emperor he acquired the power to harness this legacy (cultural, religious, and philosophical) to forge the future he had in mind, among other things by curbing the growing influence of Christianity.

My argument will be restricted to two orations (Or. 6 and 7 in the LCL ordering) in which the emperor confronts contemporary Cynics. Contrary to what is often assumed, in neither of these does Julian argue against the Cynic philosophy itself, but rather against some specific exponents of Cynicism he has recently come across. In both instances he accuses these Cynics of misrepresenting or misunderstanding the true ancient version of the philosophy. In the process he makes himself guilty of selective memory by relying on previous attempts to render Cynicism more palatable to the educated levels of society. More peculiarly, he sets his 
recollection of the Cynics in a Neoplatonist synthesis of classical Greek thought, with Cynicism representing the practical side of a religio-ethical construct which included all the ancient philosophical schools (the Epicureans excepted), and which he traced back to the Delphic Apollo.

The two Cynic orations are controversial in scholarship on two scores: whether they are philosophically motivated or mere incidental ad hominem displays, and how they relate to Julian's politics and his restoration of traditional Greek cult. The two poles of the controversy seem irreconcilable. Athanassiadi (1992: 130-41) argues for the Cynic orations' integration into Julian's programme (a close-knit

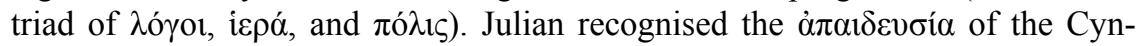
ics contemporary to himself and grabbed the opportunity to educate them on the 'deep unity of Hellenic thought' (Athanassiadi 1992: 137). At the other pole, Smith (1995: 49-90) finds little that would suggest they were crucial to such a vision. In Smith's view, the two orations are essentially performance pieces in which the emperor voiced, to an intimate audience at the imperial court, his irritation with the Cynics he recently encountered. These Cynics posed no threat to either his ideological or his cultic reforms, nor was Julian novel in his dealing with false philosophers and false Cynics. The two discourses, therefore, do little more than express Julian's scepticism towards the Cynic challenge to social hierarchies in the empire: 'the philosophical pretentions of the uneducated poor were not to be taken seriously' (Smith 1995: 61).

While scholarship rightly questioned Athanassiadi's over-sympathetic reading of these texts as the coherent development of an educational ideal (see the rather scathing reviews by Bowersock 1983 and Van der Horst 1985), it would be a mistake to let Julian the rhetor completely overshadow Julian the philosophically minded emperor. Though no great intellectual innovator, his dealings with Cynic tradition amount to more than a 'familiar repertoire of literary invective' (Smith 1995: 90; see also Tanaseanu-Döbler 2008: 127-8). His self-identification as a serious scholar and a new Marcus Aurelius, even dressing the part, renders unlikely a mere pretence of researches into the long and complex Cynic tradition. It is generally assumed that in the pieces Julian wrote while in Constantinople, the newly crowned augustus was concerned with impressing religio-philosophical convictions onto the socio-political realm for which he assumed responsibility. ${ }^{5}$ In consequence, it seems likely that the two orations were about more than display and personal honour. But even if it may be conceded that Julian is serious about philosophy, the question remains why he gives such attention to a single school of thought, and an atypical one at that.

\section{Fourth-century Cynicism}

At the time of Julian, the figure of the Cynic founder Diogenes exerted considerable influence on the intellectual imaginations of pagans and Christians alike, but the sources do not mention significant contemporary exponents of the philosophy (Krueger 1993: 34). Apart from Julian's adversary Heraclius, only a slightly younger contemporary by the name of Maximus Hero gets mentioned by Gregory of Nazianzus (Or. 25, De vita sua). Late sources such as the Suda and 
Photius refer to a certain Sallustius of Emesa who flourished some 50 years later. Smith (1995: 87) regards Sallustius as little more than 'a picturesque Christian,' and indeed the philosophical purity (if that ever existed) of these figures can be doubted: Photius Bibl. 242.342b mentions Sallustius as mingling authentic Cynic features with doubtlessly inauthentic ones such as prophecy (cf. Döring 2006: 98-9; Dudley 1937/2003: 202-8). With this Sallustius, Döring claims, ancient Cynicism came to an end, still a century before Justinian's closure of the philosophical schools in 529 CE. Justinian's edicts to block pagan teaching were the inverse of what Julian attempted 170 years earlier when he blocked Christians from public teaching positions: ${ }^{6}$ as Julian thought the Christians could not teach what they did not believe in, so Justinian thought the philosophical schools were contending faith systems that could not be given the chance to gain influence or dignity. While Justinian's edict did not mean that all philosophy and ancient learning came to an abrupt end, it did drive the final nail into the coffin of Julian's ideas on merging traditional cult and Hellenic learning (cf. Constantelos 1964: 374-6 on paganism under Justinian).

In general, scholarship does not give Cynicism much prominence in the philosophical firmament of the later Roman Empire. It is therefore remarkable that Julian mentions only Homer and Plato with greater frequency than he does Diogenes the Cynic (Smith 1995: 49). Whence, we need to ask, this unexpected attention? Of those who do not misread the orations as an attack against Cynicism, some regard it as merely the result of a chance occurrence, others as the starting point, insignificant in itself, for Julian to move to the important task of developing a philosophical synthesis with which to counter Christianity (Athanassiadi 1992: 128). It may also be possible, however, that our written sources give an inaccurate impression of the school's attraction for a broad cross-section of society in Julian's time; after all, according to a remark by Augustine, it outlived all the other philosophical schools apart from the Platonists and the Peripatetics (August. C. Acad. 3.19.42; cf. Smith 1995: 245 n.30). It may, furthermore, be that the very nature of the movement fitted well with Julian's vision for his future empire, provided that he could make it more acceptable by separating the philosophy from its vulgar associations. For its sanitation, he 'remembered' selectively from a tradition that by his time already had a history of almost 700 years and had passed through various stages.

\section{Orations 6 and 7: redeeming Cynicism}

The two orations in which Julian engages with Cynics are set by scholars during Julian's brief stint as augustus in Constantinople (late 361-mid 363), with the speech Against Heraclius (Or. 7) during the spring of $362 \mathrm{CE}$, and the shorter but more considered Against the uneducated Cynics (Or. 6) shortly after the summer solstice of that year. ${ }^{7}$ Julian claims to have written both speeches in double-quick time, Against Heraclius in a single day, and the second speech over a mere two days. ${ }^{8}$ The speeches have had ample scholarly attention, so I will only refer to three examples in order to illustrate how he deals with Cynic tradition. ${ }^{9}$ 


\section{The respectable Cynic}

In both speeches Julian accepts the traditional high regard for the early Cynics (Diogenes of Sinope in particular) but goes beyond the usual practice of referring to them by way of anecdotes and as moral exempla. The Cynics appear to have used anecdotes as a textual strategy since the late fourth century BCE. The very

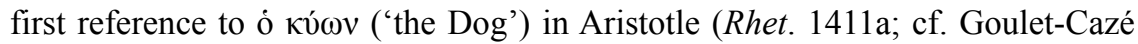
1996: 414-5 on whether it refers to Diogenes or Antisthenes) is already aphoristic, and anecdotes were integral to compilations of Cynic material, whether Theon's Progymnasmata, the philosophical histories of Diogenes Laertius, or Cynic biography in Lucian's Demonax. Julian goes further: he claims to have 'reviewed' (the term is $\varepsilon \pi \varepsilon \rho \chi \varepsilon \sigma \theta \alpha$; cf. $L S J 1953: 618$ ) not only the early tragedies attributed to Diogenes of Sinope but also the works of the imperial Oenomaus of Gadara. Furthermore, Julian displays careful consideration of the school's philosophical significance and intellectual coherence, often lost on other authors who merely tapped into the anecdote tradition for exemplary material. His idealising interpretation is not novel and sets him in the company of the likes of Dio Chrysostom and Epictetus - that is, authors who 'bowdlerised' Diogenes. But it is not naïve either and displays a scholarly awareness of the problems posed by the tradition, so that Julian has to engage in some deft footwork in order to maintain his idealised picture. In particular, his insistence on the respectability of the early Cynics, and especially on their piety, makes him go against the grain of what is known about the early Cynics from earlier sources.

Against Heraclius (Or. 7) contains a reasonable amount of information on the context of the speech. It is the emperor's public response (something he professes to have loathed) to a visiting orator who claimed to be a Cynic and invited Julian to a public performance which Smith (1995: 49) suggests could have been at the imperial court in Constantinople (cf. Julian Or. 6.205b; 7.235a). In this speech, Heraclius employed a mythos which Julian found offensive not only for its irreverence towards the gods, but also because Heraclius in Julian's interpretation used Zeus to represent himself, and Pan to represent the emperor. Julian's response is too tendentious to reconstruct the Cynic's argument, but it is likely

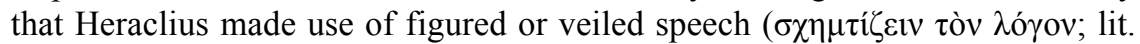
'to dress up a speech') - a popular form of conveying uncomfortable messages to those in power without having to address them directly (cf. Jażdżewska 2019). It was either a clumsy attempt or-more typical of the Cynic mode-his $\sigma \chi \eta \dot{\mu} \alpha$ was deliberately so thin as to become a parody of the rhetorical technique. In a contorted way, Heraclius tested the limits of tolerance traditionally afforded to Cynic $\pi \alpha \rho \rho \eta \sigma i ́ \alpha$ ('free speech'). Julian starts his oration (204a-205a) by occupying the moral high ground: he obviously did not enjoy the experience, but nonetheless acted with great restraint in not breaking up the meeting. To his further credit, he did not resort to such physical revenge as his status would have allowed, but decided on a scholarly response to the insult, that is, by way of a public $\lambda$ ó o ${ }^{10}$ He then (205b) sets out the goals of his response as, firstly, to argue that Cynics ought rather to employ $\lambda$ ó $\gamma \circ \varsigma$ and not $\mu \tilde{v} \theta 0 \varsigma$ as Heraclius did, then to specify what kinds of myth might be appropriate, and lastly to make a few 
remarks on $\varepsilon \dot{\lambda} \lambda \alpha \dot{\beta} \varepsilon 1 \alpha$ (divine reverence, religious scruple). The central argument, on the correct kind of myth to be invented for furthering the aims of Cynicism, includes the lengthy allegory in which Julian himself plays the main part and by which the emperor spells out his own calling from the supreme god himself $(227 \mathrm{c}-234 \mathrm{c})$.

In the first part of the speech, Julian reminds his addressee that a Cynic ought simply to resort to the unvarnished truth, like his predecessors Diogenes and Crates did. He goes on to ask, rhetorically, if the true Cynic is to display such an

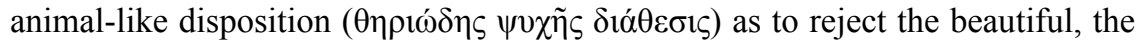
good, and the serious:

Now, by the Muses, tell me this about Cynicism, whether it is non-sensical and an inhumane life, the disposition of an animalistic soul that respects neither the beautiful, nor the serious, nor the good? For Oenomaus would that many hold such views on it. If you made an effort to review them, you would have come to know this well from the Cynic's Direct utterances and Against the oracles, frankly from everything the man wrote. Such being the case, it results in doing away with all piety towards the gods, disrespecting all human prudence, trampling on not only law in accordance with the good and just, but also on those laws from the gods in us as if written on our souls, by which we are all, without having been taught, convinced that the divine exists and that we keep it in sight, and I think that we are so disposed of soul to be drawn to it as I think we are of sight to light.

$(\text { Or. } 7.209 \mathrm{a}-\mathrm{c})^{11}$

The 'animal-like disposition' relates to the early Cynic identification with animalism (the early Cynics turned the derogatory label кú our) but the values of Julian's list (the beautiful, the good, and the serious) do not feature prominently in the early layers of the tradition. In Julian's view, however, the early Cynics did not reject such values: this only happened in the aberrations of men like Oenomaus. The passage contains the first reference in the two speeches to this controversial Cynic, whose attack on the pagan oracles was quoted extensively by Eusebius (Praep. ev. 209b-243c, 225b-261c; cf. Hammerstaedt 1988). Julian seems to have first-hand knowledge of Oenomaus's work, on the basis of which he came to the conclusion that the offensive author scorned

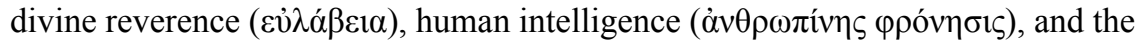
respect for the law (vó ${ }_{0} \varsigma$ ), as well as those laws which the gods engraved on our

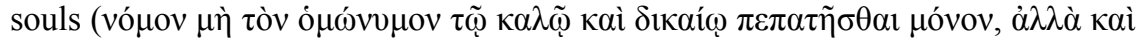

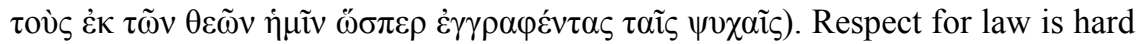

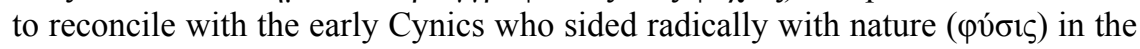

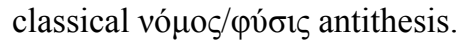

In a second reference to Oenomaus, Julian sets him explicitly against the - in his view - true Cynic Diogenes, who may not have been overtly religious but who nonetheless worshipped the gods where it really mattered, namely in his soul: ${ }^{12}$ 
So then, let the Cynic not be shameless or impudent in the manner of Oenomaus, nor disdainful of everything divine or human, but rather pious towards divine things like Diogenes. For he was obedient to the Pythian temple and did not regret his obedience. But if anyone would think it a sign of godlessness that he did not visit or attend to temples and cult statues and altars, he would be wrong. For he possessed no such things, no incense or libation, nor money with which to buy them. But if he understood the gods correctly, that was sufficient in itself. For he worshipped them with his very soul.

(Or. 6.199a)

Both Diogenes's poverty and his aloofness to cult are well attested in the Cynic tradition, and Julian cleverly links the two to shift the attention to inner worship. A saying of the proto-Cynic Antisthenes on 'one god according to nature' (Cic. De nat. deor. 1.32) does seem to hint at rejection of cult but not of divinity itself in

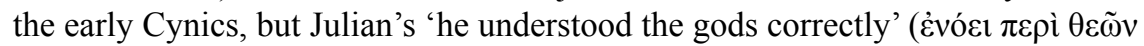
o $\rho \theta \tilde{\omega} \varsigma)$ is probably due more to Neoplatonic conceptions than to early Cynicism.

By setting Cynics against each other, Julian draws on an established literary tradition which favoured a more respectable, educated version of the sect over the presumably illiterate street Cynics: we find the distinction in authors like Dio Chrysostom, Epictetus, Lucian, and pseudo-Lucian. The dichotomy was partly due to Stoic influence, as the Stoics needed to establish a Socratic pedigree for their own founder Zeno (cf. Smith 1995: 53, 244 n.16 on the Stoic succession; Goulet-Cazé 2003 on the relationship between the schools). The respectable version suppressed the shameless, anti-cultural Cynic. Oenomaus, on the other hand, belonged to neither of these groups, but rather to a third group of 'literary' Cynics which included the likes of Bion, Menippus, and later Lucian with his Cynic hat

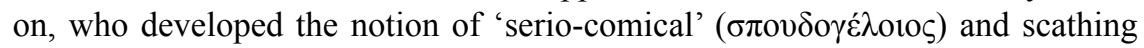
social criticism in parody and satire. Naturally they all claimed to be the true heirs of the founders Diogenes and Crates. The proponents of the sanitised version in particular had difficulties with reconciling themselves with the tradition on the early Cynics which depicted them as shameless. Julian in Or. 6.201C-202C makes a brave (and not altogether unconvincing) attempt to explain away the $\dot{\alpha} v \alpha i \delta \varepsilon 1 \alpha$ of the early Cynics, but cannot overlook the same faux pas in the later Cynic Oenomaus.

Cynic tradition also knew a body of literature transmitted under the name of Diogenes that included tragedies justifying cannibalism and incest (cf. Diogenes Laertius 6.80; Döring 1993). Julian appears to have read some of these works and refers to them twice in Against Heraclius. In the first reference, he seems undecided about their authorship, but expresses his disgust with them whether they are by Diogenes or not: ${ }^{13}$

Regarding the tragedies attributed to Diogenes, which are acknowledged to be the writings of some Cynic but disputed on whether they are by the master, Diogenes, or by his pupil Philiscus: who having read them would not be 
disgusted by them and consider them to be vulgar in the extreme, not even surpassed by prostitutes?

In what follows, he compares these tragedies to those of Oenomaus, which he finds even more abhorrent. In a second reference, also in Against Heraclius, he is more intent on divorcing Diogenes from these works by noting the disservice done by Philiscus in ascribing them to Diogenes: ${ }^{14}$

Let Diogenes, then, not be known as the kind of person with regard to gods and men as it would appear from Oenomaus's writings or from the tragedies of Philiscus who, by ascribing them to the name of Diogenes, greatly slandered the divine figure, but rather the kind of person as from the deeds he did.

(Or. 7.211d-212a)

When he returns a few months later to the literary output of Diogenes, Julian concedes that they might after all be by the early Cynic himself, but offers a different solution to the problem posed by their shamelessness: ${ }^{15}$

The much talked about tragedies of Diogenes are said to be by one Philiscus of Aigina, though even if they were by Diogenes, it is not out of place for the wise man to be playful, since many philosophers are known to have done this. They say Democritus also used to laugh when he saw people being grave. Let us not fixate on their jests like those who least desire to learn something of import.

(Or. 6.186c-d)

Here Julian employs the hermeneutical strategy of genre-casting, a further way of divorcing Diogenes from the shamelessness of his writings: they are the product of literary jesting ( $\pi \alpha i \zeta \varepsilon v v)$ common to other great men as well-their frivolity ( $\tau \dot{\alpha} \varsigma \pi \alpha \imath \delta 1 \alpha \dot{\zeta}$ ) makes evident that they should not be mistaken as representing the essence of his thought. Even though Julian seems well informed about the Cynic tradition (not only the content of works but also authorship issues), he shows himself quite prepared to forget such aspects that are unsuitable to his own purposes.

\section{The Cynic slogan-made in heaven}

A second strategy adopted by Julian is to tie Cynicism tightly into his Neoplatonist synthesis of ancient thought. Himself a great admirer of Iamblichus, Julian would not allow dissonance in his envisaged coherent choir of philosophical voices. Therefore, for him the only real difference between the true Cynics and the other philosophical schools is that the former stressed practice over theory. Occasionally, his amalgamation goes further, as can be illustrated by how he deals

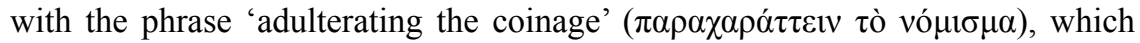
belongs to the earliest layers of the Cynic tradition and is duly recorded in all 
its variety in Diogenes Laertius. The phrase was associated with the reasons for Diogenes's initial departure from Sinope, as he apparently himself acknowledged in one of his notorious writings entitled Pordalos ('The Farter'). But the tradition was undecided on the details, and Diogenes Laertius lists no fewer than six different versions of the story: ${ }^{16}$

Diogenes was a native of Sinope, son of Hicesius, a banker. \#1 Diocles relates that he went into exile because his father was entrusted with the money of the state and adulterated the coinage. \#2 But Eubulides in his book on Diogenes says that Diogenes himself did this and was forced to leave home along with his father. Moreover, Diogenes himself actually confesses in his Pordalus that he adulterated the coinage. \#3 Some say that having been appointed to superintend the workmen he was persuaded by them, and that he went to Delphi or to the Delian oracle in his own city and inquired of Apollo whether he should do what he was urged to do. When the god gave him permission to alter the political currency, not understanding what this meant, he adulterated the state coinage, and when he was detected, \#4 according to some he was banished, \#5 while according to others he voluntarily quitted the city for fear of consequences. \#6 One version is that his father entrusted him with the money and that he debased it, in consequence of which the father was imprisoned and died, while the son fled, came to Delphi, and inquired, not whether he should falsify the coinage, but what he should do to gain the greatest reputation; and that then it was that he received the oracle.

(Diogenes Laertius 6.20, trans. Hicks 2005: 23)

The expression lends itself to metaphor, with vó $\mu 1 \sigma \mu \alpha$ alluding to the law-nature (vó $\left.\mu \varsigma_{\zeta}-\varphi \tilde{v} \sigma ı\right)$ antinomy, and $\pi \alpha \rho \alpha \chi \alpha \rho \alpha ́ \tau \tau \varepsilon ı v$ having a range of meanings, from the neutral 'altering' to 'defacing' to 'adulterating' to 'falsifying.' At some stage the expression got fastened to the early Cynic questioning of commonly accepted opinion, and it was converted into a Delphic oracle on analogy with Socrates. Julian 'forgets' all versions of its origin except the last one. In Against the uneducated Cynics, he sets out with a lesson on the Delphic 'know yourself' ( $\gamma v \tilde{\omega} \theta \mathrm{l}$

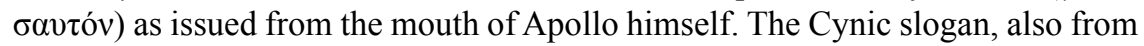
Apollo, merely extends the same thought: ${ }^{17}$

The main exponent, to whom it [Cynicism] must first be attributed, is not easy to establish, even if some accept it to be Antisthenes and Diogenes. This then Oenomaus seems right to say: Cynicism is neither Antisthenism nor Diogenism. For the best among the Cynics say that the great Heracles too, just as he was the cause of other good things for us, also left behind to humans the best example of this life. If I wish to speak well of the gods and of those who went on to an excellent end, I am convinced that even before him there were some, not only from among the Greeks but also from the barbarians, who philosophised in this manner. For this philosophy seems somehow to be universal and most natural, and not to require any special study, as it 
suffices simply to select the best by desiring virtue and shunning vice. It is not necessary to open countless books - as they say, much learning does not teach sense - nor to undergo any such things as those suffer on entering the other sects. It is enough just to obey two things the Pythian god urges, 'know yourself' and 'restamp the currency'. It has become evident to us that the founder of the philosophy is he who, I think, is behind all the good things for the Greeks, the common leader and lawgiver and king of Hellas, the god of Delphi.

(Or. 6.187b-188a)

The relationship between the two sayings hinges on unmasking false opinion. The real Cynic's task is an uncompromising search for truth, regardless of the opinion of the ignorant. Cynicism is therefore a mode of thinking-cum-acting ordered by Apollo himself, in no way contradicting the aims of the other philosophies.

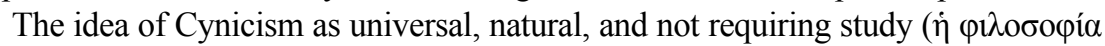

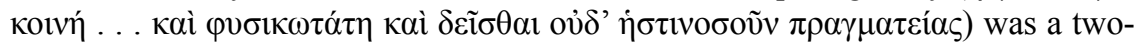
edged sword that complicated the distinction between educated and uneducated Cynics, which makes Julian's positive appraisal here all the more remarkable. Smith (1995: 52-5) correctly notes the lack, at the level of appearance and conduct, of a clear measure to distinguish between those Cynics acting on philosophical principle and the uneducated imposters, the consequent blurring of social distinctions, and the hostility against other, more theoretical schools of thought.

\section{The pious Dog}

An even more remarkable part of Julian's conception of the Cynic tradition is his emphasis on the piety of the Cynic founders. Julian's preferred term in this

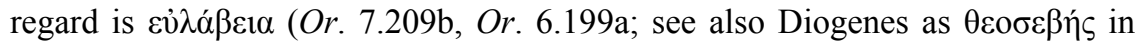
Or. 7.212d). The problem here is of course that neither religiosity nor discretion were part of the early Cynic make-up. Julian either simply 'sneaks' the idea into his treatment or he resorts to rather contrived arguments to arrive at the point. Among the latter are that Diogenes visited Olympia and Corinth in response to the calling of Zeus, and that Crates wrote pious prayers to the gods (Or. 7.212-14). Another strategy is simply to argue that Apollo originated the philosophy, and that Diogenes obediently lived it out. The Dogs have become godlike by their self-sufficiency ( $\alpha \dot{v} \tau \dot{\alpha} \rho \kappa \varepsilon \iota \alpha$ ) and their freedom ( $\dot{\varepsilon} \lambda \varepsilon v \theta \varepsilon \rho i \alpha)$. The very problematic nature of the attempt should be an indication not of Julian's superficial knowledge, but rather of how important he regarded this aspect of his reimagined true Cynics to be.

\section{Julian's version of Cynicism: a weapon against the Christians?}

Lastly, I briefly speculate with Döring on how Julian might have found a sociopolitical application for a repurposed memory of the school in his long-term plans for the empire. To be sure, there are other reasons as well why Julian wished to 
refashion the early Cynics. He certainly was attracted to their lifestyle: the 'puritanical pagan' (Bowersock 1978: 79-93) even dressed like a Cynic as demonstration of his adherence to simplicity and austerity. The Cynic universality and its practical focus also resonated with him personally. But a case can be made that he found in them convenient allies, from classical Greece at that, in his cultural push-back against the advancing Christians. ${ }^{18}$ Three points can be adduced in support of such a claim.

\section{Cynics and Christians: so close, yet so far}

Firstly, Cynics and Christians had a number of affinities and were often associated. Space disallows a detailed discussion here; suffice it to say that a few figures might even have claimed double allegiance. ${ }^{19}$ From the Christian side, the fathers of the church were sometimes, in the same argument, both repelled and attracted (cf. Griffin 1996, albeit referring to Romans from an earlier era). To the apologists, Cynicism was sometimes the epitome as well as the ultimate example of the failure of Greek philosophy. But the Christian authors every so often express their admiration for Cynicism as well, especially since their rejection of the pagan gods prepared the way for the gospel. Mainly, however, they were admired for their asceticism. Desmond (2008: 216-20) notes that the early Christians objected to the pride and shamelessness of the Cynics, but would compare them to the Old Testament prophets and even Christ himself, and often imitated the Cynics in lifestyle and dress (see also Smith 1995: 87-9). While Desmond claims (2008: 219) that Cynics and early Christians 'occupied different cultural spaces,' Gregory of Nazianzus's first panegyric for Maximus Hero, and then invective against him, indicates that it was not considered impossible to be a Cynic and a Christian at the same time. Much like Julian, Gregory (Or. 7.224b) condemns not the philosophy of his adversary but rather his person. Julian himself compares the contemporary Cynics with the Christian sect of the 'renouncers' ( $\dot{\alpha} \pi \circ \tau \alpha \kappa \tau \iota \sigma \tau \alpha i)$ who, like the Cynics, 'make small sacrifices in order to win much gain.' The reason for Heraclius's erroneous interpretation of the essence of Cynicism, Julian maintains, is that he considers Cynicism as a shortcut to philosophy without appreciating how demanding that particular shortcut is. Like the other uneducated Cynics, Heraclius in Julian's view does not have the proper philosophical grounding for Cynic practice, namely two related things: despising opinion and turning to the self and to God (Or. 7.225c-d). It seems probable that Julian thought his version of Cynicism could answer to the same social needs that Christianity managed to do with such apparent success.

\section{Cynicism's practicality: a mode of living}

Unlike the other philosophies of Greek antiquity, Cynicism did not require much book learning, and Julian more than once notes its universality, the only philosophy that preceded Heracles and was common among the barbarians (Or. 6.187b-188a). One may think in this regard of Anacharsis the Scythian and 
the Indian gymnosophists (cf. Strab. 15.1.61-6; Romm 1996; Martin 1996). Cynicism boasted to have discovered the 'shortcut' to virtue (cf. Prince 2017), and though Julian warns against the effort it requires, the shortcut consists essentially of simply searching out the good and rejecting evil: ${ }^{20}$

They say they are travelling by the tough shortcut and the tough obligation to virtue, but you should rather go by the long road as you would more easily arrive by that than by the other. Do you not know that shortcuts entail great difficulties? ... Whoever wishes to be a Cynic rejects all customs and human opinions and turns first of all to himself and to god.

$($ Or. $7.225 \mathrm{c}-\mathrm{d})$

Naturally, this made Cynicism suitable to widespread adherence also among the uneducated and less philosophically minded. ${ }^{21}$

Did Julian contemplate the institutionalisation of a pagan form of monasticism? Döring (2006: 95-6) notes, on the basis of remarks in Gregory and Sozomen,

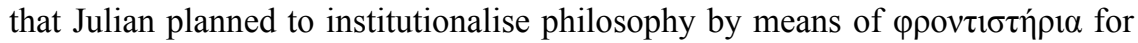
men and women throughout the empire; he might have envisaged such places for practising the kind of austerity he applied to his own life, thus a form of pagan monasticism. This would obviously have been to counter the beginnings of Christian monasticism he noticed around him. It seems plausible that the Cynic mode of living - as philosophy in practice - could have been the model on which he would have liked monastic life to be organised: the virtues of humility ( $\dot{\alpha} \tau v \varphi i ́ \alpha)$,

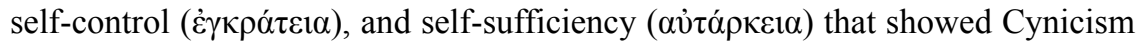
to be the 'most common and most natural philosophy' of them all.

\section{Exposing folly and returning to the gods of Hellenism}

When Julian came to power in $361 \mathrm{CE}$, Christianity had been given some five decades of valuable breathing space. From Julian's perspective, that had been a

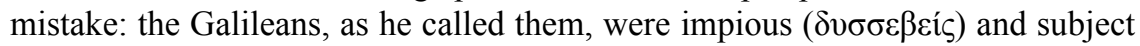

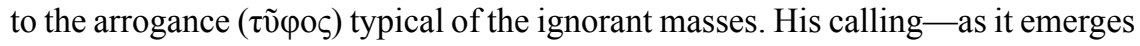
from the myth in the speech to Heraclius - was to reverse this history and to turn the empire back to the gods of old. Also in this conception of a calling, I would argue, he found in Cynicism an ally-the philosophy that exposed arrogance and theatrical display and promoted humility ( $\dot{\alpha} \tau v \varphi i ́ \alpha)$ and austerity ( $\varepsilon \dot{\tau} \tau \dot{\varepsilon} \lambda \varepsilon 1 \alpha)$ (Or. 7.214b).

But equally important, Greek philosophy had to have a religious dimension. To Julian, the distinction between cultural Hellenism and paganism was blurred if not absent. And while Gregory criticised him on that score, we need not think it strange at all: the times set religion as the driving force behind both history (Constantine) and philosophy (Neoplatonism). That is why, as we saw, it was so important to present the ancient Cynics as reverent towards the divine ( $\varepsilon \dot{\lambda} \lambda \alpha \beta \varepsilon i \bar{\zeta})$. 


\section{Conclusion}

What has emerged, I hope, is that Julian aimed to remember the Cynics of utopian times in a form that suited his own immediate purposes. Both versions-his and that of the contemporary Cynics he encountered - could arguably be traced back to Cynic beginnings, but Julian could not afford to give legitimacy to their 'perverted' version. He allowed the culturally acceptable features like freedom,

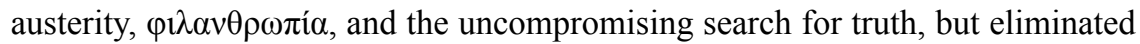
their shamelessness, their mockery, and their anti-cultural stance. His Cynic lived in a utopia long in the making: the classical past that had for centuries been the singular focus of the Greeks of the empire. But Julian wished to resurrect this utopian Cynic for the battle at hand: it had to expose the arrogance ( $\tilde{v} \varphi \circ \varsigma)$ of the ignorant Christians, it had to advocate a mode of living with popular appeal, and it had to re-establish respect and reverence for the gods of Hellenism. The Cynic founders now became, among their many other commendable traits, examples of a universal kind of religion that underpinned the very essence of philosophy.

\section{Notes}

1 By the later fourth century CE, the standard term among Christian authors for what we would term 'pagan' was 'Hellene,' and Julian was probably the first non-Christian to (defiantly?) adopt this use in his repositioning of Hellenic culture as religion ( $\lambda$ ó $\gamma o 1$

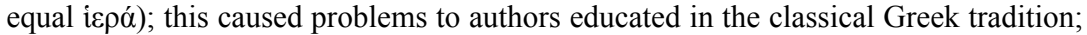
cf. Greg. Naz. Or. 4.5, Bernardi 1983: 92 'First of all, he dishonestly changed the meaning of the word to believe, as though to speak Greek was a religious rather than a linguistic affair. This was his excuse for banning us from literature as though we were stealing the goods of another'; Or. 4.107, Bernardi 1983: 258, 260: 'Do you own Hellenism?'; trans. Cameron 1993: 26. Contemporary authors like Themistius, Libanius, and Synesius seem rather to keep to the cultural connotation of Hellenism.

2 On Julian's final sojourn in Antioch (see Amm. Marc. 22.10-23.2) soured relations concluded in Julian's vicious Misopogon; cf. Amm. Marc. 22.14.1-3; Bowersock 1978: 94-105; see also Tougher 2007: 59-62.

3 On the sources and the literary receptions of Julian, see Bowersock 1978: 2-11; an extensive Nachleben in Rosen 2006: 394-462; see also Tougher 2007: 3-11 and Ross 2016, specifically on Ammianus.

4 For brief summaries of scholarly opinions, see Smith 1995: 220; Tougher 2007: 3, 5-7, 72-73; the divide typically lies between the admiring like Athanassiadi 1981, 1992 and the critical like Bowersock 1978, all in the grand tradition of the Hellenic and Christian historiographers since antiquity.

5 Cf. Perkams 2008: 105-25 on how Julian resorts to Dio Chrysostom and the $\pi \varepsilon \rho i$ $\beta \alpha \sigma i \lambda \varepsilon i \alpha \varsigma$ ('On imperial rule') literature to fill a gap in Neoplatonic thought.

6 Codex Justin. Corpus Juris Civilis 2.63-64, Krueger 1906. Justinian's edict against pagan philosophy, proclaimed in 529, parallels that of Julian, proclaimed on 17 June 362 (CTh 13.3.5; see Banchich 1993: 8 n.10). In Ep. 36 Julian probably comments upon the edict as requiring strict correlation between character, belief, and teaching; see also Amm. Marc. 22.10.7; 25.4.20; Bowersock 1978: 83-4; Banchich 1993; Teitler 2017: 64-70.

7 The Cynic orations are linked to the Caesars and the Hymn to the Mother of the Gods, the latter written for the Pessinus festival of Cybele on 22-25 March 362; cf. Smith 
1995: 49 and 243 n.4; Liebeschütz 2012: 216-17; Döring 2006: 88-9; Bringmann 2004: 107, 115 links Against Heraclius, on the basis of Julian's myth, to the Caesars.

8 Lib. Or. 18.157; Against the uneducated Cynics 203b; the (un)likelihood that Julian expended so little effort on his Cynic engagements, especially on the lengthy To Heraclius, points to his deliberate trivialising of the matter as a mere side-issue among the weighty responsibilities of running an empire.

9 Discussions of Julian's Cynic orations in esp. Athanassiadi 1992: 128-40 (on Julian's thoughts on paideia); Smith 1995: 49-90; Bringmann 2004: 111-16 sees the core of Against Heraclius in the correct use of myth, and of Against the uneducated Cynics, in their failure to recognise Cynicism's inner coherence with Socratic philosophy; Döring 2006: 88-96; Tanaseanu-Döbler 2008: 124-8 in the Neoplatonist reinterpretation of classical thought as stemming from self-knowledge and inner piety; Marcone 2012.

10 As was his professed way, expressed in Ep. 41.438b, Wright: $\lambda o ́ \gamma \omega \delta \dot{\varepsilon} \pi \varepsilon i ́ \theta \varepsilon \sigma \theta \alpha \iota ~ \chi \rho \eta े$

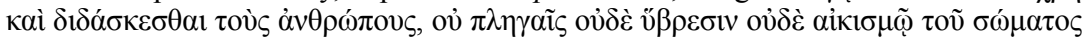
('It is by reason that we ought to persuade and instruct men, not by blows, or insults, or bodily violence'). I owe this reference to Teitler 2017: 140.

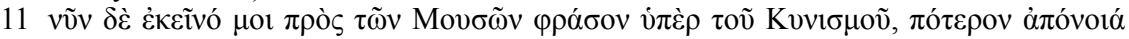

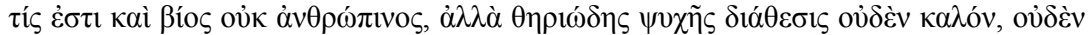

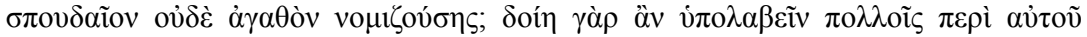

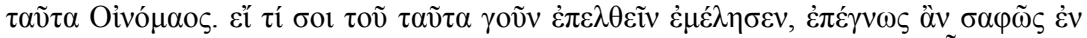

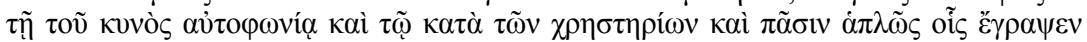

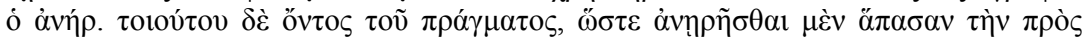

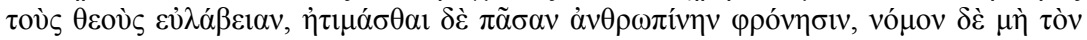

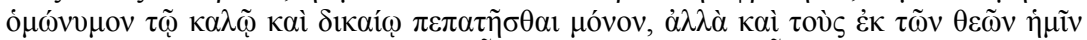

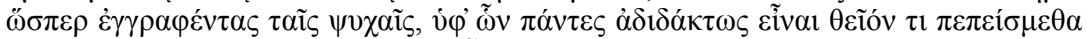

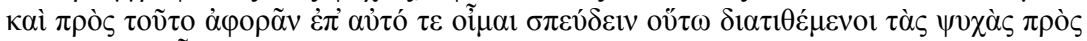
$\alpha$ ủंò

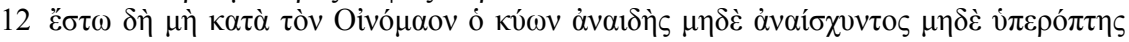

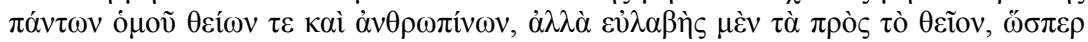

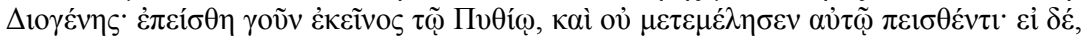

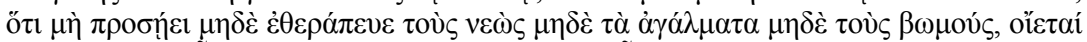

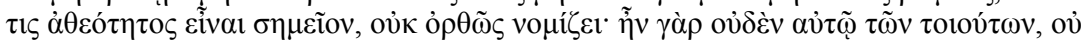

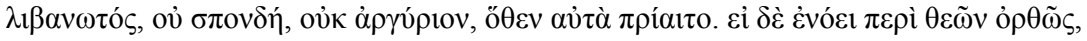

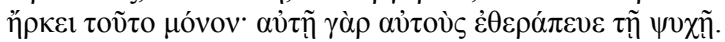

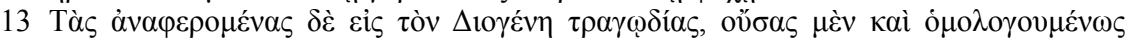

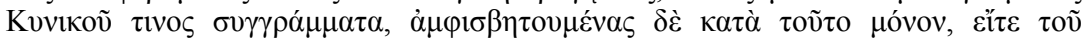

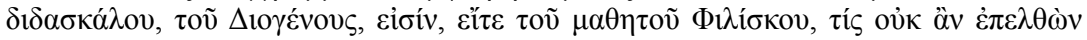

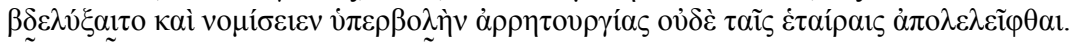

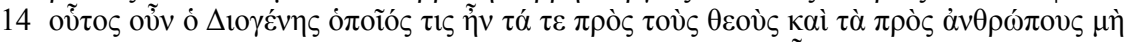

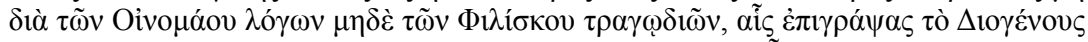

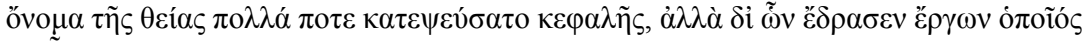
$\tau ı \varsigma \tilde{\eta} v \gamma v \omega \rho \iota \zeta \dot{\varepsilon} \sigma \theta \omega$.

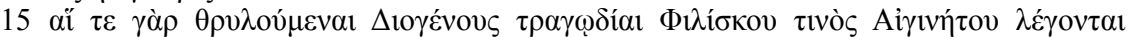

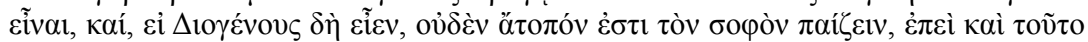

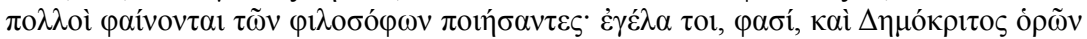

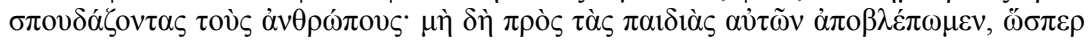

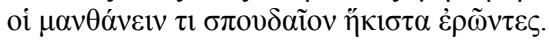

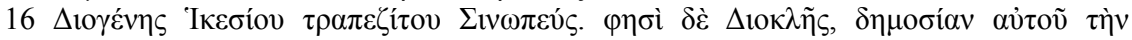

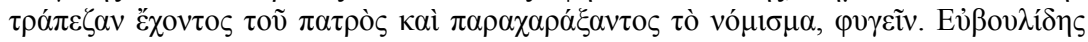

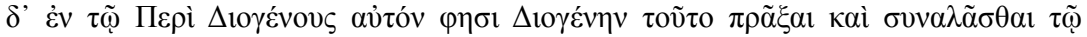

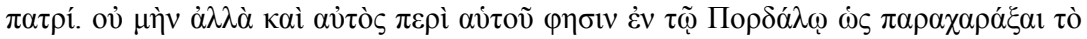

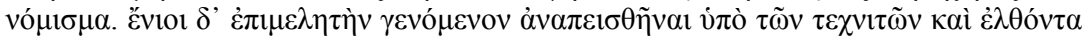

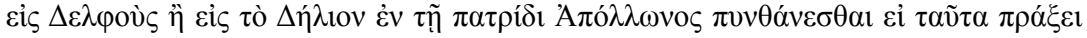

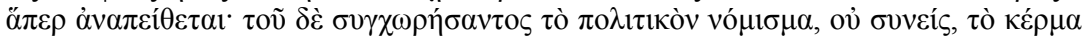




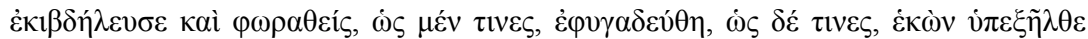

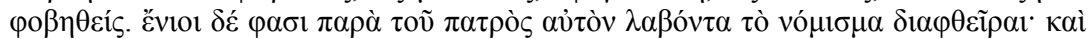

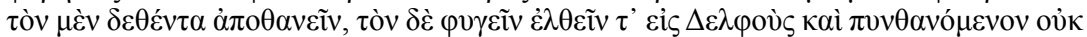

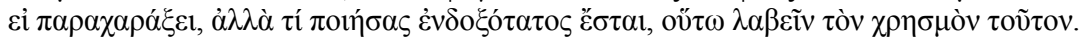

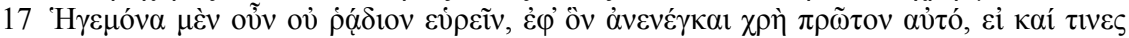

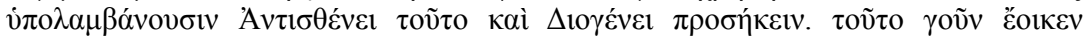

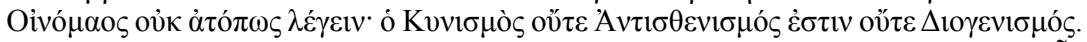

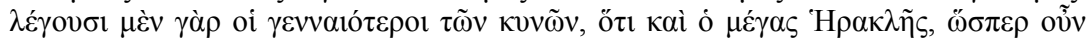

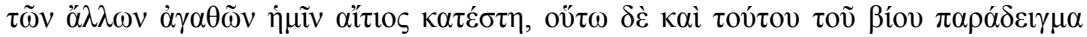

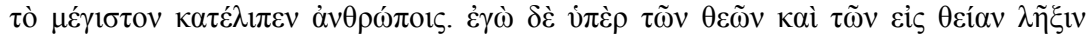

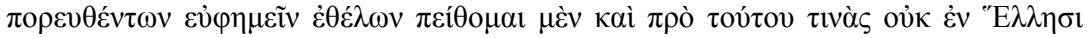

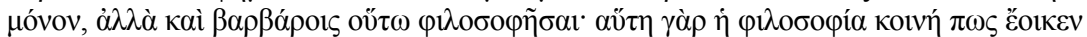

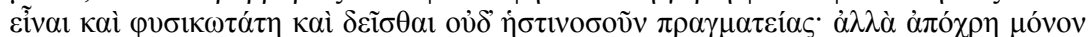

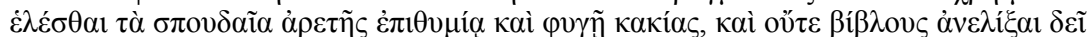

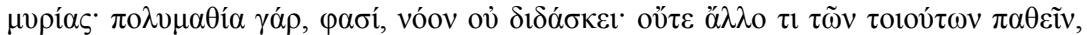

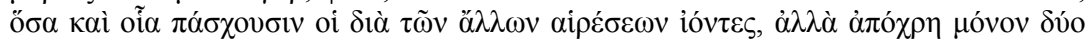

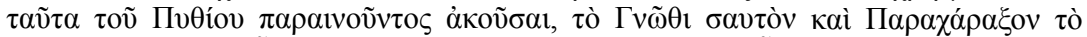

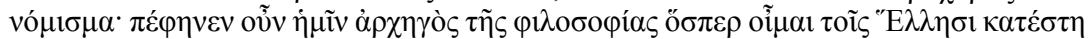

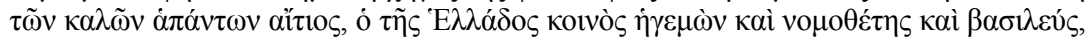

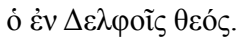

18 On Christian reactions to Julian after his death, see Teitler 2017, who finds little truth in the accusations of a 'war against Christianity' during Julian's attempt to revive paganism.

19 Lucian's Peregrinus Proteus and Maximus of Alexandria; Döring 2006: 60-3, 100; on Maximus, Krueger 1993: 40-2; Smith 1995: 88 is more nuanced: 'If he [Peregrinus] provides an instance of a man moving easily from a Christian to a Cynic milieu, that is a subtly different thing: it is revealing of the appeal of both movements at a comparable social level at the time, not of a positive ideological rapport.'

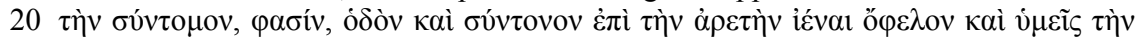

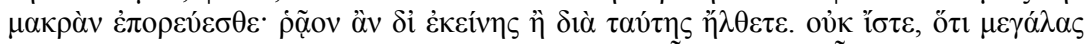

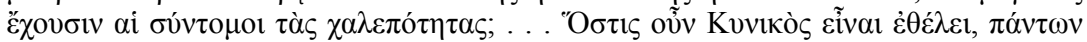

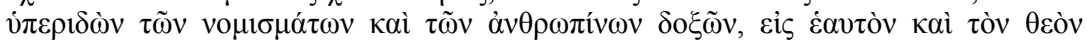

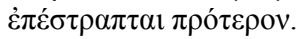

21 Branham and Goulet-Cazé 1996: 5 refer to 'the pre-eminent popular philosophy of the Roman empire'; Smith 1995: 56-8 doubts any real philosophical commitment especially among the educated: Dio's Cynicism 'spoke of a way of life that upper-class students of philosophy might at least claim to be minded to follow.' Epictetus's treatment 'breathes the leisurely air of the lecture-room.'

\section{Bibliography}

\section{Primary sources}

Ammianus Marcellinus (1940) History, volume II: Books 20-26. Translated by Rolfe, J. C. LCL, 315. Cambridge, MA: Harvard University Press.

Corpus iuris civilis. Vol. 2: Codex Justinianus (1906) Edited by P. Krueger. Berlin: Weidmann.

Gregory of Nazianzus (1983) Oratio 4. Edited and Translated by J. Bernardi. Discours 4-5: Contre Julien. SC, 309. Paris: Cerf.

Julian (1913) Volume II: Orations 6-8: Letters to Themistius, To the senate and people of Athens, To a priest: The Caesars: Misopogon. Translated by W. C. Wright. LCL, 29. Cambridge, MA: Harvard University Press. [Repr. 2006]. 


\section{Philip Bosman}

Laertius, D. (1923) Lives of eminent philosophers in two volumes. Vol. II. Translated by R. D. Hicks. LCL, 185. Cambridge, MA: Harvard University Press. [Repr. 2005].

\section{Secondary sources}

Athanassiadi-Fowden, P. (1981) Julian and Hellenism: An intellectual biography. Oxford: Clarendon Press.

- (1992) Julian: An intellectual biography. London: Routledge.

Baker-Brian, N. and Tougher, S. (eds.) (2012) Emperor and author: The writings of Julian the apostate. Swansea: Classical Press of Wales.

(2012b) 'Introduction'. In Baker-Brian and Tougher (eds.), 13-21.

Banchich, T. M. (1993) 'Julian's school laws: Cod. Theod. 13.5.5 and Ep. 42'. AncW, 24/1: 5-15.

Bowersock, G. W. (1978) Julian the apostate. London: Duckworth. (1983) 'Review of Athanassiadi-Fowden (1981)'. The American historical review, 88/1: 90-1.

Branham, R. B. and Goulet-Cazé, M. O. (eds.) (1996) The Cynics: The Cynic movement in antiquity and its legacy. Berkeley: University of California Press.

Bringmann, K. (2004) Kaiser Julian. Darmstadt: Wissenschaftliche Buchgesellschaft.

Cameron, A. (1993) 'Julian and Hellenism'. AncW, 24/1: 25-9.

Constantelos, D. J. (1964) 'Paganism and the state in the age of Justinian'. The Catholic Historical Review, 50/3: 372-80.

Desmond, W. (2008) Cynics. Stocksfield: Acumen.

Döring, K. (1993) “"Spielereien, mit verdecktem Ernst vermischt”: Unterhaltsame Formen literarischer Wissensvermittlung bei Diogenes von Sinope und den frühen Kynikern'. In Kullmann, W. and Althoff, J. (eds.), Vermittlung und Tradierung von Wissen in der griechischen Kultur. Tübingen: Gunter Narr, 337-52. (2006) Die Kyniker. Bamberg: Buchner.

Dudley, D. R. (1937) A history of Cynicism from Diogenes to the 6thcentury AD. [Repr. London: Duckworth, 2003].

Fowden, G. (1978) 'Bishops and Temples in the Eastern Roman Empire A.D. 320-435'. Journal of Theological Studies 29/1: 53-78.

Goulet-Cazé, M. O. (1996) ‘Appendix B: Who was the first dog?' In Branham and GouletCazé (eds.), 414-5.

_ (2003) Les Kynika du stö̈cisme, Hermes-Einzelschriften, 89. Stuttgart: Franz Steiner.

Griffin, M. (1996) 'Cynicism and the Romans: Attraction and repulsion'. In Branham and Goulet-Cazé (eds.), 190-204.

Hammerstaedt, J. (1988) Die Orakelkritik des Kynikers Oenomaus. Frankfurt a.M.: Athenäum.

Jażdżewska, K. (2019) 'Entertainers, persuaders, adversaries: Interactions of sophists and rulers in Philostratus' Lives of Sophists'. In Bosman, P. R. (ed.) Intellectual and empire in Greco-Roman antiquity. London: Routledge, 160-77.

Krueger, D. (1993) 'Diogenes the Cynic among the 4th century fathers'. $V C$, 47: 29-49.

Liebeschütz, J. H. W. G. (2012) 'Julian's Hymn to the mother of the gods: The revival and justification of traditional religion'. In Baker-Brian and Tougher (eds.), 213-28.

Marcone, A (2012) 'The forging of an Hellenic orthodoxy: Julian's speeches against the Cynics'. In Baker-Brian and Tougher (eds.), 239-50. 
Martin, R. P. (1996) 'The Scythian accent: Anacharsis and the Cynics'. In Branham and Goulet-Cazé (eds.), 136-55.

Perkams, M. (2008) 'Neuplatonische politische Philosophie bei Julian?'. In Schäfer, C. (ed.), Kaiser Julian 'Apostata' und die philosophische Reaktion gegen das Christentum. Berlin: De Gruyter, 105-25.

Prince, S. (2017) 'Antisthenes and the short route to happiness'. In Bosman, P. R. (ed.), Ancient routes to happiness: Acta Classica, Supplementum, 6. Pretoria: Classical association of South Africa, 73-96.

Romm, J. (1996) 'Dogs heads and noble savages: Cynicism before the Cynics?'. In Branham and Goulet-Cazé (eds.), 121-35.

Rosen, K. (2006) Julian: Kaiser, Gott und Christenhasser. Stuttgart: Klett-Cotta.

Ross, A. (2016) Ammianus' Julian: Narrative and Genre in the Res Gestae. Oxford: Oxford University Press.

Smith, R. (1995) Julian's gods: Religion and philosophy in the thought and action of Julian the apostate. London: Routledge.

Tanaseanu-Döbler, I. (2008) Konversion zur Philosophie in der Spätantike: Kaiser Julian und Synesion von Kyrene. Stuttgart: Franz Steiner.

Teitler, H. C. (2017) The last pagan emperor: Julian the apostate and the war against Christianity. New York: Oxford University Press.

Tougher, S. (2007) Julian the apostate. Edinburgh: Edinburgh University Press.

Van der Horst, P. W. (1985) 'Review of Athanassiadi-Fowden (1981)'. Mnemos, 38(1/2): 218-20. 


\title{
3 Memories of trauma and the formation of a Christian identity
}

\author{
Jonathan P. Conant
}

Conflict casts a long shadow over the landscape of Christian memory. Scholars routinely acknowledge, for example, that, whatever its lived realities, the experience of persecution was deeply traumatic to the early church, and that memories of victimisation profoundly shaped Christian worldviews for centuries to come. While trauma has long been well studied in modern populations (Herman 1992; Leys 2000), much work remains to be done in terms of exploring its enduring effects on group behaviour in the pre-modern world. On one level, then, this chapter is an appeal to consider the role that collective trauma may have played in shaping late-Roman society in general, and in shaping memory and conflict within contemporary Christian communities in particular. Here, of course, it is of paramount importance to proceed with caution, if for no other reason than that, with few notable exceptions, the interior lives of inhabitants of the later Roman world are not readily accessible to modern observers. Nonetheless, in recent years scholars have become more attuned to the emotional and psychological realities of ancient and medieval societies (see e.g. Barton 1993; Konstan 2006; Rosenwein 2006; Harper 2013; Meineck and Konstan 2014; Turner and Lee 2018). In this context, it is surely also worth considering the long-term impact of events in Late Antiquity that overwhelmed a 'sense of control, connection, and meaning' on either an individual or a collective level, and which would thus be defined in a modern context as 'traumatic' (Herman 1992: 33). Doing so has the potential not just to add complexity and nuance to our narratives about the past but also to enrich our understanding of why Christians remained extremely sensitive to perceived threats to their faith community even after any substantive danger had long since faded away. Such an endeavour might thus help illustrate why, from the fourth century onward, Christians began to appear so frequently in the sources as perpetrators of religiously motivated violence, or at least violence legitimated in religious terms - a problem that continues to bedevil modern scholarship on Late Antiquity (see e.g. Drake 1996; Gaddis 2005; Drake 2006; Shaw 2011).

This study is by its nature a preliminary one, as much a thought-piece as a proof-piece. It is impossible to consider here the diverse and multifaceted landscape of the Christian Mediterranean in its entirety. I shall therefore focus on the case of early fourth-century North Africa, which provides a particularly illuminating example for two reasons: first, the survival of a small but exceptionally rich 
constellation of contemporary and near-contemporary sources, and second, the centrality of conflict and its memory to that source base. When fourth-century African Christians asked themselves why their society was so riven by religious violence, the stories they told invariably returned to the so-called Great Persecution. Focused on the suppression of Christian worship, this series of increasingly repressive measures was initiated by the eastern augustus Diocletian on 23 February 303. In the West, however, it was only half-heartedly implemented by his imperial colleague Maximian, and the persecution was rescinded by Maximian's son and successor Maxentius upon his accession in the winter of 306-7. In succeeding generations, North African Christians would come to dwell on the betrayals of faith and of fellow Christians that they believed had rent their community in these years, and which they remembered as acts of primordial evil that paralleled Judas's betrayal of Jesus (Shaw 2011: 66-106; see e.g. Opt. 1.13-20; Aug. c. litt. Petil. 2.93.202; Passio Saturnini 20). The sectarian rivalry sustained by stories of this sort, somewhat inaptly labelled the 'Donatist conflict' by modern historians, has been so thoroughly explored that it might seem there is little new to say about it (see esp. Frend 1952; Shaw 2011; Miles 2016). As the recent study of Brent Shaw (2011) has made clear, however, much work remains to be done in terms of understanding the religious tensions unquestionably present in early fourthcentury North African society - and doing so from a vantage point that does not assume the inevitability of the region's eventual polarisation into 'Catholic' and 'dissident' or 'Donatist' factions. Furthermore, recent scholarship has done much to illuminate the sociological, discursive, spatial, and even neurological foundations of religious conflict in the late-antique Mediterranean (see esp. Gaddis 2005; Sizgorich 2009; Shaw 2011; Shepardson 2014; and, for a recent overview, Mayer 2013). Such studies invite us to reconsider the dialogic and mutually reinforcing relationship between violence and memory both in the world of Late Antiquity in general and in North Africa in particular. Indeed, I shall suggest that in late Roman Africa memories of the persecution were dynamic and that, as these memories changed over time, the construction of narratives served as only one among many ways of remembering the past. Reconsidering developments in Africa in the first decades of the fourth century in this light allows us to move beyond oppositional dichotomies and to gain new insights into the underlying factors that may have been at work as simmering hostilities erupted into religious conflict, but before that conflict was aggressively polemicised, factionalised, and deeply embedded within African society.

In order to understand how Christians processed and came to terms with violence and its associated trauma in Late Antiquity, it is imperative to understand events as far as possible through sources as close in time as possible to the events that they describe. Yet most of the available North African sources reflecting back on the aftermath of the Great Persecution date from two or more generations after the event, by which point conflicting and competing memories about the past were already being reshaped by the intense and bitter rhetoric of sectarian disputation (Shaw 2011, esp. 146-94). This chapter therefore deliberately sets aside the best-known accounts of the origins and development of Africa's fourth-century 
ecclesiastical schism, those of Optatus and Augustine, except in the key instances where these authors claim to collect, transcribe, or quote earlier documents. In the place of these later, self-consciously ideological narratives, this chapter draws on the few sources whose origins can, with greater or lesser degrees of plausibility, be attributed to the early fourth century, for the most part before the death of Constantine in May 337. These include early acta and passiones of the martyrs, but also a remarkable set of records drawn up by one of the city officials charged with the implementation of the Great Persecution and two Constantinian-era inquests into how events unfolded at the municipal level in the spring of 303 (all preserved by Optatus; on which, see Duval 2000); a brief excerpt from the acts of an ecclesiastical synod putatively held in Cirta in Numidia shortly after the cessation of the persecution (quoted by Augustine); as well as a handful of early inscriptions and archaeological evidence. None of these sources are unproblematic. As we shall see, for example, all the relevant martyrs' acta continued to be edited after the cessation of the persecution. The polemical context in which Optatus preserved early fourth-century documentary evidence casts at least a shade of doubt on its reliability. The same is true of the acts of the council of Cirta (Barnes 1975: 14-16). Moreover, these sources - material and textual alike - were for the most part composed against the backdrop of a contentious legal dispute between fractious North African bishops over control of ecclesiastical property and the succession to the see of Carthage. From at least 312 onward, this dispute was to range from Africa to Rome, Arles, and the imperial court at Trier, and to consume the attention of municipal and imperial officials, an array of western bishops, and even the emperor Constantine himself (Lenski 2016).

Read critically, the evidence nonetheless suggests that, though the scope of imperial anti-Christian activity was fairly limited in Africa in 303-4, the persecution was still both troubling and disruptive to those who lived through or witnessed it. Indeed, the stories that Christians told themselves at the time about the experience of state violence suggest that its rending of normative social bonds and social expectations could be as traumatic as the torture and execution of physical bodies. Before examining those stories, though, it will be important to consider first how the persecution unfolded in Africa, what its effects were on African Christians, and how Africans remembered the events of 303-4 over the course of the succeeding generation. In doing so, I will argue that the narratives fourth-century Christians chose to construct about the past probably reinforced the communal trauma of the persecution, creating a culture of hypervigilance and aggression with respect to perceived threats that helps to explain the regularity of conflict both in Africa and, in all likelihood, mutatis mutandis, across the late Roman world.

\section{Revisiting the Great Persecution in Africa}

Scholars agree that the implementation of the Great Persecution was considerably less harsh in Africa - as in the West in general - than it was in the East (see inter alia Rebillard 2012: 58-59; Barnes 2010: 97-150; Clarke 2005: 647-65; Lepelley 
1979/1:333-43; Ste. Croix 1954: 84-96). The western augustus Maximian promulgated only the first of Diocletian's four increasingly severe edicts of persecution. This edict, issued in February 303, forbade Christians to hold assemblies and ordered the destruction of their churches and the burning of their scriptures (Rebillard 2012: 58; see Euseb. Hist. eccl. 8.2.4; Lactant. De mort. pers. 12-13). In Africa the proconsul C. Annius Anullinus was said to have supplemented the imperial decree with an edict of his own whose terms are not entirely clear but which seems to have required Christians to choose between offering sacrifice and surrendering whatever scriptures they had in their possession (Acta purg. Fel., 198.26-27). Even so, it is unlikely that there was ever a general directive in Africa that the populace as a whole should sacrifice, as Diocletian would demand the following year in the East (notwithstanding the evidence of Passio Crispinae, 33.9-12, on whose compositional history, see the following discussion). The proconsular edict seems to have applied primarily to members of the Christian clergy, who may perhaps have been expected to constitute a majority of those with scriptures in their possession in any case. Christian laypeople might have had to keep their heads low, but generally they seem to have been able to avoid the proconsular injunction (Rebillard 2012: 58; see also Ste. Croix 1954: 77). The sole known exception to this rule is a woman named Crispina who was executed in Tébessa in Numidia on 5 December 304 (Passio Crispinae). The circumstances of Crispina's arrest are unknown, however, and so it is conceivable that she had been entrusted with church goods of some sort-possibly even scriptures-leading to a demand that she either surrender them or sacrifice. In the towns of Abitina and Thimida Regia rank-and-file congregants were also said to have been arrested while illicitly gathered in worship, in contravention of the imperial decree, which may well have been an anxiety in Christian circles across Africa (Acta Gallonii; Passio Saturnini, but with Dearn 2004; Lepelley 1979/1:335-36; Lepelley 1999; Lancel 1999). For the most part, though, the brunt of the persecution seems to have been borne by the ecclesiastical leaders of the Christian community.

In fact, a range of contemporary and near-contemporary sources make clear that the primary concern of the municipal authorities charged with the implementation of anti-Christian measures in Africa was to secure the surrender of scriptures so that they could be burned (Arn. Adv. nat. 4.36.4 and in the next paragraph). At times this process could become violent. At least, in Africa Proconsularis, Bishop Felix of Thibiuca was said to have been executed in 303 for refusing to surrender his church's holy books to the city's curator (Passio s. Felicis; see also Acta Gallonii 9-12, 25-31, and 41). However, according to the contemporary and well-informed testimony of Lactantius (De mort. pers. 11.8), Diocletian wanted his first edict to be applied as far as possible without bloodshed (sine sanguine), and for the most part this seems to have proved possible in the empire's North African provinces. It would appear, for example, that a significant number of clerics sought refuge in flight, or at least arranged to be personally absent from their cities while the scriptures and church property entrusted to their care were being collected (Gesta ap. Zen., 186.4-11 and 188.24-30; Acta purg. Fel., 199.18-19 and 201.20-1). In fact, Felix of Thibiuca was himself said to 
have left his hometown for Carthage on the very day that the edict of persecution was posted locally, though he returned home shortly thereafter, to face arrest and eventually trial and execution (Passio s. Felicis 1 and 9).

Then too, although clerical compliance with the edict would become a source of bitter reproach after the worst of the persecution was past, in 303-4 many members of the clergy seem to have acquiesced to the authorities' demands (see, in general, Wendebourg 1987). In the Numidian provincial capital of Cirta, for example, the magistrate charged with the implementation of the imperial edict was the urban curator Munatius Felix, who was careful to record his actions in a set of official acta dated to 19 May 303. Preserved by the Catholic polemicist Optatus in the mid-fourth century as the African church descended into rancorous sectarian conflict, Munatius Felix's acta reveal that in the church of Cirta, one sub-deacon, five lectors, and the wife of another lector (who had himself apparently fled the persecution) collectively surrendered thirty-seven books to the authorities (Gesta ap. Zen., 186-88). Something similar was said to have happened in Abthugni in Africa Proconsularis, where an official inquiry dating to the reign of Constantine (also preserved by Optatus) found that a Christian by the name of Galatius had handed over scriptures to be burned (Acta purg. Fel., esp. 199.15-17).

In each of these two cases the local bishops managed to avoid giving up their church's holy books, but elsewhere bishops too were later accused of having surrendered scriptures. Shortly after the end of the persecution, a synod of Numidian bishops convened in Cirta to ordain a new episcopal colleague for the provincial capital, and Augustine purports to quote a fragment of the transcript in the context of his own polemical writings. The testimony of the document is highly suspect, as it might well have been doctored or even fabricated wholesale by a disgruntled cleric from Cirta with an axe to grind sometime before 13 December 320 (Barnes 1975: 14-16; see also Lancel 1979). Yet one does not have to accept the contents of the acta uncritically to get a sense of the techniques of compliance and evasion that those who lived through the persecution thought contemporary bishops might plausibly have employed in order to survive. Most prominently, the text shows Bishop Victor of Rusicade seeking the forgiveness of his peers and of God for having surrendered an effaced and defective copy of the gospels. Other bishops were said to have avoided this kind of situation by resorting to a kind of tricksterism (on which, see in general Boyarin 1999: 42-66). Thus one of Victor's fellow bishops supposedly claimed to have given up medical codices, while another allegedly handed over the church's archives, in each case presumably with the tacit knowledge and consent of the local municipal authorities (Aug. c. Cresc. 3.27.30; Lepelley 1979/1: 337; see also Aug. Brev. coll. 3.13.25).

Examples like these also suggest that it is possible - even likely - that critical concepts like what constituted a betrayal of the Christian faith or community changed between the perilous years of 303-4 on the one hand, and the period after the emperor Maxentius revoked the edict of persecution (probably in the winter of 306-7) on the other (Opt. 1.18). Whatever its truth value, the extant fragment from the acts of the synod of Cirta demonstrates that in the aftermath of 
the persecution, and by 320 at the latest, handing over a holy book was unambiguously seen as an act of perfidy and faithlessness. As the persecution itself was unfolding, however, in some African communities it may well have been regarded as permissible to surrender such texts, as it always was in the contemporary East. According to the acta of Munatius Felix, for example, immediately after surrendering a codex to the curator of Cirta, a sub-deacon named Catullinus was asked to name the lectors who had the rest of the church's scriptures. Together with one of his colleagues, however, Catullinus balked, declaring, 'We are not traitors (proditores)!' The two sub-deacons even offered to lay down their lives, braving arrest rather than informing on their fellow Christians (Gesta ap. Zen., 187.29-188.2). At the same time, another of Catullinus's fellow sub-deacons, Silvanus, surrendered a silver lamp and a silver capitulata (perhaps an incenseburner), but similarly refused to inform the city's curator where his church's lectors lived (Gesta ap. Zen. 187.15-17 and 188.6-10; Caseau 2007: 570-71). In later years, after he had become bishop of Cirta, Silvanus seems to have been confused at accusations that handing over the lamp and the capitulata made him a traditor (Gesta ap. Zen., 193.26-7). T. D. Barnes (2010: 135) has recently and rightly reminded scholars that the documents preserved by Optatus, including the acta of Munatius Felix, require 'critical, even sceptical assessment,' and it is important not to push the evidence of these two instances too far. Significantly, though, they do at least raise the possibility that in Cirta - and perhaps elsewhere in Africa-what was seen as constituting a betrayal of the Christian community in the spring of 303 was not the handing over of the church's holy books or liturgical silver. Rather, it was the naming of names, the handing over of fellow Christians to the local representatives of the imperial administration. If this was, in fact, the case, then the acta further-and critically - suggest that the definition of betrayal quickly changed once the immediacy of the threat of persecution had passed.

Overall, the evidence indicates that in Africa the persecution of 303-4 was not a bloodbath. Rather, over time there was a hardening of attitudes about how individuals ought to have behaved in the face of danger, and the past was judgedand even remembered - in light of the ever-changing standards of what was fundamentally a different society with different expectations, needs, and beliefs. Indeed, throughout the fourth and into the fifth century, there seems to have been something of an ongoing debate among African Christians about what constituted a legitimate response to persecution; a debate focused not just on the handing over of church property, but also on whether flight was permissible, or informing on fellow believers, or the kind of tricksterism said to have been deployed by the Numidian bishops mentioned previously.

\section{Christian reactions to the Great Persecution in Africa}

However bloodless the persecution may have been in North Africa, it was still both troubling and disruptive for local Christian communities. Christians' responses to, and even their understandings, interpretations, and recollections of 
the events of 303-4, unquestionably built on a long legacy of earlier experiences with state repression (see, inter alia, Frend 1965; Keresztes 1979; Bowersock 1995; Burns 2002; Selinger 2004). Yet, ever since the emperor Gallienus rescinded his father Valerian's persecutory measures in 260 (Euseb. Hist. eccl. 7.13), Christians throughout the Roman world had lived with a growing sureness that the age of martyrs had come to an end. Diocletian's edict of February 303 upended that belief, and as such abruptly overturned two generations of Christians' assumptions about the security, protection, and opportunities for advancement that would be afforded them under the imperial regime. The fear and anger caused by this sudden and unsettling turn of events underlies in different ways all the surviving Christian literature written by Africans in the early fourth century, including not only accounts of the martyrs' passions but also the rhetor Arnobius of Sicca's forceful apology for the Christian faith and his student Lactantius's embittered account of the Deaths of the Persecutors. To be sure, in the city of Abthugni in Africa Proconsularis, the Christian clergy were on familiar enough terms with the local duovir that the two parties were able to work out an accommodation which complied with the imperial edict but would also protect the reputation of the city's bishop in the years to come (Acta purg. Fel., esp. 199.8-200.17). Even in a larger city like Cirta, the church's lectors were known to the urban exceptores, a fact that saved the local bishop and his clergy from having to give up the names of their coreligionists (Gesta ap. Zen., 186.24-29 and 188.6-11). At least in Christian memory, though, neither secular nor ecclesiastical leaders could be relied upon to be so accommodating. Moreover, as Africa's subsequent history of successive persecutions would later demonstrate, withdrawing official protection from a specific group could easily enflame tensions and conflicts already present in local society (see esp. Shaw 2011 and Whelan 2018). In the later recollection of Alfius Caecilianus, the duovir of Abthugni, in cities like Zama Regia and Furnos Maius - and presumably elsewhere across North Africa - the newly disfavoured status of Christians was made physically manifest in 303 by the pulling down of their churches. Even in Abthugni itself Caecilianus saw to it that the local bishop's chair was burned along with the scriptures (Acta purg. Fel., 199.10-12 and 199.16-17). In circumstances such as these, it is hard not to imagine that Christian communities felt themselves to be vulnerable, however accommodating local officials might be.

Even after Maxentius and then Constantine put an end to the imperially sponsored persecution, that sense of vulnerability is particularly visible in the epigraphic record of Mauretania Caesariensis, roughly comparable to the territory of modern western and central Algeria. An epitaph from the port city of Tipasa, for example, indicates that a certain Victorinus was martyred on 8 May, a Sunday, in either 315 or 320 (Duval 1982/1: 367-71, no. 174). Similarly, a mensa martyrum from Sufasar, some $50 \mathrm{~km}$ or so inland from Tipasa along the Roman roads, indicates that Dativus and a boy named Maximus were martyred in 322 (Duval 1982/1: 386-87, no. 182). Much further west, a limestone tablet found in Médiouna commemorates four martyrs named Rogatus, Maientius, Nasseus, and Maxima who died on 21 October 329 (Duval 1982/1: 402-5, no. 191). These 
inscriptions make clear that in parts of western North Africa, the age of martyrs was not seen as having drawn to a close with the end of the Great Persecution. Otherwise, however, they are a testament to how little we understand of the history of Mauretania in the early 300s (see Février 1986); for the circumstances of these individuals' deaths are obscure to us, and may have taken place amidst intra-Christian sectarian violence, conflict between Christians and adherents of traditional cult, or other conditions about which we are entirely ignorant.

These inscriptions help illustrate two trends in Christian memory in the early fourth century, though, both of which may help deepen our understanding of Christian reactions to the earlier persecution of 303-4. First, the process of making martyrs into objects of cultic veneration was not as slow to develop in North Africa as it appears to have been elsewhere in the Mediterranean. ${ }^{1}$ Indeed, from a very early date, Christian memory in Africa focused on the communal and ritual celebration of the dead. To be sure, there will have been plenty of Christians who chose not to remember the Diocletianic persecution, or to remember as little about it as possible (Lifshitz 2002: 316-18). Already by the 320s, however, Christian communities in western North Africa were remembering their martyrs in a striking range of ritual contexts which would become increasingly familiar as the fourth century advanced. The inscriptions from Tipasa and Médiouna both follow advice given by Cyprian to his clergy two generations earlier and record the precise dates on which local martyrs died, so that their births into eternal life could be honoured on the anniversaries of their passing. ${ }^{2}$ As such, these inscriptions also testify to the ongoing coalescence of local liturgical calendars. This is palpably the case with the memoria from Médiouna: its commemoration of four martyrs who passed on 21 October - the twelfth day before the Kalends of Novemberwas later augmented by a mention of Sts Benagius and Sextius, who died on the Kalends (Duval 1982/1: 402-5, no. 191). A fourth early inscription, this one from Altava and dating to sometime between 309 and 338, both attests to local celebration of the funerary meal at the martyr's mensa and provides the earliest secure evidence for the practice of ad sanctum burial anywhere in Roman Africa (Duval 1982/1: 412-17, no. 195; see also Acta Maximiliani 3.4, but with Woods 2003 and Barnes 2010: 379-86). Similarly, in a fifth early inscription dating to 325 or 329, a certain Januaria commended her own tomb in Aïn Kebira in what was then Mauretania Sitifensis to the protection of the martyrs - probably local ones, given the early date of the inscription (Duval 1982/1: 302-4, no. 143).

The communal celebration of the Christian dead also quickly came to be physically inscribed in the suburban townscapes of early fourth-century Africa. This development is implied by the dedication of the memoriae and mensae martyrum attested in the epigraphy, but it is visible elsewhere too. The epitaph of the early fourth-century martyr Victorinus was discovered buried deep behind the masonry of a mensa martyrum, about $200 \mathrm{~m}$ west of the city wall of Tipasa in a cemetery area that, over the course of the rest of that century, was elaborated with numerous Christian tombs and eventually annexed to a chapel built by the local bishop (Leschi 1957: 381-6; Duval 1982/1: 367-71, no. 174). Januaria of Aïn Kebira was probably buried in a cemetery area whose character was increasingly 
Christian too (Duval 1982/1: 302-4, no. 143). Similarly, at some point in the first half of the fourth century, a memorial church was built in a burial ground just outside Tébessa, on the site that would later be elaborated into a massive pilgrimage complex dedicated to the city's most famous martyr, St Crispina (see esp. Février 1968; Christern 1976: 107-29; Duval 1982/1: 123-8, no. 57). Only a few fragments of this early church remain, but it seems to have consisted of a single room with an entrance to the north. Almost exactly at the mid-point of the room's northsouth axis, a sealed conical clay pot was deposited (Christern 1976: 122 and 123, fig. 25). Its contents - a fragment of bone, two teeth, two fragments of bronze with some fabric remains, and a bone needle - suggest that the vessel was probably a reliquary (Février 1968: 186-8; Christern 1976: 115-16; Duval 1982/1: 125, no. 57). After the pot's deposition, a mosaic floor was laid over at least part of the room, including the reliquary's burial spot. Precisely when this chapel was built is not clear, but it must have been fairly early in the fourth century: with time, the room was repaved, and between the earlier and the later flooring layers, twentieth-century excavators uncovered two coins of Constantius II dating to 351/4 (Christern 1976: 114; Février 1968: 179; Duval 1982/1: 125, no. 57). Even as the site as a whole continued to develop and expand, the chapel remained the focal point of cultic activity at Tébessa. In the second half of the fourth century it was adorned with a mosaic inscription dedicated to seven saints cautiously identified by modern scholars as the companions attributed to Crispina in the Hieronymian Martyrology (Février 1968: 177-8 and 189-90; Christern 1976: 125-6; Duval 1982/1: 126-8, no. 57). Irrespective of the strengths of that association, it seems likely that the chapel itself was originally built at least in part to provide a physical space for the celebration and remembrance of local martyrs.

The second aspect of Christian memory that the Mauretanian inscriptions help illustrate is the fact that, for all their communal aspects, memories of persecution were also close and intimate for at least a generation. The memoria to the four martyrs from Médiouna who died in 329 was erected by two men who identify themselves as the fathers (genitores) of the deceased (Duval 1982/1: 402-5, no. 191). Martyrs from the age of Diocletian and Maximian were also said to have been survived by their families. The father of Maximilian, a Christian recruit put to death at Tébessa in 295 for refusing military service, was said to have been present at his son's trial and execution (Acta Maximiliani 1.1, 2.3, and 3.3). According to Augustine (Enarr. in Psalm. 137.7), Crispina was a matron with children who seem to have visited her in prison. While leading a clandestine worship service in Abitina, the priest Saturninus was said in a later and much elaborated account to have been arrested together with his daughter and three sons. Yet two of these children may have survived the persecution. At least, the passio of the Abitinian martyrs says nothing about the execution or even the questioning of Saturninus's daughter Maria, and from the account of her young brother Hilarianus's interrogation it is not entirely clear that he was ever put to death (Passio Saturnini 2 and 18). The fathers and mothers (patres matresque) of other Christians arrested in Abitina were also said to have attempted unsuccessfully to visit their children in prison in Carthage (Passio Saturnini 20). As with the martyrs 
of Médiouna, it seems reasonable to suppose that the cult of such earlier martyrs initially involved the nurturing of their memory not just within the local Christian community as a whole but also specifically among those members of their families who outlived them.

Then too the martyr cults that are visible throughout most of the fourth century were resolutely local in character. In the late fourth and early fifth century, in the relatively cosmopolitan port city of Hippo Regius, Augustine (Serm. 273-335) would preach a series of sermons on saints from across the western Mediterranean. These included not only Africans like Cyprian, Perpetua, Felicitas, Marianus, and James but also the overseas martyrs Laurence of Rome, Gervasius and Protasius, both of Milan, the martyrs of Marseille, and Vincent of Saragossa. Of course, Augustine had a remarkably universalist outlook. Yet over the course of the late imperial period, a range of inscriptions from across Africa would also come to celebrate the Roman saints Peter and Paul, ${ }^{3}$ as well as relics of the Holy Cross. ${ }^{4}$ In the early fourth century, though, the inscriptions from Tipasa and Médiouna that provide the earliest dated epigraphic evidence for the development of North African liturgical calendars both focus specifically on home-grown martyrs, commemorated in the first instance by people who were close to them. A handful of undated but early inscriptions also record dies natalium celebrated in communities across Byzacena and Numidia, all of them seemingly those of local martyrs too. ${ }^{5}$

Indeed, the extensive fourth- and early fifth-century North African epigraphic record in general is overwhelmingly focused not just on African saints, but specifically on individuals or small groups of martyrs who were only ever venerated in a single community or at most within a micro-region (Duval 1982/2: 697-748). In a society like this, where the very special dead had themselves once been members of local communities and families, memories of persecution may have played out on a cosmological level, but they were not distant and abstract. They were concrete, immediate, and personal.

\section{Storytelling and memories of persecution}

In this context, storytelling provided a way of working through a past that was real and that mattered. The few early stories that we are still able to hear have a striking focus on the twin themes of self-justification and the displacement of blame onto others. These impulses underlie at least two official proceedings from the reign of Constantine held to determine whether bishops had surrendered church property during the persecution: one held sometime after 314, which exculpated Bishop Felix of Abthugni (Acta purg. Fel.), and the other held in 320, which condemned Bishop Silvanus of Cirta (Gesta ap. Zen.) - both of these probably foreordained conclusions. They also inform the uncertain testimony attributed to the Numidian bishops at the synod of Cirta to the effect that they had only surrendered defective or non-scriptural texts to the authorities (Aug. c. Cresc. 3.27.30). Perhaps most famously, they are at the very heart of the bitter struggle over the succession to the episcopal see of Carthage that would so profoundly 
shape North African ecclesiastical history for centuries to come. But these same impulses are visible at a less exalted level as well. In the inquest into the case of Bishop Silvanus of Cirta, for example, a grammarian named Victor was called to testify because he had been one of the lectors of the church in June 303. According to the acta drawn up for the urban curator Munatius Felix, Victor himself had been a traditor: he was recorded as having personally surrendered two codices and four pamphlets (quiniones) to the authorities in compliance with the imperial edict (Gesta ap. Zen., 188.14-20). Even when confronted with Munatius Felix's records seventeen years later, however, Victor rejected this version of the past. Instead, he repeatedly asserted that he had not been present in Cirta during the persecution, because he had fled to the mountains with two fellow clerics. The codices, he maintained, had been taken from his house while he was away (Gesta ap. Zen., 186.4-11, 188.34, and 192.21).

By 320 the term traditor had become a stinging insult that could be hurled about quite freely. Indeed, in the post-Diocletianic period it could even create its own realities. According to the dubious acts of the council of Cirta, for example, the primate of Numidia confronted Bishop Purpurius of Liniata about having murdered two of his own nephews. Purpurius lashed out at his accuser and insinuated that in order to have survived the persecution the primate must himself have handed over scriptures, or at least ordered them to be handed over (Aug. $c$. Cresc. 3.27.30). The entire case against Bishop Felix of Abthugni seems to have had its origins in a similar exchange. Felix had publicly faulted another bishop, Maurus of Utica, for having bought his episcopacy, to which one of Maurus's friends, a certain Ingentius, shot back that Felix was a traditor (Acta purg. Fel., 201.15-20). Ingentius then seems to have set about trying to concoct evidence that would make the accusation stick. Critically, though, rhetorical strategies like these relied on a broader Christian discourse, already dominant in Africa by the end of the first decade of the fourth century, that displaced feelings of anger and aggression away from the actual perpetrators of the persecution-the emperors, the imperial administration, and the local municipal authorities - and rationalised projecting them instead onto fellow victims of the anti-Christian edict of February 303 (on modern manifestations of this phenomenon, see e.g. Chaitin 2008).

Over time, this kind of storytelling would entwine with a corresponding search for Christian heroes of the persecution. By the early fourth century, the witness of martyrs, even to the point of death, had long been seen both as confirming their special status within the framework of salvation and also as bringing glory to the community of the faithful. In Augustine's day the acta of the martyrs were being read out in churches as part of the liturgical service open to catechumens as well as to baptised Christians, though the practice remained controversial (Grig 2004: 37-38; on the controversy: Conc. Hippon. [8 Oct. 393] 5; Brev. Hippon. 36d; Reg. eccl. Carthag. excerpta 46). Accounts of this sort probably had their origins in the stenographic records routinely kept by late Roman officials, but their reliability as unadulterated trial transcripts has repeatedly - and rightly - been called into question by modern scholars (see in general Lanata 1973; Dehandschutter 1995; and Moss 2012: 122-44). 
The use as historical sources of the acta and passiones of African martyrs executed in the Diocletianic persecution is particularly complicated, because these documents manifestly did not cease to be edited in 303-4. Rather, they were living texts that continued to be elaborated over time. This is perhaps most clearly the case with the (slightly earlier) Acts of Maximilian, the late third-century military draftee, which, as Constantin Zuckerman (1998) has compellingly demonstrated, conflates two non-contemporaneous forms of recruitment into the late Roman army, suggesting that the text was revised sometime after 370 . Moreover, in the passion as it stands Maximilian is also said to have rejected a lead seal (signaculum) as a sign of his conscription; but as David Woods has argued (2003: 270-73), the lead seal is otherwise unattested as a symbol of military service in the Roman world and it seems to speak instead to the author's knowledge of the administration of the Islamic jizya. This in turn suggests a second revision of the text at some point in the eighth century, after the Islamic conquest of North Africa (Barnes 2010: 379-86, pace Woods 2003: 266 and 276). All the other martyrdom accounts from the age of Diocletian and Maximian were similarly adapted over time. The Acts of the Abitinian Martyrs (or Passio Saturnini) in particular appear to have been greatly elaborated, and though scholars disagree about the precise dating of this text, they have long recognised that, in its current form, it is probably a product of the early fifth century (Monceaux 1901-23/3:147; Franchi de' Cavalieri 1935: 1-5; Dearn 2004). Other accounts were relocated in space from Africa to Italy or Spain (Delehaye 1921; Gaiffier 1943; Gaiffier 1969; Gaiffier 1970; and, on the spread of African cults in general, Conant 2010). Sceptical modern readers have found signs of interpolation in even the least augmented texts, like the acts of Gallonius (Barnes 2010: 129-31, contra Chiesa 1996: 242). And, as Paul Monceaux (1903) demonstrated long ago, the version of the Passion of St Crispina known to Augustine, read out to his congregation, and discussed in a number of his homilies is clearly not the version that survives today. The point here is not that the martyrdom accounts make for poor historical sources, but rather that they were successively reworked over time in order to suit the needs of the communities that used them. Unfortunately, however, the time frame over which this process unfolded is not always clear, and this fact makes it difficult to use the texts to illuminate any particular period in the past.

Nevertheless, at least two general trends of this reworking are particularly striking, both of which were probably already at play in the fourth century. First, narratives about the past were stripped bare - and in some cases built up againto emphasise Christianity per se as a source both of victimisation in the saeculum and of transcendent spiritual strength for its adherents. The stories that the various witnesses told in the course of the proceedings against Felix of Abthugni and Silvanus of Cirta paint a startlingly vibrant portrait of provincial life in early fourth-century Africa. By contrast, in the course of universalising a handful of contemporary martyrdom accounts for consumption across Africa and the western Mediterranean, those stories were actively decontextualised. The resulting texts present the social historian with a tangle of insoluble questions about life in late third- and early fourth-century North Africa: why, after attaining the 
rank of centurion, did the soldier Marcellus suddenly decide that his Christianity was incompatible with his military service? What business brought Bishop Felix of Thibiuca to Carthage on the very day that the edict of persecution was proclaimed in his town, and why did he go back home so suddenly? How did the municipal authorities in Thimida Regia learn about the clandestine worship service led by the local Christian cleric Gallonius? We have no answers to these or similar queries, which might plausibly have been raised at the trials in question, because the surviving accounts lack virtually any of the details about local conditions and circumstances that make the Constantinian-era inquest records so rich as social-historical sources. The process of reducing the martyrdom accounts to their essential elements may still have been ongoing into the fifth century and beyond. Augustine (Enarr. in Psalm. 120.13 and 137.7) knew details about Crispina that are not found in the extant version of her passio, including the facts that she was a wealthy clarissima from a noble family, that she was married and had children, and that she suffered from poor health (Monceaux 1903: 384-85). Even in Augustine's account, however, Crispina is little more than a type-the Christian matron - to be contrasted with other types, like the virgin Agnes (Serm. 286.2.2 and Serm. 354.5). The same is true of Maximilian the recruit, Marcellus the soldier, Felix the bishop, and Gallonius the cleric. The details about their lives, the decisions they made, and how and why they found themselves facing execution were utterly unimportant, except in one regard: the way these facts illustrate the martyrs' totalising self-sacrifice on behalf of the Christian faith.

Second, as these stories about the saints were distilled down to their essence, the reality that they sought to convey about the past was fundamentally emotional rather than historical. This aspect of the texts is easy to miss, because like most Christian literature from early fourth-century North Africa, the language of the martyrdom accounts is not particularly emotive. Yet the sense of danger that hangs over the texts is palpable. The proconsul Dion repeatedly threatens the recruit Maximilian with a painful death (Acta Maximiliani 2.1, 2.5, 2.7, and 2.11). The proconsul Anullinus similarly has the cleric Gallonius hung from the rack, and then proceeds to threaten him with torture and death (Acta Gallonii 11, 15, 28, and 32). Bishop Felix of Thibiuca is confined to the deepest part of the prison in Carthage, before being produced in chains for a nighttime trial before Anullinus (Passio s. Felicis 26). The same proconsul threatens Crispina too: first just vaguely with the power of the law, but then twice with beheading and-bizarrely, in what is almost certainly a later addition to the text - with cutting off her hair and shaving her head in order to disgrace and disfigure her (Passio Crispinae, 33.2-3, 33.9-11, 34.14-15, and 34.17-19; see also 33.14-16 and 33.20-21). That the literary purpose of all these threats, verbal or physical, was to induce a sense of fear in the audience is suggested in the first instance by Crispina's own response to Anullinus's bluster: 'I am not afraid of what you say. This is nothing' (Quod dicis non timeo; hoc nihil est) (Passio Crispinae, 33.22).

That tension, between fear and witness, is the essential dilemma that all the early martyrdom accounts seek to address. In the fourth century, it gained additional 
power from the fact that it was not entirely fictive. Late Roman capital trials were doubtless terrifying affairs. More to the point, as the acta of Munatius Felix show, in the course of rounding up scriptures and other church property the municipal authorities of Cirta had threatened the Christian clergy with warnings like, 'You would be dead if you had not found these things' and 'If anything less had been done, you would be in danger' (Gesta ap. Zen., 187.18 and 188.31-32). It seems to have mattered deeply to those who curated the memory of the persecution that they bear witness not just to the sacrifice of those who had been executed by the imperial authorities but also that they make their audiences feel the sense of anxiety that had accompanied actively self-identifying as Christian at the time. As the events of the persecution dimmed in living memory, some Christian authors seem to have become increasingly insistent on this point. At least, later accounts like the Acts of the Abitinian Martyrs began to dwell with lurid fascination on the details of the torture to which the faithful were subjected, as did some sermons delivered by Christian preachers in the North African tradition (see e.g. PLS 2, cols. 1011-12 and PLS 2, cols. 1091-3). Authors like these did not seek to convey dry historical facts about an increasingly distant past, but rather, through an intensified appeal to the language of violence, to construct for succeeding generations an emotional reality of fear in the face of persecution.

\section{Conclusions}

For those who lived through it, the persecution was doubtless a traumatic experience. Even if they were able to reach some kind of accommodation with the municipal authorities charged with enforcing the imperial edict, Christian leaders were forced to resort to a variety of strategies in order to survive, including compliance, flight, tricksterism, or even informing on fellow members of their communities. Martyrdom, of course, was an alternative, although contemporary and near-contemporary evidence for it is limited. It is impossible to assess how far the sense of vulnerability to which the persecution gave rise extended, but it does not appear to have been limited to those in clerical orders. At least, prominent laypeople like Arnobius of Sicca were clearly unsettled, and we hear stories of ordinary congregants who were put to death after being caught at clandestine worship services, an anxiety that may have been very widespread indeed. The fact that those who were executed were survived by parents, children, spouses, and friends ensured that early memories of the persecution were close and intimate; but they were also communal and liturgical, and they very rapidly came to be prominently embedded in the built environment. For in fourth-century North Africa, memories of the persecution did not rely solely on narratives about the past: they could also focus on the simpler acts of naming those who had suffered and situating that suffering in space and time. When African Christians did tell stories about the past, their memories proved to be particularly malleable. What Christians regarded as laudable - even tolerable - strategies in the face of persecution seems to have changed quickly and dramatically after $303-4$, as early 
narratives about the persecution itself became tools for self-justification and the displacement of blame away from imperial and municipal authorities and onto fellow victims of repression.

In such a context, it is hardly surprising that Christians sought to bring purpose and meaning to an otherwise sordid experience by telling stories of perfect witness too. Martyrdom accounts were doubtless intended to preserve and honour the memory of the departed; but in the long term, the choices that Christians made about how, specifically, they would remember the experiences of the very special dead may also have served to reinforce the collective trauma of the persecution. That trauma was grounded less in the absolute number of executions (which seems to have been relatively small, at least in 303-4) than it was in the sense that torture and execution were now, suddenly, a very real possibility, and the disruption that this entailed to Christians' sense of security and belonging within the imperial order. However, in the aftermath of the persecution, valorising one form of witness - execution - at the expense of all others left little space for survivors to work through whatever sense of pain and guilt they may have felt about the choices that they had made in order to endure, even while others faced torture or death (on these points, see esp. Sato 1992, esp. 621-23; Lifshitz 2002: 318; Herman 1992: 54; and Krahn 2011). Nor did early Christian martyrdom accounts provide much room to mourn. The stories that fourth-century Christians told themselves about the experience of persecution thus did not even address, let alone resolve, some of the most critical issues underlying and informing the trauma of those who actually confronted and lived through its terrors. Critically, though, the acta and passiones of the martyrs did validate feelings of fear. For the generation of survivors, martyrdom narratives subtly reaffirmed perceptions that the world was a dangerous and frightening place. For their descendants, such stories may have helped make sense of otherwise enigmatic feelings of anxiety, mistrust, anger, grief, or guilt exhibited by the previous generation. Thereafter, in what amounted to a radical experiment with repetitive memory, the liturgical reading of the martyrs' acts and their elaboration in sermons focused not just on the essentials of remembrance-naming the dead and recollecting when and where they passed - but also on the annual reliving of the traumatic event. The lived experience of persecution had been necessarily messy and complicated. Collectively, fourth-century North Africans' decisions as to what to remember about the past and how to remember it resulted in the erasure of much of that complexity, produced a truly dystopic vision of the experience of 'pagan' rule, and extended the persecution through storytelling to become a shared experience of all Christians.

Recent scholarship has rightly tended to emphasise the rhetorical and strategic nature of this kind of curation of social memory in Late Antiquity. Viewing those same memories through the lens of trauma raises important questions about the emotional and psychological substrata over which more self-consciously rhetorical and strategic layers may have been built. In closing, let me broach just one: whether the proclivity of Christians to find themselves embroiled in conflict in Late Antiquity may have had something to do with intergenerational legacies of 
trauma. Since World War I, ample work in the social sciences has shown that in modern populations trauma affects the body on a psychophysiological level in an extensive and enduring way. In essence, it reconditions the human nervous system to heighten the traumatised person's sensitivity to potential dangers and intensify the 'fight-or-flight' response, even in the face of small provocations (Herman 1992, esp. 35-36; but see also Leys 2000). Ancient observers did not frame their interpretations in the same way. Nonetheless, they too were aware that the soul was physically shaped by its experiences, and Christian authors - including Africans like Tertullian, Lactantius, and Augustine - regarded with particular anxiety the brutalising and coarsening effects that violence could have on its witnesses (Castelli 2004: 104-33; Smith 2010; see esp. Them. Or. 21.248d-249c).

If early fourth-century Christians were, indeed, traumatised by the Great Persecution, they did not have to look far to find threats of abiding danger, real or imagined. Even after the cessation of repressive measures in Africa, for example, the arch-persecutor of Christian memory, the proconsul C. Annius Anullinus, continued to enjoy access to the highest circles of power in Rome, before falling from political favour under Constantine (Chron. 354, s. aa. 306-7 and 312: 66-67). Constantine's conversion, however, did not fundamentally reorient the concerns of the imperial administration, which remained resolutely secular, while at the municipal level, most figures of power continued to be devotees of traditional cult — not Christians — well into the fourth century (Shaw 2011: 195-259). Such continuities in the basic power structure of the empire left open the very real possibility that a sudden and unexpected reversal of status analogous to the Great Persecution could befall Christians at any moment—as, indeed, some felt happened in 361-3, in the brief reign of the traditionalist emperor Julian.

By Julian's day, of course, the generation who had lived through and personally experienced the traumas of the Great Persecution was rapidly thinning. But the catch is that, at least in modern populations, trauma is both contagious and heritable. Emotional identification with the experience of the victim can include adopting the victim's sense of helplessness, rage, and grief (see e.g. Herman 1992: 140-7; Danieli 1998; Kidron 2003; Chaitin 2008; Dekel and Goldblatt 2008; Krahn 2011; Ramos 2013). Thus the kind of fear validated by the narratives through which early Christians chose to curate their memories of the past could well have helped to reinforce a heightened sensitivity to perceived threats-real or imagined - not just in the generation of survivors, but in subsequent generations as well. Such fear may also have validated an aggressive response, already displaced from the representatives of the late Roman state and redirected instead towards those who were labelled as in any way 'Other,' regardless of whether or not they were the cause of any actual pain or suffering. These processes did not inevitably lead to violence. The eruption of hostilities was always grounded in the specificities of local circumstance. In fourth- and early fifth-century Africa, however, developments of this sort almost certainly underlay, at least in part, the escalating and intensifying eruptions of sectarian conflict between Catholics and their dissident or 'Donatist' rivals, recently explored so ably by Shaw (2011). Critically, too, both the disruptive effects of imperial persecution and the choice to 
validate the witness of those who died for their faith through liturgical storytelling were felt far beyond Roman Africa and, indeed, far beyond Christian communities. It is beyond the scope of this chapter to explore the role that intergenerational legacies of trauma may have played in late-antique Christian obsessions with weeding out such perceived threats as heterodoxy and heresy; the destruction of pagan temples, homoian (or 'Arian') churches, and Jewish synagogues; and even the phenomenal rise in popularity of ascetic practice and the resulting struggles between episcopal and ascetic leaders in Late Antiquity. But it is well worth asking the question.

\section{Notes}

1 Delehaye 1933; Herrmann-Mascard 1975; Saxer 1980; Martin 1990; Markus 1990: 85-106; Buc 1997; Lifshitz 2002; Grig 2004.

2 Duval 1982/1: 367-71, no. 174, and Duval 1982/1: 402-5, no. 191; Cyprian, Ep. 12.2, $39.3,80.1$.

3 Duval 1982/1: 5-6, no. 1; 1982/1: 142-3, no. 65; 1982/1: 202-7, no. 97; 1982/1: 331-7, no. 157 ; $1982 / 1$ : 357-8, no. 169 ; 1982/1: 394-6, no. 186 ; and 1982/2: 633-44.

4 Duval 1982/1: 331-7, no. 157; 1982/1: 351-3, no. 167; and 1982/ 2: 615-16.

5 Duval 1982/1: 59-63, no. 27; 1982/1: 245-7, no. 117; and 1982/1: 293-5, nos 138-9; see also 1982/1: 212, no. 103.

\section{Bibliography}

\section{Primary sources}

Acta Gallonii (1996) Edited by Chiesa, P. 'Un testo agiografico africano ad Aquileia: Gli acta di Gallonio e dei martiri di Timida Regia'. Analecta Bollandiana, 114: 265-8.

Acta Maximiliani (1987) Edited by Bastiaensen, A. A. R. et al., Atti e passioni dei martiri. Milan: A. Mondadori, 238-44.

Acta purgationis Felicis episcopi Autumnitani (1893) Edited by Ziwsa, C. CSEL, 26. Vienna: F. Tempsky, 197-204.

Arnobius of Sicca (1953) Adversus nationes. Edited by Marchesi, C. Turin: I.B. Paraviae. Augustine (1865) Sermones. PL, 38-9.

(1909a) Contra Cresconium. Edited by Petschenig, M. CSEL, 52. Vienna: F. Tempsky, 323-582.

- (1909b) Contra litteras Petiliani. Edited by Petschenig, M. CSEL, 52. Vienna: F. Tempsky, 1-227.

(1974) Breviculus collationis cum Donatistis. Edited by Lancel, S. CCSL, 149A. Turnhout: Brepols, 259-306.

(1990) Enarrationes in Psalmos. Edited by Dekkers, E. and Fraipont, J. 3 vols. CCSL. Turnhout: Brepols, 38-40.

Breviarium Hipponense (1974) Edited by Munier, C. in Concilia Africae a. 345-a. 525. CCSL, 149. Turnhout: Brepols, 30-53.

Chronographus anni CCCLIII (1892) Edited by Mommsen, T. MGH Chronica Minora, 1. Berlin: Weidmann, 39-148.

Concilium Hipponense [8 Oct. 393] (1974) Edited by Munier, C. in Concilia Africae a. 345-a. 525. CCSL, 149. Turnhout: Brepols, 20-1. 
Cyprian (1871) Epistulae. Edited by Hartel, W. A. CSEL, 3.2. Vienna: C. Geroldi Filium. Eusebius (1903-8) HE. Edited by Schwartz, E. 2 vols. Griechischen christlichen Schriftsteller der ersten drei Jahrhunderte, 9. Leipzig: J. C. Hinrichs.

Gesta apud Zenophilum (1893) Edited by Ziwsa, C. CSEL, 26. Vienna: F. Tempsky, 185-97.

Lactantius (1984) De mortibus persecutorum. Edited by Creed, J. L. Oxford: Clarendon Press.

Optatus (1893) Contra Parmenianum Donatistam. Edited by Ziwsa, C. CSEL, 26. Vienna: F. Tempsky, 1-182.

Passio s. Crispinae (1902) Edited by Franchi de' Cavalieri, P. Nuove note agiografiche, Studi e Testi, 9. Rome: Tipografia Vaticana, 21-35.

Passio ss. Dativi, Saturnini presbyteri et aliorum (1935) Edited by Franchi de' Cavalieri, P. in 'La "Passio" dei martiri Abitinensi'. Note agiografiche, 8. Studi e Testi, 65. Vatican City: Biblioteca Apostolica Vaticana, 47-71.

Passio s. Felicis episcopi (1921) Edited by Delehaye, H. 'La passion de s. Félix de Thibiuca'. Analecta bollandiana, 39: 241-76.

Registri ecclesiae Carthaginensis excerpta (1974) Edited by Munier, C. in Concilia Africae a. 345-a. 525. CCSL, 149. Turnhout: Brepols, 182-228.

Themistius (1832) Orationes. Edited by Dindorf, W.. Leipzig: K. Knobloch.

\section{Secondary sources}

Barnes, T. D. (1975) 'The beginnings of donatism'. JTS n.s., 26: 13-22. (2010) Early Christian hagiography and Roman history. Tria corda, 5. Tübingen: Mohr Siebeck.

Barton, C. A. (1993) The sorrows of the ancient Romans: The gladiator and the monster. Princeton, NJ: Princeton University Press.

Bowersock, G. W. (1995) Martyrdom and Rome. Cambridge: Cambridge University Press.

Boyarin, D. (1999) Dying for God: Martyrdom and the making of Christianity and Judaism. Stanford, CA: Stanford University Press.

Buc, P. (1997) 'Martyre et ritualité dans l'antiquité tardive. Horizons de l'écriture médiévale des rituels'. Annales: Histoire, Sciences Sociales, 52: 63-92.

Burns, J. P., Jr. (2002) Cyprian the bishop. London: Routledge.

Caseau, B. (2007) 'Objects in churches: The testimony of inventories'. In Lavan, L., Swift, E. and Putzeys, T. (eds.), Objects in context, objects in use: Material spatiality in Late Antiquity. Late antique archaeology, 5. Leiden: Brill, 551-80.

Castelli, E. A. (2004) Martyrdom and memory: Early Christian culture making. New York: Columbia University Press.

Chaitin, J. (2008) 'Bridging the impossible? Confronting barriers to dialogue between Israelis and Germans and Israelis and Palestinians'. International Journal of Peace Studies, 13/2: 33-58.

Chiesa, P. (1996) 'Un testo agiografico africano ad Aquileia: Gli acta di Gallonio e dei martiri di Timida Regia'. Analecta bollandiana, 114: 241-68.

Christern, J. (1976) Das frühchristliche Pilgerheiligtum von Tebessa: Architektur und Ornamentik einer spätantiken Bauhütte in Nordafrika. Wiesbaden: F. Steiner.

Clarke, G. (2005) 'Third-century Christianity'. In Bowman, A. K., Garnsey, P. and Cameron, A. (eds.), The crisis of empire, A.D. 193-337, Cambridge Ancient History, 12. Cambridge: Cambridge University Press, 589-671.

Conant, J. (2010) 'Europe and the African cult of saints, circa 350-900: An essay in Mediterranean communications'. Speculum, 85: 1-46. 
Danieli, Y. (ed.) (1998) International handbook of multigenerational legacies of trauma. New York: Plenum Press.

Dearn, A. (2004) 'The Abitinian martyrs and the outbreak of the Donatist schism'. Journal of ecclesiastical history, 55: 1-18.

Dehandschutter, B. (1995) 'Hagiographie et histoire: À propos des actes et passions des martyrs'. In Lamberigts, M. and van Deun, P. (eds.), Martyrium in multidisciplinary perspective: Mémorial Louis Reekmans, Bibliotheca ephemeridum theologicarum Lovaniensium, 117. Leuven: Peeters, 295-301.

Dekel, R. and Goldblatt, H. (2008) 'Is there intergenerational transmission of trauma? The case of combat veterans' children'. American Journal of Orthopsychiatry, 78/3: 281-9.

Delehaye, H. (1921) 'La passion de s. Félix de Thibiuca'. Analecta bollandiana, 39: 241-76. (1933) Les origines du culte des martyrs. 2nd edn. Subsidia hagiographica, 20. Brussels: Société des bollandistes.

Drake, H. A. (1996) 'Lambs into lions: Explaining early Christian intolerance'. Past \& Present, 153: 3-36.

- (ed.) (2006) Violence in Late Antiquity: Perceptions and practices. Aldershot: Ashgate.

Duval, Y. (1982) Loca sanctorum Africae. Le culte des martyrs en Afrique du IVe au VIIe siècle, 2 vols, Collection de l'École française de Rome, 58. Rome: École française de Rome.

(2000) Chrétiens d'Afrique à l'aube de la paix constantinienne: Les premiers échos de la grande persécution. Collection des études augustiniennes, Série antiquité, 164. Paris: Institut d'études augustiniennes.

Février, P. -A. (1968) 'Nouvelles recherches dans la salle tréflée de la basilique de Tébessa'. Bulletin d'archéologie algérienne, 3: 167-91.

(1986) 'Aux origines du christianisme en Maurétanie césarienne'. Mélanges de l'École française de Rome, Antiquité, 98: 767-809.

Franchi de' Cavalieri, P. (1935) 'La "passio" dei martiri Abitanensi'. Note agiografiche 8. Studi e Testi, 65. Vatican City: Biblioteca Apostolica Vaticana, 1-46.

Frend, W. H. C. (1952) The Donatist church: A movement of protest in Roman North Africa. Oxford: Clarendon Press.

(1965) Martyrdom and persecution in the early church: A study of a conflict from the Maccabees to Donatus. Oxford: Blackwell.

Gaddis, M. (2005) There is no crime for those who have Christ: Religious violence in the Christian Roman Empire. TCH, 39. Berkeley: University of California Press.

Gaiffier, B. de (1943) 'S. Marcel de Tanger ou de Léon? Évolution d'une légende'. Analecta bollandiana, 61: 116-39.

(1969) 'À propos de s. Marcel le centurion'. Archivos leoneses, 45-46: 13-23.

(1970) 'Un nouveau témoin de la passion de s. Marcel le centurion'. Analecta sacra Tarraconensia, 43: 93-6.

Grig, L. (2004) Making martyrs in Late Antiquity. London: Duckworth.

Harper, K. (2013) From shame to sin: The Christian transformation of sexual morality in Late Antiquity. Revealing antiquity, 20. Cambridge, MA: Harvard University Press.

Herman, J. L. (1992) Trauma and recovery. New York: Basic Books.

Herrmann-Mascard, N. (1975) Les reliques des saints: Formation coutumière d'un droit. Collection d'histoire institutionelle et sociale 6. Paris: Klincksieck.

Hornblower, S., Spawforth, A., and Eidinow, E. (eds.) (2012) The Oxford classical dictionary, 4th edn. Oxford: Oxford University Press.

Jones, A. H. M., Martindale, J. R., and Morris, J. (eds.) (1971-92) The prosopography of the later Roman Empire. 3 vols. Cambridge: Cambridge University Press. 
Keresztes, P. (1979) 'The imperial Roman government and the Christian church'. In Temporini, H. and Haase, W. (eds.), Aufstieg und Niedergang der römischen Welt, vol. 2.23.1. Berlin: De Gruyter, 247-315 and 375-86.

Kidron, C. A. (2003) 'Surviving a distant past: A case study of the cultural construction of trauma descendant identity'. Ethos, 31/4: 513-44.

Konstan, D. (2006) The emotions of the ancient Greeks: Studies in Aristotle and classical literature. Toronto: University of Toronto Press.

Krahn, E. (2011) 'Lifespan and intergenerational legacies of Soviet oppression: An autoethnography of Mennonite women and their adult children'. Journal of Mennonite studies, 29: 21-43.

Lanata, G. (1973) Gli atti dei martiri come documenti processuali. Studi e testi per un Corpus Iudicorum, 1. Milan: Giuffrè.

Lancel, S. (1979) 'Les débuts du Donatisme: La date du "Protocole de Cirta" et l'élection épiscopale de Silvanus'. Revue d'études augustiniennes et patristiques, 25: 217-29.

_(1999) 'Le proconsul Anullinus et la grande persécution en Afrique en 303-304 ap. J. -C.: Nouveaux documents'. Comptes rendus des séances de l'Académie des inscriptions et Belles-Lettres, 143: 1013-22.

Lenski, N. (2016) 'Imperial legislation and the Donatist controversy: From Constantine to Honorius'. In Miles (ed.), 166-219.

Lepelley, C. (1979) Les cités de l'Afrique romaine au bas-empire, 2 vols. Paris: Études augustiniennes.

- (1999) 'L'apport d'actes des martyrs nouvellement découverts à la connaissance de la géographie historique de l'Afrique proconsulaire'. Bulletin de la Société nationale des antiquaires de France (no number): 205-21.

Leschi, L. (1957) 'Fouilles à Tipasa dans l'église d'Alexandre (suite)'. In Études d'épigraphie, d'archéologie et d'histoire africaines, Paris: Arts et métiers graphiques, 377-88.

Leys, R. (2000) Trauma: A genealogy. Chicago: University of Chicago Press.

Lifshitz, F. (2002) 'The martyr, the tomb, and the matron: Constructing the (masculine) "past" as a female power base'. In Althoff, G., Fried, J., and Geary, P. J. (eds.), Medieval concepts of the past: Ritual, memory, historiography. Washington, DC: German Historical Institute, 311-41.

Maier, J. -L. (ed.) (1987) Le dossier du donatisme. 2 vols. Texte und Untersuchungen zur Geschichte der altchristlichen Literatur, Berlin: Akademie-Verlag, 134-5.

Markus, R. A. (1990) The end of ancient Christianity. Cambridge: Cambridge University Press.

Martin, J. (1990) 'Die Macht der Heiligen'. In Martin, J. and Quint, B. (eds.), Christentum und antike Gesellschaft. Darmstadt: Wissenschaftliche Buchgesellschaft, 440-74.

Mayer, W. (2013) 'Religious conflict: Definitions, problems and theoretical approaches'. In Mayer, W. and Neil, B. (eds.), Religious conflict from early Christianity to the rise of Islam. Arbeiten zur Kirchengeschichte, 121. Berlin: De Gruyter, 1-19.

Meineck, P. and Konstan, D. (eds.) (2014) Combat trauma and the ancient Greeks. New York: Palgrave Macmillan.

Miles, R. (ed.) (2016) The Donatist schism: Controversy and contexts. TTH, Contexts, 2. Liverpool: Liverpool University Press.

Monceaux, P. (1901-23) Histoire littéraire de l'Afrique chrétienne depuis les origines jusqu'à l'invasion arabe, 7 vols. Paris: E. Leroux.

(1903) 'Les actes de sainte Crispine, martyre à Theveste'. In Mélanges Boissier. Recueil des mémoires concernant la littérature et les antiquités romaines dédié à Gaston Boissier. Paris: Albert Fontemoing, 383-9. 
Moss, C. R. (2012) Ancient Christian martyrdom: Diverse practices, theologies, and traditions. New Haven, CT: Yale University Press.

Ramos, E. (2013) 'Crucial conversations: Exploring intergenerational trauma in postconflict Guatemala'. Columbia Social Work Review, 4: 11-23.

Rebillard, É. (2012) Christians and their many identities in Late Antiquity. North Africa, 200-450 CE. Ithaca, NY: Cornell University Press.

Rosenwein, B. H. (2006) Emotional communities in the early middle ages. Ithaca, NY: Cornell University Press.

Sato, Y. (1992) 'Martyrdom and apostasy'. In Attridge, H. W. and Hata, G. (eds.), Eusebius, Christianity, and Judaism. Detroit: Wayne State University Press, 619-34.

Saxer, V. (1980) Morts, martyrs, reliques en Afrique chrétienne aux premiers siècles. Les témoignages de Tertullien, Cyprien et Augustin à la lumière de l'archéologie africaine. Théologie historique, 55. Paris: Beauchesne.

Selinger, R. (2004) The mid-third century persecutions of Decius and Valerian. 2nd edn. Frankfurt am Main: Peter Lang.

Shaw, B. D. (2011) Sacred violence: African Christians and sectarian hatred in the age of Augustine. Cambridge: Cambridge University Press.

Shepardson, C. (2014) Controlling contested places: Late-antique Antioch and the spatial politics of religious controversy. Berkeley: University of California Press.

Sizgorich, T. (2009) Violence and belief in Late Antiquity: Militant devotion in Christianity and Islam. Philadelphia: University of Pennsylvania Press.

Smith, G. A. (2010) 'The physics and metaphysics of late ancient slavery'. A paper presented at the American Historical Association, 124th Annual Meeting, San Diego, CA.

Ste. Croix, G. E. M. de (1954) 'Aspects of the "Great” Persecution'. HTR, 47: 75-113.

Turner, W. J. and Lee, C. (2018) Trauma in medieval society. Explorations in medieval culture, 7. Leiden: Brill.

Wendebourg, D. (1987) 'Das Martyrium in der alten Kirche als ethisches Problem'. Zeitschrift für Kirchengeschichte, 98: 295-20.

Whelan, R. (2018) Being Christian in Vandal Africa: The politics of orthodoxy in the postimperial west. Oakland, CA: University of California Press.

Woods, D. (2003) 'St. Maximilian of Tebessa and the jizya'. In Defosse, P. (ed.), Hommages à Carl Deroux, 5 vols, Collection Latomus, 279. Brussels: Latomus, vol. 5, 266-76.

Zuckerman, C. (1998) 'Two reforms of the 370s: Recruiting soldiers and senators in the divided empire'. Revue des études byzantines, 56: 79-139. 


\title{
4 Augustine's memory of the 411 confrontation with Emeritus of Cherchell
}

\author{
Geoffrey D. Dunn
}

Emeritus of Cherchell ${ }^{1}$ does not spring rapidly to mind when we think of the Donatist opponents confronted by Augustine of Hippo Regius (in the province of Africa Proconsularis). ${ }^{2}$ Indeed, Cherchell, a town located about halfway along modern Algeria's coastline and the second-largest port on African shores (Raven 1993: 70-1; Sears 2011: 41-3), was far removed from the heart of Roman Africa that centred on Carthage. The standard modern biography of Augustine in English (Brown 2000) does not include any reference to Emeritus at all.

Yet Emeritus of Chercell was an individual of some significance in Augustine's life. Augustine wrote to him on a couple of occasions, including Epistula 87 (NBA, 21/2: 736-50; Dunn 2018). Augustine recorded the homily he preached in Cherchell in 418 (Sermo ad Caesariensis ecclesiae plebem; NBA, 16/2) ${ }^{3}$ and an encounter with Emeritus on a visit to Cherchell in September 418 (Gesta cum Emerito Donatistarum episcopo liber unus; NBA, 16/2). ${ }^{4}$

These two texts preserve the memory of that encounter between Augustine and Emeritus, but also a utopianised memory of an earlier encounter between the two, which took place in Carthage in 411. The aim of this chapter is to examine how Augustine reshaped and re-presented the events of 411 seven years later, and to identify those (reimagined) arguments of 411 that remained valid for Augustine's continuing struggles against the Donatists.

Emeritus was one of the seven Donatist episcopal representatives selected to speak $^{5}$ at what is often loosely termed the conference or colloquy of Carthage in 411, a debate against Augustine and his fellow representatives on the other side, known as the Caecilianists. These were named after Caecilian, whose controversial election as bishop of Carthage in 311 at the hands of a traditor bishop had started the controversy (see Chapter 3 by Jonathan Conant in this volume for some of the early history of Donatism). ${ }^{6}$ Both sides claimed to be catholic in this controversy, which had emerged as a result of the persecution under Diocletian, and was characterised by disputed interpretations on the necessity of the purity and sinlessness of the celebrant for the validity of sacraments. While scholarship traditionally divides them into Donatists and Catholics, I prefer to label both parties after their 'founders' or early leading figures, since their catholicity or otherwise was the contested issue. 
Rather than calling the meeting in 411 a 'conference,' the Latin collatio is better translated as a confrontation, or as Tilley put it, 'an imperial administrative process' (Tilley 1991: 10). This meeting between Donatists and Caecilianists was not an episcopal synod, but an imperially mandated legal proceeding before an imperially appointed arbitrator (Marcellinus). Marcellinus heard an application for a court order to enforce previous legal decisions or to appeal against previous imperial rulings against the Donatists. ${ }^{7}$ The term collatio indicates a contestation, and hence 'conference' is too mild an English translation.

The confrontation between the two parties was necessary because previous rulings had been overturned in an unpreserved 'act of tolerance,' produced in early 410 in the aftermath of instability at Ravenna following the assassination of Stilicho in August 408. This act of tolerance was revoked on 25 August 410 (CTh 16.5.51), the day after the sack of Rome under Alaric. The timing might have been purely coincidental since news of Rome's capture would not have reached Ravenna that swiftly, but given that the imperial court in Ravenna was engaged in a power struggle until the emergence of Flavius Constantius to replace Stilicho in 411, it would not be surprising that in the jockeying for power overtures of placating religious tensions would be made to Africa, vital for food supplies in Italy. The move to revoke the new tolerance that had been initiated by the Caecilianist bishops after their 14 June 410 synod (Reg. eccl. Carthag. excerpta 107b, CCSL, 149: 220), and had been accepted by the emperor on 14 October 410 (Gesta 1.4, SC, 195: 564-68 and CTh 16.11.3), and by Marcellinus himself (Gesta 1.5-10, SC, 195: 568-86), makes it unlikely to have been an appeal, even though this is what the Donatists wanted. As such, it was a process in which the Donatists were the defendants, even though the Caecilianists did not want to be plaintiffs (Lancel 2002: 293-300).

Emeritus too offered a reshaped memory of the 411 confrontation, albeit one that was only one sentence long, if we accept that Augustine, upon whom we are entirely dependent for Emeritus's interventions, has not turned him into more of a literary mute than he was. While Emeritus believed that his side had won the argument in 411 , his near silence in 418 would suggest that he was well aware that the decision in 411 had gone against them. For Augustine, 411 was a triumph. It created the ideal situation for the Caecilianists or for Christians in general as far as he was concerned, as we shall see in detail in this chapter. The possibility he had in mind was the church in Africa without schism, a church identical with that of the Caecilianists, but one in which the Donatists had not disappeared but rather had been reabsorbed into unity. The dice was loaded against the Donatists from the start, but in Augustine's constant retelling of the story the outcome became nothing less than total victory. In this sense we can apply Thomas More's concept of utopia (More 1516) to Augustine's interpretation of the 411 confrontation, since it created an ideal that did not match the reality (Fitting 2009). It is more usual for Augustine's De ciuitate Dei to be analysed for its contribution to the formation of a Christian utopia, albeit one located not on earth but in heaven (or, more accurately, on earth but not earthly or secular) (Raitiere 1973; Kaufman 2007; Lee and Dupont 2016) and for its influence upon Thomas More (1516). I am arguing 
here that the brief record of an encounter in 411 implied the existence (and a reshaped existence at that) of what we may call a utopia with regard to the resolution of the Donatist controversy. ${ }^{8}$

Unlike More's sense of utopia, which was something unattainable, Augustine believed that the ideal created in 411 could be implemented. Yet his interpretation of the ideal was gradually reshaped over the years that followed. The landscape created in 411 needed to be rewritten as he realised the continuing resistance to it, resistance personified in Emeritus himself. Most of the record of the confrontation has been preserved, and it is against this that we can assess Augustine's version of events; yet it is Augustine's retelling that is most familiar to us.

Gesta cum Emerito is not a utopia of the present or the future like De ciuitate Dei (a work, incidentally, dedicated to Marcellinus), but a utopia about the past that had implications for the present. Its attention is focused not outside the church but inside it. While Augustine could imagine two cities co-existing in De ciuitate $D e i$, his vision of the heavenly city on earth could not allow for the continuing existence of Donatists. A Donatist utopian ecclesiology is less accessible to us (but see Gaumer 2008) and, as we shall see, Emeritus's refusal to take an active role in the 418 encounter can be understood as a simple assertion that Donatist recalcitrants felt no need to modify their 411 position.

In this chapter I examine the reshaping of Augustine's memory in Gesta cum Emerito, one of four post-confrontation writings that he produced. It shows the utopian ecclesiology that lay behind such a reformulated memory, as well as how Emeritus interpreted that meeting. We begin by looking at the confrontation, before considering what Augustine chose to highlight during his last encounter with Emeritus in 418.

\section{Confrontation of 411}

Reconstructing the confrontation of 411 is no simple task since we have two versions of events. As mentioned, we have Augustine's reconstruction of its proceedings (Breuiculus collationis cum Donatistis), as well as the copy with capitula made by a certain Marcellus of the officially edited minutes produced by the imperial scribes at the confrontation (Gesta collationis Carthaginiensis), which has suffered some alteration due to the vicissitudes of manuscript transmission, as is the case with most ancient evidence (Weidmann 2015). The confrontation has been little studied as a legal process in scholarship, with a few exceptions in more recent years (Alexander 1970, 1973, 1977, 1984; Tilley 1991; Hermanowicz 2008: 188-220; Graumann 2011; Weidmann 2015; and the essays by Lenski, McLynn, and Miles in Miles 2016). As the late Maureen Tilley (1991: 7) noted: 'Although most biographies of Augustine and histories of Christianity in North Africa mention this conference, they spend little time on the substance of the discussion which took place between the two parties.' Indeed, we still have no English translation of the two volumes of text in the SC series. Further, except for Merdinger (2013), the 418 episode at Cherchell has been the subject of little scholarly research. 
The gathering in 411 was not simply a 'public debate' (Marone 2015: 77), but, as Honorius's edict Inter imperii of 14 October 410 indicated, an opportunity for the vain error and unproductive conflict that had stained Africa caused by the Donatist superstition to be refuted by clear reason (Gesta 1.4, SC, 195: 562-4). It was a debate but one with legal consequences, and one that placed the Donatists at an extreme disadvantage in that they did not start as equal participants but as the subjects of hostile prejudice and bias from the man who was to decide the outcome, as they themselves realised (Gesta 1.14, SC, 195: 588-92). Augustine had anticipated this some years previously in a letter to Januarius (Ep. 88.10, NBA, 21/2: 766), Donatist primatial bishop of Negrine (ancient Casae Nigrae in the province of Numidia): 'But we want you to confer, not in order that the case may be brought to an end once again, but in order that it may be shown to those who do not know it that it has already been brought to an end.'

Tilley argued (1991: 14), against scholars like Frend (1952: 279) and even against Augustine's own presentation, that the Donatists were not engaged in delaying tactics during the confrontation but wanted to debate substantive issues about who could claim Catholic identity (Gesta 3.91-7, SC, 224: 1054-8). This was something that had already been decided in favour of the Caecilianists, in that, scattered throughout the official records of the confrontation, each of them is mentioned as a bishop of the catholic church ('episcopus ecclesiae catholicae'), while each Donatist bishop was only described as an 'episcopus.'

Both sides presented a summary of their positions in their mandata: first the Caecilianists (Gesta 1.55, SC, 195: 642-70; Alexander 1970: 9-15) and second the Donatists (3.258, SC, 224: 1194-218), which is described more as a letter than a mandatum (Alexander 1970: 15-25). While many scriptural passages could be produced, none was more important for the Caecilianists than the parable of the wheat and the weeds from Matthew 13, or Jeremiah 23:28b for the Donatists (Alexander 1973, 1984; Dunn 2017b). The substantive issue was about the nature of the church and membership. The universality of the communion the Caecilianists enjoyed, in contrast with the basic Donatist isolationism (cf. Eno 1972), was also important for the Caecilianists in establishing their identity as true members of the church (Gesta 1.18, SC, 195: 602-16). The supposed failure of Caecilianists to remove known (as opposed to unknown) sinners from their ranks was a sign of Caecilianists condoning sin, according to the Donatist Emeritus (Gesta 3.263, SC, 224: 1222). The Donatists could appeal to the interpretations and practices of Tertullian and Cyprian, for whom all schismatics should be excluded from the church. Cyprian showed more openness, at least progressively, for the reconciliation of repentant schismatics than did the Donatists, an argument not really exploited by Augustine in any of his attempts to rehabilitate Cyprian for the Caecilianists and dislodge him from Donatist adulation (Gaumer 2016).

Emeritus had objected to the procedure outlined by Marcellinus. He wanted not Roman law but the scriptures to arbitrate (Gesta 1.31, SC, 195: 626-8). In this he was echoed by Petilian (Gesta 1.53, SC, 195: 640-2, and 3.149 and 153, SC, 224: 1102 and 1104), who said that bishops who appealed to civil law were really not bishops at all. Petilian also wanted each bishop to be identified so that the 
full strength of the Donatists would make an impression on Marcellinus (Gesta 1.61 and 65, SC, 195: 674, 676-8). The Donatists argued that the Caecilianists historically, both from their origins as traditores and from their recent actions in appealing to the imperial court, and theologically, from their reading of scripture, could not be Christian and were not fit to be a party to the matter and that as a result the Donatists had no case to answer. If the Caecilianists were not holy they were not members of the church. Marcellinus was prepared to let them argue from one basis, historical or theological, but from one basis only (Gesta 3.156, $\mathrm{SC}, 224:$ 1106-8). In response to the Donatist complaint that the Caecilianists were breaking their promise to use only scripture in their arguments, Augustine replied that this applied only to their arguments about the nature of the church, and that with regard to the case of Caecilian himself, they would have recourse to historical documents (Gesta 3.214, SC, 224: 1156). It is only towards the very end of the record of proceedings ${ }^{9}$ that the substantive matter is explored, and this happened not because the Donatists were satisfied now with the rules of engagement, but because at every turn Marcellinus had hindered their efforts to direct the proceedings.

After the Donatists had presented their letter, the rest of the contest, until the record breaks off, became one of debate about the scriptural parables of the wheat and the weeds (Matt 13:24-30), the net (Matt 13:47-52), the sheep and goats (Matt 25:31-46), and the threshing floor (Matt 3:12) (Gesta 3.259-81, SC, 224: 1220-40). The argument centred on the question of whether these parables refer to a separation of good and bad members of the church in the present age or at the last judgement, or whether the point of reference was to the church or the world, and to when bad elements were discovered (Alexander 1973; Tilley 1997: 164).

We know that Marcellinus's ultimate decision was a foregone conclusion. As Graumann (2011: 333) says, 'It is important to realise that the Donatists had few illusions about the true character and the expected outcome of the meeting or their chances of a fair hearing.' This judgement in favour of the Caecilianists was one part of Augustine's utopia, a situation in which the state upheld the legitimacy of the Caecilianists as being the legitimate church. This was part of an even bigger utopia, one in which the Donatists did not exist. Of course, the official ruling did not silence the Donatists, just as they had not been silenced in the face of official rulings for the previous century. How did Augustine remember this utopia in later years? We may turn briefly to his Breuiculus before turning attention to the encounter in 418 at Cherchell.

\section{Augustine's Breuiculus collationis}

Augustine's own summary of the gesta of the confrontation was produced within several months of the event. In the Breuiculus collationis he accused the Donatists of having ignored the central issue (Breu. 1, praef., NBA, 16/2: 94). We find out later that the central issue in Augustine's opinion was the universality of the church (Breu. 3.8.10, NBA, 16/2: 138-40). As Alexander (1970: 28) points 
out, Augustine was employing some creative memory here, for Augustine had earlier accepted that it was not the central issue during the confrontation (Gesta 3.261, SC, 224: 1220-2). Augustine also creatively twisted his memory of the scriptural arguments deployed by the Donatists to his own advantage (Alexander 1970: 28-9).

Augustine (Breu.3.8.12, NBA, 16/2: 144) asserted that the Donatists' letter read out at the confrontation had failed to respond to the Caecilianists' arguments about the tolerance shown by Cyprian and the Donatists in reconciling and recognising the clerical status of the Maximianists. ${ }^{10}$ Yet Alexander points out that Augustine actually was trying to avoid making any response to some telling blows landed by the Donatists (Alexander 1970: 30-1). Maximian certainly features more significantly in Augustine's Breuiculus (and would again in Gesta cum Emerito) than he did in the gesta of the confrontation.

The Donatists claimed at the confrontation that they were the persecuted church, ${ }^{11}$ which they illustrated by standing rather than sitting during the three days, exemplifying the biblical precepts of Psalms 1:1 and 25:4-5, as well as Jesus standing in the presence of Pilate his persecutor. ${ }^{12}$ Against this claim, Augustine pointed out that it was the Donatists who had first appealed to Emperor Constantine (Breu. 3.8.13, NBA, 16/2: 144-6). Further, Augustine asserted in his retelling of the events of the confrontation that the Donatists had not answered Caecilianist arguments about the very root cause of the schism: the innocence of Caecilian and Felix, one of his ordaining bishops (Breu. 3.8.14, NBA, 16/2: 146-8). Augustine was duplicitous here, for Caecilian's 'evil' did not go undetected. It had been revealed by 312 (Alexander 1970: 34) and at the confrontation that the Caecilianists had insisted in their mandatum that the question of Caecilian was separate from the question of the nature of the church, which could be demonstrated from scripture (Gesta 1.55, SC, 195: 642-70).

In retelling the debate after the reading of the Donatist letter, Augustine asserts in Breuiculus that the Donatists interrupted constantly and only as a delaying tactic to cover the weakness of their position (Breu. 3.9.15-16, NBA, 16/2: 148-52). From his comparison with the extant text of Gesta, Alexander posits that the Donatists were not alone in interrupting and that they were raising valid objections and not just stalling (1970: 54). On Breuiculus's reporting of the Donatist letter, Alexander (1970: 36) concludes: '[I]t may reasonably be said that Augustine's summary of the Donatist Letter would be very misleading if it could not be checked against the actual Gesta of the Conference.'

\section{Memory of the confrontation at the 418 encounter at Cherchell}

Augustine's memory of a Caecilianist victory and supposed Donatist ineptitude in 411 was altered even further in 418 when he met Emeritus again at Cherchell. On 20 September, Augustine recalls meeting Emeritus, who had been living in a self-imposed exile outside the capital, two days earlier, when he attended a service where Augustine was the preacher (Sermo ad Caesariensis ecclesiae plebem). Augustine expresses disappointment that Emeritus still refused to adopt the 'right' version of Christianity, but he refused to give up hope (Gesta cum 
Emerito 1, NBA, 16/2: 378-80). The point of the encounter on 20 September, at least in Augustine's retelling, was not to get Emeritus finally to admit defeat, but to sustain and reinforce the faith of those former Donatists whose adoption of Caecilianist Christianity might have been just a veneer (Gesta cum Emerito 2, NBA, 16/2: 382). Augustine was always interested in correcting any real or apparent views that were not aligned with his own (Ebbeler 2012). He wanted to show the former Donatists that Emeritus recognised that he had been seduced into Donatism, and he hoped that Emeritus would not remain stubborn.

Augustine makes it clear that, following the confrontation, Emeritus continued to advocate on behalf of the Donatists. He and other die-hard Donatists had complained that Marcellinus's favourable decision for the Caecilianists was the result of bribery, that Marcellinus had not acted fairly during the confrontation, and that he had 'permitted them to say very little of all the things they wanted and rather oppressed them with his power than through proper conduct, not accept what they were saying' (Gesta cum Emerito 2, NBA, 16/2: 382). ${ }^{13}$ At its heart, this encounter was a debate, and a fairly one-sided debate at that, about how fair the confrontation of 411 had been to both parties.

Augustine argued that it was not force that defeated the Donatists back in 411 but the truth (Gesta cum Emerito 3, NBA, 16/: 384). Emeritus would not answer the question directly, saying only enigmatically that 'the acts indicate if I have been defeated or have defeated, if I have been defeated by the truth or overpowered by force' (Gesta cum Emerito 3, NBA, 16/2: 384). Augustine asked the next logical question: why had Emeritus turned up, in that case? Emeritus replied: 'So that I may answer what you ask' (Gesta cum Emerito 3, NBA, 16/2: 384). After that Emeritus fell silent.

Emeritus's near silence at the 418 encounter needs to be explained, especially in the light of Frend's assessment (1952: 281) of Emeritus at the 411 confrontation as 'a long-winded, pedantic, and exasperating speaker.' Indeed, Emeritus was second only to Petilian in arguing the Donatist position at the confrontation (Alexander 1970: 41). It would seem from his participation, or lack thereof, in the 418 encounter that Emeritus realised that it was pointless to argue a lost cause, especially since Augustine was not really the person with whom he needed to be arguing. The only thing that could help the Donatists would be for the imperial administration to change its mind, and there was no representative here this time. Indeed, such a representative would not to be swayed by the truth (as the Donatists saw it), so Emeritus naturally felt it was better to say nothing. Given that the Donatist position had been twisted at the 411 confrontation, any engagement with Augustine only risked making the situation even worse. Alternatively, as Lancel (2002: 352) suggests, Emeritus's silence could be read as an act of defiance, attuned to the lack of sincerity in the hearts of the former Donatists in the congregation. Thus, Emeritus kept his memory of the confrontation to himself, although his silence did speak volumes about his continuing adherence to Donatist ecclesiology as expressed back in 411 .

Augustine wanted the memory of the 411 confrontation to be kept alive. He noted that in the cities of Carthage, Thagaste, ${ }^{14}$ Constantina, and his own city of Hippo, the proceedings of the 411 confrontation were read out to the Christian 
assembly during the season of Lent (Gesta cum Emerito 4, NBA, 16/2: 386). Such a reading from official records gave the memory of that event an aura of objectivity and independence from selective reconstruction. The proceedings consisted mainly of argument and counter-argument, as well as the imperial interventions, so the utopia that the Caecilianist Christians (as well as ex-Donatists who had succumbed to the pressure of abandoning their church) heard was a constructed one in the first place. However, Emeritus's minimal interventions in 418, denying the legitimacy of the result of the confrontation, meant that Augustine could not simply hold up the results of the confrontation to the people of Cherchell to illustrate the utopia he believed ought to exist; he still needed to justify its outcome.

\section{Aurelius's Ep. 128 to Marcellinus}

In Cherchell Augustine felt that it was impracticable to read aloud those proceedings, so he had Alypius read out most of Epistula 128 instead, which had been sent by Aurelius, bishop of Carthage, and his fellow African bishops, to Marcellinus, the imperial commissioner, before the confrontation of 411. This letter had been included within the proceedings of that confrontation (Gesta 1.16, SC, 195: 592-600), and Augustine had mentioned it in his Breuiculus (1.5, NBA, 16/2: 98). In that letter the Caecilianist bishops had promised that, if they lost the confrontation, they would surrender their episcopal status and give the Donatists free rein. If, instead, the Caecilianists were found to be true and continuing members of the church, then the Donatists ought to embrace them in unity, and the plurality of bishops in individual churches ought to cease (Ep. 128.1-3, NBA, 22: 54-60= Gesta cum Emerito 5, NBA, 16/2: 386-90). By having this letter read out, Augustine hoped to show that the Caecilianists, before the confrontation, were interested more in reconciliation than revenge, and that Emeritus's assertion that the Caecilianists had only won because Marcellinus had ruled in their favour out of bias could not be upheld.

While Epistula 128 was read out and incorporated into the proceedings of the confrontation, it was a preparatory document. In turning to it in this encounter in 418 in Cherchell, Augustine was no longer directly referring to past events in which Emeritus had played a leading role, but to the theological issues and arguments at the heart of the North African schism. It was not a memory of the event or its outcome, but it evoked the ideas debated at the event. Augustine subtly diverted attention away from Emeritus's brief point that the outcome of the confrontation had been fixed in a deal between the imperial commissioner and the Caecilianists and turned it back to the substantive arguments about the truth, as he envisaged it, of the competing ecclesiologies that had been debated back in 411. The utopian situation that the confrontation of 411 had created had to be put to one side.

After Alypius had read out a sizeable portion of Epistula 128, Augustine interrupted his friend and colleague to add his own comment about the sincerity of the Caecilianists' offer. It seems that among his own side there had been a couple of bishops less than willing to make such an offer, and they had to be talked 
round. That they were talked around was now remembered as an indication of the integrity of the Caecilianists (Gesta cum Emerito 6, NBA, 16/2: 390-2). As Alypius returned to reading the letter of 411 this exact point was mentioned (Ep. 128.3, NBA, 22: 58-60 = Gesta cum Emerito 7, NBA, 16/2: 392), and Augustine interrupted him yet again to observe, in words vaguely reminiscent of Paul in 1 Corinthians 9:19-23, that being a faithful and obedient Christian is what everyone ought to be for their own sake and for the sake of others, provided it does benefit and not harm (and the idea that being such a person could be harmful must surely have been hypothetical) (Gesta cum Emerito 7, NBA, 16/2: 392). The aim, as Alypius continued to read out, was for the bishop to bring people into unity, even if that could only be achieved by surrendering his status (Ep. 128.3, NBA, 22: 58-60 = Gesta cum Emerito 7, NBA, 16/2.392).

In words reminiscent of the imagery of the watch-tower built in the vineyard in Isaiah 5:1-2, Augustine commented that the bishop occupies a higher rank in the church, just as the watchman occupies a higher place in the tower, in order to offer protection and supervision to those below him (Gesta cum Emerito 7, NBA, 16/2: 392-4). ${ }^{15}$ It was not only the reading of the letter that prompted Augustine to offer this extended commentary on the positive dimensions of the episcopal role within the church. The terse comment from Emeritus stemmed from what he considered to be the unfair and unwarranted victory enjoyed by the Caecilianists back in 411. This comment, together with an uneasy feeling about the true feeling of the former Donatists present before him, forced Augustine to offer several points to defend his good faith and the validity of his triumph back in 411. It was not based on any corrupt influence over the commissioner, but on the truth of the Caecilianists, exemplified by their concern to preserve the unity of the church in humility.

\section{The question of rebaptism}

Alypius then read the last part of the letter. Unity was more important than preserving one's episcopal status. Here Aurelius and others had stated that unity required only reconciliation not rebaptism (Ep. 128.4, NBA, 22: $60=$ Gesta cum Emerito 7, NBA, 16/2: 394). This was even accepted by the Donatists in the case of those Maximianists who wished to leave that schismatic group and return to the Donatist fold; their baptism was accepted as valid, but, more to the point, Donatist clerics who had joined the Maximianists had been welcomed back and allowed to maintain their clerical status. The point that had been made in the letter in 411 was that as the Donatists were prepared to welcome back repentant Maximianists, so too the Caecilianists were prepared to welcome back repentant Donatists.

It is unknown how many of them were baptised in the Maximianist schism and how many had received an undisputed baptism within the Donatist church before joining the Maximianists and then wanted to return. Augustine indicated that many had not only been baptised into the Donatist schism but then had been rebaptised into the Maximianist schism (Gesta cum Emerito 9, NBA, 16/2: 400). 
The inconsistency of the Donatists was on not rebaptising the Maximianists when they re-joined the Donatist community. It might have been that most of the Maximianists had received valid Donatist baptism already, which was not removed by Maximianist baptism, and therefore did not need the sort of rebaptism that Caecilianists needed if they joined the Donatists. While Merdinger (2013) notes that Mauretanian Donatists were not keen on practising rebaptism, we are talking here about a decision made in Numidia. ${ }^{16}$

After Alypius had finished reading this last section of the letter, Augustine, prompted by this reference to the Maximianists, launched into the climax of his argument. In the years after the confrontation, ${ }^{17}$ the Maximianist schism had loomed large in Augustine's defence of the integrity of the Caecilianist argument. By way of contrast, Maximian did not feature much in the confrontation. Besides the reference to him in Epistula 128, which, as we have noted, was incorporated into the proceedings of the confrontation along with Epistula 128 (Gesta 1.18, SC, 195: 602-16) - referred to in Breuiculus 1.5-7 (NBA, 16/2: 98-100)only mentioned in the mandatum presented from the Caecilianists (Gesta 1.55, SC, 195: 662 and 666). In other words, the Maximianist schism was not a topic discussed at all during the confrontation.

Given that the Maximianist schism had played a role in Augustine's musings on the failings of the Donatists in the years before $411,{ }^{18}$ as well as after, but not during the confrontation, it would be reasonable to conclude that, during the confrontation, the Caecilianists had deliberately avoided mention of it. Perhaps it was in an effort not to embarrass or antagonise them any more than necessary. After all their purpose was to reconcile with the Donatists, not just defeat them.

On the other hand, the Caecilianists were willing to do for the Donatists what the Donatists had done for most of the Maximianists, so reference to that schism could have been appropriate. Thus, when Augustine stated in Cherchell in 418 that Emeritus had nothing to say at the confrontation in response to probing about the Maximianists (Gesta cum Emerito 11, NBA, 16/2: 402) (as he had nothing to say about them in 418), he was exaggerating, since even our brief list of references shows that the Maximianists were not a topic of discussion in 411 as they were to be in Augustine's later writings. To reiterate, in the encounter in Cherchell in 418 Augustine turned the memory away from the 411 confrontation as an event, to some extent, and onto the ideas that underpinned the differences between the two sides.

It is interesting to note that Augustine argued that the Maximianists had been a major topic during the confrontation: 'since we had presented so many times that matter of the Maximianists in our confrontation, they were able to say nothing against it.' 19

Augustine reshaped the history of those events to show that, just as Emeritus now had fallen silent before him, so too the Donatists back in 411 had fallen silent before the telling blow of reference to their hypocrisy evidenced in their treatment of the Maximianists. That the Donatists had not fallen silent back then was no problem to Augustine's argument, since it appeared that Emeritus was not going to correct him. Indeed, he was so confident that he would not be challenged that he dared Emeritus to disagree with his reconstructed memory (Gesta cum 
Emerito 8, NBA, 16/2: 396: Ecce hic est, audit me: si mentior, redarguat, probare me compellat).

\section{The Maximianist schism}

Augustine then retold the story of how the schismatic Maximianists had treated Primian the same way as the Donatists had treated Caecilian nearly a century before. The Maximianists had been condemned just as Donatus had been condemned by those who supported Caecilian (Gesta cum Emerito 9, NBA, 16/2: 396). This was a source of information he had exploited for the same purpose more than a decade previously in Contra Cesconium grammaticum Donatistam libri quatuor. As an example, he referred to the fact that most of those clerics who had initially supported the Maximianists were welcomed back at the synod of Ksar Baghai in 394 into the Donatist community, with their clerical status intact, a deviation from the common practice in Africa with regard to reconciliation. The rehabilitated clergy included Felician of Musti (in the province of Numidia) and Praetextatus of Henchir-Zenfour (ancient Assuri in the province of Africa Proconsularis), both Maximianist bishops who had held out against being reincorporated into the Donatist community until attacked by the Donatist bishop Optatus of Colonia Marciana Ulpia Traiana Thamugadi (Timgad).

It must be remembered that there were two types of Maximianists (those like Maximian himself and his ordaining bishops who were condemned at Ksar Baghai and all the others who would be welcomed back into the Donatist fold if repentant), and this enabled Augustine to get double the mileage out of them. The Donatist inconsistency in readmitting Maximianists but in rejecting Caecilianists was one point Augustine could make against the Donatists; the other was between the Donatists harsh treatment of Maximian himself and the Caecilianists' willingness to deal kindly with the Donatists after 411. Augustine wished to make the point that it was Emeritus at the 394 synod who had directed the Donatist condemnation of Maximian and his twelve ordaining bishops with a 'concentrated invective' (as Frend 1952: 217 described it), such as his references to Dathan, Korah, and Abiram of Numbers 16:32 and the passage from Romans 3:14-18, which Augustine had used before in Contra Cresconium (3.19.22, NBA, 16/1: 212; 4.4.5, NBA, 16/1: 328). Also, Emeritus had been key in the efforts to welcome the other repentant Maximianists back into their fold (Gesta cum Emerito 10, NBA, 16/2: 400-2). In Augustine's view these Donatists, exemplified in the person of Emeritus himself, were inconsistent: they persecuted the Maximianists through the legal system, so their complaints about the Caecilianists turning to the same law enforcement agencies rang hollow; they were prepared to welcome back some of the Maximianists but were not prepared to unite with the Caecilianists; and they considered the Caecilianists to be pollutants to their purity, yet they were prepared to be reconciled with most of the Maximianists, who must have been equally corrupting.

We can illustrate these three points from Augustine's statements that marked the climax of the encounter in Cherchell. When he targeted the Maximianists, Emeritus was like fire to hay, according to Augustine (Gesta cum Emerito 10, 
NBA, 16/2: 402). In contrasting the Donatists' welcoming back of the Maximianists with their obstinacy over Caecilian himself and his followers, Augustine wanted to highlight that the Maximianists and Caecilianists were in the same boat, either both guilty or both innocent: 'Alternatively, if you confess that you have received an innocent person [Felician of Musti], you confess that you have condemned an innocent one [Caecilian]' (Aut si fateris innocentis te fuisse receptorem, fateris te innocentis fuisse damnatorem) (Gesta cum Emerito 11, NBA, 16/2: 406). Augustine asked the silent Emeritus: 'I ask that he deigns only to explain to me how the shoots of the sacrilegious cuttings have not polluted them' (Rogo, mihi dignetur exponere, quomodo eos sacrilegi surculi non polluere plantaria) (Gesta cum Emerito 11, NBA, 16/2: 404). As Frend (1952: 218 n.7) observed, Augustine drew no attention to the fact that Donatists would only reconcile with those Maximianists who disowned Maximian. For them, this could mean that they would have to reconcile with Caecilianists who disowned Caecilian, something they were not prepared to do. There is something opportunistic and forced in Augustine's references to the ways in which the Donatists treated the Maximianists justifying the ways in which the Caecilianists had treated the Donatists in 411 .

\section{Conclusion}

The last part of Gesta cum Emerito in 418 is not a memory of the utopia that was supposed to flow for the church in Africa after the Caecilianists' victory in 411 . Emeritus's intervention during this encounter in 418 was minimal but effective. His refusal to engage diverted Augustine away from the outcome of the confrontation and back to the arguments that were presented during it. However, it seems likely that Augustine realised even before he saw Emeritus again in Cherchell that this would be the case. One cannot imagine that he just happened to have Epistula 128 at hand for Alypius to read out, as well as the gesta from the 394 synod at Ksar Baghai containing Emeritus's words. Emeritus's involvement in the Maximianist schism was vital for Augustine's efforts in proving that what the Caecilianists had achieved at Carthage in 411 was justified; the Donatists had done the same and therefore were inconsistent in condemning the Caecilianists for the very same practices.

All this was in an effort to demonstrate that, far from being a corrupt outcome, the decision of Marcellinus in 411 was the only feasible and legitimate one. The Donatist argument that they were persecuted was demolished by showing Emeritus to be a persecutor of the Maximianists. The Caecilianist position of desiring reconciliation was not incompatible with being Christian, as the Donatist willingness to reconcile with the Maximianists showed.

In part, Augustine saw the Caecilianist victory at the 411 confrontation in Carthage as a utopian moment. However, since Emeritus still would not accept that outcome, Augustine felt compelled to go back over some of the arguments that led to the 411 victory. Given the importance of Emeritus's role in both condemning the Maximianists and in later being willing to reconcile with them, the 
Donatist arguments used in 411 against the Caecilianists fell away, according to Augustine.

The memory to which Augustine referred during his 418 encounter with his old sparring partner Emeritus recalled the 411 defeat, but also, as the second half of Gesta cum Emerito indicates, the inconsistency of Donatist thinking and behaviour in the years leading up to that initial confrontation. This point was not reiterated at the confrontation (even though Augustine would claim that it had been central), but in Augustine's commentary on it in subsequent years. Augustine's memory was indeed dynamic. His tenacity in going over the same ground years after 411 demonstrates his determination to ensure that the Donatist schism would be overcome as much by intellectual persuasion and conversion as it was by judicial victory and imperial enforcement. Yet it was a persuasion based solely upon his version of events.

\section{Notes}

1 Ancient Caesarea in the province of Mauretania Caesariensis: see the map of the Byzantine Mediterranean at the front of this volume.

2 One thinks more of Petilian, bishop of Constantina (ancient Cirta, renamed Constantina, in the province of Numidia), or Parmenian and Primian, bishops of Carthage, or Gaudentius, bishop of the now-ruined Colonia Marciana Ulpia Traiana Thamugadi in the province of Numidia.

3 See Ep. 190, NBA, 23: 202-30; Merdinger (1997); and Lancel (2002: 348-50), for the circumstances of Augustine's trip to this remote province.

4 Frend (1952: 295), in speaking about the encounter on 20 September, called it a sermon. Nearly a decade later Augustine would recall his trip to Cherchell and his very florid sermon against the annual ritual of free-for-all blood sport (caterua) that divided the town (De doctrina Christiana 4.24.53, NBA, 8: 266-8; see Shaw 2011: 18-20). This non-extant homily, which is not our focus here, needs to be distinguished from both the sermo and gesta involving Emeritus.

5 On this restriction of the number of speakers see Gesta 1.10 (SC, 195: 578) and for the Donatist selection see Gesta 1.148 (SC, 195: 798-800).

6 Marone (2007-8) and Tilley (2011) discuss the problems of defining the two parties; and recently, (Miles 2016; Hoover 2018).

7 On those previous rulings, such as the 405 rulings against Donatists, e.g. CTh 16.6.4, to be enforced by CTh 16.11.2, see Marone (2015).

8 While Barr (1962), Donnelly (1977), and Lee and Dupont (2016: 100) reject the idea of De ciu. Dei being a utopian writing, this is because they rightly deny that Augustine was interested in political utopianism. However, this is not to say that Augustine was not interested in an eschatological and ecclesiological utopia.

9 For the rest we must rely upon Augustine's Breniculus and the capitula of the missing parts of the gesta.

10 These were the followers of Maximian, a Carthaginian deacon ordained bishop in opposition to the election of Primian as Donatist bishop back in 391 or 392 . After orchestrating the excommunication of Primian at a synod in the otherwise unknown Cebarsussa, Maximian was excommunicated at the synod of Ksar Baghai in 394 (ancient Bagai in the province of Numidia) (Augustine, Enarr. in Ps. 36/2.19, NBA, 25: 792-4; Frend 1952: 213-20; Gaumer 2012).

11 A topic on which Jonathan Conant says more in Chapter 3.

12 Gesta $1.145, \mathrm{SC}, 195.796-8$ and $2.3-5, \mathrm{SC}, 224.924-6$. For the symbolic meanings see Graumann (2011). 
13 All translations from this text are my own.

14 Mod. Souk Ahras, in the province of Numidia, where his friend Alypius was bishop.

15 As in Enarrationes in Psalmos 126.3 (NBA, 28/1: 141-3).

16 On Donatist rebaptism more generally see Merdinger (2015).

17 As revealed by Epistulae 141 (NBA, 22.308-22), 173 (NBA, 22.822-32); and 185 (NBA, 23.10-74; see Dunn (2017a); and Breuiculus 1.12 (NBA, 16/2.108-10); 3.8.11 (NBA, 16/2.142-4); 3.9.18 (NBA, 16/2.154); and 3.16.28 (NBA, 16/2. 174-6).

18 E.g., Epistulae 106 (NBA, 21/2.1044), 108 (NBA, 21/2.1048-80), and 118 (NBA, 21/2.1028-176); De baptismo 1.1.2 (NBA, 15/1.268); 1.6.8 (NBA, 15/1.280); 2.7.10 (NBA, 15/1.328); 2.12.17 (NBA, 15/1.338-40); 3.2.3 (NBA, 15/1.350); 5.5.6 (NBA, 15/1.446); 7.54.103 (NBA, 15/1.604); Contra litteras Petiliani Donatistae libri tres 1.11.12-1.19.21 (NBA, 15/2.40-50); 1.24.26-1.26.28 (NBA, 15/2.54-6); 2.7.16 (NBA, 15/2.70); 2.15.35 (NBA, 15/2.88); 2.20.45-2.21.48 (NBA, 15/2.96-100); 2.43.102-2.45.106 (NBA, 15/2.148-50); 2.58.132-2.59.134 (NBA, 15/2.168-70); 2.84.184 (NBA, 15/2.198-200); and 3.36.42-3.40.46 (NBA, 15/2.326-32); and Contra Cresconium 3.12.15-3.27.30 (NBA, 16/1.200-24); 3.43.47-3.45.49 (NBA, 16/1.250-6); 3.52.58-3.63.69 (NBA, 16/1.268-86); 4.1.1-4.18.21 (NBA, 16/1.320-56).

19 'causam ergo istam Maximianistarum cum toties obiecissemus in nostra Collatione, nihil aduersus eam dicere potuerunt' Gesta cum Emerito 8 (NBA, 16/2: 396).

\section{Bibliography}

\section{Primary sources}

Augustine (1967-77) Sermones. NBA, 25-28/2. Rome: Città nuova editrice.

—_(1969-92) Epistulae. NBA, 21/1-23A. Rome: Città nuova editrice.

(1979-2002) Enarrationes in psalmos. NBA, 29-35/2. Rome: Città nuova editrice. (1992) De doctrina Christiana. NBA, 8. Rome: Città nuova editrice.

(1998) De baptismo contra Donatistas. NBA, 15/1. Rome: Città nuova editrice, 266-606.

(1999) Contra litteras Petiliani Donatistae libri tres. NBA, 15/2. Rome: Città nuova editrice, 26-372.

(2000a) Breuiculus collationis cum Donatistis. NBA, 16/2. Rome: Città nuova editrice, 94-202.

(2000b) Gesta cum Emerito Donatistarum episcopo liber unus. NBA, 16/2. Rome: Città nuova editrice, 378-406.

- (2000c) Post collationem contra Donatistas. NBA, 16/2. Rome: Città nuova editrice, $220-324$.

(2000d) Sermo ad Caesariensis ecclesiae plebem. NBA, 16/2. Rome: Città nuova editrice, $336-56$.

(2002) Contra Cresconium grammaticum Donatistam libri quatuor. NBA, 16/1.

Rome: Città nuova editrice, 40-442.

CTh (1990) Edited by Mommsen, T. and Krüger, P. Codex theodosianus, vol. 1: Theodosiani Libri XVI cum constitutionibus Sirmondinis, part 2: Textus cum apparatu. Hildesheim: Weidmann.

Lancel, S. (1972-91) Gesta conlationis Carthaginiensis/Actes de la conference de Carthage en 411, SC, 194, 195, 224, and 373. Paris: Cerf. [Repr. as Lancel (1974)].

- (1974) Gesta conlationis Carthaginiensis anno 411 accedit sancti Augustini Breuiculus conlationis cum Donatistis, CCSL, 149A. Turnhout: Brepols.

Munier, C. (1974) 'Registri ecclesiae Carthaginensis excerpta'. In Concilia Africae a. 345-a. 525, CCSL, 149. Turnhout: Brepols, 182-228. 
Weidmann, C. (2016) Collatio Carthaginensis anni 411 (Gesta Collationis Carthaginensis; Augustinus, Breviculus collationis; Augustinus, Ad Donatistas post collationem), CSEL, 104. Berlin and Boston: De Gruyter.

\section{Secondary sources}

Alexander, J. S. (1970) 'The Donatist case at the conference of Carthage of A.D. 411'. PhD diss., St Andrews.

(1973) 'A note on the interpretation of the parable of the threshing floor at the conference of Carthage of A.D. 411'. JTS n.s., 24: 512-19.

(1977) "A note on the identity of the "man of God" of 1 Kgs: XIII in Gesta coll. Carthag. 3. 258'. JTS n.s., 28: 109-12.

(1984) 'Aspects of Donatist scriptural interpretation at the conference of Carthage of 411'. StP, 15: 125-30.

Barr, R. R. (1962) 'The two cities in saint Augustine'. Laval théologique et philosophique, 18: 211-29.

Brown, P. (2000) Augustine of Hippo: A biography, rev. edn. Berkeley and Los Angeles: University of California Press.

Donnelly, D. F. (1977) 'The City of God and utopia: A revaluation'. Augustinian studies, 8: 111-23.

Dunn, G. D. (2017a) 'Discipline, coercion, and correction: Augustine against the violence of the Donatists in Epistula 185'. Scrinium, 13: 114-30.

- (2017b) 'Ecclesiology in early North African Christianity: The parable of the wheat and the weeds'. Augustinianum, 57: 371-401.

- (2018) 'Romani principes adversum nos provocantur: Augustine of Hippo's Epistula 87 to Emeritus of Caesarea'. Scrinium, 14: 7-24.

Dupont, A., Gaumer, M. A., and Lamberigts, M. (eds.) (2015) The uniquely African controversy: Studies on Donatist Christianity, Late-Antique History and Religion, 9. Leuven: Peeters.

Ebbeler, J. (2012) Disciplining Christians: Correction and community in Augustine's letters, Oxford Studies in Late Antiquity. Oxford: Oxford University Press.

Eno, R. B. (1972) 'Some nuances in the ecclesiology of the Donatists'. Revue des études augustiniennes, 18: 46-50.

Fitting, P. (2009) 'A short history of utopian studies'. Science Fiction Studies, 3: 121-31.

Frend, W. H. C. (1952) The Donatist church: A movement of protest in Roman North Africa. Oxford: Clarendon Press.

Gaumer, M. A. (2008) 'The evolution of Donatist theology as response to a changing lateantique milieu'. Augustiniana, 58: 201-33.

_ (2012) 'The election of Primian of Carthage: The beginning of the end of Donatist Christianity?'. Zeitschrift für antikes Christentum, 16: 292-310.

- (2016) Augustine's Cyprian: Authority in Roman Africa, Brill's Series in Church History and Religious Culture, 73. Leiden and Boston: Brill.

Graumann, T. (2011) 'Upstanding Donatists: Symbolic communication at the conference of Carthage (411)'. Zeitschrift für antikes Christentum, 15: 329-55.

Hermanowicz, E. T. (2008) Possidius of Calama: A study of the North African episcopate at the time of Augustine, Oxford Early Christian Studies. Oxford: Oxford University Press.

Hoover, J. A. (2018) The Donatist church in an apocalyptic age, Oxford Early Christian Studies. Oxford: Oxford University Press. 


\section{Geoffrey D. Dunn}

Kaufman, P. I. (2007) Incorrectly political: Augustine and Thomas More. Notre Dame, IN: University of Notre Dame Press.

Lancel, S. (2002) St Augustine. Translated by Nevill, A. London: SCM Press.

Lee, G. W. and Dupont, A. (2016) 'Augustine's two cities revisited: Contemporary approaches to De civitate Dei'. Archiwum Historii Filozofii Myśli Społecznej, 61: 79-105.

Marone, P. (2007-2008) 'The use of the term "Catholic" in the Donatist controversy'. Pomoerium, 6: 81-91. $71-84$

Merdinger, J. E. (1997) Rome and the African church in the time of Augustine. New Haven and London: Yale University Press.

_ (2013) 'Before Augustine's encounter with Emeritus: Early Mauretanian Donatism'. StP, 70: 371-9.

(2015) 'In league with the devil? Donatist and Catholic perspectives on prebaptismal exsufflation'. In Dupont et al. (eds.), 153-77.

Miles, R. (ed.) (2016) The Donatist schism: Controversy and contexts, TTH, Contexts, vol. 2. Liverpool: Liverpool, University Press.

More, T. (1516) Utopia: Containing an impartial history of the manners, customs, polity, government, etc., of that island. Translated by R. Robinson. London, 1551.

Raitiere, M. N. (1973) 'More's Utopia and the City of God'. Renaissance Studies, 20: 144-68.

Raven, S. (1993) Rome in Africa, 3rd edn. London and New York: Routledge.

Sears, G. (2011) The cities of Roman Africa. Stroud: The History Press.

Shaw, B. D. (2011) Sacred violence: African Christians and sectarian hatred in the age of Augustine. Cambridge: Cambridge University Press.

Tilley, M. A. (1991) 'Dilatory Donatists or procrastinating Catholics: The trial at the conference of Carthage'. Church History, 60: 7-19.

(1997) The Bible in Christian North Africa: The Donatist world. Minneapolis: Fortress Press.

(2011) 'Redefining Donatism: Moving forward'. Augustinian Studies, 42: 21-32.

Weidmann, C. (2015) 'Recording and reporting the Gesta collationis Carthaginiensis: Problems and solutions'. In Dupont et al. (eds.), 85-100. 


\section{Part II}

\section{Forging a new utopia}

Holy bodies and holy places 
$\because$ Taylor \& Francis Taylor \& Francis Group http://taylorandfrancis.com 


\title{
$5 \quad$ Purity and the rewriting of memory
}

\author{
Revisiting Julian's disgust for the \\ Christian worship of corpses and \\ its consequences
}

\author{
Wendy Mayer
}

As Bronwen Neil points out in the introduction to this volume, utopianism is allied with laying claim to a pure religion. Utopianist discourses of this kind, as she explains, are ideological and seek to reclaim or restore a pristine past, a past that is rarely real and is more often imagined. The consequences can be not just discursive but also physical, resulting in a literal reconfiguration of the landscape. In this chapter, in seeking to understand how both discourse and action of this kind come about, I appeal to research and theories from the cognitive sciences. My concern is with what purity, when it is invoked, activates in the brains of both listeners and religious actors.

Before proceeding, some background is in order. This chapter is part of a larger research project on religious conflict in Late Antiquity. ${ }^{1}$ Interrogating the precise nature of the relationship between religion and violence (Mayer forthcoming) has led me to question how we should approach reported violence in the literature of Late Antiquity. The questions asked until now have for the most part been: Was the reported violence real? To what degree are such accounts accurate or exaggerated? Questions of this kind drive the lively debates in recent scholarship about whether as many Christians were really martyred in various times and places as our sources report (e.g. Moss 2013; Teitler 2013; Harrison 2017) and how many temples and synagogues Christians really destroyed or whether these incidents are over-reported (e.g. Hahn et al. 2008; Dijkstra 2011; Busine 2013). My current conclusion is that it is perhaps more useful to ask: What does the narrative violence $d o$ to the community reading and listening to these texts? And how does this in turn help us to understand the production of such narratives in the first place? The thesis put forward here is that recent advances in the cognitive sciences offer explanatory models that encourage us to interrogate late-ancient narratives in this way. Further, these same models allow us to explore the agency not just of reported violence but also of narratives that commemorate past resistance and acts of desecration. ${ }^{2}$ Narratives of this kind, as I hope to show, provide the scaffolding for ideological constructions of the past, as well as setting off a chain of actions and reactions in the present that have future consequences. 
This chapter proceeds in three parts. In parts one and two I adduce two case studies, both associated with the city of Antioch in the second half of the fourth century. The first concerns the emperor Julian's disgust for the martyr cult, the second John Chrysostom's treatment of Jews and Judaisers. The two are interconnected, as I will show. In part three I draw larger conclusions about the implications to be drawn and about the role each narrative might have played in the climate of Antioch.

\section{Case study one: the emperor Julian and the martyr cult}

The first case study centres on the emperor Julian and his response to the emerging martyr cult among Christians. Much has been said in scholarship already about his disgust for the martyr cult (Cook 2002: 294, 322-6; Torres 2009; Finkelstein 2018: 120-7) and his response to the 'contamination' by the relics of the local martyr Babylas of the oracle at the Temple of Apollo in Daphne (Hahn 2004: 161-73; Célérier 2013: 333-57; Shepardson 2014: 58-91). The concern here is to look at these events more closely from Julian's perspective. What was it that led him to rewrite the landscape of Late Antiquity by moving Christian bodies? By focusing on the language of pollution and disgust that permeates Julian's writings on the topic, I explore the utility of Moral Foundations Theory (MFT) for explaining both the agency of Julian's discourse in escalating anti-Christian feelings of disgust and why the bodies of the Christian dead were a particular target.

To put this in context, when we read Julian's surviving writings carefully, although older scholars characterise him as religiously conservative and, along with the 'theurgic Neoplatonists,' militantly anti-Christian (e.g. Bregman 1997: 350), Julian himself for the most part promoted freedom of religious practice and tolerance between religions, among which Christianity, for all his dislike of it, is included. ${ }^{3}$ The most recent study of his alleged 'war on Christianity' in fact calls for careful distinction between 'persecutions started by Julian himself and those that were perpetrated in his name but without his consent or knowledge' (Teitler 2017: 5). It concludes that the evidence for active persecution of Christians by Julian is slim and that he strictly rejected violence (Teitler 2017: 141). Julian's tolerance includes instruction to the citizens of Bostra to avoid violent action towards Christians, even though Christians themselves, as he claims, are responsible for inciting civic violence (ep. 114, Bidez 1924: 193-5, esp. 195.13-18). That is, no matter the provocation at the state, polis, or personal level, he argues, one should not respond to violence with violence. Eirenic as this overt message is, however, there is a second covert message promoted at the preconscious level by Julian's consistent deployment in regard to Christians of the language of pollution. Ep. 114 concludes, for instance, with reference to the penalty that will come 'to those who have turned aside from the gods to corpses and relics' (195.21-3), while throughout his writings his most common label for Christians, in addition to 'Galileans,' is 'those who worship a corpse' (CG 194D, 205E_-206A, Masaraccia 1990: 138.13-16, 142.2-7). This latter expression encourages contempt for a religion that venerated a god in corporeal form whose body was subject to those most polluting of corporeal 
processes, death and putrefaction. The two messages - that of peace, tolerance, and anti-violence, on the one hand, and of pollution and disgust, on the other-would not only have aroused conflicting responses in the listener, if heard or read often enough; the latter message is more likely to have had priority. In a moment I will explain why this is the case, and in particular why, despite his stated policy of religious freedom, in his actions against Christians, dead bodies were a singular target rather than buildings, statues, or other material objects of veneration.

Before I do this, however, we should place Julian's response to Christian veneration of dead bodies and their tombs in context. As Torres points out (2009: 211), the Christian veneration of martyrs' physical remains, let alone the distribution of them, was in the early 360s not universally accepted across the empire by Christian leaders, particularly in the West. For many the old beliefs concerning the polluting effect of corpses persisted. Together with Julian, for these Christians the cult of the martyrs constituted necrolatry. The strict purification rituals required in order to properly worship the gods after even the sight of a dead body lay at the heart of such anti-martyr attitudes (Retief 2005a, 2005b). If to venerate god or the gods after actual physical contact with a corpse or to situate a corpse inside civic boundaries was abhorrent, to situate a corpse inside the temenos of a temple or church - buildings in which a god or gods were numinously present - let alone venerate or worship a corpse itself, was in this context unthinkable. Julian himself famously sums up this point of view in the explanation that accompanies his edict on funerals:

The thing is in every way intolerable. For those who meet the funeral are often filled with disgust ( $\left.\alpha \eta \delta \delta^{\prime} \alpha\right)$, some because they regard it as an evil omen, while for others who are on their way to the temples it is not permitted (ov $\theta \varepsilon \dot{\varepsilon} \mu \varsigma$ ) to approach for worship till they have cleansed themselves from the pollution ( $\pi \rho \mathrm{i} v \dot{\alpha} \pi \mathrm{o} \lambda \sigma v ́ \sigma \alpha \sigma \theta \alpha \mathrm{l}$ ). For after such a sight it is not permitted to approach the gods who are the cause of life and of all things most alien to

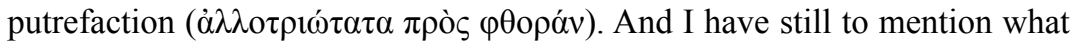
is worse than this. And what is that? The sacred precincts and temples of the gods lie open; and it often happens that in one of them someone is sacrificing or pouring libations or praying, at the moment when men carrying a corpse are passing close by the temple itself, and the voice of lamentations and speech of ill omen is carried even to the altars.

(ep. 136b, Bidez 1924: 199.18-200.1; Wright 1923: 193-5, modified)

After explaining further why it is appropriate for funerals - per the link between the gods of the underworld and souls of the dead-to be conducted after dark and before dawn, Julian concludes: 'let the pure day be consecrated for both pure

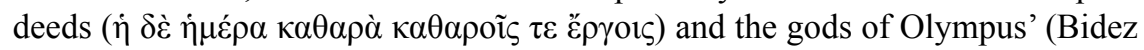
1924: 200.23-4).

The implications of the language Julian uses here become evident when we turn to the findings of recent experimental research on disgust, contamination, and 
purity in the field of moral psychology. Disgust, for these researchers, is more than an emotion. It is an emotion that is, in essence, morally encoded (Strohminger and Kumar 2018). To put it in very simple terms, while what triggers disgust (together with the behaviour that disgust activates) is culturally determined - a matter of nurture (Feder 2016a) - the cognition of disgust is common across cultures - a matter of evolution or how the brain is wired (Rottman et al. 2018). The emotion is associated with the activation of a reflexive moral judgement at the preconscious level in the brain, which the individual may rationalise after the fact, but of the source of which this same individual is usually unaware (Haidt 2012). The priority in the decision-making process of gut instinct over reason in the case of what the researchers label moral foundations is without exception (Haidt 2012: 32-60). Disgust is the characteristic emotion associated with the purity/degradation foundation or intuition (Haidt 2012: 146). This is one of five moral foundations identified as the universal cognitive modules upon which cultures construct moral matrices that facilitate group cohesion (Graham et al. 2013). Supported by extensive analysis of the anthropological literature, these have been extracted from the adaptive challenges of social life discussed by evolutionary psychologists (Haidt 2012: 146). The purity/degradation moral matrix is considered an evolved response to the particular challenge the individuals within social groups face in respect to keeping themselves and their 'kin free from parasites and pathogens, which spread quickly when people live in close proximity' (Haidt 2012: 146). ${ }^{4}$ A high death rate from poor hygiene together with the spread of infection can rapidly undermine a group's viability and prosperity. Explaining how and why a direct link cognitively between physical hygiene and moral and religious purity occurs has been a recent concern of moral psychologists. Equally recently, this explanatory model has been applied with considerable success to ritual purification prescriptions and behaviours in ancient Near-Eastern and Hebrew religion.

In a series of recent articles Feder explores at length how, in Mediterranean Near-Eastern cultures, physical contagion as a result of contaminants like dirt, faeces, or corpses became intuitively and cognitively linked to concepts of pollution, sanctity/purity, and desecration (Feder 2013, 2016a, 2016b). Of particular interest is his investigation of the associated development of religious systems of purificatory and avoidance responses, even when the perceived contagion was no longer literal. What Feder contributes to the discussion is a useful explanation for how the moral matrix constructed by individual societies on the common purity/ degradation foundation becomes culturally encoded. Each society develops a 'pollution theory,' which informs culturally conditioned ways of viewing contamination and culturally specific ritualised actions and responses. That is, while contamination avoidance or disease avoidance is a commonly evolved human behaviour, the pollution beliefs linked to that response are culturally variable (Feder 2016a). Feder argues for a feedback loop between individual (gut-level) contamination appraisals and (rationalised) collective pollution beliefs or theories to the point that the latter themselves can become automatic within a particular culture or society. It is those pollution theories that 'will define whether contact with a contaminant (e.g., excrement, corpses) is inherently dangerous, or whether 
this threat is restricted to a particular (e.g., religious) context, and they will also suggest the means by which this contamination can be removed (purification)' (Feder 2016a: 1577).

In both Graeco-Roman and ancient Near-Eastern societies bodily emissions and blood were significant triggers. The study by Bond (2016) of taboo trades demonstrates how pervasively the pollution theories associated with these contaminants impacted law codes and social interaction in Roman culture. Their implications for ritual behaviour in Greek religion is brought out by Parker (1996) and in Roman religion, Lennon (2014). In that context, as in many societies ancient and modern, corpses, which decayed and leaked bodily fluids and odours, were of particular concern as a source of pollution. That collective pollution beliefs or theories can become automatic or intuitive within a particular culture links in turn to the 'moral common-sense' discussed by the moral psychologists - something that I will elaborate on further in case study two. This can differ from group to group, often bringing groups into conflict.

It is here that we return to the emperor Julian and his accusation that Christians worship a corpse, his disgust with their veneration of the corporeal relics and tombs of martyrs, and his deep concern with the polluting effect of those bodies on the gods and their priests and worshippers. Within the framework just described and within the context of Graeco-Roman pollution theories, which remained prevalent in Late Antiquity, we can see that Julian's response is informed by a moral common-sense that is as inevitable as it is natural. All the indicators that for Julian the purity/desecration intuition had been triggered are present in the passage cited previously. There he explicitly connects with the emotion of disgust the effect sight of a corpse has on the viewer (ep.136b, Bidez 1924: 199.19-20). Twice he points out that it is sacrilegious to approach the gods without having washed off the pollution from a corpse or in a state of impurity (199.20-4). The gods themselves, he claims, are at the other end of the spectrum from putrefaction or decay and are strongly associated with purity (199.22-3). It is also noteworthy that he says that just seeing a corpse or having it pass by can render the viewer impure and that the temple precincts are open and vulnerable to contamination by the sound of the mourners' wailing (199.25-200.1). Underlying these pollution theories for Julian, and readily understood in the ancient to late-ancient Mediterranean world, are medical ideas about how disease spreads and thus how sound, smell, and sight are vehicles for infection. ${ }^{5}$

Recognition of how powerful in the late-ancient world these pollution theories were helps to make sense of how, on the one hand, Julian could at a rational level propose tolerance of all religions, including Christianity, and at the same time at a gut level target Christian practice in relation to dead bodies as something that was literally detrimental to pure worship of the pure gods. It is in this light that we should view Julian's removal of Christian bodies from pagan sites, although it should be noted that only cases documented by non-Christian sources are likely to be reliable. ${ }^{6}$ Examples are his order that the bodies of Babylas and other Christians be removed from the temenos of the Temple of Apollo at Daphne, which Julian himself mentions (Mis. 33-4, Nesselrath 2015: 203) along with Ammianus 
(22.13.1-3, Seyfarth et al. 1978: 1.279) and Libanius (Or. 60.5, Foerster 1908: 314-15), and his order that a number of bodies be dug up and moved from the Castalian spring at Delphi. In this latter case, recorded by Ammianus, the same ritual used by the Athenians to purify the island of Delos is said to have been enacted (Amm., 22.12.8, Seyfarth et al. 1978: 1.178). It should be noted, however, that in neither case does Julian order that the bodies be destroyed. They are relocated so that purity can be restored to each site. In the case of Babylas, that Christian veneration following the translocation continued uninterrupted is well documented (Mayer and Allen 2012: 43-8). This speaks against the reliability of the Christian historian Sozomen's accusation (HE 5.20.7, Hansen 1995: 227) that Julian ordered the governor of Caria to burn down and demolish the martyrs' chapel next to the Temple of Apollo at Didymium, near Miletus. Julian's policy in regard to martyr bodies at other sites does not support deliberate destruction of a building, although it is unsurprising that his intentional disinterment and translocation of bodies were viewed as desecration by Christian communities. His actions were not intended to obliterate the memory of Christian martyrs from the landscape, but rather to displace them in memory so that the pure and true religion of the gods of the past was restored to priority.

Exploring the agency of concepts of purity and disgust in how memory is shaped is useful from another perspective. If Julian himself did not destroy Christian tombs, he does supply evidence that there were others within the wider community who took his rhetoric of disgust as a licence for violent anti-Christian behaviour. Research concerning the impact of emotional rhetoric on the brain of the listener and regarding the cognitive link between language and action suggests that Julian's rhetoric of disgust and pollution tapped into a strongly instantiated purity/desecration intuition on the part of some of his listeners. ${ }^{7}$ The moral judgement thus activated had behavioural entailments. In his Misopogon Julian refers to citizens of Emesa who had set fire to Christian tombs and to people near Antioch who had both destroyed Christian tombs and attacked Christians (Mis. 28, 33, Nesselrath 2015: 198.28-9, 202). In the context of a satire it is hard to know how to treat Julian's claim that he had given the signal for this attack and that the attackers had been more stirred up than Julian had intended. In his letters to the citizens of Bostra (ep. 114, Bidez 1924: 195.15-18) and to Atarbius (ep. 83, Bidez 1924: 143-4), however, his claims that he has to keep admonishing enthusiasts of the 'true religion' to stop physically and verbally attacking Christians suggests at the very least that his rhetoric implicitly encouraged such anti-Christian violence on the part of the general populace, even if he himself explicitly discouraged it.

That there is a complexity to teasing out the agency of subliminal messages is indicated by one final example in this regard. ${ }^{8}$ In a letter to the citizens of Alexandria, Julian takes them to task for their violent murder of the Christian bishop, George of Cappadocia, allegedly in retaliation for his anti-pagan policies. Here Julian explicitly charges the Alexandrians themselves with desecration of the city

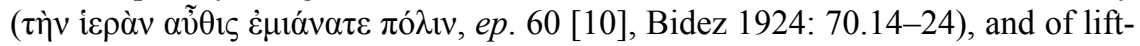
ing up to the gods hands stained with blood. At the same time he faults them not for the deservedness of their actions - he agrees that George has committed 
extremely sacrilegious acts ( $\tau$ òv óví $\alpha \tau \alpha \delta v \sigma \sigma \varepsilon \beta \eta ́ \sigma \alpha v \tau \alpha)$ —but that they addressed George's sacrilege by illegal means. 'I want to praise you,' he writes, 'but I cannot, because you have committed a crime' (Bidez 1924: 70.14-24). As he concludes the letter, Julian in fact lets them off the hook, making it clear that he sympathises with their actions (Bidez 1924: 70-2) and thus implicitly supports them. The subconscious message conveyed by this letter is that the pollution caused by the murder is expiated by its justification, perhaps even effecting a purification of the city by exterminating a more serious source of pollution.

\section{Case study two: Jews, Judaisers, and John Chrysostom}

My second case study involves the notorious anti-Jewish homilies delivered in Antioch twenty-five years later by the presbyter John Chrysostom. These were preached to a sectarian group within the larger Christian community. ${ }^{9}$ Although hom. 1 is the most excessive in its imagery, for methodological reasons to do with the repeated effect of emotional rhetoric on the brain and neural binding, I focus here on the sequence of six homilies delivered over four weeks in autumn 387 (hom. 4, 2, 5-7). Whereas the bulk of arguments to date have drawn primarily from hom. 1 (preached in 386), my interest lies naturally with the other six because it is in constant and repeated activation of particular neural circuits associated with specific conceptual metaphors, intuitions, and frames, that, as I will argue, individuals and groups become increasingly convicted of a particular position. For the purposes of my argument I will also gloss over the extensive scholarly discussion about the target and addressees of the homilies-whether Judaisers or Jews - and assume that, since in the minds of the listeners the categories 'Jew' and 'Judaiser' would have been collapsed, negative emotions and actions on the part of the audience would have been directed primarily towards Jews. I also assume that the persons John himself conceived of as 'Judaisers' were not present. That is, regardless of what Christians in his audience practised themselves and how blurred the boundaries between Judaism and Christianity in regard to ritual and praxis really were, the rhetorical Judaiser in these homilies is intentionally constructed as something distinct and other from the audience-in fact, not a half-Christian, but a half-Jew - and that this would have fed into the concepts and emotions about Jews being activated by their language. ${ }^{10}$ What we have instead, I argue, is a cluster of homilies being preached to insiders of the sectarian Meletian-Nicene Christian group in service of a two-fold strategy, as identified by Côté (2012). That is, as he puts it, in order to achieve dominance within poly-religious Antioch the Meletian sect, on the one hand needed concurrently to prove that it surpassed the other Nicene sect in orthodoxy and to disqualify the homoians as heretics; on the other, to demonise as enemies its external rivals, the Greeks and Jews.

With these caveats and constraints in place, we now turn to the six homilies preached in 387 and John's diagnosis of Judaisers as sick with 'the Jewish disease' (Mayer 2019: 102). This is of considerable interest in light of the reappraisal of the cognitive function of rhetoric that has taken place over the past 
three decades, which now counters the highly influential argument put forward by Wilken (1983). Where Wilken argued in essence for indifference on the part of the fourth-century listener on the basis that the rhetorical excess that the homilies exhibit was normative - that the homilies were ineffective because the listeners had heard it all before-it is precisely because the rhetoric was so normative that we should expect that the homilies were effective. That is, we should presume that the most commonly used metaphors tapped into ways of viewing the world that in the fourth century were commonly held and, through repetition, thus conceptually strengthened them. A way of looking at language, and especially metaphoric language, that was unthinkable when the Age of Reason held sway in the 1980s - when Wilken wrote John Chrysostom and the Jews - is now in an era of politicians like Donald Trump, Rodrigo Duterte, and Marine Le Pen extraordinarily persuasive. Indeed as Musolff (2007: 23) argues in his analysis of the metaphors prevalent in Hitler's discourse:

The metaphors that Hitler employed were by no means particularly extravagant or unconventional; on the contrary, they largely consist of well-worn phrases and idioms and, even when they focus on the Jews as the target of his greatest hatred, they are not creative as regards their 'image' content.

As Musolff (2007: 25-31) proceeds to show, it is precisely the conventional body-disease metaphor in the Adversus Iudaeos homilies Wilken (1983: 117), labelled 'much overworked,' that in Hitler's political rhetoric became blended with a number of other metaphoric concepts, leading to the highly problematic inference that quarantining and ultimately killing off the Jews was an appropriate therapy for racial blood-poisoning. When we combine Conceptual Metaphor Theory with Moral Foundations Theory - the one from cognitive linguistics, the other from experimental moral psychology - we can come to understand how such metaphors can covertly subvert reason in the brain with the result that such inferential judgements become moral common-sense.

That said, I do not by any means claim that exactly the same blending with its horrific consequences takes place in John's homilies against the Jews. For one thing, the parasite as pathogen metaphor that played a significant role in Hitler's anti-Semitic discourse is, as Musolff (2014) points out, based on a specifically modern understanding of parasites. What did remain unchanged from the fourth to twentieth century, however, and what underwrites both sets of anti-Jewish discourse, is the metaphor of 'the body politic.' The concept of the nation, or, in John's case, the church, as a body is ancient and goes back at least to the time of Plato (Musolff 2007: 25-6). And the idea that an entire social group can be affected by non-literal disease - such as infected by revolution or contaminated or polluted by murder - is, as Lloyd (2003: 7) has pointed out, a prevalent and potent concept within the ancient Greek imagination. These concepts are equally valent in the Roman legal system and society (Bond 2016). Indeed, as Fournier (2016, cf. Ralph 2016) demonstrates, this translates in Christian Late Antiquity into the intuitively natural concept of exile as amputation. That is, if the Christian body has 
a part that has become necrotic - i.e. with heresy - then the appropriate therapy is to cut off the gangrenous part so that the rest of the body remains healthy and uncontaminated. How this metaphoric concept translates into action is determined by how the disease or sickness is conceptualised and with what other concepts the body-sickness-cure metaphor is blended. In the homilies Adversus Iudaeos the metaphor is complicated by its blending with the concept 'The Church is a family' (Mayer 2019: 118-19), directing listeners towards conflicting inferences. When the concept 'A Judaiser is a brother/sister' blends with the concept 'The Church is a body,' and part of that body (Judaisers) is sick with the Jewish disease, the inference is that the sickness is not fatal and Judaisers can and need to be cured. When 'the Jewish disease' is strongly associated with blood pollution-Jews are Christ-killers - the inference is that Judaisers are infectious and their sickness capable of killing healthy Christians. They need to be amputated or excised. Both sets of ideas mingle confusingly within the homilies.

When we turn to how these concepts are applied to the Jews within these homilies, in the context of Graeco-Roman society and the late-antique householdboth of which are hierarchical and demand strict discipline and punishment- the inferences they intuitively encourage in the minds of their listeners are particularly disturbing. Here I draw attention in greater detail to the five moral intuitionscare/harm; fairness/cheating; loyalty/betrayal; authority/subversion; and sanctity/ degradation-Haidt and his colleagues are in the process of experimentally confirming as foundational to social group cohesion (Graham et al. 2013; Haidt 2012: 146 fig. 2). These five foundations, they argue, sit beneath all preconscious moral judgements in all societies. Here it is important to remember that the bulk of neuroscientific research in moral cognition accepts that moral decision-making occurs at the instinctual level first and is rationalised after the fact (Clarke 2014: 74-81). The work of both Greene and Haidt further explains how these preconscious moral intuitions that enable social groups to cohere also facilitate moral blindness towards other groups. For Greene, the moral common-sense of one group butts up against the moral common-sense of another (Greene 2013: 4-5). For Haidt, that moral common-sense lies in the degree to which a group places emphasis on each of the five moral foundations (Haidt and Graham 2009). Strong emphasis on loyalty, authority and sanctity encourages strong ingroup-outgroup bias and exclusion of those who are perceived as disloyal, not submissive to authority, and impure. Strong emphasis on care and fairness encourages greater inclusivity and inter-group tolerance or collaboration.

Turning back to the body-illness-cure metaphor, I discussed in case study one the direct conceptual link in the ancient Mediterranean world between health and religious purity. In both the ancient Near-Eastern and Graeco-Roman worlds the categories 'infection' and 'defilement' were not just conflated; religious pollution was conceived of as literally contagious (Feder 2013: 155-9). This has important implications cognitively for the constant assertion in the homilies that, while Judaisers are sick with the Jewish disease, the Jews, who carry that contagion, are sacrilegious and impure (Mayer 2019: 105 n.166). Further, that the Jews are repeatedly said to be not just sacrilegious, disgusting, and unclean but also 
criminals and murderers (Mayer 2019: 105 n.167) would have activated a very particular set of concepts in the audience's minds. Within Christianity's parent cultures there was a strong conceptual link between cleanliness, religious pollution, crime, and punishment. Murder, the charge most commonly adduced against the Jews in the homilies, tainted the offender with blood pollution, pollution required expiation, and thus in the case of acts that rendered the offender polluted the penalty tended towards retributive rather than restitutive or compensatory justice (Feder forthcoming).

In a retributivist as opposed to restitutive approach, as Feder puts it, penalty is concerned with the moral culpability of the wrongdoer. The offender is deemed to 'deserve' punishment and 'justice is defined by the past-facing orientation of making the punishment fit the crime' (Feder forthcoming). Prior to the emergence of MFT the cognitive linguist Lakoff attempted to make sense of this by viewing retributive justice as an entailment of Strict Father morality, in which Moral Strength, Moral Authority, and Moral Health are core concepts (Lakoff 2002: 65-104). Within this conceptual framework and its accompanying narrative, children who are ill disciplined 'need to be punished strictly and painfully when they do wrong, so they will have an incentive to do right in order to avoid punishment' (Lakoff 2009: 78). In essence, within this particular morally informed view of crime and punishment the 'hivist' moral foundations (loyalty/betrayal, authority/ subversion, sanctity/degradation) are being invoked. The significance for our argument here is that in these homilies it is a Strict Father view of society and the household that is preconsciously culturally dominant. That is, John is preaching from the perspective of, and to an audience immersed in, Graeco-Roman cultural norms. This is a hierarchical patriarchal society in which, along with the maintenance of civic and Roman loyalty, the concept of male authority in every sphere (domestic, administrative, military, imperial, ecclesiastical) is normative, and in which concepts of pollution and purity are an explicit part of everyday life. That this is a society with a Strict Father view of justice we see in the assertion in these homilies that it is appropriate for a master to punish (by whipping) a domestic slave - an assertion with disquieting potential anti-Semitic entailment when we consider that the bulk of hom. 5 is concerned with remembering the three periods of slavery that the Jews endured, and concludes with the assertion that God never set an end to the third period and that this continues to the present day (Mayer 2019: 108). Whether the Jews are metaphorically being conceived of as slaves or children, throughout the first four of the six homilies preached in 387 Jews are consistently being promoted as morally weak and ill-disciplined and in need of strict punishment (Mayer 2019: 108 n.178).

If we consider that the audience was predisposed neurally to receptivity towards this concept (that it is one's moral duty to teach Jews discipline through harsh punishment), since it conformed to their entrenched experiential narrative framework, then we need to consider that for a member of late-ancient Graeco-Roman society the normative consequences for blood pollution held equal valency. That is, that although John Chrysostom never once says 'the Jews should be executed; they deserve it,' for a person listening to all six homilies in 387 this would have 
been a natural inference. Capital punishment was the assumed penalty for homicide within the ancient to late-ancient Greek and Roman worlds (Hillner 2015: 82-4). Whether it was enforced in every case is irrelevant for our purposes. What is important is that it was conceived of as a natural and inevitable consequence. Of further significance for the mutual activation of the fairness/cheating and sanctity/ degradation foundations via the rhetoric of these homilies is recognition that within a purity-crime-punishment framework the death penalty, while concerned with expiation and retribution (making the punishment fit the crime- a life for a life) as well as moral responsibility (the deservedness of the punishment), was conceptually and perhaps even more importantly concerned with social anxiety and social hygiene. Blood irreparably stains (Lennon 2014: 90-135, Parker 1996: 104-43). Execution, conceived of as ritual purification, removed permanently from the body politic a source of otherwise ineradicable pollution and potentially fatal infection. Also native to this moral framework is the concept of justifiable homicide. The killer remained pure, for instance, if the internal social threat was transformed into an enemy, externalising the threat of contamination to the community (Eck 2012: 323-81). When blended with the body-illness-cure scenario, the enemy becomes a hostile pathogen that it is necessary and justifiable to exterminate to restore health to the body.

That both Judaisers and Jews were morally weak and that the Jew was constructed as an enemy in these homilies is confirmed by Mullen's analysis (1990) of a narrative frame to which the metaphoric systems in these homilies contribute. He identified three major metaphor families. These have been overshadowed by the emphasis on hom. 1, with its picture of the Jews as animals and synagogue as demonic and a den of thieves. The three domains posited by Mullen are legal (fairness, cheating, justice); medical (body-illness-cure); and military (battle, enemy, defence, victory-defeat, war-wounded, surveillance, weaponry, church as army). What Mullen identified is what Graham and Haidt (2012) now label an ideological narrative of the kind that establishes sacred values that must be protected and that engenders inter-group hostility and violence. Within the homilies, it is the Jews, not Judaisers, who are the villains, and the ideological narrative runs as follows: The Christian way of life is sacred; it is constantly being contaminated/ attacked by the Jews, who have seduced away/infected Christians with Judaism; if we could just vanquish the Jews and their way of life, Judaising would cease, and the pure Christian way of life would be restored.

\section{From Julian to John Chrysostom: the consequences of moral framing}

This brings us to part three. When we read the religious rhetoric of Late Antiquity through the lens of cognitive theory concerning pollution appraisals, conceptual metaphors and frames, moral intuitions and judgements, and ideological narratives, our attention is drawn to the importance not of what a text says on the surface, but of what message it activates at the preconscious level in the brains of its listeners. This message is often unintentional. For historians attempting to trace 
the relationship between cause and effect, that relationship, although predicated by this research as direct, at first glance seems minimal and counterintuitive. But that is precisely the point. Reason has little role to play when moral intuitions and the narratives associated with them are activated. More to the point, the activation of such intuitions can have far-reaching consequences. Once we are attuned to Julian's religiously and culturally encoded disgust of corpses, the motivation behind his policy of rebuilding the Jewish temple in Jerusalem takes on another dimension. This is the period in which mimetic shrines and cultic rituals were being established by the Christian communities in Jerusalem that elevated the life and death of the Christian's incarnate god, overwriting and displacing the Jewish history of the city (Kalleres 2015: 115-48). Dominating all this was Christ's tomb and the Church of the Holy Sepulchre, which stood in stark contrast to the rubble of the abandoned Temple Mount. When we consider the emphasis this topography gave to veneration of Jesus the Judean's corpse, restoration of the temple by Julian can be read as a project intended simultaneously to destabilise the veneration of the corpse of the Christian god and, in restoring the proper blood sacrifices of the ancient Hebrew religion, purify the city.

Exploration of Julian's moral common-sense in regard to the contamination appraisals triggered by corpses is helpful at another level. It offers support for Teitler's (2013) negative conclusion regarding the alleged execution by Julian of Christians during his reign, especially the claim that this gave rise at Antioch to a new wave of indigenous martyrs. The Christian discourse of Julian as a persecutor is in this respect at odds with what we can now say about his religious sensibilities. Given his deep disgust with the martyr cult and his concern for the polluting effect of bodies, the last thing Julian would have wanted was to escalate devotion by Christians to their martyrs by creating new ones. As Teitler (2013) points out, in instances where Julian did execute individuals, legitimate legal grounds were adduced, usually a charge of treason. It is Christians who styled them as martyrs, as a result of their own opposing moral common-sense and its consequent ideological narrative. Equally, Julian's programme to rebuild the Jerusalem temple, even though never achieved, set off markedly hostile reactions within the Christian community. In Chrysostom's homilies against the Jews the temple and its continued obliteration feature prominently (Brändle 2013).

In Christian memory the two actions (Julian's 'persecution' of Christian bodies and temple programme) became intertwined. Not long after 387, when he directs his audience to recall Julian's reign, Chrysostom consciously aligns that emperor's actions concerning Babylas's body with the failure of his temple rebuilding programme (De laudibus sancti Pauli hom. 4.6, Piédagnel 1982: 190-4). The intuitive framing behind this becomes clear in that homily when John uses language of desecration and pollution to describe Julian and his actions (Piédagnel

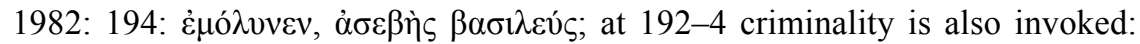
$\pi \alpha \rho \alpha v o ́ \mu o v, \pi \alpha \rho \alpha v o \mu i ́ \alpha)$. As in John's homily on St Babylas, ${ }^{11}$ the emperor and his actions are repeatedly punished with divine retribution. A fire breaks out at the building site of the temple in Jerusalem and permanently halts construction; lightning burns down the Temple of Apollo, forever silencing its oracle; while 
Julian's actions are terminated when he is killed at the Persian front, a de facto form of righteous capital punishment. Viewed through a cognitive lens, we can see that the way in which Julian's moral common-sense expressed in actions and policies in the $360 \mathrm{~s}$ in turn triggered and neurologically strengthened among local Christians an opposing moral common-sense, giving rise by the $380 \mathrm{~s}-90 \mathrm{~s}$ to an ideological narrative in which Julian was the villain and in which good triumphed over evil. Chrysostom's anti-Jewish orations at Antioch sit naturally within this larger picture. When narratives heighten local tensions in this way, they can result in hostile behaviours. We might suspect that the bodies, houses, shops, and religious sites of the local Jews of Antioch, even though they had only a marginal stake in these hostilities, took on collateral damage (the conclusion of Mayer 2019).

\section{Conclusions}

This said, what larger conclusions can we draw? Explanatory theories of this kind illustrate that, if we wish to study behavioural cause and effect, the preconscious messages that narratives of this kind activate in the brains of their listeners are likely to prove more important than the messages that these narratives convey at the rational level. Narratives of the triumphant smashing of pagan statues or the burning of temples may not reflect historical reality (see Chapters 12 and 15). They may, however, have encouraged such behaviour subsequently through their telling and retelling. The same can be said of a group that repeatedly tells itself that it is persecuted through celebration of the stories of its martyrs, both real and imagined (see Chapter 3). The telling and retelling of these stories activates particular moral intuitions repeatedly, resulting in their neurological strengthening and particular behavioural entailments. Resistance stories are ideological narratives in which the world is divided into good and evil, encouraging violent action. Remembering the past in particular ways not only validates the present but has future consequences. When memories of the past are rewritten in these kinds of ways they may prove to be a poor record of historical acts - as is increasingly being shown to be the case. They may well, however, have created a cognitive climate in which such acts became natural and, for some listeners within some communities, inevitable.

\section{Notes}

1 For the initial phase see Mayer and Neil (2013).

2 The approach here is different from that of 'history of memory' approaches (e.g. Borrut 2018), although it shares a concern with how an event is remembered.

3 Tanaseanu-Döbler (2013: 144-5) views this as a natural consequence of Julian's Iamblichan theology: the wisdom imparted by divine revelation can be sourced from a variety of age-old cults and rituals, which are all expressions of it. His rejection of Christianity as atheism and a mental illness likewise has its basis in his medical-philosophical interpretation of Iamblichan theology (Swist 2018). This informs his view that correction is not coercive but concerns changing the individual mindset. 
4 Since Rozin et al. (2008) formulated their original theory, new research by Rottman et al. (2018) is reexamining the relationship between physical and social origins in the evolution of disgust.

5 The link between the senses, the brain, and soul, and the theory of ventricular location play a role in the concept that passers-by can be affected via the senses. See Wright (2016: 114-73, 193-204, esp. 194).

6 Collated by Torres (2009: 212-14). Christian sources claim that Julian's policies exceeded translocation, resulting in destruction.

7 On the neurological effect of emotional rhetoric see Ingram (2013). The case that language can tap into moral intuitions is made at length in Mayer (2019).

$8 \mathrm{I}$ am indebted to the anonymous reviewer of the chapter for suggesting this example. This episode constitutes a precursor to the riots that attended the 'destruction' of the Serapeum in Alexandria in the early 390s (Hahn 2011: 165-6). Dijkstra (forthcoming) argues that the cause was not as simple as a pagan-Christian conflict.

9 We rehearse here in brief an argument made in significantly greater depth and with full supporting evidence and literature in Mayer (2019).

10 For a survey of the scholarship on these contested points and the basis for these conclusions see Mayer (2019: 70-9).

11 De sancto Babyla (Grillet and Guinot 1990). Not only does that homily focus deliberately on Julian's actions, but it is explicitly framed as a response to 'the Greeks' and to the question of whether dead Christian bodies are polluted or cause pollution (Célérier 2013: 333-57). In support of Julian's policy of not destroying dead Christian bodies, it is noteworthy that here John argues that, if Julian really did find such bodies disgusting and polluting, he should have destroyed them (De sancto Babyla 7, Grillet and Guinot 1990: 306).

\section{Bibliography}

\section{Primary sources}

Ammianus Marcellinus (1978) Res gestae. Edited by Seyfarth, W. et al., Ammianus Marcellinus. Rerum gestarum libri qui supersunt, 2 vols. Leipzig: B.G. Teubner.

John Chrysostom (1862) Adversus Iudaeos orationes 1-8. PG, 48: 843-942.

(1982) De laudibus s. Pauli hom. 1-7. Edited by Piédagnel, A. Jean Chrysostome. Panégyriques de Saint Paul, SC, 300. Paris: Éditions du Cerf.

- (1990) De s. hieromartyre Babyla. Edited by Grillet, B. and Guinot, J.-N. Jean

Chrysostome. Sur Babylas, SC, 362. Paris: Éditions du Cerf, 279-313.

Julian (1924) Epistulae. Edited by Bidez, J. L'Empereur Julien, Oeuvres complètes, I.2, Lettres et fragments. Paris: Les Belles Lettres. [Repr. Paris: Les Belles Lettres, 2004].

(1990) Contra Galilaeos. Edited by Masaraccia, E. Giuliano Imperatore Contra Galilaeos, Testi e commenti, 9. Rome: Ateneo.

(2015) Misopogon. Edited by Nesselrath, H.-G. Iuliani Augusti opera, Bbliotheca

Teubneriana 2018. Leipzig: Teubner, 174-213.

Libanius (1908) Oratio 60. Edited by Foerster, R. Libanii opera, 4, Orationes LI-LXIV.

Leipzig: B. G. Teubner, 311-21.

Sozomen (1995) HE. Edited by Hansen, G. C. Sozomenos. Kirchengeschichte, GCS Neue Folge, 4. Berlin: De Gruyter.

\section{Secondary sources}

Bond, S. E. (2016) Trade and taboo: Disreputable professions in the Roman Mediterranean. Ann Arbor, MI: University of Michigan Press. 
Borrut, A. (2018) 'The future of the past: Historical writing in early Islamic Syria and Umayyad memory'. In George, A. and Marsham, A. (eds.), Power, patronage, and memory in early Islam: Perspectives on Umayyad elites. New York: Oxford University Press, $275-300$.

Brändle, R. (2013) 'Der steinerne Beweis. Geschichtstheologische Überlegungen zur Zerstörung des Jerusalemer Tempels in den Reden gegen die Juden von Johannes Chrysostomus'. Theologische Zeitschrift, 69: 548-62.

Bregman, J. (1997) 'The emperor Julian's view of classical Athens'. In Hamilton, C. D. and Krentz, P. (eds.), Polis and polemos: Essays on politics, war, and history in ancient Greece in honor of Donald Kagan. Claremont, CA: Regina Books, 347-61.

Busine, A. (2013) 'From stones to myth: Temple destruction and civic identity in the lateantique Roman east'. JLA, 6/2: 325-46.

Célérier, P. (2013) L'ombre de l'empereur Julien. Le destin des écrits de Juliens chez les auteurs païens et chrétiens du IVe au VIe siècle. Paris: Presses universitaires de Paris Nanterre.

Clarke, S. (2014) The justification of religious violence. Malden, MA: Wiley Blackwell.

Cook, J. G. (2002) The interpretation of the New Testament in Greco-Roman paganism. Peabody, MA: Hendricksons.

Côté, D. (2012) 'Le problème de l'identité religieuse dans la Syrie du IVe siècle. Le cas des "Pseudo-Clémentines" et de 1'“Adversus Judaeos" de saint Jean Chrysostom'. In Mimouni, S. C. and Pouderon, B. (eds.), La croisée des chemins revisitée. Quand l'église et la synagogue se sont-elles distinguées? Actes du colloque de Tours, 18-19 juin 2010. Paris: Éditions du Cerf, 339-70.

Dijkstra, J. H. F. (2011) 'The fate of the temples in late-antique Egypt'. In Lavan, L. and Mulryan, M. (eds.), The archaeology of late-antique 'paganism', Late-antique archaeology, 7. Leiden: Brill, 389-436.

(forthcoming) 'Crowd behaviour and the destruction of the Serapeum at Alexandria in 391/392 CE'. In Dijkstra, J. H. F. and Raschle, C. (eds.), Religious violence in the ancient world: From classical Athens to Late Antiquity. Cambridge: Cambridge University Press.

Eck, B. (2012) La mort rouge: homicide, guerre et souillure en Grèce ancienne, Collection d'études anciennes, série grecque, 145. Paris: Les Belles Lettres.

Feder, Y. (2013) 'Contagion and cognition: Bodily experience and the conceptualization of pollution (tum 'ah) in the Hebrew Bible'. Journal of Near Eastern Studies, 72/2: 151-67.

(2016a) 'Contamination appraisals, pollution beliefs, and the role of cultural inheritance in shaping disease avoidance behavior'. Cognitive Science, 40: 1561-85.

- (2016b) 'Defilement, disgust and disease: The experiential basis of Hittite and Akkadian terms for impurity'. Journal of the American Oriental Society, 136/1: 99-116.

_ (forthcoming) 'Purity and sancta desecration in ritual law: A Durkheimian perspective'. In Barmash, P. (ed.), The Oxford handbook of biblical law. Oxford: Oxford University Press.

Finkelstein, A. (2018) The specter of the Jews: Emperor Julian and the rhetoric of ethnicity in Syrian Antioch. Oakland: University of California Press.

Fournier, É. (2016) 'Amputation metaphors and the rhetoric of exile: Purity and pollution in late ancient Christianity'. In Hillner, J. et al. (eds.), Clerical exile in Late Antiquity. Frankfurt am Main: Peter Lang, 231-49.

Graham, J. and Haidt, J. (2012) 'Sacred values and evil adversaries: A moral foundations approach'. In Mikulincer, M. and Shaver, P. R. (eds.), The social psychology of morality: Exploring the causes of good and evil. Washington, DC: American Psychological Association, 11-31. 
Graham, J. et al. (2013) 'Moral foundations theory: The pragmatic validity of moral pluralism'. Advances in Experimental Social Psychology, 47: 55-130.

Greene, J. D. (2013) Moral tribes: Emotion, reason, and the gap between us and them. New York: Penguin Books.

Hahn, J. (2004) Gewalt und religiöser Konflikt. Studien zu den Auseinandersetzungen zwischen Christen, Heiden und Juden im Osten des Römischen Reiches (von Konstantin bis Theodosius II). Berlin: Akademie Verlag.

(2011) 'Gewaltanwendung ad maiorem gloriam dei? Religiöse Intoleranz in der Spätantike'. In Nesselrath, H.-G. et al. (eds.), Für Religionsfreiheit, Recht und Toleranz: Libanios' Rede für den Erhalt der heidnischen Tempel. Tübingen: Mohr Siebeck, 227-52.

Hahn, J., Emmel, S., and Gotter, U. (eds.) (2008) From temple to church: Destruction and renewal of local cultic topography in Late Antiquity, RGRW, 163. Leiden: Brill.

Haidt, J. (2012) The righteous mind: Why good people are divided by politics and religion. New York: Vintage Books.

Haidt, J. and Graham, J. (2009) 'Planet of the Durkheimians: Where community, authority, and sacredness are foundations of morality'. In Jost, J. T. et al. (eds.), Social and psychological bases of ideology and system justification. New York: Oxford University Press, 371-401.

Harrison, J. R. (2017) 'The persecution of Christians from Nero to Hadrian'. In Harding, M. and Nobbs, A. (eds.), Into all the world: Emergent Christianity in its Jewish and Greco-Roman context. Grand Rapids, MI: Eerdmans, 266-300.

Hillner, J. (2015) Prison, punishment and penance in Late Antiquity. Cambridge: Cambridge University Press.

Ingram, B. (2013) 'Critical rhetoric in the age of neuroscience'. PhD diss., University of Massachusetts, Amherst. Available at: http://scholarworks.umass.edu/open_access_ dissertations $/ 690 /$.

Kalleres, D. (2015) City of demons: Violence, ritual, and Christian power in Late Antiquity. Oakland: University of California Press.

Lakoff, G. (2002) Moral politics: How liberals and conservatives think, 2nd edn. Chicago: The University of Chicago Press.

(2009) The political mind: A cognitive scientist's guide to your brain and its politics. New York: Penguin Books.

Lennon, J. (2014) Pollution and religion in ancient Rome. Cambridge: Cambridge University Press.

Lloyd, G. E. R. (2003) In the grip of disease: Studies in the Greek imagination. Oxford: Oxford University Press.

Mayer, W. (2019) 'Preaching hatred? John Chrysostom, neuroscience, and the Jews'. In de Wet, C. L. and Mayer, W. (eds.), Revisioning John Chrysostom: New approaches, new perspectives, Critical Approaches to Early Christianity, 1. Leiden: Brill, 58-136.

- (forthcoming) 'Religious violence in Late Antiquity: Current approaches, trends and issues.' In Dijkstra and Raschle (eds.), forthcoming.

Mayer, W. and Allen, P. (2012) The churches of Syrian Antioch (300-638 CE), LateAntique History and Religion, 5. Leuven: Peeters.

Mayer, W. and Neil, B. (eds.) (2013) Religious conflict from early Christianity to the rise of Islam, Arbeiten zur Kirchengeschichte, 121. Berlin: De Gruyter.

Moss, C. R. (2013) The myth of persecution: How early Christians invented a story of martyrdom. San Francisco: HarperOne.

Mullen, W. L. (1990) 'The polemical sermons of John Chrysostom against the Judaizers: A dramatic analysis'. PhD diss., University of Nebraska-Lincoln. 
Musolff, A. (2007) 'What role do metaphors play in racial prejudice? The function of antisemitic imagery in Hitler's Mein Kampf'. Patterns of Prejudice, 41/1: 21-43.

(2014) 'From social to biological parasites and back: The conceptual career of a metaphor'. Contributions to the History of Concepts, 9/2: 18-32.

Parker, R. (1996) Miasma: Pollution and purification in early Greek religion, 2nd edn. Oxford: Oxford University Press.

Ralph, A. (2016) 'Metaphors of sickness and the social body in the Constantinian era'. PhD diss., The Catholic University of America.

Retief, F. P. (2005a) 'Burial customs, the afterlife and the pollution of death in ancient Greece'. In Retief and Cilliers (eds.), 44-61.

- (2005b) 'Burial customs and the pollution of death in ancient Rome: Paradoxes and procedures'. In Retief and Cilliers (eds.), 128-46.

Retief, F. P. and Cilliers, L. (eds.) (2005) Health and healing, disease and death in the Graeco-Roman world, Acta theologica supplementum, 7. Bloemfontein: University of the Free State.

Rottman, J. et al. (2018) 'The social origins of disgust'. In Strohminger and Kumar (eds.), $27-52$.

Rozin, P., Haidt, J., \& McCauley, C. R. (2008) 'Disgust'. In M. Lewis, J. M. HavilandJones \& L. F. Barrett (eds.), Handbook of emotions, 3rd edn. New York: Guilford Press, 757-76.

Shepardson, T. (2014) Controlling contested places: Late-antique Antioch and the spatial politics of religious controversy. Berkeley: University of California Press.

Strohminger, N. and Kumar, V. (eds.) (2018) The moral psychology of disgust. London: Rowman \& Littlefield International.

Swist, J. J. (2018) 'Medicine in the thought and action of the emperor Julian'. The International Journal of the Platonic Tradition, 12/1: 13-38.

Tanaseanu-Döbler, I. (2013) Theurgy in Late Antiquity: The invention of a ritual tradition. Göttingen: Vandenhoek \& Ruprecht.

Teitler, H. C. (2013) 'Ammianus, Libanius, Chrysostomus, and the martyrs of Antioch'. VC, 67: 263-88.

(2017) The last pagan emperor: Julian the Apostate and the war against Christianity. New York: Oxford University Press.

Torres, J. (2009) 'Emperor Julian and the veneration of relics'. Antiquité tardive, 17: 205-14.

Wilken, R. L. (1983) John Chrysostom and the Jews: Rhetoric and reality in the late fourth century, TCH 4. Berkeley: University of California Press.

Wright, J. (2016) 'Brain and soul in Late Antiquity'. PhD diss., Princeton University, Princeton, NJ.

Wright, W. C. (trans.) (1923) The works of the Emperor Julian, vol. 3, LCL. London: William Heinemann and New York: G. P. Putnam's Sons. 


\title{
6 Constructing the sacred in Late Antiquity
}

\author{
Jerome as a guide to Christian identity
}

\author{
Naoki Kamimura
}

By the end of the fourth century, both Rome and Jerusalem had long functioned as centres of liturgical, spiritual, and pastoral life in the Mediterranean world. Jerome of Stridon (c. 347-420) formulated his perception of pilgrimage and the importance of visiting sacred sites in the Holy Land in the context of his longrunning conflict with Christian communities in Jerusalem. Jerome was rarely reluctant to voice his criticism of local ecclesiastical leaders, first in Rome, where he lived on and off until the death of his patron Pope Damasus (384 CE), and then in Jerusalem, while living in the neighbouring city of Bethlehem (388-420). ${ }^{1}$

In this chapter, I explore the basis for the development of Jerome's discourse of sacred geography and his interest in creating a new religious identity, one that promoted the creation of a Christian utopia (Ferguson 1975; Dawson 1992: 276-90; Neil, Chapter 1 in this volume). In seeking to explain the reasons why Jerome changed his mind about Jerusalem as a suitable destination for pilgrims, I restrict myself to an examination of Jerome's arguments in Letters 46 and 58. My aim is to show how his enthusiasm for shaping a new landscape of sacred sites and his interest in a new model of Christian identity shaped his views on suitable religious behaviour for fourth-century Christians in the Middle East.

Jerome's enthusiasm for pilgrimage and its religious significance is repeatedly mentioned in his letters, ${ }^{2}$ for example, Letter 108, a rich source of information about Jerome's pilgrimage with Paula, his long-time patron and very dear friend. The letter was written in 404 as his epitaph (epitaphium) to Paula (Cain 2013: 5 n.32). Jerome refers briefly to his purpose in composing the work, which was to console Eustochium on her mother Paula's death (Jerome, Ep. 108.2.2, CSEL, 55: 308), and to express his own grief, as profound as that of Eustochium (Ep. 108.32, CSEL, 55: 350). However, the consolatory motive could be considered marginal. In so far as he intended to circulate the letter among a wider audience (Lamprecht 2017), the letter should be interpreted as a commemoration of his devoted disciple and monastic collaborator, with essentially hagiographic features (Cain 2010). As a result, the epitaph turns out to be a source of information for the biography of Paula with a comprehensive catalogue of the holy sites Jerome claims they visited and a description of their experiences in those places. Although he says that he will 'only name such places as are mentioned in the sacred books' (Jerome, Ep. 108.8.1, CSEL, 55: 313), ${ }^{3}$ he understands the importance of these experiences in portraying 
Paula as an exemplar of his ascetic ideal (Cain 2010: 124). The letter emphasises the craving of a devout pilgrim to see and touch sacred sites, as I will discuss.

A second letter reflects the intellectual attraction of holy places. Letter 53 was written in c. 394 (Cain 2009: 215 n.47) in reply to Paulinus's initial request for advice on the study of the scriptures. Jerome responded with an exhortation to a radical renunciation of all possessions, a life detached from clerical duties and concentrated scriptural study (Trout 1999: 90-3). He also encouraged Paulinus to travel to Bethlehem and to study with him, where they would be partners in the study of scripture (Jerome, Ep. 53.10.2, CSEL, 54: 464). He claimed that travelling to Palestine, together with the aim of learning, was crucial to Paulinus's hope of following the monastic way of life.

Further evidence of Jerome's invitations to pilgrimage is found in other letters he wrote. For example, in Letter 76 written in 399 to Abigaus, a blind presbyter in Spain, Jerome asked him to take special care of Theodora, who had recently lost her husband Lucinius (Jerome, Epp. 71 and 75). He encouraged her to persevere in her pilgrimage (Bitton-Ashkelony 2005: 68-9, 96) and visit the 'sacred place' (Jerome, Ep. 76.3.2, CSEL, 55.36; see Letters 47, 68, and 71; Krewson 2017: 120-1). This letter sets out the reward for the hardships of her journey: Theodora will receive a 'second circumcision' immediately after her entrance to the holy land (Bitton-Ashkelony 2005: 69 n.25; Cain 2013: 276).

Despite his mutually contradictory stances in the two well-known letters, Letter 46 and Letter 58, Jerome makes his approach to pilgrimage and the value of visiting biblical sites quite explicit. His attitude changed from firm support for pilgrimage to biblical sites to a later denunciation of pilgrimage for over a decade. Some scholars have suggested that Jerome's ambivalence in attitude towards pilgrimage and the earthly Jerusalem can be explained by the tensions between popular religious phenomena and established church practices in Late Antiquity. The reservations about pilgrimage were voiced by intellectuals, though ordinary people shared an expression of piety in the holy places (Bitton-Ashkelony 2005: 2-5, 86-7). Other scholars have drawn attention to the historical context in which he responded to the phenomenon of pilgrimage popular and prevailing from the mid-fourth century on (Bitton-Ashkelony 2005: 87-8). When he wrote Letter 58 to Paulinus, whose hope was to travel to Palestine and settle in Jerusalem, Jerome was in conflict with the church in Jerusalem. He was extremely reluctant to encourage Paulinus to visit Palestine because Jerome himself was forbidden to enter the place by the local church. He had no alternative but to minimise the importance of visiting the holy places.

\section{Letter 46 and the uniqueness of Jerusalem ${ }^{4}$}

In the early spring of 386, following his journey with Paula and moving to Bethlehem (Bitton-Ashkelony 2005: 71 n.35), Jerome wrote Letter 46 to Marcella, his influential patroness who had stayed behind in Rome..$^{5}$ Although the letter was sent to her in the names of Paula and her daughter Eustochium, most scholars have assumed that Jerome himself wrote the letter. ${ }^{6}$ The close relationship 
between these women might be the reason he hid behind the voices of Paula and Eustochium. They had joined Jerome's circle of aristocratic female disciples at Rome, in which they might share the same model of ascetic piety. Although Jerome served as their spiritual mentor in the circle, he assumed that Paula and Eustochium were fit to invite Marcella to join them and follow their way of life (Bitton-Ashkelony 2005: 71 n.35).

Jerome quotes a passage from Genesis 12:1, taking it as a starting point for his discussion of pilgrimage, a discussion in which he indicates to Marcella that it was God's first command to Abraham: 'Get thee out of thy country and from thy kindred unto a land that I will show thee' (Jerome, Ep. 46.2.1, CSEL, 54: 330). ${ }^{7}$ Jerome also quotes passages from the Old Testament in support of this view (Ezekiel, Psalms, and Deuteronomy), thereby providing a biblical basis for the act of pilgrimage. He then switches from the spatial to the temporal aspect: 'Well, then, to bring forward something still more out of place, we must go back to yet remoter times' (Ep. 46.3.2, CSEL, 54: 331-2). The emphasis on the unique history of Jerusalem leads him to confirm that this city has had a privileged position in human history: 'Tradition has it that in this city, nay, more, on this very spot, Adam lived and died. The place where our Lord was crucified is called Calvary [sc. Golgotha], because the skull of the primitive man was buried there' (Ep. 46.3.2, CSEL, 54: 332). He maintains that this tradition affords proof of the special status of Jerusalem: there have been 'prophets and holy men who have been sent forth from this place' (Ep. 46.3.3, CSEL, 54: 332).

He adds etymological explanations of its names: these names-Jebus, Salem, and Jerusalem - correspond to the teaching of the Trinity (Ep. 46.3.3). However, although such a triad reveals itself to be a vision of our faith, it is also relevant to the successive steps of the Christian way of life, in particular, the realisation of the monastic ideal: 'from the fight against the passions (Jebus as calcata), through the impassibility gained from it (Salem as pax), up to the beatitude of perfection (Jerusalem as uisio pacis)' (Perrone 1999: 232). ${ }^{8}$ Jerome emphasises the unique status of Jerusalem by introducing both biblical and non-biblical elements; this differs from other Christian writers such as Origen, who stripped Jerusalem of its historical and political significance, and instead made it significant only as a symbol of the heavenly city (Wilken 1992: 66-78). While Eusebius of Caesarea was influenced by Origen's spiritual interpretation of Jerusalem as the 'land of promise' (Wilken 1992: 78-81, 127-8), Jerome's stance was consistent with that of Cyril, the bishop of Jerusalem.

In contrast to the claim of his adversaries that Jesus had prophesied destruction of Jerusalem and the Temple (Matt 23:37-8), Jerome directs his attention to Josephus's Bellum Judaicum (6.5.3), which gave details of the destruction of the Temple in Jerusalem. ${ }^{9}$ He also alludes to the command of Jesus to the apostles (Matt 28:19 and Acts 13:46): 'All the spiritual importance of Judaea and its old intimacy with God were transferred by the apostles to the nations' (Jerome, Ep. 46.4.3, CSEL, 54: 334; Perrone 1999: 232). Although it seemed likely that Jerusalem's privileged status was limited only to the past, he provided a clear answer to this problem as follows: 
The difficulty is strongly stated, and may well puzzle even those proficient in Scripture; but for all that, it admits of an easy solution. The Lord wept for the fall of Jerusalem (Luke 19:41-2), and He would not have done so if $\mathrm{He}$ did not love it. He wept for Lazarus because He loved him (John 11: 35-6).

(Ep. 46.5.1, CSEL, 54: 334)

In this way, Jerome takes the scriptural texts to establish the validity of his claim. ${ }^{10}$ Further development of his argument is to be found in the connection between the divine abandonment of Jerusalem and the sins of its inhabitants. In other words, the loftiness of the city was to be differentiated from the people who had offended against God.

The truth is that it was the people who sinned and not the place. The capture of a city is involved in the slaying of its inhabitants. If Jerusalem was destroyed, it was that its people might be punished... . As regards its site, lapse of time has but invested it with fresh grandeur.

(Ep. 46.5.1-2, CSEL, 54: 334)

After making the point that its abandoned state was linked with Jerusalem's inhabitants, he uncoupled its Jewish past from its site as a Christian city. ${ }^{11}$ Thus, he discounts the view that this city was no longer worthy of honour. Jerome intends to free the city as a whole as far as possible from its Jewish past, thereby showing that the destruction of Jerusalem did not represent its abandonment by God.

In Letter 46, Jerome went on to consider the holiness of this city. By recounting his experience of seeing the tomb of Jesus, he illustrated the significance of physical contact. Here Jerome provides Marcella with a vivid description not only of his experience but also of the power of his experience, thus urging her to contemplate Christian history. Although Jerome realised that most Christians were not familiar with Jerusalem's sacred sites (Wilken 1992: 217-8), he assured Marcella that they were not new places but places that Christians had inherited: 'Long before this sepulchre was hewn out by Joseph, its glory was foretold in Isaiah's prediction, 'his rest shall be glorious' (Isa 11:10)' (Jerome, Ep. 46.5.3, CSEL, 54: 334). Therefore, he asked Marcella to concentrate on the feelings people experienced in holy places: 'As often as we enter it we see the Saviour in His grave clothes, and if we linger we see again the angel sitting at His feet, and the napkin folded at His head' (Ep. 46.5.3, CSEL, 54: 334). He thought it was crucial that believers saw and touched holy places to remind them of the events of the past in Jerusalem.

Furthermore, by drawing on the prophetic words in Isaiah, he turned Marcella's attention from divine judgement of its Jewish past to the veneration of Christian holy places in the city. He shifted the focus to a perpetual honour in the presence of Jesus. The sanctity of Jerusalem is, thus, confirmed by reference to Isaiah: 'his rest shall be glorious' and 'the place of the Lord's burial should be held in universal honour' (Isa 11:10). ${ }^{12}$ Jerome here wanted to impose a new duty on Christians, to visit the tomb of Jesus, a duty for which there was no scriptural basis. How did he support his claim? 
His position was hard to justify when it came to proving that Jesus was crucified at Jerusalem, interpreted as 'Sodom and Egypt.' He quoted Revelation 11:8: 'the great city [sc. Jerusalem] which spiritually is called Sodom and Egypt, where also their Lord was crucified' (Jerome, Ep. 46.6.1, CSEL, 54: 335). The problem was how Sodom could be a holy place. Jerome resolved the difficulty by extending the phrase's literal meaning and making a new interpretation of Revelation. ${ }^{13}$ His task was both to eliminate any possible confusion between Sodom and the earthly Jerusalem and to argue against associating it with the heavenly Jerusalem. He refers to the passage from Revelation in which 'he [sc. John] speaks of Jerusalem as the holy city (Rev 11:1-2)' (Ep. 46.6.2, CSEL, 54: 335). Thus, Jerome is certain that he can define the term holy city as the heavenly Jerusalem and show 'that which is called Sodom is the earthly one tottering to its downfall' ( $E p$. 46.6.3, CSEL, 54: 335).

Since it is difficult to give a coherent interpretation of the text, he resorts to another passage from the book of Revelation, in which the new Jerusalem, that is, the holy city within John's vision of 'a new heaven and a new earth' (Rev 21:1), is depicted as the 'great city' in its spiritual dimension (Rev 21: 16-18). However, his interpretation is not straightforward. ${ }^{14} \mathrm{He}$ interprets it mystically: this 'great city' is the one 'Cain first built (Gen 4:17)' (Ep. 46.7.1, CSEL, 54: 336), which 'must be taken to represent this world' (Ep. 46.7.1, CSEL, 54: 336). It is called 'Sodom' and 'Egypt' (Ep. 46.7.1, CSEL, 54: 336). He rejects the connection between Egypt and the earthly city: 'We never read of Egypt as put for Jerusalem: it always stands for this world' (Ep. 46.7.2, CSEL, 54: 337). Insofar as it is fixed as the city that sinned and was rebuilt, it becomes clear that the 'great city' rather stands for the present world: the future Jerusalem of Revelation is neither celestial nor terrestrial. Jerusalem is, therefore, the city in which 'the psalmist commands us to worship the Lord at his footstool (Ps 132:7)' (Ep. 46.7.6, CSEL, 54: 338).

\section{The status of the earthly Jerusalem}

Jerome goes on to consider the high status of the earthly Jerusalem. He cites Matthew 27:52-53 to provide proof for the status and holiness of the earthly city (Wilken 1992: 124). ${ }^{15}$ In fact, it is the site of the Lord's resurrection and other saints with him: '[A]nd the graves were opened; and many bodies of the saints which slept arose and came out of the graves after his resurrection, and went into the holy city and appeared unto many' (Jerome, Ep. 46.7.5, CSEL, 54: 337-8). He interprets this passage to mean that the 'holy city' is not the heavenly Jerusalem: '[T] he apparition there of the bodies of the saints could be no sign to men of the Lord's rising' (Ep. 46.7.6, CSEL, 54: 338). Although he knows well that there are different interpretations of the 'holy city' as the heavenly Jerusalem, his reading serves his purpose. Indeed, he is aware that Christian faith needs to relate the tangible evidence back to the past in order to express itself. He adds further support to his argument:

Since, therefore, the evangelists and all the Scriptures speak of Jerusalem as the holy city, and since the psalmist commands us to "worship the Lord at 
his footstool' (Ps 131:7 LXX), allow no one to call it Sodom and Egypt, for by it the Lord forbids men to swear because 'it is the city of the great king' (Matt 5:35).

It is noteworthy that he quotes a part of the passage from Psalm 131:7: 'Let us go into his tabernacle: let us worship at his footstool. ${ }^{16}$ Jerome suggests this means that we should worship Jesus's burial place. His concern to construct a sacred geography is prominent in his interpretation of this Psalm as a reference to the obligation of Christians to visit and worship at Jesus's tomb. ${ }^{17} \mathrm{He}$ explains the religious and intellectual rewards of the act of pilgrimage: '[T]he bishops, the martyrs, the divines ... have come to Jerusalem from a feeling that their devotion and knowledge would be incomplete and their virtue without the finishing touch, unless they adored Christ in the very spot where the gospel first flashed from the gibbet' (Ep. 46.9.1, CSEL, 54: 339; italics mine). When he describes what it is that he appreciates in this mode of religious practice, he enumerates the desirable characteristics - devotion, knowledge, and virtue - to be found in those who have completed 'a Christian's education' (Ep. 46.9.2, CSEL, 54: 339) by their worship at a particular holy site. This is the innovative aspect of Jerome's argument. Here the connection between the rewards of pilgrimage and an effective way of forging Christian identity form the basis of religious practice: for Christians of his day, he believes, visiting a unique earthly site is an obligation and, in fulfilling this obligation, they should also share his perception of pilgrimage and the earthly Jerusalem.

\section{Jerome's persuasion of Paulinus of Nola: Letter 58}

In 395, a year after he wrote Letter 53 to Paulinus of Nola to encourage him to renounce property and travel to Bethlehem, Jerome wrote Letter $58 .{ }^{18}$ While Jerome was still involved in a conflict with the Jerusalem church, Paulinus was thinking about the possibility of his visit to Palestine and hoping to become a monk. ${ }^{19}$ Many friends of Paulinus were living in the vicinity. For example, Melania the Elder, probably kin to Paulinus (Paulinus of Nola, Ep. 29.5, CSEL, 29: 251), had founded a double monastery on the Mount of Olives. She was soon joined by her friend and companion, Rufinus of Aquileia. Paulinus referred to her residence in Jerusalem and praised her for having firmly committed to the monastic way of life (Ep. 29.10-13, CSEL, 29: 257-61). He also mentioned Rufinus in terms of affection and expressed high esteem for his intellectual attainments (Ep. 28.5, CSEL, 29: 246). Despite the former promised hospitality to Paulinus, however, Jerome was now disinclined to encourage Paulinus's plan to visit and settle in Jerusalem. Indeed, he could ill afford to offer Paulinus a warm reception. Not only had Jerome's relations with the monks on the Mount of Olives been difficult and strained, he was also embroiled in a controversy with John, bishop of Jerusalem, over the evaluation of Origen's teachings. That controversy had resulted in his excommunication (Nautin 1971-73). He and all who belonged to his community had been barred from entering the Church of the Holy Sepulchre as well 
as other churches in the diocese of Jerusalem. Accordingly, Jerome was obliged now to take a different view of visiting holy places.

\section{The traditional view of pilgrimage and the value of proximity to Jerusalem}

Jerome's crucial concern in Letter 58 was to dissuade Paulinus from travelling to holy places, and to give him a compelling rationale for being devoted to the monastic life in Italy, without compromising his faith. The way he presented his argument is noteworthy for the tone of his words. In comparison with Gregory of Nyssa's considerable reservations about pilgrimage in his Letter 2 (written in the 380s), Jerome did not press his claim. While Gregory stated explicitly that pilgrimage to Jerusalem was potentially harmful, in particular for monks and nuns, ${ }^{20}$ Jerome took a cautious approach. He would have been fully conscious of the difficulty of defending his changed position on pilgrimage and the status of the earthly Jerusalem, which had been based both on his own experience as a pilgrim and on the arguments he had previously formulated in Letter 46 (Bitton-Ashkelony 2005: 90-1). Although his attempt to prove the insignificance of pilgrimage is explicit within this letter, his reservations indicate the ambivalence expressed by his contemporary theologians against the practice of pilgrimage. ${ }^{21}$

From the beginning of Letter 58, Jerome directed Paulinus's attention to traditional Christian ideas in the New Testament: the refusal to endorse the religious significance of Christian holy places as a component of Christian faith (Wilken 1992: 46-64; Pullan 2005). He approached the issue from a moral viewpoint, in pursuit of his aim to reject the spiritual status of Jerusalem.

What is praiseworthy is not to have been at Jerusalem but to have lived a good life while there. The city which we are to praise and to seek is not that which has slain the prophets and shed the blood of Christ, but that which is made glad by the streams of the river, which is set upon a mountain and so cannot be hid, which the apostle declares to be a mother of the saints $(\mathrm{Gal}$ 4:26), and in which he rejoices to have his citizenship with the righteous (Phil 3:20).

(Jerome, Ep. 58.2.3, CSEL, 54: 529-30; italics mine)

He admits that his interest lies in the moral fabric of the city. He begins his appeal for the proper moral conduct to be expected of inhabitants of the city with an interpretation of scriptural texts: Paul's epistles to Galatians 4:26 and Philippians $3: 20$. These passages were the basis for the 'spiritualistic detachment from historical Jerusalem in the name of the heavenly one' (Perrone 1999: 234), designed to erase the special status of any particular space and to belittle the value of pilgrimage. Here Jerome highlighted the impossibility of the divine presence being coupled with any specific geographical site: 'Each believer is judged not by his residence in this place or in that. . . The true worshippers worship the Father neither at Jerusalem nor on mount Gerizim' (Jerome, Ep. 58.3.1, CSEL, 54: 530). ${ }^{22}$ 
In this way, he argued against the special status of the earthly Jerusalem and the act of pilgrimage, and anchored his arguments in scriptural texts.

However, while Jerome rejected the traditional view he had advanced in Letter 46, he did not accept the classic dichotomy made between the heavenly and the earthly Jerusalem (Bitton-Ashkelony 2005: 15-17). Nor did he draw on Paul's words to the Hebrews 12:22 on the 'heavenly Jerusalem' and to the Galatians 4:26 on the 'Jerusalem above.' Instead, he linked the importance of making pilgrimage to Jerusalem with the sanctity of the city. With this, he stripped Jerusalem, the city, of its earlier sinful history and shifted the blame for those sins onto the inhabitants of the city. Thus, unlike his innovative attitude in Letter 46, Jerome's approach in Letter 58 was typical of fourth-century Christian theologians (Cardman 1982; Prawer 1996). While he reminded Paulinus of the Pauline view of Jerusalem and holy places, Jerome also referred to his own experience: 'I, like Abraham, have left my home and people' (Jerome, Ep. 58.3.1, CSEL, 54: 530). This allusion to Genesis 12:1 also appears at the beginning of Letter 46 to justify his own pilgrimage (Ep. 46.2.1, CSEL, 54: 330).

Jerome juxtaposed the legitimation of his own travelling to holy places with arguments against pilgrimage in Letter $58 .{ }^{23} \mathrm{He}$ might have defended his choice by pointing out that the divine presence was located in a particular place - that is, the destination of his pilgrimage - but he did not reconcile the contradiction. It was never properly resolved. His emphasis is, therefore, on the discrepancy between a moral way of life and proximity to holy places. Citing the Johannine texts, such as Jesus's dialogue with the Samaritan woman, Jerome focused on the behaviour of believers:

Each believer is judged . . . according to the deserts of his faith. The true worshippers worship the Father neither at Jerusalem nor on mount Gerizim; for 'God is a spirit, and they that worship Him must worship Him in spirit and in truth.' (John 4:24) 'Now the spirit bloweth where it listeth' (John 3:8).

(Ep. 58.3.1, CSEL, 54: 530)

Here he appealed again to the Pauline view of a holy place and cast doubt on associating God with places connected with the earthly life of Jesus. He pointed out that the gospel message was given to the whole world: 'God ceased to be known in Judah only and His name to be great in Israel alone' (Ep. 58.3.2, CSEL, 54: 530). ${ }^{24}$ Thus, he articulated the limits of holy places: 'If heaven and earth must pass away, obviously all things that are earthly must pass away also' (Ep . 58.3.2, CSEL, 54: 531).

It followed that the sites of the crucifixion and resurrection profited only those who made themselves worthy of the holiness of these sites (Ep . 58.3.3, CSEL, 54: 531), ${ }^{25}$ excluding those who were only proud of their place of residence. Jerome shifted the focus from the merely physical to a spiritual closeness with God. Admittedly, his argument was directed against his opponents in Jerusalem. Recalling the passages from Pauline epistles, he wrote: 'Those who say "the temple of the Lord, the temple of the Lord," (Jer 7:4) should give ear to the words of 
the apostle: "ye are the temple of the Lord, and the Holy Ghost dwelleth in you" (1 Cor 3:16)' (Ep. 58.3.3, CSEL, 54: 531). ${ }^{26}$ If 'the kingdom of God is within you' (Luke 17:21), it could be found in Britain as well as in Jerusalem, he maintained (Ep. 58.3.3, CSEL, 54: 531). ${ }^{27}$ Here Jerome emphasised the inner meaning of pilgrimage and proposed that a serious obstacle to the hope of seeking the 'kingdom of God' in Jerusalem be the temptations of that crowded city. Thus, having stressed the importance of the righteousness of faith, he observed that many monks had never visited Jerusalem, and that the hermit Hilarion, who did go to Jerusalem, had never wanted 'to appear to confine God within local limits' (Ep. 58.3.4, CSEL, 54: 531; see Wilken 1992: 151).

\section{The enhanced function of the sacred sites}

It is noteworthy that in Jerome's letter to Paulinus he did not dismiss the value of sacred space entirely. While he concentrated on the holy places in Jerusalem, he seems to have avoided any mention of the place of Christ's nativity in Bethlehem. Bethlehem was the centre of the network of Christian sacred sites in Palestine (Markus 1990: 139-55; Bitton-Ashkelony 2005: 93-4). Indeed, in the very moment he was refuting the religious value of holy places, he described Bethlehem as 'that most venerable spot in the whole world' (Ep. 53.3.5, CSEL, 54: 532). ${ }^{28}$ His attitude towards holy places was once again ambivalent. Jerome asked himself why his lengthy letter had to be sent to Paulinus: he did not want to impose his views on Paulinus, and his tone is apologetic, assuring Paulinus that 'nothing is lacking to your faith although you have not seen Jerusalem . . . whether you dwell here or elsewhere, a like recompense is in store for your good works with our Lord' (Ep. 58.4.1, CSEL, 54: 532). While praising Paulinus's eloquence and his classical learning, ${ }^{29}$ Jerome appears to offer another approach to sacred sites, and once again invites Paulinus to a journey, a different journey. The proposed itinerary was as follows: not 'through the Aonian mountains and the peaks of Helicon' revered by classical poets, but 'through Zion and Tabor and Sinai, the high places of scripture' (Ep. 58.8.3, CSEL, 54: 538). It is unreasonable to suppose that Jerome offered to escort Paulinus in person to 'the high places.' But, even if Jerome was not receptive to Paulinus visiting holy places, he might have considered 'Zion and Tabor and Sinai' to be of particular importance. He made clear his intention to chart a specific course: 'If I might teach you what I have learned myself and might pass on to you the mystic rolls of the prophets, then might we give birth to something' (Ep. 58.8.3, CSEL, 54: 538; italics mine), something that could be more brilliant than the secular learning in which Paulinus had already excelled. His message was thus an invitation to a joint task of scriptural exegesis. He passionately hoped to be able to share his biblical expertise with Paulinus: '[G]ive ear for a moment that I may tell you how you are to walk in the holy scriptures' (Ep. 58.9.1, CSEL, 54: 538).

He had extended the same invitation in the preceding letter, that is, Letter 53, where Jerome had urged Paulinus to join him in scriptural study (see above in this chapter). A notable characteristic of these letters is that they refer to physical 
localities. In Letter 53 Jerome enumerated biblical sites-Egypt, Judah, Israel, Assyria, Ephraim, Canaan, Edom, and Nineveh (Ep. 53.8.1-14, CSEL, 54: 45460) — when he summarised the contents of scriptures. Then, in Letter 58 'Zion and Tabor and Sinai' are mentioned in the itinerary which Paulinus is expected to take in order to 'walk in the holy scriptures.' What then is the importance of 'Zion and Tabor and Sinai'? The places listed in Letter 53 are not meant to refer to actual places or past events; rather, the names are spatial metaphors. Jerome considers these names 'an entirety of scriptural space' (Chin 2007: 105) - that is, the texts of scriptures to be interpreted and explained. Particular places such as 'Zion and Tabor and Sinai' are very likely meant to be read as a holy space, to be entered through scriptural exegesis. ${ }^{30}$ Jerome's invitation is for Paulinus to enter the textual space of scriptures, not to visit different locations in Palestine. This suggests that 'Zion and Tabor and Sinai' are the symbolic entrance through which the reader enters and explores the scriptures. Jerome is setting a course for Paulinus and planning to be a guide to show him the path: 'Oh! that it were mine to conduct a genius like you ... through Zion and Tabor and Sinai, the high places of scripture' (Ep. 58.8.3, CSEL, 54: 538).

\section{Conclusion}

Initially, Jerome argued for the importance of visiting sacred sites. In his letter to Marcella (Ep. 46), he wanted to convince her to travel to holy places, defending the privileged position of the earthly Jerusalem with biblical and extra-biblical motifs. He claimed that the sanctity of the city should not encompass the failings of its inhabitants, nor its Jewish past pollute its holiness as a Christian city. When advocating the necessity of pilgrimage to the tomb of Jesus, Jerome wrote approvingly of associating divine presence with a defined locus. However, to avoid criticism, he emphasised the virtues of the monks and virgins in Jerusalem: '[T]here is no arrogance, no disdain of self-restraint; all strive after humility, that greatest of Christian virtues' (Ep. 46.10.3, CSEL, 54: 340). Ten years later, writing to Paulinus of Nola (Ep. 58), Jerome revised his view of the sanctity of Jerusalem and proposed a rather more traditional view, based on Pauline passages that reject any spiritual significance for the earthly city. In now trying to dissuade Paulinus from travelling to holy places, he is critical of the earthly Jerusalem, criticism directed at his opponents there who did not support the importance of holy places. Jerome had to reconsider whether Jerusalem was an appropriate location for those who were most intent on pursuing a monastic way of life. In his conflict with the church in Jerusalem, the city had lost its appeal.

It is clear that, after his three-year period of excommunication ended, Jerome did not hesitate to once again express a positive attitude towards pilgrimage and to stop attacks on the people of Jerusalem. He encouraged his friends to visit holy places. He might have feared that his friends would be hostile after meeting with his opponents, but the danger passed (Krewson 2017: 130). Despite the profound impact of his past conflict with the bishops and church of Jerusalem, he could renew his commitment to pilgrimage. It is evident, therefore, that Jerome 
regarded his appeal to the traditional Pauline view as a tentative reservation. His message to Paulinus in Letter 58 was a consequence of his unfavourable situation. Since he was acutely conscious of the conflicting attitudes towards pilgrimage in the two letters, he reverted quickly to his former standpoint when the situation returned to normal. However, it is not true to say that Letter 58 never contained an exhortation to Paulinus to make a journey. Jerome invited him to a 'spatial' journey. It was through a course of scriptural study that Jerome encouraged Paulinus to enter the textual space of scriptures. Scriptural texts were the destination which Jerome had in mind, with hope to accompany Paulinus and serve as a trustworthy guide to scriptural exegesis. He warns Paulinus against wandering: 'I may tell you how you are to walk in the holy scriptures' (Ep. 58.9.1, CSEL, 54: 538). Scriptural space is a challenging territory to negotiate without a guide who can show travellers the appropriate route to the goal.

We can but conjecture why Letters 46 and 58 reacted so differently to sacred geography. We could surmise that, after the excommunication of Jerome and his community, he had to revise his previous emphasis on the historical contrast between the Jewish past of Jerusalem and its status as a Christian city (Ep. 46) to focus directly on the behaviours of contemporary people who vaunted their proximity to holy places ( $E p$. 58). Jerome was so intent on the monastic ideal, which embraced alienation from the world and the construction of a Christian way of life inclined towards pilgrimage, that he had to stress the gap between the uniqueness of the earthly Jerusalem and the reality of the city. Because of his disappointments and frustrations with the city, and the conflict with his opponents, he was obliged to belittle the importance of sacred geography. The change of attitude, therefore, did not result from a theoretical investigation of the status of the earthly Jerusalem but instead from his disillusionment with the Christian utopia he had hoped for and from 'his relations to others' (Leyerle 1996: 132).

Despite his dissatisfaction with contemporary Jerusalem, he did not dismiss the significance of sacred sites entirely. Although the realities of the city did not drastically change after his reconciliation with the church in Jerusalem, in some letters he retained and expressed a deep affection for holy places (BittonAshkelony 2005: 96-7). In his letters both to Marcella and to Paulinus, which evidence contradictory attitudes to sacred geography, Jerome endows the earthly Jerusalem with unique moral values: three names of the city-Jebus, Salem, and Jerusalem-represent the progressive stages of the monastic ideal (Ep. 46.3). These desirable characteristics - devotion, knowledge, and virtue - associated with the worship at Jesus's tomb, are essential for Christians (Ep. 46.9). In Letter 58 Jerome encouraged his addressee to traverse a new, different utopia, not to contemporary Jerusalem, where he would not be able to realise the monastic ideal. Abandoning the Pauline view of a heavenly Jerusalem, but drawing on the language of sacred geography and scriptural exegesis, Jerome creates a kind of Christian utopia where the textual space could open to guide his friends to their destined goal (Ep. 58.8). As a result, he could define the city as a unique physical location, appropriate for a Christian way of life, but also ensure that the scriptures were a credible and utopian space for a journey into scriptural exegesis. Both 
letters thus served Jerome as means to construct a visual and imaginative geography for fourth-century Christians, in which Jerome himself and the letters he sent to his friends were intended to be a guide for them to cultivate a new Christian way of life. His goal was to invite them to a new religious identity, laying the foundation for the perception of sacred geography and promoting the creation of a Christian utopia.

\section{Notes}

1 For Jerome's relationship with the church in Rome, (see Kelly 1975: 104-15; Rebenich 2002: 31-40; Cain 2009: 99-128). For the circumstances in which he became involved in the Origenist controversy, see (Kelly 1975: 200-3; Kim 2013). The most comprehensive review is Clark (1992).

2 For fourth-century attitudes towards pilgrimage, in particular in Jerome's letters, (see Hunt 1982: 192-4; Cardman 1982; Maraval 1988; Leyerle 1996: 130-2; Newman 1998; Perrone 1999; Limor 2001; Maraval 2002: 71-3; Bitton-Ashkelony 2005: 65-105; Pullan 2005; Cain 2010; Cain 2013; Limor 2014: 39-45; Falcasantos 2017: 99-113; Krewson 2017: 99-137; Lamprecht 2017).

3 Translations of Jerome's writings are taken from Jerome (1983).

4 Several manuscripts transmit Ep. 46 under the title 'Exhortatory letter regarding the holy places', CSEL, 54: 329.

5 For general treatments of Ep. 46, (see Maraval 1988: 346-51; Newman 1998: 218-21; Perrone 1999; Bitton-Ashkelony 2005: 70-85; Limor 2014: 40-5; Krewson 2017: 116-30). For the dating of Ep. 46, (see Nautin 1973: 213-39; Cain 2010: 114 n.47).

6 For the problem of Jerome's authorship of this letter, (see Limor 2014: 40 n.41; Falcasantos 2017: 108 n.77).

7 For his reference to Gen 12:1 as the justification of pilgrimage, (see Wilken 1992: 332 n.46; Perrone 1999: 231 n.47; Cain 2010: 120 n.73).

8 For these names of Jerusalem, see Ep. 108.9.1; 129.5.3. See also Perrone (1999: 238 n.51).

9 For the dependence of Jerome and other Christian writers on Josephus, see Weingarten (2005: 208-9).

10 For similar arguments, see Ep. 120.8.9, CSEL, 55: 492; Ep. 122.1.13, CSEL, 56: 60. See also (Wilken 1992: 137; Bitton-Ashkelony 2005: 74).

11 For Jerome's discussion on the ruins of Jerusalem, see Comm. in Es. 1.18: CCSL, 73: 740-1. See also Wilken (1992: 132-7). For the similarities between Jerome and Eusebius regarding its Jewish past, see Bitton-Ashkelony (2005: 75 n.54).

12 On the importance of touch and sight to pilgrims, (see Wilken 1992: 115-20; Frank 2000: 118-33; Falcasantos 2017: 99-109). For the interpretation of Isa 11:10, (see Limor 2014: 40-1; Krewson 2017: 117).

13 For the difficulties in which he was involved, see (Bitton-Ashkelony 2005: 77 n.62). See also (Perrone 1999: 233, 238 n.56; Pullan 2005: 403-4).

14 For the traditional reading of Revelation, see (Wilken 1992: 55-6, 96-7, 291 n.27).

15 For Jerome's interpretation of the Matthaean passage in his commentaries and its difference from other Christian writers, see (Wilken 1992: 91, 292 n.37; Bitton-Ashkelony 2005: 79-81; Krewson 2017: 126-7).

16 For the reading of the Hebrew text, see (Wilken 1992: 97-8).

17 For his emphasis on such worship, considered indispensable to the Christian faith, see Ep. 47. See also (Newman 1998: 219; Bitton-Ashkelony 2005: 81; Krewson 2017: 120).

18 For general treatments of Ep. 58, see (Rebenich 1992: 224-39; Newman 1998; BittonAshkelony 2005: 90-7; Pullan 2005: 404-5; Chin 2007; Krewson 2017: 127-30). For the dating of Ep. 58, see Nautin (1973). 


\section{Naoki Kamimura}

19 For a survey of historical circumstances in which Jerome was involved, see (Kelly 1975: 195-209; Trout 1999: 90-101; Rebenich 2002: 41-51). For Jerome's relationship with Paulinus, see Rebenich (1992: 220-39).

20 E.g. Ep. 2.18, (Silvas 2007: 121). See also (Wilken 1992: 117-18; Newman 1998; Bitton-Ashkelony 2005: 51-7).

21 For Jerome's ambivalent attitude, see (Markus 1990; Cardman 1982; Prawer 1996; Bitton-Ashkelony 2005).

22 For the question of the locus of God's presence, see (Wilken 1992: 91, 292 n.36; Perrone 1999).

23 For his continuing advocacy of the Pauline view, see also (Jerome, Comm. in Es., written between 408 and 410; Bitton-Ashkelony 2005: 93 n.127).

24 For the same contrast described in his works, see Ep. 60.4.1, CSEL, 54: 552; Tract. in Ps. 75.2: CCSL, 78: 49.

25 He had made the same claim c. 390; see Tract. in Ps. 95: CCSL, 78: 154-5. See also Newman (1998: 221-2).

26 For the same argument but a reference to 2 Cor 6:16, see Gregory of Nyssa, Ep. 2.1617, SC, 363: 120-3. See also Maraval (2002: 73-4).

27 For a similar argument, see Comm. in Hiez. 13.43.8: CCSL, 75: 625. Concerning the same argument to be found in Late Antiquity, see also Hunt (1982: 91-2; Maraval 1988: 353; Pullan 2005).

28 For the priority for Bethlehem in his writings, see (Bitton-Ashkelony 2005: 94 n.136; Krewson 2017: 135-7).

29 For the interpretation of his metaphorical message in Ep. 58.8-9, see (Pullan 2005: 404-5; Chin 2007: 103-7; O'Reilly 2017: 219).

30 For the relation of a sacred site to the scriptures, see (Chin 2007; Limor 2014: 39-45). Limor examines some of Jerome's writings, but with no reference to Letters 53 or 58.

\section{Bibliography}

\section{Primary sources}

Gregory of Nyssa (1990) Epistulae. Edited by Maraval, P. Lettres, SC, 363. Paris: Cerf. - (2007) Gregory of Nyssa: The letters. Translated by A. M. Silvas. Leiden and Boston: Brill.

Jerome (1910-18) Epistulae. Edited by Hilberg, I. Hieronymi epistulae, CSEL, 54-56. Vienna: F. Tempsky.

(1958) Tractatus sive homiliae in psalmos: In Marci evangelium. Alia varia argumenta. Edited by Morin, G., Capelle, B., and Fraipont, J., CCSL, 78. Turnhout: Brepols. (1963) Commentariorum in Esaiam libri I-XI. Edited by Adriaen, M., CCSL, 73. Turnhout: Brepols.

- (1964) Commentariorum in Hiezechielem libri XIV. Edited by Glorie, F., CCSL, 75. Turnhout: Brepols.

Paulinus of Nola (1894) Epistulae. Edited by Hartel, G., CSEL, 29. Vienna: F. Tempsky.

\section{Secondary sources including anthologies}

Bitton-Ashkelony, B. (2005) Encountering the sacred: The debate on Christian pilgrimage in Late Antiquity, TCH, 38. Berkeley and Los Angeles: University of California Press.

Cain, A. (2009) The letters of Jerome: Asceticism, biblical exegesis, and the construction of Christian authority in Late Antiquity, Oxford Early Christian Studies. Oxford: Oxford University Press. 
(2010) 'Jerome's Epitaphium Paulae: Hagiography, pilgrimage, and the cult of Saint Paula'. Journal of Early Christian Studies, 18/1: 105-39.

(2013) Jerome's epitaph on Paula: A commentary on the Epitaphium sanctae Paulae, Oxford Early Christian Texts, 17. Oxford: Oxford University Press.

Cardman, F. (1982) 'The rhetoric of holy places: Palestine in the fourth century'. StP, 17: $18-25$.

Chin, C. M. (2007) 'Through the looking glass darkly: Jerome inside the book'. In Klingshirn, W. E. and Safran, L. (eds.), The early Christian book, CUA Studies in Early Christianity. Washington, DC: The Catholic University of America Press, 101-16.

Clark, E. A. (1992) The Origenist controversy: The cultural construction of an early Christian. Princeton, NJ: Princeton University Press.

Dawson, D. (1992) Cities of the gods: Communist utopias in Greek thought. Oxford: Oxford University Press.

Falcasantos, R. S. (2017) 'Wandering wombs, inspired intellects: Christian religious travel in Late Antiquity'. Journal of Early Christian Studies, 25/1: 89-117.

Ferguson, J. (1975) Utopias of the Classical World. Ithaca, NY: Cornell University Press.

Frank, G. (2000) The memory of eyes: Pilgrims to living saints in Christian Late Antiquity, TCH, 30. Berkeley and Los Angeles: University of California Press.

Fremantle, W. H. (trans.) (1983) The principal works of St. Jerome, A Select Library of Nicene and Post-Nicene Fathers of the Christian Church, 2.6. Grand Rapids, MI: Eerdmans.

Hunt, E. D. (1982) Holy land pilgrimage in the later Roman empire, AD 312-460. Oxford: Clarendon Press.

Kelly, J. N. D. (1975) Jerome: His life, writings and controversies. London: Duckworth.

Kim, Y. R. (2013) 'Jerome and Paulinian, brothers'. VC, 67(5): 517-30.

Krewson, W. L. (2017) Jerome and the Jews: Innovative supersessionism. Eugene, OR: Wipf \& Stock.

Lamprecht, J. C. (2017) 'Jerome's letter 108 to Eustochium: Contemporary biography in service of ascetic ideology?'. HTS Teologiese Studies/Theological Studies, 73/3: 1-10. https:/doi.org/10.4102/hts.v73i3.4503.

Leyerle, B. (1996) 'Landscape as cartography in early Christian pilgrimage narratives'. Journal of the American Academy of Religion, 64/1: 119-43.

Limor, O. (2001) 'Reading sacred space: Egeria, Paula and the Christian holy land'. In Hen, Y. (ed.), De Sion exibit lex et verbum domini de Hierusalem: Essays on medieval law, liturgy and literature in honour of Amnon Linder, Cultural Encounters in Late Antiquity and the Middle Ages, 1. Turnhout: Brepols, 1-15.

_ (2014) 'Conversion of space'. In Katznelson, I. and Rubin, M. (eds.), Religious conversion: History, experience and meaning. Farnham: Ashgate, 31-59.

Maraval, P. (1988) 'Saint Jérôme et le pèlerinage aux lieux saints de Palestine'. In Duval, Y.-M. (ed.), Jérôme entre l'Occident et l'Orient: XVIe centenaire du départ de saint Jérôme de Rome et de son installation à Bethléem: Actes du colloque de Chantilly, septembre 1986. Paris: Études augustiniennes, 345-53.

(2002) 'The earliest phase of Christian pilgrimage in the Near East (before the 7th century)'. DOP, 56: 63-74.

Markus, R. A. (1990) The end of ancient Christianity. Cambridge: Cambridge University Press.

Nautin, P. (1971-73) 'L'excommunication de saint Jerôme'. École pratique des hautes études, 80-1: 7-37.

_ (1973) 'Études de chronologie hiéronymienne (393-397) (suite)'. Revue des études augustiniennes, 19: 69-86, 213-39. 
Newman, H. I. (1998) 'Between Jerusalem and Bethlehem: Jerome and the holy places of Palestine'. In Houtman, A., Poorthuis, M. J. H. M., and Schwartz, J. (eds.), Sanctity of time and space in tradition and modernity. Leiden and Boston: Brill, 215-27.

O'Reilly, J. (2017) 'The Bible as map, on seeing God and finding the way: Pilgrimage and exegesis in Adomnán and Bede'. In Boulton, M., Hawkes, J., and Stoner, H. (eds.), Place and space in the medieval world. Milton: Routledge, 210-26.

Perrone, L. (1999) "The mystery of Judaea" (Jerome, Ep. 46): The holy city of Jerusalem between history and symbol in early Christian thought'. In Levine, L. I. (ed.), Jerusalem: Its sanctity and centrality to Judaism, Christianity, and Islam. New York: Continuum, 221-39.

Prawer, J. (1996) 'Christian attitudes towards Jerusalem in the early Middle Ages'. In Prawer, J. and Ben-Shammai, J. (eds.), The history of Jerusalem: The early Muslim period, 638-1099. Jerusalem: Yad Izhak Ben-Zvi and New York: New York University Press, 311-47.

Pullan, W. (2005) 'Intermingled until the end of time: Ambiguity as a central condition of early Christian pilgrimage'. In Elsner, J. and Rutherford, I. (eds.), Pilgrimage in GraecoRoman and early Christian antiquity: Seeing the gods. Oxford: Oxford University Press, 387-409.

Rebenich, S. (1992) Hieronymus und sein Kreis: Prosopographische und Sozialgeschichtliche Untersuchungen. Stuttgart: Steiner.

(2002) Jerome, The Early Church Fathers. London and New York: Routledge.

Trout, D. (1999) Paulinus of Nola: Life, letters, and poems, TCH, 27. Berkeley and Los Angeles: University of California Press.

Weingarten, S. (2005) The saint's saints: Hagiography and geography in Jerome, Ancient Judaism and Early Christianity, 58. Leiden and Boston: Brill.

Wilken, R. L. (1992) The land called holy: Palestine in Christian history and thought. New Haven: Yale University Press. 


\title{
7 Utopia, body, and pastness in John Chrysostom
}

\author{
Chris L. de Wet
}

Utopia and dystopia are complex phenomena. Some utopian thought may long for a perfect distant past, or a flawless future that will soon arrive. A utopia may be in the past, present, or future. As the introduction of this book has noted, utopias are constructed through various means, and some of them may be, and often are, violent. In this study, however, I am more interested in some of the conceptual slippage of utopian and dystopian thought, namely pastness. When I speak of pastness, I refer to a state of (un)being that is rendered past and, by implication, obsolete. Pastness is not history. Pastness is that which has been left behind or discarded. Yet, as I will demonstrate, pastness is also something we can barely escape. The notion of pastness presses us to enquire about the very nature of the relationship between utopia/dystopia and temporality, between perfection/ imperfection and time. One of the main issues with which contemporary utopia studies grapple is that of temporality: 'Utopias and dystopias are histories of the present' (Gordin et al. 2010b: 1).

Using the works of the prolific fourth-century priest, and later bishop of Constantinople, John Chrysostom (349-407 CE), as a case study, in this chapter I aim to investigate more closely how the links between pastness, utopia, and body may have been conceptualised in late-ancient Christianity. This impetus raises several questions. How does Chrysostom understand the nature of the body, and the problem of embodiment, and what are the conditions of corporeal transformation? Does he even allow for the possibility of a 'utopian body' and if so, how is the body turned away from its state of pastness? By understanding these links between pastness, body, and utopia in an early Christian author like Chrysostom, we are afforded the opportunity to engage in further research into memory, utopia, and the destruction of the past by highlighting parallels, correlates, and also disjunctures between the construction and deconstruction of society and culture through the construction and deconstruction of the body. ${ }^{1}$ In a very insightful study, Alexandre Franco de Sá (2012: 23-34) has shown that because of modern teleological rationality, some societies have considered themselves to occupy a space at the end of history (especially contemporary Western societies), being established in a 'time outside of time.' Franco de Sá (2012: 33) refers to this as 'uchronia': 'As a result of positioning themselves at the final stage of the development of political institutions, our societies view the future as an indefinite continuation of what 
they already are.' Such societies (Franco de Sá does indeed speak of post-modern societies) conceptualise not so much a future utopia, but rather shape themselves according to normative ideas or ideals that are always unfinished and perfectible (see also Jameson 2010: 21-44). Franco de Sá (2012: 34) uses Derrida's notion of 'democracy to come' as an example. Derrida (1997: 306; see also Franco de Sá 2012: 34) writes the following about democracy:

For democracy remains to come, this is its essence insofar as it remains: not only will it remain indefinitely perfectible, hence always insufficient and future, but, belonging to the time of the promise, it will always remain, in each of its future times, to come [à venir]: even when there is democracy, it never exists, it is never present, it remains the theme of a non-presentable concept.

As a uchronian concept, for Derrida, democracy is always to come but never arrives.

It is possible, then, to position the notion of pastness as a parallel to Franco de Sá's notion of uchronia. ${ }^{2}$ Pastness, too, is a time outside of time. Pastness assumes that 'we are no longer what we were,' that 'we are better now than we were,' and that 'the future to come will even be better.' Whereas uchronia represents unattainable ideals worth striving for, pastness represents an ambiguous temporal state from which we must constantly distance ourselves, from which we are constantly attempting to escape but often cannot. Both uchronia and pastness are absolute, while only differing in their orientation. The notion of pastness is marked by a strong measure of redundancy. By placing 'something' or 'sometime' in the realm of pastness, the object of placement is relegated to a state that is open to destruction.

Pastness's oppositional stance to what is organic and alive could not escape the eye of one of the founding theorists of Time Studies, Julius Fraser. In his influential work, Time, the Familiar Stranger (1987: 146), Fraser notes: 'Memory, in its rigid instinctual form and, in the most advanced species in flexible forms, gave a definition to pastness also with reference to the organic present. It is thus that with life, time's arrow was born.' Fraser's link between life and temporality necessitates the fact that pastness (and futurity) inevitably shapes the self and, perhaps more concretely, the body. The organic nature of life is nowhere less present and evident than in the body. Fraser (1987: 367), with regard to time and the (inner) self, develops the notion of nootemporality or noetic time, which he defines as follows:

This is the temporal reality of the mature human mind. It is characterized by a clear distinction among future, past, and present; by unlimited horizons of futurity and pastness; and by the mental present, with its changing temporal horizons, depending on attention.

For Fraser (1987: 367), noetic temporality is 'the most sophisticated yet most familiar (the time of the human mind)' form of temporality. Pastness also reaches 
into the realm of the biological, ${ }^{3}$ the embodied, but in a more limited sense, with the death of the organic subject. We observe then an established link between pastness, utopia, and the body.

The concept of pastness, along with its relationship to life and death/destruction, did not escape early Christian thinkers, especially not one as industrious as the apostle Paul. ${ }^{4}$ In Romans 6:6-8, Paul writes:

We know that our old self [ho palaios ... anthrōpos] was crucified with him so that the body of sin [to sōma tēs hamartias] might be destroyed, and we might no longer be enslaved to sin. For whoever has died is freed from sin. But if we have died with Christ, we believe that we will also live with him.

(ESV 2001)

The 'old person' and the 'new person' in Paul's moral theology are, as Destro and Pesce (1998: 188) rightly note, temporal distinctions. They are categories of unbecoming and new becoming. Accompanied by these temporal distinctions are the spatial distinctions (Destro and Pesce 1998: 188-9) of 'outer person' (ho exō anthrōpos) and 'inner person' (ho esō anthrōpos) from 2 Corinthians 4:16. As the old person must be transformed into the new, the inner person grows despite the outer person perishing.

This idea of dual subjectivity became very popular with the earliest admirers of Paul. The idea of putting off the 'old man' and clothing oneself with the 'new' is a well-developed theme in the Deutero-Pauline epistles. Ephesians 4:17-18, 22, reads:

[Y]ou must no longer walk as the Gentiles do, in the futility of their minds. They are darkened in their understanding, alienated from the life of God ... put off your old self, which belongs to your former manner of life and is corrupt through deceitful desires ... [and] put on the new self, created after the likeness of God in true righteousness and holiness.

(ESV 2001)

Colossians 3:1-17 has very similar rhetoric. In these verses, Paul and the authors of Ephesians and Colossians not only relegate their audiences' Gentile past to history, but also to pastness. The 'old self' and the 'body of sin' must be crucified and destroyed. For these authors, in the light of the Christ event, the old self is a self bereft of life and purpose. A transition is needed from the old self to the new. Paul's discourse about body, self, and identity is fundamentally dualistic (Lindgård 2005). And as Ferguson, in his Utopias of the Classical World (1975: esp. 61-79, 146-53, 167-88), has shown, this type of dualistic thought (old vs. new, pastness vs. futurity) is common in ancient conceptualisations of utopia. Such notions of duality and transition bring us to an important aspect of utopian thought, namely transformation. Utopia and dystopia are potentialities of transformation.

The body stands central to this rhetoric of transformation; without body, there can be no utopia or dystopia, and no pastness or uchronia. ${ }^{5}$ Michel Foucault 
(2006: 229) has also identified the body as being a problem of utopian ideals: 'My body, it's the opposite of a utopia: that which is never under different skies. My body, pitiless place.' As a relic of pastness, this body of flesh and blood was not an insignificant problem in early Christian thought. In late-ancient Christian thought the present earthly body — with all its passions and inevitable rot—was a sign of a dystopia, a fragment of pastness. The advent of early Christian asceticism may be understood as one response to this problem of corporeality. Early Christian asceticism operated on the basis that through acts of corporeal mortification (the slow and systematic destruction of the body) the soul is vitalised. Body as such is not negated but shifted to a different place. The body is shifted away from pastness. Ephemeral acts of ascetic violence imagine a new body, a new temple, a new self.

\section{Body, soul, and utopia in John Chrysostom}

Chrysostom believed that both Romans and Ephesians were written by the same person. So in his exposition of the 'old person' and the 'new person' in Ephesians 4:22-4, he provides allusions to Romans 6:6-8 and also quotes Romans 7:23, thereby harmonising the voice of the so-called authentic Paul and Deutero-Paul. He states:

Paul therefore outlines four persons for us. And of these I will provide an exposition. Here he mentions two, saying the following: 'Putting away the old person, be renewed in the spirit of your mind, and put on the new person.' And in the Epistle to the Romans he lists two more, as where he says: 'But I see a different law in my members, waging war against the law of my mind, and bringing me into captivity under the law of sin which is in my members' [Rom 7:23]. And these he mentioned last stand in relation to those former two, the new person to the inner person, and the old person to the outer person [cf. 2 Cor 4:16]. However, three of these four were subject to corruption. Or rather there are three, the new and the old [kainos kai palaios], and this person in his substance and nature [houtos ho ousiōdēs kai physikos]. 'And that you be renewed,' he says, 'in the spirit of your mind' [Eph 4:23]. In order that no one may assume that, when he speaks of old and new, he is introducing a different person, notice what he says: 'That you be renewed.' To be renewed is when the same thing which has grown old is renewed, changed from one thing to another. In this way the subject is the same [to men hypokeimenon to auto], but the change relates to how the subject turns out. How then is the renewal to take place? 'In the spirit of your mind,' he says. Whoever then has the Spirit, will perform no old deed, since the Spirit will not tolerate old practices.

(Hom. Eph. 13.2, Field 1852: 238)

Chrysostom initially speaks of an old person and a new person and makes the outer self and inner self correspond with these respectively. There are tensions 
between these different selves. But he then clarifies his point by stating that the subject (to hypokeimenon) remains the same but is transformed. The subject, for Chrysostom, is the combination of the inner and outer self. The substantial or essential (ousiōèes) aspect of the self may correspond with Paul's inner self, while the physical or natural (physikos) self may correspond to Paul's outer self. He thus establishes a very close conceptual relationship between the self and embodiment. The transformation (or in this case, 'renewal', that is, he ananeosis) of the self is inevitably a corporeal transformation.

In Hom. Eph. 13.2, Chrysostom elaborates on Paul's use of the clothing metaphor to better explain the transformation of the self. The clothing of vice must be removed, and one must be dressed in the robes of righteousness and virtue. The use of the clothing metaphor establishes the notion of modality in the argument. Metaphorical 'clothing' represents different modes of corporeality and subjectivity. Representations of virtue and vice had to be visible in the way one carried oneself — or in Bourdieu's (1984: 166-8) terms, in one's habitus — so the clothing metaphor is highly appropriate. The renewed Christian body must take up a new behavioural 'dress code,' so to speak. ${ }^{7}$

The body itself is therefore not the problem for Chrysostom. Nor are the passions of the body the real problem for him (we will return to this point in the following section). The problem of the body is that it is clothed in pastness, the fact that the body is 'subject to corruption' (diephtarēsan). It is subject to sin, vice, and death. The body in its current modality stands as a monument of a time and world that has been relegated to pastness after the Christ event. And as the Greek verb diaphtheiro denotes, when the body stands in its old modality it will be utterly destroyed.

Furthermore, Chrysostom constantly stresses Paul's view that the transformation must take place in the 'spirit of your mind' (en tō pneumati tou noos hymōn). We are again reminded of Fraser's notion of noetic temporality. The old and the new modalities, pastness and that which is here and to come, are temporalities of the mind. The body can only experience the necessary transition-or perhaps, 'transitioning,' since the body never fully transitions during its earthly life, if we are to use Franco de Sá's uchronian terms - through the intermediary activity of the mind. ${ }^{8}$ The changes wrought by the mind may then be understood as the different modes of corporeality and, thus, subjectivity. The first thesis of this study therefore is that for Chrysostom, the body is inextricably linked to the self, and the transformation of the body and self through the mind relates not to changes in the subject's substance but rather in modes of corporeality and subjectivity.

What are the characteristics of these different modes of corporeality in Chrysostom? In his thirteenth homily on the Epistle to the Romans ${ }^{9}$ he elaborates further on the nature and problems of the modes of corporeality outlined above:

For with death, Paul says, the trouble of passions also came in. For when the body had become mortal, it was hence required of it to receive concupiscence, and anger, and pain, and all the other passions, which required a great deal of discipline to prevent them from flooding us, and sinking reason 
into the depth of sin. For in themselves they were not sinful; but, when their excessiveness was unbridled, it resulted in this transgression.

(Hom. Rom. 13.1; Field 1849: 199)

The fact that the body in its modality of pastness is subject to death and destruction, Chrysostom argues, means that it necessarily wants to experience as much pleasure and indulgence as it can while it is still alive. When Paul asks, in Romans 7:24, 'Who will deliver me from this body of death?' (ESV 2001), he makes a point similar to the one made above regarding the meaning of 'this body of death.' It is not the body or flesh in itself that is sinful. 'Do not think that he is accusing the flesh,' he says in reference to Romans 7:24. 'Flesh' here is basically 'the mortal body, that which has been overcome by death, not that which generated death' (Hom. Rom. 13.3; Field 1849: 205). The phrase means that death restrains the body, but the body does not produce death. Although he does not mention Manichaeism explicitly in this section, he may be making this point against Manichaean views of the body that considered the body itself to be an evil. ${ }^{10}$

Being a creation of God, the body is not sinful per se, although being subject to death does make the body weak. This weakness is manifest in the body's management of the passions. Chrysostom's understanding of the passions is very important to take note of here. Unlike the Stoics, he does not feel that passions in themselves are evil. ${ }^{11} \mathrm{He}$ does not believe that the utopian body and the utopian self is passionless (apathēs), or at least, unmoved by passion, as some Stoic thought seems to indicate. ${ }^{12}$ Rather, Chrysostom adopts a Platonic stance to say that passion in its excess is what brings the body and self to ruin. Our second thesis therefore needs to be clearly marked at this point: Chrysostom does not consider the body itself to be evil, nor are the passions in themselves evil, but it is excessive passion that weakens the body and brings about death and the destruction of the self. A subject's corporeal modality is therefore determined by the body's indulgence (or not) in the passions. The fact that the body is in its essence good means that a concept of a utopian body or corporeality is a possibility for Chrysostomfor others the concept of a utopian body may sound like an oxymoron.

Because of the thorny relationship between the body and the passions, and the tendency of the body to gravitate towards pathic excess, each subject is adorned with a soul, which is supposed to govern the body. Since the soul is supposed to rule over the body (often as a master should rule over a slave, ${ }^{13}$ as will be shown), the soul necessarily occupies a higher position in what we may call the hierarchy of the self in Chrysostom's thought. 'Now we agree that the flesh is not as great as the soul, and is inferior to it, yet not contrary, or in opposition to it, or evil,' he explains, 'but that it is placed beneath the soul as a harp beneath a harper, and as a ship under the pilot' (Hom. Rom. 13.1; Field 1849: 201). So the soul becomes the navigator of the body's orientation towards a particular modality. But he stresses again that Paul 'is not finding fault with the body, but pointing out the soul's superiority ... [he is] giving the governing power [kyros] to the soul' (Hom. Rom. 13.1; Field 1849: 201-2). ${ }^{14}$ 
The soul is therefore enabled to orient and guide the body, and hence the subject, to a modality that will escape the threat of corruption. In Chrysostom's thought, soul is always an indicator of rule and governance, whether it is over the self, with which we are concerned here, or over the cosmos. This point is particularly clear in his reading of the creation narrative(s) in Genesis. In his exposition of Genesis 1:26, which reads, 'Let us make man in our image and likeness' (ESV 2001), Chrysostom states:

So 'image' refers to the matter of control [tēs archēs], not anything else, in other words, God created man as having control of everything on earth, and nothing on earth is greater than man, under whose authority everything falls.

(Hom. Gen. 8.9; PG, 53: 72; Hill 1999: 110)

Being created in the image (eikōn) of God is therefore an indication of control or rule $(\operatorname{arch} \bar{e})$. The endowment of a rational soul is what makes humanity, overall, able to rule. There is a natural tension between body and soul, however. While the soul links the human subject to the divine, the body links it to materiality and this makes the subject vulnerable to pathic excess. 'What is mortal, the soul or the body?' he asks. 'Clearly the body: the soul is naturally immortal, the body naturally mortal' (Serm. Gen. 7.346-8; Brottier 1998: 336-7; Hill 2004: 127). Humanity finds itself between the incorporeal divine and the fleshly bestial, a soul entangled and intertwined in a body:

[R]ealizing the nobility of our soul, let us be guilty of no behaviour unworthy of it nor defile it with unfitting actions, subjecting it to the thrall of the flesh and showing so little appreciation and regard for what is so noble and endowed with such pre-eminence. After all, because of the soul's being, we who are intertwined with a body can, if we wish and under the influence of God's grace, strive against disembodied powers, can walk on earth as though coursing across heaven, and pass our lives in this manner, suffering no inferiority. How that can be, I will tell you. You see, when people prove, despite entanglement with a mortal body, to live the same life as those supernatural powers, how will they not be deemed worthy of grace from God for keeping untarnished the soul's nobility, though subject to the body's necessities.

(Hom. Gen. 12.17; PG, 53: 104; Hill 1999: 167)

Chrysostom now clarifies the guidance of the body by the soul: psychic guidance is equal to domination. This was seen previously, where he used the Platonic image of the rational soul dominating over its bestial thoughts and appetites. The soul occupies a position of primacy over the body, and the purpose of the soul is to control the passions, or 'impulses of the flesh,' as Chrysostom says. ${ }^{15}$ He explains that the soul should dominate the body like a slave, ${ }^{16}$ so that if the passions of the flesh overcome the soul, it is like a slave rebellion. 
Chrysostom, however, does not consider the soul to be divine in and of itself. Despite its close links with divinity, the soul is not a part of God. Expounding Genesis 2:7, he states:

In this regard, some senseless people, moved by their own reasoning, and having no regard for what is proper to God nor any appreciation of the considerateness revealed in the words, try to say that the soul comes from the substance of God. Such madness, such stupidity!

(Hom. Gen. 13.7; PG, 53: 106; Hill 1999: 172)

Chrysostom is probably again refuting the Manichaean doctrine that the soul is of one substance with the divine (the point that such thinking is 'madness,' that is, mania, may be a pun directed towards the Manichaeans). In a different homily, he accuses the Manichaeans of introducing the essence of God into apes, dogs, and many other animals, and murderers and sorcerers (In diem natalem 1; PG, 49: 359). This interpretation of Genesis 2:7 was common in anti-Manichaean polemic. Similarly, the soul is situated on a higher level than the body, according to Chrysostom, but it is by no means a part of God. The third thesis in this study is then the following: According to Chrysostom, the orientation of the body towards a particular modality lies in the superior ambit of the soul; the nature of the guidance the soul provides, though, is that of domination. The turn that the soul compels the body to take is a forceful and even violent turn.

How then is the turn towards the utopian body by the soul accomplished? While the soul was not corporeal, it was seen as being material and closely interwoven with the body. ${ }^{17}$ The matter (hyle) of which the soul consisted was lighter and often drier than that of the flesh, but the soul remained material. ${ }^{18}$ The soul was distributed throughout the body in three parts: the rational soul was located in the brain, the vital soul in the heart, and the appetitive soul in the liver. This Platonic division of the soul throughout the body was also adopted by Chrysostom (Mayer 2015: 14-16). It is especially the rational soul-which is the representation of the link between soul and mind - that should exercise governance over the body of the subject.

The type of embeddedness of the soul within the body meant that physical discipline, especially with regards to regimen and daily habits, had a direct effect on the soul (Shaw 1998: 131-8; Mayer 2015: 11-26). In Chrysostom's thought, the soul is strengthened through ascetic discipline, and through this same discipline, the body is renewed. By means of the nourishment of spiritual exercises, the soul will be "strengthened and thus able to resist the rebellion of the flesh and the constant battle waged within us to reduce our soul to servitude if we are disposed to drop our guard even for a short space of time' (Hom. Gen. 10.20; PG, 53: 90; Hill 1999: 141). Spiritual disciplines like fasting, vigils, and prayer are therefore central to sculpting the utopian body and escaping the threat of pastness.

This discourse of the soul's domination of the body in Chrysostom is also quite paradoxical. 'Do not permit your body then to live in this world, so that it may live then! Make it die, that it may not die,' he says, '[T]he one who is dead to this 
life, is then most alive' (Hom. Rom. 13.5-6; Field 1849: 218). Utopian corporeality therefore dawns from the daily practices of self-renunciation and corporeal mortification, practices that represent the sole foundation of Christian subjectivation. Life is achieved through the ascetic art of dying (de Wet 2015a: 4). 'Let us continually mortify the flesh in its works,' Chrysostom admonishes, 'I do not mean in its substance, certainly not, but in its impulses towards evil works' (Hom. Rom. 13.6; Field 1849: 218). The substance of the body should not be destroyed, but merely its modality, its garment of pastness.

For Chrysostom the aim of asceticism is to displace the current earthly body through acts of self-control and self-mortification, to bring it to a point where it practically eclipses the soul. The body is not negated or destroyed, but saved from the prison of its pastness. If a body does not transform, if it remains in its modality of pastness, it will eventually be destroyed in the eschaton. This vision of utopian corporeality is accessible and practical. Although he admires the monks in the mountains who excessively discipline their flesh, his own rhetoric about how to deal with the problem of the body is far more moderate. In contrast, when reading a hagiographical text like Theodoret's History of the Monks of Syria (Canivet and Leroy-Molinghen 1977, 1979; Price 1985), we find that Theodoret sketches the lives of the monks in such a way as to bring his audience to a point of fearful awe and reverent admiration. The audience is not expected to imitate the monks. Never does Theodoret expect, for instance, that his audience members will ascend a pillar like Symeon the Stylite (Hist. rel. 15; Price 1985: 160-72), or develop customised ascetic devices to subdue their bodies, like James of Cyrrhestica who fashioned such heavy chains and belts for his body that they nearly cost him his life (Hist. rel. 21; Price 1985: 133-47). In fact, he attempts to 'soften' the heterodox appearance of some of the practices of his ascetic subjects to make them slightly more palatable for his audience. The utopian bodies of the monks displayed in Theodoret, bodies withered by rigorous fasting, brutal chaining, and merciless exposure to the elements, are for the audience's viewing pleasure only. Chrysostom's vision of utopian corporeality is much more accessible and practically achievable. There is further evidence of this in the fact that one can have a virgin soul even without being a physical virgin. By practising even a moderate asceticism the Christian is able to set him- or herself on a path of utopian transformation.

Chrysostom's utopian corporeality is also based on the principle of paradoxical truth. Ascetic practice is both deconstructive and constructive in terms of the body. It often violently breaks down the earthly body with the vision of building a utopian body to come. The mortification of the flesh brings life. True satisfaction is the hunger of the fast, true rest is the vigil, true fertility is virginity (virginity, of body and/or soul, is probably one of the defining traits of the utopian body for Chrysostom), and true freedom is enslavement to God and not to the passions. The earthly body may be enslaved to sin and the passions, but ascetic discipline, in turn, represents the enslavement of the body to the soul and, thus, God.

Interestingly enough, Chrysostom's utopian corporeality is quite domestic. The deserts and mountains where the monks dwell are less the utopias where bodies 
are transformed to freedom; it is in Christian households that the fires of renewal are lit, as Peter Brown (1988: 305-22) showed some decades ago. Most of Chrysostom's moderate ascetic practices take place within the household and among members of the family. In Chrysostomic thought, the location of utopian corporeality is the household. All these characteristics democratise utopian corporeality. It is not only the highly devoted monks of the desert who can fashion a utopian body. Utopian bodies may also be found in the devout Christian households of the city.

My final thesis is then this: Chrysostom's vision of the utopian body is achieved through ascetic practices of corporeal mortification (including following an ascetic regimen and practising virginity) as initiated by the soul. This makes Chrysostom's truth about the utopian body paradoxical — life is achieved through practices of mortification. This notion implies that the subject must take into his or her own hands the responsibility for destroying his or her modality of pastness. One must not simply wait for the judgement, punishment, and destruction of corporeal pastness by God at the eschaton. Through the self-violence of asceticism, ${ }^{19}$ the subject through his or her own agency begins to bring an end to the dystopian corporeality of pastness, and begins to usher in the future utopian corporeality.

The theses outlined here are also relevant for understanding Chrysostom's notion of the resurrected body, which will be the utopian body in its final form. Because the body, both in essence and nature, is good, he believes in a carnis resurrectio, a physical resurrection. In his homilies on Paul's doctrine of the resurrection in 1 Corinthians 15, Chrysostom constantly (again) refutes Manichaean views that there will be no physical resurrection, but only a resurrection from sin (de Wet 2011: 92-114).

\section{The utopian body and the utopian society in Chrysostom}

Chrysostom cannot think of the self outside of its corporeality. Body is not the only aspect of self - there is also mind, soul, and relationality with others, especially those within the church. But the body remains a divine creation, which means that it has a purpose beyond this life. Furthermore, while the self consists of various parts, he also presents a hierarchised version of the self. The body occupies a somewhat inferior position to the mind and soul.

Despite its inferior position in the hierarchised self, because the body is good it has utopian potential. The problem of the body, though, is difficult to articulate. It finds itself caught in a present pastness that needs to be overcome if it is to be transformed. But this mode of pastness, and being subject to death and destruction, causes the body to indulge excessively in the passions, which only hastens its destructive fate. In order to be transformed or renewed to its utopian modality, the body must be turned away from its mode of pastness. This can only be achieved by the guidance of the soul. Ironically and paradoxically, the soul must dominate the body and lead it to ascetic acts of self-mortification. Thus, to escape the destruction of pastness that will come with the eschaton, the self must destroy the body through its own psychic agency. 
An important principle arises in this instance: Transformation towards utopian corporeality is achieved, practically, through acts of self-violence and destruction. However, in Chrysostom there is a very strong link between body and society, and he argued that without total psychic control, social control would never fully be achieved. In his Serm. Gen. 4.1.21-31 (Brottier 1998: 220-1) he states that after humanity's fall into sin, three types of 'slavery' were introduced to mitigate the effects of sin and the indulgence in the passions, namely marriage, institutional slavery, and imperial governance. Yet these institutions are simply external correlates of internal psychic control. Chrysostom goes on to argue in this sermon, however, that the person with full psychic control (the true ascetic, in other words) has no need of these institutions, not even imperial governance. ${ }^{20}$ These institutions are not utopian, but are there to ensure that postlapsarian society does not tear itself apart. He does not see his society in terms of Franco de Sá's scheme of uchronia, but all three of these ancient institutions work on the principle of control, dominance, and in some form or another, violence. Although John, among others, felt that the perfectly disciplined Christian had no need of imperial governance, Van den Heever (2002: 297-334) has convincingly shown that Christian utopian rhetoric even from its nascent stages employed a potent rhetoric of imperiality of which the Christian empire of Late Antiquity is a direct result. Christian authors often differed on whether the current Christian empire was a sign of utopia to come. Both Chrysostom and Augustine, for instance, felt that although many in the church would be part of the future eschatological utopia (or City of God, in Augustine's case), the future to come also included saints, martyrs, and in some cases even non-Christian figures who were never part of the earthly church. ${ }^{21}$

The question for further study is to ask whether early Christian views like that of Chrysostom, which proposed that the utopian body is constructed through the destruction of its modality of pastness, also assumed that the utopian society is constructed through the destruction of its remnants of pastness. If a Christian, for instance, had to destroy the corporeal (that is, behavioural and/or habitual) remnants of his or her non-Christian or 'pagan' pastness through asceticism, did this principle also entail a destruction of the material remnants of a non-Christian pastness? Was the destruction of 'pagan' structures, whether through acts of violence or abandonment (or in some cases, 'redeployment'), also justified ideologically by similarly relegating these structures to the realm of pastness? Could the conflict and violence against 'pagan' material artefacts and structures be understood as a type of ascetic cleansing (and punishment, perhaps) of landscape and culture?

There is already a firmly established link between asceticism and space. Schroeder (2004: 521) notes the following: 'The church building thus proves to be a powerful symbol for late-antique authors who sought to express their particular visions of asceticism both textually and architecturally.' If the construction of church buildings stood in a direct relationship with ascetic discourse and practice, then the opposite - the destruction (which I mean in the broad sense, including abandoning) of non-Christian religious structures and spaces may also have had an ascetic impetus. 


\section{Chris L. de Wet}

Architectural metaphors, moreover, are often used to speak about the body and the soul. The body is often, from New Testament tradition up to Chrysostom and beyond, referred to as a temple, and the soul is often seen as a city or a fortress that must be protected (compare Bronwen Neil's Chapter 8 on the centrality of architectural language in ancient conceptualisations of memory and mnemonic systems).

\section{Conclusion}

What is left to determine is how such visions of utopian corporeality and the disciplining of pastness run parallel to discourses and practices of the 'material' discipline and punishment of inanimate structures, be they buildings, statues, or texts and the like. Understanding utopian corporeality in Chrysostom, and in early Christianity more broadly, may assist us in better understanding how the utopian society was envisioned in Late Antiquity, and what measures some took to push society towards such a utopian and even uchronian reality. When Paul spoke of the transformation of the self, of removing the self from the modality of the old person to that of the new, it remains unclear how this could be achieved practically. But in Chrysostom the matter is clear: the self is transformed to its utopian corporeal modality through the practice of a form of self-violence, namely asceticism.

What we do know is that the utilisation of dualistic discourse is never neutral or without social effects. Destro and Pesce (1998: 188) note that with dualistic discourses like those of the old and new, inner and outer persons, "[w]e are again faced with a spatial dimension that implies areas marked off by boundaries, and does not construct a harmonic model of society, but a stretching apart of social spaces.' The discursive dynamics between pastness, utopia, and body, which we have extrapolated in this study, could lead to social polarisation. And if self-violence was required to transform the body into its utopian modality, it may be that some individuals perceived violence towards those who represented a life and society long past to be the only path to a social utopia.

\section{Notes}

1 Vorster (2006: 98-118) has already engaged in similar research, although his work does not touch on the issue of utopia as such.

2 Pastness may even be theorised in terms of 'dyschronia,' but this is a task for a different study.

3 Or what Fraser (1987: 367) refers to as biotemporality, or biological time.

4 For a fuller discussion of this topic in Paul's thought, see Deibert (2017).

5 For an excellent exploration of the relationship between body, utopia, temporality, and transgender transformations in our current society, see Nirta (2018: 38-84).

6 All translations of Chrysostom's works are my own unless otherwise indicated.

7 See esp. Harlow (2004: 44-70); Upson-Saia (2011: 33-58); Doerfler (2014: 37-54).

8 See also the relevant work of Laird (2012: 44-70) on the importance of the mindset or gnōmē in Chrysostom.

9 Note that the numbering of the homily differs in the Field (1849: 198-225) text, where it is listed as the fourteenth homily. I will use the traditional numbering throughout this chapter for the sake of readers unfamiliar with the Field text and numbering. 
10 It should be made clear here that this view of Manichaean corporeality is that which Chrysostom himself held-it is, in other words, his own (somewhat simplistic and polemical) interpretation of Manichaeism. We know that Manichaean views of the body were rather complex in themselves; see BeDuhn (2000, 2001: 5-37); Mara (2008: 195-9); De Wet (2015a: 1-6).

11 Stoic views of the passions, and being passionless or unmoved by passion, are directly related to Stoic understandings of the body/soul dichotomy. As Bartsch (2006: 174) notes, Stoicism often views the body simply as a covering or case for the soul, almost like a shoe for one's foot. We do find later valorisations of the body in Stoic thought.

12 For more on Stoic apatheia in late-antique Christian thought, see the thoughtful discussion of Elm (2015: 96-8).

13 On the notion of the soul being a master and the body a slave in Chrysostom's thought, see De Wet (2015b: 45-81).

14 See also De Wet (2015a: 3). On Chrysostom's use of Platonic images to explain the governance of the soul over the body, see Bosinis (2006: 433-8).

15 See esp. Hom. Gen. 10.1-2 (PG, 53: 82-3), 11.1 (PG, 53: 91).

16 In fact, in Hom. Gen. 2.3 (PG, 53: 27) Chrysostom speaks of the flesh being chastened by fasting, just like an obedient slave-girl, no longer resisting the dominion of her mistress, namely the soul.

17 For more on the interchanges between corporeality and materiality in early Christian discourses about body and soul, see Martin (1995: 14-15, 86-7); and Deibert (2017: 36-46). Foucault (1977: 29) rightly believed that in cases such as this the soul acts almost as a duplication of the body.

18 On the consistency of souls and spirits, see esp. Smith (2008: 479-512).

19 On asceticism, generally, as self-violence, see Olson (2015: 81-115).

20 See also Pagels (1985: 67-99) on Chrysostom's (and Augustine's) often contrasting views about the nature of sin and whether the believer requires the discipline of imperial governance.

21 For Chrysostom, see Verosta (1960: esp. 35-45) and, more generally, Bosinis (2005); for Augustine, see Ferguson (1975: 181-8).

\section{Bibliography}

\section{Primary sources}

ESV (2001) The holy Bible: English standard version. Wheaton, IL: Crossway.

John Chrysostom (1849) In epistulam ad Romanos homiliae. Edited by Field, F. Ioannis Chrysostomi interpretatio omnium epistularum Paulinarum, vol. 1. Oxford: J. H. Parker. - (1852) In epistulam ad Ephesios homiliae. Edited by Field, F. Ioannis Chrysostomi interpretatio omnium epistularum Paulinarum, vol. 4. Oxford: J. H. Parker.

- (1862) In diem natalem. PG, 49.

(1862) In Genesim homiliae. PG, 53.

(1998) In Genesim sermones. Edited by Brottier, L. Jean Chrysostome: Sermons sur la Genèse, SC, 433. Paris: Cerf.

(1999) St. John Chrysostom: Homilies on Genesis 1-17, FOTC, 74. Translated by

Hill, R. C. Washington, DC: Catholic University of America Press.

(2004) St. John Chrysostom: Eight sermons on the book of Genesis. Translated by

Hill, R. C. Brookline, MA: Holy Cross Orthodox Press.

Theodoret (1977/1979) Historia religiosa. Edited by Canivet, P. and Leroy-Molinghen,

A. Théodoret de Cyr: Histoire des moines de Syrie, 2 vols., SC, 234, 257. Paris: Cerf.

(1985) A history of the monks of Syria by Theodoret. Translated by Price, R. Trappist, KY: Cistercian Publications. 


\section{Secondary sources}

Bartsch, S. (2006) The mirror of the self: Sexuality, self-knowledge, and the gaze in the early Roman empire. Chicago: University of Chicago Press.

BeDuhn, J. (2000) The Manichaean body: In discipline and ritual. Baltimore: Johns Hopkins University Press.

(2001) 'The metabolism of salvation: Manichaean concepts of human physiology'. In Mirecki, P. and BeDuhn, J. (eds.), The light and the darkness: Studies in Manichaeism and its world, Nag Hammadi and Manichaean Studies. Leiden: Brill, 5-37.

Bosinis, K. (2005) Johannes Chrysostomus über das Imperium Romanum: Studie zum politischen Denken der Alten Kirche. Mandelbachtal: Cicero.

(2006) 'Two Platonic images in the rhetoric of John Chrysostom: "The wings of love" and the "charioteer of the soul". StP, 41: 433-8.

Bourdieu, P. (1984) Distinction: A social critique of the judgement of taste. Cambridge, MA: Harvard University Press.

Brown, P. R. L. (1988) The body and society: Men, women, and sexual renunciation in early Christianity. Ithaca, NY: Columbia University Press.

Deibert, R. I. (2017) Second Corinthians and Paul's gospel of human mortality: How Paul's experience of death authorizes his apostolic authority in Corinth, WUNT, II, 430. Tübingen: Mohr Siebeck.

Derrida, J. (1997) The politics of friendship. Translated by G. Collins. London: Verso.

Destro, A., and Pesce, M. (1998) 'Self, identity, and body in Paul and John'. In Baumgarten, A. I., Assmann, J., and Stroumsa, G. G. (eds.), Self, soul, and body in religious experience, Studies in the History of Religions. Leiden: Brill, 184-97.

de Wet, C. L. (2011) 'John Chrysostom's exegesis on the resurrection in 1 Corinthians 15'. Neotestamentica, 45/1: 92-114.

- (2015a) 'The practice of everyday death: Thanatology and self-fashioning in John Chrysostom's thirteenth homily on Romans'. HTS Theological Studies, 71/1: 1-6.

(2015b) Preaching bondage: John Chrysostom and the discourse of slavery in early Christianity. Oakland: University of California Press.

Doerfler, M. E. (2014) 'Coming apart at the seams: Cross-dressing, masculinity, and the social body in Late Antiquity'. In Batten, A. J., Daniel-Hughes, C. and Upson-Saia, K. (eds.), Dressing Judeans and Christians in antiquity. Farnham: Ashgate, 37-54.

Elm, S. (2015) 'Gregory of Nazianzus: Mediation between individual and community'. In Rebillard, É. and Rüpke, J. (eds.), Group identity and religious individuality in Late Antiquity. CUA Studies in Early Christianity. Washington, DC: Catholic University of America Press, 89-110.

Ferguson, J. (1975) Utopias of the Classical World. London: Thames and Hudson.

Foucault, M. (1977) Discipline and punish: The birth of the prison. New York: Vintage.

- (2006) 'Utopian body'. In Jones, C. A. (ed.), Sensorium: Embodied experience, technology, and contemporary art. Cambridge, MA: MIT Press, 229-34.

Franco de Sá, A. (2012) 'From modern utopias to contemporary uchronia'. In Vieira, P. and Marder, M. (eds.), Existential utopia: New perspectives on utopian thought. New York: Continuum, 23-34.

Fraser, J. T. (1987) Time, the familiar stranger. Amherst: University of Massachusetts Press.

Gordin, M. D., Tilley, H., and Prakash, G. (eds.) (2010a) Utopia/dystopia: Conditions of historical possibility. Princeton, NJ: Princeton University Press.

(2010b) 'Introduction: Utopia and dystopia beyond space and time'. In Gordin et al. (eds.), 1-20. 
Harlow, M. (2004) 'Clothes maketh the man: Power dressing and elite masculinity in the later Roman world'. In Brubaker, L. and Smith, J. M. H. (eds.), Gender in the early medieval world: East and West, 300-900. Cambridge: Cambridge University Press, 44-70.

Jameson, F. (2010) 'Utopia as method, or the uses of the future'. In Gordin et al. (eds.), 21-44.

Laird, R. J. (2012) Mindset, moral choice and sin in the anthropology of John Chrysostom. Early Christian Monographs. Strathfield: St. Paul's Publications.

Lindgård, F. (2005) Paul's line of thought in 2 Corinthians 4:16-5:10, WUNT, II, 189. Tübingen: Mohr Siebeck.

Mara, M. G. (2008) 'Aspetti della polemica antimanichea di Giovanni Crisostomo'. In Padovese, L. (ed.), Atti dell'undicesimo simposio Paolino: Paolo tra Tarso e Antiochia, Archeologia/storia/religione. Rome: Pontificia università antonianum, 195-99.

Martin, D. B. (1995) The Corinthian body. New Haven, CT: Yale University Press.

Mayer, W. (2015) 'Medicine in transition: Christian adaptation in the later fourth-century East'. In Greatrex, G. and Elton, H. (eds.), Shifting genres in Late Antiquity. Farnham: Ashgate, 11-26.

Nirta, C. (2018) Marginal bodies, trans utopias. London: Routledge.

Olson, C. (2015) Indian asceticism: Power, violence, and play. Oxford: Oxford University Press.

Pagels, E. (1985) 'The politics of paradise: Augustine's exegesis of Genesis 1-3 versus that of John Chrysostom'. HTR, 78/1-2: 67-99.

Schroeder, C. T. (2004) "“A suitable abode for Christ”: The church building as symbol of ascetic renunciation in early monasticism'. Church History, 73/3: 472-521.

Shaw, T. (1998) The burden of the flesh: Fasting and sexuality in early Christianity. Minneapolis: Fortress.

Smith, G. A. (2008) 'How thin is a demon?'. Journal of Early Christian Studies, 16/4: 479-512.

Upson-Saia, K. (2011) Early Christian dress: Gender, virtue, and authority. New York: Routledge.

Van den Heever, G. A. (2002) 'From the textures of texts to a Christian utopia: The case of the Gospel of John'. In Porter, S. E. and Stamps, D. L. (eds.), Rhetorical criticism and the Bible: Essays from the 1998 Florence conference, Journal for the Study of the New Testament Supplement Series, 195. Sheffield: Sheffield Academic Press, 297-334.

Verosta, S. (1960) Johannes Chrysostomus: Staatsphilosoph und Geschichtstheologe. Graz: Verlag Styria.

Vorster, J. N. (2006) 'Construction of culture through the construction of person: The construction of Thecla in the Acts of Thecla'. In Levine, A.-J. and Robbins, M. M. (eds.), A feminist companion to the New Testament apocrypha. London: T. \&. T Clark International, 98-118. 
$\because$ Taylor \& Francis Taylor \& Francis Group http://taylorandfrancis.com 


\section{Part III}

\section{Rewriting landscapes}

Creating new memories of the past 
$\because$ Taylor \& Francis Taylor \& Francis Group http://taylorandfrancis.com 


\title{
8 Memories of peace and violence in the late-antique West
}

\author{
Bronwen Neil
}

It is very edifying to see men working such miracles, for we gain a glimpse of the heavenly Jerusalem in its citizens here on earth. ${ }^{1}$

In her classic work on the ancient art of memory in Rome and Greece, using places (loci) and mental images (imagines), Frances Yates noted that in the classical period the most common type of mnemonic place system was architectural. Different mental images, each corresponding to part of the speech or text to be remembered, were stored as if in different rooms of a large building (Yates 1966: 63); readers may recall Sherlock Holmes's 'memory palace.' The order of the mental journey through each room of the chosen building corresponds to the order of parts of the speech to be memorised. The anonymous tract Rhetorica ad Herennium, written in 86-82 BCE and once attributed to Cicero, instructs writers to make their works memorable by arousing an emotional response in the reader or hearer: 'The things we easily remember when they are real we likewise remember without difficulty when they are figments, if they are carefully delineated' ( $A d$ Her. 3.22, Caplan 1954: 221). On this passage, Yates remarks:

Our author has clearly got hold of the idea of helping memory by arousing emotional affects through these striking and unusual images, beautiful or hideous, comic or obscene. And it is clear that he is thinking of human images, of human figures wearing crowns or purple cloaks, bloodstained or smeared with paint, of human images dramatically engaged in some activity—doing something.

(Yates 1966: 10)

This description of a classical Roman tract on the act of memorising tells us something about what Romans believed was easiest to remember: activity, people, unusual physical features, and not the normal, the mundane, the commonly encountered, or the static. In a similar vein, Mary Carruthers showed that medieval memory was a process of attaining and retaining knowledge (Carruthers 1990, 1998).

Gregory of Tours (c. 538-594) was one of the first to grasp the significance of the exaggerated tale for imparting theological truths to his audience of relatively 
new Christian converts. ${ }^{2}$ Gregory's hagiography of sixth-century Merovingian Gaul included the Life of the Fathers - the singular being used to indicate the unity of life of all who follow Christ in an exemplary fashion - and the lives of its most famous saints, Martin of Tours and Julian. These may be compared with similar hagiographic collections of two other western authors of similar periods: the Dialogues attributed to Gregory the Great (590-604), and the anonymous Spanish Lives of the Fathers of Mérida (VPE), which dates to the mid-seventh century. Their stories of saints and sinners are meant to be memorable but also believable, though perhaps not ad verbum. The purpose of the next section is to sketch the landscape of what we know about the ancient and medieval understanding of memory.

\section{Recent studies on ancient and medieval memory}

In the Carolingian period, the rituals for the memory of the dead were built on structures that used location, space, and architecture as devices for creating mnemonic images for remembering those who had passed on (McClure 2015: 2). McClure provides an overview of recent memory scholarship in medieval historiography and hagiography pertaining to Gaul (McClure 2015: 8-22). ${ }^{3}$ While McClure mainly speaks of such rituals in reference to ordinary believers rather than saints, we can see this development as a function of the increasingly localised memoria sanctorum in the earlier Merovingian period. McClure questioned whether such mnemonic techniques as Yates and Carruthers identified for individual rhetoricians were relevant to the memory of the dead (memoria mortuorum), which is both private and social. She concluded that the medieval interpretation of the 'spaces, locations and architecture' that were used to remember the dead was physical, rather than mental. This theoretical foundation, she argues, underpinned Carolingian funerary practices of burying ordinary laypeople near the saints, so that they could partake in their memory and their being remembered.

In the earlier, Merovingian tales of Gregory of Tours, it is clear that the act of commemoration is essentially communal-though also familial in Gregory's case, due to his connections with episcopal ancestors-because it focuses not on the hero-saint as moral exemplar, as do most hagiographers and funeral orators, ${ }^{4}$ but on affecting the listeners' memories, not just their behaviour, through their emotive response to the text.

The ancient connection between emotion and memory was first recognised by Aristotle and received by the scholastic philosophers of the Middle Ages (Carruthers and Ziolkowski 2002: 8-9). As Carruthers put it: 'The matters memory presents are used to persuade and motivate, to create emotion and stir the will' (1998: 67). Similar to other ancient biography, hagiography creates a common memory, established by the presence of the dead subject (Hägg and Rousseau 2000: 24). Patricia Cox Miller has pointed to the emergence of a new literary genre, collective biography, in the late fourth century. Miller argues that the shift towards a 'hagiographical impulse' reflected the recognition that holiness was a single subjectivity, one shared by many individuals who tried to be the same 
rather than different. This impulse was not confined to Christians, nor monks, as the pagan biographer Eunapius's Lives of the Philosophers shows: All but one of his subjects were pagans (Cox Miller 2000: 222). Evidence for this shift is found in Gregory's preface to the Vita Patrum (Life of the Fathers), where he discusses why he chose the singular vita rather than vitae for his title, because 'although there is a diversity of merits and miracles, nevertheless one life of the body nurtures all men in the world' (Miller 2000: 221).

Apart from brief treatments by Cox Miller (2000: 221-2), Moreira (2000: 81-107), and McClure (2015: 65 n.8), scholarship on Gregory and memory has been sparse, given his rich material on the late-antique/early medieval boundary between past and present remembering, and the blurring of our postEnlightenment distinction between what is remembered and what is imagined. Carruthers is right to point out that the distinction between the remembered (what is real) and the imagined (not real), a feature of modern cognitive studies, which assign to memory 'the particular function of storing what is past,' was irrelevant to medieval monastic culture (Carruthers 1998: 68). What the Merovingians cared about most was remembering the Last Judgement, heaven, and hell. This sort of calling to mind in the memory would motivate people to act; in other words, recollecting was primarily a moral activity rather than an intellectual or rational one (Carruthers 1998: 68; Kreiner 2014: 92-104).

\section{Establishing an eschatological utopia}

The emphasis on End Times and the Final Judgement in the texts considered here reveals the authors' attempts in the sixth and seventh centuries to establish an eschatological utopia through memorable story-telling. These hagiographic collections feature many generic characteristics of contemporaneous Byzantine apocalyptic literature, ${ }^{5}$ such as the use of dreams, both true and false, as indications of the imminent End Times (Neil 2017: 356). Prophetic visions often conveyed a divine message, one which can relate to the present or the future life after death. The rising frequency of violent miracles as evidence of spiritual authority is another apocalyptic feature. Saintly miracles included cursing, killing, causing illness, fires, and the collapse of buildings. Such miracles positioned the saints, and especially bishops, as prosecutors of divine law, in place of the blood-price (wergild/vergild) system that characterised Salic, Ripuarian, Lombard, and Visigothic law. Bishops and abbots became protectors of sacred property, custodians of relics, prosecutors of adultery, and defenders of the poor. Now let us see how these apocalyptic features were used in Gregory of Tours's Life of the Fathers, the Dialogues, and the VPE.

\section{Gregory of Tours, The Life of the Fathers}

Miracle stories such as frequently appear in Gregory of Tours's collections of saints' lives are not unusual in themselves. What is unusual about his hagiography is the characteristic violence of these miracles, and the agency that Gregory 
accords to relics as vehicles of divine power. It is no longer just monks or bishops who can channel the divine but also their earthly remains. The dead are raised, the blind are given sight, the mute made to speak (even formerly mute animals in some cases). I argue that these tales call to mind an eschatological utopia, grounded in the past but functioning to remind people of their eternal future. These cautionary tales serve to remind people of the eternal consequences of their actions in this life, a concept that was relatively new to them. The next life took on frightening new characteristics in these texts, and the impious were given a foretaste of eternal condemnation through blinding, maiming, even murder by a saintly hand. Our sixth- and seventh-century hagiographers also seek to recast the pre-Christian past, but not, as one might expect, as a dystopia where the rule of might was the norm. Rather they seek to show that God and the saints were equally active in the past, but adopted the role of the lords in a vergild (blood-price) system that was equally or more punitive than the pre-Christian one. ${ }^{6}$

As Liebeschuetz (2015: 193-5) has highlighted, the violence of the Frankish legal system and to some extent also the Visigothic, based as they were on the proper compensation of the victim or the victim's family, was fundamentally incompatible with the Roman system, in which victims were obliged to seek compensation through the courts. Convincing people that they should waive their traditional right to seek compensation directly from the perpetrator, and instead seek justice from either an episcopal court, which required voluntary participation, or a Roman tribunal, was a slow and difficult process. Through the interweaving of the old with the new, Gregory aims to establish not just the ideal reward of an eschatological utopia dystopia but also to secure the new political order as a viable alternative to earlier methods of dealing with interpersonal violence.

Heaven and hell, or indeed any kind of afterlife, were still relatively foreign concepts at the end of the sixth century, and stories like these were designed to put the fear of God into people. The reminders of the eternal consequences of human actions were constantly reinforced wherever possible from scripture. In this way the vengeful acts and pronouncements of the Old Testament and even the Gospels and Pauline books were constantly brought to mind, as a living template for processing memories of violence and shaping expectations of utopia.

From the conversion of Clovis in 486, and his imperial coronation in 507 in Tours (HF 2.38) and baptism the following year, the Merovingian Franks had struggled to assert their legitimacy by urban displays of ceremonial power. As Hendrik Dey notes:

Such displays were all the more essential given the turbulent and fragmented nature of Merovingian politics, when strife and often open warfare between the kings of the various subkingdoms was endemic, and further exacerbated by an unending succession of local rebellions and attempted usurpations.

(Dey 2014: 161)

As far as they could they maintained Roman imperial administrative systems, largely run by a developing upper class of Christian aristocracy. From one of 
these ruling Gallo-Roman families came Gregory, bishop of Tours, who wrote his works on Merovingian political and ecclesiastical history in the last two or three decades of his life (d. 594). His History of the Franks concentrates on administrative history, while his Life of the Fathers and other saints' lives were directed towards a lay and monastic audience of relatively new converts to the faith. The Life of the Fathers especially focuses on the region of Clermont, where Gregory grew up in an aristocratic family that contained several bishops before he became bishop of the ecclesiastically and administratively important see of Tours, whose shrine outside the city walls housed the relics of the Merovingians' most famous saint, Martin. The cathedral of the early medieval city of Tours and the extramural shrine of St Martin were aligned on an axis which passed through the centre of the city and led to the royal palace (Dey 2014: 162-4). The laws of this early conversion period, the sixth century, were an interesting mix of Christian morality and old-fashioned loyalty to the powerful reinforced by conspicuous displays of wealth and power, ramified by threats of dispossession and corporal or capital punishment. The Merovingian rulers travelled widely throughout their domains to reinforce their royal power with visual spectacle (Dey 2014: 161). Their laws were imposed from the top down, although ordinary people had the right to exact revenge within the strict limits of the blood-price system.

Let us first consider how the saints dealt with three groups of crimes against God - theft of church property, interference with holy relics, and acts of adulterybefore turning to the more positive miracles, those of healing and manipulation of the elements.

\section{Protectors of church property}

Let us consider a story from GM 78, of the demise of the Arian count of Agde, appointed by the Spanish Visigoths. The count, Gomacharius, invaded a field belonging to the cathedral of Agde, which 'rejoices in its relics of the apostle Andrew' (GM 78, Van Dam 2004: 73-4). The field was used to produce food for the poor and needy. Leo, its bishop, tried to remonstrate with the count but was dismissed 'because he [sc. Gomacharius] was a heretic.' Gomacharius then grew ill with a fever, and also with a tormented heart. He sent to the bishop and asked for prayer, promising to give up control of the field. As soon as he recovered, he expressed disbelief that his fever had anything to do with his seizing of the field, and he refused to hand it back. The bishop warned him not to cancel out his good deed and expose himself to divine vengeance. The count dismissed him with threats to have him tied to an ass and paraded around the city as an object of ridicule. The bishop went home silently to his 'familiar protection' (by which I understand the relics in the cathedral) and prayed to God, after breaking all the lamps and promising that no light would be lit 'until God takes vengeance on his enemies and restores this field that belongs to his house.' At that point, the heretic collapsed from a revived fever. Finding himself on the verge of death he begged three times that the bishop pray for him, promising to restore 'with double restitution the field that I have unjustly taken.' Still the bishop refused, 
and as he was forced into the cathedral (where the relics were held) the count died. 'Immediately the church took back its property.' There are obviously limits to God's forgiveness.

A few things to note here: First, when the count was struck with a fever, he doubted that his illness was a divine punishment, attributing it to mere physical processes. Twice he is mentioned as refusing the bishop, not out of greed but because he was a heretic. His offence was against the poor and the bishop was not obliged to forgive the count's offence, even though he was asked three times. The saints (here St Andrew) have become guarantors of the possessions of bishops, part of the vergild system. Note the use of the phrase 'double restitution.' They also back the power of the bishops to wield divine vengeance.

In Book 5 of $V P$ we read the curious history of Bishop Portianus, formerly a runaway slave, who often took refuge in a monastery. The abbot would get him a pardon and hand him back to his barbarian master. Finally the master came angrily to the monastery to find his slave, and the abbot asked the runaway what he wanted him to do. 'Hand me back with a pardon,' was the reply. Runaway slaves could legitimately be killed by their masters. The slave apparently wanted to go back (perhaps out of consideration for justice), but when his master tried to take him he was blinded. The blind master asked the abbot to plead to the Lord and take the slave into the Lord's service, because he could not see. The abbot asked the slave Portianus to lay his hands on the master's head, but he refused. Eventually, after the bishop continued to press, the slave made the sign of the cross over him, and the man regained his sight. The master must have freed Portianus because he was later ordained, but this is implied rather than stated.

\section{Custodian of relics}

One of many incidents involving the saints' protecting their relics relates to St Julian (cf. HF 3.12, Brown 2011: 42 n.27), who was forced to protect his tomb from thieves: 'Although the man who brought violence to the holy church had often heard these stories, goodness was unable to control a wicked mind once it had been affected by a defect' (VJ 20, Van Dam 1993: 177). Gregory reinforced this message with a citation from the book of Solomon: Wisdom does not enter a soul that plots evil (Wis 1:4). The man crept into the church at night to steal its jewelled cross but could not find the door to exit in the dark, even though he had a torch. He fell asleep and was grabbed in the night by its custodians, who incarcerated him. His punishment is not specified.

More drastic is the punishment of a man who let soldiers into a church in the village of Brioude where all the possessions of the poor had been stored in the face of an attack. The villagers and clerics had also taken refuge there. Under the direction of this man, Theuderic's soldiers broke in and divided up the spoils, both human and material. The man who had betrayed his village was later punished with death by a fire from heaven. 'Even though they piled up stones on top of him, thunder uncovered him. He died without a grave' (VJ 13, Van Dam 1993: 172). Some of the soldiers who had ransacked the church were killed by the king; 
all the rest died painful deaths upon return to their homelands. When Theuderic heard this, he returned everything that had been stolen from the church. Then he ordered that no one use violence within seven miles of the church.

\section{Prosecutors of adultery}

The accusation of adultery, defined as a woman having sex with a man who was not her husband, was 'the most serious charge that could be brought against a woman, since it tainted her reputation and compromised the integrity of her family' (Van Dam 2004: 66 n.84). In the fourth-century law codes it was a criminal offence punishable with death. The original penalty for adulterers, being sewn in a sack and burnt alive (CTh 11.36.4 a law of 339), was reduced from death to exile by Majorian in 459 (Novella Majoriani 9.1) (Kuefler 2007: 356; Brundage 1987: 132-3). Copies of the CTh were made and continued to be used as legal precedent in Merovingian Gaul (Kuefler 2007: 364 and n.90; Wood 2010: 161-77). Under the vergild system, hefty fines were levied on men who abducted, raped, or had consensual sex with women who were married or betrothed to another. The penalty by the ninth century was the hefty fine of 200 gold coins (200 solidi). ${ }^{7}$ As an alternative to the vergild system, the system of trials by water was introduced by bishops, but these were no less violent. A popular form of judging a woman accused of adultery was to submerse her in water. If she somehow avoided drowning, through miraculous intervention, she was judged innocent. Under Lombard law an accuser who was unable to prove his case lost all rights over the woman he accused, so this was not an accusation to be undertaken lightly, as Brundage remarks. ${ }^{8}$

Sometimes the saints intervened, as in the case of a woman falsely accused by her husband of adultery. Her hem got caught on a submerged branch so that her head was suspended above water, and she was thus deemed innocent and lived to tell the tale. Later her husband confessed to his crime. These are the kind of stories that Gregory finds most satisfying: The just get saved from wrongful violence, and the wicked get their just deserts.

\section{Healing of states caused by sin}

Gregory of Tours's two-fold purpose is illustrated in the following quote from the Life of Julian. Gregory prefaced his story of the robber soldiers who were punished by death with the words: 'It seems to me that just as illnesses are reversed by the saint's power, so also the depravities of unbelievers are restrained and exposed by his prayers for other people, so that they may avoid similar follies. For the glory of the saint is apparent in both situations: he restores ill people to health so that they may suffer no longer, and he censures unbelievers lest they be condemned in a future court' (VJ 13, Van Dam 1993: 171).

The man who picked up an axe to fix his plow as he plowed his field on a Sunday and was punished by having the handle stuck to his hand, a painful state that continued for two years until he celebrated the vigil of St Julian, and was healed, again on Sunday. Never again did he dare work on the day of the Lord's 
resurrection ( $V J 11)$. Here we can see the saints operating as part of a medical protection racket.

\section{Manipulators of the elements}

In the spiritually charged world of Gregory's day, water and other natural elements such as rain and storms and lightning were instruments of divine wrath and reward. First there is the case of a priest who asked God to avert a storm that threatened to drown him on Lake Leman, when he was bringing relics back to King Guntram. Gregory claims that the priest himself told him the story, indicating that it came from the recent past:

[The priest] took from his neck the reliquary that held the relics of the saints and in his faith threw it into the swelling waves. With a loud voice he invoked the protection of the saints and said: 'Glorious martyrs, I request your power so that I may not die in these waves. I ask that you who always aid those who are dying instead deign to extend your right hand of salvation to me.'

(GM 75, Van Dam 2004: 71, paraphrased)

As he said this, the wind died down, the waves subsided, and they were brought to shore, just as in the gospel of Matthew 8:23-7 and Mark 4:35-41, when Jesus calmed the waves on Lake Galilee. The use of the reliquary as an object of power was increased in this period by such tales. The saints, like Jesus, were lords of the wind and waves.

A common feature of classical utopias was the constant clemency of the weather (Burton 2016: 10). In Vitae Martyrum Gregory subtly reinforced the direct line from contemporary saints back to the times of Christ and his apostles by narrative similarity. He tells how John the Evangelist acted as a weather god in first-century Ephesus, but insists that the utopian effects on that mountain peak were still being felt in Gregory's own time:

In Ephesus there is the place in which this apostle wrote the Gospel that in the church is called by his name. On the peak of this mountain there are four adjacent walls without a roof. John waited in these walls, praying earnestly and constantly beseeching the Lord on behalf of the sins of the people. It was granted to him that no storm would threaten that place until he had completed his Gospel. Even today the place is so distinguished by the Lord that no rain falls there and no violent storm comes near.

(GM 29, Van Dam 2004: 26)

Like John the Evangelist, the Gallic bishop Quintianus (506-25), first bishop of Rodez, then of Clermont, also had power over the weather (VP 4.1). During a period of drought, he organised rogations before Ascension (days of prayer and fasting for a good harvest). Citing the petition of 2 Chronicles 6:26-7 ('When the heavens are shut up and there is no rain because your people have sinned against 
you ... send rain on the land that you have given your people as an inheritance'), he prayed for God to send rain to his people and a heavy rain soon fell (VP 4.4, James 1991: 26-7). In the equation of Gallic farmland with the land that God gave to his people Israel as an inheritance, we can see a recasting of the utopian motif of God's personal care for his people from the Hebrew scriptures to the present day. The onlookers were filled with admiration (VP 4.4), baptised in a sense by the rain that fell in response to the bishop's prayer.

Those celebrating the feast of the martyr Genesius, who fell into the river Rhone when the bridge on which the large crowd was standing collapsed, were saved by the power of Saint Genesius, who had, paradoxically, died swimming (GM 68). This incident happened in the early fifth century, during the episcopacy of Honoratus (427-30) (GM 68, Van Dam 2004: 64-5 n.82).

A similar tale is told in Sermo de miraculo sancti Genesii, where the saint rescued people from a broken pontoon bridge (PL, 50: 1273-6). This sermon has also been attributed with some probability to Hilary of Arles, Honoratus's successor. We find Bishop Gregory constantly recycling stories of earlier incidents, from the more recent past to 150 years earlier. His cautionary tales Christianised the landmarks that people knew, and made the natural landscape and built environment alike witnesses to the saving power, but also the vengeance, of the saints. In this way, Gregory kept the power of the saints alive. Whether his stories were fictive or true was irrelevant, as Carruthers remarks of the Biblical notion of remembering that is operative in Christian commemorative texts:

And the 'accuracy' or 'authenticity' of these memories - their simulation of an actual past - is of far less importance (indeed it is hardly an issue at all) than their use to motivate the present and to affect the future.

(Carruthers 1998: 67)

In his portrayal of a divinely ordered world where people were burnt to death by lightning and storms were calmed, where saints averted danger from the pious and rewarded the poor by saving their possessions, Gregory summons a vision of utopia (on earth as in heaven) that is equally weird as the dystopian eschatological future of the damned. These feel-good stories also served to remind people of the rewards of pious living: an eschatological utopia in the afterlife. Their corollary, the cautionary tales of divine punishment for crimes such as theft of church property, adultery, the unwitting interference with relics, and working on Sundays, are put forward as a powerful disincentive to disobey the bishops and abbots who governed the new order of Christian Gaul. So far so normal — whether this is just a divine extension of the protection racket that was medieval Frankish feudalism is open to debate. Let us turn now to our second example, the Dialogues of Gregory the Great.

\section{Gregory the Great's Dialogues}

The Dialogues were almost certainly written by Gregory while he was bishop of Rome (590-604). In spite of Francis Clark's protracted attempt to dispute the 
work's authenticity, claiming that the text was constructed from archival papal documents only c. 670-680 (Clark 1987), most scholars now accept their attribution to Gregory or someone who knew his works well and was a contemporary (Demacopoulos 2015: 45-51). The four books of the Dialogues between Gregory and his close friend, Peter of Triacola, called Peter the Deacon, are presented in question-and-answer format, and were intended as edifying tales of the saints of Italy, to fill the gap that Gregory perceived in his homeland. They are strongly infused, as were most of Gregory's other works, with a sense of the imminent end of times and Last Judgement, which was largely owed to his experience of the devastation of Italy by the Lombards from the 560s onward (Baun 2013). The whole second book was taken up with Italy's favourite saint, the monk Benedict, who coined the monastic rule that bears his name (or something like it). The miracles that occurred through the holy man are remarkable, not least for their accomplishment through dreams and visions.

In the miraculous tales of the Dialogues, we can see how Gregory spiritualises political conflict to make Rome's enemies, the Lombards (who were not Trinitarian Christians), synonymous with devil worshippers and the Antichrist, signalling the end of the world.

Gregory describes a vision received by Redemptus, bishop of Ferentino, which warned of the coming of the end of the world in the time of Pope John III (561-74). Redemptus saw the same blessed martyr Euthicius standing before him as he slept in the church, who told him: 'The end of all flesh is come; the end of all flesh is come!' After he had repeated these words thus three times, the martyr vanished out of his sight (Dial. 3.38).

The 'end of all flesh' was equated firmly in Gregory's mind with the arrival of the Lombards in the 560s, during which time Alboin established himself as king of Italy (rex totius Italiae), in the absence of the Byzantine general Narses. Not only were the Lombards devil-worshippers, they were also Arians, or followers of the Homoean (meaning 'of like substance' and referring to the Son's relationship to the Father) creed which subordinated Christ to God. Gregory describes the Arians' violent persecution of Catholics in Spain (Dial. 3.31) and Africa (Dial. 3.32), as well as Rome (Dial. 3.30) and Italy (Dial. 3.29). In Spoleto an Arian bishop was miraculously struck blind and prevented from entering a church he sought to take by force with the aid of a mob (Dial. 3.29).

The Dialogues are full of examples of the exposure of those who stole or took more than their share of scarce resources (Neil 2017), and these are often grouped together for extra effectiveness. On one occasion, some beggars who hid their ragged clothes and, half-naked, begged for more were given their own rags back by the holy man Isaac (Dial. 3.14). In the same chapter, a servant who had stolen a basket of food intended for Isaac was warned to beware the serpent that had climbed into the basket when he went back to retrieve it from its hiding place (Dial. 3.14; see also 3.26).

Faithful service as a monk or nun or bishop, or even confessor of the faith, did not always prevail over the barbarian invaders, as demonstrated in the incident of the goat's head, an account of Italian prisoners who refused to participate in the Lombards' devil worship: 
Eodem quoque tempore, dum fere quadringentos captiuos alios Langobardi tenuissent, more suo immolauerunt caput caprae diabolo, hoc ei currentes per circuitum et carmine nefando dedicantes. Cumque illud ipsi prius submissis ceruicibus adorarent eos quoque quos ceperant hoc adorare pariter conpellebant.

At the same time [as Menas triumphed over the honey-thief], the Lombards, having almost 400 other prisoners on their hands, sacrificed a goat's head to the Devil, as is their custom, by running around with it in a circle and dedicating it to him with a blasphemous song. After they had worshipped it with heads bowed, they tried to compel their prisoners to do the same.

(Dial. 3.28, de Vogüé and Antin 1978-80/2: 374; my translation)

When the prisoners refused to comply, the Lombards drew their swords and killed them, making them martyrs (Dial. 3.28).

If the Lombards were the main enemy of Italian Catholics, the Devil was the ultimate 'ancient enemy of mankind' (Dial. 2.8). The second book of the Dialogues is a Life of St Benedict, purported author of the Rule on which most Italian monastic communities were founded from the sixth century onwards. Benedict's desire to Christianise the landscape led him to destroy the ancient altar of Apollo and cut down the trees in the sacred groves where the country people offered sacrifices to various demons, just as their ancestors had done (Dial. 2.8). In response to this outrage, the Devil appeared to Benedict not 'secretly or in a dream but coming to meet the same father before his very eyes in plain sight' (Dial. 2.8.12, de Vogüé and Antin 1978-80/2: 168). Others could hear the Devil but not see him. Benedict described the sight of him as 'utterly terrifying in appearance, enveloped in a flame and seeming to rage against the man of God with flames darting from his eyes and mouth' (Dial. 2.8.13, 1978-80/2: 168-70).

Visions of the saints' impending deaths were common in the Dialogues, as in this example, where Benedict saw the soul of Germanus, bishop of Capua, being carried up by angels into heaven in a fiery globe. Germanus died at the very moment that Benedict saw him ascending into heaven (Dial. 2.35). Similar accounts are given of the nun Romula's visions of light at her deathbed (Dial.4.15), and the deathbed visions of the monks Anthony, Merulus, and John (Dial. 4.47). The Devil and his angels sometimes appeared in frightening visions, dragging evil souls down to hell (Dial. 4.35, 4.36), including on one occasion a child whose father had neglected to chastise him for blasphemy (Dial. 4.18). Demons were everywhere, even sitting on salad leaves, as a certain nun found out when she greedily picked a lettuce leaf and ate it before blessing it with the sign of the cross:

Moxque hortum isdem pater ingressus est, coepit ex eius ore quasi satisfaciens ispe qui hanc arripuerat diabolus clamare, dicens: 'Ego quid feci? Ego quid feci? Sedebam mihi super lactucam. Venit illa et memordit me. 'Cui cum gravi indigatione uir Dei praecepit ut abscederet, et locum in omnipotentis Dei famula non haberet.

As soon as the holy man entered the garden, the Devil, using the nun's voice, began to justify himself. 'What have I done?' he kept shouting. 'What have 
I done? I was sitting here on this lettuce, when she came and ate me!' Full of indignation, the man of God ordered him to depart and vacate the place he held in this handmaid of almighty God.

(Dial. 1.4.7, de Vogüé and Antin 1978-80/2: 44; my trans.)

This was an unpredictable world, where even the most ordinary action could leave one open to demonic attack, and being a nun or monk was no protection. On the contrary, they became 'places' which the Devil sought to colonise in his ceaseless war against the people of God.

The cult of Roman martyrs was flourishing in Gregory's day, but in the Dialogues we see him attempting to rein in its focus on the gory details of the martyrs' deaths and portray them rather as models of virtuous living for emulation in the present (Leyser 2000), even if Gregory did pursue a vigorous trade in Roman relics as pope. This new model of sanctity did not allow ordinary people to seek the death of their enemies in prayer, as Gregory pointed out in a homily on the Feast of St Pancras (Hom. Ev. 2.27.7; see Leyser 2000: 303-4). The blood-price system did not apply anymore. Ordinary people could not call on the new Christian Lord to be their avenger.

The emphasis on the End Times in Gregory's Dialogues is further evidence of attempts in the sixth and seventh centuries to establish an eschatological utopia through memorable story-telling about the afterlife. The Dialogues are full of householder virgins who experienced prophetic visions, usually of their own impending death. Gregory's holy men and women routinely predict their own deaths, following the example set by the greatest saint of the Dialogues, Benedict of Nursia, whose exploits are the subject of Book 2. Benedict also had a vision of the soul of his sister, the saintly Scholastica, ascending to heaven at the time of her death (Dial. 2.34, Zimmerman 1959: 104).

Most of Gregory's examples of women foretelling their own or their sisters' ends appear in Book 4, which is mostly concerned with the afterlife. Gregory related how a young girl called Musa saw a vision of the Virgin Mary surrounded by 'little girls of her own age dressed in white.' Mary encouraged Musa to give up the girlish vices of laughter and foolishness, and to adopt a life of sobriety and self-restraint, if the girl wanted to join her heavenly court of virgins. Musa did so and thirty days later, apparently healthy, gave up her life and was taken up to heaven (Dial. 4.18, Zimmerman 1959: 211-12). Similar portents were seen by Romula, a consecrated virgin who was paralysed and bed-ridden for many years in the home she shared with another unnamed virgin and their leader, an aged woman called Redempta who 'lived as a recluse in the mountains of Praeneste' (Dial. 4.16, Zimmerman 1959: 208-10). Romula's death, which was foretold in a vision, was accompanied by heavenly music of the psalms and a pleasant odour (Dial. 4.16, Zimmerman 1959: 210). Gregory's aunt Tarsilla is said to have seen a vision of her forebear, Pope Felix III (48392), who summoned her home to heaven. Shortly afterwards, she too died (Dial. 4.16, Zimmerman 1959: 211). The same story is told in Gregory's Homilies on the Gospels (Hom. Ev. 2.38.15). 
A curious tale is told of Galla, a young and wealthy widow who eschewed a second marriage in favour of an ascetic life in seclusion in the convent of the Church of St Peter. A girl of a 'very passionate nature,' Galla began to grow a beard and was told that her only hope of stopping the hirsutism was to remarry. Nevertheless she persisted in her life of celibacy, preferring 'a spiritual marriage with the Lord' alongside several other women, one of whom was her particular friend. So close was their bond that when she received news from St Peter in a vision that she would very soon die of breast cancer, she begged for her fellow nun, Benedicta, to be taken to heaven at the same time. St Peter refused to grant this request instantly, but allowed another sister to die with Galla, promising that Benedicta would soon follow. A month later, Galla's bereaved companion also died and joined her sister in heaven (Dial. 4.14, Zimmerman 1959: 205-6). Clearly a different social order is being envisaged and endorsed here, one in which celibacy and an early death were rewards rather than signs of the waste of human potential.

The introduction of a new dispensation in Italy's recent past is neatly encapsulated in Gregory the Great's Dialogues by an old man who was an eye-witness of the miracles of Fortunatus of Todi. Of his bishop, Fortunatus, the old man said: 'That man was far different from those men we see now' (Dial. 1.10.12). ${ }^{9}$ The miracle related by the old man concerned a Gothic leader, who abducted two boys and flatly refused Fortunatus's repeated offers to ransom them. The Goth was punished by a fall from his horse, an 'accident' in which he broke a rib. He returned the boys immediately to the bishop, with a request for his deacon to come and see him. The deacon brought holy water, the application of which healed the broken rib immediately. Gregory comments that the Goth was satisfied even though he had to give back the boys 'with no hope of recompense' (Dial. 1.10.15, de Vogüé and Antin 1978-80/2: 106; Zimmerman 1959: 47). This is an indication that the blood-price system of Lombard Italy had been trumped by Christianity, as we saw in Gregory of Tours's Life of the Fathers. The Goth knew that the holy man had cursed him and he was lucky to escape with his life. These holy bishops, although they had existed in living memory, were indeed very different from the men of Gregory's day.

Not all the visions related by Gregory in this chapter portray such happy outcomes. Several deal with punishments after death, particularly of men and women who had been buried in churches, a mark of their high status in the Christian community. The degree of punishment they receive may seem to us out of all proportion to their faults. Chaste nuns are punished for 'foolish talk,' and 'loose tongues,' by hell fire. In such cases the punishment is only part-time. A sacristan saw a vision in the church where a nun guilty of such talk was buried: she was cut down the middle, with one half burning and the other not. Two other nuns, reported as being of high birth and unable to embrace suitable humility in their lives as consecrated virgins, were seen by their ancient nurse to rise out of their tombs in the church each Sunday at the time when the priest called for non-communicants to leave the church before communion, as if they had been anathematised. This was on account of their insulting and uncharitable remarks 
to a layman who served them (Dial. 2.23, Zimmerman 1959: 91-3). These stories served as warning to consecrated noble women against forgetting their place in the new holy order. Scornful treatment of servants was no longer acceptable behaviour for such women.

The increasing role of retributive violence is clearly illustrated by Gregory's account of a five-year-old boy who was seen being dragged to hell by evil spirits because he repeatedly committed the sin of blasphemy (Dial. 4.19). Another young boy was thrown into the fire in front of his horrified parents. They had unwisely invited a demonic stranger into the house under the guise of hospitality, but with the intention of hearing untrue gossip about their bishop, the holy Fortunatus of Todi whom we mentioned previously. The demon left the stranger and went straight into the boy, casting him into the open hearth, where he burnt to death. Only too late did the wretched father realise he had welcomed into his home the same evil spirit previously expelled by Bishop Fortunatus (Dial. 1.10.7, de Vogüe and Antin 1978-80/2: 98). This is a terrifying story not about domestic fire prevention but about the importance of sincere intentions: what might look like an act of charity will not fool God.

Other stories of divine punishment concern sexual misdemeanours, and portray the male perpetrators as unable to resist the temptations of beautiful women, even nuns. A layman who raped a young girl in his home, the night after he had sponsored her baptism, was given one more week to live, at which point he went straight to hell, which was obvious to all from the flames that gradually consumed his body in the grave (Dial. 4.33).

The Dialogues became one of the most popular works of the Middle Ages, being copied by the 680s in Britain (in Jarrow, Malmesbury, and Iona), in Spain (in Toledo and Ligugé), and by c. 700 they were being read in Ireland by Adomnán (Meyvaert 1988: 338-9). They were translated into Greek in the early eighth century by the Greek pope Zacharias ( $L P 1: 435$ ), although the earliest evidence for the availability of Dialogoi in Byzantine Greek is found a century later in Photius's Bibliotheca (Codex 252, Henry 1974: 207-9). The short stories of the miracles that happened around various monks and bishops of the recent past were exciting to read, especially compared with most monastic literary fare available at the time.

\section{The Lives of the Fathers of Mérida}

Mérida became an important Visigothic foundation from the reigns of Athanagild, Liuva, and his brother Leovigild (sole ruler from 572) and up to the midseventh century. The Lives of the Fathers of Mérida (CPL 2079) opens with a homage to Gregory the Great's Dialogues. Its anonymous author is directly indebted to Pope Gregory for his aspiration to enforce ascetic moral and structural reform on the inhabitants of the newly Christianised city of Mérida, including its lay leaders and kings (Dumézil and Joye 2012: 20-2). Its attribution to the mid-seventh century Paul the Deacon, also the author of a life of Gregory the Great, has no basis. The notion that author was a deacon is confirmed by his description of himself as a 'Levite of Christ' (VPE 1.22), but no other 
biographical details are given. Like Gregory of Tours, the author is at pains to stress that these miracles of bishops of Mérida are not made up. He warns his readers in the prologue not to think that such miracles belong to the ancient past and could not happen now. His purpose is to strengthen the faith of those who heard these tales (VPE Prologue).

The collection proper starts with a vivid image of utopia: the story of the innocent and pious boy Agustus who fell gravely ill and related to the author his vision of a heavenly banquet where he was received by the Lord of heaven as an honoured guest, although he was a country-dweller (rusticus) (VPE 1.14). Agustus described the place where the banquet was laid as an earthly utopia:

Fui in locum amenum, ubi erant multi odoriferi flores, erbe uiridissime, rose [sic] hac lilie et corone ex gemmis et auro multe, uela olosirica innumerabilia et aer tenuis flabrali frigore flatu suo cuncta refrigerans. Ibi etiam uidi sedes innumerabiles positas ad dextera leua que. In medio uero sedis multo sublimior posita prominebat. Ibi namque adstabant pueri innumerabiles, omnes ornati et pulcri, preparantes mensas et conbibium eximium.

I was in a pleasant place where there were many sweet-smelling flowers, the greenest grass, roses and lilies, and many crowns of gems and gold, countless silk drapes, and a soft breeze which cooled everything with its chill breath. And there I saw countless seats placed on the left and right, but the seat placed in the middle stood out much higher. And there countless servants were present, all decorated and beautiful, preparing the tables and an excellent banquet.

$(V P E 1.7)$

Jesus is represented as a man of incredible beauty, taller than anyone else and pure white in appearance. The heavenly host invited the boy to stand behind him and promised as his protector to feed and clothe him and never leave him (VPE 1.15). During the banquet, some men were brought before the Lord's tribunal, wailing, and the Lord commanded the 'wicked servants' (malos seruos) to be dragged outside. When asked, Agustus said he had recognised none of the men, but 'the men we saw there were far from these men we see now' (homines, quos ibi uidi, longe erant ab his hominibus quos uidemus modo) (VPE 1.19) - they had a different form and wore different clothes. We may only speculate as to the probable identity of these foreigners, but the salient point is that they were not 'people like us.' We saw the same phrase used in Gregory the Great's Dialogue by an eye-witness of the miracles of Bishop Fortunatus of Todi ('That man was very different from those men we see now') (Dial. 1.10.12) but this time it is used in a negative sense. The idealisation of the past was not a consistent habit.

The Lord gave Agustus a personal tour of his garden before leading him back to his sickbed. Again the locale is described in utopian terms:

[E]duxit me in ortum amenissimum, ubi erat ribus in quo erat aqua uitrei que coloris et sequus ribo ipso flores multi et siluas aromatum fragrantes redolentes que diuersis suauitatis odoribus. 
$[\mathrm{H}] \mathrm{e}$ led me to a most beautiful garden, where there was a river with water the colour of glass and along its bank were many flowers and woods scented with incense and smelling of various pleasing fragrances.

(VPE 1.20, Fear 1997: 49)

Within hours of this vision, the boy Agustus died, after relating its details in the same way twice more, proving that it was 'not at all fantastical' (fantasticam uisionem nullam) (VPE 1.6). The same life features a 'truthful and artless boy' (puer simplex et uerax) (VPE 1.27), one Veranianus, who saw Agustus clothed in white the night after he died, before he was buried. The miraculous visions of Agustus and Veranianus contain all the themes we have encountered in the VPE and the Dialogues. These include the truth of the tale and sincerity of the teller; divine protection for the righteous and violent punishment for the rest; a sacred topography; and the depiction of the heavenly reward in material terms, with the elect dressed in pure white raiment and adorned with jewels (compare the white elect in VPE Prologue).

In the second life, the exploits of the holy abbot Renovatus are introduced by an explicit reference to hell (the caves of Tartarus, antris Auerni Tartareis) and the monks who followed their abbot on the 'narrow roads and paths to heaven' (artis semitis callibus que prosequeretur celicis) (VPE 2.3). In other stories of the Fathers of Mérida, the houses or burial places of the saints gain miraculous protection. Many of these miracles took place in the basilica of the most famous Méridan saint, Eulalia, a young virgin who was killed because she refused to be married to a pagan. She was particularly important in establishing the authority of one of the city's first Catholic bishops, Masona (c. 570-c. 600/610) (Díaz 2010: esp. 4-7). Her tunic was the city's most important relic, and Masona had to face off the Arian Visigothic king Liuvigild to protect it (VPE 5.6.12-21; see Wood 1999: 200). Eulalia was invoked in inscriptions carved on ordinary houses and churches to protect the dwelling and its inhabitants from harm, as in this example from Mérida:

Hanc domum iu | ris tui placate posside | martir Eulalia | ut cognoscens inimicus | confusus abscedat, | ut domus hec cum habi | tatoribus te propitiante | florescant.|Amen.

Be pleased to take this dwelling under your rule, martyr Eulalia, so that the Enemy, knowing this, flees in confusion, allowing this dwelling to flourish along with its inhabitants by your intercession. Amen.

(Inscripcion 348, Vives 1942: 119; my trans.)

Vergild was a feature of the law codes of Visigothic Spain, as in the Salic, Ripuarian, and Lombard laws cited previously. God undertook to punish evil doers in $V P E$, usurping the local law codes. An example is the story of the slaves whom Masona manumitted when he was suffering from an illness that he thought would kill him. Along with their freedom, Masona gave the ex-slaves some small properties (exiguas possessiunculas), by which to support themselves. He omitted, 
however, to make proper compensation to the church for the loss of its property, as the law demanded (Lex Iudiciorum IV. 1. 2-3, Wood 1999: 198, 204-5). In the belief that he would soon be the next bishop of Mérida, the archdeacon Eleutherius was challenging the documents of manumission and threatening the slaves with torture, when he was miraculously killed (VPE 5.13, Fear 1997: 101 n.228). Masona of course recovered from his illness. ${ }^{10}$

The VPE survives only in six manuscripts and a few fragments (Clarke 1987: 131-5). Nevertheless, it is testament to the widespread influence of the Dialogues of Gregory, and its message of social reform is similar.

\section{Conclusion}

This chapter has focused our attention on how sixth- to seventh-century hagiographers latched onto the 'spectacular' aspect of marking memory, as advised in the Rhetorica ad Herennium, cited in my introduction. All three western hagiographers studied here-Gregory of Tours, Gregory the Great, and the author of the Lives of the Méridan Fathers - co-opted the relatively recent past in their re-education programmes. Stories of failed crops and injury, untimely death, sudden illnesses, and loss of stock are recast as instances of providence in action, of the divine hand at work. What these stories gave their hearers and readers was a lens for remembering the past and imagining the future, a world where divine might was right. Remembering was a call to action in the present for the future.

Their saints' Lives were peopled with caricatures: the stupid thief, the dishonest cleric, the wrongly accused wife, the dumb but honest farmer who lost his horse. They followed the formula for memorability described in Rhetorica ad Herennium, presenting images that were by turns striking and unusual, beautiful or hideous, comic or obscene. They were sometimes even comical in their descriptions of divine punishment: recall the farmer who got an axe stuck to his hand when fixing his plow on the Lord's Day. It was the very exaggerated nature of these figures that taught Merovingian, Italian, and Visigothic Christians the precepts of their new religion. They must not work on Sunday; they must treat relics with care and devotion; they must respect their bishop; they must remember the saints on holy days. They attempted to instil a new social order and specifically one where the blood-price no longer applied.

The kind of heavenly utopia that such stories sought to portray has been described here as eschatological: It had one eye fixed on this life, the other on the life to come. Violence was sanctioned as long as it ensured the stability of the new religious order. The places that were frequented for worship, especially saints' shrines and their holy relics, were sanctified by miracles of maiming that enforced respect. Visions of heaven and glimpses of hell as told in these stories reinforced the message in a new and graphic way. Read in this light, these hagiographic collections are anything but tedious. They are shocking, thrilling, amusing, and frightening by turns. Whatever else they were intended to be, they were not easily forgotten. 


\section{Notes}

1 Gregory the Great, Dial. 3.35.6: Magnae aedificatio uitae est uidere viros mira facientes, atque in ciuibus suis Hierusalem caelestem in terra conspicere (de Vogüé and Antin 1978-80/2: 406; Zimmerman 1959: 176).

2 I thank Shane Bjornlie, Chris Bishop, and others who read this chapter in draft and made useful suggestions for its improvement.

3 See Carruthers (1998: 7-59) on collective memory and memoria rerum, and the essays edited by Carruthers and Ziolkowski (2002).

4 E.g. Augustine, Ambrose, Jerome, Fortunatus, Cassiodorus, Isidore, Paschasius, Bede, and Alcuin.

5 On the distinctive features of Byzantine apocalyptic, see Alexander (1985) and the useful summary in Mango (1980: 201-17).

6 See Collins (1998: 5-6, 11-16) on the influence of the CTh on the Lex Salica, the composition of which he dates to the mid-sixth century. It cannot reliably be dated to the rule of Clovis (c. 511-33), as is often assumed. The original 65 titles of the Pactus Lex Salicae (Eckhardt 1959) were reissued and expanded under 100 titles by Charlemagne in the Lex Salica Karolina (Drew Fischer 2012); on the Frankish background see Drew Fischer (2012: 28-31, 2012: 50-1) on violence, theft, and homicide.

7 Lex Salica Karolina 23 [24] no. 12: 'If anyone takes another's wife while the husband still lives, he shall be liable to pay eight thousand denarii (i.e. 200 solidi).' Drew Fischer (2012: 189). Higher fines of 600 solidi or 1800 solidi were charged for other causes, such as injuring or killing a man. By comparison consensual sex with a free girl who is betrothed is valued at 45 solidi; the rape of a free girl by force, at 62.5 solidi.

8 Brundage (1987: 132 and n.31); Rothair, Leges langobardorum 196, Bluhme (1869: 47-8).

9 Qui ait: Homo ille longe fuit ab istis hominibus quos videmus modo (de Vogüé and Antin 1978-80/2: 102).

10 Wood (1999) explores many other examples of Masona flouting Visigothic law, including the Codex Euricianus, which was based on a system of kinship, rather than episcopal or secular patronage.

\section{Bibliography}

\section{Primary sources}

CTh (1990) Edited by Krüger, P., Mommsen, T., and Meyer, P. M, 3 vols. Hildesheim, NY: Weidmann.

Gregory the Great (1959) Dialogues. Translated by Zimmerman, O. St Gregory the Great, Dialogues, FOTC, 39. Washington, DC: Catholic University of America Press.

- (1978-80) Dialogi. Edited and translated by de Vogüé, A. and Antin, P. S. Gregorii magni Dialogi, 3 vols. SC, 251, 260, 265. Paris: Cerf.

(1999) Homilia in evangelia. Edited by Étaix, R. S. Gregorii magni homiliae in evangelia, CCSL, 141. Turnhout: Brepols.

Gregory of Tours (1884) Libri decimi historiae Francorum. Edited by Krusch, B. and Levison, W. Gregorii Turonensis Opera, MGH SRM, 1.i. Hanover: Hahn.

(1969a) Liber in gloria confessorum. Edited by Krusch, B. Gregorii Turonensis opera, MGH SRM, 1.2, Miracula et opera minora, rev. edn. Hanover: Hahn, 294-370.

(1969b) Liber in gloria martyrum. Edited by Krusch, B. Gregorii Turonensis opera, MGH SRM, 1.2, Miracula et opera minora, rev. edn. Hanover: Hahn, 34-111. (1969c) Liber vitae patrum. Edited by Krusch, B. Gregorii Turonensis opera, MGH SRM, 1.2, Miracula et opera minora, rev. edn. Hanover: Hahn, 211-93. 
(1969d) Vita Juliani. Edited by Krusch, B. Gregorii Turonensis opera, MGH SRM, 1.2, Miracula et opera minora, rev. edn. Hanover: Hahn, 112-34.

(1969e) Vita Martini. Edited by Krusch, B. Gregorii Turonensis opera, MGH SRM, 1.2, Miracula et opera minora, rev. edn. Hanover: Hahn, 134-211.

(1988) Gloria confessorum. Translated by Van Dam, R. Glory of the confessors, TTH, 5. Liverpool: Liverpool University Press.

(1991) Vitae patrum. Translated by James, E. Life of the fathers, TTH, 1, 2nd edn. Liverpool: Liverpool University Press.

(1993a) Vita Juliani. Translated by Van Dam, R. Life of Julian, in Saints and their miracles in late-antique Gaul. Princeton, NJ: Princeton University Press, 162-95.

- (1993b) Vita Martini. Translated by Van Dam, R. Life of Martin, in Saints and their miracles in late-antique Gaul. Princeton, NJ: Princeton University Press, 199-303.

- (2004) Gloria martyrum. Translated by Van Dam, R. Glory of the martyrs. TTH, 4, rev. edn. Liverpool: Liverpool University Press.

Hilarius (?), Sermo de miraculo sancti Genesii. PL, 50: 1273-6.

Lex Salica Karolina (1959) Edited by Eckhardt, K., MGH Legum Nationum Germanicarum, IV.2. Hannover: Hahn.

(1991) The laws of the Salian Franks, The Middle Ages Series. Translated by Drew Fischer, K. Philadelphia: Pennsylvania University Press. [Repr. 2012].

LP (1955-57) Edited by Duchesne, L. and Vogel, C. Le Liber Pontificalis, 2nd edn., 3 vols. Paris: Bibliothèque de l'École française de Rome.

Novellae Majoriani (1905) Edited by Meyer, P. M. Leges novellae ad Theodosianum pertinentes. Berlin: Weidmann.

Photius (1974) Bibliotheca. Edited by Henry, R. Bibliothèque. Codex 252. Paris: Les Belles Lettres.

Rhetorica ad Herennium [De ratione dicendi] (1954) Translated by Caplan, H., LCL, 403. London: Heinemann and Cambridge, MA: Harvard University Press.

Rothair (1869) Leges Langobardorum. Edited by Bluhme, F., MGH Leges Langobardorum, Leges, IV. Hanover: Hahn.

Vitae patrum emeretensium (1992) Edited by Maya Sánchez, A. Vitae sanctorum patrum emeretensium, CCSL, 116. Turnhout: Brepols.

(1997) Lives of the Meridan fathers in Lives of the Visigothic fathers. Translated by Fear, A., TTH, 26. Liverpool: Liverpool University Press, 45-106.

Vives, J. (ed.) (1942) Inscripciones cristianas de la España romana y visigoda. Barcelona: J. M. Viader.

\section{Secondary sources}

Alexander, P. J. (1985) The Byzantine apocalyptic tradition. Berkeley and Los Angeles: University of California Press.

Baun, J. (2013) 'Gregory's eschatology'. In Neil, B. and Dal Santo, M. (eds.), A companion to Gregory the Great. Leiden: Brill, 157-76.

Brown, W. C. (2011) Violence in medieval Europe. London: Longman.

Brundage, J. A. (1987) Law, sex, and Christian society in medieval Europe. Chicago and London: University of Chicago Press.

Burton, D. (2016) 'Utopian motifs in early Greek concepts of the afterlife'. Antichthon, 50: $1-16$.

Carruthers, M. (1990) The book of memory: A study of memory in medieval culture, Cambridge Studies in Medieval Literature, 10, 2nd edn. Cambridge: Cambridge University Press. 


\section{Bronwen Neil}

(1998) The craft of thought, Cambridge Studies in Medieval Literature, 34. Cambridge: Cambridge University Press.

Carruthers, M. and Ziolkowski, J. M. (2002) The medieval craft of memory: An anthology of texts and pictures. Cambridge: Cambridge University Press.

Clark, F. (1987) The pseudo-Gregorian Dialogues, 2 vols. Leiden: Brill.

Collins, R. (1998) 'Law and ethnic identity in the western kingdoms in the fifth and sixth centuries'. In Smyth, A. P. (ed.), Medieval Europeans: Studies in ethnic identity and national perspectives in medieval Europe. London: Palgrave, 1-23.

Cox Miller, P. (2000) 'Strategies of representation in collective biography'. In Hägg, T. and Rousseau, P. (eds.), Greek biography and panegyric in Late Antiquity. Berkeley and Los Angeles: University of California Press, 209-54.

Demacopoulos, G. E. (2015) Gregory the Great: Ascetic, pastor, and first man of Rome. Notre Dame, IN: University of Notre Dame Press.

Dey, H. (2014) The afterlife of the Roman city: Architecture and ceremonial in Late Antiquity and the early Middle Ages. Cambridge: Cambridge University Press.

Díaz, P. (2010) 'Late-antique Mérida: The apotheosis of a Christian city'. Reti medievali rivista, 11/2: 67-79.

Dumézil, B. and Joye, S. (2012) 'Les "Dialogues” de Grégoire le Grand et leur postérité: Une certaine idée de la réforme?'. Médiévales, 62: 13-31.

Hägg, T. and Rousseau, P. (2000) 'Introduction: Biography and panegyric'. In Hägg, T. and Rousseau, P. (eds.), Greek biography and panegyric in Late Antiquity. Berkeley: University of California Press, 1-28.

Kreiner, J. (2014) The social life of hagiography in the Merovingian kingdom. Cambridge Studies of Medieval Life and Thought. Cambridge: Cambridge University Press.

Kuefler, M. (2007) 'The marriage revolution in Late Antiquity: The Theodosian Code and later Roman marriage law'. Journal of Family History, 32/4: 343-70.

Leyser, C. (2000) 'The temptations of cult: Roman martyr piety in the age of Gregory the Great'. Early Medieval Europe, 9: 289-307.

Liebeschuetz, W. (2015) East and West in Late Antiquity: Invasion, settlement, ethnogenesis and conflicts of religion. Leiden: Brill.

Mango, C. (1980) Byzantium, the empire of new Rome. London: Charles Scribner.

McClure, A. S. (2015) 'A tender spot: Care, memory and place in Carolingian memoria mortuorum'. MA diss. University of Kentucky, Lexington, KY.

Meyvaert, P. (1988) 'The enigma of Gregory the Great's Dialogues: A response to Francis Clark'. Journal of Ecclesiastical History, 39: 335-81.

Moreira, I. (2000) Dreams, visions, and spiritual authority in Merovingian Gaul. Ithaca and London: Cornell University Press.

Neil, B. (2017) 'Apocalypse then: Dreams and visions in Byzantine apocalyptic in the context of conflict'. In Jackson, H. and Minchin, E. (eds.) Materiality and text: Essays on the ancient world in honour of G.W. Clarke, Studies in Mediterranean Archaeology and Literature. Uppsala: Astrom Editions, 349-58.

Van Dam, R. (1993) Saints and their miracles in late-antique Gaul. Princeton, NJ: Princeton University Press.

Wood, I. (1999) 'Social relations in the Visigothic kingdom from the fifth to the seventh century: The example of Mérida'. In Heather, P. (ed.), The Visigoths from the migration period to the seventh century: An ethnographic perspective. Woodbridge: Boydell Press, 191-207. (2010) 'The code in Merovingian Gaul'. In Harries, J. and Wood, I. (eds.) The Theodosian code: Studies in the imperial law of Late Antiquity, 2nd edn. London: Bloomsbury, 161-77.

Yates, F. A. (1966) The art of memory. Chicago and London: University of Chicago Press. [Repr. in Yates, F. A. (2013) Selected works of Frances Yates, vol. 3, London: Routledge]. 


\title{
9 Two foreign saints in Palestine Responses to religious conflict in the fifth to seventh centuries
}

\author{
Pauline Allen and Kosta Simic
}

Narratives of religious conflict during the fifth, sixth, and seventh centuries are mostly dominated by debates between adherents and opponents of the Council of Chalcedon (451 CE) (Frend 1972; Menze 2008). In other words, these narratives are concerned broadly speaking with utopian or dystopian ideas of the religious past. Miracle stories abound in this literature, as do hagiographical works either in favour of or against the controversial Council. One of the salient components of this literature is the attention paid to the Theotokos - in fact we could say that mariology (the study of Mary) came to the fore in Christological debate particularly in the sixth and seventh centuries (Brubaker and Cunningham 2001). Another feature of the literature of this period is the debates about Judaism, and monastic literature, particularly from Palestine. In this period Palestine is mostly anti-Chalcedonian, with some notable exceptions, such as the lives of Chalcedonian monastics written by Cyril of Scythopolis (Schwartz 1939; Price 1991) and John Moschus (Nissen 1938: 351-76; Wortley 1992), ${ }^{1}$ and to a lesser extent the early seventh-century Life of George of Choziba (House 1888: 95-144, 336-59; Vivian and Athanassakis 1994: 35-92).

Of the two hagiographical works under discussion in this chapter, one, that of Peter the Iberian, has an anti-Chalcedonian agenda (Horn and Phenix 2008: $2-281),{ }^{2}$ which harks back to the perceived unifying utopian force of the Council of Nicaea, while the second, that of Anastasius the Persian, concerns the conflict between Christianity and Zoroastrianism in Palestine in the first part of the seventh century, and is thus concerned with the dystopian attitudes of Persian converts to Christianity (Flusin 1992; Horn and Phenix 2008: 15 n.7). In neither of these hagiographies do we find advocacy of the cult of Mary, but there are references to Jews, ranging from the banal to the surprising. In addition, the Cross of Christ features prominently, particularly in the account about Anastasius, which can be explained on historical grounds, as we shall see.

\section{The hagiographers}

Let us consider first the authors of these two works. The Life of Peter the Iberian was ostensibly composed by a close associate of the saint, John Rufus, who would have been ordained priest in Antioch before 476. He was apparently a native of 
Arabia, of which Roman province the Life exhibits detailed knowledge (Steppa 2002: 58, 164; Menze 2008: 104, 160, 229-30, 233-4; Horn and Phenix 2008: ixxcii). Another anti-Chalcedonian work is attributed to him, namely the Plerophoriae or Assurances (CPG 7507), which is a collection of miracle stories intended to demonstrate the wrongs perpetrated by the Council of 451. It is supposed that Peter died in 491 and his Life was composed by his supposed episcopal successor, John Rufus (Steppa 2002: 58), to commemorate the first anniversary of the saint's death. Otherwise concrete details are scarce.

We turn next to the author of one of the accounts of the martyrdom of Anastasius the Persian, composed by an intimate of this saint, possibly a fellow monk in the Palestinian monastery where Anastasius finally engaged in the monastic life. This author has many concrete details about the martyr at his disposal, which indicate his relationship with the martyr and the fact that he too, like Anastasius, suffered under the Persian occupation of Palestine in the first quarter of the seventh century. This document probably dates from shortly after the martyr's death on 22 January 628.

Let us turn now to the contents of these two hagiographical works, in which travel plays an important part in their responses to conflict, as can be seen from the list of their major destinations in the appendix to this chapter (Ellis and Kidner 2004; Gorce 1925; Cribiore 2013: 34).

\section{The Life of Peter the Iberian}

According to the hagiographer, Peter was born in Georgia, a country which, like Armenia, at the time rejected the Council of Chalcedon, although after 583 the Council gained acceptance in Peter's native land. Peter's birth name was Nabarnugios (ch. 5; 7), and he was a Christian prince of the realm of Georgia. Even as a child, according to the hagiographer, he effected miracles, but this did not stop him from being hidden in the care of a pious woman so that he could escape the Persians, who, because of his rank, wanted him as a hostage (ch. 9; 11). When Nabarnugios was about twelve years old, his father, Bosmarios, the king of Georgia, sent the boy to Constantinople to the court of Theodosius II because he 'preferred the friendship of the Romans as Christians rather than the assistance of the impious Persians,' that is, those who practised Zoroastrianism (ch. 24; 31). Peter then grew up as a hostage of the imperial family and embraced the ascetic life in private from this early age. In his bedroom in the palace, we are told, he had a shrine of relics belonging to Persian martyrs, before which he would sleep and honour the martyrs with incense, lights, and prayers (ch. 26; 35). At a later date (438 CE) these relics were deposited by Cyril of Alexandria in a martyrion on the Mount of Olives. Although Peter was kept under guard lest he escape and thereby damage relations between Georgia and Byzantium (ch. 29; 41), he managed to make his way to Jerusalem in his pursuit of the ascetic life. From Jerusalem he went to Gaza (ch. 54; 77), where eventually he was to build his own monastery in Maiuma. However, at this juncture reprisals against anti-Chalcedonians became so severe that they were forced to go to Egypt (ch. 62; 91), which had become a 
haven for those opposed to the Council of 451 and continued as such well into the sixth century, as we can see from the large numbers of bishops, clergy, and monastics who ended up there after the Chalcedonian restoration by Emperor Justin I in 518. As Peter's biographer relates, 'the city of Alexandria became heaven in those days' (ch. 96; 145). After about twenty years in Egypt, where he visited many monasteries as well as Alexandria and Oxyrhynchus, Peter returned from Alexandria to Ashkelon in Palestine (ch. 105; 157), and from there he went to Arabia to restore his health in two hot springs or onsen after a life of punishing asceticism (ch. 113-18; 167-77), working many miracles along the way. Still in Arabia he travelled to Madaba before returning to Jerusalem (chs. 127-30; 187-93), only to go to Gaza again (ch. 137; 201), from where he went on to Phoenicia (ch. 141; 207). Subsequent travels took Peter and his companions to Tripoli, Beirut, Tyre, Caesarea, Ptolemaïs, and Jamnia, where he eventually died in 491. According to the account of the hagiographer, Peter's whole life was a series of miracles which demonstrated the evil and dystopia embodied in the Council of Chalcedon.

There are several sub-themes in John Rufus's depiction of Peter's responses to the religious conflict caused by the Council of 451 . One of these is the significant role played by the monks of the anti-Chalcedonian movement, particularly in Palestine and Egypt, whose networks were extensive. Peter's responses to the conflict were in fact more comprehensive in Egypt than in Palestine because of the demise of anti-Chalcedonianism in Palestine, particularly in monastic circles, and the more homogeneous character of Egyptian monasticism. His continual travelling in order to connect with monastic communities was another feature of his response (Horn 2004). Another sub-theme in the hagiographer's report is the importance of the Cross, a feature that we shall also find even more pronounced in the hagiography of Anastasius the Persian from the seventh century. In the Life of Peter there are so many references to the Cross that in the recent edition and translation of this work it is asserted that the Cross became a characteristic of antiChalcedonian monks, whether it referred to the fact that they were taking up the Cross in a symbolic way to follow Christ or to a part of their monastic dress (Horn and Phenix 2008: 24 n.3; Horn 2006: 338-42). On their travels Peter and his companions took with them a relic of the Cross, which effected miracles as they went along (ch. 34; 47). Much is made in the Life of Helena's discovery of the Cross (ch. 56; 80-1), which enables the hagiographer to give a retrospective account of Peter's life in the imperial family, where he was given a small part of the relic:

He covered it in a [little bit of] wax, which he wrapped up in a clean cloth to keep it secure with honour, and placed it in a golden box. Every Sunday and especially on solemn feasts, he would take it out, and having blessed himself with it and kissed it, he would return it again to its place.

Not surprisingly for a saint who spent much of his time in Palestine, Peter had encounters with the indigenous populations of Jews and Samaritans. Sometimes John Rufus reports in banal fashion the effrontery of the Jews against Christ 
(ch. 55; 79) and their godlessness (ch. 77; 111), but in another part of the Life (ch. 154; 227) Peter is credited with having converted a Jewish girl to Christianity (presumably of the anti-Chalcedonian variety), and eventually to the ascetic vocation. Elsewhere (ch. 170; 247-9) Peter is said to have cast out demons not only from believers but also from Jews and Samaritans. In the same episode the saint is said to have exorcised a demon from a Jew by making the sign of the cross on his stomach, after which the man, restored to health, became a Christian. According to his Life, the saint continually worked miracles during his travels, which in a utopian way proved the orthodoxy of Nicaea and of the anti-Chalcedonians, as opposed to the evil ways of the proponents of the Council of 451 .

\section{The Martyrdom of Anastasius the Persian}

From 581, several acts of the Martyrdom of Anastasius the Persian were composed (Flusin 1992/1: 9). The one we are dealing with here was seemingly written by one of the monks in the monastery outside Jerusalem where Anastasius eventually embraced the ascetic life. The hagiographer claims to have been commissioned to write the work (ch. 5; 45-7), which significantly opens with a summary of the Nicene creed, rather than the creed of Chalcedon. From the narrative it appears that Anastasius, like Peter the Iberian, was a foreigner, a Persian born south of modern Teheran, who later changed his birth name from Magoundat ('created by the magi'). He himself, like his father, was a magus, and went to Seleucia-Ctesiphon where he joined the army of Shah Chosroes II (r. 591-628 CE) (ch. 6: 47). About this time (614 CE) the Persians sacked Jerusalem, destroying many religious sites but keeping the Cross, which they took back to Persia with them (ch. 6-7; 47-9). It was this encounter with the Cross in Persia that introduced the Zoroastrian Anastasius to Christianity, an episode which, together with the veneration of the Cross especially in Palestine, helps to explain the centrality of this sacred relic to the entire hagiography. We can also note that the restoration of the Cross by Emperor Heraclius took place in Jerusalem in 630, two years after the martyrdom of Anastasius (Flusin 1992/2: 293-319; Drijvers 2002: 175-90). The march with Chosroes's army reputedly took the troops as far as Chalcedon, which may be a utopian adumbration of Anastasius's subsequent religious life in what we suppose was a Chalcedonian monastery outside Jerusalem. When the army took a U-turn and went east to Hierapolis (Syriac: Mabbug, in eastern Syria), the saint took the opportunity to desert and take lodging with a Persian Christian there who was a jeweller (ch. 8; 49). Shortly thereafter Anastasius asked his host to arrange for him to be baptised, at a time when baptism was a capital offence in the region, and he was then inspired by seeing icons of martyrs in the local church (ch. 9; 51). After Hierapolis, the martyr went to Jerusalem to another jeweller, and was finally baptised with the permission of Modestus, who was to become the patriarch of that city for a short tenure in 630 (ch. 10; 51). In an interesting aside, the biographer relates that Anastasius did an eight-day retreat after 
his baptism before going to the monastery of St Anastasius near Jerusalem to become a monk (ch. 11; 53), probably in 619-20 CE. Here he was taught Greek and the Psalter, combining his religious duties with looking after the kitchen and the garden (ch. 12; 53), a task that reminds us of a story in John Moschus's Spiritual Meadow (ch. 226; Nissen 1938: 360; Wortley 1992: 204), where a newly recruited brother in Egypt performed these duties for seven years. Enter the demons. They torment Anastasius and tell him to return to his Zoroastrian religion and his calling as a magus. Naturally Anastasius refuses, being supported by the abbot of the monastery, and shortly afterwards begins his travels, sojourning in Caesarea Palestine, where he goes to pray at the Church of St Euphemia, a significant detail since she was the patron saint of the Council of Chalcedon (ch. 16; 57-9; Schneider 1975). Along the way he encounters a group of magi performing their rites in a house. To them Anastasius says, 'Why are you astray and leading others astray by your acts of sorcery?' and in reply the magi ask him not to divulge their secrets to anyone. Possibly this encounter is the catalyst for Anastasius's arrest and three-day incarceration by Persian soldiers and his subsequent trial before the marzban, or governor, who insists that he reject Christ (ch. 19; 61) and prostrate himself in the manner of the Persians. The prisoner refuses to do either. The ensuing interrogation is as follows:

MARZBAN: Where are you from? Who are you?

ANASTASIUS: I am a true Christian. But if you wish to know also from where I come, I am a Persian by birth. ... I was a soldier and a magus: I left the darkness and have come into the light.

MARZBAN: Leave this error, return to your first religion, and we shall give you horses, silver, and protection.

This is the first of several occasions when the martyr refuses to reject Christ, a tenacity that is probably meant to contrast with the apostle Peter's three denials of Christ. Anastasius's smart talk enrages the marzban, who incarcerates him in a garrison where he is forced to transport rocks while being chained to another prisoner and bearing chains around his neck and feet. Upon being beaten and interrogated, for the second time the martyr refuses to deny Christ (ch. 21; 63-5), an act which culminates in the marzban's order for him to take the instruments of the magi, in particular the collection of sacred lengths of wood used in Zoroastrian fire worship, and to sacrifice, upon which Anastasius provocatively asks what god he is supposed to sacrifice to - the moon, fire, a horse, the mountains, the hills, or the rest? There follows a third confession of the Christian faith by Anastasius (ch. 23; 65-7). In prison he says Psalms all night and is observed by a Jewish prisoner, who has a vision of angels around the martyr-to-be and communicates this to another prisoner, a Christian governor of Scythopolis (chs 25-6; 67-71). When for the fourth time Anastasius refuses to deny Christ, the marzban announces that the Shah has ordered the recalcitrant to be taken to Persia (chs 27-8; 71-3), and accordingly Anastasius and two other Christians (presumably of Persian origin) leave Caesarea with one of the monks. The deportees, we are told, 
were farewelled by 'citizens, Christians, Persians and others' (ch. 31; 75), a detail no doubt intended to reinforce in the reader's/hearer's mind the impact which as an ex-Zoroastrian Anastasius had in a foreign country. On the way back to Persia the entourage and its escort travel through Hierapolis, and then possibly to Nisibis, before arriving at Dastagerd, the residence of Shah Chosroes II, north of modern Baghdad (ch. 32; 77). During his interrogation by one of the Shah's officials Anastasius refuses to speak Persian and also, for the fifth time, to deny Christ, despite on this occasion again being promised high honours, golden belts, and horses (ch. 33; 77-9). The rest of the hagiography encompasses the saint's sixth refusal to deny Christ, his removal to another prison, and finally his execution (chs. 36-40; 81-7), just before the Byzantine Emperor Heraclius arrived in Persia on campaign on 1 February 628 , where the hagiographer, who had been sent by the abbot of their monastery in Palestine to accompany the martyr, addressed him in Greek (ch. 43; 89-91). After travelling back to Byzantium through Armenia with the emperor, a journey which is said to have taken one year, the hagiographer brought back one of the martyr's tunics to Anastasius's monastery in Palestine where, we are told, it effected a miracle (ch. 44; 91).

The writer of the Martyrdom of Anastasius the Persian was, as we have said, apparently an intimate of the martyr. In addition, as we are told that he was Greekspeaking, this goes some way in explaining the structure of the work, because the author was acquainted with the tropes of martyrs' acts. These tropes included the repeated interrogations by an official, usually a pagan or at least someone hostile; the questions to the accused persons about their provenance and religion; the demands to sacrifice; details of the torture of the condemned, and so on (Delehaye 1966). Unlike most other hagiographical works of this period, that concerning Anastasius has a different goal — namely, responding to religious conflict between Christianity and Zoroastrianism. In this account, as in the near-contemporary Life of George of Choziba, the preoccupation of the writers is the Persian menace, and the usually all-dominating Council of Chalcedon is in the background, although from reading between the lines it becomes clear that Anastasius was a convert to the Chalcedonian faith and to its monastic life.

Despite their quite remarkable travels in their response to conflict, the efforts of both hagiographers, John Rufus and the monk-companion of Anastasius, were to be rendered otiose when the Persians had to withdraw from Palestine and other occupied western Byzantine territories in c. $630 \mathrm{CE}$ and the Arabs subsequently took over, provoking different responses to different conflicts, although not immediately.

\section{The cults of Peter the Iberian and Anastasius the Persian}

The development of Peter's cult fits well in the broader historical context, when the liturgical commemoration of certain saints became increasingly widespread. Peter himself instituted veneration of his several family members as 'recompense for the quiet life that they had conferred upon him and that he had chosen for himself so as to cast off the world' (Vita 10). Furthermore, Peter also established a practice in his monastery to perform annual liturgical commemorations of certain 
martyrs, when their martyrdoms were read (Vita 26). The brethren of his monastic community apparently continued this practice by inserting Peter's name in their calendar and commemorating him annually. As a matter of fact, the annual celebration of the memorial of Peter's death and burial is regarded as the occasion for the composition of his Life (Horn 2006: 16-17).

However, there is little doubt that the main driving force behind the establishment of Peter's cult was his anti-Chalcedonian orientation. As one of the most prominent opponents to the Council of Chalcedon, who at the same time followed a rigorous ascetic life, he was an ideal type of a saint whose biography could be used for propaganda purposes. For that reason, his Life has been characterised as 'a propagandist composition in hagiographic dress, merging the hero's life with the religious controversy that ensued after the Council of Chalcedon in 451 in the Eastern Empire' (Bitton-Ashkelony 2004: 108). By connecting the ascetic way of life to orthodoxy, John Rufus carried on the well-established tradition in Egypt, where a close link between the monastic movement and the episcopal or patriarchal authority date to Athanasius the Great. During the Arian controversy, which marked Athanasius's entire life, he structured his church based on ascetic ideals and spiritual authority of the patriarch (Brakke 1995: 11-16). As a result, in the following centuries it was not an easy task to distinguish between the bishop's life and the ascetic concerns characteristic of contemporary monasticism. The Life of Peter the Iberian needs to be seen in this light, since its author's intention was to present him both as a bishop and a monastic leader (Vita 1). Furthermore, in his insistence on Peter's orthodoxy, John Rufus connects the confession of the true faith with asceticism and the Council of Nicaea.

It is hard to determine if Peter's cult involved some other expressions, such as the veneration of sacred images depicting him or whether there were churches dedicated to his name.

The Georgian Life of Peter the Iberian, although without value as a source for his life and career, is nevertheless important as a testimony to an attempt to develop his cult in Georgia, too. However, in this Life Peter is presented as a Chalcedonian saint, thereby turning on its head the intention of John Rufus and his followers and their utopian/dystopian models of the Council of 451 . The translator of the Georgian Life, who identifies himself as the monk Makarios, bypassing the chapters of the theological and polemical characters, suppresses Peter's anti-Chalcedonian inclinations. Rather, he limits himself mostly to edifying parts of the Life and focuses on Peter's miracles (Marr 1896). Scholars have not determined even the approximate time of the Life's translation. Marr believes that the Georgian translation was produced as late as the thirteenth or fourteenth centuries (Marr 1896: xxi). At any rate, it was made after 583, when Georgia embraced the theological and canonical decisions of the Council of Chalcedon (Horn and Phenix 2008: xxxi).

Many centuries later, namely in the context of the emergence of the national self-determination among the Georgians in the first half of the eighteenth century, there were some attempts to declare him a saint. In 1711, Peter's name was included in the Georgian chronicle, and the mention of his name is accompanied 
by a prayer addressed to him for the regent Vakhtang (d. 1737) and his wife and children (Marr 1896: xiii). Furthermore, the manuscript containing a short version of Peter's Life, which is precisely dated to 1736, is accompanied by an icon of Peter the Iberian (Marr 1896: xvii).

All this is a far cry from the utopian leanings of John Rufus and the antiChalcedonian movement in the fifth and sixth centuries, which privileged the Council of Nicaea, but it is also an egregious example of the manipulation of late-antique texts which intended to change a utopian reading of the evidence to a dystopian one.

The cult of Anastasius the Persian is more straightforward and more shortlived than that of Peter, but also more difficult to track precisely. The cult began in Anastasius's lifetime, among the inhabitants of Caesarea Palestine and other places where the saint had travelled in the western Mediterranean. It spread to Persia, before going westward to Rome and Constantinople (Flusin 1992/2: 32952). The saint's head went to Rome and was deposited before 683 in the monastery of Aquae Salviae, where the apostle Paul was supposedly decapitated (Flusin 1992/2: 370-4), while the rest of the body went to Constantinople (Flusin 1992/2: 381-93). The head had been first deposited in Jerusalem, then as a result of the Arab incursions was brought to Rome, probably by eastern monks, whom we may assume to have been Chalcedonian. This would bear out the argument, suggested previously, that Anastasius's conversion to Christianity was to Chalcedonianism. In any case, the monastery of Aquae Salviae continued in existence until the eleventh century, and presumably the cult of Anastasius endured with it until that time in Rome. In Constantinople, on the other hand, the cult lost its vigour towards the end of the eighth century (Flusin 1992/2: 392-3).

To sum up, the examples of the two prominent Palestinian saints' lives discussed in this chapter illustrate how hagiographical texts were mobilised in religious conflicts either to serve the utopian ideals of the anti-Chalcedonians or to present the Persian empire as a dystopia. In addition, Peter's Life in its Georgian translation represents a striking illustration of the manipulation of the saint's memory for ideological purposes as it is adapted to the utopian needs of the Chalcedonians. Both lives abound with miracles as direct results of the 'true faith.'

\section{Notes}

1 The bibliography on Palestinian monasticism is extensive. As a selection we cite Chitty (1995); Hevelone-Harper (2005); Bitton-Ashkelony and Kofsky (2006).

2 The references in what follows refer first to the paragraph numbering and then to the translation.

\section{Bibliography}

\section{Primary sources}

Antonius Chozibita (1888) Edited by House, C. 'Vita sancti Georgii Chozibitae auctore Antonio Chozibita'. Analecta Bollandiana, 7: 95-144, 336-59. 
Athanasius of Persia (1992) Saint Anastase le Perse et l'histoire de la Palestine au début $d u$ VIIe siècle, 2 vols. Edited by Flusin, B. Paris: Éditions du CNRS.

Cyril of Scythopolis (1939) Kyrillos von Skythopolis, Texte und Untersuchungen, 49/2. Edited by Schwartz, E. Leipzig: J. C. Hinrichs Verlag.

(1991) The lives of the monks of Palestine. Translated by Price, R. M. Kalamazoo: Cistercian Publications.

John Moschus (1938) Edited by Nissen, T. 'Unbekannte Erzählungen aus dem Pratum Spirituale'. Byzantinische Zeitschrift, 38: 351-76.

Publications.

John Rufus (1994) The life of Saint George of Choziba and the miracles of the most holy Mother of God at Choziba. Translated by Vivian, T. and Athanassakis, A. N. San Francisco and London: International Scholars Publications, 35-92.

(2008) John Rufus and the lives of Peter the Iberian, Theodosius of Jerusalem, and the monk Romanus, Writings from the Greco-Roman World, 24. Edited and translated by Horn, C. and Phenix, R. Atlanta: Society of Biblical Literature, 2-281.

Vita Petri Iberiae (1896) 'Life of Peter the Iberian'. In Marr, N. (ed. and trans.), Pravoslavnyy Palestinskiy sbornik, 47, XVI/2. St Petersburg: Imperatorskoe pravoslavnoe Palestinskoe obschestvo, 1-78 (Georgian text), 81-115 (Russian translation).

\section{Secondary sources}

Bitton-Ashkelony, B. (2004) 'Imitatio Mosis and pilgrimage in the Life of Peter the Iberian. In Bitton-Ashkelony, B. and Kofsky, A. (eds.), Christian Gaza in Late Antiquity. Leiden: Brill, 107-129.

Bitton-Ashkelony, B. and Kofsky, A. (2006) The monastic school of Gaza, Supplements to $V C, 78$. Leiden and Boston: Brill.

Brakke, D. (1995) Athanasius and the politics of asceticism. Oxford: Oxford University Press.

Brubaker, L. and Cunningham, M. (eds.) (2001) The cult of the Mother of God in Byzantium: Texts and images. Farnham and Burlington, VT: Ashgate.

Chitty, D. (1995) The desert a city: An introduction to the study of Egyptian and Palestinian monasticism under the Christian empire. Oxford: Basil Blackwell.

Cribiore, R. (2013) Libanius the Sophist: Rhetoric, reality, and religion in the fourth century, Townsend Lectures/Cornell Studies in Classical Philology. Ithaca and London: Cornell University Press.

Delehaye, H. (1966) Les Passions des martyrs et les genres littéraires, 2nd edn. Subsidia hagiographica, 13 B. Brussels: Société des Bollandistes.

Drijvers, J. (2002) 'Heraclius and the restitutio crucis. Notes on symbolism and ideology'. In Reinink, G. and Stolte, B. (eds.), The reign of Heraclius (610-641): Crisis and confrontation, Groningen Studies in Cultural Change, 2. Leuven, Paris, and Dudley, MA: Peeters, 175-90.

Ellis, L. and Kidner, F. (eds.) (2004) Travel, communication and geography in Late Antiquity. Aldershot and Burlington, VT: Ashgate.

Frend, W. (1972) The rise of the monophysite movement: Chapters in the history of the church in the fifth and sixth centuries. Cambridge: Cambridge University Press.

Gorce, D. (1925) Les voyages, l'hospitalité et le port des lettres dans le monde chrétien des IVe et Ve siècles. Wépion-sur-Meuse, Belgium: Mont Vierge and Paris: A. Picard.

Hevelone-Harper, J. (2005) Disciples of the desert: Monks, laity, and spiritual authority in sixth-century Gaza. Baltimore: Johns Hopkins University Press. 


\section{Pauline Allen and Kosta Simic}

Horn, C. (2004) 'Weaving the pilgrim's crown: John Rufus's view of Peter the Iberian's journeys in late-antique Palestine'. Journal of Eastern Christian Studies, 56: 171-90. (2006) Asceticism and Christological controversy in fifth-century Palestine: The career of Peter the Iberian, Oxford early Christian Studies. Oxford: Oxford University Press.

Menze, V. (2008) Justinian and the making of the Syrian orthodox church, Oxford early Christian Studies. Oxford: Oxford University Press.

Peltomaa, L. M., Külzer, A., and Allen, P. (eds.) (2015) Presbeia Theotokou. The intercessory role of Mary across times and places in Byzantium (4th-9th century), Veröffentlichungen zur Byzanzforschung, 39. Vienna: Verlag der Österreichischen Akademie der Wissenschaften.

Schneider, A. (1975) 'Sankt Euphemia und das Konzil von Chalkedon'. In Grillmeier, A. and Bacht, H. (eds.), Das Konzil von Chalkedon. Geschichte und Gegenwart, vol. 1. Würzburg: Echter Verlag, 291-302.

Steppa, J.-E. (2002) John Rufus and the world vision of anti-Chalcedonian culture, Gorgias Dissertations: Ancient Christian Studies, 1. Piscataway, NJ: Gorgias.

Wilken, R. (1992) The land called holy: Palestine in Christian history and thought. New Haven and London: Yale University Press. 


\section{Appendix}

\section{Travels of Peter the Iberian}

429 CE-From Iberia (Georgia) to Constantinople, where he lived as a hostage at the court of Theodosius II

$437 \mathrm{CE}$ - Jerusalem

$444 \mathrm{CE}$ - Gaza, where he built his own monastery in Maiuma

$455 \mathrm{CE}$-Egypt, where he visited many monasteries as well as Alexandria and Oxyrhynchus

475 CE-Ashkelon (Palestine)

481 CE - Caesarea Palaestina

490 CE-Jerusalem

Post 490 CE - Gaza

\section{Travels of Anastasius the Persian [few chronological} details available]

c. $614 \mathrm{CE}-$ Teheran to Seleucia-Ctesiphon, where he joined the army of Shah Chosroes

614-15 CE-Chalcedon

Hierapolis (Mabbug), where he deserted from the Persian army

Jerusalem, where he was baptised and went to the monastery of St Anastasius near Jerusalem to become a monk

Diospolis (on coastal road from Jerusalem)

620-27 CE-Caesarea Palaestina, where he prayed at the Church of St Euphemia

Hierapolis

Nisibis?

Before 1 Feb 628 CE-Dastagerd (residence of Chosroes II, $90 \mathrm{~km}$ NE of Baghdad), where he was interrogated and executed 


\title{
10 Remembering the damned Byzantine liturgical hymns as instruments of religious polemics
}

\author{
Kosta Simic
}

The fact that the main purpose of liturgical hymns, due to their lasting use at liturgical gatherings, is to perpetuate a certain memory, renders them highly relevant to the objectives of this volume. When hymns refer to intra-Christian doctrinal conflicts and mention certain historical figures involved in them, then they also preserve a memory of those people, regardless of their positive or negative role in such disputes. Accordingly, when protagonists of such hymns are denounced and condemned by Church councils as 'heresiarchs,' then those hymns perpetuate their bad memory. Hence, this practice fits well into the category of damnatio memoriae with the main purpose to dishonour the memory of a certain individual, but without its entire eradication (Hedrick 2000: 93). The first part of this chapter is mostly focused on this category of Byzantine hymns. In the second part, the focal point are the hymns related to inter-religious disputes, namely to the antiJewish and anti-Muslim polemics, in which Byzantine hymnographers, motivated by utopian ideals, lay exclusive claim to the true and pure religion.

From New Testament times, Christian worship employed distinctive songs. According to the Gospel reports, Jesus and his disciples sang at the Last Supper: 'And when they had sung a hymn, they went out to the Mount of Olives' (Matt 26:30). Furthermore, the apostle Paul exhorts the Ephesians to use hymns, 'Speak to yourselves in psalms, hymns, and spiritual songs, singing and making melody in your heart to the Lord' (Eph 5:19). ${ }^{1}$

Pliny the Younger (d. 113), who was the governor of the Roman province Bithynia (Asia Minor), offers the earliest non-biblical testimony about the use of hymns in Christian worship. In his Letter 96 to the emperor Trajan he writes that Christians 'were in the habit of meeting on a certain fixed day before it was light, when they sang in alternate verses a hymn to Christ, as to a god' (quod essent soliti stato die ante lucem convenire carmenque Christo quasi deo dicere secum invicem seque) (ep. 10.96).

By the fourth century, the Church prioritised Psalms, so that non-biblical hymnody was rare, but not completely absent. However, it seems that composition of non-biblical hymns was closely related to doctrinal disputes from the very beginning. Some early Christian authors refer to the use of the 'orthodox' verse to denounce the dogmatic teaching of their opponents. For example, Brian Dunkle mentions Irenaeus of Lyon (d. 202), who cites a hymn composed to challenge the 
Gnostic leader Marcus. Although Irenaeus is not very clear, it is possible to draw a conclusion that the hymn was composed exclusively for polemical purposes (Dunkle 2016: 20). The use of hymns as suitable and powerful agents designed to convey certain messages to the congregation in both inter-religious and intraChristian conflicts became increasingly common in both East and West in the fourth century. Some of the most prominent examples of church figures using hymns to promote teachings believed to be the sole path to salvation include Arius (d. 336), Hilary of Poitiers (d. 367), Ephrem the Syrian (d. 373), Ambrose (d. 374), Basil the Great (d. 379), and Augustine (d. 430). The poetic activities of each author were caused by doctrinal disputes.

The use of liturgical hymns is explicitly attested in relation to the Arian controversy. Arius himself composed hymns widely circulated as a compilation known as the Thalia ('Banquet'), which allegedly contained the key concepts of his Trinitarian theology. It is believed that his hymns largely contributed to the popularity and longevity of the Arian doctrine even after its several synodical condemnations. Its popularity was one of the main reasons that Athanasius of Alexandria criticised and mocked the Thalia in his two main polemical treatises, namely at the beginning of his Orations Against the Arians and On the Councils of Ariminum and Seleucia. Athanasius's critique is multilayered. First, he denounces the genre of Thalia by stating that Arius imitated Sotades, the third-century BCE poet:

Instead of Moses and the other saints, they have made the discovery of one Sotades, a man whom even Gentiles laugh at, and of the daughter of Herodias. For of the one Arius has imitated the dissolute and effeminate tone, in writing Thalia on his model; and the other when he writes that, by singing the songs of Arius, Christians are announcing a new heresy.

(Contra Arianos 1.2; see also De synodis, 15)

Athanasius then proceeds to condemn the content of Thalia by emphasising that Arius denies the Son, 'reckoning Him among the creatures' (Contra Arianos 1.4).

A direct link between doctrinal conflicts and hymnody can also be found in some reports about the genesis of antiphonal singing. For example, Theodoret of Cyrrhus (d. c. 466) argues that Diodore of Tarsus (d. c. 394) and Flavian of Antioch (d. 404), both vigorous opponents of Arianism, introduced the practice of antiphonal singing in the services of the Church:

That excellent pair Flavianus and Diodorus, though not yet admitted to the priesthood and still ranked with the laity, worked night and day to stimulate

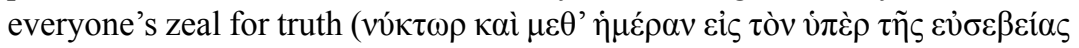

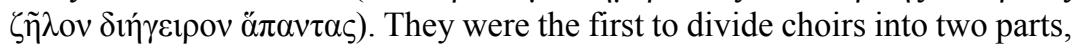
and to teach them to sing the psalms of David antiphonally.

(HE 2.19: 154)

Theodoret's mention of their activity to stimulate people's zeal for truth indicates that they used hymnody to counter Arianism and advocate Nicene orthodoxy. 
Nicetas Choniates (d. 1217), based on other early sources, develops this account by citing Theodore of Mopsuestia (d. 428), who reports that Flavian and Diodore first introduced a translation of the Syriac formula 'Glory to the Father and the Son and the Holy Spirit' into the Greek psalmody of Antioch to counter the Arians (Thesauri orthodoxae fidei 5.30, PG, 139: 1390). According to the historian Philostorgius, the Arians sang 'Glory to the Father through the Son in the Holy

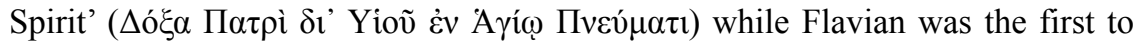
have his congregation sing 'Glory to the Father and to the Son and to the Holy

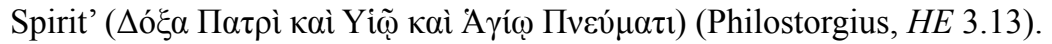

Furthermore, other distinguished church fathers from the same period composed hymns to confront their opponents' doctrinal teachings, thus perpetuating their condemnation. For example, Ephrem had to face doctrinal divisions at Nisibis and Edessa caused by Marcionites, Manicheans, and followers of Bardaisan (d. ca. 222). In addition, Ephrem's hymns also abound with references against Judaism (Drijvers 1985: 88-102; Shepardson 2008) and pagans. Composed in the context of conflict, Ephrem's hymns (madrāšê) were introduced into liturgy to protect his flock by promoting the ideals of Nicene orthodoxy. It has been proposed that even his anti-Judaism needs to be seen in the light of his anti-Arian polemic. According to Shepardson, Ephrem used "the familiar figure of "the Jew" more broadly as an anti-type of an orthodox Christian' in order to establish 'clear Nicene boundaries around his community' (Shepardson 2008: 6, 68).

The same holds true for Ambrose. According to his biographer, the Arian controversy was behind his motives to compose hymns: 'On this occasion, antiphons, hymns, and vigils first began to be practised in the church at Milan. And the devotion to this custom remains even to this very day, not only in the church, but through almost all the provinces of the West.' (Vita Ambrosii 3.13). Ambrose himself believed that liturgical hymns were highly effective tools for endorsing the orthodox faith: 'in a hymn you may understand the distinction of persons in the Trinity, and the oneness of the Godhead' (ut etiam in hymno distinctionem trinitatis et diuinatis intellegas unitatem) (De spiritu sancto 3.16.110; CSEL, 79: 197).

Augustine also used hymns to spread his dogmatic teaching. His Psalmus contra partem Donati (NBA, 15/1: 20-40) was composed as a response to songs of the Donatists. Augustine's intention was to provide the orthodox party with their own chant in which he would simultaneously focus on two main topics in Donatist polemic, namely 'the church as corpus permixtum and the universality of the body of Christ' (Dunkle 2016: 36). Of equal importance is his general approval of church music, which had great impact on him after his conversion (Confessiones 10.33.49-50, NBA, 1: 342).

Condemnation of doctrinal opponents in liturgical hymns, which were usually used in liturgy for a long period of time, had more than one purpose. Not only did they contribute to the protection of the orthodox party against those regarded as heretics, but also perpetuated the memory of the condemned 'heretics.' Most importantly, future generations, by singing such hymns, were also given the opportunity to condemn the famous 'heresiarchs' at their liturgical gatherings. 


\section{The Byzantine tradition}

Similarly to the early period, Byzantine hymnographers also invested their hymns with a polemical dimension and mobilised them to promote particular ideals, whether doctrinal or even political, and whether or not they were a matter of concern to contemporary audiences. Another goal was to preserve the memory of prominent 'heresiarchs.' One of the peculiarities of Byzantine Orthodoxy is the liturgical celebration of the councils of the Church and the doctrines they proclaimed. The Byzantine calendar, which is still followed in the Eastern Church, includes four feasts that are specifically devoted to the fathers who produced the conciliar doctrines and definitions. They include the Sundays of the First, Fourth, and Seventh Councils together with the Sunday of Orthodoxy, which was established after the defeat of iconoclasm. Hymns composed for these feasts abound with references to and condemnations of the individuals who were considered creators of the doctrines that were condemned by the ecumenical councils. By composing such hymns for congregational use, their authors made them an instrument through which the proponents of the doctrines condemned by councils were also condemned annually at each gathering of the faithful to celebrate victory over a specific 'heresy.'

The main protagonist of the hymns composed for the bishops of the First Ecumenical Council is Arius. In the first sticheron at Lord, I Have Cried, which is based on Psalm 109, Arius is denounced for calling the second person of the Trinity a creature:

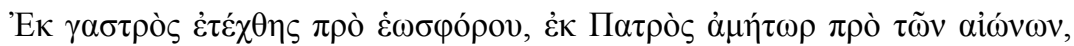

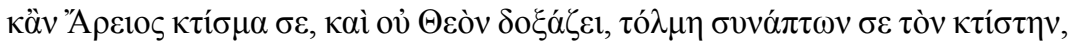

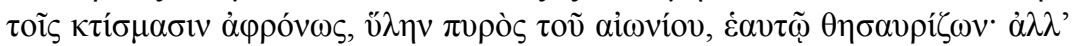

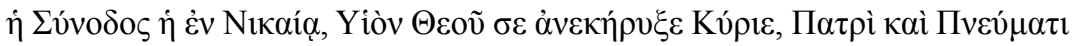

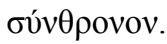

From the womb, before the morning star, you were born from the Father without a mother before the ages. Arius, however, called you a creature, and does not glorify you as God, mindlessly identifying you, the Creator, with the creatures, and laying up for himself as treasure fuel for the eternal fire. But the Council in Nicaea proclaimed you, O Lord, to be Son of God, co-enthroned with the Father and the Spirit.

(Pentecostarion, 158)

Notably, the same quotation from Psalm 109:3, 'I have begotten you from the womb before the morning star,' was also used as an inscription above the representation of the standing Virgin Mary in the semi-dome of the apse in the Church of the Dormition at Nicaea (destroyed in 1922). The inscription, a slightly modified version of Psalm 109:3, which read ЕГГА ГЕГЕNHKA (sic) $\Sigma$ E ('From the womb before the morning star I have given birth to you') and dated to the seventh century, served to preserve the memory of the Council, which formulated one of the basic Christian dogmas, namely that the 
Son was not a creature, but born from the Father's nature before the ages (Mango 1993-94: 168-70).

The second sticheron is inspired by the vision of Peter of Alexandria (d. 311) recorded in the account of his martyrdom. According to this story, the twelveyear-old Jesus appeared in front of Peter wearing a tunic divided into two parts. When Peter asked why his tunic was torn apart, he answered that Arius did it, alluding to the division in the church caused by Arius's teaching about the God Logos (Viteau 1897: 71):

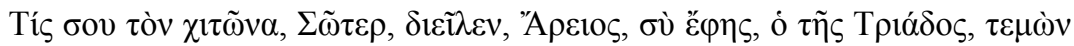

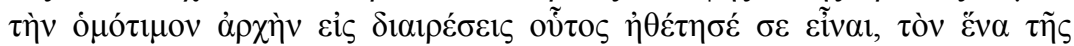

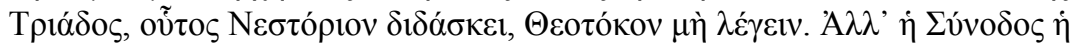

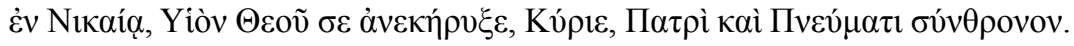

Who divided your garment, O Saviour? You said, 'Arius', who cuts into divisions the authority of the Trinity equal in honour. He denied that you were one of the Trinity. He taught Nestorius not to say 'Mother of God'. But the Council in Nicaea proclaimed you, O Lord, to be Son of God, equal in rank with the Father and the Spirit.

(Pentecostarion, 178)

The third sticheron for the same feast takes its point of departure from the book of Acts' account of Judas's death: 'With the payment he received for his wickedness, Judas bought a field; there he fell headlong, his body burst open and all his intestines spilled out' (Acts 1:18). The author of the hymn compares Arius's death with that of Judas:

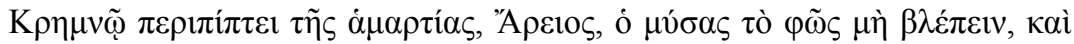

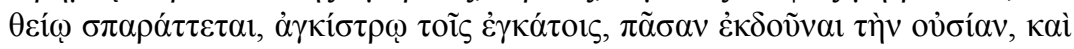

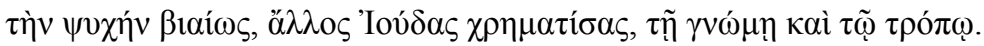

Having shut his eyes so that he could not see the light, Arius fell into an abyss of sin, and his bowels were torn apart by a divine hook so that along with his entrails he forcibly emptied out all his substance and his soul, and in this way became another Judas, through his teaching and the manner of his death.

(Pentecostarion, 178)

Finally, the last sticheron worth citing is the one which refers to all the most prominent 'heretics' anathematised by the first four ecumenical councils. It reads as follows:

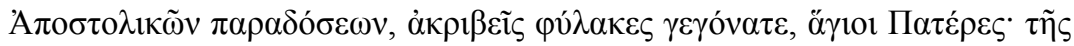

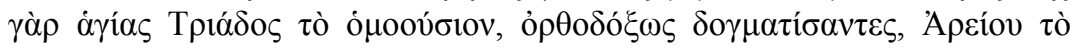

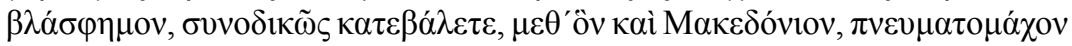

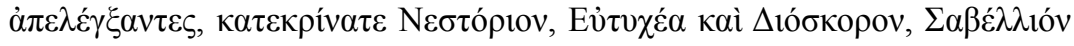
$\tau \varepsilon \kappa \alpha i ̀ ~ \Sigma \varepsilon \beta \tilde{\eta} \rho \circ v$ tòv $\alpha \dot{\kappa} \varepsilon \dot{\varphi} \varphi \lambda$ ov. 
O holy Fathers, you became strict guardians of the apostolic traditions, for by teaching the orthodox doctrine that the Holy Trinity is consubstantial, you in synod overthrew the blasphemy of Arius; after him you refuted Macedonius, opponent of the Spirit, you condemned Nestorius, Eutyches and Dioscorus, Sabellius and the headless Severus.

(Pentecostarion, 179)

Hymns composed for the bishops of the Fourth Ecumenical Council not only refer to the proponents of the doctrine of one nature, but also to Nestorius and several other champions of one energy and one activity in Christ after his incarnation, including two patriarchs of Constantinople, Pyrrhus $(638-41,654)$ and Sergius (610-38); Pope Honorius (625-38); the Constantinopolitan archimandrite Eutyches, one of the main architects of the doctrine about one nature in Christ; and Dioscorus, patriarch of Alexandria (444-51). In other words, it can be argued that on this feast three ecumenical councils are commemorated, namely the third, the fourth, and the sixth. Here is an example of how an anonymous hymnographer refers to the proponents of the condemned doctrines:

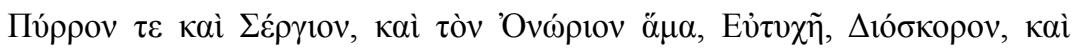

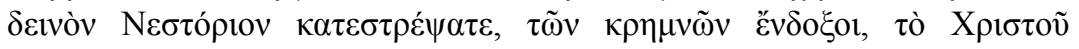

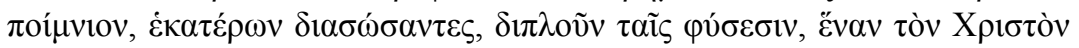

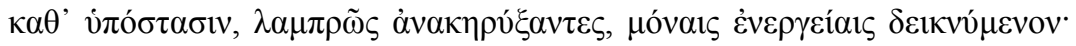

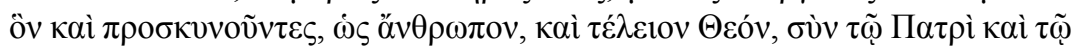

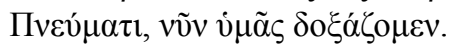

O glorious [Fathers], you defeated Pyrrhus and Sergius, with Honorius, Eutyches, Dioscorus and dread Nestorius, saving Christ's flock from both sheer cliffs by clearly proclaiming Christ to be one by hypostasis, but double in nature, revealed by energies alone; as we also worship him as man and perfect God, with the Father and the Spirit, we now glorify you.

$(M V 1889 / 11: 59)$

Sergius and Pyrrhus were monothelite patriarchs of Constantinople; Honorius was a bishop of Rome who seemed on occasion to support the formula of 'one will' in Christ (see further Strickler's Chapter 11). The two 'sheer cliffs' referred to here are Nestorianism and monophysitism (Lash 2006: 157). Hence, the author's intention was to emphasise that the fathers had to protect the church community from both by formulating the dogmatic teaching that Christ was one by hypostasis, but in two natures.

The cited hymns from the Byzantine tradition reveal in a more obvious way their authors' intention both to condemn 'heretics' and to keep their bad memory alive. Moreover, their primary function was to provide a setting within which those figures could be condemned continually. In this regard, we can discern a sort of contradiction since, along with the widespread practice of destroying the writings of 'heresiarchs,' there also was a tendency to save them from oblivion. However, the purpose of the latter practice was to perpetuate their condemnation. 


\section{Kosta Simic}

\section{Anti-Jewish polemic}

One of the important features of Byzantine hymns still sung in the liturgy of the Christian East during Holy Week is their anti-Jewish character. In the aftermath of the Holocaust, their liturgical use is frequently criticised as blatant anti-Semitism. This has initiated discussions over whether such hymns should be excluded from the liturgy (Theokritoff 2003; Groen 2008; Azar 2015; Bucur 2017). Some Orthodox theologians openly propose such a solution, as the following example shows:

The Orthodox Church as a whole, and especially and more effectively the hierarch, should revise and discard anti-Judaic statements and allusions from hymnography and from liturgy itself, as a matter of fact. The poetry of Eastern Orthodox hymns is too sublime to be marred by such low sentiments echoing from a past dominated by religious quarrels and controversies.

(Pentiuc 2014: 40)

The 'anti-Judaic statements' that the author has in mind include the phrases which designate the Jews as 'God-Slayers, the lawless nation of the Jews,' 'the destructive band of evil men,' 'a swarm of God-Slayers,' 'the lawless assembly,' 'most malicious race of Jews,' 'pack of dogs,' and so on.

However, for the purpose of this study, I will leave aside the hymns with such insulting phrases without any theological meaning. Rather, I will pay close attention to a hymn from the same 'anti-Jewish' category, but which could be interpreted in the light of the Christian replacement or supersession theology. As is well-known, Christianity from its onset saw itself not only as a continuation of Judaism but also as its fulfilment and replacement (Woudstra 1988; Thettayil 2007). The latter view actually prevailed in the end. According to this perception, after denouncing Jesus Christ as the Messiah, all promises given to the Old Israel were fulfilled spiritually in the Christian church that was mostly comprised of gentiles.

Among the hymns that need to be seen in the light of fulfilment theology is the following, which is sung on Holy Friday:

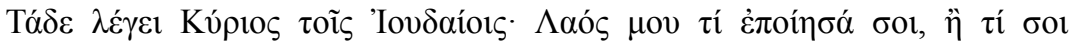

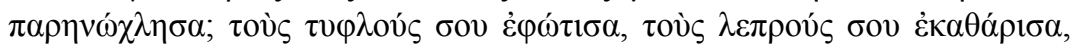

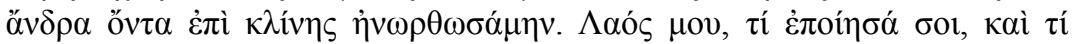

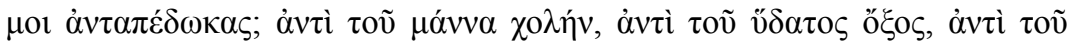

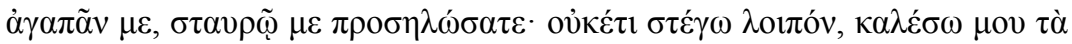

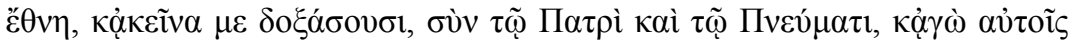

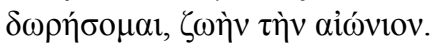

Thus says the Lord to the Jews: O my people, what have I done unto thee? Or wherein have I wearied thee? I gave light to thy blind and cleansed thy lepers, I raised up the man who lay upon his bed, O my people, what have I done unto thee, and how hast thou repaid me? Instead of manna thou hast given me gall, instead of water vinegar; instead of loving me, thou hast nailed me to the 
Cross. I can endure no more. I shall call my Gentiles, and they shall glorify me with the Father and the Spirit; and I shall bestow on them eternal life.

(Lenten Triodion 1978: 583)

After reproaching the Jews for their ingratitude for all the good that God had done for them in the Old Testament, this hymn, similarly to a large number of other hymnographic texts composed for Holy Week, concludes that, because of their ingratitude, God chose to give 'eternal life' to the gentiles. It should be pointed out that Holy Week, a period when the Church commemorates Christ's suffering and death that culminated in the Resurrection, was very suitable for developing this idea. From the very beginning, the Christian communities closely associated these events from Christ's life with the Jewish Passover (Greek Pascha). Since the Christian Pascha was based on the Jewish one, initially its liturgical celebration included the commemoration of both the Old Testament's deliverance of the Israelites from Egypt and the New Testament's salvation from death accomplished through Jesus Christ. Gradually, the feast was entirely Christianised, so that only typological meaning was given to the events of the Exodus of the Jews from Egypt. As a result, Byzantine hymnographers started to emphasise that God chose 'us' rather than 'them,' especially through the hymns for this originally Judaic feast (Azar 2015). Hence, according to these authors, the promises of the future kingdom of God and eternal life no longer referred to the physical Israel, but to the Christians as the new Israel.

The purpose of this brief treatment of the anti-Jewish polemic in the hymns composed for the paschal period is not to determine if they should be removed from the liturgical books or not. Rather, my intention was to show how the hymns were used by Byzantine theologians to advance Christian supersessionist theology initiated by utopian ideals.

\section{Anti-Muslim polemic}

As for the anti-Muslim polemic reflected in Byzantine hymnography, hymns for the feast of the veneration of the Holy Cross are especially imbued with such references. The development of the cult of the Cross from the fourth century onwards had a direct impact on liturgical poetry. Liturgical hymns for the Exaltation of the True Cross repeatedly stress not only the spiritual dimension of the Cross in Christian life, but also its military and triumphant functions. Hymnographers frequently eulogise the Cross as a powerful weapon, which brings victories to the emperors and secures peace in the empire. In the kontakion sung annually on the feast of the Exaltation of the True Cross, as well as at weekly offices, namely, on Wednesday and Friday Matins, it is sung:

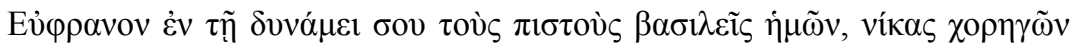

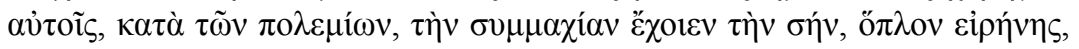

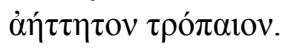


Make our faithful emperors glad in your strength, giving them victory over their enemies: may your Cross assist them in battle, weapon of peace and unconquerable sign of victory.

(Festal Menaion 1969: 148)

Kosmas the Melode's kanon for this feast is preoccupied with the idea of imperial victory to such a degree that Alexander Kazhdan has called it 'a political document' (Kazhdan 1999: 114). Kazhdan explains this feature by the fact that Kosmas was writing in Palestine, which was occupied by Muslim Arabs. The kanon, accordingly, expresses the author's hope for liberation by the Byzantine emperor. Characteristic of Kosmas's insistence on the link between the emperors and the True Cross is the third of the eighth ode of his Kanon for the Exaltation of the Holy Cross:

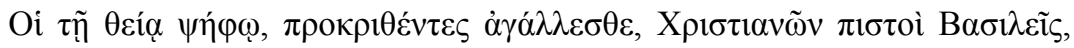

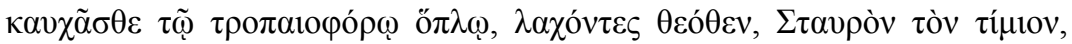

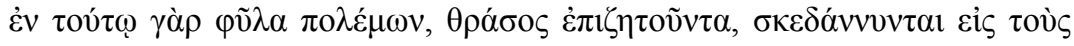

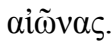

You, faithful Christian emperors, forechosen by divine decree, rejoice. Receiving from God the venerable Cross, make this victorious trophy your glory, for by it the tribes of the enemy that rashly seek battle are scattered unto all ages.

(Festal Menaion 1969: 150)

In addition to such invocations of the Cross's might phrased in rather generic terms, there are hymns which contain specific references to the power of the Cross against the Muslims. The rise and expansion of Islam represented the most acute threat to the Byzantine empire in both military and ideological terms from the seventh century onwards, since the Muslim Arabs laid claim to the same territory and cultural heritage as Byzantium (Speck 2003: 144). Furthermore, according to the Islamic replacement theology, Islam was the original, primordial expression of the Abrahamic monotheism that God revealed to his chosen people. To counter the new religion, many Byzantine authors engaged in polemics with its proponents by producing separate polemical writings, often in the form of a dialogue between a Christian and a 'Saracen.' The earliest one is Controversy between a Saracen and a Christian, attributed to John of Damascus, but apparently composed in the second half of the eighth century (Sahas 1972: 142-55). This kind of polemic was also frequently incorporated into more popular literary genres, including saints' lives. For instance, the Life of Constantine, the apostle of the Slavs, relates the protagonist's dispute with a Muslim during his mission to the Caliphal court in Baghdad (Dvornik 1933: 354-8). Echoes of this existential threat to the empire found their way into liturgical texts, especially hymns, through which the faithful prayed for imperial victory.

One of the best examples is the kanon for the Exaltation of the True Cross ascribed to Germanos I, Patriarch of Constantinople (d. c. 740). Its author glorifies 
the emperor and expresses his hope that the offspring of Hagar will be defeated by the power of the True Cross. This idea is articulated in the fourth troparion of the third ode:

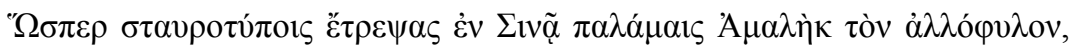

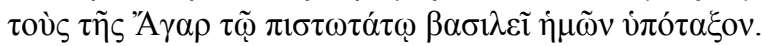

In the same way as you defeated the Amalekites, the foreigners in Sinai, by the hands put in the form of the Cross, subject the [race] of Hagar to the most pious emperor.

(Sinait. gr. 552, f. 128)

In this hymn, the Muslims are denoted as descendants of Hagar: 'those of Hagar' or 'the offspring of Hagar.' Originally, in its biblical usage, the word Hagarenes designated the offspring of Abraham's slave Hagar (Gen 16; 1 Chr 5:19; and Ps 82:7). However, after the appearance of Islam, Byzantine authors employed the terms Hagarenes or Hagarites to denote the Arabs, who were believed to be the offshoot of Hagar's son Ishmael (De haeresibus 100: 60). Another common term for Arab Muslims was Saracens, especially in the earliest Byzantine sources dealing with the Arab conquests. For example, both Sophronius, patriarch of Jerusalem (d. 638), and the author of the Doctrina Jacobi nuper baptizati, use this term in 634 (Usener 1886: 501-16; Déroche 1991: 47-229; Kaegi 1969: 139-49). By applying these names to the followers of the new religion, Byzantine authors apparently wished to disconnect them from the promises given to Abraham and the chosen people of the ancient Israel.

One of the central concerns articulated in this hymn is the hope that the Hagarenes will be subjected to the emperor. The same concern is encountered already in the earliest Byzantine writings that make reference to the Arab Muslims. In his Synodical Letter, Sophronius of Jerusalem expressed his wish that the 'strong and mighty sceptre' of the Christian emperors would destroy the pride of all barbarians, 'but especially of the Saracens' and 'cast down their insolent acts' (Allen 2009: 154-5). Gradually, this idea found its way into liturgical poetryone should recall that Sophronius himself was a distinguished hymnographerbut instead of the 'sceptre' Byzantine hymnographers invoked the strength of the Cross.

In the present troparion, the author, appealing to God to subject the Muslims to the emperor, refers to the Old Testament battle of the chosen people against the Amalekites (Ex 17:8-16). He provides a typological interpretation of the biblical event according to which the Israelites won the battle because Moses had his hands raised during the battle: 'As long as Moses held up his hands, the Israelites were winning' (Ex 17:11). The author sees the figure of the Cross in the position of Moses's hands. In this, the author follows a well-established tradition, for ever since Justin Martyr (d. 165) Christian exegetes claimed that Moses kept his hands lifted in a cruciform fashion. By pointing to this interpretation, the author sent a message to the congregation that the power of the Cross, which in its Old Testament type had brought victory to the Old Israel, could now help the emperor, as 
the leader of the New Israel, to defeat 'those of Hagar,' that is, the Muslims. It is worth mentioning that, aside from hymnographic texts, other Byzantine sources of liturgical character also refer to the Arab Muslims as Amalekites. For example, in the late seventh century, Anastasios of Sinai (d. after 700) in his sermon on

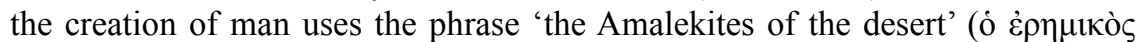
A $\left.\mu \alpha \lambda \eta^{\prime} \kappa\right)$ referring to the Arabs: 'and swiftly arose the Amalekites of the desert,

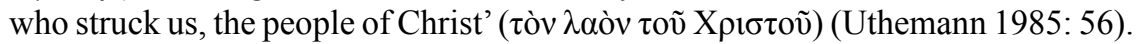
A similar expression is also used in the chronicle of Theophanes: 'Amalek rose up

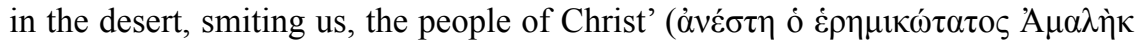

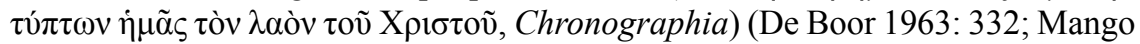
and Scott 1997: 462: see under Theophanes Confessor). Furthermore, Maximus

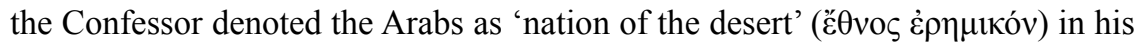
dogmatic epistle a century earlier ( $\mathrm{PG}, 91: 540 \mathrm{~A})$.

The correlation between the Muslims and the Amalekites contains hints of theological polemics against Islam. More specifically, since Islam also claimed its right to the title of the Chosen People and the ultimate fulfilment of God's promises to the Old Israel, Byzantine authors, including the composer of the hymn under discussion, were eager to associate their Muslim foes with the Amalekites. Their intention seems to have been to declare that, if the followers of the new religion have any place within the larger framework of the divinely conceived unfolding of human history, it is to be sought among the enemies of the Chosen People.

Another allusion to the Muslims in this kanon, which also includes an appeal to God to subject them to the emperor, is found in the fourth troparion of the fourth ode:

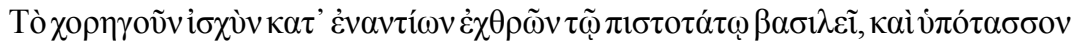

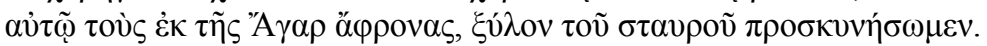

Let us bow before the wood of the Cross, which provides the power to the most pious emperor against enemies, and subjects to him the foolish offspring of Hagar.

(Sinait. gr. 552, f. 128v)

Apart from associating the Cross with imperial power, this poetic statement contains elements of a dogmatic polemic against Islam. The explicit reference to the veneration of the 'wood of the Cross,' which is posited as a source of strength against the Hagarenes, should be understood in the light of Muslim anti-Christian polemical literature. This literature focused, among other things, on the Christian veneration of the Cross, which the Muslims considered mere wood and thus unworthy of reverence (Corrigan 1992: 91-4; Brubaker 2006). For example, the anonymous middle Byzantine sermon published by Marc de Groote features a phraseology very similar to the one used in our troparion: 'The Hagarenes allege that you wor-

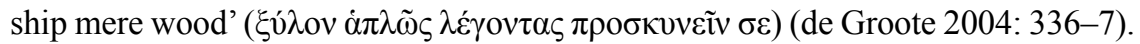
By using a similar vocabulary, the hymnographer seeks to convey the message 
to the congregation that this 'wood' is a strong weapon in imperial hands that could be deployed against the Muslims. It is well documented that members of the Umayyad dynasty worked systematically to remove or destroy crosses and sacred images. The most extreme step in this direction was undertaken by Caliph Yazid II (720-4), who issued a decree prohibiting crosses (and icons) from public display in 721 (Vasiliev 1955/1956: 23-47; Schick 1995: 215-17; Guidetti 2016: 87-8). Byzantine theologians felt it necessary to respond to these attacks against the main Christian symbol. John of Damascus refers to this issue in his treatise On Heresies, in which he treats Islam in a separate chapter: 'They also defame us as being idolatrous because we venerate the Cross, which they despise' (De haeresibus 100: 64; Sahas 1972: 137; Griffith 1985: 65; Griffith 2007). The Byzantine response to the Muslim attacks against the veneration of the Cross can also be discerned in the marginal psalters produced in the ninth century (Corrigan 1992: 86, 91-2). I would argue that the entire context of the anti-Muslim polemic during that period points to a sort of Byzantine reaction to the Islamic view that Islam is the final and most authentic expression of Abrahamic monotheism, replacing both Judaism and Christianity. Therefore, Byzantine hymnographers attempted to separate the Muslims from the God's chosen people as they believed that Christianity inherited the eschatological promises given to the Old Israel.

\section{Conclusion}

The hymns under consideration here show that liturgical poetry could serve as an instrument of intra-Christian and inter-religious polemics. Addressed to a wide audience, these texts could be effectively mobilised to communicate messages that delineate dogmatic differences and strengthen the congregation's sense of identity vis-à-vis a common foe, either internal or external. The ultimate goal was to demonstrate that certain dogmatic teachings, especially those formulated at ecumenical councils, embodied the authentic religious ideals, which secured the salvation of the Church community. Furthermore, hymns composed to celebrate the ecumenical councils were regarded not only as potent tools to maintain the bad memory of the condemned 'heresiarchs' but also to give an opportunity to orthodox communities to condemn them perpetually.

In addition, the hymns were used as tools to condemn other religious practices, specifically those of Judaism and Islam, which are particularly connected to the principles of replacement theology. Namely, the authors tried to present Christians as the new chosen people who replaced Israelites as favourites in the eyes of God. Byzantine hymns composed to be sung for Holy Week are frequently imbued with anti-Semitic sentiments. While most of anti-Jewish expressions are usually empty of any theological meaning, many of these hymns reflect the well-established theological concept that the events related to Jesus's sufferings and resurrection are a new Pascha, which was based on a new memory. Hence, building upon the early Christian tradition, Byzantine hymnographers continued to manipulate Jewish religious texts (i.e. the Old Testament) as well as the content of the most important Jewish feast to justify a 'new' memory of the past. 
A revision of memory was also characteristic of Islam, another late-antique religion derived from Judaism, which laid claim to the pure Abrahamic monotheism in order to supersede both Judaism and Christianity. The Muslim Arabs also posed a serious political threat to the structures of the Byzantine Empire as a Christian state, since their goal was to conquer Constantinople and replace Byzantium. The purpose of the Byzantine anti-Muslim hymns was to counter this threat by unveiling Muslims as innate enemies of the new chosen race of Christians, and associating them with the Amalekites, the enemies of the Old Israel.

\section{Note}

1 Biblical scholars have found evidence for the texts of these early songs in the New Testament, as for example in Luke $(1: 46-55,67-79 ; 2: 14,29-32)$; Revelation $(1: 5-6$; $4: 8,11 ; 5: 9-14 ; 7: 10-12,15-17 ; 11: 15-18 ; 12: 10-12 ; 15: 3-4 ; 16: 5-7 ; 19: 1-8 ; 22: 13)$; in some of Paul's letters, including Romans (11:33-6) 1 Corinthians (13), Ephesians (1:3-14), Philippians (2:6-11), Colossians (1:15-20), and 1 Timothy (3:16); and in 1 Peter (2:21-5) (Sanders 1971).

\section{Bibliography}

\section{Primary sources}

Ambrose of Milan (1964) De spiritu sancto. Edited by Faller, O. Sancti Ambrosii opera, CSEL, 79. Vienna: Hoelder-Pichler-Tempsky, 1-222.

Anastasius of Sinai (1985) Sermones. Edited by Uthemann, K.-H. Anastasii Sinaitae sermones duo in constitutionem hominis secundum imaginem Dei, CCSG, 12. Turnhout: Brepols.

Athanasius of Alexandria (1940a) Apologia contra Arianos. Edited by Opitz, H. G. Athanasius Werke, vol. 2.1. Berlin: W. de Gruyter, 87-168.

- (1940b) De synodis Arimini in Italia et Seleuciae in Isauria. Edited by Opitz, H. G. Athanasius Werke, vol. 2.1. Berlin: W. de Gruyter, 231-78.

Augustine of Hippo (1965) Confessiones. Edited by Trapè, A. Opere di sant'Agostino: Le confessioni, NBA, 1. Rome: Città nuova editrice.

- (1998) Edited by Lombardi, A. Opere di sant'Agostino: Polemica con I Donatisti. Psalmus contra partem Donati, NBA, 15/1. Rome: Città nuova editrice, 20-40.

de Groote, M. (2004) 'An anonymous sermon against the Hagarenes, the Bogomils, and the Jews'. HTR, 97/3: 329-34, 336-51.

Déroche, V. (ed.) (1991) 'Doctrina Jacobi nuper baptizati'. Travaux et mémoires, 11: 47-229.

Festal Menaion (1969) Translated by Mother Mary and Ware, K. London: Faber and Faber. John of Damascus (1981) De haeresibus. Edited by Kotter, B. Die Schriften des Johannes von Damaskos IV. Opera polemica. Berlin: W. de Gruyter.

Lenten Triodion (1978) Translated by Mother Mary and Ware, K. London: Faber and Faber. Maximus Confessor, Epistola dogmatica. PG, 91: 533B-44C.

MV. Menaia in twelve volumes, Venice: O ФOINI $\Xi, 1889$.

Nicetas Choniates, Thesauri orthodoxae fidei. PG, 139: 1101A-444B.

Pentecostarion, Athens: Anestes Constantinides, 1902. 
Philostorgius (1981) HE. Edited by Winkelmann, F. Kirchengeschichte, GCS. Berlin: Akademie Verlag.

Pliny (1947) Epistolae. Edited and translated by Melmoth, W. and Hutchinson, W. M. L. Pliny: Letters, LCL. Cambridge, MA: Heinemann.

Sophronius of Jerusalem (1886) Sermo natalis. Edited by Usener, H. 'Weihnachtspredigt des Sophronios'. Rheinisches Museum für Philologie, 41: 501-16.

(2009) Epistula synodica. Translated by Allen, P. Sophronius of Jerusalem and seventh-century heresy: The Synodical Letter and other documents, Oxford early Christian Texts. Oxford: Oxford University Press.

Theodoret of Cyrrhus (1954) HE. Edited by Parmentier, L. Kirchengeschichte, 2nd edn, GCS, 44. Berlin: Akademie-Verlag.

Theophanes Confessor (1963) Chronographia. Edited by de Boor, C. Theophanis chronographia, vol. 1. Leipzig: Teubner.

(1997) Translated by Mango, C., Scott, R., and Greatrex, G. The chronicle of theophanes confessor: Byzantine and Near Eastern history, AD 284-813. Oxford: Clarendon Press.

\section{Secondary sources including anthologies}

Azar, M. G. (2015) 'Prophetic matrix and theological paradox: Jews and Judaism in the Holy Week and Pascha observances of the Greek orthodox church'. Studies in ChristianJewish Relations, 10: 1-27.

Bastiaensen, A. A. R. (ed.) (1975) Vite dei santi III. Milan: Fondazione Lorenzo Valla.

Brubaker, L. (2006) 'In the beginning was the word: Art and orthodoxy at the Councils of Trullo (692) and Nicaea II (787)'. In Louth, A. and Casiday, A. (eds.), Byzantine orthodoxies: Papers from the thirty-sixth spring symposium of Byzantine studies, University of Durham, 23-25 March 2002, Society for the Promotion of Byzantine Studies, 12. Aldershot: Ashgate, 95-101.

Bucur, B. G (2017) 'Anti-Jewish rhetoric in Byzantine hymnography: Exegetical and theological contextualization'. St Vladimir's Theological Quarterly, 61/1: 39-60.

Corrigan, K. (1992) Visual polemics in the ninth-century Byzantine psalters. Cambridge: Cambridge University Press.

Drijvers, H. J. W. (1985) 'Jews and Christians at Edessa'. Journal of Jewish studies, 36: 88-102.

Dunkle, B. (2016) Enchantment and creed in the hymns of Ambrose of Milan. Oxford: Oxford University Press.

Dvornik, F. (1933) Les légendes de Constantin et de Méthode vues de Byzance. Prague: Orbis.

Griffith, S. (1985) 'Theodore Abu Qurrah's Arabic tract on the Christian practice of venerating images'. Journal of the American Oriental Society, 105: 53-73.

(2007) 'Christian, Muslims, and the image of the one God: Iconophilia and iconophobia in the world of Islam in Umayyad and early Abbasid times'. In Groneberg, B. and Spieckermann, H. (eds.), Die Welt der Götterbilder. Berlin: W. de Gruyter, 347-80.

Groen, B. (2008) 'Anti-Judaism in the present-day Byzantine liturgy'. Journal of Eastern Christian Studies, 60: 369-87.

Guidetti, M. (2016) In the shadow of the church: The building of mosques in early medieval Syria. Leiden: Brill.

Hedrick, C. (2000) History and silence: Purge and rehabilitation of memory in Late Antiquity. Austin: University of Texas Press. 
Kaegi, W. (1969) 'Initial Byzantine reactions to the Arab conquest'. Church History, 38/2: $139-49$.

Kazhdan, A., Sherry, L. F., and Angelidi, C. (1999) A history of Byzantine literature (650-850), Research Series 2. Athens: The National Hellenic Research Foundation, Institute for Byzantine Research.

Lash, A. E. (2006) 'Byzantine hymns of hate'. In Louth, A. and Casiday, A. (eds.), Byzantine orthodoxies: Papers from the thirty-sixth spring symposium of Byzantine studies, University of Durham, 23-25 March 2002, Society for the Promotion of Byzantine Studies, 12. Aldershot: Ashgate, 151-64. [Repr. London: Routledge, 2017].

Mango, C. (1993-94) 'The Chalkoprateia annunciation and the pre-eternal Logos'. Deltion tis Christianikis archaeologikis etaireias, 17: 165-70.

Pentiuc, E. J. (2014) The Old Testament in eastern Orthodox tradition. Oxford: Oxford University Press.

Sahas, D. (1972) John of Damascus on Islam: The "heresy of the Ishmaelites". Leiden: Brill.

Sanders, J. (1971) The New Testament christological hymns: Their historical religious background. Cambridge: Cambridge University Press.

Schick, R. (1995) The Christian communities in Palestine from Byzantine to Islamic rule: A historical and archaeological study. Princeton, NJ: The Darwin Press.

Shepardson, C. (2008) Anti-Judaism and Christian orthodoxy: Ephrem's hymns in fourthcentury Syria. Washington, DC: The Catholic University of America Press.

Speck, P. (2003) 'The origins of the Byzantine Renaissance'. In Speck, P. (ed.), Understanding Byzantium: Studies in Byzantine historical sources, Variorum Collected Studies Series. Aldershot: Ashgate: 143-62.

Theokritoff, E. (2003) 'The orthodox services of Holy Week: The Jews and the new Sion'. Sobornost, 25: 25-50.

Thettayil, B. (2007) In spirit and truth: An exegetical study of John 4:19-26 and theological investigation of the replacement theme in the Fourth Gospel. Leuven: Peeters.

Vasiliev, A. (1955/56) 'The iconoclastic edict of the Caliph Yazid II, A.D. 721'. DOP, 9/10: 23-47.

Viteau, J. (ed.) (1897) Passions des saints Écaterine et Pierre d'Alexandrie, Barbara et Anysia, publiées d'après les manuscrits grecs de Paris et de Rome. Paris: E. Bouillon.

Woudstra, M. H. (1988) 'Israel and the church: A case for continuity'. In Feinberg, J. S. (ed.), Continuity and discontinuity: Perspectives on the relationship between the Old and New Testaments. Wheaton, IL: Crossway, 221-38. 


\title{
11 Paradise regained? \\ Utopias of deliverance in seventh- century apocalyptic discourse
}

\author{
Ryan W. Strickler
}

In keeping with the theme of this volume, this chapter examines the relevance of utopias and dystopias as they appear in seventh-century apocalyptic discourse. Of interest is the use of these categories by authors to transform the political and religious identities of the communities under Roman cultural hegemony, first during the Persian invasions followed by the Muslim invasions. The specification of cultural hegemony is important, as I include not only communities under direct Roman political control, including Jews and Greek-speaking Chalcedonian Christians, but also Syriac-speaking Christians, on the imperial periphery and outside of Roman political domination, who nevertheless understood Rome to be the centre of God's kingdom on earth.

The seventh century was a period of radical transformation within the communities of the Mediterranean world. Two global empires - the Romans and Sassanid Persians - fought an extended campaign which nearly brought about their mutual destruction. In the earliest decades, the Sassanids took advantage of political instability among the Romans to make unprecedented advances into imperial territory, most notably capturing Jerusalem in 614 (Haldon 1990: 42-3). By 628, the emperor Heraclius had managed to restore imperial territories, however, in less than a decade, Arab tribes united by the newly founded religion of Islam had taken advantage of the chaos to conquer the Persian empire and make significant advances into Roman territory, eventually capturing Jerusalem for a second and final time in 637 (Kaegi 1992: 95). The Romans themselves, whose identity was closely linked to the idea that God demonstrated his favour through success in battle, were forced to reassess their position in the divine economy in the face of defeat by two non-Christian foes (Olster 1994). The same was true for Syriacspeaking supporters on the periphery of Roman cultural and political influence who nevertheless considered the Christian Roman Empire to be the centre of God's kingdom on earth.

Although accustomed to instability, the Jewish community was affected by political transformation in other ways. Evidence suggests that, in the initial years of Persian occupation of Jerusalem, Sassanid governors had restored religious freedom to the Jews, permitted their return to the city, and may have even allowed for a level of self-rule (Sivan 2000). Surviving Jewish literature suggests a renewed hope in the rise of a messiah who would liberate God's people from 
Roman oppression (Stoyanov 2011: 46). These initial hopes were short lived, however, as the Persians reversed their tolerant position, and soon afterwards the Romans reconquered the holy city. In response to perceived Jewish betrayal of the empire, Heraclius instituted punitive anti-Jewish policies, including his notorious edict of forced baptism in 634 (Strickler 2016).

The success of the Persians and subsequently the Arabs created an intolerable anxiety among late-Roman subjects, including Christians and Jews, which required resolution. One technique was to employ apocalyptic discourse, through which authors placed the Romans and their adversaries in a providential narrative where defeat, rather than being evidence of divine disfavour, was transformed into paedagogical chastisement. Within this paradigm, God punished his chosen people, either the Christians or Jews depending on the author, by inflicting their enemies upon them as a rod of chastisement.

I will show how Byzantine authors employed the memory of an idealised biblical and classical past rhetorically to transform their landscapes through a process of deconstruction and reconstruction, which this chapter traces as a process of decline into dystopia, followed by supernatural deliverance by a divinely raised emperor or messiah, and the establishment of a final terrestrial utopia. To examine a broad cross-section of literary production, this chapter addresses three exemplary authors corresponding to three major communities under Roman cultural hegemony and covering the chronological scope of the seventh century. Representing Greek-speaking court literature, we examine the poems On Heraclius's Return from Africa and the Heracliad by George of Pisidia. The former depicts the dystopic state of the empire after the reign of the usurper Phocas and the hopes for deliverance by his successor Heraclius (r. 610-41), while the latter reflects upon the woes inflicted by the Persians and the subsequent restoration of the empire after Heraclius's success.

Our remaining two sources focus on the liberation of God's chosen people from oppression and conclude with the transformation of Jerusalem into an idealised centre of God's kingdom. The so-called Sefer Zerubbabel, a Hebrew messianic apocalypse composed in the immediate aftermath of Roman victory over the Persians, reveals the progression of Jewish hopes for liberation by the Persians, the response by the community to the ultimate success of the Romans, and the assurance that the Jews would eventually be restored as God's chosen people and the miraculous expansion of Jerusalem. Finally, the Syriac Apocalypse of PseudoMethodius records the reaction of the Christian periphery to the establishment of Islamic hegemony over former Roman territory and the hopes for an eventual Roman resurgence in which the Christian community would be vindicated, and Christ would eventually reign in person from Jerusalem.

After a brief discussion of the themes and terminology used, I examine the way in which each source, in chronological order, employs the progression from dystopia to deliverance, and finally, utopia. I argue that each author uses this progression to explain the intolerable circumstances faced by each community, to reinforce communal identity as God's chosen people, and to provide hope for eventual deliverance through the restoration of a terrestrial utopia. 


\section{Seventh-century utopias and dystopias}

The cycle of construction-destruction-reconstruction is a recurring theme in this volume. This theme can be observed, in a rhetorical fashion, in the narratives examined here through the cycle of dystopia-deliverance-final utopia. Although the first stage, dystopia, has its roots in contemporary invasions or mismanagement by enemies, the remaining stages are aspirational. Our authors conceive of the destruction of the dystopian order by an eventual, supernaturally raised hero, and the final reconstruction of a utopia of deliverance.

The usefulness of Bronwen Neil's definition of utopia (and its corollary, dystopia) in the introduction to this volume is borne out in the evidence discussed here. The dystopias described in our sources are largely exaggerated imaginings of contemporary crises, in which human adversaries and the material deprivation are depicted in supernatural terms. In these accounts, the authors' communities languish under oppression in their homelands, longing to return to an imagined state of freedom and prosperity recently taken away by the oppressor.

The dystopias of our sources serve two major purposes - to acknowledge the anguish of the community and to establish a contrast by which the prophesied utopia can be appreciated. Perhaps contrary to expectation, the utopias envisioned are largely terrestrial, not eschatological. All three authors envision an imminent deliverance and restoration of their community to a position of earthly power. In some cases, the utopia is simply a restoration of an idealised former state. In others, the utopia is an idealised, divinely perfected version of a former or imagined polity. Even so, it is worth emphasising that in each instance the world does not end but continues under the dominion of the restored community.

\section{Transformation of landscapes and identity}

The impact that modification and reconception of landscapes had upon religious identity, a central concept explored in other chapters, is central to understanding the strategies employed by the authors considered here. In the seventh century, this transformation was largely rhetorical and placed in the future, though this was generally in response to changes inflicted upon contemporary adversaries. George of Pisidia, in his On Heraclius's Return from Africa, suggests that the empire itself was altered and profaned by the emperor Phocas, while he blames the Persians in his Heracliad. For the authors of the Sefer Zerubbabel, the transformation of the Mount of Olives as God's sanctuary is central to the utopian vision of the author. For both the Sefer Zerubbabel and the Apocalypse of Pseudo-Methodius, Jerusalem is transformed in differing ways into an idealised form to accommodate the utopian kingdom of God. For each of the authors under consideration, this transformation is essential to the maintenance of communal identity as God's chosen people, an identity which the authors find threatened by contemporary defeat.

As we will see, each of the authors uses the memory of the past to transform the future. George of Pisidia employs a mix of biblical and classical tropes to place contemporary enemies and heroes into a legendary narrative. 


\section{Ryan W. Strickler}

Pseudo-Methodius and the author of the Sefer Zerubbabel appeal to the Hebrew Bible, recalling prophetic heroes and enemies. In each case, the community and its foes are emplotted into the past, while simultaneously the past is transformed into the present.

\section{Apocalyptic discourse}

The utopian cycles discussed in this chapter are all considered as part of a larger category of apocalyptic discourse. As I have written on this subject at length elsewhere (Strickler 2018), here I will only summarise material relevant for this study. I use the term apocalyptic discourse to refer to the use of apocalyptic tropes, such as divine revelation, prophecy, dreams, visions, and occasionally eschatology to attribute political and social crises to divine causation. This typically functions to provide meaning and hope in otherwise intolerable circumstances. Such discourse can be found in multiple genres, including historiography, hagiography, letters, and homilies; and is not strictly limited to literature traditionally considered apocalyptic.

This approach builds upon foundational studies which recognise the importance of apocalypticism and eschatology in comprehending periods of crisis (Alexander 1968, 1985; Podskalsky 1972; McGinn 1979; Brandes 1990; Magdalino 1993; Reinink 2001; Kraft 2012; Bonura 2013, 2016; Shoemaker 2014). I agree largely with Shoemaker $(2012,2014$, and 2018) in his assessment of the seventh century as a period in which apocalypticism was used by Romans to understand the shifting political landscape, and his emphasis on the importance of the apocalyptic milieu in understanding the rise of Islam and the importance of the Prophet Muhammad and the formation of Islamic identity, a point echoed by Damien Casey (2013). Averil Cameron (2017) critiques Shoemaker by arguing essentially that Muslims and Christians were independent communities with their own traditions. I find this argument unconvincing, as it minimises the level of cultural exchange present in the Near East. Thomas Sizgorich (2004) and Arietta Papaconstantinou (2008) have argued that in fact it took several decades for a distinct Islamic identity to manifest.

I depart from the larger trend of these scholars who entangle apocalypticism and eschatology, including Shoemaker (2018), who sees imperial eschatology as the central theme to apocalyptic discourse. Although this theme is important, it overlooks the larger use of apocalypticism to promote group cohesion and rhetorically transform identity. Likewise, I resist the urge of some scholars to associate apocalypticism with folk literature and to dismiss the possibility that the Roman literary elite would employ such a 'superstitious' outlook (cf. Martinez 1987; Brandes 1990).

In this respect, I largely agree with David Olster (2003), who notes that many authors of Byzantine apocalyptic literature were more concerned with their place in the divine order of kingdoms than with the end of days, and employed sophisticated literary techniques to depict their views. By employing the category of 'apocalyptic discourse' instead of limiting our gaze to 'apocalypse' as a genre we 
can achieve a more comprehensive view of the way in which Romans conceived of their place in a narrative of divine causation.

Applying this perspective to the examination of seventh-century utopias is useful, particularly in the study of George of Pisidia, a skilled court poet who is rarely discussed as an apocalyptic writer. Likewise, it allows us to trace apocalyptic discourse as a cross-cultural phenomenon, employed in Greek, Syriac, and Jewish milieus which are often considered isolated from and indeed hostile to one another.

\section{George of Pisidia}

Let us now turn to our first author, George of Pisidia. Although born in Pisidia in Asia Minor, George made a name for himself in Constantinople, befriending the patriarch Sergius and serving as a deacon and record keeper at Hagia Sophia (Whitby 1998: 247-9). He is best known for his collection of poetry, largely composed in iambic trimeter, written in praise of Heraclius and the patriarch Sergius (Whitby 1998, 2002).

George's poetry is a valuable source on Roman morale during the first decades of the seventh century. His first poem, On Heraclius's Return from Africa, was composed in response to Heraclius's overthrow of the usurper Phocas (r. 602-10), who received the brunt of blame from George and his contemporaries for incurring God's wrath for overthrowing the beloved emperor Maurice (r. 539-602). Unlike other contemporary sources, which were written after Heraclius's ultimate victory over the Persians, George's poetry was composed throughout the conflict, even before Heraclius had an opportunity to prove himself, and thus gives a unique perspective into the hopes of those at court for the newly ascendant emperor.

In On Heraclius's Return from Africa, George depicts an empire on the brink of collapse, brought low by Phocas's folly. The poet writes:

But you accomplish these things even when you contend with the time, whenever troubles, like floods inundate the earth with so many struggles. But there is hope concerning the present troubles that the concerns will utterly be brought to an end by you; for if the state has been utterly destroyed having fallen by the neglect of those who rule even now the state will be saved by God by the care of the pious ruler.

(On Heraclius's Return from Africa 33-7, Pertusi 1959: 64) ${ }^{1}$

In this passage we see the dystopic state wrought by Phocas, although he is not mentioned by name. The whole earth has been flooded with troubles, and in a stark admission for a Roman author, the state has been 'utterly destroyed' by the 'the neglect of those who rule.' Such admissions were almost unprecedented in previous decades, as the Roman state was considered invincible.

However, George provides hope of a future utopian restoration: The newly ascendant Heraclius, the pious ruler raised and directed by God, will save the 
empire. Admittedly George does not expound on what this saved state will look like, yet he predicts its salvation all the same. It is worth remembering here that Heraclius had only recently taken the throne and had not yet had a chance to act against the Persians.

Later in the poem George expounds further upon the dystopic state of the empire and uses Biblical tropes to predict its deliverance by Heraclius. George writes:

But you did not fall from such hope rather as faithful Phineas in spirit you held the murderess of murders. Having freed us from the damage of tyranny you hold us as slaves from God from which a terrible flow of blood the fruitless stream of evils sprang forth. Continually keeping the memory of these things, $\mathrm{O}$ greatest ruler, and having cast your hope up toward God, you will look upon God himself again speedily the second salvation of your hope. For he will open the door to peace for us again altogether through your pursuits showing that she [peace] is your coregent in rule.

(On Heraclius's Return from Africa, 56-69, Pertusi 1959: 66)

In this passage, we find two contrasting worlds. The dystopia of the empire under Phocas is described as a tyranny flowing with blood from which streams of evil had sprung forth. This is compared with a future utopia under Heraclius. George uses the memory of Phineas, the hero of the Hebrew Bible (Num 25), to transform Heraclius typologically. By extension, the Midianite woman whom Phineas slew becomes an unspoken allusion to Phocas. Heraclius's piety is once again highlighted as the poet proclaims that he will look upon God himself and bring about a second salvation, and most importantly, a personified Peace, who becomes the emperor's co-regent.

The lack of direct mention of Phocas, or even his typological counterpart, might be considered a literary damnatio memoriae, though I hesitate to take this too far. His name is stricken from memory, yet the results of his tyranny remain. Nevertheless, Heraclius is depicted as the keeper of memory, entrusted with remembering those things which ought to be stricken from record in order to fulfil his role as deliverer. Thus, in this utopia of deliverance, the destroyer remains nameless while the dystopia he created is overcome by the divinely raised Heraclius. In this case, the utopia is a return to a pre-fallen empire, idealised as free from troubles, and forgetful of the turmoil of previous rulers.

If George composed high praise of Heraclius's reign before his potential would be realised, his panegyric of the emperor after his defeat of the Persians is not surprising. This praise was exemplified in the poet's epic Heracliad, written to commemorate Heraclius's victory. Here, the cause of dystopia shifts from Phocas to the Persians themselves, and in particular, the Persian shah Chosroes II.

In Book I, George employs biblical memory to depict his characters, transforming Heraclius into David and Daniel, and Chosroes II into Nebuchadnezzar. However, in one passage George shifts from biblical to classical memory, transforming Heraclius into Heracles: 
O Homer! You were right of old not to heedlessly consider Heracles a god for what benefit for the common good is a slain boar or a strangled lion? Rather marvel, reasonably, that there is one among men who is the deliverer of the Cosmos, Heraclius; for he descended into the nethermost gates of Hades and strangled the rage of the voracious dog. He raised up the empire as Alcestis, he destroyed the bloodthirsty dragon he subdued the hydra, the many-necked monster he purged the life covered before with filth, he strangled the worldpolluting lion and now Heracles went forth into the state having taken the golden apples, the whole city.

(Heracliad I.65-79, Pertusi 1959: 198, trans. mine)

Here, George uses classical memory to create a dystopia. Under this typology, the empire is transformed into Alcestis, trapped in Hades. Defeat by the Persians is transformed into the trials of Heracles. Conversely, Heraclius becomes a new and better Heracles. Most importantly, George bestows the rare title of 'Deliver of the Cosmos' on the emperor, an epithet which carries semi-messianic overtones, establishing Heraclius as the saviour of the entire created order, not just empire. In this case, the idealised classical past, an age of heroes becomes the utopia to which the poet longs to return.

George's poetry may not seem like an obvious source for apocalyptic discourse and utopian idealism. However, we see apocalyptic language employed, especially to describe the beginning of Heraclius's reign. George depicts the empire in an exaggerated state of despair, brought to utter destruction by Phocas and held prisoner in Hades by the Persians. In other words, terrestrial, human adversaries are transformed into supernatural foes who are able to bring the empire to its knees. When hope is lost, God raises a divine champion in Heraclius. George simultaneously transforms biblical and classical memory, turning the emperor into a hero, a semi-messianic figure who restores the empire to an idealised prefallen state. This utopian empire is at once an image of a pristine empire of Maurice and his predecessors and a return to the classical past where heroes such as Heracles performed great deeds, only now on behalf of the empire rather than for individual glory.

For George, the restoration of Roman hegemony over lands captured by the Persians was the realisation of a utopian vision predicated on Heraclius's overthrow of Phocas. For the empire's Jewish community, Heraclius's rally represented an entirely different set of circumstances. Initial Persian success had provided a glimmer of hope for possible liberation of the Jewish community from Roman oppression. This hope, it seems, was not entirely unwarranted. Based on literary evidence including the Sefer Zerubbabel and multiple liturgical piyyutim, Hagith Sivan (2000) argues that the Persians, after their conquest of Jerusalem in 614, permitted the Jews to return for the first time since their expulsion in $70 \mathrm{CE}$, and may have permitted the resumption of religious activities on the Temple Mount.

Like the Christians, Jewish authors turned to apocalyptic speculation to respond to the Persian invasions, seeing the Persians as a potential liberating force. This is significant, as after the destruction of the temple and expulsion by Titus during 
the reign of Vespasian, Jewish literary activity increasingly focused on midrash and interpretation of the Torah and avoided speculation about a future messiah (Himmelfarb 2012: 621).

This trend saw a dramatic reversal in the seventh century. With this initial decline of Christian hegemony over the holy city, Jews once again, though with some caution, composed messianic texts, such as liturgical piyyutim, which predicted the return of God's presence (Bamberger 1940; Lewis 1974; Ben-Eliyahu 2016). The importance of landscape to this vision became clear, as the Mount of Olives was consistently considered to be the location of the return of God's presence, an event which would bring an end to Roman oppression (Ben-Eliyahu 2016).

While initial victory of the Sassanids had provided hope that the return of God's presence was imminent, the final Roman victory over the Persians and the second expulsion of the Jews from Jerusalem suppressed initial hopes (Déroche 1999). However, this renewed messianism did not disappear. Rather, seventh-century Jewish authors pushed their hopes into the future, finding their greatest expression in our next document, the so-called Sefer Zerubbabel.

\section{The Sefer Zerubbabel (Book of Zerubbabel)}

Martha Himmelfarb (2017: 13-15) has recently confirmed that the Sefer Zerubbabel was almost certainly composed in the immediate aftermath of the emperor Heraclius's rally against the Sassanid Persian empire in 628. As such, it reflects both the trauma faced by the Jewish community after the collapse of hopes of imminent deliverance and the ability of Jewish authors to adapt their message of hope to rapidly changing circumstances.

Biblical memory is central to the Sefer Zerubbabel, beginning with the attribution to the biblical governor of Judah charged with rebuilding the Temple after the Babylonian captivity in the book of Ezra. The choice of visionary is certainly deliberate, as the vision ends with the final restoration of the Temple, though one not built by human hands, and harks back to a previous utopian state and historical parallel, the deliverance of the Jews by an earlier Persian dynasty, the Achaemenid empire under Cyrus the Great.

The text is presented as a series of visions revealed to Zerubbabel by a 'despicable man,' who is revealed to be the final messiah, along with the angels Michael and/or Metatron. After revealing himself to Zerubbabel, the despicable man makes the following prediction:

And in the future I shall fight the wars of the Lord at the side of the Lord's anointed, the one sitting before you, against the king with the arrogant face (Dan 8:23) and against Armilos son of Satan, who came forth from the stone statue. The Lord appointed me as commander of his people and those who love him to fight against the commanders of the nations.

(Sefer Zerubbabel, Himmelfarb 2017: 149-50)

In this passage we find a summary of the entire vision. The characters presented will avenge Jewish oppression. The despicable man then reveals a series of ex 
eventu prophecies beginning with the expulsion of the Jews in $70 \mathrm{CE}$, and ending with Roman victory over the Persians under Heraclius. The emperor, who initiated a series of anti-Jewish policies including an edict of forced baptism, is depicted as the anti-messianic Armilos. We also see the transformation of biblical memory by associating Armilos with the 'king with the arrogant face' of the book of Daniel.

The rise of Armilos represents the dystopian phase of the Sefer Zerubbabel. This dystopia involves contemporary oppression under Heraclius, as well as further oppression predicted to come. The following passage illustrates the dystopia in detail:

He showed me a marble stone in the shape of a virgin, and its appearance and form were most lovely and beautiful to behold. 'This stone is the wife of Belial,' he answered. 'Satan will come and lie with it, and a son named Armilos will come forth from it: "he will destroy the people" in the Hebrew language.... He will rule over all, and his dominion will reach from one end of the earth to the other.... He will worship strange gods. No one will be able to stand before him. Anyone who does not believe in him, he will slay by the sword, and he will slay many of them. He will attack the people of the holy ones of the Most High (Dan 7:27).... He will kill the messiah, son of Joseph, that is, Nehemiah b. Hushiel, and sixteen righteous men will be killed with him. They will exile Israel to the wilderness in three groups.'

(Sefer Zerubbabel, Himmelfarb 2017: 152)

The despicable man predicts that Armilos will rise up and bring misery upon the Jews, expelling them into the desert and slaying the present messiah, here called Nehemiah b. Hushiel. Hagith Sivan and John C. Reeves have suggested that the messiah may correspond to an actual Jewish leader during the Persian occupation of Jerusalem (Sivan 2000: 288-91; Reeves 2013: 460-1). This vaticinium ex eventu corresponds closely to Heraclius's expulsion of the Jews from Jerusalem upon his re-conquest, as well as his general anti-Jewish policy, which culminated in the edict of forced baptism.

These two passages represent the dystopian stage of the Sefer Zerubbabel. The oppressor Armilos is an idolater, the spawn of Satan, who is permitted to wage unstoppable war against God's people. This represents an exaggeration of an admittedly bleak state of affairs and provides a stark contrast upon which the author builds his utopian vision of deliverance. Faced with the gravity of the predicted circumstances, Zerubbabel is filled with despair. This moment of malaise provides an opportune moment to transition to the deliverance stage of the cycle. When circumstances seem at their worst for the Jews, the author reveals, God will see his people's suffering and intervene on their behalf. The intervention is depicted as follows:

The Lord God of Israel will descend upon the Mount of Olives. . . He will sound a great shofar. All the strange gods and temples of images will fall to the ground, and every wall and cliff will fall to the ground. ... The anointed 
of the Lord will come, that is, Menahem b. Ammiel, and he will breathe on Armilos's face and slay him. The Lord will put men's swords on each other's neck, and there they will fall dead as corpses.

(Sefer Zerubbabel, Himmelfarb 2017: 154-5)

This narrative of deliverance is rich with imagery associated with seventh-century Jewish apocalyptic discourse. Here, we see once more the importance of the transformation of landscape as the Mount of Olives becomes the geographic locus of a future utopia. This is where God's presence returns, as with earlier piyyutim, to destroy idolatry and avenge God's people. The 'temples of images' likely represent Christian churches and the use of icons. God raises a champion, the messiah Menahem b. Ammiel, revealed as the despicable man who speaks to Zerubbabel and kills Armilos by merely breathing on his face. God inspires chaos in the ranks of the Roman army, resulting in their defeat.

After a bloody battle, which avenges the oppression of the Jews and restores their position, the author depicts the full restoration of Jewish worship and control. This utopia is constructed in two stages, the first of which is depicted as follows:

After all this has come to pass, Menahem b. Ammiel will come, and Nehemiah b. Hushiel and all Israel with him. All the dead will come to life, and Elijah the prophet will be with them. They will go up to Jerusalem, and there will be great joy for Israel. They will offer sacrifices to the Lord, and the Lord will accept them. Israel's offering will be pleasing to the Lord as it was before, in ancient times. The Lord will smell the sweet savor of his people Israel and rejoice greatly.

(Sefer Zerubbabel, Himmelfarb 2017: 155)

Several elements stand out in this first stage of the Sefer Zerubbabel's utopia of deliverance. First, perhaps unexpected in a Jewish text, is the resurrection of the dead, including the slain messiah Nehemiah b. Hushiel, along with the longanticipated return of the prophet Elijah. The landscape of Jerusalem is rhetorically transformed from a Christian-dominated city into an idealised utopia, recalling the biblical period in which Jewish sacrifices and worship are restored in a manner pleasing to God.

The restoration of proper worship is what brings about the final stage of the Sefer Zerubbabel's utopia of deliverance. The restoration of temple sacrifices prompts the following response from the Lord, as the author predicts:

Then the Lord will bring down to earth the temple that was built above, and the pillar of fire and the cloud of incense will ascend to heaven. The messiah will go forth on foot to the gates of Jerusalem, and all Israel after him. The holy God will stand on the Mount of Olives. His awe and his glory will rest upon the heavens and the highest heavens [sic], over the whole earth and its depths.

(Sefer Zerubbabel, Himmelfarb 2017: 155) 
Once more, the landscape of Jerusalem and the Mount of Olives is rhetorically transformed by God's presence into an idealised utopia. The utopian Jerusalem is crowned with a third and final Jewish Temple, not built by human hands but pre-assembled in heaven and delivered by God himself. The memory of Exodus is employed, as a pillar of fire and a cloud of incense represent God's presence. Most importantly, God dwells in this utopia. Here again the centrality of the Mount of Olives in seventh-century Jewish apocalyptic discourse is evident, the locus of God's arrival, whence he will fill the whole of creation with his glory.

Soon after, we see the full extent to which the landscape of Jerusalem is transformed, when Zerubbabel asks Metatron, the angelic messenger, about the extent of the utopian city:

'Sir, show me Jerusalem, how long it is and how wide, and its buildings.' So he showed me the walls around Jerusalem, walls of fire, from the great wilderness to the western sea to the Euphrates River. He showed me also the temple building. The temple was built on five mountain tops that the Lord chose to bear his sanctuary: Lebanon, Mount Moriah, Tabor, Carmel, and Hermon.

(Sefer Zerubbabel, Himmelfarb 2017: 156)

The utopian Jerusalem is rhetorically transformed to expand well beyond the confines of the contemporary earthly city. The ancient walls are replaced with walls of fire, spreading as far as the Euphrates, and the Temple itself rests on five mountain tops. This expansive, idealised city is central to the revival of Jewish identity, standing as a testament of God's power and the Jews' status as God's chosen people.

It is worth noting here that utopian Jerusalem and its Temple are terrestrial and represent the consummation of God's plan for creation. This is not a heavenly Jerusalem, but rather an idealised and expanded Jerusalem, spreading across known locations. The Sefer Zerubbabel is not eschatological in the sense that it predicts an end of creation. Rather, it anticipates the imminent deliverance of the Jews, and the fulfilment of the Abrahamic Promise. God comes to dwell on earth, not to destroy it, and the Jews are established in their place as God's chosen people, while their enemies are slain.

Thus, within the Sefer Zerubbabel we see an increasingly familiar pattern present in apocalyptic discourse. Biblical memory is used to depict the plight of a contemporary people, in this case the Jews, which is magnified in a dystopian vision of horror and despair. In this case the persecution of the emperor Heraclius is depicted as the conquest of the spawn of Satan, an anti-messiah raised for the purpose of attacking the Jewish people. When circumstances seem most dire, God intervenes and raises a supernatural champion to avenge the abuse of his people. After the complete defeat of the adversary, God builds a utopia, which not only recalls the idealised utopia of the biblical age but is made greater than previously imagined. God's people, elevated to their proper status, have this identity 
confirmed in an idealised landscape, now the terrestrial home of God's presence and his people.

\section{The Apocalypse of Pseudo-Methodius}

Roman success against the Persians was imbued with apocalyptic significance by Christians and Jews alike, playing a pivotal role in the utopian visions of George of Pisidia and the Sefer Zerubbabel. Even so, the comfort the Romans took in their victorious position would be short-lived, as the Muslim Arabs grew increasingly threatening. Heraclius died with significant portions of Roman territory in Muslim hands, including the Middle East and Jerusalem, along with Mesopotamia and North Africa (Kaegi 1992). Much of this territory had only recently been recaptured from the Sassanid Empire. Even as the hopes invested in Heraclius faded, many Romans, and those under their cultural hegemony, hoped that God would raise up a champion on the imperial throne who could once and for all restore the empire to its rightful glory.

No document expressed this hope more vividly than the Apocalypse of PseudoMethodius. The Apocalypse, attributed to fourth-century martyr Methodius of Patara, was composed in Syriac but was almost immediately translated into Greek. From Greek it was translated into Latin in the early eighth century, and its Latin version was swiftly disseminated throughout Europe (Reinink 1992: 149-52). Gerrit Reinink convincingly relates its composition to reactions to the construction of the Dome of the Rock, and the institution of the dhimmi tax on non-Muslim subjects by the Caliph Abd al-Malik (Reinink 2001). This is in line with Bonura's (2016) view, based on Pseudo-Methodius's attention to taxation, that the Apocalypse was not composed in response to the arrival of the Arabs per $s e$, but the centralisation of Arab government in the region.

The text can be roughly divided into two sections. The first provides the fanciful genealogy of the Roman emperor and a pseudo-history in the style of a world chronicle. The second carries the narrative to the Arab invasions and beyond. The pseudo-historical section is followed by a series of ex eventu prophecies up until the taxation regime imposed upon the recently conquered Christian subjects. It describes in detail the invasions of the sons of Ishmael (i.e. the Muslims), whom the author 'predicts' will be permitted to be victorious over the Romans: 'not because God loves them, but because of the iniquity and the sin that is being wrought by the Christians' (Ps-Methodius, Apoc. XI, ed. Martinez 1985: 77-8, trans. 140).

The apocalypse gives a list of 'chastisements' inflicted by the Ishmaelites which include the defilement of churches, rape, infanticide, and especially excessive taxation. This represents the first of three dystopic stages in the Apocalypse. After this list, the author notes:

After these calamities and chastisements of the sons of Ishmael, mankind will be lying in the peril of that chastisement. There will be no hope of their being saved from that hard servitude. They will be persecuted and oppressed, 
and will suffer indignities, hunger and thirst. All the while, those tyrants will dress up like bridegrooms and adorn themselves as brides, and blaspheme by saying, 'There is no Savior for the Christians.'

(Ps-Methodius, Apoc. XIII, ed. Martinez 1985: 86, trans. 148-9)

Adding to the insult of their captors are the actions taken by apostates from Christianity. Of these, the author writes:

A great part of those who are sons of the Church will deny the true faith of the Christians, and the Holy Cross and the life-giving mysteries. Without violence, torments or blows, they will deny Christ, and make themselves like the pagans. For this reason, the Apostle also preached about them, 'In the last times, men will abandon the faith and will follow the unclean spirits and the teaching of the demons.' And they will become insolent and slanderers, arrogant, enemies of good things, traitors, and cruel. All those who were false and weak in the faith will be tested and made known in that chastisement. And they themselves will separate from the assembly of the Christians by their own will, for that time will invite them to follow its abomination.

(Ps-Methodius, Apocalypse XII, ed. Martinez 1985: 83-4, trans. 145-7)

The dystopia described by the Apocalypse is bleak. Christians languish in poverty, oppressed by their captors who live in gratuitous luxury as well as their former brethren who lord it over them, defiling the sacraments and treating the faithful with cruelty. The success of the sons of Ishmael leads them to boast of their superiority while the Christians are powerless to oppose.

At this point, when the situation seems most dire, as their captors taunt Christ, a champion arises to bring their awaited deliverance. Pseudo-Methodius describes the deliverance of the Christians in terms of destruction of the desert peoples: their servitude will be one-hundredfold more bitter than theirs (Ps-Methodius, Apoc. XIII, ed. Martinez 1985: 86-7). In a narrative similar to the deliverance of the Jews depicted in the Sefer Zerubbabel, the oppressing forces are overwhelmingly defeated and avenged. Those who are not killed are enslaved, including women and children, and their enslavement is worse than that imposed upon the Christians themselves.

Likewise, the deliverance of the Christians paves the way for the construction of a utopia, in this case based on the restoration of former Roman lands. This utopia of deliverance is described as a time of peace and plenty:

There will be peace on the earth, the like of which there had not been (before); there will be joy on the whole earth; men will dwell in great peace; the churches will be renewed; the cities will be rebuilt, and the priests will be set free from tax. At that time, priests and (lay)men will be at rest from trouble, care and anxiety. They will eat and drink; men will take wives and women will be given to men; they will build buildings and plant vines.

(Ps-Methodius, Apoc. XIII, ed. Martinez 1985: 87, trans. 149-50) 
This peace, however, will not be lasting. The Apocalypse of Pseudo-Methodius is unique in containing multiple dystopic phases. The second phase catches the Romans by surprise, and is described as follows:

Now, while 'they are eating and drinking,' rejoicing and exulting, without evil or the care for evil, without fear or trembling in their hearts, in that peace the gates of the North will be opened and the armies of those peoples who were enclosed there will come out, and the earth will shake before them. Men will be terrified and flee and hide themselves in the mountains, the caves and the graves. They will be eaten in the sight of their parents while they are watching. For these peoples that will come out from the North eat human flesh, drink the blood of wild beasts, and eat the creeping things of the earth. They will slaughter the children and give (them) to their mothers and force them to eat the bodies of their sons. They even eat dead dogs and kittens and all kinds of abomination. They will destroy the earth, and nobody will be able to stand before them.

(Ps-Methodius, Apoc. XIII, ed. Martinez 1985: 88, trans. 151)

In this passage the author appropriates biblical memory, employing the unclean nations of Gog and Magog from the book of Ezekiel. In the context of Syriac apocalyptic literature and earlier references to Alexander the Great, the author is likely employing the memory of legendary accounts of Alexander's imprisonment of the unclean nations of the North, which play an important role in the Syriac Alexander legends of the early seventh century (Van Donzel and Schmidt 2010). At any rate, the Christians of the Apocalypse are placed in the narrative of established prophecy. The unclean nations are cannibalistic and betray barbaric traits that frighten the population to the core. They will be permitted to destroy the world.

However, once more, when circumstances appear most dire, God will raise up another champion. The author describes the circumstances thus:

But after a week of calamity, they will all gather in the plain of Joppa, and there, God will send against them one of the commanders of the angels, and he will destroy them in one hour. Then, the king of the Greeks will come down and dwell in Jerusalem for a week and a half, that is, ten and a half years in number.

(Ps-Methodius, Apoc. XIII, ed. Martinez 1985: 88, trans. 151)

The commander of the angels and the king of the Greeks swiftly destroy the armies of Gog and Magog, once again delivering his people and restoring a utopia. Here, as in the Sefer Zerubbabel, Jerusalem is rhetorically transformed, becoming the seat of power for the king of the Greeks. The state of Jerusalem at this time is not described in any detail; however, it remains a centre of peace for the Romans who are permitted to live a carefree existence for a time. 
At this stage of the narrative, when God's champions appear to have defeated the adversaries of the Christians, the author depicts a third and final dystopia. Now it is the son of perdition, the Antichrist, who overtakes the righteous:

But at our Lord's coming from heaven, he will be delivered to the 'Gehenna of fire' and to 'the outer darkness,' and he will be there in 'weeping and gnashing of teeth.'

(cf. Matt 13:42) (Ps-Methodius, Apoc. XIV, ed. Martinez 1985: 92, trans. 173)

The author ends abruptly with the prayer that God will preserve his readers against temptation and that they will endure the coming trials with faith. In this short passage the author describes the final dystopic stage, set in Jerusalem, in which the son of perdition commits blasphemy and leads the faithful astray. The terrors of this period are described less vividly and end abruptly at the second coming, where Christ himself will deliver his people and the holy city, saved and restored in an idealised form. This may be considered a final eschatological scenario and receives the least attention.

Despite the dystopic future predicted by Pseudo-Methodius, the ultimate message is one of hope for his readers. The author addresses his audience's immediate concern, the Arab occupation, by exaggerating the circumstances and providing hope for imminent deliverance. God would raise a champion who would avenge the community and restore it to an idealised state of peace that was imagined to exist prior to occupation.

The author uses biblical memory to place Christians into a larger narrative of prophecy. By placing their defeats within a larger story, in which prophesied adversaries will come well after the Arabs, and in which will God continue to defeat their enemies, the present sufferings are brought into perspective. Those who endure to the end will be fortunate to witness the transformation of Jerusalem into the seat of government. By predicting future dystopias and corresponding utopias of deliverance, the author could reassure his readers that they were not yet in the end times. God would continue to deliver his people until the son of perdition was cast into Gehenna.

\section{Conclusion}

The Apocalypse of Pseudo-Methodius employs a three-part cycle of dystopia, followed by deliverance by a champion and ultimate restoration. Although the scheme in the Apocalypse provides three dystopian cycles rather than one, the text's use of cycles is strikingly similar to George of Pisidia and the Sefer Zerubbabel, and to the patterns of construction, destruction, and reconstruction of physical landscapes observed elsewhere in this volume. It is unlikely that PseudoMethodius had read either of these sources, or that the anonymous author of the Sefer Zerubbabel had read George of Pisidia. This cyclical pattern is not evidence 
of direct influence but does suggest a shared cultural phenomenon as authors from a variety of religious and linguistic communities under Roman hegemony employed similar strategies to cope with unprecedented crises.

Each of our authors, writing in three different languages from diverse cultural perspectives, strategically employed cultural memory to construct their narratives. George used damnatio memoriae to remove Phocas from his historical record, while using classical memory to reshape the Romans into a heroic society and the inheritors of the Greek legendary past. All three authors used biblical memory to varying degrees to place their communities into a larger narrative of salvation history. Likewise, each author rhetorically transformed their landscapes to recall an idealised past state while simultaneously suggesting that the future would surpass even the greatest stages of imagined history.

Central to all three narratives was the reliance on a divinely raised champion who would restore his people to a utopian state. For George, the unproven Heraclius would restore the whole world and the Byzantine empire which had been destroyed by his predecessor. For the author of Sefer Zerubbabel, God would restore the kingdom of the Jews in Jerusalem, envisioned as an idealised city whose territory will be expanded across the Middle East, bringing final fulfilment to the promise of Abraham. An idealised Jerusalem plays an important role as well in the Apocalypse of Psuedo-Methodius as the centre of Christ's kingdom on earth; however, the primary focus of the apocalypse is the restoration of losses under the Arabs. For those who survived the crises of the seventh century, the hope of a brighter future captured the imagination and inspired faith in God's continued love, even when contemporary circumstances suggested his absence.

\section{Note}

1 All translations from the Greek are my own unless otherwise indicated.

\section{Bibliography}

\section{Primary sources}

George of Pisidia (1959) On Heraclius's return from Africa and Heracliad. Edited by Pertusi, A. Giorgio di Pisidia. Poemi, vol. 1. Panegirici epici. Ettal: Buch-Kunstverlag, 62-8, 240-92.

Pseudo-Methodius (1985) Apocalypse. Edited and translated by Martinez, F. J. 'Eastern Christian apocalyptic in the early Muslim period: Pseudo-Methodius and pseudoAthanasius'. Unpub. PhD diss. Catholic University of America, Washington, DC.

Sefer Zerubbabel (2017) Translated by Himmelfarb (2017), 148-57.

\section{Secondary sources}

Alexander, P. J. (1968) 'Medieval apocalypses as historical sources'. The American Historical Review, 73: 997-1018. 
(1985) The Byzantine apocalyptic tradition. Berkeley and Los Angeles: University of California Press.

Bamberger, B. J. (1940) 'A messianic document of the seventh century'. Hebrew Union College Annual, 15: 425-31.

Ben-Eliyahu, E. (2016) "“On that day, his feet will stand on the Mount of Olives": The Mount of Olives and its hero between Jews, Christians, and Muslims'. Jewish History, 30: $20-42$.

Bonura, C. (2013) 'Did Heraclius know the legend of the Last Emperor?'. StP, 62: 503-14. (2016) 'When did the legend of the Last Emperor originate? A new look at the textual relationship between the Apocalypse of pseudo-Methodius and the Tiburtine Sibyl'. Viator, 47: 47-100.

Brandes, W. (1990) 'Die apokalyptische Literatur'. In Winkelmann, F. and Brandes, W. (eds.), Quellen zur Geschichte des frühen Byzanz (4.-9. Jahrhundert): Bestand und Probleme. Amsterdam: Akademie Verlag, 305-22.

Cameron, A. (2017) 'Late-antique apocalyptic: A context for the Qur'an?'. In Amirav, H., Grypeou, E., and Stroumsa, G. G. (eds.), Visions of the end: Apocalypticism and eschatology in the Abrahamic religions, 6th-8th centuries. Leuven: Peeters, 1-20.

Casey, D. (2013) 'Muhammad the eschatological prophet'. In Mayer, W. and Neil, B. (eds.), Religious conflict from early Christianity to the rise of Islam. Berlin: de Gruyter, 229-44.

Déroche, V. (1999) 'Polémique antijudaïque et l'émergence de l'Islam (VIIe-VIIIe siècles)'. Revue des études byzantines, 57: 141-61.

Haldon, J. F. (1990) Byzantium in the seventh century: The transformation of a culture. Cambridge: Cambridge University Press.

Himmelfarb, M. (2012) 'Sefer Zerubbabel and popular religion'. In Mason, E. F., Thomas, S. I., Schofield, A., and Ulrich, E. (eds.), A teacher for all generations: Essays in honor of James C. VanderKam, vol. 2. Leiden: Brill, 621-36.

(2017) Jewish messiahs in a Christian empire: A history of the Book of Zerubbabel. Cambridge, MA: Harvard University Press.

Kaegi, W. E. (1992) Byzantium and the early Islamic conquests. Cambridge: Cambridge University Press.

Kraft, A. (2012) 'The last Emperor topos in the Byzantine apocalyptic tradition'. Byzantion, 82: 213-57.

Lewis, B. (1974) 'On that day: A Jewish apocalyptic poem on the Arab conquests'. In Salmon, P. (ed.), Mélanges d'Islamique: volume dédié à la mémoire de Armand Abel par ses collègues, ses élèves et ses amis. Leiden: Brill, 197-200.

Magdalino, P. (1993) 'The history of the future and its uses: Prophecy, policy and propaganda'. In Beaton, R. and Roueché, C. (eds.), The making of Byzantine history: Studies dedicated to Donald M. Nichol. Brookfield: Variorum, 3-34.

Martinez, F. J. (1987) 'The apocalyptic genre in Syriac: The world of pseudo-Methodius'. In Drijvers, J. W. et al. (eds.), IV Symposium syriacum 1984: Genres in Syriac literature (Groningen-Oosterhesselen 10-12 September). Rome: Pontificium institutum orientalium studiorum, 337-52.

McGinn, B. (1979) Visions of the end: Apocalyptic traditions in the Middle Ages. New York: Columbia University Press.

Olster, D. (1994) Roman defeat, Christian response and the literary construction of the Jew. Philadelphia: University of Pennsylvania Press.

(2003) 'Byzantine apocalypses'. In McGinn, B., Collins, J. J, and Stein, S. J. (eds.), The Continuum history of apocalypticism. New York: Continuum, 254-72. 
Papaconstantinou, A. (2008) 'Between umma and dhimma: The Christians of the Middle East under the Umayyads'. Annales islamologiques, 42: 127-56.

Podskalsky, G. (1972) Byzantinische Reichseschatologie. Die Periodisierung der Weltgeschichte in der Grossreichen (Daniel 2 und 7) und dem tausendjährigen Friedensreiche (Apok. 20). Munich: Wilhelm Fink.

Reeves, J. C. (2013) 'Sefer Zerubbabel: The prophetic vision of Zerubbabel ben Shealtiel'. In Bauckham, R., Davila, J. R., and Panayotov, A. (eds.), Old Testament pseudepigrapha: More noncanonical scriptures, vol. 1. Grand Rapids, MI: Eerdmans, 448-66.

Reinink, G. (1992) 'Ps.-Methodius: A concept of history in response to the rise of Islam'. In Cameron, A. and Conrad, L. I. (eds.), The Byzantine and early Islamic Near East: Problems in the literary source materials. Princeton: Darwin Press, 149-87.

(2001) 'Early Christian reactions to the building of the Dome of the Rock in Jerusalem'. Khristianskii Vostok, 2: 227-41.

Shoemaker, S. (2012) The death of a Prophet: The end of Muhammad's life and the beginnings of Islam. Philadelphia: University of Pennsylvania Press.

(2014) "“The reign of God has come": Eschatology and empire in Late Antiquity and early Islam'. Arabica, 61: 514-58.

(2018) The apocalypse of empire: Imperial eschatology in Late Antiquity and early Islam. Philadelphia: University of Pennsylvania Press.

Sivan, H. (2000) 'From Byzantine to Persian Jerusalem: Jewish perspectives and Jewish/ Christian polemics'. Greek, Roman and Byzantine studies, 41: 277-306.

Sizgorich, T. (2004) 'Narrative and community in Islamic Late Antiquity'. Past \& Present, 185: 9-42.

Stoyanov, Y. (2011) Defenders and enemies of the true cross: The Sasanian conquest of Jerusalem in 614 and Byzantine ideology of anti-Persian warfare. Vienna: Verlag der Österreichischen Akademie der Wissenschaften.

Strickler, R. (2016) 'The wolves of Arabia: A reconsideration of Maximus the Confessor's Epistula 8'. Byzantion, 86: 419-39.

(2018) 'Coping with crisis: Invasion, defeat, and apocalyptic discourse in seventhcentury Byzantium’. PhD diss., Macquarie University, Sydney.

Van Donzel, E. J. and Schmidt, A. (2010) Gog and Magog in early Syriac and Islamic sources: Sallam 's quest for Alexander's wall. Leiden: Brill.

Whitby, M. (1998) 'Defender of the cross: George of Pisidia on the emperor Heraclius and his deputies'. In Whitby, M. (ed.), The propaganda of power: The role of panegyric in Late Antiquity. Leiden: Brill, 247-73.

(2002) 'George of Pisidia's presentation of the emperor Heraclius in his campaigns'. In Reinink, G. and Stolte, B. (eds.), The reign of Heraclius (610-641): Crisis and confrontation, Groningen Studies in Cultural Change, 2. Leuven, Paris, and Dudley, MA: Peeters, 157-73. 


\title{
12 Ausonius, Fortunatus, and the ruins of the Moselle
}

\author{
Chris Bishop
}

The Mosella of Decimus Magnus Ausonius, a poem in widespread distribution by the year 371, describes the Moselle valley (das Moseltal) in some detail. Two centuries later, another visitor to that valley, Venantius Honorius Clementianus Fortunatus, depicted the same region in his own poetry, but where Ausonius's vision was one of bucolic splendour, Fortunatus's countryside had begun to decay- the lofty villas had disappeared, the town walls were broken, the high places bristled with fortifications and weapons of war. There are political and cultural continuities, to be sure, in the poems of Ausonius and Fortunatus, but far more striking is the evidence of the transformations experienced by the region in the centuries that separated them. The Moseltal of Ausonius lay squarely within the jurisdiction of the western augustus, and the focus of its citizenry extended south into the heart of the Roman Empire, whereas the power structures evidenced by Fortunatus seem far more localised, and more intensely polyvalent. Transformations within these patterns of governance find resonance in the poets' descriptions of the constructed landscape itself, with the bustling Moseltal of Ausonius subsiding into the ruinous wilds of Fortunatus, and yet, despite these differences, both poets seem to derive very similar cultural memories from these divergent artefacts.

This chapter will begin, therefore, with an analysis of the constructed landscape of the Moseltal as presented by Fortunatus, comparing that description to Ausonius's testimony, before contextualising both within the political history of the region in Late Antiquity. The landscapes of poetry, however, exist only partly within a phenomenal world, and so the second aim of this chapter is to contemplate also the role of the idealised landscape in the ontology of these two poets, and to discuss the ways in which we might see, or cannot see, transformation here as well.

\section{Das Moseltal, c. 370 and c. 570 CE}

Ausonius was more than a mere visitor to Trier. Invited to the city by the emperor Valentinian I in the early 360s, Ausonius served as tutor to Prince Gratian and accompanied the emperor on his expedition against the Alamanni in the winter of 368-9. With Gratian's succession to the throne, Ausonius was elevated first to the Prefecture of Gaul, and then to the Prefecture of the West. By 379 he had become 
consul. He returned to his home town of Bordeaux following the assassination of Gratian in 383, to work his estates and to concentrate on his poetry. Ausonius's Mosella, however, found publication long before his enforced retirement-we know from a letter written to the poet by the Roman statesmen Quintus Aurelius Symmachus (Ep. 1.14) that the work was in circulation by the early 370 s.

Obviously but not inelegantly didactic, Ausonius's Mosella is an extended meditation on the beauty of nature and the folly of human craft — as I have written elsewhere: 'in the Mosella, we witness a criticism of artifice that is strikingly at odds with Ausonius's Golden Age predecessors' and 'the beginning of a Christian and late-antique rejection of the man-made' (Bishop 2017: 17). But the aspect of Ausonius's Mosella that draws our attention in this chapter is not the moral he draws from the landscape of the Moselle valley, but rather his description of the countryside itself.

The environment that Ausonius presents in his Mosella is predominantly a constructed one, an 'urbanised and cultured' nature, 'filled with domiciles and baths' (Pavlovskis 1973: 36). The fields that line Ausonius's Moselle are not expressions of a natural landscape, but rather testaments to agriculture. They are agri (1. 23), arva (11.4, 9, 472), or, most commonly, cultūs (11. 6, 72, 298, 325, 347, 460)all words that pertain to cultivated fields rather than wild spaces. The poem is dominated by descriptions of villas adorned with marble-floored atriums (1. 20, 11. 48-9), bath complexes (1. 341), cities ringed by defensive towers and walls (11. 454-6), and fortresses and granaries (11. 457-60), all of which culminate thematically in a prolonged discussion of architecture that occupies some twenty lines at the very centre of the poem (11. 298-317): 'who has the skill to unfold the countless embellishments?' asks Ausonius, and then proceeds to answer his question by doing so himself. Even the river itself seems subjugated by rapacious fishermen (11. 240-282) and ships of all sizes (11. 27, 39-47, 196-239), but, while humans dominate Ausonius's poem, it is important to note that the Moseltal of Ausonius is not that of Fortunatus.

Michael Roberts has described the influence of Ausonius upon the poetry of Fortunatus as 'detectable, but not obtrusive' and has elucidated the relationship between the two (Roberts 2009: 83-6). We can see the antecedent for Fortunatus's 'smoke-wreathed roofs of villas on the shores' (villarum fumantia culmina ripis, 10.9, 1. 17) in Ausonius's 'roofs of the villas perched on the overhanging shores' (culmina villarum pendentibus edita ripis, Mos. 1. 20), while the 'through lofty hills and a hollow valley' (per exstantes colles et concava vallis, 10.9, 1. 19) of the former recalls Ausonius's 'through vine-green hills and pleasant streams' (virides baccho colles et amoena fluenta, Mos. 1. 21) in both diction and form - a relationship already understood as early as 1823, when the Valpy edition of Ausonius's works was published (Valpy 1823: 1139 n.355). A century after Valpy, Carl Hosius noted that just as the vine-covered slopes in Ausonius's Mosella 'entice the wandering eye' (sollicitentque vagos Baccheia munera visus, 1. 153), so too the meadows below Nicetius's villa in Fortunatus 3.12 'delight the wandering minds' (oblectant animos mollia prata vagos, 1. 118) (Hosius 1926: 46). Hosius also noted that this oblectant animos in Fortunatus was also used 
by Ovid in his Remedia amoris (Hosius 1926: 169), but if a number of Fortunatus's poems offer descriptions of the Moselle valley, for the reader, and in particular, the reader familiar with the earlier work of Ausonius, the most striking feature of these poems is the absence of human construction in the landscapes they describe.

The first seven books of Fortunatus's poetry were published at the urging of his friend and patron, Gregory of Tours, probably around 576 (Fortunatus 2017: viii). The last of these books opens with four poems dedicated to Gogo, a man whom Fortunatus had met some ten years earlier at the marriage of King Sigibert and Brunhilde. Gogo was a close advisor to the Merovingian king and may have become Mayor of the Palace (Fortunatus 2010: 49). In Fortunatus 7.4 the poet imagines Gogo catching salmon from the Rhine:

\section{[P]rope fluctivagi remoratur litora Rheni ut salmonis adeps rete trahatur aquis, an super uviferi Mosellae obambulat amnem, quo levis ardentem temperet aura diem, pampinus et fluvius medios ubi mitigat aestus: vitibus umbra rigens, fluctibus unda recens.}

[L]ingering by the shores of the wave-washed Rhine so that a fat salmon, trapped, can be dragged from the water, or roaming along the grape-laden Moselle's course where a gentle breeze tempers the heat of the day where vine and river mitigate the midday heat: the steady shadow of the foliage, the fresh billow of the waves.

The harmony of the landscape is made manifest in the harmony of Fortunatus's lyric - the breeze (aura) is contrasted against the day (diem), as are the pertinent adjectives gentle (levis) and burning (ardentem), with both the adjectival grouping and that of the nouns separated by the active verb (temperet). This symmetry is then reinforced in the sound and the scansion of the final line of the quatrain, the 'steady shadow of the foliage' (vitibus umbra rigens) with the 'fresh billow of the waves' (fluctibus unda recens).

It is a well-crafted piece of poetry, and it describes a beautiful scene, but it is largely a description of a natural, rather than constructed, environment. The grapevines are there, and they are heavy with fruit (super uviferi), but it cannot be under grape-vines that Gogo shades himself from the sun's intense heat, the foliage of a vineyard is too sparse, and so it is to the heavy shade on the banks of the river that Gogo retreats, where the wild vines proliferate-Venantius uses the term pampinus here, and we are reminded of Pliny's use of the same term to describe smilax aspera, the sarsaparille or rough bindweed (Naturalis Historia 16.63.153). More importantly for the argument at hand, Gogo does not seek shelter in a courtyard, for villas are all but absent in Fortunatus's description of the Moselle. 
Fortunatus 3.13 is dedicated to Vilicus, the bishop of Metz and, in that poem, we witness the same Moseltal of Fortunatus 7.4. To be sure, there are still burgeoning fields (vernantibus arvis, 1. 11) of grain (sata, 1. 12), and roses (rosas, 1. 12), presumably cultivated roses, but wild vegetation proliferates.

What first meets our imagined gaze are not cultivated fields, but meadows of spring grass (vernanti gramine, 1. 3) and wild herbs (herbarum, 1. 4). The hills are clothed in shady foliage (umbrosos vestitos palmite colles, 1. 13)-we should recall here Lewis and Short's equation of palmes with pampinus (the plant from Fortunatus 7.4), and Pliny's use of palmes to describe plants of the family Arecaceae (Naturalis historia 13.4.6). Pliny's Natural History makes a sharp distinction between the cultivated palms of the East, which produce fruit, and their wild European relatives, which do not, so the varying forms of fertility (varia fertilitate, 1. 14), like those of Fortunatus 7.4, include a predominance of wild variants.

The poem does give a glimpse, however, of the buildings that dot the vine-clad hillsides and grassy river banks of the Moselle, for the river is also part of the defences of Metz, a city fortified not only by the walls that surround it, but also by the merits of its bishop: 'City, though fortified strongly by wall and by river, you stand stronger still by the merits of the bishop' (Urbs munita nimis, quam cingit murus et amnis, pontificus merito stas valitura magis, 11. 15-16). The intrusion of the fortifications serves as a reminder of the political climate traversed by men like Vilicus (and Fortunatus). Where Ausonius's Moselle was filled with people, people whose agency was to be seen everywhere and at all times, the Moselle of Fortunatus is a wilder watercourse, punctuated by fortresses and the scant fields that surround them.

Moreover, the constructed landscapes we witness in the poetry of Fortunatus are in a worse state of repair than those of Ausonius - at least part of Vilicus's merit rests in the implementation of his programme to 'restore the roofs of broken churches' (Culmina templorum renovasti, 1. 39). Similarly, in Fortunatus 3.11, we read of Nicetius, the bishop of Trier, doing the same:

\section{Templa vetusta Dei revocasti in culmine prisco} et floret senior te reparante domus.

$$
\text { (11. 21-2) }
$$

You have restored the ancient church of God to its former height and the old house flourishes through your repair.

There is a spiritual value to all this labour, of course-Simon Coates, for example, has written on the importance of (re)building churches as an episcopal duty (Coates 2000) - and it is clearly the intention of Fortunatus to elucidate the role of these men both in rebuilding churches and in rebuilding the Church, but we must not ignore the physical reality of this work as well - the roofs have actually collapsed, the buildings are falling down. This is not the architectural affluence that prompted Ausonius to reprimand his contemporaries on their pride. This is a landscape of fortified ruin. 
Fortunatus's lionising of Nicetius continues in the next poem of book three, in which the episcopal castle at Trier is described in some detail. Fortunatus 3.12 divides neatly into two halves. The first eighteen lines survey, once again, the landscape of the Moselle: the 'fertile plowlands' (frugiferos . . . sulcos, 1. 13); the 'fields covered in verdant herbage' (ager tectus viridantibus herbis, 1. 17); the 'soft meadows' (mollia prata, 1. 18). But the poem takes a sharp turn at line nineteen with a protracted metaphor - the shepherd of this flock has constructed a serious defence to keep the wolves at bay. Here Fortunatus makes use of a trope that had enjoyed considerable popularity among Christian scholars since at least the time of Gregory of Nyssa (c. 335-c. 395), whose protracted meditations on the parable of the lost sheep had featured in both his Against Eunomius and his Against Apollinaris (Radde-Gallwitz 2018: 191). The sheepfold (ovile, 1. 20) of Nicetius is a wall of towers, and just as the thirty towers of Nicetius enclose the congregation of Trier, so too Fortunatus uses the thirty towers (turribus . . ter) to constrain the verb of enclosure itself (incinxit): 'the hill enclosed on every side by thirty towers' (Turribus incinxit ter denis undique collem, 1. 21).

The castellum (1. 28) of Nicetius is twice described in this poem as a palace (aula, 11. 25 and 29), so huge the viewer imagines the roofs must cover acres of land (iugera tecta putes, 1. 32). Indeed, perched upon a mountain top, the house of Nicetius is itself a mountain (et monti imposito mons erit ipsa domus, 1. 26). Nor is the bishop's castle defended by the word of God alone. Fortunatus describes a war-machine maintained by Nicetius, the 'twin-flight ballista' (gemino ballista vollatu, 1. 35) 'which leaves death in its wake while it itself flees' (quae post se mortem linquit et ipsa fugit, 1. 36).

On the face of it, Fortunatus would seem to be describing a trebuchet-wheelmounted stone-throwers that recoil rapidly away from their targets once their payload is released - but we have no reliable references to such weapons predating the crusades. Leif Petersen has suggested that Nicetius's ballista may have been a traction trebuchet, a very modern weapon for the late sixth century to be sure, but not anachronistically so (Petersen 2013: 412-3). Still, the description offered by Fortunatus hardly seems suitable for anything but the wheel-mounted version, and it remains an intriguing (although insoluble) mystery. Less intangible, however, is Nicetius's presence at the forefront of military technology, the extent of his fortifications, and his investment in the military infrastructure of his bishopric.

In this respect Fortunatus compares the castellum of Nicetius to the Praemicum, the fortified villa of bishop Leontius in Bordeaux. Leontius had not constructed the Praemicum, indeed it had been celebrated in poetry a century before by Sidonius Apollinaris, but Leontius (who married the great-granddaughter of Sidonius, Placidina) had fortified the villa and used it as a base of operations during his rebellion against the Merovingian King Charibert (Wickham 2005: 171). Nicetius's castle, therefore, like the Praemicum of Leontius, was a distinctive feature of the new landscape (both physical and political) of sixth-century Frankia, a landscape quite unlike the peaceful river-lands of Ausonius's Moselle, where the fortresses had been turned into granaries (Ausonius, Mosella, 11. 457-460). 
Fortunatus 10.9 describes a river-journey from Metz to the fortress of Andernach undertaken by King Childebert II and his mother Queen Brunhilde probably around 588. Fortunatus evidently accompanied the monarchs on their expedition, composing several poems dedicated to them, none of which were to find publication until after Fortunatus's death in the very early seventh century. For the modern reader of Fortunatus 10.9 it seems clear that the royal pair are proceeding through a series of fortresses, and that the terrain between these fortresses is wild and uninhabited.

Leaving the safety of Metz, the company traverses a series of rapids which lead them into 'open plains' (campos, 1. 11). The sense of this first section is one of wilderness, and Fortunatus offers the reader no description of the landscape's inhabitants, their agricultural activity, or their buildings until we reach the 'smoke-wreathed roofs of the villas' (villarum fumantia culmina, 1. 17) that mark the point where the Moselle is joined by the Sauer - the old Roman establishment of Biliacum, modern Wasserbillig. Leaving Biliacum the landscape becomes once again desolate and eerie as Fortunatus skips forward to the arrival at Trier.

Fortunatus's descriptions of Trier, and later Andernach, do include praise for their vineyards and farmland, but the reader gets the sense that these signs of habitation exist only in the immediate proximity of the settlements themselves. Between the fortresses, the cultivated flora gives way to the fugitive and the wild. 'Throughout the journey' (omne per illud, 1. 49), here perhaps referring to the leg between Trier and Andernach, but possibly referring to the entire trip from Metz, the party amuses themselves with music, but the voices of the lyres are met only by echoes from the rocks and the scrub:

Vocibus excussis pulsabant organa montes
reddebantque suos pendula saxa tropos.
Laxabat placidos mox aerea tela susurros,
respondit cannis rursus ab alpe frutex. (11. 53-6)

The shimmering voices of the instruments were striking the mountains and the overhanging rocks were returning the music.

The bronze web was releasing the gentle whisper,

The alpine scrub replying with reedy echoes.

'One voice' may have 'united the rocks and the river in song' (collibus et fluviis vox erat una tropis, 1. 60), but the only human voices are those of the royal party. Nor are the settlements themselves unmarked by the wrath of war.

For the reader approaching Fortunatus's Trier through the memory of Ausonius, the initial vision of the city is a confronting one. We are longing for rest after our long voyage, and the consolation and safety of a 'Rome in the North,' but what we see first are the broken walls of the old imperial capital:

Perducor Treverum qua moenia celsa patescunt, urbs quoque nobilium nobilis aeque caput. 
Ducimur hinc fluvio per culmina prisca senatus, quo patet indiciis ipsa ruina potens.

I am led to Trier, its lofty walls torn open,

Noble city and noble capital too.

The river takes us hence by what once had been the roof of the senate-house That, broken, betokens power by its very ruin.

The image is made all the more jarring by Fortunatus's use of the verb patēscere (to reveal, to open) which, like so many inchoative verbs, is intransitive. The implication, therefore, is of a change of state or an ongoing action, and we think immediately of the violent 'opening up' of Priam's halls in the Aeneid (apparet domus intus et atria longa patescunt, Aen. 2.483; and crebrescunt optatae aurae portusque patescit, Aen. 3.530). We might like to imagine the walls of Trier opening before us to welcome us in, but the patet and the ruina that follows in the wake of patescunt deny us this consolation. Trier is a broken city and in this Fortunatus is, once again, delineating for us the immense changes that the Moseltal underwent between the era of Ausonius and that of Fortunatus.

\section{Trier: decline and fall}

Ausonius begins his Mosella by 'marvelling at the defensive walls newly erected around Bingen' (addita miratus veteri nova moenia Vinco, 1. 2). The Historia of Ammianus Marcellinus informs us that Bingen was only one of seven northern cities to be fortified by the emperor Julian in 359 (Marc. Hist. XVIII. ii. 4), evidencing both the strategic importance of these citadels and the pressure being brought to bear against them from across the Rhine.

Prior to this the office of the Praetorian Prefect of Gaul had been established in 337, and Augusta Treverorum (Trier) served as the seat of the prefecture from the outset. Magnus Maximus, augustus of the West from 383 until 388, had also made Trier his imperial residence, but his defeat in 388 must have signalled a sharp decline in the city's fortunes. The Frankish general Arbogast seized the city for Theodosius I, augustus of the East, and carried out retaliations against the followers of Maximus. The city was stripped of its imperial function, and by 407 (but perhaps as early as 395), the praetorian prefecture was transferred from Trier to Arles.

This transferral of power was neither arbitrary nor punitive, but rather, recognised a shifting of borders. The imperial war-machine combined with Roman soft-power had pushed the northern limes deep into the Germanic heartlands, but a shift in power was in the process of contracting those borders. Trier, once well within the shelter of Roman auctoritas, was now on the frontier, a fact delineated dramatically on the night of 31 December 406 when an army of Vandals, Alans, and Suebi, unprecedented in its size, crossed the frozen Rhine.

That army must have impacted on the city of Trier, even if they made no direct assault against it—Jerome omits Trier from the long list of cities sacked 
(Ep. 123.16) - and their loss of control over the major north-south trunk road that linked Marseilles, Arles, and Trier must have been a critical factor in the Roman decision to abandon the northern capital (Mitchell 2007: 364). We know that Constantine III took Trier in 407, during the ongoing Roman civil war of the early fifth century. A few years later, perhaps as early as 411 but certainly no later than 418 , the city was sacked by the Franks, and by 439 Salvian was able to claim that Trier had been sacked four times that century (De gubernatione Dei 6.13). The eighth-century Liber historiae Francorum reports that Attila's Huns also sacked Trier during their incursions into the empire in 451 (Liber historiae Francorum 5).

By the late 1960s, Edith Wightman was arguing that Trier and the surrounding region had gone into a sharp economic decline during the first half of the fifth century, and that thesis still enjoys widespread acceptance among scholars today (Wightman 1970: 250). ${ }^{1}$ Certainly, the archaeological evidence supports the written sources from Late Antiquity, with 'considerable deposits of material, principally pottery' in the city's major monuments indicating the 'disuse or "destruction" of these complexes' towards the middle of the fifth century (Esmonde-Cleary 2013: 426). We know also that settlement patterns in the surrounding region changed dramatically during the first half of the fifth century, with the effective disappearance of the traditional (indefensible) villa (Van Ossel and Ouzoulias 2000: 138, 143). Nor did this situation improve in the decades following the death of Attila.

Only six years after the Hunnic sack of the city, the Ripuarian Franks captured Trier (in 457) (Kim 2013: 221 n.325). By the 470s the city was being governed by the comes Arbogast, a Romanised Frank and descendant of the fourth-century magister militum Flavius Arbogastes. Arbogast may have held the city for a Frankish king, the origin of his military commission remains unclear, but the praise heaped upon him by the famously partisan Sidonius Apollinaris (Ep. 4.17) urges us to identify the man as a Roman general rather than a Germanic warlord. Sidonius's characterisation of Arbogast as the last bastion of Romanitas on the Rhine is also supported by the archaeological evidence, for while the depredations against Trier are visible, it has also been noted that Frankish graves are entirely absent from the area before the turn of the sixth century (Staab 1997). The Franks attacked Trier often, but they do not seem to have settled there before 500 .

Nevertheless, the situation must have remained difficult, and Wightman was no doubt correct when she equated Arbogast, the late fifth-century bishop of Chartres, with his namesake the comes of Trier-it would seem that Arbogast was forced out of Trier in the mid-to-late 480s, possibly by yet another Frankish attack (Wightman 1985: 304). ${ }^{2}$ A decade later, Trier was caught up in the war between Clovis and the Alamanni. A letter from the Ostrogoth king Theodoric to Clovis dated to around 504 (Cassiodorus, Variae 2.41) congratulates Clovis on his success in this war, but warns him also that the remnant Alamanni have fled into the protection of Theodoric. We know from Ennodius's panegyric to Theodoric (15) that the Ostrogoths took control of the region of Rhaetia about this time, but just how far this control extended geographically is difficult to discern-Gregory of 
Tours's Life of the Fathers (6.2) would seem to indicate that this control extended as far as Trier.

Theodoric's control over Trier, if it existed at all, could only have been fleeting as, indeed, was that of Clovis. The death of the Merovingian king ushered in a series of dynastic disputes which were rapidly exploited by Burgundians from within the empire, and Saxons from without. Theuderic, one of Clovis's four sons, inherited Trier as part of his patrimony and was soon at war with the Burgundians Sigismund and Godomar, and, shortly after that, became embroiled in the Thuringian civil war fought between King Hermanfrid and his brother Baderic (Wood 2014: 50). It was the devastation of this later war that was to be immortalised in the De excidio Thuringiae, a poem written from the first-hand perspective of the Thuringian princess Radegund and variously attributed either to Venantius Fortunatus or to Radegund herself.

It should come as no surprise, then, to find the landscape of the Moselle so radically altered in Venantius's poetry. Ausonius had written as a citizen of an empire at the height of its power, and as a visitor to a city both cosmopolitan and extensive. The Trier of Ausonius may have housed as many as 80,000 , but by the end of the following century, that number had shrunk to perhaps $5,000 .^{3}$

\section{The ruined city as topos}

David Lowenthal has argued that the 'overriding message' of decay 'is our own mortality,' and that ruins serve as 'memento mori, reminders of death's implacable imminence,' but this impulse is not evident in the poetry of Fortunatus, for whom 'the sky glimpsed through a fallen roof' did not induce a discernible melancholy (Lowenthal 2015: 277). If the poetry of Fortunatus seems resolute despite our projection of decline upon his landscape, we must remember that 'Fortunatus, Gregory, and their contemporaries still related their environs to a Roman past,' and that theirs was perhaps 'the last generation in Gaul to have a strong enough connection to the symbolic weight of the empire and the imagery of its grandeur' (Buchberger 2017: 146). For them, any monumental building, no matter its state of disrepair, provided evidence of the continuity 'between the world of fourthcentury Gallo-Romans and the sixth-century Merovingian kingdoms' (Roberts 2009: 83).

Thus, the work of later Roman authors such as Ausonius and Fortunatus bears witness to the sorts of transformative acts upon which we have been focusing in this section of Memories of Utopia. These poems embraced the constructed landscape inherited by the new children of empire - a landscape strewn with decaying monuments both foreign and pagan - and repurposed it to create 'new' memories of the past, new memories that were self-affirming, restorative, even nurturing. Fortunatus and Ausonius, in a very real sense, fashioned Utopia from the Waste Land. Which begs the question: If not in the ruin poetry of Late Antiquity, then when did the 'melancholy impulse' establish itself in European poetry?

The Romantic literature that serves as Lowenthal's focus postdates that of Fortunatus by more than 1,200 years and is itself a development of earlier memento 
mori that sought to contextualise the apparent vicissitudes of fate within a greater, Christian, ontology. What interests me at this point, however, is the possibility of determining the period in which the change from elegy to memento mori occurred. If we compare, for example, Fortunatus's De excidio Thoringiae to Alcuin's De clade Lindisfarnensis monasterii, two poems separated by roughly two centuries, we see two poets using very similar material to entirely different ends.

De excidio Thoringiae is written in the voice of Queen Radegund and renders an elegy to her people, the Thuringiae, who were overwhelmed by the Frankish kings Theuderic and Chlothar in the early 530s. Chlothar later took the captive princess as a consort (one of six) but, by 550, he had murdered Radegund's brother, the last surviving male member of the Thuringian royal family. Radegund then fled to the protection of the Church, eventually founding a monastery at Sainte-Croix in Poitiers, from where she continued her membership of a close literary circle that included not only Fortunatus but also Gregory of Tours. We know that Radegund wrote frequently to her learned friends, and we know that these writings included poetry (Dronke 1984: 86). It was this knowledge, perhaps, that led Charles Nisard to accept that the former queen might well have been the author of the Excidio - an idea that gained greater currency in the 1980s (Nisard 1887; McNamara and Thiebaux 1987; Cherewatuk and Wiethaus 1993). Today, the weight of scholarly opinion has shifted back to crediting Fortunatus with the poem's composition (Wasyl 2015; Reimitz 2015; Fielding 2017).

Fortunatus's Excidio is firmly founded in the classical tradition. The influence of Ovid upon the works of Fortunatus in general (and upon the Excidio in particular) has also been noted elsewhere (Wasyl 2015) and, as Christine Fell wrote some time ago, the poem 'looks to Troy for comparison' (Fell 1993: 178). There are ruins in De excidio Thoringiae, but, like the ruins of Troy, and in keeping with the classical tradition, they do not serve as memento mori.

For classical writers, it would seem, ruins did not bring in the same 'eternal note of sadness,' as Matthew Arnold would later write in Dover Beach (Arnold 1867). We are put in mind of Servius Sulpicius using a meditation upon ruins to console his friend Cicero on the death of Tullia. While sailing the Saronic gulf, Sulpicius found himself midway between Aegina and Megara, with Corinth and Piraeus also in clear view:

[Q] uae oppida quodam tempore florentissima fuerunt, nunc prostrata et diruta ante oculos iacent. coepi egomet mecum sic cogitare: 'hem! nos homunculi indignamur, si quis nostrum interiit aut occisus est, quorum vita brevior esse debet, cum uno loco tot oppidum cadavera proiecta iacent? visne tu te, Servi, cohibere et meminisse hominem te esse natum? 'crede mihi cogitatione ea non mediocriter sum confirmatus.

(Cic. Fam. 4.5.4)

[A]11 of them towns which once had flourished, now lying broken before my eyes and fallen into ruin. I began to think to myself: 'Huh! We little humans resent it if one of us dies or is killed — we, to whom so short a life is owedwhen the corpses of so many cities lie scattered in a single place! Can you not 
control yourself, Servius, and remember that you were born a man?' Believe me, I was more than a little fortified by that thought.

The final book of Ovid's Metamorphoses features a similar meditation, no doubt referencing Cicero (Met. XV 11. 420-9), and some four centuries later, Ambrose used the ruined cities of southern Italy in the same manner to console his friends on the recent death of a member of their community (Ambrose, Ep. 39.3). This classical use of the ruined city topos is what finds resonance in Fortunatus's Excidio. There is sadness in the poem, of course, but it is not a sadness without hope, and it is not a sadness that questions the purpose of living.

That Alcuin knew the work of Fortunatus is beyond doubt-compare his 'Noble city of the kingdom and primary power of kings' (nobilis urbs regni et prima potentia regum, De clade Lind., 1. 31) with Fortunatus's 'Noble city and noble capital too' (urbs quoque nobilium nobilis aeque caput, 10.9, 1. 22)-but Alcuin's poem is at least as didactic as it is elegiac. For Alcuin, the destruction of the Northumbrian monastery during a Viking raid illustrated a lesson in morality, and his subsequent poem located itself within a greater genre of ruin elegies which include Gildas's sixth-century De excidio et conquestu Britanniae, as well as Biblical antecedents such as the books of Revelation, Jeremiah, and Isaiah. But Alcuin's poetry is more than just salutary instruction, there is tangible melancholy underlying it as well, a quality described by Chris Abram as 'that most AngloSaxon of preoccupations: the transitoriness of worldly glory' (Abram 2000: 23).

The extant poetry of the Anglo-Saxons that so manifestly preoccupies itself with the 'transitoriness of worldly glory' (The Ruin, The Seafarer, The Wanderer, Deor, and the like) belongs to a vernacular corpus that found inscription following the reforms of the late ninth-century West-Saxon king Alfred, but it seems reasonable to assume that any such editions must represent written exemplars of an older (perhaps much older) poetic tradition. The depredations of time have left us very few specimens of early vernacular poetry from any of the Anglo-Saxon polities. Yet we know from what does survive (the inscriptions on the monument at Ruthwell, for example, and the Franks Casket) and from contemporary sources such as Bede's Historia Ecclesiastica, that the Anglo-Saxon kingdoms, and particularly the kingdom of Northumbria, had a long-established tradition of native poetry.

We should remember that Alcuin was a Northumbrian by birth, educated in the cathedral church of York under Archbishop Ecgbert, himself a disciple of the Venerable Bede. Alcuin was not a young man by the time he became master of the Palace School of Charlemagne and he must have retained much of his Northumbrian sensibilities, artistic and otherwise. Christine Fell's observation, therefore, that ' $[\mathrm{m}]$ any of the themes that we find later in Old English vernacular poetry are signalled in Alcuin' (Fell 1993: 178) should come as no surprise.

The distance between the Anglo-Saxon ontology of ruin and that of their classical precursors is most demonstrable when we look at the development of $u b i$ sunt poetry. Ubi sunt (lit. 'where are ...') poems trace their lineage back to the rhetoric of classical Rome, but where politicians like Cicero used such phrases for rhetorical effect- 'where on earth are those ancestral ways, where that equality of 
law, where that ancient liberty?' (ubinam ille mos, ubi illa aequitas iuris, ubi illa antiqua libertas, Cic. Planc. 13.33) - the Anglo-Saxons seem to have adopted the simple question to express deep and nagging doubts about the value of existence itself. Compare Boethius's Ciceronian apostrophe, 'Where now are the bones of faithful Fabricius? What of Brutus or unyielding Cato?' (ubi nunc fidelis ossa Fabricii manent, quid Brutus aut rigidus Cato?, Boethius, Consolatio, 2.m7.156) to the Anglo-Saxon 'translation' credited to Alfred the Great:

Hwcet synt nu paes foremeran 7 paes wisan goldsmiðes ban Welondes? Forpi ic cwað paes wisan forpy pa craftegan ne mag nafre his craft losigan, ne hine mon ne mag pon eð on him geniman ðe mon mag pa sunnan awendan of hiere stede. Hwcer synt nu paes Welondes ban, oððe hwa wat nu hwar hi wceron? Oððe hwcer is nu se foremcera 7 se arceda Romwara heretoga se was haten Brutus, oðre naman Cassius? Oððe se wisa 7 foestrceda Cato, se woes eac Romana heretoga; se wces openlice uðwita. Hu ne wceran pas gefyrn forðgewitene? 7 nan mon nat hwcer hi nu sint. Hwcet is heora nu to lafe, butan se lytla hlisa 7 se nama mid feaum stafu awriten?

(Alfred 1899: 46)

Where now are the bones of Weland, the wise and famous goldsmith? I call him wise, because the man of craft can never lose his cunning - he can no more be deprived of it than the sun can wander from its course. Where now are the bones of Weland, or who now knows where they are? Or where now is the famed and courageous Roman chieftain that was called Brutus, or by his other name Cassius? Or the sagacious and steadfast Cato, who was also a war-leader of the Romans, and well known for his wisdom? Did they not depart long ago? And not a man knows where they are now. What is there left of them now, but this paltry glory, and a name written with a few scratchings?

Fortunatus's poem lacks any such existential crisis. Indeed, rather than questioning the 'paltry glory' of a 'few scratchings,' it states explicitly that Radegund's ruined Thuringia lives on in the stories of her people: 'such manliness might recall our forebears, such praise our kindred.... Believe me father, if words remain, you are not gone entirely' (qua virtute atavos repares, qua laude propinquos ... crede, parens, si verba dares, non totus abesses, 11. 77-9).

Alcuin, by comparison, begins his Excidio in a tone only too familiar to readers of The Seafarer: "After the first man had given up the gardens of Paradise and, a destitute exile, was venturing into the wretched lands-having paid, with his children, the penalties for that bitter banishment' (postquam primus homo paradisi liquerat hortos, et miseras terras exul adibat inops, exilioque gravi poenas cum prole luebat, Excidio, 11. 1-3) before plunging into the heart of the matter, 'because of the perfidies and the heinous sins it bears, each mortal life hastens towards myriad calamities and all men endure conflicting days' (perfidiae quoniam furta maligna gerit, per varios casus mortalis vita cucurrit, diversosque dies omnis habebat homo, Excidio, 11. 4-6). The ultimate subject of the poem 
therefore, the ruin of Lindisfarne, is, like all vicissitudes of this world, a logical consequence of Adam's fall.

\section{Conclusion}

The shrinking of the western Roman Empire brought war into the northern provinces, and with war came ruin. Buildings were broken, walls were toppled, roofs caved in. Naturally then, ruins abound in the Moseltal of Fortunatus, both in the physical landscape he experienced and in the poetic landscape he subsequently chose to create. A modern reader, conditioned by the Waste Land imagery of later poetry, might expect these ruins to function as locus to meditation, symbols of the caprices of fate or the transience of life, but this impulse is entirely lacking in Fortunatus's work. And yet, as we have seen, the Carolingian poet Alcuin, himself a student of Fortunatus's work, used the ruined landscape of his day to do just that.

In Alcuin's Excidio the ruined landscape can be seen to engender some level of spiritual disquiet, although this disquiet does not reach the level of ontological anxiety displayed in the later vernacular Anglo-Saxon poems. The Ruin, The Wanderer, and the Gnomic verses of the Cotton manuscript all depict civilisations fallen to ruin for no reason beyond the whim of fate. The people of these poems were not akin to those of biblical Sodom and Gomorrah, no charges of wantonness or vice are laid against them, no crimes enumerated. Nevertheless, their destruction was absolute.

Significantly, though, the ruined civilisations depicted in the poems of Fortunatus were not those of the Anglo-Saxon poets, but ancient, 'other' cultures. I have written elsewhere on the conception of 'giants' in Anglo-Saxon vernacular poetry (Bishop 2006), but for the discussion at hand it is important to recall that when Anglo-Saxon poets depicted the ruins that haunted their landscapes as the work of a fallen race of giants, they were demonstrating their profound dissociation from both the beings that created those structures and the ruins themselves. Moreover, the disquiet of Alcuin and his cengelcynn correspondents is altogether absent in the poetry of Fortunatus precisely because, I suspect, Fortunatus did not experience alienation from his subject in any way comparable to Alcuin or the later Anglo-Saxon poets.

A capacity to relate constructions within his environment to the achievements of a Roman past, and to interpret in their survival (no matter how vestigial) a continuity between that past and his own present, meant that Fortunatus could read these ruins in his landscape as signifiers of an ancient ancestral connectionas symbols of endurance, stability, even permanence. But as the Roman Empire receded further into the collective memory of Western intellectuals, this association became less profound, less persuasive. The new, Germanic courts that began to flourish during the seventh century-Toledo, Paris, Aachen - imagined their geneses as lying beyond the limes, outside the orbit of imperium and the classical world. For them, these inherited ruins were the crumbling edifices of a distant and dissolute people, broken by time, but also by their opposition to the living word and to the incarnation of God, born, like them, on the edge of empire. 


\section{Notes}

1 Cf. Bailey (2016: 94-5).

2 See also Anton (1987: 55-8).

3 For a more conservative estimate of this decline in population see, for example, Benes (1998).

\section{Bibliography}

\section{Primary sources}

Alfred (1899) King Alfred's Old English version of Boethius. De consolatione philosophiae. Edited by Sedgefield, J. Oxford: Clarendon Press.

Ambrose (1881) Epistulae. Edited by Walford, H. Oxford: James Parker and Co.

Arnold, M. (1867) 'Dover Beach'. In New poems. London: MacMillan.

Ausonius (1823) Opera omnia, volumen tertium. Edited by Valpy, A. J. London: A. J. Valpy. (1921) Ausonius. Edited and translated by White, H. G. E. London: W. Heinemann. Boethius (1990) Consolatio philosophiae. Edited by O'Donnell, J. J, 3 vols. Bryn Mawr, PA: Thomas Library, Bryn Mawr College.

Cassiodorus (1992) Cassiodorus: Selected Variae, TTH. Translated by Barnish, S. Liverpool: Liverpool University Press.

Cicero (1923) Pro Plancio. Edited and translated by Watts, N. London: William Heinemann. (2004) Epistulae. Edited by Shackleton Bailey, D. Cambridge: Cambridge University Press.

Fortunatus (1881) Opera poetica. Edited by Leo, F. Berlin: Weidmann.

- (2010) Poems to friends. Translated by Pucci, J. Indianapolis: Hackett. (2017) Poems/Venantius Fortunatus, Dumbarton Oaks Medieval Library, 46. Edited and translated by Roberts, M. Cambridge, MA: Harvard University Press.

Liber historiae Francorum (1973) Edited and translated by Bachrach, B. Lawrence, KA: Coronado Press.

Marcellinus, A. (1971) Historia. Edited and translated by Rolfe, J. London: W. Heinemann. Ovid (1976) Metamorphoses. Edited and translated by Miller, F. London: William Heinemann. Pliny the Elder (1906) Naturalis historia. Edited by Mayhoff, K. Leipzig: Teubner.

Symmachus (2011) Epistulae. Translated by Salzman, M. and Roberts, M. The letters of Symmachus. Atlanta: Society of Biblical Literature.

\section{Secondary sources}

Abram, C. (2000) 'In search of lost time: Aldhelm and the ruin'. Quaestio, 1: 23-44.

Anton, H. (1987) Trier im frühen Mittelalter. Munich and Paderborn: Schöningh.

Bailey, L. (2016) The religious worlds of the laity in late-antique Gaul. London: Bloomsbury. Benes, M. (1998) 'Cities in turmoil and transition: The continuity of Trier and Regensburg between the late Roman empire and the early Middle Ages'. Kroeber Anthropological Society Papers, 83: 1-17.

Bishop, C. (2006) 'Pyrs, ent, eoten, gigans-Anglo-Saxon ontologies of giant'. Neuphilologische Mitteilungen, 107/3: 259-70.

(2017) 'The dissemblance of the constructed landscape in Ausonius' Mosella'. The Journal of the Australian early Medieval Association, 12: 1-17.

Buchberger, B. (2017) Shifting ethnic identities in Spain and Gaul, 500-700: From Romans to Goths and Franks. Amsterdam: Amsterdam University Press. 
Cherewatuk, K. and Wiethaus, U. (eds.) (1993) Dear sister: Medieval women and the epistolary genre. Philadelphia: University of Pennsylvania.

Coates, S. (2000) 'Venantius Fortunatus and the image of episcopal authority in lateantique and early Merovingian Gaul'. The English historical review, 115(464): 1109-37.

Dronke, P. (1984) Women writers of the Middle Ages: A critical study of texts from perpetua to Marguerite Porete. Cambridge: Cambridge University Press.

Esmonde-Cleary, S. (2013) The Roman West, AD 200-500: An archaeological study. Cambridge: Cambridge University Press.

Fell, C. (1993) 'Perceptions of transience'. In Godden, M. and Lapidge, M. (eds.), The Cambridge companion to Old English literature. Cambridge: Cambridge University Press, 172-89.

Fielding, I. (2017) Transformations of Ovid in Late Antiquity. Cambridge: Cambridge University Press.

Hosius, C. (1926) Die Moselgedichte des Decimus Magnus Ausonius und des Venantius Fortunatus. Marburg: N. G. Elwertsche.

Kim, H. (2013) The Huns, Rome and the birth of Europe. Cambridge: Cambridge University Press.

Lowenthal, D. (2015) The past is a foreign country: Revisited. Cambridge: Cambridge University Press.

McNamara, J. and Thiebaux, M. (1987) The writings of medieval women. New York: Garland. Mitchell, S. (2007) A history of the later Roman empire, AD 284-641. Malden: Blackwell. Nisard, C. (1887) Fortunatus. Opera poetica. Paris: Nisard.

Pavlovskis, Z. (1973) Man in an artificial landscape: The marvels of civilisation in imperial Roman literature. Leiden: E. J. Brill.

Petersen, L. (2013) Siege warfare and military organization in the successor states (400-800 $A D)$. Leiden: Brill.

Radde-Gallwitz, A. (2018) Gregory of Nyssa's doctrinal works: A literary study. Oxford: Oxford University Press.

Reimitz, H. (2015) History, Frankish identity and the framing of western ethnicity, 550-850. Cambridge: Cambridge University Press.

Roberts, M. (2009) The humblest sparrow: The poetry of Venantius Fortunatus. Ann Arbor: University of Michigan Press.

Staab, F. (1997) 'Les royaumes francs au Ve siècle'. In Rouche, M. (ed.), Clovis, histoire et mémoire. Actes du colloque international d'histoire de Reims, vol. 1. Paris: Presses universitaires de la Sorbonne, 541-66.

Van Ossel, P. and Ouzoulias, P. (2000) 'Rural settlement economy in northern Gaul in the late empire: An overview and assessment'. Journal of Roman Archaeology, 13: 133-60.

Wasyl, A. (2015) 'An aggrieved heroine in Merovingian Gaul: Venantius Fortunatus, Radegund's lament on the destruction of Thuringia, and echoing Ovid's Heroides'. Bollettino di Studi Latini, 45/1: 64-75.

Wickham, C. (2005) Framing the early Middle Ages: Europe and the Mediterranean, 400-800. Oxford: Oxford University Press.

Wightman, E. (1970) Roman Trier and the Treveri. New York: Praeger. (1985) Gallia Belgica. Berkeley: University of California Press.

Wood, I. (2014) The Merovingian Kingdoms, 450-751. Abingdon: Routledge. 
$\because$ Taylor \& Francis Taylor \& Francis Group http://taylorandfrancis.com 


\section{Part IV}

\section{Memory and materiality}


$\because$ Taylor \& Francis Taylor \& Francis Group http://taylorandfrancis.com 


\title{
13 Spitting on statues and shaving Hercules's beard
}

\author{
The conflict over images (and idols) \\ in early Christianity
}

\author{
Robin M. Jensen
}

In early August 2017, the city of Charlottesville, Virginia, became the focus of intense media coverage. The planned removal of a Confederate general's statue from a city park prompted an organised demonstration by white nationalists who objected to its elimination. This in turn sparked a counter demonstration by those who wanted the statue taken away. The rally quickly exploded into an ugly scene of racial taunting and brawling, culminating when a hate-fueled individual drove his car through the crowd of counter protestors, causing one death and several serious injuries.

Although no great work of art, the statue at the centre of this story is an imposing public monument of a type fairly common in the American South (Figure 13.1). Memorials to anonymous Confederate soldiers as well as to other prominent Confederate generals and leaders are ubiquitous in cities across the region from New Orleans to Nashville, and include Jefferson Davis, president of the Confederacy (Figure 13.2), and Nathan Bedford Forrest, a founder and early member of the Ku Klux Klan.

Charlottesville's larger-than-life equestrian statue of Robert E. Lee, the work of New York sculptor Henry Merwin Shrady, was erected in Lee Park in 1924. Lee is an almost mythical figure of Confederate heroism, and many regard his honorific portrait more as a memorial to Southern heritage than to the man himself. Similarly, but regarded from an opposing viewpoint, others consider the monument as a prominent and all-too enduring symbol of a culture that practiced slavery and-like the Confederate flag-is brandished by those who hold racist attitudes and champion white superiority.

For most of its earlier existence, however, Lee's image was like other, rather ordinary, honorific portraits set up in public spaces. It was neither particularly controversial nor noteworthy for its aesthetic qualities. Yet, because of its subject and escalating sensitivities to racial injustice and discrimination, it became the focus of protest. For example, in 2012 someone sprayed the phrase 'Black Lives Matter' on its base. ${ }^{1}$ Although the graffito was partially removed, the vandalism prompted the city council to conclude that the statue should be removed and put someplace where it would be less offensive to a large segment of the community.

Such events graphically illustrate the way inanimate objects can evolve from symbols of venerated ancestral customs to despised reminders of past injustices. 


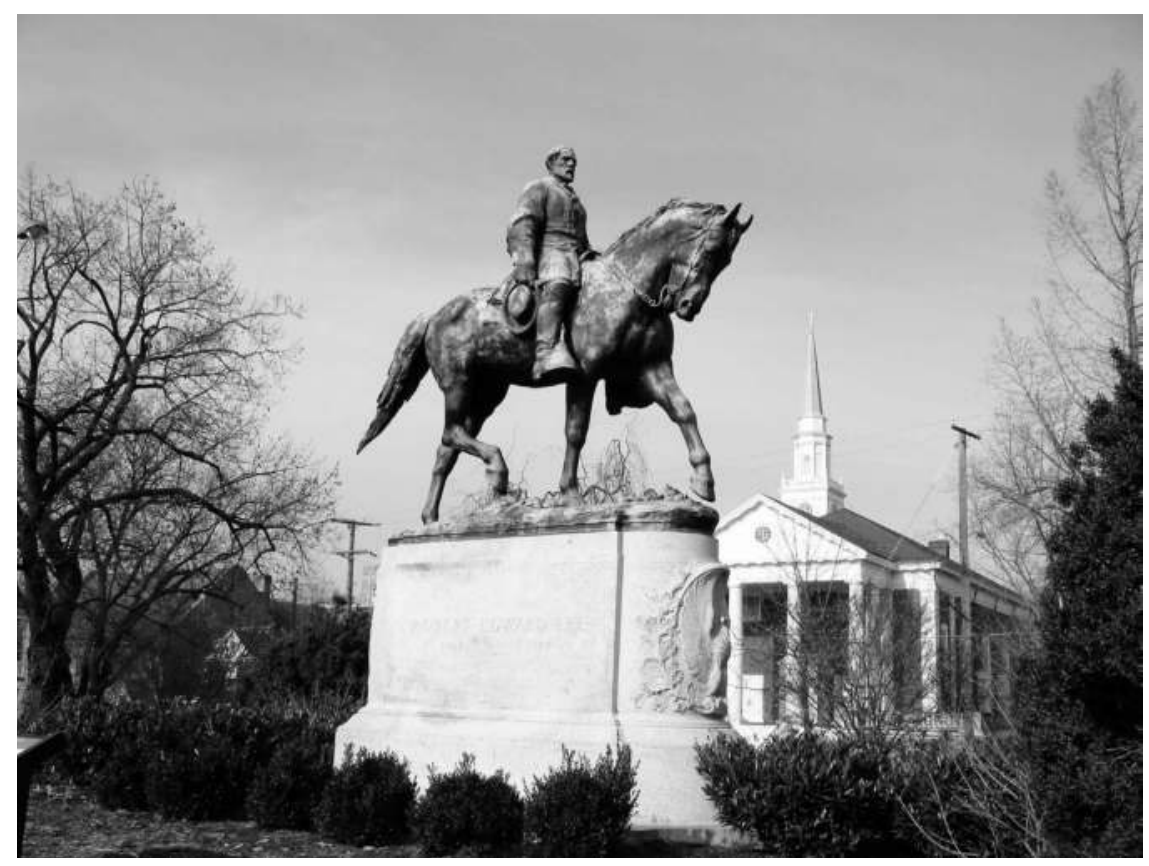

Figure 13.1 Robert E. Lee statue, Charlottesville, Virginia, USA.

Source: Photo credit: Cville dog (via Wikimedia Creative Commons).

The problem, then, is really not with the image or statue as such, but with what they symbolise (Freedberg 1989: 389-90). The protests in Charlottesville prompted a domino-like movement. A few days after the events in Charlottesville, another gathering of activists in Durham North Carolina spontaneously tore down the statue of a Confederate soldier. ${ }^{2}$ They were breaking the law in doing so, but their commitment was strong enough to call for a principled act of civil disobedience. Some of the protestors trampled or spat on the downed statue. Evidently, the police chose to look the other way. Subsequently, Baltimore's mayor decided it was best to remove four other similar sculptures in the middle of the night. ${ }^{3}$

Defenders of these statues have argued that, like them or not, they serve a useful, educational purpose; that eradicating them is tantamount to denying or trying to expunge the historical record. Some suggested that they might be supplemented with didactic labels to provide helpful context and educate viewers about both their positive and negative significance. Others, either from an interest in historical artifacts or perhaps regarding them as aesthetically valuable, proposed moving them to museums. Protesters responded that the problem was not that people have forgotten (or might forget) the past, but that these objects serve to galvanise those who cherish their memories and would like to return to the past and restore the old regime. For their part, museum curators were unwilling to 


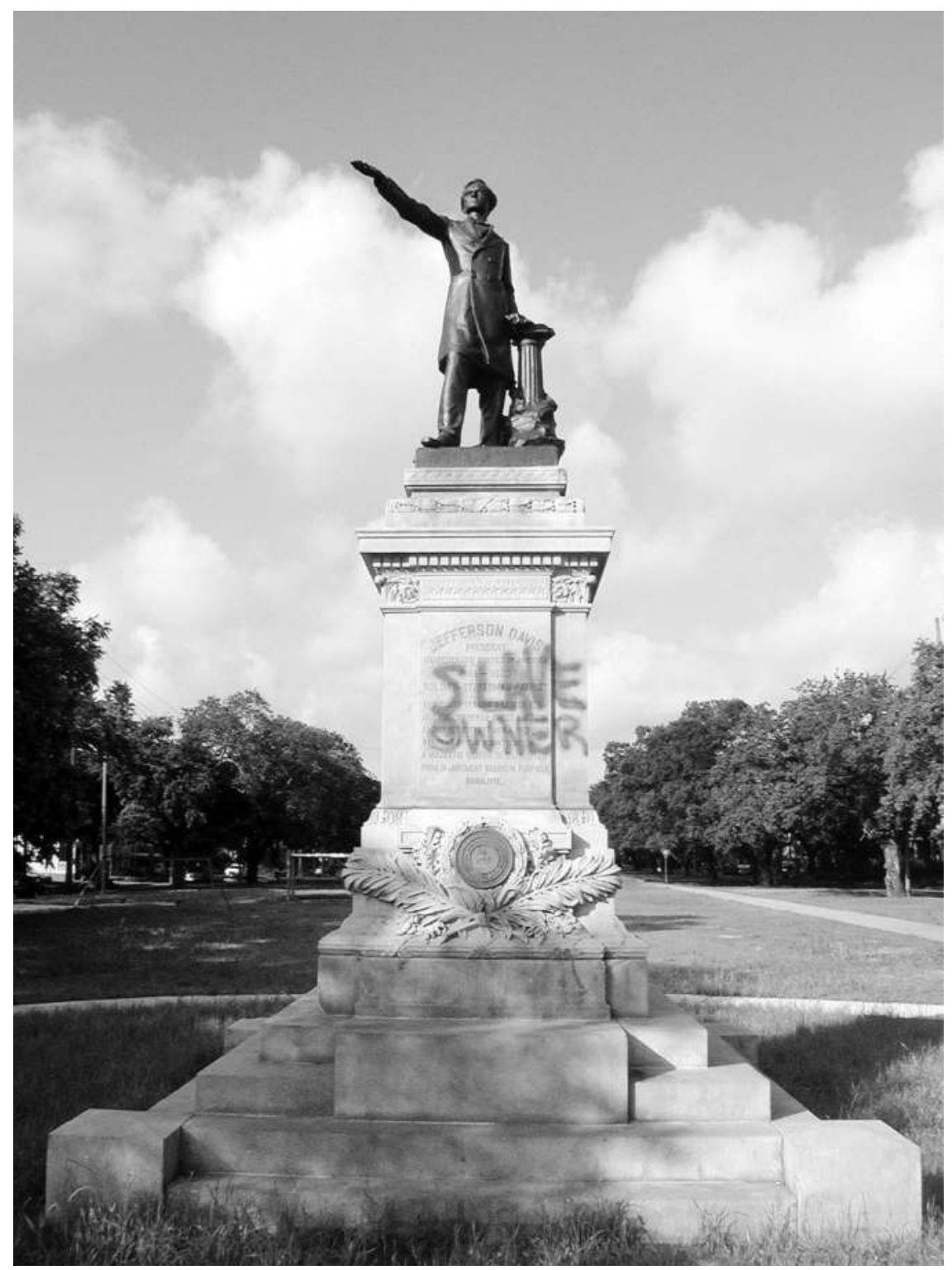

Figure 13.2 Jefferson Davis statue, New Orleans, Louisiana, USA.

Source: Photo credit: Bart Everson (via Wikimedia Creative Commons).

accept the offered statues as works of art worthy of display or long-term storage. ${ }^{4}$ Evidently, the desire either to remember these figures, or alternatively to publicly condemn them and their actions through some kind of didactic display, are not compelling arguments for their preservation. 


\section{Robin M. Jensen}

The Charlottesville episode has countless historical parallels. Roman citizens from the Republican era through Late Antiquity similarly witnessed the symbolic desecration and destruction of portraits of rulers who had fallen out of favour for one reason or another (Figure 13.3), an action intended to obliterate an individual's reputation or public memory that scholars have termed damnatio memoriae. Names could be erased from dedicatory inscriptions, but the most vivid instances involved pulling down, publicly mocking, and mutilating portrait images (Stewart 1999).

Angry citizens who might have preferred to inflict damage upon living bodies of reviled villains instead vented their wrath upon representative but inanimate statues, treating them as they judged their living models deserved. A famous instance, described by the satirist Juvenal, befell Sejanus, Emperor Tiberius's

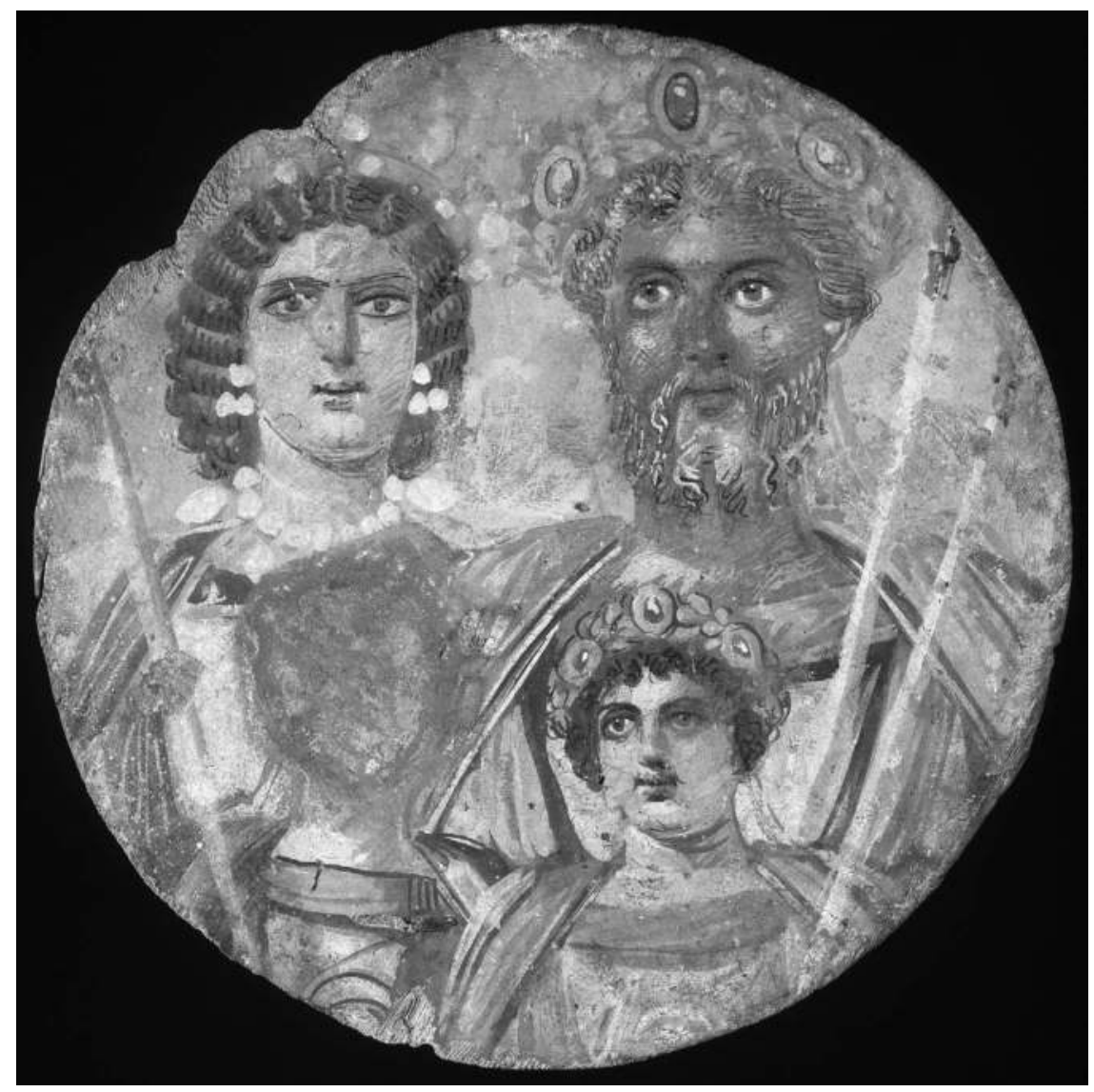

Figure 13.3 Septimius Severus with Julia Domna, Caracalla, and Geta (with erased face). Egypt, ca. 200 CE.

Source: bpk Bildagentur/Staatliche Museen/Johannes Laurentius/Art Resource, NY. 
treacherous second-in-command and dreaded personal bodyguard. When he suddenly fell into disgrace in $31 \mathrm{CE}$, an exultant mob pulled down his statues and dragged them through the city. After they had vented their fury on his proxy images, they piled on one last indignity by melting them down and fashioning them into frying pans and slop pails (Sat. 10).

Such actions often are aimed at more than defaming an individual's character or annihilating his memory, however. Sejanus was not just a single corrupt and powerful man, to many he was a representative symbol of a despotic and cruel reign. As in the case of the American Confederate generals the statues are often judged to stand for far broader evils, and their destruction is the performed condemnation of what they signify as much as whom they portray. These actions are aimed at what Charles Hedrick termed 'remembering to forget' (Hedrick 2000: 89-130). Thus, General Lee himself was not the primary target of those who wanted him removed. Rather, his image provided a focus for public outrage against an unjust political and social system. Moreover, the act of despoiling his statue was not intended to remove his memory so much as to ensure that his memory was revised, changing him from a celebrated hero to an accursed villain.

A famous story of ancient iconoclasm may help this consideration. The 'Riot of the Statues' (as historians have come to call it) took place in Antioch in the spring of 387. This so-called riot is probably better characterised as a popular protest against the imposition of a new tax possibly imposed partly to fund an anniversary celebration of the emperor's reign. However, it also seems to have been provoked by an accumulation of grievances after decades of deprivations and political conflicts (Browning 1952: 13-20). ${ }^{5}$ According to both John Chrysostom and Libanius, the insurrection was fomented either by demons or outside rabble rousers, and apparently, rather than confronting those who levied or collected the taxes, the demonstrators attacked monumental images of Emperor Theodosius I as well as those of his wife and children (Chrysostom, Stat. 2.10; Libanius, Or. 20.3-4). Even if the only damages were to possibly second-rate figures carved in soft marble, the destruction of imperial images was tantamount to an act of treason. This is partly explained by the fact that the emperor's image served as a simulation of his actual presence and - what is more - that presence had a divine aspect to it, and so extending any kind of indignity, from merely spitting at it to physically smashing it, warranted severe reprisals (Stewart 1999, 2003: 267-78). Conversely, an imperial image might be received into a city just as the man himself would have been: greeted with joyous acclamations, entertainments, refreshments, obeisant prostrations, and ceremonial enthronement. The honours extended to imperial portraits did not disappear once the emperor had converted to the new religion, although it may have been somewhat moderated. In the early fifth century, for example, Emperor Theodosius II moved to limit excessive honours to the emperor's images, arguing that a vainglorious show on public occasions was unseemly and inappropriate, and that acts of worship should be accorded only to the Supreme Deity (CTh 15.4.1).

Nevertheless, during the reign of Theodosius I, according to contemporary reports, including some of John Chrysostom's extant homilies, the urban populace 
of Antioch was terrified in expectation of some kind of imperially ordered repercussions for their acts against the statues (Chrysostom, Stat. 2.4-6, 11; Libanius, Or. 19.39-40, 20.5). Their fears were not unfounded, given the emperor's ordered massacre three years later in Thessaloniki after a rioting mob murdered a Roman official for imprisoning a popular charioteer (Sozomen, Hist eccl. 7.25.1-7; Theodoret, Hist. eccl. 5.17). In his effort to appease the emperor's wrath and avert ghastly consequences, Chrysostom appealed to the ruler's self-regard. Rather than offering to replace the images that had been destroyed, he assured Theodosius that he had it in his personal power to set up better, more glorious imagesnot of gold or bronze or inlaid with gems, but intangible ones arrayed in the robes of mercy. Thus, he insists,

Every man will set you up in his own soul; and you will have as many statues as there are men who now inhabit, or shall hereafter inhabit, the whole world! For not only we, but all those who come after us, and their successors, will hear of these things, and will admire and love you, just as if they themselves had experienced this kindness!

(Stat. 21.10-11, Stephens 1889: 485) ${ }^{6}$

Attacking a statue of the emperor was similar but not quite the same as destroying cult images of the Roman gods, however. Gods' statues were ubiquitous in most Roman cities and towns. They were set up in the temples, as well as in secular facilities (baths and civic buildings). They also ornamented private gardens, libraries, reception halls, and domestic shrines. Images of the gods were so prevalent in the cityscape that it would have been almost impossible to conduct one's daily business without passing several, and Christians had to decide how to confront them. In the first centuries CE, before Christianity had been recognised as a legitimate cult, Christian authorities universally condemned the veneration of these statues, but held different attitudes regarding their danger to the faithful and suggested various approaches to living with them. Some regarded the images as foolish but benign artifacts of a dying tradition, bound to gradually rust and decay. ${ }^{7}$ In this case they were best simply avoided if possible and ignored if not. Others, however, regarded them as dangerous, either as representations of a perverse religious cult or as habitats of evil demons. ${ }^{8}$ Origen of Alexandria even claimed the demons were invited into gods' statues through ritual incantations or other magical arts (Cels. 3.34; 7.69). Cases of demon-possessed statues harming innocent bystanders were reported, along with stories of holy men and women combatting demonically animated images (Brakke 2006). This attitude presented more problems, of course, as it seemed to require the pious Christian to take some kind of action against them in order to protect innocent souls.

Yet, while their leaders verbally criticised the polytheists' deities and their idolatrous images, prior to the mid-fourth century, Christians seemingly refrained from attacking the shrines and statues of the traditional gods. This may be because to do so would have courted arrest and possible death and caused even more trouble for an already unpopular sect. Few, if any, reports of martyrs' trials 
include accusations of sacrilegious acts concerning official cult images, which is revealing in itself. Furthermore, there is little evidence that early church leaders overtly encouraged destruction or desecration of idols or regarded it as laudable or virtuous.

Reluctance to harm the images is already evident in the New Testament. According to the account in the book of Acts, Ephesus's town clerk rose to defend Paul and his companions when the makers of Diana images felt threatened with a loss of trade and tried to rouse the citizens to foment a riot against them. Assured that the apostles were neither temple robbers nor blasphemers of the goddess, they were allowed to go peacefully (Acts 19:23-20:1). In his own words, Paul acknowledges that while his readers may abhor idols, stealing them from temples is against the Law (Rom 2:22).

While early Christian writers like Minucius Felix and Tertullian held that the lifeless statues of pagan deities were likely abodes of demons, they were restrained in their recommended treatment by merely suggesting that Christians practice mild, exorcistic behaviours like spitting or hissing at them. ${ }^{9}$ Almost no surviving evidence reports church authorities as urging or condoning actual acts of destruction or desecration. For example, Origen insisted that Celsus must have been misinformed when he alleged that Christians regularly mocked and battered gods' statues. Citing 1 Corinthians 6.10, Origen affirms that Holy Scripture denies revilers entry to the kingdom of heaven. Taking a realistic approach, he adds that such contemptuous actions would be useless for changing pagan minds in any case (Cels. 8.38). Of course, the fact that Origen had to defend against the accusation suggests that Celsus might have been right, or that at least there were some fairly trustworthy reports of Christian culprits harming images.

Another instance of restraint is recorded, shortly after the end of the Great Persecution, in the canons of a local ecclesiastical council that met in Elvira, Spain (ca. 306). One of these denied the title of martyr to Christians put to death for destroying idols (Can. 60). The inclusion of this restriction suggests a practice that apparently needed to be curtailed, at least in that part of the world. Perhaps the would-be martyrs courted dangers for entire communities, but possibly their leaders were simply wary of causing more hostility. Moreover, if they truly regarded these objects as powerless artifacts of a gradually dying cult, attacking them served no constructive purpose.

Whether or not Church authorities were successful in dissuading the zealous from combatting paganism by attacking polytheists' cult images, they were ultimately frustrated. Christian assaults on these objects apparently began to increase around the early fourth century, once the Christian emperors offered their patronage, protection, and even approval of such acts. This probably did not happen immediately, however. In his Life of Constantine, Eusebius claimed that Constantine banned pagan sacrifices shortly after his victory over Licinius in 324 and added that Constantine demolished several temples, including one at Mamre in Palestine in order to erect a church, and a temple of Asclepius in Asia Minor (Vit. Const. 2.44; 3.54-8). Yet historians have questioned whether these events actually happened or should rather be attributed to one of his sons (Bradbury 1994: 
120-39). In fact, the first indisputable legislation promulgated against temples and gods' images dates to the reigns of his sons Constans and Constantius II (CTh 16.10.2-3). Constantine evidently had no scruples about stripping cities of countless objects of art and transferring them to Constantinople to adorn his new capital, including statues of Greek and Roman deities, but Eusebius explains that he did this in order to expose them to public mockery (Vit. Const. 3.54).

Once the church's political situation grew more secure, legally sanctioned assaults on temples, sacrifices, and ritual images became both safer and more common. From the 340s on, emperors prohibited performances of the traditional sacrifices, ordered the eradication of gods' images, and transferred temples to secular use. However, the legislation indicated that they also desired to inhibit mob action in order to maintain a level of civic peace and respect for attractive monuments. In 382, the emperors Gratian, Theodosius I, and Valentinian I issued a degree that protected a temple at Edessa and ordered that it be continually open to visitors and, while banning sacrifices, protected any images deemed to have artistic merit (CTh 16.10.8).

This apparently moderate position suggests that few polytheists reacted violently to these incidents of image desecration or temple destruction. Around 386, the rhetorician Libanius crafted a defence of the monuments that not only petitioned for toleration and the maintenance of order but further argued that destruction was ultimately futile as a means of terminating polytheist practices. Any who claim to have converted under pressure were merely making a pretence; any attempt to prohibit religious practice by destroying magnificent monuments and dispossessing their patrons of the superb sculptures they contained would only make adherents stronger in their faith $(\mathrm{Or} .30 .11-13,22)$. He additionally maintained that the stability of the empire depended on the maintenance of the temples, if only because they were the pride of cities and a source of revenue for the imperial treasury (Or. 30.33, 42-3 and Or. 11.125).

A decade later the emperors Arcadius and Honorius promulgated a series of laws that seem to have been in agreement with Libanius, as they forbade individuals from claiming authority to destroy ornaments of public works and tried to prevent public disturbances by decreeing that the removal of idols be supervised by properly designated officials (CTh $16.10 .15-16,18)$. Nevertheless, forestalling unauthorised actions was not always practicable, and it can be assumed that the situation varied widely from place to place. According to early fifth-century historians Socrates, Sozomen, and Theodoret, when the apostate Emperor Julian (361-3) closed churches and restored temples, certain groups of Christians reacted on their own initiative, mutilating or destroying the cult images in the temples, and some of them suffering torture and execution for doing so. ${ }^{10}$

These historians' writings are filled with tales of brutality by pagans against Christians in retaliation for actions against cult images. Both Theodoret and Sozomen recount the story of a certain Mark, bishop of Arethusa, who was caught in the act of demolishing the temple itself and murdered by a vengeance-seeking mob (Theodoret, Hist. eccl. 3.3; Sozomen, Hist. eccl. 5.10). ${ }^{11}$ Sozomen also reports an incident in Alexandria, in which Christians attempted to take over a mithraeum, 
removed the images, and paraded them through the city in order to hold them up to ridicule. Furious pagans then turned upon the instigators with swords and stones, killing many of them, some reportedly by crucifixion in a responding form of derision against the Christian religion (Hist. eccl. 5.7). However violent and bloody the reprisals, Christian zealots clearly persisted. Theodoret reports that Julian's attempt to reestablish the traditional religions and protect its temples was overturned by his successors, Jovian and Valentinian, followed by a period of laissez faire during the reign of Valens. When Theodosius I came to power he reinstated the restrictions on pagan sacrifices and images (Hist. eccl. 5.20).

Sources also mention Christian witnesses reporting heavenly signs of approval for the destruction of temples. In a story that echoes the contest between Elijah and the priests of Baal (1 Kings 18), Theodoret narrates the case of Bishop Marcellus of Apamea (d. 389) who, following the edicts of Theodosius, attempted to destroy the city's magnificent Temple of Jupiter. Failing to accomplish the destruction by simple means because of the building's strength, the bishop prayed for a miracle. A stranger appeared who offered to burn the temple but was thwarted by a demon who was able to keep the fire from taking hold. Eventually the bishop brought a pail of water to the altar, made a sign of the cross over it, and then had a deacon sprinkle the site. The demon was unable to withstand the power of the holy water and fled. Once the fire was lit, the water acted as an incendiary element and the temple was instantly burned to the ground. Unfortunately, the bishop ultimately was murdered by assassins hired by infuriated local pagans (Hist. eccl. 5.21).

Possibly the most famous incident of all, the razing of the Serapeum in Alexandria in 391, brought about murders of both Christians and pagans. ${ }^{12}$ Although the destruction of the temple and its sacred images had precedents in local anti-pagan actions elsewhere in Egypt (Kristensen 2013: 118-23), according to Socrates, this particularly violent episode was explicitly ordered by Emperor Theodosius in response to a petition from the city's bishop, Theophilus, whom Theodosius then put in charge of the demolition (Hist. eccl. 5.16). According to ancient sources, the assailants were initially reluctant to attack the statue of Serapis himself for fear that the furious god might cause the earth to split open and the sky to fall. After a moment's pause, however, a soldier took up an axe and began to bash the image's face. Once it was evident that it was safe to carry on, he pulled the head off the torso, chopped up other parts of the body, and dragged all the pieces off, including the torso, to be torched in the city's amphitheatre in the sight of all the citizens (Theodoret, Hist. eccl. 5.22). One of the shrine's pagan defenders, a certain Olympus, encouraged his collaborators' almost hopeless resistance by insisting that death was preferable to neglecting their ancestral gods and that the loss of their divine images did not warrant their renouncing their traditional religion. ${ }^{13}$

Once calm was restored, Emperor Theodosius is said to have dispatched a letter to Bishop Theophilus, both granting official pardon to surviving pagan offenders who would convert to Christianity and permitting the bishop to destroy any remaining temples and cult images in the city. In addition, according to Sozomen, Theodosius further proclaimed that someone who suffered for acts of image- or temple-destruction could be officially counted as a martyr - a declaration that 
clearly overturned earlier restrictions on such claims such as the previously mentioned canon from the Council of Elvira (Hist. eccl. 7.15).

A church named for the emperor Arcadius eventually replaced the Serapeum. According to legend, this transformation was foretold by certain miraculous signs, including a lone voice heard singing the Hallelujah just before the temple was razed and, among the rubble, the discovery of stones inscribed with crosses that signalled the site's future consecration to Christianity. Socrates relates that all but one of the gods' images were melted down or smashed. Theophilus evidently preserved this one as an example for future ridicule and proof of polytheism's foolishness (Hist. eccl. 5.16). A few months later, Theodosius, along with Valentinian and Arcadius, promulgated a law prohibiting pagan worship generally and addressed it in a rescript to Evagrius, the Augustal Prefect and Romanus, the Count of Egypt (CTh 16.10.11).

Laws prohibiting sacrifices or other types of honours (e.g. offerings of incense or gifts) shown to images in any place, including domestic shrines, continued in the next few years, during the joint reigns of Theodosius and his sons Arcadius and Honorius. One, dated to 392 and reaffirmed in 395, explicitly designated the making of offerings to vain images made by human hands a complete outrage against true religion (CTh 16.10.12-13). Yet, following this, were those laws issued by Honorius and Arcadius that evidently aimed at protecting certain temples as public monuments and specifying that any removal of idols from public spaces be officially supervised and only carried out after proper investigations had been conducted (CTh 16.10.15-16 and 18). The temples themselves, once empty of offending idols, were to be left undamaged.

These provisions appear to have been overridden eight years later (in 407), when a more forcefully written law omitted the appeal for orderly removal and once more authorised the forcible removal of cult images and altars from temples and shrines (CTh 16.10.19). Moreover, one of its clauses empowered Christian bishops to prohibit certain traditional funerary rights. This suggests ecclesiastical authorities could have felt justified in taking action also against statues, temples, and sacrificial altars, rather than leaving this to secular magistrates. Arguably, it also describes how the African bishop, Augustine of Hippo regarded his episcopal role and responsibilities in the early fifth century, although he took a very different stance, one that was much more compromising than that of Theophilus of Alexandria.

\section{The situation in North Africa}

Augustine's comparatively placating stance is evident in a series of his extant sermons and letters. Some of these recount episodes of Christian attacks on gods' images and resulting civic disturbances. They also reveal Augustine's efforts to mediate conflict between those who tried to protect the gods' images and those who wanted them eliminated. Thus, as in earlier times, at least this church authority tried to appease both sides without appearing to be tolerant of idolatry. While he allowed that those caught sacrificing to idols could be subject to capital 
punishment, Augustine firmly believed that Christians should act only with the sanction of secular authorities (Ep. 93.10).

One particular episode centred on a statue of Hercules, set up in ancient Carthage, which drew the ire of Christian citizens around the turn of the fifth century. Evidently, another faction of the city's residents sought to have the statue regilded, an expensive process that probably would have been paid for by a tax assessment. Contributing to the embellishment of the statue deeply offended those who regarded such things as idolatrous and probably even proscribed by imperial law.

Augustine happened to be in town at the time that the controversy had just started. Hoping to forestall a riot, he preached a sermon that he hoped would appease the protestors' desire to see the statue removed without provoking backlash from traditionalist defenders of their city's public monuments. The transcript of Augustine's text not only describes the conflict between zealous Christians and the remaining pagan populace but also exposes evident tensions between church authorities and the Christian laity (Serm. 24).

Ostensibly, local devotees (or perhaps priests) of the cult of Hercules had determined that the cult statue was due for regilding. ${ }^{14}$ Hercules was a particularly important god in Roman Africa (Figure 13.4). Along with Melqart, he may have been identified with the Punic sun god (Bonnet 1988; Shaw 2011: 249; Figure 13.5). Facing a protest from the Christian citizens who objected to funding the restoration, the newly installed proconsul, who authorised such expenditures, surreptitiously allowed Christian protestors to shave the statue (presumably by chiseling off the god's facial hair), hoping that would mollify the protestors.

Unfortunately, his strategy did not succeed, and the Christian mob began to agitate for a full-scale demolition of all existing temples and cult images. Augustine's effort to pacify the crowd while also appearing to share their anti-pagan sentiments was clever and tactical. With deft conciliatory rhetoric, he attempted to persuade the agitators to recognise that the Christian God (through his human agents) had demonstrated his superiority by shaving off the symbol of Hercules's strength: his beard. Because such a humiliating form of damnatio memoriae was better even than knocking off the statue's head, he insisted they should be content to leave it at that. After all, like the despoiling of disgraced imperial figures, the humiliation of a god by physically marring his statue was more effective than simply removing it from sight. Instead of being content, however, the Carthaginian Christians began chanting, 'As in Rome, so in Carthage!' (Serm. 24.6). Their chant may have referred to the purging of gods' images in Rome in the 390s, after the so-called 'pagan last stand' of Emperor Eugenius and his allies who had tried to reinstate the traditional Roman cults (Magalhäes de Oliveira 2006: 245-62). ${ }^{15}$ Continuing his effort to placate the protestors, Augustine acknowledges their anger, while attempting also to defuse it:

Am I saying, 'Don't want what you want'? On the contrary, let us be grateful that you want what God wants. . . . Consider, brethren, their gods are Roman gods. And when Christians were being compelled to worship, and when they refused, they had to endure their savagery to the shedding of blood. The 


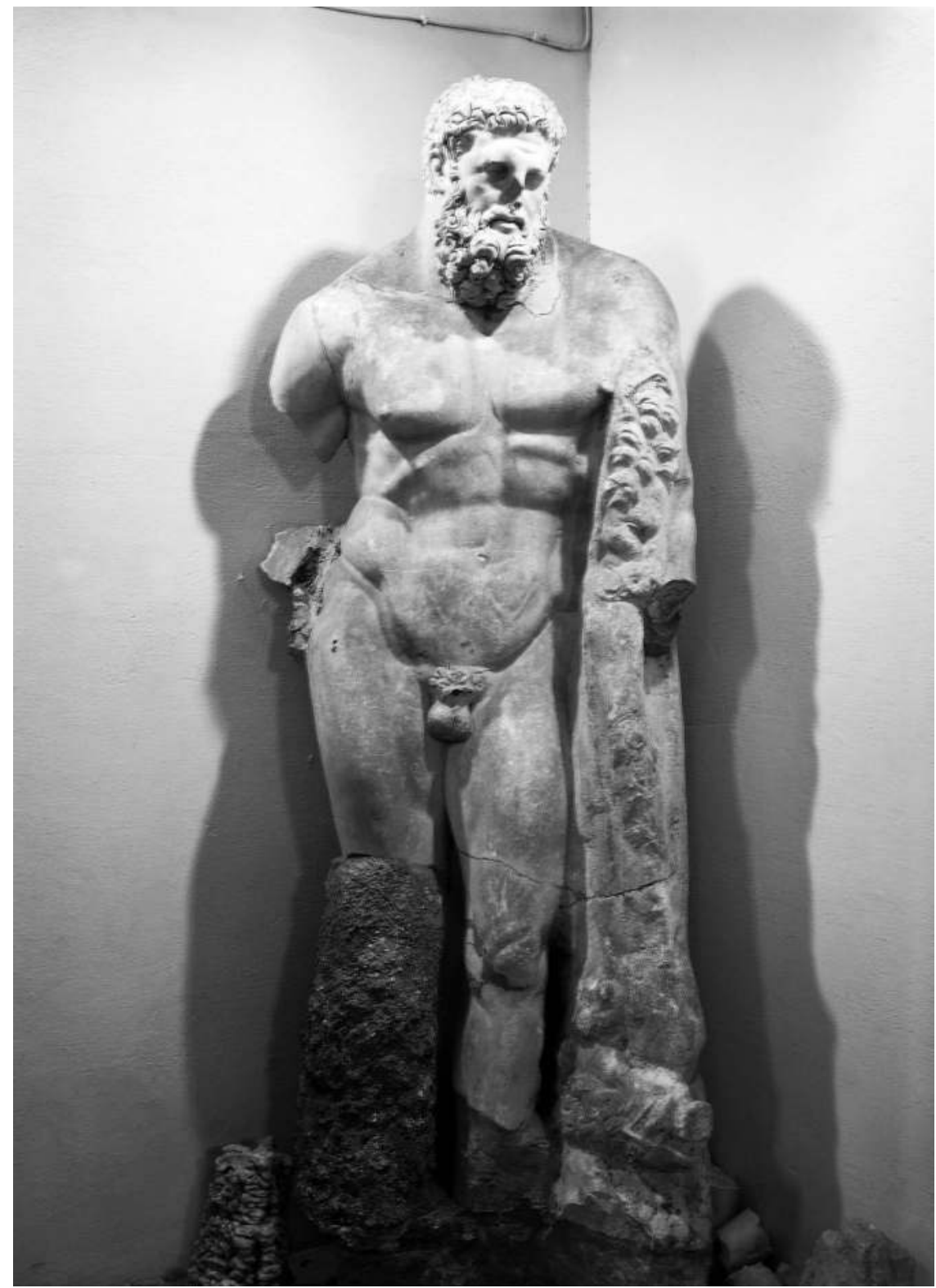

Figure 13.4 Colossal statue of Hercules, replica of the Farnese Hercules, found in the baths at Hippo Regius (Annaba, Algeria).

Source: DeAgostini/Getty Images. 


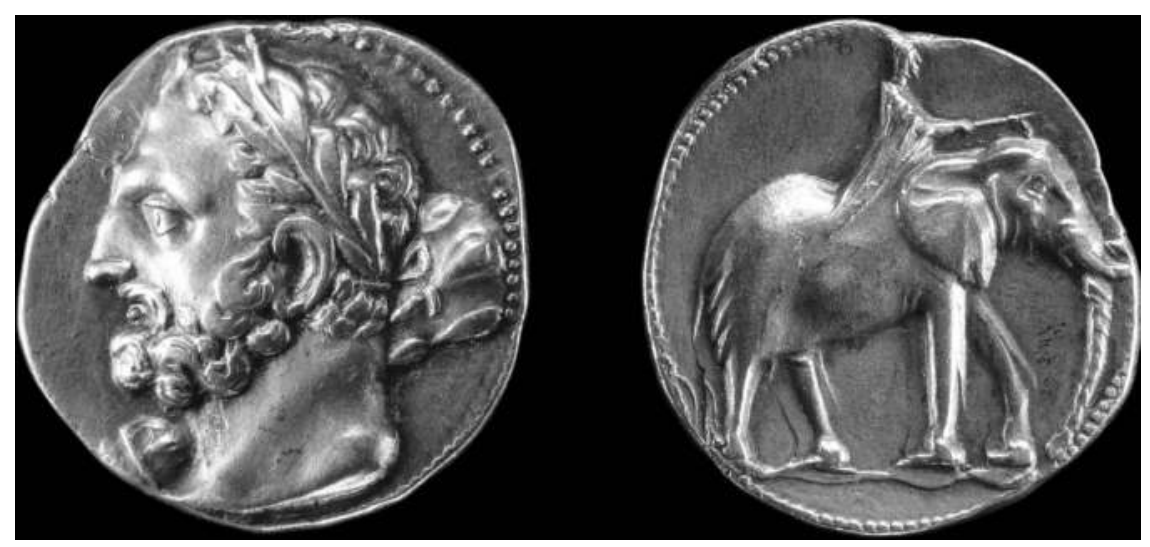

Figure 13.5 Silver double shekel of Carthage with obverse of Melqart and reverse of Hannibal. Issued by the Barcid family in Spain. From the Mogente Hoard, Valencia, Spain, around 230 BCE. Now in the British Museum, Inv. no. $1911,0702.1$.

Source: (C) The Trustees of the British Museum/Art Resource, NY.

entire crime of those martyrs whose blood was shed seems to have been that they refused to venerate the Roman gods, that they were spurning Roman ceremonies, that they would not pray to Roman gods.

(Serm. 24.6, CCSL, 41: 331-2)

Apparently, Augustine's pleadings on this occasion were successful and-for the moment at least - the Christian faction backed down. Beneath the surface, however, this episode reveals some crucial underlying issues. Inanimate statues were clearly perceived as more than objectionable pagan idols; they had been implicated in violence perpetrated against the church's honoured saints. Condemning the gods' statues for their role in the trials and persecution of Christians was part of Augustine's placating strategy. Courageous and faithful men and women had shed their blood because they refused to sacrifice before some of those statues. Augustine simply asked the angry crowd to be content to punish (by mutilation) a lifeless object for the injustice human agents had inflicted upon their heroes. Rather than attacking the living people who may have been the perpetrators of injustices, the protestors were willing to take their revenge on a representative object, and Augustine convinced them to accept a further compromise.

Yet, while this punishment was representative, it also needed to be overt and public, just as the martyrs had publicly refused to sacrifice and been publicly executed. It was not enough to mentally repudiate them, or even to tolerate their discreet removal. It was important to perform their condemnation. Vengefully destroying or mutilating them was to wreak justice, and perhaps became a kind of religious ritual in its own right (Stewart 1999: 167, 180-1). The statues' role 
in Christian martyr trials was reason enough for destroying them. Yet, in their actions, the attackers not only reenacted the resistance of the martyrs; in some instances, by doing so they may have invited their own deaths, thus consciously or unintentionally achieving that same status.

One such event, recorded in one of Augustine's shortest letters, probably took place sometime in the late summer of 399, two years earlier than the events surrounding the regilding of Carthage's Hercules statue. This time a group of Christians apparently toppled a different cult statue of Hercules, one that had been standing in the central forum of the colony of Sufes (modern Sbiba) in the African province of Byzacena ( $E p$. 50). According to Augustine's letter, this attack on the statue of the town's patron deity inflamed certain members of the population, who turned on the troublemakers and massacred sixty of them. Perhaps, recalling Emperor Theodosius's decree that those who died while destroying idols were to be counted as martyrs, the dead subsequently were commemorated in the Roman Martyrology on August 30 (which may be the actual date of the riot).

If we believe Augustine's narrative, participants in the events that took place in Sufes that year (399) evidently disregarded (or were unaware of) the imperial edicts aimed at restraining vigilantism on the part of unauthorised Christian citizens. Whether their actions were justifiable or not, the massacre was far worse than the act that prompted it. In his letter to the leaders, chiefs, and elders of the colony of Sufes, Augustine condemns the town's defenders of Hercules for shedding innocent blood. Interestingly, however, his tone changes as he mockingly offers to return their statue while also suggesting they should likewise restore the lives they took:

If you say that it was your Hercules, we shall give him back to you: metal is at hand; rocks are not lacking; various kinds of marble are available as well as an abundance of artisans. Although your god is diligently sculpted, turned, and ornamented, we will add some red pigment to represent the shame that defines your sacred rites. For, if you say that it was your Hercules, we have collected coins one by one for a replacement. You also restore then the lives that your savage hand has taken. Just as we restore to you your Hercules, so also restore those many lives!

(Ep. 50, CCSL, 30: 214)

The remainder of his letter illuminates Augustine's tricky position. His proffered olive branch clearly is meant sarcastically, yet he also acknowledges that those who were guilty likely would not suffer legal reprisals. He ultimately concludes that it was better to restore civic order than risk escalating hostilities by threatening reprisals against the murderers. In any case, Augustine apparently tried to steer a course that was both conciliatory and faithful to what most of his coreligionists would have regarded as firmly opposed to pagan idolatry.

A decade or so later, he preached a sermon in which he mockingly criticised those who tried to argue that the image of the genius of Carthage was not really a god and, in doing so, reasserted that, while Christians should be the enemies of idols, they should pray that God would turn them over lawfully to be smashed 
(Serm. 62.10, 17). Around that same time, Augustine would write that certain philosophers had praised Christ and contended that Christ did not encourage the destruction of temples and images or condemn sacrifices, but that his disciples had taught differently and thus were the source of the problem. The motivation for such a claim, he insists, is to tear apart the Christian faith by claiming a division between Jesus and his followers. He fervently asserts that not only Christ but also the prophets had commanded the destruction of idols. Furthermore, those prophets had predicted that this would finally be accomplished during Christian times (Cons. 1.16).

\section{Different perspectives}

In contrast to a figure like Bishop Theophilus of Alexandria, who trusted he had the backing of Emperor Theodosius for his actions against pagan temples and images, Augustine chose to comply with later imperial admonitions for gradual, supervised, and orderly removal of the offending idols. Presumably, he judged that restraining mob action was in everyone's best interests, that unlawful removal would only provoke hostility, and that praying for the voluntary conversion of polytheists was more likely to work than destroying their treasured religious symbols (Serm. 178). The best approach, he argued, is to help them smash the idols in their hearts rather than getting angry and damaging their belongings (Serm. 62.17). While he clearly desired and expected the eventual eradication of traditional rites and cult statues, he simultaneously adopted a moderately tolerant stance towards them, particularly if they were the possessions of private citizens and housed on their personal property.

The fact that some pious citizens revered their cult statues as religious objects while others saw them as demonic and idolatrous was a primary problem, but perhaps not the only one. While many polytheists must have perceived the gods' images as sacred objects that needed to be honoured and protected, others could have regarded them more as important monuments of their cultural patrimony or treasured works of art (Lepelley 1994; Hannestad 1999: 173-203; Witschel 2007). In a 2011 essay, Béatrice Caseau also argues that statues were 'positional goods' that 'testified to the social standing and education of their owners' (Caseau 2011: 479-502, esp. 479-89). As she points out, rather than prizing them for their beauty or antiquity, as we moderns tend to do, ancient peoples treasured these objects for different reasons. They indicated the wealth and cultivated taste as much as the piety of their owners. Thus, what Christian mobs set out to destroy was a core aspect of both the religious identity and socially positive self-regard of certain groups of citizens. In sum, even if their viewpoints varied, Roman polytheists seem to have considered Christian image smashers as intolerant, unenlightened, unpatriotic, and atheistic. ${ }^{16}$ Moreover, their reported reactions to incidents of Christian assaults upon these objects tells us that they would (apparently) react with violence to protect them.

The polytheists' perspective is presented and defended in a 2012 article by the Roman art historian John Pollini. Writing with a pronounced polemical tone, Pollini describes the destruction of cult statues and shrines as the 'despicable and 
sacrilegious acts of destruction and desecration' committed by Christian extremists and adds 'a number of Christians still consider [them] to be commendable and even justifiable' (Pollini 2012: 444). In this article, Pollini further claims that Christians were more responsible for the loss of polytheistic religious culture than any group before or since, and thus Pollini holds ancient Christians particularly responsible for the loss of an enormous amount of classical art and architecture. He characterises the Christian movement as 'a very aggressive missionary religion that eventually targeted even Roman citizens'; its leadership not only 'verbally attacked the gods of others and created civil disturbances and violence' but went 'beyond the bounds of proper religious behavior not only in actively professing hatred of the gods and of the religious beliefs of other people but also in promoting zealotry and fanaticism among its adherents' (Pollini 2012: 259-60).

Among the instances Pollini cites is the destruction of the Athenian Parthenon by fire in Late Antiquity that has often been blamed on invading Herulians, but which Pollini suggests was actually the vicious work of Athenian Christians who were inspired by a decree of Emperor Theodosius in 380 (CTh 16.1.2), which outlawed polytheism and called for the demolition of the temples (Pollini 2012: 249-50). This, followed by the destruction of Alexandria's Serapeum in 391, he asserts, communicated to all Christians throughout the empire that it was their religious duty to destroy sacred polytheistic shrines and images, a duty which continued into the modern era. As an example, he points to the damage done to Athens's Parthenon frieze during the bombardment of the Acropolis in 1687 commanded by Francesco Morosini, whom Pollini describes as a 'Christian and obviously not respectful of Classical antiquity’ (Pollini 2012: 251).

By contrast, many scholars have convincingly argued that episodes of Christian iconoclasm have been overstated, and challenged the perception that these occurrences indicate pervasive Christian iconoclasm. Rather, they suggest that earlier studies overestimate the extent of the violence, rely too much on textual sources (rather than archaeological evidence), and misunderstand the historical circumstances (e.g. Salzman 2006: 265-85; Riggs 2012: 285-30; Rebillard 2013: 73-87). For their part, archaeologists have argued that many cult statues were removed and preserved in neutral or safe places and others were simply accepted and left in place (e.g. Stirling 2005; Kristensen and Stirling 2016; Jacobs 2010). Thus, despite the undeniable losses, a large number were evidently accommodated, repurposed, transformed, rescued, and reinterpreted, even while historians and theologians chronicled their violent destruction. Some were simply reused as available building materials, embedded into walls or rescued and recut for other decorative purposes. This continued into the Middle Ages and beyond (CoatesStephens 2007: 171-87). Many of them survived simply because their Christian owners found them beautiful and could not bear to destroy them or melt them down. This is supported by a statement made by Palladas of Alexandria, who conceded that wealthy fourth-century Egyptian Christians were holding on to their statues of the gods because they saw them as works of art rather than objects of monetary value (Anth. pal. 9.528; Cameron 1965: 17-30). Evidently, the images shed their identification as pagan idols and became simply artifacts of Roman 
heritage (Lepelley 1994: 5-15). This may explain why so many survived to fill the galleries of art museums around the world.

Meanwhile, artisans continued to produce objects depicting images of the gods and incorporating mythological motifs into the fifth century and beyond. Christian patrons clearly commissioned and treasured them. Once removed from obviously cultic contexts like temples or shrines, depictions of the Graeco-Roman deities could be regarded as merely decorative as well as symbols of enduring Roman culture and tradition. One famous late fourth-century example, the Projecta Casket, combines images of Venus with a dedication that implies a wish for a pious Christian marriage ('Secundus and Projecta, live in Christ'). Their Christian owners evidently did not see the images as dangerous objects of pagan idolatry but rather as aesthetic ornaments that exhibited their cultured sensibilities or personal wealth and were no longer a threat in a thoroughly Christianised culture. In this respect they were not different from the recovery of classical literature in Late Antiquity. Socially elite but also deeply pious Christians like Melania the Younger and her husband Pinian apparently owned a collection of household furnishings that included mosaics and a sculpture of Cupid and Psyche mixed in with silver lamps that bore crosses or similar Christian motifs (Jacobs 2010: 270-1; Stirling 2005: 166-7). Furthermore, by the early fifth century, Christians had begun to have - and venerate - their own sacred images. While there is some reliable evidence that this had begun among many groups of Christians even by the second century, it was an established practice no later than the late fourth century.

In some cases, statues of gods and members of the imperial family appear to have been exorcised, purified, or even 'baptised' by the addition or inscription of Christian crosses on foreheads or torsos (Figures 13.6 and 13.7). If the works were deemed especially valuable, this may have been a way to make them acceptable (Marinescu 1996; Kristensen 2013: 126-7, 2012: 31-66). As a possible solution, it has a parallel in the purification of former temple sites. In 435 Emperor Theodosius II, along with Valentinian, ordered the erection of crosses in the ruins of destroyed temples in order to cleanse them of their pollution (CTh 16.10.25), a practice that seems to have been carried out even in purely secular buildings (Wiśniewski 2016: 14-15). Pollini, pointing out instances also of the mutilation of images' hands, feet, and genitals, proposes that more extreme forms of damage were prompted by 'negative Christian attitudes toward nudity, sex, and fertility' (Pollini 2012: 260).

In his essay Pollini also suggests that Christian attacks on gods' images were modeled on actual judicial punishments meted out by particularly savage Christian emperors and provoked by stories that the Church concocted about martyrs in order to arouse 'hateful and contemptuous Christian attitudes toward the shrines, images and religious beliefs of other people' (Pollini 2012: 259-60). In Making and Breaking the Gods, Troels Myrup Kristensen examines many of the examples that Pollini cites and concludes that, while Christians may have 'castrated' a number of nude statues out of a belief that they were indecent and perhaps demonic, they viewed them as acceptable works of decorative art once 'restored' (Kristensen 2013: 223-5). 


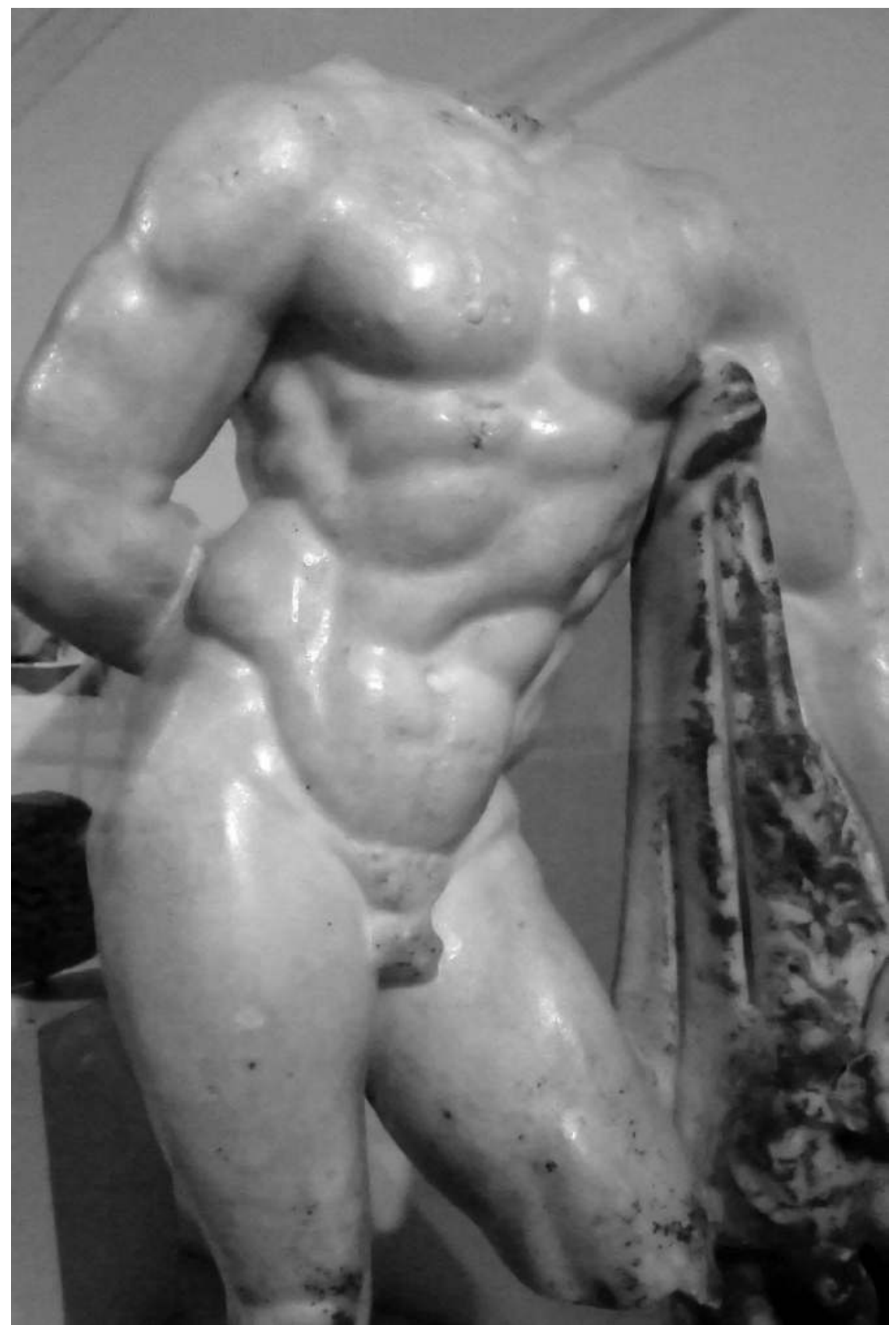

Figure 13.6 Marble statue of Hercules holding apples, inscribed with cross, ca. 100 CE, from Tralles (Turkey).

Source: Photo courtesy of the Phoebe Hearst Museum of Anthropology and Regents of the University of California. Photo Credit: Mary Harrsch, accessed from Flickr. 


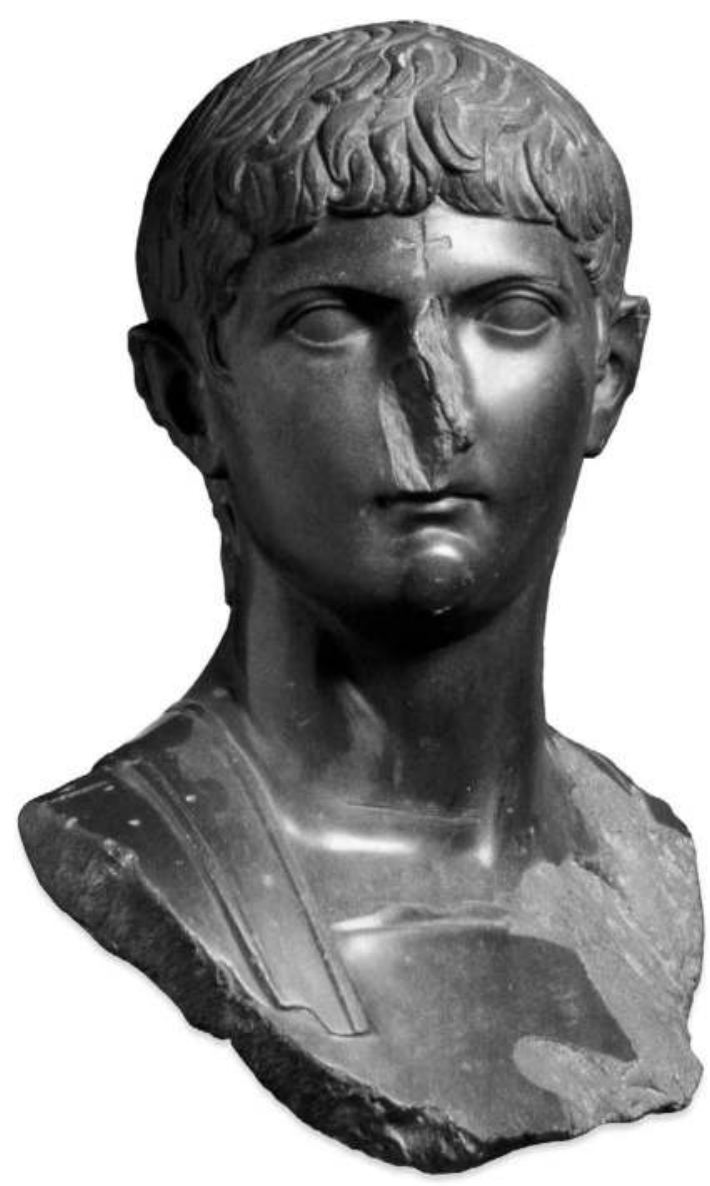

Figure 13.7 Bust of Germanicus with incised cross, originally made in Egypt, ca. 14-20 $\mathrm{CE}$, now in the British Museum.

Source: (C) The Trustees of the British Museum/Art Resource, NY.

Unfortunately, we cannot know exactly why these carvings, erections of crosses, or mutilations were carried out since there is no surviving textual evidence that discusses them, much less explains their purpose. Furthermore, we are not sure when most of these disfigurements were performed or if they were always deliberate. Because crosses also appeared on portrait images of mortals as well as gods and the loss of genitals from ancient statues has any number of possible explanations, it is impossible to do more than speculate. Kristensen draws attention to statues simply being cut down to be used as building blocks and an instance at Antioch of a bath converted into a church that retained its statue of Hygeia whereas a statue of Asclepios was smashed and discarded (Kristensen 2013: 225-6). 
What surviving literary evidence does demonstrate, however, is that Christians had complicated and varied reasons for destroying images of the pagan gods. Some genuinely regarded gods' statues as religiously offensive or even as demonically possessed idols that required eradication and made their destruction a pious duty. Others were mobilised by more human or mundane sentiments that may have perceived the cult images as harmless in themselves but whose violent destruction expressed harboured rage against perceived injustice that might have been fueled by reading or recalling of martyrs' narratives. In most cases, both impulses were probably in play. Whether idols, effigies, or simply hated symbols, the cult images were both proper and convenient targets of their righteous contempt and anger.

\section{Conclusion}

Jumping ahead, centuries later, a parallel set of events transpired that might be worth considering for the sake of comparison. During the sixteenth century, instances of Protestant iconoclasm arguably were provoked by certain political social dynamics as well as by theologically based condemnation of the role of visual images in churches. In many parts of Europe, some of the middle and lower classes turned against statues, crucifixes, and stained-glass windows because they represented the power or dominance of certain social groups, not only because they were regarded as idolatrous images at the centre of an overly materialistic liturgy. Although the circumstances are complex and varied from region to region, destruction of religious images was driven as much then as earlier by a combination of religious piety and righteous anger (Eire 1989).

Certainly fueled to a large extent by official preaching against the religious dangers posed by idol worship, instances of unauthorised activity against saints' statues as well as non-figurative objects like candlesticks or Eucharistic vessels were prompted by resentment that money spent on them could be better used to feed and support the poor. In some cases, the images themselves evidently endorsed a corrupt ruling class that needed to be overthrown. That led to the beheading and mass burial of images, like the twenty heads of the ancient Kings of Judah from the eastern façade of the Cathedral of Notre Dame in Parisidentified or confused with portraits of hated royalty-during the French Revolution (Figure 13.8).

Ironically, not unlike the recovery of the classical gods in late-antique and early medieval art, the removal of these 'idols' during the Protestant Reformation and French Revolution prompted the re-inclusion of the pagan gods in artworks produced for non-religious - domestic and secular-spaces owned by wealthy patrons who formerly would have endowed churches with depictions of the Madonna or various saints. These works were no longer objects of religious devotion but valued instead as aesthetically fine and cultured evocations of the classical past, while also serving as status symbols for those who owned them. In this way they were remembered rather than forgotten. Mythological themes depicting the ancient gods were accorded new appreciation in the Renaissance and not regarded as in any direct conflict with Christian truth. And, of course, one 


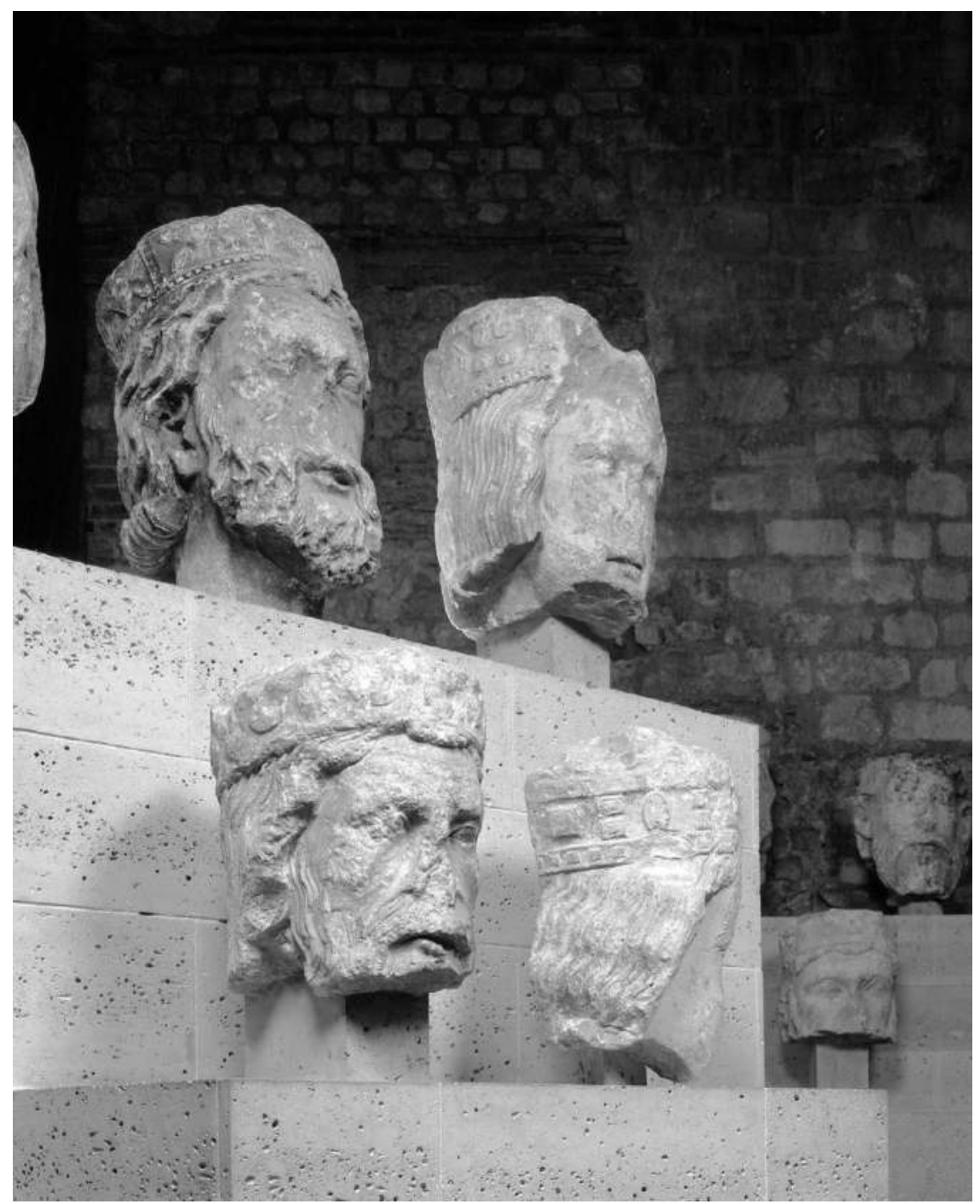

Figure 13.8 Four heads of the Kings of Judah, from the Gallery of Kings on the west façade of the Cathedral of Notre Dame, Paris, now in the Musée national du Moyen Age, Paris, France.

Source: Photo: Gérard Blot, C RMN-Grand Palais/Art Resource, NY.

can still view the statues of the Judaean kings that once adorned the Cathedral of Notre Dame in Musée national du Moyen Age, Paris, France.

In summary, whenever they have arisen, Christian assaults on pagan statues were prompted by a variety of reasons, only some of them purely religious. An ostensibly pious duty to attack idols may have been a justification for wreaking 
revenge for past injustices or some sort of social oppression. Similarly, those who came to the defense of the images probably had similarly mixed motives. Many would have been genuinely appalled by the disrespect shown to the traditional gods; others simply may have been angry about losing social status. A few may even have lamented damage done to objects of artistic value. Moreover, each situation was unique, which makes both the impetus and the outcome especially complex.

Thus, as we consider the recent events of statue demolition and mutilation in places like Charlottesville, Virginia, we may see that the circumstances surrounding the protest and resulting violence are not superficially simple. The statues of Lee or other Confederate leaders are not pagan idols or even religious figures, but some viewers regard them as heroic and almost god-like. They may be inanimate objects, made of base materials and powerless in themselves, but they are nevertheless powerful symbols of either revered traditions or representatives of a reviled part of the past. Some want to eradicate them, others to neutralise them, still others to honour them. The power of a piece of monumental art to galvanise both detractors and defenders is as old as time. Whether cherished or hated symbols of some either honourable or detestable history, they influence the ways we regard our past and envision our future.

\section{Notes}

1 www.nytimes.com/2017/08/13/us/charlottesville-rally-protest-statue.html, accessed $1 / 30 / 19$.

2 www.nytimes.com/2017/08/14/us/protesters-in-durham-topple-a-confederate-monument. $\mathrm{html}$, accessed 1/29/19.

3 www.baltimoresun.com/news/maryland/baltimore-city/bs-md-confederate-statues20180813-story.html, accessed 1/30/19.

4 See the article from PRI's the world: www.pri.org/stories/2017-08-17/what-do-americas-confederate-statues-and-monuments, accessed 1/30/19.

5 On the Antioch statue riots see John Chrysostom, Stat. and Libanius, Or. 19-20; and later historians Theodoret, Hist. Eccl. 5.19.1; and Sozomen, Hist. Eccl. 7.23.

6 Libanius likewise appealed to the emperor's clemency and for mercy, arguing that the ruler would be justified in punishing the perpetrators, but it would be godlike of Theodosius to be merciful and pardon them (Or. 19.9-12).

7 That the statues of gods were lifeless and foolish is a common Christian trope. See, for example, Tertullian, Apol. 13 (Dekkers 1954a); Minucius Felix, Oct. 24.

8 This is asserted by Justin Martyr, 1 Apol. 18; Minucius Felix, Oct. 27; Tertullian, Apol. 21.31 (Dekkers 1954b); Spec. 8.10 (Dekkers 1954c); Idol. 7.1 and 15.5 (Reifferscheid and Wissowa 1954a). Also by Eusebius, Vit. Const. 3.55, regarding the Temple at Aphaka (Phoenicia).

9 On spitting at, stoning, or otherwise reviling the statues see Minucius Felix, Oct. 8.4; Tertullian, Idol. 11.7 (Reifferscheid and Wissowa 1954a), Apol. 23.16 (Dekkers 1954b), Scap. 2 (Dekkers 1954c). Also Eusebius, Hist. eccl. 10.4.14-15; Julian, Ep. 79; and Augustine, Cont. Jul. 6.23 (7).

10 Sozomen, Hist. eccl. 5.9 and 11 tells the stories of Eusebius, Nestabus, and Zeno of Gaza, and Macedonius, Theodolus, and Tatian from the Phrygian city of Misos; Theodoret, Hist. eccl. 3.3; see also Socrates, Hist. eccl. 3.15 (on Macedonius, Theodulus, and Tatian, their city here identified as Merum). 
11 Sozomen, Hist. eccl. 5.11 recounts similar case Ancyra, by Eupsychius, a Cappadocian noble from Caesarea who destroyed a temple dedicated to Fortuna.

12 The destruction of the Serapeum is recounted by Sozomen, Hist. eccl. 7.15; Socrates 5.16; Theodoret, Hist. eccl. 5.22; Rufinus, Hist. eccl. 11.22-3 and in a number of other ancient sources, including a famous papyrus from a fifth-century world chronicle written in Alexandria, which includes an illustration of Theophilus triumphantly standing atop the Serapeum. On the links among these various documents see Baldini (1985: 97-152) and Amidon (1997: 80-3).

13 This is also mentioned in Sozomen, Hist. eccl. 7.15 and Socrates, Hist. eccl. 5.16.

14 Gilding of cult statues is mentioned by Tertullian, Idol. 8 (Reifferscheid and Wissowa 1954a).

15 For Augustine's account of the revolt of Eugenius and a miracle associated with Theodosius's victory (and the overthrow of Jupiter statues) see Civ. Dei 5.26.

16 See Minucius Felix, Oct. 8.4 for an example of this view.

\section{Bibliography}

\section{Primary sources}

Augustine Contra Julianum. PL, 44: 641-874.

Sermon 62. PL, 38: 414-23.

- Sermon 178. PL, 38: 960-6.

(1900) De consensu evangelistarum. Edited by Zycha, J. CSEL, 41. Tempsky:

Vienna, 141-83.

(1955) De civitate Dei. Edited by Dombart, B. and Kalb, A., CCSL, 47-48. Vienna:

F. Tempsky.

- (1997) Sermones. Edited by Lambot, C., CCSL, 41. Turnhout: Brepols.

(2004) Epistulae. Edited by Daur, K. D., CCSL, 31. Turnhout: Brepols.

CTh (1952) Theodosian code. Translated by Pharr, C. Princeton: Princeton University Press.

Eusebius of Caesarea (1991) Vita Constantini. Edited by Winkelmann, F., GCS, 7.1. Berlin: Akademie-Verlag.

John Chrysostom, Statuis. PG, 49: 15, 1222.

(1889) On the statues. Translated by Stephens, W. R. W., NPNF, ser. 1, 9. Grand Rapids, MI: Eerdmans.

Julian (1913) Epistulae. Edited and translated by Wright, E. W. C. The works of the Emperor Julian, 3 vols., LCL, 157. Cambridge, MA: Harvard University Press.

Justin, M. (1914) Apologia. Edited by Goodspeed, E. J. Göttingen: Vandenhoeck \& Ruprecht.

Juvenal (1940) Satirae. Edited and translated by Ramsay, G. G. Juvenal and Persius, LCL, 91. Cambridge, MA: Harvard University Press.

Libanius (2015) Orationes. Edited and translated by Norman, A. F. Autobiography and selected letters, 4 vols., LCL, 478. Cambridge, MA: Harvard University Press.

Minucius Felix (1931) Octavius. Edited and translated by Glover, T. R. and Rendall, G. H., LCL, 250. Cambridge, MA: Harvard University Press.

Origen (1899) Contra Celsum. Edited by Koetschau. P., GCS, 2-3. Berlin: Akademie-Verlag. Palladas of Alexandria (2014) The Greek anthology. Edited and translated by Paton, W. R., LCL, 67. Cambridge, MA: Harvard University Press.

Rufinus (1908) Historia ecclesiastica. Edited by Schwartz, E. and Mommsen, T., GCS Neue Folge, 6.2. Berlin: Akademie-Verlag. 
Socrates Scholasticus (1995) Historia ecclesiastica. Edited by Hansen, G. C., GCS Neue Folge, 1. Translated in NPNF, ser. 2, 2. Berlin: Akademie-Verlag.

Sozomen (1995) Historia ecclesiastica. Edited by Hansen, G. C., GCS Neue Folge, 4. Berlin: Akademie-Verlag.

Tertullian (1954a) De idololatria. Edited by Reifferscheid, A. and Wissowa, G., CCSL, 2. Turnhout: Brepols, 1099-24. $85-171$.

(1954b) Apologeticum. Edited by Dekkers, E., CCSL, 1. Turnhout: Brepols, $85-171$. $1125-32$.

(1954d) De spectaculis. Edited by Dekkers, E., CCSL, 1. Turnhout: Brepols, 227-53.

Theodoret of Cyrus (1998) Historia ecclesiastia. Edited by Scheidweiler, F., GCS Neue Folge, 5. Berlin: Akademie-Verlag.

\section{Secondary sources}

Amidon, P. S. J. (1997) The church history of Rufinus of Aquileia, books 10 and 11. Oxford: Oxford University Press.

Baldini, A. (1985) 'Problemi della tradizione sulla "destruzione" del Serapeo di Allesandria'. Rivista storica del 'antichità, 15: 97-152.

Bonnet, C. (1988) Melquart: Cultes et mythes de l'Héraclès tyrien en Méditerrannée. Namur: Peeters.

Bradbury, S. (1994) 'Constantine and the problem of anti-pagan legislation'. Classical Philology, 89: 120-39.

Brakke, D. (2006) Demons and the making of the monk: Spiritual combat in early Christianity. Cambridge, MA: Harvard University Press.

Browning, R. (1952) 'The riot of A.D. 387 in Antioch: The role of theatrical claques in the Later Empire'. Journal of Roman Studies, 42: 13-20.

Cameron, A. (1965) 'Palladas and Christian polemic'. Journal of Roman studies, 55: 17-30.

Caseau, B. (2011) 'Religious intolerance and pagan statuary'. In Mulryan, M. and Lavan, L. (eds.), The archaeology of late-antique “paganism”. Leiden: Brill, 479-502.

Coates-Stephens, R. (2007) 'The reuse of ancient statuary in late-antique Rome'. In Bauer, F. A. and Witschel, C. (eds.), Statuen in der Spätantike. Wiesbaden: Riechert, 171-87.

Eire, C. (1989) War against the idols: The reformation of worship from Erasmus to Calvin. Cambridge: Cambridge University Press.

Freedberg, D. (1989) The power of images: Studies in the history and theory of response. Chicago: University of Chicago Press.

Hannestad, N. (1999) 'How did rising Christianity cope with pagan sculpture?' in Chrysos, E. and Wood, I. (eds.), East and West: Modes of communication. Proceedings of the first plenary conference at Mérida. Leiden: Brill, 173-203.

Hedrick, C. (2000) History and silence: Purge and rehabilitation of memory in Late Antiquity. Austin: University of Texas Press.

Jacobs, I. (2010) 'Production to destruction? Pagan and mythological statuary in Asia Minor'. American Journal of Archaeology, 114: 267-303.

Kristensen, T. M. (2012), 'Miraculous Bodies: Christian Viewers and the Transformation of 'Pagan' Sculpture in Late Antiquity.' In Kristensen, T. M. and Poulsen, B. (eds.), Patrons and Viewers in Late Antiquity. Aarhus: Aarhus University Press, 31-66. 
Kristensen, T. M. (2013) Making and breaking the Gods: Christian responses to pagan sculpture in Late Antiquity. Aarhus: Aarhus University Press.

Kristensen, T. M. and Stirling, L. (eds.) (2016) The afterlife of Greek and Roman sculpture. Ann Arbor: University of Michigan Press.

Lepelley, C. (1994) 'Le museé des statues divines. La volonté de sauvegarder le patrimoine artistique païen à la époque théodosienne'. Cahiers Archéologiques, 42: 5-15.

Magalhäes de Oliveira, J. C. (2006) 'Ut maiores pagani non sint! Pouvoir, iconoclasme et action populaire à Carthage au début du Ve siècle'. Antiquité tardive, 14: 245-62.

Marinescu, C. (1996) 'Transformations: Classical objects and their re-use during antiquity'. In Mathisen, R. W. and Sivan, H. S. (eds.), Shifting frontiers in Late Antiquity. Aldershot: Variorum, 285-98.

Pollini, J. (2012) 'The archaeology of destruction: Christians, images of antiquity, and some problems of interpretation'. In Ralph, S. (ed.), Archaeology of violence. Interdisciplinary approaches. Albany: State University of New York Press.

Rebillard, E. (2013) 'The Christian mob and the destruction of pagan statues: The case of North Africa in the age of Augustine'. In Rebillard, E. Transformation of religious practices in Late Antiquity. Aldershot: Variorum, 73-87.

Riggs, D. (2012) 'The continuity of paganism between the cities and countryside of late Roman Africa'. In Burns, T. S. and Eadie, J. W. (eds.), Urban centers and rural contexts in Late Antiquity. East Lansing, MI: Michigan State University Press, 285-300.

Salzman, M. R. (2006) 'Rethinking pagan-Christian violence'. In Drake, H. (ed.), Violence in Late Antiquity: Perceptions and practices. London: Routledge, 265-85.

Shaw, B. (2011) Sacred violence. Cambridge: Cambridge University Press.

Stewart, P. (1999) 'The destruction of statues in Late Antiquity'. In Miles, R. (ed.), Constructing identities in Late Antiquity. London: Routledge, 159-89.

(2003) Statues in Roman society: Representation and response. Oxford: Oxford University Press.

Stirling, L. (2005) The learned collector: Mythological statuettes and classical taste in late-antique Gaul. Ann Arbor: University of Michigan Press.

Wiśniewski, R. (2016) 'Pagan temples, Christians, and demons in the late-antique East and West'. Sacris erudiri, 54: 111-28.

Witschel, C. (2007) 'Statuen auf spätantike Platzanlagen in Italien und Africa'. In Bauer, F. A. and Witschel, C. (eds.), Statuen in der Spätantike. Wiesbaden: Reichert, 113-69. 


\title{
14 Athena, patroness of the marketplace
}

\author{
From Athens to Constantinople
}

\author{
Janet Wade
}

The goddess Athena was an important part of Greek, Roman, and Byzantine cultural tradition and memory. To date, late-antique images or depictions of the popular deity - and her Roman counterpart Minerva with whom she became inextricably linked ${ }^{1}$ - have generally been considered secular; devoid of all previous pagan or non-Christian meaning. Alternatively, the continued popularity of the goddess has been seen simply as the result of an antiquarian interest in the classical past (Weitzmann 1979: xx, xxiv and 127-8; Liebeschuetz 1995: 193-7; Dunbabin 2003: 199, 299; Deacy 2008: 139-56; Pitarakis 2012: 421-2; Pitarakis 2016: 221; Wade 2014: 272-3). This chapter suggests that not everyone in Late Antiquity saw Athena and Minerva in these ways. Based on an analysis of steelyard weights of the fifth- to seventh-century period and prominent statues in cities like Athens and Constantinople, I argue that many people saw Athena as a contemporary deity; one who belonged as much in the present as she did in the past.

Athena remained a prominent figure throughout Late Antiquity. As we shall see, the goddess who protected the most powerful city of the classical world, Athens, continued to be viewed as a guardian of her home city during this period. Memories of Athena's past glory and tutelary power gave her cult a sense of utopian authority, and she also came to be recognised as the protector of Constantinople after the city's foundation in the fourth century. Athena's role in commercial and maritime affairs is not always acknowledged; yet, throughout antiquity, the goddess had a place at sea, in markets, and wherever commercial transactions were conducted. Athena supervised seafaring, shipbuilding, and commercial activities and was believed to have played a part in several significant sea voyages - including Helen's fateful trip to Troy in Homer's Iliad and Jason and the Argonauts' voyage to Colchis to capture the Golden Fleece (Deacy 2008: 48-50, 136). Shearer (1998: 11, 78) notes that the protection of commerce had become one of Athena's/Minerva's most prominent roles by the Roman period. Athena's continuing place in commercial and social environments is perhaps best exemplified by her famous statue in the Forum of Constantine in Constantinople (sources mentioning the statue include Zosimus, NH, 5.24.7-8; Niketas Choniates, Annals 559-60). It is highly likely that this statue acted as the prototype for a range of weights used by merchants and traders as part of their everyday business transactions. 
Steelyard (or counterpoise) weights in the guise of Athena/Minerva-with the head of Medusa on her breastplate - became very popular in the late-antique period and have been found at a range of sites (Eliot 1976: 166; Franken 1994: 84-7; Pitarakis 2012: 419-22; Pitarakis 2016: 221). These weights were not recycled objects; they were manufactured and distributed from the fifth to seventh centuries and, as portable items, were used regularly by land and sea merchants alike. The discovery of a steelyard weight of Athena on the seventh-century Yassi Ada shipwreck (Bass and van Doorninck Jr 1982: 224-9; Meriçboyu and Atasoy 1983: 21; McClanan 2002: 47, 55) and the subsequent analysis of other extant weights overturned the long-held assumption that the Athena weights were manufactured and utilised in the period prior to the fourth century (Eliot 1976: 163-70; Franken, 1994: 93-4; McClanan 2002: 55). In his catalogue of extant late-antique steelyard weights, Franken (1994: 83-114) records 162 weights in the shape of busts. Seventy-four of these depict empresses, and sixty-one portray Athena. The other twenty-seven weights are a mixture of emperors and male officials. There are also several Athena weights not included in Franken's catalogue, including a weight found in the Yenikap1 excavations of the Theodosian Harbour (Pekin and Kangal 2007, Catalogue Item Y18) and another currently held in the Museum of Kos (Papanikola-Bakirtzi 2002; Catalogue Item 23).

The find location of many of the Athena weights is unknown; however, most of those that do have either a secure or suspected provenance are part of shipwreck finds or from coastal areas (Franken 1994: 86-7; Pekin and Kangal 2007, Catalogue Item Y18). In addition, Bass and van Doorninck Jr (1982: 224-9) note that the steelyard and other weights of Athena on the Yassi Ada wreck are of the type used for routine maritime commercial transactions, particularly for the weighing of heavy cargo. The large percentage of the overall extant weights depicting Athena demonstrate that this goddess maintained her place in fora and on ships throughout Late Antiquity. Steelyard weights of this period have been discussed extensively in recent scholarship (e.g. Eliot 1976; Franken 1994; James 2001; McClanan 2002; Pitarakis 2012; Pitarakis 2016). However, the steelyard weights of Athena have been treated by many scholars as uncomfortably pagan items in a Christian world. With the exception of Pitarakis (2012: 419-22, 2016: 221), who analyses both the empress and Athena steelyard weights in detail, scholarship has focused heavily on the contemporaneous empress weights, which are much easier to contextualise in the world of Late Antiquity. Herrin (2000: 9), for example, writes that Athena was only occasionally depicted on late-antique weights, and claims that 'the overriding association of correct weight is with an imperial feminine.' McClanan (2002: 4-5) maintains that the empress weights were the more favoured item for everyday commercial transactions. James (2001: 115) states that after the third century, 'imperial personages are virtually the only image found on these weights,' despite the large number of extant weights depicting Athena. Yet these small items depicting a Graeco-Roman deity confirm that Roman and Byzantine cultural memories of Athena remained strong. They also provide a window into the everyday commercial transactions that were being conducted during this period and, thus, deserve special consideration. 


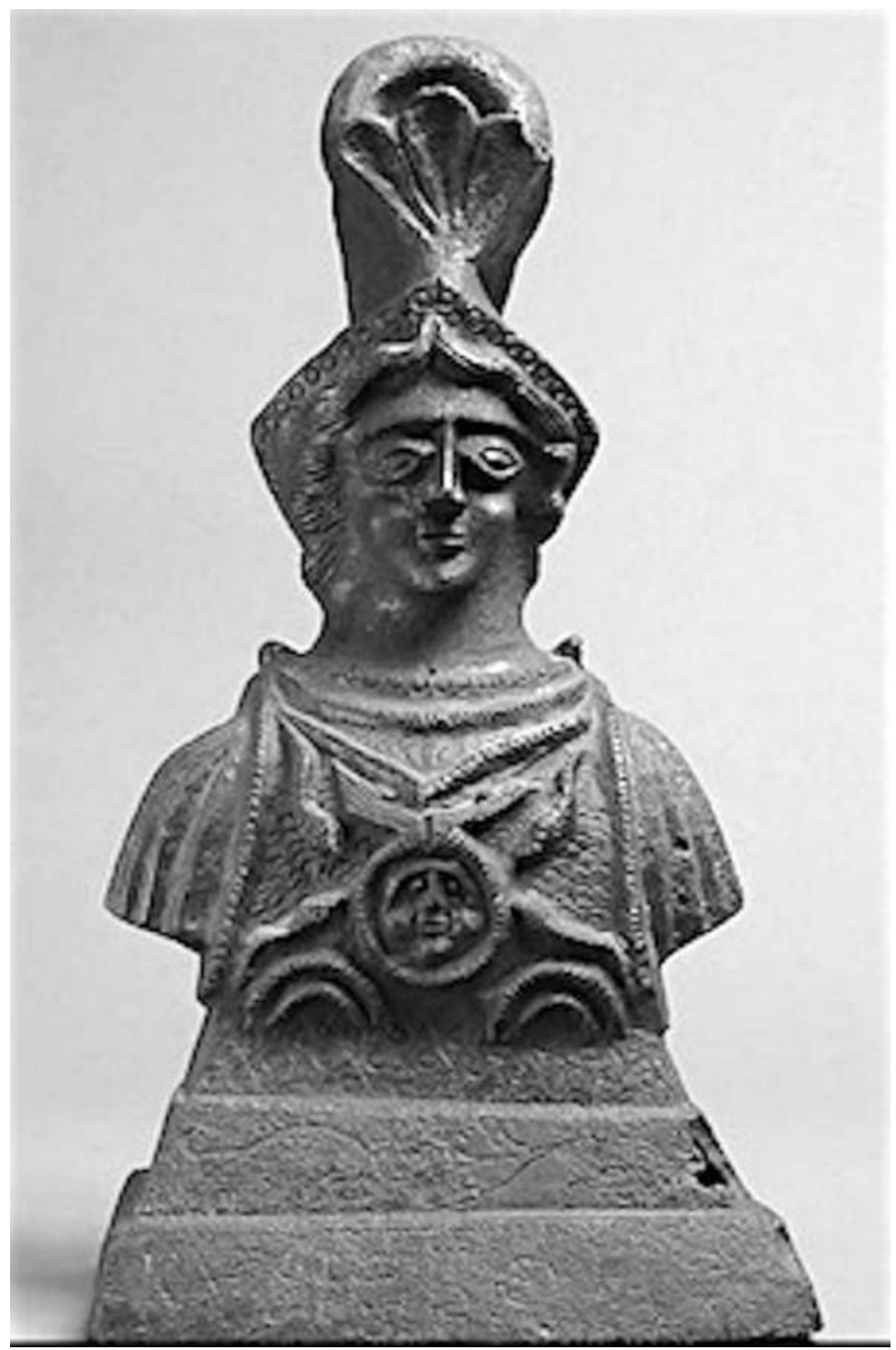

Figure 14.1 Athena steelyard weight currently held at the Metropolitan Museum of Art, Accession Number: 61.112.

Source: Image in the Public Domain.

Despite evidence to the contrary, some scholars prefer to view the Athena weights as items from an earlier period. James (2001: 115-17), for example, sees the weights as objects that could only have been manufactured and used prior to the fourth century, before Christianity became the official Roman religion. There 
were, however, very few weights of Athena or Minerva manufactured prior to the fifth century. In fact, Franken notes that weights of Athena/Minerva were not a popular type at all prior to the fifth century, when other mythological figures and deities were commonly depicted. He catalogues only two steelyard weights depicting Minerva from the Roman Imperial period (Franken 1994: 105-7; McClanan 2002: 50). Other researchers like McClanan (2002: 29-64, esp. 50 and 55-8) seem intent on providing either a Christian or purely secular meaning to these weights, despite their depiction of a well-known deity. McClanan, who has written extensively on the weights, accepts their late dating and acknowledges their popularity from the fifth century. Yet, in order to explain their existence, she searches for possible meanings that a pagan goddess could have to the Christian merchants whom she assumes were using the weights.

The late manufacture of these items does pose a conundrum if it is accepted that all merchants had cast away their traditional superstitions and beliefs by the early fourth century. But when we consider that by the end of Late Antiquity not all merchants and seafarers may have abandoned their traditional deities (Wade 2014: 269-87), and many sculptures and other objects still retained their apotropaic qualities (Mango 1963: 59; James 1996: 15-17), these small, everyday weights no longer appear out of context. Indeed, Pitarakis (2016: 212-14, $217-$ 23) notes that weighing implements and other commercial items were themselves regularly inscribed with religious or apotropaic symbols and motifs, demonstrating that such objects could be endowed with a range of protective powers. Pitarakis (2012: 421-2) highlights that Athena and her steelyard weights were clearly seen to have apotropaic qualities, and draws attention to two weights with Christian symbols or inscriptions added to them to further enhance Athena's power. This is strong evidence for the enduring memory of a classical tradition and its maintenance and transformation into a new context.

To safely consign the Athena weights to the Christian eastern empire of Late Antiquity, some historians seek to explain them in non-polytheistic terms by suggesting that they do not depict Athena at all. ${ }^{2}$ Both McClanan and James suggest that the Athena weights may in fact symbolise an imperial female or the Tyche of Rome or Constantinople (James 2001: 142). McClanan also notes that earlier scholars such as E. B. Thomas suggested that the weights symbolised Tyche or Sophia (Wisdom) (McClanan 2002: 50-2, 57-8). However, based on the fact that city Tyches are never depicted wearing an aegis (a standard feature of the Athena steelyard weights), Franken (1994: 99) sensibly rules out an identification of the weights with the Tyche of Constantinople. McClanan (2002: 50-2, 57-8) highlights instances from earlier periods where empresses were represented as deified figures. Yet, at the same time, she notes that Athena/Minerva had never been a goddess regularly appropriated by empresses. It is unclear why McClanan believes that Athena would suddenly have become so in the early Byzantine period. Supported by scholars like Mellor and Vermeule, McClanan also highlights similarities between the imagery of Roma and Athena, and ultimately suggests that the figure represented on the weights is a conflation of the empress and the personification of Rome in the guise of a secular Athena (McClanan 2002: 50-2, 57; Mellor 1975: 29-30, 35-6, 65-71, 129-31; Vermeule 1959: 75, 85; 
MacCormack 1975: 147-9). These historians use the depiction of Roma on gems as important evidence of the similarities between the iconography of Roma and Athena. Yet gems were personal items, not widely circulated or common after the early imperial period (Mellor 1975: 6; Vermeule 1959: 85). Thus, they are not indicative of the widely recognised iconography of Roma.

In contrast, Pitarakis (2012: 421-2) recognises the weights as a representation of the goddess Athena. She notes that it was certainly no accident that Athena'city divinity,' 'goddess of justice, wisdom, and crafts,' and 'protectress believed to possess apotropaic powers' - was the second most prevalent figure on steelyard weights of the sixth and seventh centuries. Yet Pitarakis too sees a 'probable allusion' to Roma in order to explain the prominence of the Athena weights in the late-antique world of commerce. As she suggests, an association between Roma and Athena would certainly have strengthened the legitimacy and meaning of weights depicting the latter. Mellor highlights that Roma's early iconography was likely to have been modelled on that of Athena (Mellor 1975: 103-4, 147-8, and 163). This is true, but it is important to note that, for the most part, contemporary viewers would not have confused these two deities. Vermeule (1959: 75) stresses that although modern viewers see striking similarities in the imagery of goddesses like Athena and Roma, there were precise definitions and formulae employed in the representation of deities in the ancient world. These definitions made each deity quite distinct in pre-modern times. Any link between Roma and the imperial office should not automatically be extrapolated to Athena, simply because of iconographical similarities between the two deities.

The goddess Athena is considered by many to have been a secular and abstract concept during Late Antiquity - the personification of wisdom, fairness, honesty, and good measure (e.g. Asal 2007: 189; Deacy 2008: 145; McClanan 2002: 57). Athena has continued to be viewed into modern times as the secular embodiment of concepts such as wisdom and honesty (Deacy 2008: 139-56). Yet, during Late Antiquity, Athena became symbolic of a utopian ideal of both the GraecoRoman past and the Christian present and future. Her qualities were such that she appealed to men and women of various religious inclinations. In their comprehensive study of Athena in Antiquity, Deacy and Villing (2001: 4) state that the goddess survived only 'as an allegorical and ethical concept' in the Christian period. This view is not surprising. When seen as a personification or abstraction, any deity can be made to seem more agreeable or acceptable to a Christian regime. If the weights of Athena represented either a secular or a purely Christian concept - as opposed to a polytheistic one - then they present far less of a conundrum to historians. But to see a figure like Athena as a mere personification is to ignore the ways that ancient and early medieval society perceived and understood abstract ideas. What modern scholars often see as a simple, secular abstraction, earlier viewers saw as something more concrete, with magical or divine powers (Isaac 2008: 575-80). Maguire (2001: 253) points out that personifications also continued to be 'a common frame of reference for pagans, Christians, Jews, and Muslims alike.' Weitzmann (1979: xxii) agrees that late-antique depictions of personifications cannot always be ascribed with certainty to a pagan or Christian 
milieu. Athena/Minerva may have survived predominantly as a Christian allegorical concept by the seventh century, but she was still seen as a Graeco-Roman goddess to many people before that time. The utopian values for which she had stood for centuries, including justice, wisdom, fairness, and intelligence, were equally as valued by Christians as they were by non-Christians (Deacy 2008: 156). Athena offered divine protection to all men and women and, as such, she was the perfect figure to watch over the commercial transactions of merchants during the transitionary period of Late Antiquity (Pitarakis 2012: 422).

To date, historians have largely dismissed the depiction of traditional deities in the fifth to seventh centuries as 'no longer objects of veneration but art objects owned by a humanistically oriented intelligentsia' (Weitzmann 1979: 20; and for a similar sentiment, see Dunbabin 2003: 199, 299). Liebeschuetz (1995: 193-7) concedes that some artistic representations may have been 'designed to express a pagan interpretation,' but argues that 'it is difficult, in the absence of a contemporary commentary, to be certain that a particular mythological image is intended to be read in a positively pagan sense.' Like Weitzmann, Liebeschuetz seems to be suggesting that, where a pagan-inspired or mythological scene is depicted, it is always most probable that it was designed with secular and humanist intentions in mind, even in the period of Late Antiquity. There are many elite objects depicting mythological subjects and deities like Athena that have survived from this period. Examples include elite dishes, serving vessels, and jewellery (Weitzmann 1979, Catalogue Items 110, 115, 118, 202, and 282). Yet this theory does not explain the continued popularity of steelyard weights depicting a goddess. These were massproduced items used by non-elite merchants as part of their everyday business transactions, not objects created for the consumption of the classically educated elite. In the late fifth century, Fulgentius recounted various classical tales presenting Athena/Minerva as the goddess of wisdom, and the Gorgon Medusa on her breast as a symbol of fear (Fulgentius, Mythologiae 1.21, 2.1, 2.6, 2.11, 3.1, and 3.7). These were no doubt popular stories and lasting cultural memories; however, the majority of merchants would not have been well versed in the classics, nor would they have seen these myths in an intellectual or antiquarian light.

The continued use of the Athena weights cannot simply be explained away by a love of, or tolerant attitude towards, the classical past. Nor should it be assumed that the men using these weights did not know who was represented on them. Later in this chapter, the discussion of statues will demonstrate that, as Athena or Minerva, this goddess was still widely recognised in the late-antique period. When we consider that other non-Christian beliefs persisted into the seventh century, it should come as no surprise that steelyard weights of Athena may have held a non-Christian meaning to at least some of the men and women who used them. Prominent scholars including Cameron, MacMullen, and Trombley have demonstrated convincingly that pagan beliefs and practices - particularly in the East-continued until at least the seventh century (Cameron 1993: 10-13, 20, 69-70, and 141-4; Cameron 2015: 3-22; MacMullen 1997; Trombley 1985: 339; Trombley 1994: 226; Bell 2013: 222-46; Bowes 2008: 222; Limberis 1994: 28-9; Sauer 2003: 111, 132, and 142). Trombley (1994: 226) states succinctly that 'No 
fundamental reason exists to derive obscure explanations for the persistence of the phenomena of pagan cult, which were everywhere about in the fifth-century empire.' Indeed, the continuous anti-pagan legislation of the fourth to sixth centuries proves that non-Christian beliefs were persistent (Harl 1990: 7-27; Cameron 1993: 143-4; Corcoran 2015: 67-94; Hunt 1993: 143-4, 157; Lavan 2011: xxiiiiv; Trombley 1993: 2).

There were clearly men and women who continued to harbour non-Christian religious beliefs and to maintain their devotion to traditional deities, even in cultural and administrative centres like Constantinople, Alexandria, and Athens (Harl 1990: 15-19, 23-4; Maas 1992: 70-2; MacMullen 1997: 146; Trombley 1993: 292-5, 316, 322; Trombley 1994: 52). There were prominent city officials in Constantinople who were conspicuously non-Christian; from the highly respected Themistius in the late fourth century, through to those targeted by Justinian's persecutions in the sixth century, including men like Asclepiodatus the Eparch, Macedonius the Referendarius, and Thomas the Quaestor, who held - or had recently held - a number of important administrative positions (Maas 1992: 70-2). Such people were not only of the elite levels of society. In his Homiliae in Matthaeum 4.7 (PG, 57: 48), John Chrysostom highlights that Christians and nonChristians frequented everyday urban environments like marketplaces and other similar settings. He notes that it was very difficult to distinguish between those of different faiths and beliefs in these busy commercial and social contexts. It was in such environments that steelyard weights, including those depicting the goddess Athena, were regularly used.

The weights of Athena include several of the standard iconographical features that had been associated with the goddess for centuries. There are numerous examples of statues from classical Greece through to the late Roman period that depict Athena and Minerva in a similar manner to the weights (e.g. Figure 14.2; Deacy and Villing 2001: 434-5, Plates 7, 9-12, 15-16, and 20; and Lexicon iconographicum mythologiae classicae 1984: 706-815). In Fulgentius's literary description of Athena/Minerva, he notes her key attributes as the Gorgon on her breast, and her helmet and plume (Fulgentius, Mythologiae 2.1). The surviving weights generally show the owl-eyed goddess wearing her signature Corinthianstyle crested helmet with thick, curly hair underneath, a chiton or peplos, and a breastplate or aegis with the face of Medusa. There are also snakes, associated with the Gorgon, depicted on the goddess's breast. Some of the weights do not include all these features; however, enough of Athena's iconography is included to clearly identify the weights as representations of the goddess (see Figure 14.3).

Eliot (1976: 167-9) conducted a comprehensive study of the stylistic similarities and differences in several of the extant weights, noting a clear stylistic deterioration corresponding with the period in which they were manufactured. Eliot points out that the weights produced in the fifth century are generally more detailed than those manufactured later. Of the Yassi Ada weight - one of the last of the series and dated to either the late sixth or early seventh century-Eliot (1976: 167) writes: 'With its lack of understanding of the details of the aegis and the severe stylization of the face, it openly betrays the distance that separates it 


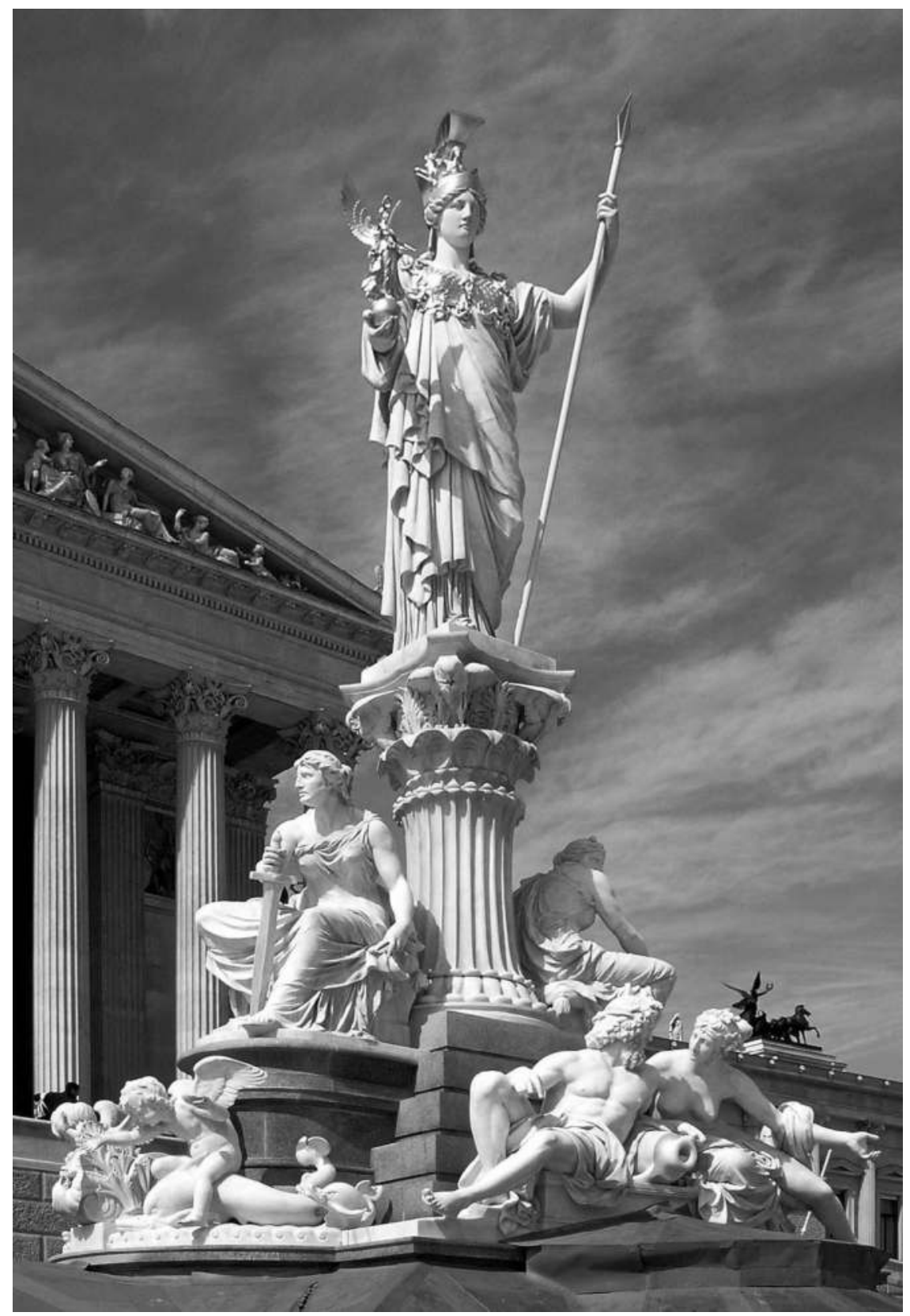

Figure 14.2 A statue of Athena in front of the Austrian Parliament Building. Source: Photo credit: Gryffindor (via Wikimedia Commons). 


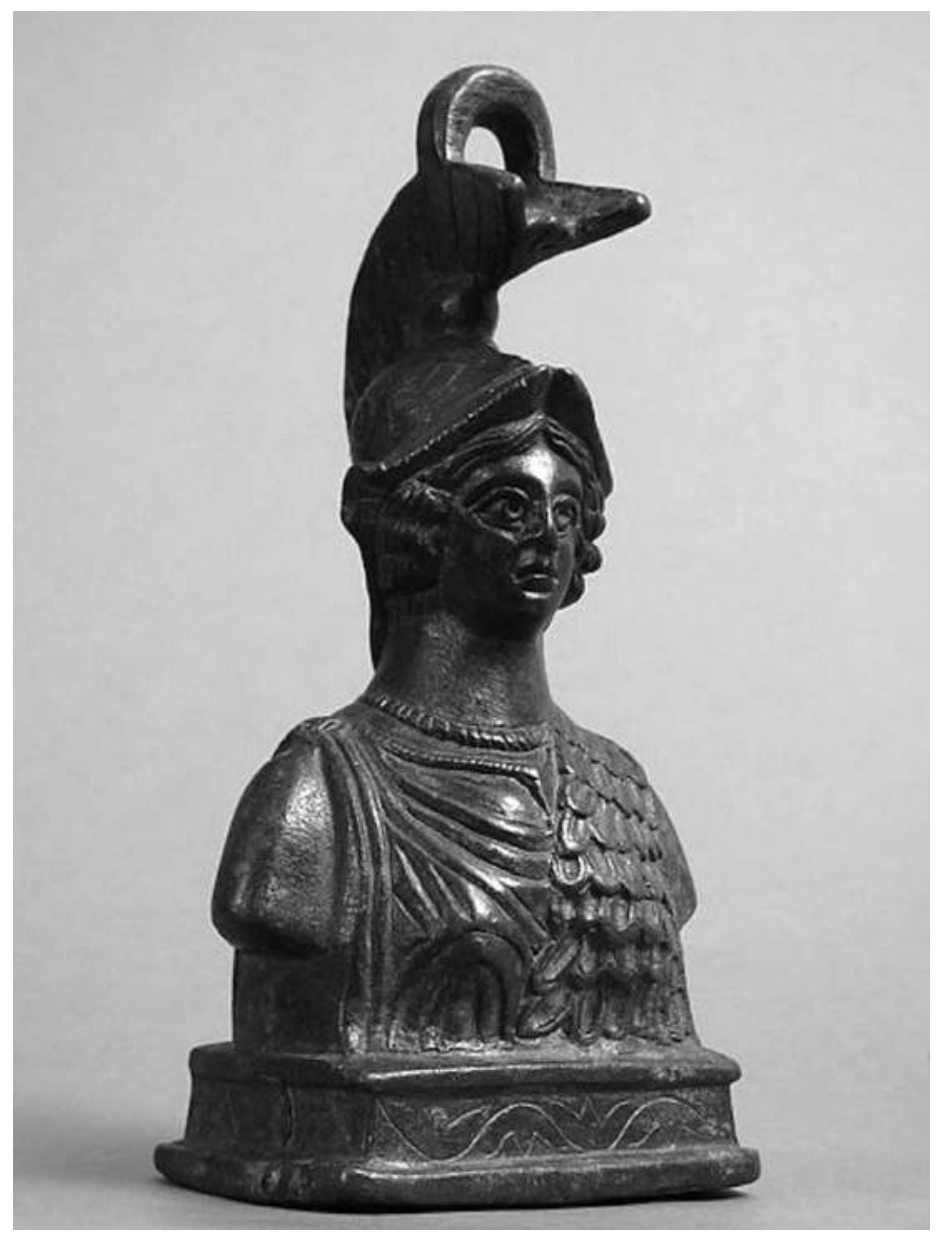

Figure 14.3 Steelyard weight currently held in the Metropolitan Museum of Art, Accession Number: 59.184.

Source: Image in the Public Domain.

from its prototype.' Eliot does stress that variations in the quality of the weights could also have been the result of the different craftsmen and workshops producing them. Franken (1994: 93-4) too records an increasing simplification of form in these weights - to the point that details such as the aegis become almost unrecognisable in later examples. However, despite this overall simplification and loss of detail, the essence of Athena's iconography is retained, even on the later weights. This makes sense. There were many who knew and loved the goddess Athena in the early fifth century, but she must have had fewer worshippers by the seventh century. Although still widely recognised as a deity, understanding of 
the individual aspects of her iconography would no longer have been universal. Interestingly, the overall quality of the weights did not diminish with time. Bass and van Doorninck (1982: 314) record that the Athena weight and scale found on the seventh-century Yassi Ada shipwreck were actually the finest of the weighing implements on board.

Despite a decrease in knowledge of the individual characteristics of Athena's iconography, the merchants using her steelyard weights were probably still aware whom they depicted. Many of the traders visiting Constantinople would have known that the figure on the steelyard weights was the same as the famous statue of Athena in the marketplace. Historians from the fourth to thirteenth centuries recorded the presence of statues of Athena in various locations throughout Constantinople, including the talismanic statue of Pallas Athena (known as the Palladium) reputed to have been placed under Constantine's porphyry column when he founded the city. Procopius mentions an engraved copy of this statue along with another of Athena in the Temple of Fortuna (Procopius, Goth . 5.15.9-14). The idea that the Palladium had been transferred to Constantinople from Rome may only have been a foundation myth, yet the thought that it was under the columnprotecting the city and its inhabitants - would have been of great significance to those who frequented this busy forum (Ando 2001: 404; Dagron 1974: 14-37; Fowden 1991: 120-1; Grig and Kelly 2012: 4; Malalas, Chron. 13.7; Zosimus, NH, 2.30; and Patria 2.45).

The bronze statue of Athena that stood near the Senate House in the Forum of Constantine was also clearly an important landmark in the city. Zosimus records that this statue and another of Zeus survived a fire in the fifth century. Some in the city saw this omen as proof that Athena and Zeus would always protect Constantinople (Zosimus, NH, 5.24.7-8). Before its destruction at the hands of a drunken mob in the early thirteenth century, the colossal statue of Athena stood for approximately 800 years in the Forum of Constantine. Sources that mention the statue in the marketplace describe it in substantial detail, including the goddess's helmet, and the Gorgon and snakes about her neck (Parastaseis 39; Patria 2.3). ${ }^{3}$ Niketas Choniates notes Medusa on Athena's breast; the aegis; her long, slender neck; her soulful eyes; and the conspicuous plume on her helmet (Annals 559-60). These were also the most obvious features of the goddess depicted on the steelyard weights. Given that the colossal statue of Athena had watched over the activities of the central forum in Constantinople since the fifth century, it is highly probable that the steelyard weights were modelled on it. In a recently published work, Pitarakis (2016: 221) also makes this same suggestion. Lavan (2011a: 439, 443, 448) notes that Christian attempts to alter the meaning or usage of statues in public places, such as those of Athena/Minerva and Tyche, had little impact before the sixth century. At the very least then, the merchants, customers, and all others who came into contact with the Athena weights must have known that they depicted this particular goddess of the marketplace.

Athena was also still inextricably linked to her home city of Athens. The cultural significance of Athens may have decreased significantly since its heyday in the fourth and fifth centuries BCE, but it remained a city with frequent travellers 
and trading ships arriving into its ports. At least one colossal statue of Athena was still on display in Athens in the late fifth century, when Marinus tells us it was removed from the Parthenon by Christians (Marinus, Vita Procli, 30; Frantz 1988: 58). The statue in the Parthenon wore a helmet, a snake-trimmed aegis, and had a Gorgon's head on its breast. Shearer (1998: 7-8) notes that there had always been two colossal statues of Athena in the city; one thirty-foot statue of Athena Promachos on the Acropolis, which could be seen by ships approaching by sea; and the other, even larger one, inside the Parthenon. Julian of Egypt wrote of one of these armoured statues of Athena when he asked in the sixth century, 'Why Trito-born, dost thou put on armour in the middle of the city? Poseidon has

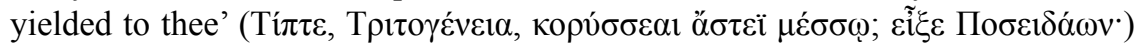
(Anth. Gr. 16.157). Evidence would suggest that the monumental statue of Athena Promachos on the Acropolis was the very one that was moved to the Forum of Constantine in Constantinople, sometime in the fifth century (Jenkins 1947: 31-3; Lundgreen 1997: 190, 195; Frantz 1988: 20, 76-7).

Despite the removal of this famous statue of the city's patroness, the cult of Athena and other traditional gods was clearly flourishing in Athens in the fourth and fifth centuries. Zosimus talks of customary public sacrifices made to the goddess at the Parthenon in the late fourth century, and her temple was still functioning as an active cult centre when the Neoplatonist Proclus arrived at its gates in 430 (Zosimus, NH, 4.18.2-3; Marinus, Vita Procli, 10). Frantz (1965: 191-2, 197) stresses that although the 'tenacity of the pagan tradition' in Athens throughout the fourth to sixth centuries may have been largely due to the influence of the Neoplatonists, their impact permeated all levels of society. Trombley (1993: 331) warns that the strength of traditional religions in Greece suggest that it would 'be dangerous to regard Proclus's beliefs and practices as a sharp exception to the popular religiosity.' Legend also has it that Athena protected the city from Alaric's assault in the late fourth century. In this story — clearly still believable to many in Zosimus's time - the city's beloved goddess appeared on the city walls in the likeness of her armoured statue and scared off the Gothic attackers. ${ }^{4}$

Further evidence of the longevity of the cult of Athena in Athens can be seen in the continued celebration of the traditional mid-summer procession known as the Panathenaia, as late as the fifth century. This procession had a distinctly maritime character, with a wooden statue of Athena carried in her sacred sailing vessel along the main thoroughfare of the city to the Acropolis (Frantz 1965: 193; Frantz 1988: 20; Robertson 1996: 27-31, 56-65; Trombley 1993: 18-20). An inscription dated to 410 and dedicated to a man who funded the procession reads, 'Plutarchos ... who thrice sailed the sacred ship and moored it at the

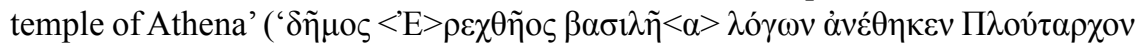

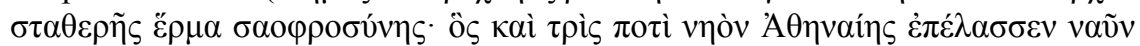

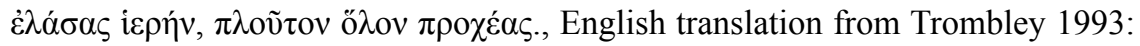
18) (IG II ${ }^{2}$, 3818: Kirchner, Inscriptiones Graecae, 1974). Himerius's late fourthcentury description of the procession demonstrates that the Panathenaia was a popular non-Christian festival of great pomp, and that it was imbued with maritime imagery (Himerius, Or. 47.12-16). During Late Antiquity, there appears to 
have been a relatively harmonious coexistence between Christians and pagans in Athens (Frantz 1965: 191-2, 197). Travellers, sailors, and merchants of different religious affiliations and beliefs were welcomed into the city's ports during this time. Just as travellers to Constantinople would have been familiar with the goddess who watched over the Forum of Constantine, so too would visitors to Athens have been well aware of that city's patroness, Athena. Considering that several of the Athena steelyard weights were found in a maritime or coastal context (Franken 1994: 86-7), many sea travellers may even have carried weights fashioned in the goddess's likeness on their ships.

The eighth-century Parastaseis syntomoi chronikai mentions another relevant statue in the Hippodrome of Constantinople. The anonymous author says he was told that the statue represented the fifth-century empress Verina. In contrast, the majority of people in Constantinople apparently believed that the statue was, in fact, Athena (Parastaseis, 61; Patria 2.78). McClanan uses this particular extract to bolster her argument that the Athena steelyard weights are likely to have represented an empress. She suggests that statues of the goddess and empress must have been easily confused during this period, suggesting 'empress-looking' and 'Athena-looking' were not such distinct categories of visual representation at the time. Rather, the merchants using the steelyard weights would have seen them as symbols of the empress and her imperial authority (McClanan 2002: 58). However, statues depicting empresses and other imperial women were familiar images in late-antique urban centres and they would have been easily recognisable, even to those of the non-elite. Machado and Lenaghan (2016: 132-5) highlight that statues of contemporary imperial females were common features in Rome, and Gehn and Ward-Perkins (2016: 137-44) list a number of statues of imperial females erected in Constantinople through to the sixth and early seventh centuries. These statues conformed to standards of imperial iconography. James (2001: 142, 2003: 53) also suggests that the Athena weights, like statues, became representative of an imperial female figure. However, this theory is largely based on the assumption that the Athena weights were forerunners to those depicting empresses and that the iconography of the goddess was appropriated to embody the imperial female. As previously mentioned, it is true that empresses could be identified with, or as, goddesses or female personifications, especially tutelary deities (Smith 1994: 86-105; James 2005: 293-308), but it is important to note that there is very little evidence that this was the case with Athena. The links between Athena and the imperial office in the Christian period are largely speculative.

Franken (1994: 83, 90-1, and 99) highlights the many contrasts between the Athena and empress steelyard weights. He notes that they differ in shape, size, and scale; they have dissimilar bases; a greater proportion of the body and arms are shown in the empress weights; and the orientation of the eye (the loop used to attach the weight to the hook of the steelyard) is different. The iconography of the empress and Athena steelyard weights is also strikingly different, and this suggests that they did not both represent female imperial authority. The Athena weights demonstrate the clear iconographical features of Athena/Minerva as she had been known - and would continue to be known — for centuries. The Lexicon 
iconographicum mythologiae classicae (1984: 706-815) includes a large collection of images of Athena and Athena/Minerva. The later examples shown in the Lexicon are particularly similar to the Athena figures on the steelyard weights. In contrast, the iconography of the empress weights is distinctly imperial, with features that conform to familiar sculptural and sepultural representations of empresses and other elite women. The females portrayed wear diadems, jewellery, robes, and carry scrolls. They have imperial hairstyles and hold one hand either in the speech gesture or on the inside of their robes (Franken 1994: 92-9). The empress weights clearly complied with officially sanctioned imperial iconography (Franken 1994: 99).

The Athena and empress weights were also produced concurrently. If the Athena weights had been manufactured in an earlier period and re-used in the fifth to seventh centuries, then the idea that they became largely representative of imperial authority might be reasonable. Yet they were manufactured simultaneously with the empress weights during Late Antiquity (Franken 1994: 92). The Athena weights may even have been produced for a century or so after the manufacture of the imperial weights had ceased (Franken 1994: 92; McClanan 2002: 55). It is unlikely that two distinct sets of weights would be created in order to symbolise the same notion of imperial authority, particularly when one set conformed to official imperial standards of representation and the other adopted the iconography of a recognised traditional deity. The story from the Parastaseis actually suggests that most people believed the statue in the Hippodrome was the goddess Athena, despite the officially sanctioned version of the statue's iconography. In their discussion of the transformation of memory and tradition in Rome, Garcia Morcillo et al. (2016: 14) highlight the significance of the collective and personal memories or stories - as opposed to official explanations - that became attached to sculptures and other objects. Gilbert Dagron (1984: 38-9) notes the importance of oral tradition in the transmission of cultural heritage and shared memory in Constantinople's history. Dagron uses the story of the statue of Verina (or Athena) as an example of the tenacity of this tradition. The fact that many people believed that the statue was Athena demonstrates that the goddess was an important part of the city's cultural memory and identity.

During the period of their popularity, it is unlikely that the steelyard weights of Athena were seen by the majority of people as depicting anyone other than the goddess herself. The iconography of the weights is clear and there were many prominent images of Athena/Minerva for contemporaries to compare them to. The iconography of Athena/Minerva, Roma, and even Tyche or an empress, may seem similar to modern viewers, but there were still clear definitions and formulae that distinguished these figures in Late Antiquity (Vermeule 1959: 75; Isaac 2008: 575-7). The fact that these weights depicted Athena may itself have given them authority. The utopian ideals for which Athena stood guaranteed her continued significance in commercial affairs and enabled a sense of continuity between the past and present for Christians and non-Christians alike.

It is possible that these weights were not officially sanctioned by the imperial authorities. Franken (1994: 91) suspects that at least some of the weights from this period were manufactured in non-authorised workshops. Even as unofficial 
weights, they could still have been used by a range of merchants - particularly those who conducted the majority of their business at sea and in portside contexts. In the late-antique period, Christian and non-Christian merchants were conducting their business side by side. Many of these traders would have appreciated that the goddess of wisdom, honesty, and good measure still had a role to play in everyday commercial transactions. This does not necessarily imply that the only merchants who carried these weights were non-Christian. Several of the Athena weights contain Christian inscriptions that were added after their manufacture, suggesting that it was Christian merchants who eventually came to own them. For example, the weight shown in Figure 14.1 bears the inscription 'KYPIE BOH $\Theta$ (E) I' ('Lord, save!'). The details of the weight are all sharply defined except for the inscription, which suggests that it was a later addition. The weight from the Yassi Ada shipwreck (Bass and van Doorninck Jr 1982: 217; Franken 1994, Item CВ39) also has a cross and the inscription 'ГЕОРГІОҮ ПРЕ $\mathrm{BY} / \mathrm{TЕРОY}$ NAYK $\Lambda E P O Y$ ' ('[Property] of the priest George, ship captain/owner') added to it. There is another weight currently in the Virginia Museum of Arts (Gonosova and Kondoleon 1994: 242-5, Catalogue item 83) which has a cross deeply incised into it. The cross does not appear to have been engraved on the weight at the time of manufacture. Much like the weights of imperial figures and officials, those of Athena could still have played a role in the protection of commercial transactions and as guarantors of true weight, regardless of their depiction of a traditional nonChristian deity.

The fact that these weights may have been owned by Christian and nonChristian merchants alike does not detract from their apotropaic function. Indeed, the inscriptions or crosses on some of the weights must have been added by Christian owners expressly for that purpose. Most importantly, the face of a Gorgon remained a popular apotropaic symbol, especially in marketplaces and wherever trade was conducted. Our sources include several examples of Gorgon sculptures that were located in Constantinople (Parastaseis, 44a and 78; Patria 2.28 and 2.46; Pitarakis 2016: 220-3; Shearer 1998: 68-9). The Gorgon remained a common apotropaic motif-whether on its own or on the breastplate of the goddess Athena - and was certainly a recognisable symbol. Statuary had always played an important role in Roman cities, and this continued into the medieval period (Machado and Lenaghan 2016: 131). James (1996: 17) relates stories regarding non-Christian statues and other sculptures which demonstrate the widespread belief that these types of objects held protective powers that could be harnessed. It is certainly possible that this was the sentiment held by the Christian merchants and traders who inscribed Christian symbols and text on their Athena weights. Still, Cyril Mango (1963: 55) reminds us that statues and other objects depicting non-Christian deities remained an essential part of polytheistic rites and beliefs, and that paganism continued into the early seventh century. This should be kept in mind. The fact that the steelyard weights of Athena were contemporary objects of trade in the fifth to seventh centuriesrather than items from the ancient past - indicates that they were made with their own contemporary commercial, protective, and sometimes non-Christian purposes in mind. 


\section{Conclusion}

Late-antique objects like the steelyard weights of Athena should not be seen simply as a reflection of past beliefs. Such items do embody cultural memories of the past, but they also reflect the culture and beliefs that existed in marketplaces and on trading ships in the period in which they were manufactured and used (Pitarakis 2016: 225). These types of objects should not be dismissed as throwbacks to the classical past. Nor is there any need to assume that the only possible explanation for such objects is that the characters they portrayed had become entirely Christianised or secularised. The evidence presented here demonstrates that Athena was still considered a deity by many people throughout the Mediterranean world in the fifth to seventh centuries. By this period, the popular female figure of Athena had come to represent different things to different people. I propose that the small, everyday weights of Athena had not been thoroughly cleansed of all non-Christian meaning during Late Antiquity. Instead, they are one further piece of evidence of the perseverance of traditional beliefs among merchants, sailors, and other non-elite men and women.

It was perhaps partly to curb the use of weights that could be deemed nonChristian that Justinian had to impose laws regarding the use of official weights and measures throughout the empire, and to increase the Church's involvement in the maintenance and storage of weights (Balaska and Selenti 1998: 58; Bendall 1996: 11). Pitarakis (2016: 211-13) notes that the proper use of weights and measures was part of 'God's law.' Weights deemed offensive to a Christian sensibility could thus have been seen as non-conformist. In the early seventh century, the patriarch of Alexandria also had to prohibit the use of weights, measures, or balances that did not conform to official standards (Bendall 1996: 11). At this time, weights depicting the goddess Athena were still being carried by merchants throughout the eastern empire, and such 'non-standard' items may have been on the list of weights to be outlawed. These small depictions of Athena were symbolic of a utopian ideal of the past; an ideal that suited many Christian and non-Christian merchants alike. Non-Christian deities like Athena were tenacious. The ecclesiastical and imperial authorities may have banished Athena from her traditional temples and shrines, but her memory and popularity lived on. We know from literary sources that there were those in elite circles who preserved polytheistic beliefs until the end of Late Antiquity; however, the survival of deities like Athena was also due, in no small part, to the merchants and sailors who carried their memory into ports and marketplaces throughout the late Roman and early Byzantine world.

\section{Notes}

1 Throughout this chapter, references to Athena in the late-antique period relate to Athena or her Roman counterpart Minerva, or a syncretised version of the two. As Deacy (2008: 123, 136) notes, 'Minerva became so successfully assimilated with Athena that the goddesses became in certain respects interchangeable' and that 'in terms of appearance ... the goddesses are identical.'

2 Franken (1994: 87) also suggests an additional theory. He speculates that the weights were manufactured in the West, despite much evidence to the contrary. This is presumably 
because it is easier to imagine such 'pagan-inspired' items originating in the West than it is in the 'Christian' East. McClanan (2002: 33) thinks that this theory could help to explain idiosyncratic differences between the empress and Athena weights.

3 Bassett (2004: 188-92) provides a list of sources for the statue, including Constantine the Rhodian 150-63, Kedrenos 1,565, and Arethas, Schol. Arist. Or. 50T, 3.

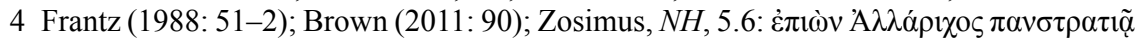

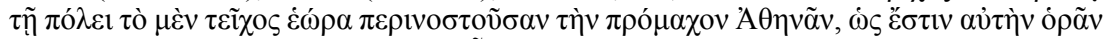

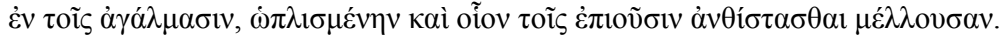

\section{Bibliography}

\section{Primary sources}

Accounts of medieval Constantinople: The Patria (2013) Translated by Berger, A. Cambridge, MA: Harvard University Press.

Fulgentius (1971) Mythologiae. Translated by Whitbread, L. G. Fulgentius the mythographer. Ohio: Ohio State University Press.

Himerius (2007) Orations. Translated by Penella, R. J. Man and the word: The orations of Himerius. Berkeley: University of California Press.

Inscriptiones Graecae (1974) Volume II, Inscriptiones Atticae Euclidis anno posteriores, part III, Dedicationes, titulos honorarios, titulos sacros, titulos sepulcrales continens, part 1, 2nd edn. Edited by Kirchner, J. Chicago: de Gruyter.

John Chrysostom, Homiliae in Matthaeum. PG, 57: 13-58.

Lexicon iconographicum mythologiae classicae (1984) vol. 2. Zurich: Artemis, 706-815.

Malalas (1831) Chronographia. Edited by Dindorf, L. Bonn: Weber.

(1986) Chronographia. Translated by Jeffreys, E., Jeffreys, M. et al. The chronicle of John Malalas: A translation, Byzantina Australiensia, 4. Melbourne: Australian Association for Byzantine Studies.

Marinus (1814) Vita Procli. Edited by Boissonade, J. F. Leipzig: Weigel.

Niketas Choniates (1984) Annals. Translated by Magoulias, H. J. O city of Byzantium: Annals of Niketas Choniates. Michigan: Wayne State University Press.

Parastaseis syntomoi chronikai (1984) Translated by Herrin, J. and Cameron, A. Constantinople in the early eighth century: The Parastaseis syntomoi chronikai. Leiden: Brill.

Procopius (1914-28) History of the wars. Translated by Dewing, H. B. LCL, 48, 81, 107, 173, and 217, 5 vols. Cambridge, MA: Harvard University Press.

Zosimus (1887) Historia nova. Edited by Mendelssohn, L. Leipzig: Teubner.

- (2006) Translated by Ridley, R. T. Zosimus: New history, Byzantina Australiensia, 2. Canberra: Australian Association for Byzantine Studies.

\section{Secondary sources}

Ando, C. (2001) 'The palladium and the pentateuch: Towards a sacred topography of the later Roman Empire'. Phoenix, 55/3/4: 369-410.

Asal, R. (2007) 'Commerce in Istanbul and the port of Theodosius'. In Pekin, A. K. and Kangal, S. (eds.), Istanbul: 8000 years brought to daylight: Marmaray, Metro, Sultanahmet excavations. Istanbul: Vehbi Koç Foundation, 180-9.

Athanassiadi, P. (1993) 'Persecution and response in late paganism: The evidence of Damascius'. Journal of Hellenic Studies, 113: 1-29.

Balaska, N. and Selenti, N. (1998) 'On the trade routes'. In Zafiropoulou, D. (ed.), Journeys on the seas of Byzantium. Athens: Hellenic Ministry of Culture, 54-69. 


\section{Janet Wade}

Bass, G. F. and Van Doorninck Jr, F. H. (1982) Yassi Ada: A seventh-century Byzantine shipwreck. Texas: Texas University Press.

Bassett, S. (2004) The urban image of late-antique Constantinople. Cambridge: Cambridge University Press.

Bell, P. N. (2013) Social conflict in the age of Justinian: Its nature, management, and mediation. Oxford: Oxford University Press.

Bendall, S. (1996) Byzantine weights: An introduction. London: Lennox Gallery.

Bowes, K. (2008) Private worship, public values, and religious change in Late Antiquity. New York: Cambridge University Press.

Brown, A. R. (2011) 'Banditry or catastrophe? History, archaeology, and barbarian raids on Roman Greece'. In Mathisen, R. W. and Shanzer, D. (eds.), Romans, barbarians, and the transformation of the Roman world. Surrey: Ashgate, 79-96.

Cameron, A. (1993) The Mediterranean world in Late Antiquity AD 395-600. London: Routledge.

(2015) 'Christian conversion in Late Antiquity: Some issues'. In Papaconstantinou (ed.), 3-22.

Corcoran, S. (2015) 'From unholy madness to right-mindedness: Or how to legislate for religious conformity from Decius to Justinian'. In Papaconstantinou (ed.), 67-94.

Dagron, G. (1974) Naissance d'une capitale: Constantinople et ses institutions de 330 à 451. Paris: Presses universitaires de France.

(1984) Constantinople imaginaire: Études sur le recueil des Patria. Paris: Presses universitaires de France.

Deacy, S. and Villing, A. (2001) Athena in the classical world. Leiden: Brill.

Deacy, S. (2008) Athena. London and New York: Routledge.

Dunbabin, K. M. D. (2003) Mosaics of the Greek and Roman world. Cambridge: Cambridge University Press.

Eliot, C. W. J. (1976) 'A bronze counterpoise of Athena'. Hesperia: The Journal of the American School of Classical Studies at Athens, 45/2: 163-70.

Fowden, G. (1991) 'Constantine's porphyry column: The earliest literary allusion'. JRS, 81: 119-31.

Franken, N. (1994) Aequipondia. Figürliche Laufgewichte römischer und frühbyzantinischer Schnellwaagen. Alfter: VDG.

Frantz, A. (1965) 'From paganism to Christianity in the temples of Athens'. DOP, 19: $185-205$.

(1988) The Athenian agora, volume XXIV, Late Antiquity: A.D. 267-700. Princeton: American School of Classical Studies at Athens.

Garcia Morcillo, M., Richardson, J. H., and Santangelo, F. (2016) 'Ruin or renewal? Places, monuments and memories in Ancient Rome'. In Garcia Morcillo, M., Richardson, J. H., and Santangelo, F. (eds.), Ruin or renewal? Places and the transformation of memory in the city of Rome. Rome: Edizioni Quasar, 9-26.

Gehn, U. and Ward-Perkins, B. (2016) 'Constantinople'. In Smith, R. R. R. and WardPerkins, B. (eds.), The last statues of antiquity. Oxford: Oxford University Press, 136-44.

Gonosova, A. and Kondoleon, C. (1994) Art of late Rome and Byzantium in the Virginia Museum of Fine Arts. Richmond, VA: University of Virginia Press.

Grig, L. and Kelly, G. (eds.) (2012) Two Romes: Rome and Constantinople in Late Antiquity. New York: Oxford University Press.

Harl, K. W. (1990) 'Sacrifice and pagan belief in fifth and sixth century Byzantium'. Past and Present, 128: 7-27.

Herrin, J. (2000) 'The imperial feminine in Byzantium'. Past and Present, 169: 3-35. 
Hunt, D. (1993) 'Christianising the Roman Empire: The evidence of the Code'. In Harries, J. and Wood, I. (eds.), The Theodosian Code. Ithaca, NY: Cornell University Press, 143-58.

Isaac, B. (2008) 'Roman victory displayed: Symbols, allegories, personifications'. In Friedland, E. A., Eliav, Y. Z., and Herbert, S. (eds.), The sculptural environment of the Roman Near East: Reflections on culture, ideology, and power. Leuven: Peeters, 575-604.

James, L. (1996) "“Pray not to fall into temptation and be on your guard": Pagan statues in Christian Constantinople'. Gesta, 35/1: 12-20.

(2001) Empresses and power in early Byzantium. London: Leicester University Press.

(2003) 'Who's that girl? Personifications of the Byzantine empress'. In Entwistle, C. (ed.), Through a glass brightly: Studies in Byzantine and medieval art and archaeology presented to David Buckton. Oxford and Philadelphia: Oxbow Books, 51-6.

(2005) 'Good luck and good fortune to the queen of cities: Empresses and tyches in Byzantium'. In Stafford, E. and Herrin, J. (eds.), Personification in the Greek world: From Antiquity to Byzantium. Aldershot: Routledge, 293-308.

Jenkins, R. J. H. (1947) 'The bronze Athena at Byzantium'. Journal of Hellenic Studies, 67: $31-3$.

Lavan, L. (2011) 'The end of the temples: Towards a new narrative?'. In Lavan, L. and Mulryan, M. (eds.), The archaeology of late-antique paganism, Late-Antique Archaeology, 7. Leiden: Brill, xv-lxv.

(2011a) 'Political talismans? Residual "pagan” statues in late-antique public space'. In Lavan, L. and Mulryan, M. (eds.), The archaeology of late-antique paganism, LateAntique Archaeology, 7. Leiden: Brill, 437-78.

Liebeschuetz, J.H.W.G. (1995) 'Pagan mythology in the Christian empire'. International journal of the Classical tradition, 2/2: 193-208.

Limberis, V. (1994) Divine heiress: The virgin Mary and the creation of Christian Constantinople. London and New York: Routledge.

Lundgreen, B. (1997) 'A methodological enquiry: The great bronze Athena by Pheidias'. Journal of Hellenic Studies, 117: 190-7.

Maas, M. (1992) John Lydus and the Roman past: Antiquarianism and politics in the age of Justinian. London and New York: Routledge.

McClanan, A. (2002) 'Early Byzantine steelyard weights: Potency and diffusion of the imperial image'. In McClanan, A. (ed.), Representations of early Byzantine empresses: Image and empire. New York: Palgrave Macmillan, 29-64.

MacCormack, S. (1975) 'Roma, Constantinopolis, the emperor, and his genius'. Classical Quarterly, New Series, 25/1: 131-50.

Machado, C. and Lenaghan, J. (2016) 'Rome'. In Smith, R. R. R. and Ward-Perkins, B. (eds.), The last statues of antiquity. Oxford: Oxford University Press, 121-35.

MacMullen, R. (1997) Christianity and paganism in the fourth to eighth centuries. New Haven: Yale University Press.

Maguire, H. (2001) 'The good life'. In Bowersock, G. W., Brown, P., and Grabar, O. (eds.), Interpreting Late Antiquity: Essays on the postclassical world. Cambridge: Harvard University Press, 238-57.

Mango, C. (1963) 'Antique statuary and the Byzantine beholder'. DOP, 17: 53-75.

Mellor, R. (1975) $\Theta E A$ PSMH: The worship of the goddess Roma in the Greek world. Göttingen: Vandenhoeck and Ruprecht.

Meriçboyu, Y. and Atasoy, S. (1983) Büst Şeklinde Kantar Ağırlıkları. [Steelyard weights in the form of busts: Archaeological museum of Istanbul]. Istanbul: Arkeoloji ve Sanat Yayınları. 
Metropolitan Museum of Art Online Collection (2018) Available at: www.metmuseum.org/ art/collection/search (accessed: 22 June 2018).

Papaconstantinou, A. (ed.) (2015) Conversion in Late Antiquity: Christianity, Islam, and beyond. Surrey: Routledge.

Papanikola-Bakirtzi, D. (2002) Everyday life in Byzantium. Athens: Hellenic Ministry of Culture.

Paton, W. R. (trans.) (1916-18) Greek anthology, LCL, 67-68 and 84-86, 5 vols. Cambridge, MA: Harvard University Press.

Pekin, A. K and Kangal, S. (eds.) (2007) Istanbul: 8000 years brought to daylight: Marmaray, Metro, Sultanahmet excavations. Istanbul: Vehbi Koç Foundation.

Pitarakis, B. (2012) 'Daily life at the marketplace in Late Antiquity and Byzantium'. In Morrisson, C. (ed.), Trade and markets in Byzantium, Dumbarton Oaks Byzantine symposia and colloquia. Washington, DC: Dumbarton Oaks, 399-426.

(2016) 'The Byzantine marketplace: A window onto daily life and material culture'. In Magdalino, P. and Necipoğlu, N. (eds.), Trade in Byzantium: Papers from the third international Sevgi Gönül Byzantine studies symposium. Istanbul: Koç University Press, 211-31.

Robertson, N. (1996) 'Athena's shrines and festivals'. In Neils, J. (ed.), Worshipping Athena: Panathenaia and Parthenon. Wisconsin: University of Wisconsin Press, 27-77.

Sauer, E. W. (2003) The archaeology of religious hatred in the Roman and early medieval World. Stroud: Tempus.

Shearer, A. (1998) Athene: Image and energy. London: Penguin Books.

Smith, A. C. (1994) 'Queens and empresses as goddesses: The public role of the personal tyche in the Graeco-Roman world'. Yale University Art Gallery Bulletin, 86-105.

Trombley, F. R. (1985) 'Paganism in the Greek world at the end of antiquity: The case of rural Anatolia and Greece'. HTR, 78 (3/4): 327-52. (1993/94) Hellenic religion and Christianization c. 370-529, 2 vols. Leiden: Brill.

Vermeule, C. C. (1959) The goddess Roma in the art of the Roman Empire. London: Spink.

Wade, J. (2014) 'Sailors, merchants and the maritime cults that sailed into the ports (and streets) of early Byzantium'. In Dzino, D. and Parry, K. (eds.), Byzantium, its neighbours and its cultures, Byzantina Australiensia, 20. Brisbane: Australian association for Byzantine studies, 269-87.

Weitzmann, K. (ed.) (1979) Age of spirituality: Late-antique and early Christian art, third to seventh century. New York: Metropolitan Museum of Art. 


\title{
15 Transformation of Mediterranean ritual spaces up to the early Arab conquests
}

\author{
Leonela Fundic
}

For many decades, constructing churches on or near sites of ancient temples was interpreted in the light of different literary sources as a brutal act of Christian emperors, bishops, or monks in the name of their God (Saradi-Mendelovici 2008; Caseau 2001). Eusebius of Caesarea's Ecclesiastical History and Life of Constantine are among the best examples of how Christian writers emphasised the supremacy of Christianity over paganism. ${ }^{1}$ Presenting Constantine (r. 312-7) as an emperor sent by God to save Christians from persecutions, Eusebius claims that he prohibited all pagan sacrifices (Vita Constantini 4.25) and ordered the destruction of four pagan temples. These were the Temple of Venus on Golgotha (Vita Constantini 3.26), the Temple of Venus at Aphaca (Vita Constantini 3.55), the Temple of Venus at Heliopolis-Baalbek (Lebanon) (Vita Constantini 3.58), and the Temple of Asclepius at Aegae in Cilicia (Vita Constantini 3.56; Bradbury 1994: 123).

Constantine also built a church at ancient Mamre, near the town of Hebron, on the site known as the 'Oak of Abraham,' where Jews, Christians, and followers of traditional religious cults gathered to venerate Abraham who received angelic visitors under a certain tree (Gen 18:1-15). According to Eusebius, the emperor Constantine ordered the burning of pagan images, the demolition of altars, and the proscription of pagan practices, and constructed a Christian basilica dedicated to St George (Vita Constantini 3.51-3). The Eusebian accounts and archaeological sources provide us with conflicting information about the conversion of the above-mentioned temples. For instance, the Church of Holy Sepulchre was built on the previous Temple of Aphrodite on Golgotha using its building material (Coüasnon 1974; Gibson and Taylor 1994). According to Eusebius, the site was destroyed and purified after removing every stone and even the soil from the flat surface (Vita Constantini 3.26).

Archaeological excavations carried out at ancient Mamre have confirmed that Constantine's church was not built on the top of the holy site with the well and the oak, possibly to avoid full Christianisation of the site (Bar 2008: 284-5). Rather, it seems that this holy place was also accessible to affiliates of religions other than Christianity. This is the second holiest site in Judaism, but also sacred to Christians and, after the seventh century, to Muslims as well. Since a major intercultural and commercial festival was held annually at Mamre with the participation of pagans too, it is very likely that Constantine did not have any intention to show 
hostility towards them. Furthermore, pagan temples were often commercial and social centres, and for that reason they were protected by emperors. For example, the decree from the year 346, issued by Constantius II (r. 337-61) and Constans (r. 337-50), protected temples located outside the city walls, due to their connection with public entertainment (CTh 16.10.3).

As mentioned previously, Eusebius claims that Constantine issued successive laws and ordinances, forbidding anyone from offering sacrifices to idols. However, this is not confirmed by other written sources. According to Libanius (d. 394), it was not Constantine but his son Constantius II who prohibited sacrifices (Pro templis 6, 37-8; Lenski 2016: 171-2).

It is widely acknowledged that Eusebius's literary aims were ideological rather than historical (Wallraff 2011), and it seems that Constantine left intact a number of pagan temples (Bardill 2012: 261). If we leave aside Eusebius's testimony about Constantine and follow other historical and archaeological sources, it will be obvious that Constantine had some positive attitudes towards pagan temples and gods, as well as towards classical heritage in general (Lee 2015: 77-95; Potter 2013; Bardill 2012; Bradbury 1994: 123). On his coinage the emperor, replacing the figure of Hercules, who was associated with the Claudian dynasty, portrayed the sun god (Sol Invictus), a patron of soldiers in the later Roman Empire (Lieu and Montserrat 1996: 75). In addition, Constantine decorated his new capital city of the empire, Constantinople, with many pagan statues (Saradi 1997; Bassett 2004). Moreover, in Constantinople, Constantine or one of his sons, in a larger context of preserving the memory of the Old Rome, modelled the newly established city of the New Rome on the image of the Old Rome (Zosimus, Historia nova 2.30) and built the Capitolium with sanctuaries dedicated to Jupiter Optimus Maximus, Juno, and Minerva.

Some examples of the destruction of pagan temples that Eusebius ascribed to the emperor Constantine are attested by other sources, but they seem to be isolated incidents. As we can observe, despite the fact that Constantine and his heirs supported Christianity, they did not always behave violently to the pagans as has frequently been believed. Firstly, we have to keep in mind that paganism was an important element in the Roman Empire, especially for the upper class and powerful local families who were mainly wealthy landowners. Their personal fortunes were related to regular markets, celebrations, and other events related to the pagan temples. The emperors tried slowly to convert them into the Christian faith, without using violence. Around the year 400, half of the imperial subjects were still followers of the traditional Graeco-Roman religious cults (MacMullen 1984: 65 n.16). They coexisted together with Christians and influenced each other (Guignebert 1923). A visible indication of peaceful coexistence between pagans and Christians is the decoration of the small temple on the Embolos in Ephesus, reconstructed between 383 and 387 . It was decorated by reliefs of the imperial family surrounded by a great range of pagan gods as well as mythological founders of the city (Bayliss 2004: 61 n.45).

Even in Palestine many pagan sites remained in place (Bar 2003). Moreover, pagan practices still flourished during Theodosius's reign and later in the fifth 
century, at the beginning of a period when this contrast was hardly possible. I will return to this in the next section.

The archaeological remains from across Greece and Asia Minor show little evidence of violent destruction of Graeco-Roman temples. Rather, excavations suggest that many pagan temples were abandoned or destroyed due to various natural disasters in the pre-Christian period or before Christianity was spread throughout certain areas. Hence, the destruction of pagan temples by Christians was generally only a sporadic phenomenon with local bishops or monks, who were the key protagonists in the fight against paganism, acting without officially granted authority (Fowden 1978: 65). Scholars frequently cite the example of the bishop Marcellus (d. 389) who reportedly destroyed the Temple of Zeus Belos at Apamea (Syria) in $386 \mathrm{CE}$. However, this case should also be revisited since similar accounts of temple destruction found in saints' lives can be characterised as fictitious stories (Busine 2013). An account of this incident is found in the Church History (5.22) by Theodoret of Cyrrhus (d. 457), who, however, is known for mixing up historical events with miraculous motives (Busine 2013: 327-8). Scholars usually regard his description as evidence of Christian hostile attitude towards pagan gods and temples, even though this may not be the case. Some scholars have expressed their doubts that there was any violence against the Temple of Zeus in Apamea (Busine 2013: 329). Since it was written long after the event it claims to record, Theodoret's account may have been written with an intention of explaining the remains of the collapsed sanctuary and/or of strengthening the identity of the Christian community at Apamea (Busine 2013: 337).

Another good example is the report of the destruction of the Marneion (the Temple of Zeus Marnas) described by Mark the Deacon's Life of Porphyry of Gaza, written a century and a half after the supposed destruction (Life of Porphyry of Gaza 26.76). Due to the considerable chronological distance from the supposed event, it cannot be regarded as a reliable source to draw a definite conclusion.

\section{Christian transformation of pagan sites}

According to various sources, it appears that Christians converted many pagan temples into Christian churches or secular public buildings. They also recycled earlier building material from pagan sites in their new constructions. For example, Libanius in his funeral oration on the emperor Julian praises him for imposing fines on those who 'used the materials of temples for building their own houses'

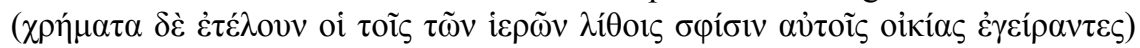
(Oration 18.126). A notable example of the transformation of a public building into a shrine is the church of Santa Maria Antiqua in the Roman Forum, a former guard house (Schuddeboom 2017: 172). Since many churches did not symbolise Christian triumph, nor was their conversion accompanied by violence as a result of religious intolerance, we should also look into the changing and reshaping of ritual spaces and temples from the fourth to the sixth centuries, instead of their violent destruction. We need to keep in mind that certain pagan buildings, especially Roman basilicas, served as prototypes for early Christian churches 
(Krautheimer and Ćurčić 1986: 39-67). The opinion that pagan culture was part of a divine plan to prepare the world to receive the ultimate truth was firmly established very early. Clement of Alexandria, for example, stressed a preparatory role of Greek wisdom, especially Plato's philosophy, when he argues that 'philosophy was given to the Greeks as a covenant peculiar to them, being, as it is, a stepping-

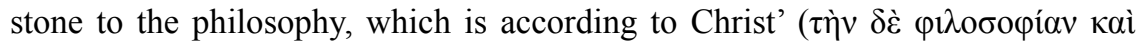

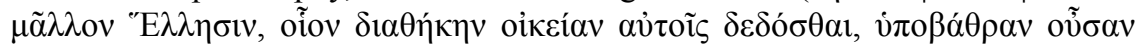

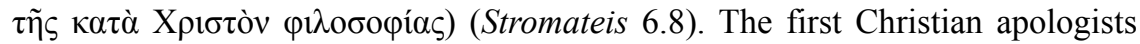
generally had alliances with the philosophers to show their readers that parts of the Greek traditions agreed with Christianity in certain respects (Jacobsen 2017: 555). Likewise, ancient monuments, both buildings and statues, were powerful manifestations of ancient culture and could be 'Christianised' on the grounds of their artistic values or as valuable means of allegoric interpretation (SaradiMendelovici 1997: 403). We should distinguish between different manners of the reuse of pagan temples by Christians.

First, in certain areas, many pagan temples were abandoned one or even two centuries before the Christian religion spread there. Furthermore, non-Christians themselves used their temples for various secular purposes. Libanius testifies to a secular usage of three pagan temples in Antioch. According to the famous rhetor, Museion was used as a school (Oration 1.102), a temple of Dionysus as a courtroom (Oration 45.26), and the one of Athena as a lawyers' meeting place (Letter 847.1). There were many other examples of temples' conversions to taverns, gaming rooms, carriage-houses, and so on (Bayliss 2004: 61). In some cases, as we have already seen, in order to protect old temples Christian emperors used them as important social centres in which many festivals, markets, and other public or commercial events, characteristic for the pagan tradition, were held.

Second, many abandoned temples were reused by necessity as places of Christian worship since this was more convenient than building a church from the beginning. Third, a great number of churches were built purposely on the sites where pagan temples pre-existed or they reshaped the existing temple into the Christian church to preserve the memory of the past and to create an idealised future. Christians reused these pagan sites and temples as a link with the Roman past to underline the legitimacy of the new empire. In many instances, Christians, who regarded themselves as heirs of the classical culture, had great appreciation for the monuments of a city's cultural heritage as well as of the artistic value of pagan monuments. They displayed statues and other pagan objects for their artistic value or for their apotropaic power. For example, the emperor Theodosius I (r. 379-95), in the Constitution from the year 382, ordered that a certain temple at Oshoene in Mesopotamia should be kept open so that the public could enjoy the aesthetic value of the statues displayed there (Saradi-Mendelovici 1990: 51; Lee 2015: 117-18). For the emperors this represented a kind of nostalgia for the illustrious and idealised past of the Greek and Roman worlds and a way to connect and return to their perceived classical inheritance. This phenomenon was not characteristic of large cities only; even in the provinces we sometimes find that pagan statues had been maintained by Christians and displayed as objects of art. 
The Gymnasium of Salamis in Cyprus is an excellent example. After its destruction by an earthquake in the fourth century, several statues were preserved by the Christians (Horster et al. 2018).

Between 363 and 375, the emperors Jovian and Valentinian followed a tolerant policy towards paganism in the Roman Empire (Lee 2015: 110-16). However, as the time progressed towards the end of the fourth century, violent attacks against pagans and their temples became more frequent in eastern provinces, even though such actions were illegal (Lee 2015: 116). The majority of such attacks were carried out during the reign of Theodosius II (r. 408-50) who compiled the CTh, which became the official law of the empire in 439 (Pharr 1952; Sirks 2007; Crogiez-Pétrequin and Jaillette 2009; Harries and Wood 2010). Even though all kinds of pagan sacrifices were prohibited, these prohibitions were not imposed in many important centres in Palestine, Syria, Greece, and Rome, which meant that pagan temples remained open as late as the sixth century or even afterwards. It has been argued that in Palestine all pagan communities were converted by the first half of the fifth century. However, based on excavations around Palestine, as for instance in Scythopolis, Caesarea Philippi (Paneas) in northern Palestine, as well as in different rural areas including Mt Hermon, it has been proved that pagan temples were in use during the sixth century (Bar 2003).

Similar examples can be found in Syria. Probably the best example is the city of Zorava (modern Ezra), $80 \mathrm{~km}$ south of Damascus, where the first Christian communities were settled very early (Figure 15.1). However, destruction and conversion of pagan temples into Christian churches started from the sixth century

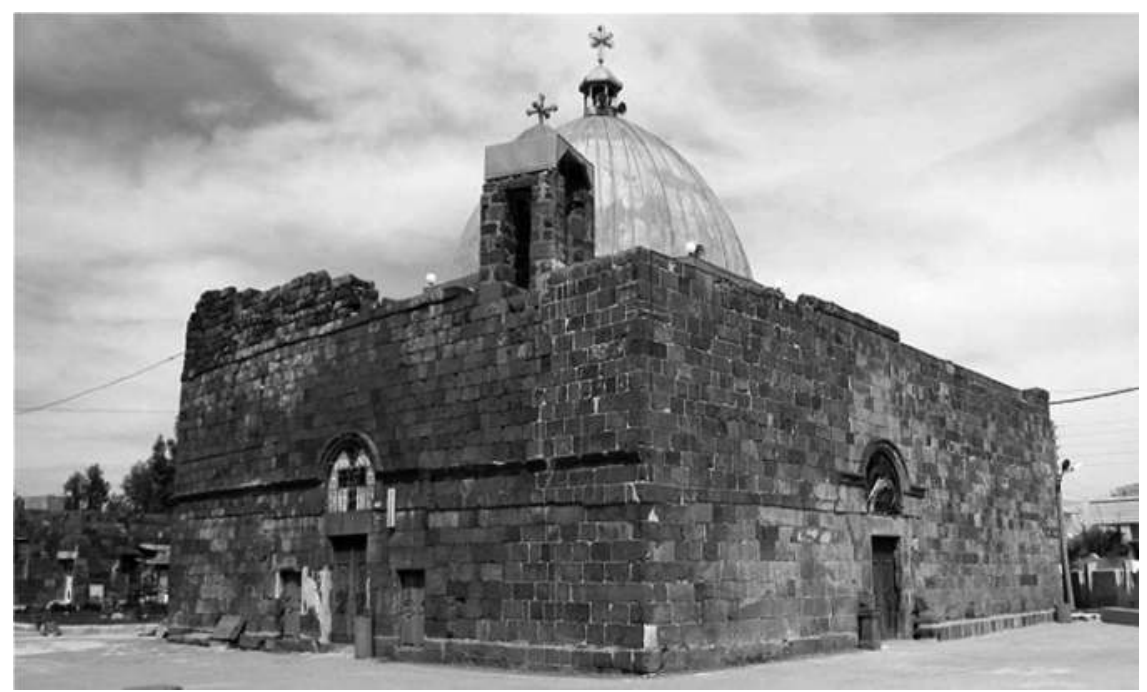

Figure 15.1 St George in Zorava (Izraa), southwest Syria.

Source: Photo credit: L. Fundic. 


\section{6}

onward, as testified by the inscription from the western entrance to the Church of St George (Deichmann 1939: 114; Chuvin 1990: 141; Bayliss 2004: 54), which reads as follows:

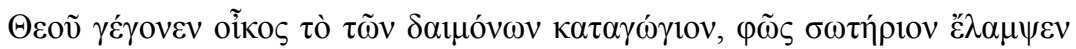

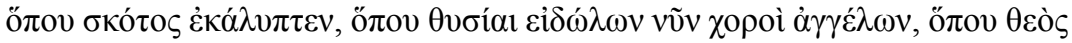

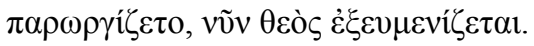

The House of Evil was turned into the House of God. Hymns of cherubs replaced sacrifices offered to idols and God settles here in peace, where people used to anger him.

(Corpus inscriptionum graecarum IV, 8627)

This church was constructed on the site of a previous temple by reusing its building material in 515. There is also another nearby church in Zorava dated to 542. The church is dedicated to St Elias and largely reconstructed today, but still preserves many ancient spolia with decorated sculpture (Warwick 2016: 289).

In Greece, and especially in Athens, pagan temples were functioning at least until the last pagan philosophical academy was closed in 560 (Cameron 1969: 9-12). The city was an important education centre and the cradle of classical culture, so the pagan tradition was protected. The Christians avoided any building activity in the centre of Athens during the fifth century (Figure 15.2). Frantz has argued that churches in or near the most important temples of Athens, such as the

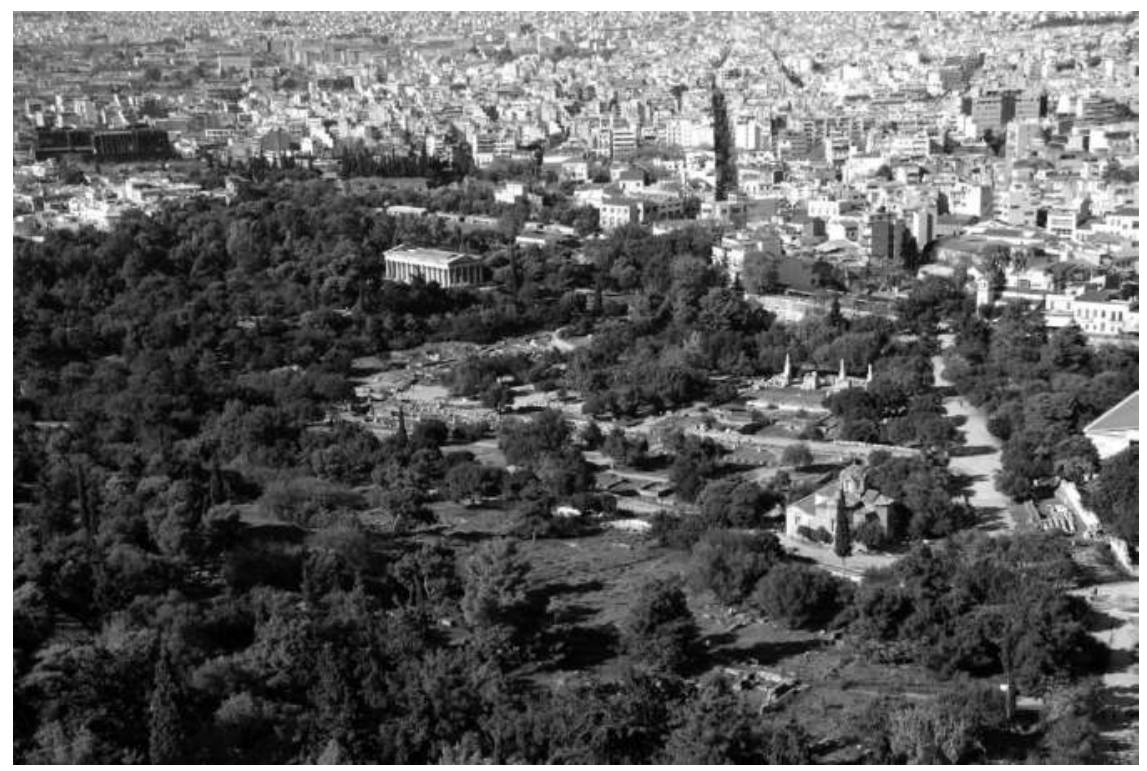

Figure 15.2 Theseion, Athens.

Source: Photo credit: L. Fundic. 
Parthenon, the Erechtheion, the Hephaisteion, and the Temple of Asclepius, were built only in the sixth or seventh centuries, not earlier, as had been previously assumed (Frantz 1965).

Similar examples of surviving ancient pagan sites are found in Egypt. The Temple of Isis at Philae in Thebais, southern Egypt, not only remained intact, but pagan rituals were performed until the mid-sixth century (Bayliss 2004: 57; Lee 2015: 146-7).

Another example includes Aphrodisias in western Anatolia, Turkey, which had an important school of philosophy and was an active centre of paganism until the end of the fifth century (Lee 2015: 139-41). Around 640, the city was renamed in Stauropolis, which means the city of the Cross (Roueché and Reynolds 1989; Chaniotis 2008; Dalgıç 2012).

A surprisingly slow process of Christianisation of pagan buildings and transformation of religious landscape can also be observed in Rome. Many pagan cults continued to exist in Rome until the sixth century. Most of the buildings were not in use, but they were preserved untouched. For instance, the Temple of Venus and Rome was closed in 391, but the site was first reused in 624, when Pope Honorius removed the bronze tiles from this temple for the re-roofing of St Peter's basilica (Hansen 2003: 115). Honorius requested permission from the emperor Hadrian for this action since ancient buildings were under legal protection. During the fourth century, no more than a handful of Christian basilicas were built in Rome, while the earliest known conversion of a pagan temple into a church, the Pantheon, dates to c. 609 ( $L P$ 1.72, Duchesne and Vogel 1955: 110; Krautheimer 1980: 35, 65-72). Several more cases of the conversion of a temple into a church include San Lorenzo in Miranda (former temple of Antoninus and Faustina); Santa Maria de Secundicerio (the temple of the harbour god Portunus); Santo Stefano delle Carrozze (former temple of Hercules Victor); and Sant'Urbano alla Caffarella (former temple of Ceres and Faustina) (Schuddeboom 2017: 173, 175). Overall, archaeological evidence suggests that in Rome only 11 out of 424 pagan temples were converted into Christian churches from the seventh century onwards (Schuddeboom 2017: 176). However, during the sixth century, outside Rome, paganism was in decline and almost every city had a Christian church, sometimes built on the site of a previous pagan temple.

From the sixth century onward, the Christians started to rebuild or reuse pagan sites more frequently. In many cases this practice was intended to keep links with the grandiose Graeco-Roman past. Along with the use of the same location and architectural material, the Christians often incorporated ancient Graeco-Roman inscriptions in their churches. The incorporation of pagan inscriptions into Christian shrines is a topic which requires further and more detailed investigation in order to shed more light on the problem of reuse or destruction of pagan temples. It has been argued that the use of these ancient inscriptions needs to be seen in the context of Christian triumphalism. At Priene, which was located on the Aegean coast of western Turkey, a great number of inscriptions was discovered on stelai built into the floor of a late-antique basilica, usually identified as a cathedral, near the Sanctuary of Athena Polias (Hiller von Gaertringen 1906; Westphalen 1998). 
The sanctuary was still standing for at least part of Late Antiquity, as evidenced by a number of Christian graffiti found on its walls (Wiegand and Schrader 1904: 88). The destruction of the temple was caused by an earthquake and a subsequent fire. Some parts of it were reused for later Byzantine building activities. It has been proposed that these stelai were transferred from the sanctuary of Athena. Saradi interprets this as evidence of a triumphalist attitude from the late-antique Christians of Priene (Saradi-Mendelovici 1997: 401). She has based her interpretation on a hagiographical source, namely on the Life of St Porphyry of Gaza, which describes the paving of a church courtyard with slabs from the famous pagan sanctuary known as Marneion, so 'that it might be trodden under foot not only of men, but also of women and dogs and swine and beasts. And this grieved the idolaters more than the burning of the temple' (Life of Porphyry, 76). However, we should not exclude the possibility that this story was made up for rhetorical or some other reasons (Busine 2013: 330).

We can find many examples of the reuse of pagan ritual spaces and incorporation of ancient inscriptions by Christians, as seen in this little known example from the south Peloponnese in Greece. The Basilica of Messene (Figures 15.3 and 15.4) was constructed on the ruins of an ancient temple (probably dedicated to Aphrodite). The temple fell during a great earthquake which destroyed the entire city at the end of the fourth century, and was further destroyed by a catastrophic raid by the Goths in $395 \mathrm{CE}$ (Luraghi 2008). The temple remained in ruins for more than 150 years. In the middle or the second half of the sixth century, a large

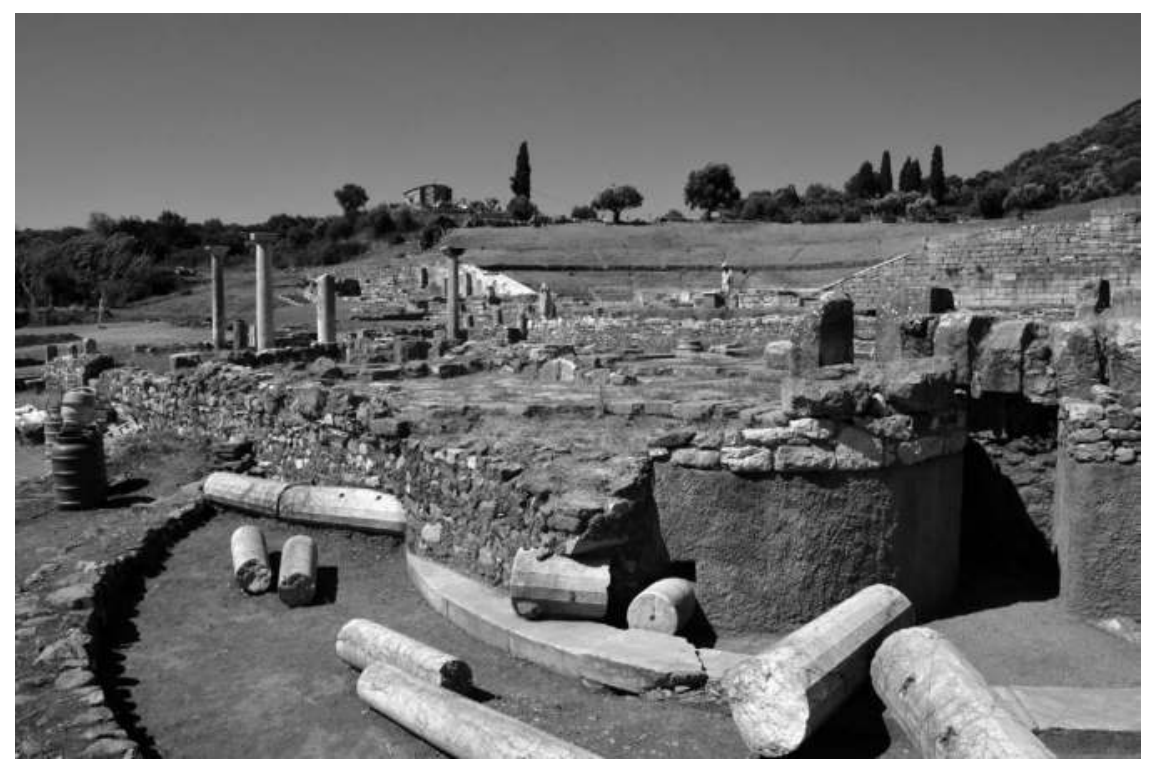

Figure 15.3 Basilica of Messene, Peloponnese, Greece.

Source: Photo credit: L. Fundic. 


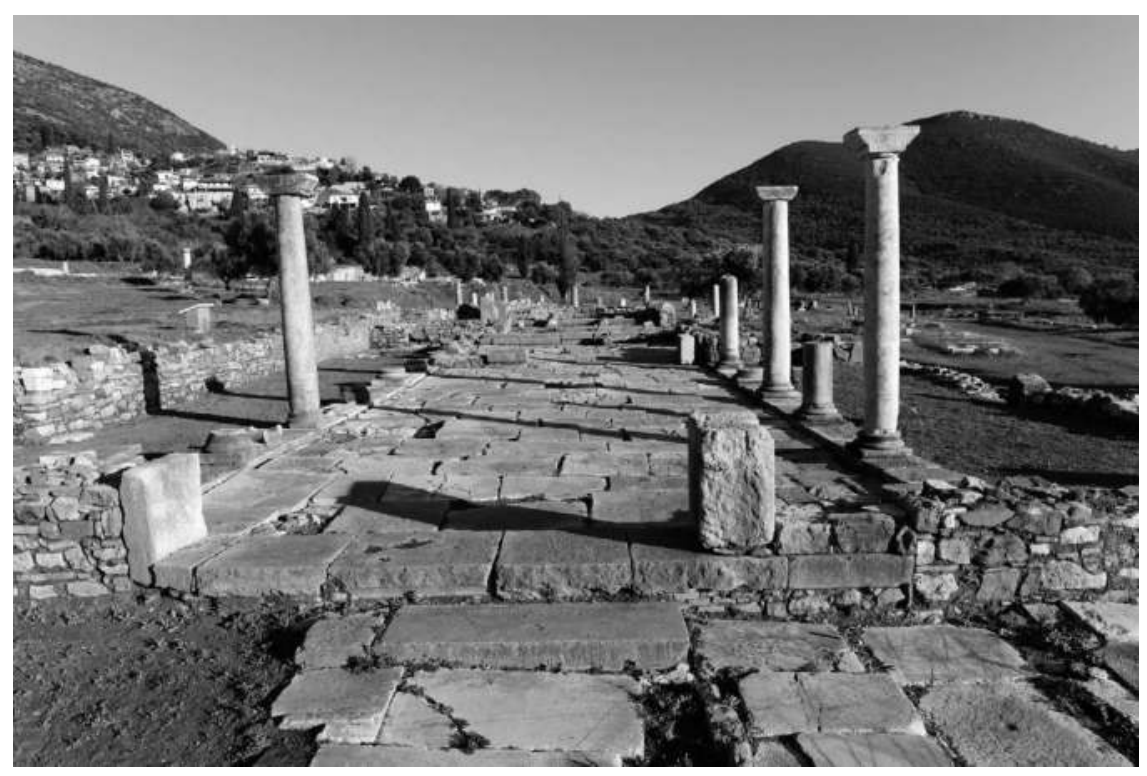

Figure 15.4 Basilica of Messene, Peloponnese, Greece.

Source: Photo credit: L. Fundic.

three-aisled basilica, which probably should be identified with the city's episcopal church, was constructed on the ruins of the ancient temple. Excavations have shown that the spolia used for the construction of the basilica had already been buried in the earth for a long time. This indicates that Christians did not destroy the ancient temple to build their church. What renders this church important for the present discussion is the existence of three inscriptions preserved in the conch of the sanctuary. The first contains the name of Aristomenes, an ancient priest of Zeus Ithomatas, and the second mentions Alexander. There is also a third long inscription preserved with the names of the ancient priests Dionysios, son of Aristomenes, and other descendants of Aristomenes.

The incorporation of these inscriptions, which refer to the ancient priests and members of the Messene elite, cannot be accidental. Rather, there is good reason to assume that the church's donor wanted to stress the supremacy of the new religion, which he demonstrated by constructing the church in the place of an ancient temple. By placing these three inscriptions in the sanctuary, the most sacred part of the church, the donor wanted to emphasise the idea of continuity between the two cultures, as well as to show that the ancient tradition was embedded in Christianity. Even if we adopt a more critical approach and exclude the possibility of an intention to show the continuity between the two cultures, the preservation of the inscriptions is further proof that the Christians were not as destructive and 
negative towards the ancient material heritage as their own sources often present them as being.

However, there was also another approach to the reusing of pagan sites. When temples were abandoned or in some cases destroyed by Christians, these sites were sometimes avoided, and churches were not built in their place. One of the reasons behind this was the Christians' firm belief that demons inhabited the pagan sites of worship. According to hagiographical sources, some saints moved to deserted pagan temples for the purpose of spiritual warfare. One of the earliest examples is the Life of St Thekla of the fifth to sixth centuries. This saint moved to the Temple of Sarpedon in Seleucia to live there and wage spiritual war on demons (Dagron 1978: 84, 278).

The challenges for Christianity were not only limited to the pagans who did not want to convert but also to the first generations of the newly Christianised aristocracy. These may not have practised animal sacrifices or devotion to the ancient gods, but they brought with them into Christianity their other old religious habits. One such habit was the private ritual of household worship, something that also affected and slowed down the transformation and Christianisation of ritual places. The first Christian worship places were patrons' homes, usually in the dining room. Gradually, these spaces for 'house churches' were modified and grew larger, as for instance in Dura Europos in Syria (Kraeling 1967; Peppard 2016). These houses belonged to wealthy Christians (White 1990; White 1997). In the first two centuries, when Christianity was an unofficial cult without public worship, this space was the most suitable for their cult. The next generation of Christians, even when Christianity became an official religion, continued to rely upon the private patronage of the Christian elite for their worship spaces. Before the sixth century, they usually did not show much interest in building sacred objects for liturgical purposes, as, for example, in constructing a major basilica in the city or martyrs' shrines.

Many of these families continued to cultivate their private devotion and construct their own private ritual spaces (Bowes 2008). They did not ask for any official approval for their private churches. Bishops, who claimed their episcopal leadership as spiritual descendants of the apostles, did not have the same power as wealthy Christian families did, and they could not control the elites' use of their own properties. Burial and baptism were outside public spaces and many Christian individuals and families cultivated their own rituals (Bowes 2008: 52-56). This phenomenon, which was quite common in Rome and generally in the West, needs to be considered against the worshippers' polytheist Roman or Jewish backgrounds. Furthermore, their patronage and construction of shrines could also be regarded as a way of ensuring popularity with the masses and promotion of their importance in a community's hierarchy.

Despite many efforts by popes, including Pius (140-55), Callixtus (217-22), Marcellus (308-9), Sylvester (314-5), Mark (336), Julius I (337-52), and Liberius (352-66), to build public basilicas in Rome, many Christians continued to gather for their worship in their private houses during the third and fourth centuries (LP 1, Duchesne 1955-57: 170, 187, 202, 205, 208; Cecchelli 2001: 288-90: 
Krautheimer et al. 1937-77, 1. 146-59, 2.173-83, 2.244-6, 3.121-3). Private aristocratic houses (domus), domestic halls (aulae), and reception halls were the main places for Christian worship during the third and fourth centuries (Bowes 2008: 72-4). Thanks to archaeological excavations, eight churches in Rome can be dated to the fourth century: San Marcello, Santa Pudentiana, Santa Maria Maggiore, Basilica Liberiana, San Lorenzo in Damaso, San Marco, Santa Anastasia, and San Clemente (Cecchelli 2001; Krautheimer et al. 1937-77; Saxer 2001).

Archaeological investigations testify that the process of building public Christian basilicas in Rome was slow and started to flourish in the last two decades of the fifth century. The aristocratic domus and aulae gradually transformed into public basilicas, as testified by archaeological excavations at Quattro Coronati, San Clemente, and Santa Susana, among others. The preserved examples of public basilicas dated to the fifth century include San Lorenzo in Lucina, San Vitale, San Pietro in Vincoli, Santa Maria in Trastevere, San Chrysogono, Santa Sabina, Santi Giovanni e Paolo in Laterano, and San Sisto Vecchio (Cecchelli 1999, 2001; Krautheimer et al. 1937-77; Saxer 2001). In all these examples of first Christian private or public ritual spaces, there is no mention of destruction or replacement of any pagan sites.

\section{Muslim transformation of ritual spaces}

Due to the Persian and Islamic conquests, sacred landscapes in the Mediterranean basin underwent fundamental changes during the sixth and especially the seventh centuries. As a result, dramatic and permanent transformations of sacred topography occurred in the same region during this period. In the first half of the seventh century, the Arabs waged numerous wars of conquest, successfully invading vast territories, including large parts of Syria and Palestine. In 661 Damascus became the centre of the Muslim world with political power concentrated in the hands of the Umayyad dynasty (Hawting 2000). However, since this was a newborn empire, they needed to create institutions of government, and learn traditions of art, architecture, and building (Yeomans 1999: 26). Consequently, they reshaped existing buildings or built new ones, employing non-Muslim architects and artists who already had such skills (Rivoira 1918). When Islam appeared as a new faith in the seventh century, it also offered a vision of replacement, asserting that it was the perfected form of both Judaism and Christianity. Based on 'replacement theology,' according to which the Graeco-Roman tradition was embedded in Christianity and Christianity in Islam (see Simic in Chapter 10), Muslim theologians regarded both Judaism and Christianity as deviations from a common Islamic origin. According to this perception, Islam was the primeval religion preached by Abraham, Moses, the Old Testament prophets, and Jesus, who was just another prophet, not the fulfilment of the prophecies, as the Christians believed. Moreover, his second coming would bring about the end of Christianity (Thettayil 2007: 464-5).

As Islam was offering the idea of fulfilment and perfection of Christianity, in the beginning Muslims did not intend to destroy Christian sacred sites and churches. Rather, they wanted to reshape them for the purpose of the new faith. 
Thanks to the Islamic respect for some Christian cults, despite their conversion to mosques, parts of certain churches retained and continued their previous functions as Christian sites of worship. One of the best-known examples is the Great Mosque of Damascus, also known as the Umayyad Mosque, founded by Abd al-Malik's son, Caliph al-Walid, in 715 (Flood 2001). The mosque was built on the site of the Cathedral of St John the Baptist. It has the same plan as a RomanByzantine basilica and is decorated with mosaics under considerable Byzantine influence. In the first years after the conquest of Damascus, the cathedral of St John was shared between Christians and Muslims. After the construction of the mosque, John's shrine continued to exist within it and is still located there. It is considered one of the largest and oldest congregational mosques in the Muslim world.

A second characteristic example is the Ayyubid mosque in Ezra. All that survives of it today is the prayer hall, which is still largely intact, with two arcades of arches supported on a variety of pillars, columns, and one double column. The corbelled ceiling is still in place, as is the black and white banded mihrab. The mosque was built between two churches, those of St George and St Elias (542 $\mathrm{CE}$ ). These two churches are the oldest buildings in Syria in continuous use as sites of Christian worship. The fact that these two churches survived through the centuries may well be due to the fact that they were dedicated to saints held in great esteem by Muslims as well. St George, one of the most popular Christian military saints, is also regarded as a saint and a martyr by Muslims. The Jewish prophet and Christian saint, Elijah, is also greatly revered in Islam. It should also be noted that St Catherine's Monastery on Mount Sinai, founded by the Byzantine emperor Justinian (r. 527-65), was protected by Muslim rulers through centuries. Within the monastery complex there is also a mosque, which, according to a legend, was built in the eleventh century and still serves Muslim guests (Friedman and Figg 2000: 102).

There are many other examples from the seventh century showing how Muslims as other 'people of the Book' chose to build their ritual spaces on the holiest sites. In Mamre, the ruins of the Christian church dated to around 570 were converted by Muslims into a mosque in the seventh century. Some other well-known examples include the Al-Aqsa Mosque in Jerusalem (Magness 2012: 355), the Great Mosque in Hama (Creswell 1959), and the Great Mosque of al-Nuri in Homs.

The conversion of a church to a mosque was not just a material inheritance, but a spiritual one, too. Many Muslim writers refer to miraculous stories of portentous phenomena such as the collapse of minarets that occurred during or after the conversion of a church to a mosque. These disasters were generally interpreted by Muslims as the work of Christian black magic and as punishment for the sacrilege committed (Hasluck 1973: 20-36).

\section{Conclusion}

From this brief overview of the process of changing and reshaping pagan temples, ritual spaces, and Christian shrines from the fourth to the eighth centuries, two 
observations can be made. First, the supremacy of the new religions of Christianity and Islam was established through constructing churches in the place of ancient temples, or mosques in the place of Christian shrines. Second, emperors and other donors also wanted to emphasise the idea of continuity between the cultures and religions. When seen in this light, as well as through the prism of the so-called replacement theology, Christian stories of violent attacks on temples during Late Antiquity should be read with great caution. This holds especially true for the accounts found in hagio-biographical literature, since such stories may have been invented to serve ideological purposes.

Furthermore, many abandoned pagan temples took on secular functions in the fourth or early fifth centuries prior to their conversion into churches or final abandonment. Others were left intact in order to preserve the memory of the glorious past or simply as signs of nostalgia for the classical heritage of the Graeco-Roman world. Hence, instead of being destroyed they were frequently reshaped for the needs of the new religion. This reflects, among other things, the belief that each new religion improves upon and is the fulfilment of the promises of the ones preceding it. The sacred places and landscapes of previous religions are thus incorporated into successive and current ritual narratives.

\section{Note}

1 Despite some recent assessments that the term paganism is inaccurate, it is still widely applied among late-antique scholars to describe the traditional Graeco-Roman religious cults (van Nuffelen 2011: 87-110; Cameron 2011: 14-32).

\section{Bibliography}

\section{Primary sources}

Clement of Alexandria (1906) Stromata. Edited by Stählin, O. Clemens Alexandrinus, Stromata, GCS. Leipzig: J.C. Hinrichs.

Corpus inscriptionum graecarum (1828-77) Edited by Boeckh, A, 4 vols. Berlin: Georg Reimer.

CTh (1905) Edited by Mommsen, T. Theodosiani libri XVI cum constitutionibus Sirmondianis. Berlin: Deutsche Akademie der Wissenschaften.

- (1952) Translated by Pharr, C. The Theodosian Code and novels and the Sirmondian constitutions. Princeton: Princeton University Press.

Eusebius of Caesarea (1902) De vita Constantini. Edited by Heikel, I. Eusebius Werke, vol. 1. Über das Leben Constantins, GCS. Berlin: J. C. Hinrichs.

- (1999) De vita Constantini. Translated by Cameron, A. and Hall, S. G. Life of constantine. Oxford: Oxford University Press.

Libanius of Antioch (1977) Orationes. Translated by Norman, A. F. Selected works, vol. 2. Selected orations, LCL, 452. Cambridge, MA: Harvard University Press.

LP (1955-57) Edited by Duchesne, L. and Vogel, C. Le Liber pontificalis, 2nd edn, 3 vols. Paris: BEFAR.

Mark the Deacon (1913) Vita Porphyrii. Translated by Hill, G. F. The Life of Porphyry of Gaza. Oxford: Clarendon Press. 


\section{Leonela Fundic}

Theodoret of Cyrrhus (2006) Historia ecclesiastica. Edited by Martin, A. et al. Théodoret de Cyr: Histoire ecclésiastique I, Livres I-II. SC, 501. Paris: Éditions du Cerf.

Vita Theclae (1978) Edited and translated by Dagron, G. Vie et miracles de Sainte Thècle: Texte grec, traduction et commentaire. Brussels: Société des Bollandistes.

Zosimus (1887) Historia nova. Edited by Mendelssohn, I. Leipzig: Teubner.

_ (1982) Translated by Ridley, R. T. Zosimus: New History, Byzantina Australiensia 2. Canberra: Australian Association of Byzantine Studies.

\section{Secondary sources}

Bar, D. (2003) 'The christianisation of rural Palestine during Late Antiquity'. Journal of Ecclesiastical History, 54: 401-21.

(2008) 'Continuity and change in the cultic topography of late-antique Palestine'. In Hahn, J., Stephen, E. and Gotter, U. (eds.), From temple to church: Destruction and renewal of local cultic topography in Late Antiquity. Leiden: Brill, 275-98.

Bardill, J. (2012) Constantine, divine emperor of the Christian golden age. Cambridge: Cambridge University Press.

Bassett, S. (2004) The urban image of late-antique Constantinople. Cambridge: Cambridge University Press.

Bayliss, R. (2004) Provincial Cilicia and the archaeology of temple conversion, BAR International Series, 1281. Oxford: Archaeopress.

Bowes, K. (2008) Private worship, public values, and religious change in Late Antiquity. Cambridge: Cambridge University Press.

Bradbury, S. (1994) 'Constantine and the problem of anti-pagan legislation in the fourth century'. Classical Philology, 89/2: 120-9.

Busine, A. (2013) 'From stones to myth: Temple destruction and civic identity in the lateantique Roman East'. $J L A, 6 / 2: 325-46$.

Cameron, A. D. E. (1969) 'The last days of the Academy of Athens'. Proceedings of the Cambridge Philosophical Society New Series, 195: 15-29. [Repr. in Cameron, A. D. E. (1985) Literature and society in the early Byzantine world. London: Variorum, no. XIII]. (2011) The last pagans of Rome. Oxford: Oxford University Press.

Caseau, В. (2001) ' $\Pi \mathrm{O} \Lambda \mathrm{EMEIN} \Lambda \mathrm{I} \Theta \mathrm{OI \Sigma}$ : La désacralisation des espaces et des objets religieux païens durant l'antiquité tardive'. In Kaplan, M. (ed.), Le sacré et son inscription dans l'espace à Byzance et en Occident: Études compares. Paris: Éditions de la Sorbonne, 61-123.

Cecchelli, M. (1999) 'Data di scavi recenti di monumenti cristiani'. Mélanges de l'École française de Rome. Moyen Âge, 111: 227-51.

- (ed.) (2001) Materiali e tecniche dell'edilizia paleocristiana a Roma. Rome: De Luca editori d'arte.

Chaniotis, A. (2008) 'The conversion of the temple of Aphrodite at Aphrodisias in context'. In Hahn et al. (eds.), 243-73.

Chuvin, P. (1990) A chronicle of the last pagans. Cambridge, MA: Harvard University Press.

Coüasnon, C. (1974) The church of the Holy Sepulchre in Jerusalem. Translated by Ross, J. P. B. and Ross, C. London: Oxford University Press.

Creswell, K. A. C. (1959) 'The great mosque of Hama'. In Ettinghausen, R. (ed.), Aus der Welt der Islamischen Kunst: Festschrift für Ernst Kühnel zum Geburtstage am 26.10.1957. Berlin: Verlag Gebr. Mann, 48-53.

Crogiez-Pétrequin, S. and Pierre Jaillette, P. (2009) Le Code Théodosien: Diversité des approaches et nouvelles perspectives. Rome: École Française de Rome. 
Dalgıç, Ö. (2012) 'Early Christian and Byzantine churches'. In Ratté, C. and De Staebler, P. D. (eds.), Aphrodisias V: The Aphrodisias regional survey. Darmstadt and Mainz: Philipp von Zabern, 367-96.

Deichmann, F. W. (1939) 'Frühchristliche Kirchen in antiken Heiligtümern'. Jahrbuch des Deutschen Archäologischen Instituts, 54: 105-229.

Flood, F. B. (2001) The Great Mosque of Damascus: Studies on the makings of an Umayyad visual culture. Leiden: Brill.

Frantz, A. (1965) 'From paganism to Christianity in the temples of Athens'. DOP, 19: 185-205.

Friedman, J. B. and Figg, K. M. (eds.) (2000) Trade, travel and exploration in the middle ages: An encyclopedia. New York: Routledge.

Gibson, S. and Taylor, J. E. (1994) Beneath the church of the Holy Sepulchre Jerusalem: The archaeology and early history of traditional Golgotha. London: Palestine Exploration Fund.

Guignebert, C. (1923) 'Les demi-chrétiens et leur place dans l'église antique'. Revue de l'histoire des religions, 88: 65-100.

Hahn, J., Emmel, S., and Gotter, U. (eds.) (2008) From temple to church: Destruction and renewal of local cultic topography in Late Antiquity. Leiden: Brill.

Hansen, M. F. (2003) The eloquence of appropriation: Prolegomena to an understanding of spolia in early Christian Rome. Analecta Romana instituti Danici supplementum, 33. Rome: 'L'Erma' di Bretschneider.

Harries, J. and Wood, I. (eds.) (2010) The Theodosian Code: Studies in the imperial law of Late Antiquity, 2nd edn. London: Bloomsbury.

Hasluck, F. W. (1973) Christianity and Islam under the sultan, vol. 1. New York: Octagon Books.

Hawting, G. R. (2000) The first dynasty of Islam: The Umayyad caliphate AD 661-750. London: Routledge.

Hiller von Gaertringen, F. (1906) Inschriften von Priene. Berlin: Georg Reimer.

Horster, M., Nicolaou, D., and Rogge, S. (eds.) (2018) Church building in Cyprus (fourth to seventh centuries): A mirror of intercultural contacts in the eastern Mediterranean. Münster and New York: Waxmann.

Jacobsen, A.-C. (2017) 'The apologists'. In Esler, P. F. (ed.), The early Christian world. London: Routledge, 547-64.

Kraeling, C. (1967) The excavations at Dura-Europus. Final report, 8.2. The Christian Building. New Haven: Yale University Press.

Krautheimer, R. (1980) Rome: Profile of a city, 312-1308. Princeton, NJ: Princeton University Press.

Krautheimer, R. and Ćurčić, S. (1986) Early Christian and Byzantine architecture, New Haven and London: Yale University Press.

Krautheimer, R., Frankl, W., and Corbett, S. (1937-77) Corpus basilicarum christianorum Romae. Monumenti di antichità, Ser. 2, 2. Vatican City: Pontificio instituto di archeologia Cristiana.

Lee, A. D. (2015) Pagans and Christians in Late Antiquity: A sourcebook. London and New York: Routledge.

Lenski, N. (2016) Constantine and the cities: Imperial authority and civic politics. Philadelphia: University of Pennsylvania Press.

Lieu, S. and Montserrat, D. (1996) From Constantine to Julian: Pagan and Byzantine views. London: Routledge.

Luraghi, N. (2008) The ancient Messenians: Constructions of ethnicity and memory. Cambridge: Cambridge University Press. 
MacMullen, R. (1984) Christianizing the Roman Empire AD 100-400. New Haven: Yale University Press.

Magness, J. (2012) The archeology of the Holy Land: From the destruction of Solomon's temple to the Muslim conquest. Cambridge: Cambridge University Press.

Nuffelen, P. van (2011) 'Eusebius of Caesarea and the concept of paganism'. In Lavan, L. and Mulryan, M. (eds.), The archaeology of late-antique 'paganism'. Leiden: Brill, 87-110.

Peppard, M. (2016) The world's oldest church: Bible, art, and ritual at Dura-Europos, Syria. New Haven: Yale University Press.

Potter, D. (2013) Constantine the emperor. Oxford: Oxford University Press.

Rivoira, G. T. (1918) Moslem architecture: Its origins and development. Oxford: Oxford University Press.

Roueché, C. and Reynolds, J. M. (1989) Aphrodisias in Late Antiquity: The late Roman and Byzantine inscriptions including texts from the excavations at Aphrodisias conducted by Kenan T. Erim. London: The Society for the Promotion of Roman Studies.

Saradi-Mendelovici, H. (1990) 'Christian attitudes toward pagan monuments in Late Antiquity and their legacy in later Byzantine centuries'. DOP, 44: 47-61.

(1997) 'The use of ancient spolia in Byzantine monuments: The archaeological and literary evidence'. International Journal of the Classical Tradition, 3/4: 395-423.

(2008) 'The Christianization of pagan temples in the Greek hagiographical texts'. In Hahn et al. (eds.), 113-34.

Saxer, V. (2001) Sainte-Marie-Majeure. Une basilique de Rome dans l'histoire de la ville et de son église. Rome: École française de Rome.

Schuddeboom, F. (2017) 'The conversion of temples in Rome'. Journal of Late Antiquity, 10/1: 166-86.

Sirks, A. J. B. (2007) The Theodosian Code: A study. Friedrichsdorf: Tortuga.

Thettayil, B. (2007) In spirit and truth: An exegetical study of John 4:19-26 and theological investigation of the replacement theme in the fourth Gospel. Leuven: Peeters.

Wallraff, M. (2011) 'Die antipaganen Maßnahmen Konstantins in der Darstellung des Euseb von Kaisareia'. In Hahn, J. (ed.), Spätantiker Staat und Religiöser Konflikt: Imperiale und Lokale Verwaltung und die Gewalt gegen Heiligtümer. Berlin: de Gruyter, $7-18$.

Warwick, B. (2016) Rome in the East: The transformation of an empire. London: Routledge.

Westphalen, S. (1998) 'Die Basilika von Priene. Architektur und liturgische Ausstattung'. Istanbuler Mitteilungen, 48: 279-340.

White, L. M. (1990) The social origins of Christian architecture, vol. 1. Building God's house in the Roman world. Harvard Theological Studies, 42. Valley Forge, PA: Harvard University Press.

- (1997) The social origins of Christian architecture, vol. 2. The Christian domus ecclesiae and its environment. Harvard Theological Studies, 42. Valley Forge, PA: Harvard University Press.

Wiegand, T. and Schrader, H. (1904) Priene: Ergebnisse der Ausgrabungen und Untersuchungen in den Jahren 1895-1898. Berlin: Georg Reimer.

Yeomans, R. (1999) The story of Islamic architecture. London, UK: Garnet Publishing. 


\title{
Epilogue
}

\author{
Rajiv K. Bhola
}

Once called 'No-place' by men of old,

A land in isolation;

Now challenger to Plato's state,

Perhaps its subjugator-

For what it sketched with words, I have

With men, wealth, and best laws surpassed;

'Good-place,' I must be rightfully called.

Utopia priscis dicta ob infrequentiam,

Nunc civitatis aemula Platonicae,

Fortasse victrix, (nam quod illa literis

Delineavit, hoc ego una praestiti,

Viris et opibus, optimisque legibus)

Eutopia merito sum vocanda nomine. ${ }^{1}$

When it comes to conflict, religion by no means exercises a monopoly. Yet, violence has traditionally been considered a sine qua non of religion and religious violence in many ways exceptional from other expressions of aggression. In recent years, a number of notable studies drawing on topics from antiquity to the modern day have emerged that aim to temper our approach to religious violence and that challenge such issues as the reliability of reports of violence, the role of violence in the formation of group identity, the perception of the predominance of violence in religion, and the uniqueness of religious conflict. Among several others, one could name Thomas Sizgorich's Violence and Belief in Late Antiquity (2009), William Cavanaugh's The Myth of Religious Violence (2009), Jonathan Sacks's Not in God's Name (2015) and the recent volume it has inspired (Burridge and Sacks 2018), as well as Peter van Nuffelen's Penser la tolérance durant l'Antiquité tardive (2018) and the collection Reconceiving Religious Conflict, edited by two contributors to the present volume (Mayer and de Wet 2018), which constitute an ongoing effort across various disciplines to arrive at a better understanding of the roots of religious violence and how violence manifests in and transcends religion.

It is a conversation that this volume participates in and helps to further by addressing the universal longing for a utopian state of existence, and the tendency 
to formulate that ideal image through the reorientation of the past. To this end, violence can be a means of implementing that vision in the present and for the future, often through the obliteration or refashioning of an undesirable past. One of the contributions of the various discussions, then, concerns how we conceive of violence and the many ways it comes to be utilised. Acts of injury against objects and persons are of course to be counted, but it is evident in any attempt to tear apart what is, which is to say, to deconstruct, usually in the interest of building what ought to be. So, across the volume, we find deconstruction-reconstruction of the past being used to counter ideological opponents; memories of violence invoked to unite and consolidate; images of violence employed to assist in the upheaval of social and political traditions; exhortations to self-violence in the pursuit of perfection; and so forth. Violence can be divisive or galvanising; it is in turns a curse, a means, and a fact of life; the past can be invoked, discarded, or retooled.

Though all the chapters focus on events, trends, and behaviours in antiquity, the scenarios and phenomena are not at all alien to us in our present circumstances. In the first chapter, Bronwen Neil reminds us of the programme currently being undertaken by ISIS to destroy sites and objects of world cultural heritage in the belief that such actions are necessary for the restoration of an age of pure religion. To this we could add a number of other examples, such as the destruction of the Bamiyan Buddhas by the Taliban in 2001, though we should take note of similar activities on a smaller scale; for example, the destruction of historic Norwegian churches in the 1990s by members of the Black Metal community in retaliation for violence against traditional practitioners during the Christianisation process and the appropriation of sacred space (Vrzal 2017). We acknowledge also that cultural genocide is not limited to the destruction of physical objects. The same term can be applied to early colonial attempts to 'civilise' the New World by removing indigenous children from their communities and depriving them of access to native language, traditions, and religion so as to eradicate the 'savage,' non-Christian past (see e.g. Regan 2010; Campbell 2014). Robin Jensen's discussion in Chapter 13 of the recent series of events in Charlottesville, Virginia, is a poignant example of modern reactions (and counterreactions) to the memory of an oppressive past. The protests for and against the removal of statues commemorating Confederate figures in Charlottesville and elsewhere not only showcases the differing perspectives regarding the symbolic value of those objects and their potential to galvanise group identity but also makes clear that physical and rhetorical resistance to symbolic objects, such as is often reported in Late Antiquity, is not a purely religious phenomenon. (As she points out, even in antiquity this was not the case.)

To turn towards a temporally relevant example of the reimagining of the past and the utopian ideal, there is quite a lot to unpack in the political rally-cry 'Make America Great Again' (see e.g. Douglas 2018; Flisfeder 2018). The extreme effectiveness of this unabashed utopian slogan is due mainly to its ambiguity. At a surface level, it expresses dissatisfaction with the present state of affairs and a desire to return to a more glorified past, which is signalled as being achievable. 
However, there is no attending attempt to identify a specific period in American history that is definitive of the slogan's claim of 'great,' let alone the qualities that constitute 'greatness.' As such, its ambiguity bestows upon it the versatility to appeal to any demographic; the utopian image can mean something different to each listener according to their particular dissatisfactions, be it social, economic, or possibly ethnic. No limitation is set on the imagination of the utopian dreamer, but in every case it is a call to arms against aspects of the status quo that have poisoned the future hopes of the utopian past and resulted instead in a dystopic present.

There are numerous parallels that can be drawn with contemporary civilisation, some more direct than others, both within and outside of the strict borders of religion. However, as examinations of the ancient world, the chapters in this volume enrich our knowledge regarding the organisation of memory and variability of the utopian ideal, and the manifold uses of violence in association with these in antiquity. Among the several themes that emerge throughout, these are perhaps central, but in this final entry to the volume I would like to devote space to highlighting some additional themes that are no less important and that connect the diverse subject matter, as well as discuss some of the ways that the individual contributions operate together.

\section{The landscape of Memories of Utopia}

The reader will note, for instance, the creative use of the designation 'landscape' across the various contributions, but the notion of spatiality is nuanced and encompasses both the physical and mental traversal of space. In the more-orless literal sense of 'the space which one inhabits and can be viewed,' landscape maintains its usual topographical meaning. It can refer to the objects of veneration that pepper the cityscape or that occupy sacred space, and the transformation of that religious landscape through destruction, reutilisation, or displacement. Naturally, the perusal of sites of significance becomes the focus of some discussions, though it does not necessarily entail the physical navigation of space. One can make their way through the Moselle countryside in the mind's eye, the culmination of Christian education embodied by pilgrimage can be achieved through scriptural exegesis, and the conceptualisation of Jerusalem as a locus of power and identity, whether worldly or otherworldly, becomes a nexus of competing apocalyptic visions. Also in the literal sense of 'the space which one inhabits and can be viewed,' landscape can be used to describe the body, which it is possible to transform and recast in a purer image through violence, though the veneration of the body does represent a form that the topographical landscape can assume. Alternately, collective and cultural memory becomes a landscape in itself as an aspect of space that one can visualise, navigate, and manipulate. Memories of the past can be treated as objects, insofar as they too can be destroyed, reutilised, or displaced. The act of remembering can serve to manufacture, reinforce, or oppose identity; to unite groups according to a unique vision; to realign or rewrite the historical record; and even to inspire and justify the use of violence. As such, 
reimagining, reinventing, reorienting, reframing, and redacting the past are all useful tools for transforming that navigable, albeit imaginary, space.

In the section that follows, however, I would like to draw attention to one theme especially that permeates the volume; namely, the blurring of the distinction (or dichotomy) between the utopian idealist and the ideologue that emanates from the various analyses of these ancient situations.

\section{In practice, made perfect}

As Neil aptly notes in Chapter 1, utopia is a construct of the imagination. Indeed, this quality is built into the very name of Thomas More's titular island (More 1516), from which we derive our designation for both the concept and the genre. As a play on 'no-place' and 'well-place,' Utopia is a place that is good, but does not exist. Although responding to real conditions and conceiving alternatives to them, there is nevertheless the inherent sense of the unattainability or even the impracticality of the vision of perfection. Not just through the comparisons to the real world, but by the very name of our guide to Utopia-Hythlodaeus, meaning roughly 'one who spreads hogwash' - we are constantly reminded by More's (intentionally pessimistic?) narrative that his fantasy world does not reflect reality. It would be fair to say, then, that 'utopia' is automatically relegated to the realm of speculation as intellectual exercise, thought experiment, or simple wishful thinking. Certainly, this is how the concept has come to be popularised in the nineteenth and twentieth centuries, along with its counterpart, the failed-utopia (i.e. dystopia) or anti-utopia (see e.g. Kumar 1987; Baccolini and Moylan 2003).

With respect to the ancient world, focus has traditionally been on literary utopias and 'Golden Age' narratives (see e.g. Ferguson 1975; Evans 2008). Unsurprisingly, the utopia genre and its associated tropes have provided much fodder in the study of apocalyptic and prophetic literature (see e.g. Ben Zvi 2006; Schweitzer 2007). The connection is palpable, even natural: usually written in times of crisis, such works express a dissatisfaction with reality and conceptualise a better past or a more glorious future, in this world or the next. Some papers in this volume deal with utopia as a product of the imagination, and their findings certainly give us pause for thought. Ryan Strickler's juxtaposition, in Chapter 11, of three apocalyptic narratives of utopian renewal from differing cultural perspectives in response to roughly the same historical episodes and exhibiting the same sense of victimisation mixed with hope, exemplifies well the idiosyncrasy of the utopian vision, but also the common yearning for it. Meanwhile, our journey through the Moselle countryside in Chapter 12, especially the ruinous survey by Venantius Fortunatus, is enriched by Chris Bishop's insight into pre-Renaissance imagery. Contrary to modern expectation, the violent depictions of death and decay nevertheless create a positive link with the past and do not proffer a pessimistic view of the present and future such as we find in T. S. Eliot's The Waste Land.

By contrast, Naoki Kamimura's Jerome is shown, in Chapter 6, to be standing at the crossroads of the real and the imaginary in his advice to Paulinus of Nola. Although previously he had strongly advocated physical pilgrimage as essential 
for Christian education, Jerome's conflict with the Jerusalem church led him, albeit temporarily, to offer himself as a guide on a mental expedition - what we could very well term a 'pilgrimage of the mind'-through scriptural exegesis to reach the same goal. Similarly, a great many papers in this volume demonstrate the practical efforts to make the utopian state of being a lived reality, whether aiming at an idealised past-cum-present and/or cum-future. Such is the case certainly for material destruction or displacement (as discussed in Chapters 5, 13, and 15), but subtler attempts can be observed in the actions and behaviour of individuals like Julian, Augustine, and John Chrysostom, who regard their utopias as achievable and show that the line between idealist and ideologue can be somewhat thin.

Although Julian's critique, studied by Bosman in Chapter 2, is addressed to contemporary Cynics, his selective remembering of the Cynic founder Diogenes is intended to advance his own set of values for practical philosophy and absorb this dimension of Greek life into his sphere of control. His intention is not to denounce Cynicism, Bosman shows, but to offer up his reimagined, purified Cynic as a serious contender in the fight against a Christian future. In a similar vein, the selective reconstruction and intentional misrepresentation of the collatio of 411 by Augustine, discussed in Chapter 4, is yet another practical attempt to achieve the ideal state. By envisioning the weakness of the Donatist position at that meeting and presenting his version of events as objective and historical fact, Geoffrey Dunn's Augustine attempts nothing less than to inculcate and bring about his vision of a state-supported and unified North African Church; a world in which the Donatists do not exist.

The crucial part played by manipulation of narrative and narrative context in crafting utopian images is further explored in Chapters 9 and 10. In the former, Pauline Allen and Kosta Simic show how the same essential narratives are used, in turns, to venerate or decry the Nicaean past and the Chalcedonian present, regardless of the historical reality of the doctrinal orientation of the saint in question. The content, as such, validates the respective doctrinal position that is expounded: religious utopia is a world in which miracles occur. In the latter, Kosta Simic examines how hymns were used by Christian sects as instructional tools. As a means of solidifying group identity, he shows, they were used not only to delineate and reinforce theological and dogmatic positions in intra-Christian contexts but also could be used to serve inter-religious polemical agendas, whether reinterpreting the past in order to subvert (e.g. usurping the significance of the Pascha) or invoking it to ignite (e.g. aligning the Muslim threat to the New Israel with the Amalekite threat of the Old Israel).

These chapters highlight well how groups and their individual actors give life to new memories through reimagining the past in ways that have a direct impact on the present and offer a vision for the future. The world-shaping power of memory takes a slightly different turn in the extraordinary tales of several Western hagiographies of the sixth and seventh centuries discussed by Bronwen Neil in Chapter 8. As she notes, these stories functioned in part to establish Christian morality by recounting earthly consequences - at times, quite literally, putting the fear of God into people - that presage eternal judgement, even providing 
previews of eschatological utopia or anti-utopia. However, these Vitae and Dialogues sought also (or perhaps primarily) to establish the social and political primacy of the new religious order, as well as supplant the traditional system of personal retribution with one of divine retribution.

Here the violence of the imagined past becomes an educational tool. Related to this, several papers tackle the vicissitudes of the conservation of memories of real violence. As Jonathan Conant shows in Chapter 3, the North African martyrs of early fourth-century persecutions were transformed into models that proved difficult to emulate. Almost immediately following the Diocletianic persecution, memories began to be rewritten in ways that generated or exacerbated intraChristian and inter-religious conflict, not only by the continual redaction of Acta to (re)produce feelings of fear and anxiety but also through the (re)standardisation of what constituted a betrayal of faith, which effectively transformed fellow victims into persecutorial colluders. The effects of this solidification of group identity through collective trauma is to be observed also in Jensen's discussion in Chapter 13 of the violent North African resistance to 'pagan' statuary as representatives for the human agents responsible for Christian suffering and reminders of that past injustice. In an attempt to preserve civic order, Augustine advises that the statues of Hercules should thus bear the abuse that cannot be levied against the persecutors (or should not be carried out against 'pagans') themselves and in a manner as public as the tortures which the martyrs endured.

The intersection of deference, curation, and cultivation of memory is taken up in Chapter 5, where Wendy Mayer illustrates how both Julian and Chrysostom tap into the morally encoded, but nevertheless innate, concepts of purity and disgust with respect to memorial veneration. Although commonly interpreted in antiquity and modernity as evidence of latent persecution, Julian's relocation of martyrs' remains is shown to be an attempt at displacing memory, not destroying it, and perhaps exposes an underlying aspect of traditionalists' ideological resistance to the Christian worship of Jesus. Meanwhile, in her second case study, Mayer identifies a similar approach in Chrysostom's characterisation of the Jews as a source of contamination that threatens the overall health of the Christian body politic. In both cases, physical violence is not explicitly advocated, but in accessing the ingrained notions of purity/disgust, the actions of Julian and rhetoric of Chrysostom may very well have produced justifications for it. In Chapter 7, we find an alternate dimension of violence as a tool of conditioning in Chrysostom's endorsement of the instrumentality of ascetic practices for curtailing the potential of the irrational to corrupt the rational. As Chris de Wet observes, Chrysostom's appeal to corporeal mortification does not look towards a future eschatological utopia per se, but focusses on achieving a utopian modality in the present that, if achieved, will be resurrected in its perfect form. According to Chrysostom, the body, being a divine creation, is essentially good and the Christian (utopian) body therefore possible to attain, but he further moderates the intensity of the selfviolence he advocates to render that ideal state obtainable even by those who do not pursue the lifestyle to its extremes. 
Whether manipulating memory, content, or context; creating original memories of the past, breathing new life into them, or keeping them fresh; reconceptualising the present or giving it renewed significance; conjuring pure images of the past, present, or future; or some combination of these and other methods, the papers in this volume enumerate the diverse forms utopia can assume, as well as the many manifestations of destruction that can attend them. Violence, both physical and rhetorical, can serve as a practical instrument of implementing the vision of the ideal. As the various discussions demonstrate, it is not always intentional, nor is it absolute. The analyses of Janet Wade and Leonela Fundic in Chapters 14 and 15, respectively, provide a conducive counterbalance to the discussions of remembrance and violence in their myriad forms. So, Wade argues, the Athena/Minerva steelyard weights appear to be an instance where religious representations were appreciated not merely for their aesthetic value, nor were they necessarily secularised or Christianised to legitimise their use. In her survey of temple reuse, Fundic's emphasis on the non-triumphalist transformation of sacred space and buildings, and its symbolic value within replacement theology, calls into question the appropriateness of the designation 'violence' for this phenomenon. Serving as a fitting cap on the volume, these chapters nuance our understanding of the lateantique attitude to the outmoded past.

\section{The future in sight}

While the individual arguments, approaches, and methodologies of the various papers in this volume are informative contributions to their respective disciplines and indicators of fruitful avenues for future investigations, the question stands as to what insights are to be gained from the consideration of the volume as a whole. In some ways, this is indicated in my discussion in the previous section, but I would like to highlight a few related themes more explicitly here.

Many of the authors demonstrate an overarching concern for group identity, but to reiterate, one aspect that emerges from the diverse discussions is the role of the individual in formulating, inculcating, and implementing that (at times, idiosyncratic) utopian vision. Certainly this is the case with wielders of authority, such as the emperor Julian, who controls the idealised Greek past from a position of executive power, turning throne into pulpit; Augustine, who disseminates his version of events to his assemblies as objective fact in his self-appointed role as curator of the memory of 411; as well as Chrysostom and Jerome, who play the roles of guides and coaches in the attainment of the perfect Christian state of being, physically and intellectually. Alternately, that vision might constitute the transferral of authority, such as we find in Neil's discussion of the hagiographies of Gregory of Tours and Gregory the Great, and the Lives of the Méridan Fathers, which place the reality of a social and eschatological utopia in the hands of clergy and holy men.

The analyses of Strickler and Bishop showcase the insights to be gained by those savvy to the cultural perspectives of the visionary, which comes through also in Conant's and Jensen's treatments of North African memory of the victims/ 


\section{Rajiv K. Bhola}

victors of persecution. However, as these and numerous other discussions either directly address or imply, we do not always have access to the original context, and in such cases due caution should be exercised. Admittedly, this is hardly revelatory, but regular prompts are always warranted when we consider the natural tendency to regard primary literature as sources of information, rather than texts. In this light, Dunn's chapter, which indicates how close Augustine comes to dominating the historical record - and indeed did in his own day within his circleserves as a prudent and cautionary tale, as does the chapter of Allen and Simic, which makes clear that 'translation' does not mean faithful reproduction. We are well aware (and the discussions make clear) that the same material can be used to advance vastly different agendas, but it is nevertheless a humbling reminder of the fragility of our own attempts at reconstructing the past.

Mayer applies her combined framework of Moral Foundations Theory and Conceptual Metaphor Theory specifically to Julian's attitude to martyr worship and Chrysostom's anti-Jewish rhetoric, though she notes that a similar behavioural phenomenon can be viewed in the North African maintenance of memories of the persecution, as Conant and Jensen attest in their chapters. An analogous framework might prove fruitful in investigating such literature and liturgy as Neil and Simic discuss, insofar as those sorts of productions were intended to implant and, through their (re)telling, normalise behavioural patterns and moral codes of conduct, as well as render intuitive the reactions to modes of behaviour that fall outside them. The corrective potential of promises of divine reward and punishment, and especially the conceptualisation of God and his divine agents as bogeymen standing ready to punish misbehaving Christians, are images that are especially salient for anyone who ever refused to eat their vegetables or clean their room.

But perhaps a more important take-away from this volume regards how we should aim to study the relationship between violence and religious competition. Just to mention a choice few: Mayer's discussion shows how triggering deeply ingrained, yet culturally dependent, moral values can inspire violence, even when said violence is not explicitly encouraged. De Wet notes that Chrysostom's advocation of self-violence as a means of shedding pastness to achieve the utopian body could in part account for the use of violence against symbols of the outmoded past and their proponents to achieve social utopia. Regarding North Africa, there is much attractiveness in Conant's suggestion that the practice of continually invoking the most gruesome memories of persecution effectively re-traumatised successive generations and resulted in a hypersensitivity to threats to the church, from without and within, which were at times confronted with physical violence. Jensen speaks to this as well in her observation that the statues of Hercules served as scapegoats for Christians to alleviate their anxieties.

To varying degrees, these are issues that the contributions to this volume all address, whether questioning the nature of violence, its manifestations, its causes, or its consequences; they produce a similar outlook and inform each other. In short, these studies indicate that, going forward, it might be more productive - not only for understanding the past, but making sense of the present and preparing for 
the future - to explore sociological explanations for violence and conflict, rather than accepting them as exceptional religious phenomena. Much the same as the longing for utopia, violence is universal. The ideal state of existence, be it corporeal, spiritual, political, or topographical, may itself be free from violence, but historically speaking, destruction has ironically been regarded as a viable means of creating it.

\section{Note}

1 More (1516; Logan et al. 1995: 18; translation mine). The poem is included by Thomas More in the introductory matter to his Utopia and attributed to a fictitious poet laureate named Anemolius Hythlodaeus, a name that we might render 'Blowhard Balderdasher.'

\section{Bibliography}

\section{Primary sources}

Logan, G. M. et al. (ed. and trans.) (1995) Utopia: A reading text and English translation. Cambridge: Cambridge University Press, 1-269.

More, T. (1516) De optimo rei publicae statu deque nova insula Utopia. Leuven: Thierry Martens.

\section{Secondary sources}

Baccolini, R. and Moylan, T. (2003) Dark horizons: Science fiction and the dystopian imagination. London and New York: Routledge.

Ben Zvi, E. (ed.) (2006) Utopia and dystopia in prophetic literature. Göttingen: Vandenhoeck \& Ruprecht.

Burridge, A. and Sacks, J. (eds.) (2018) Confronting religious violence: A counternarrative. Waco: Baylor University Press.

Campbell, S. (2014) 'Remembering for the future: Memory as a lens on Canada's Indian residential schools Truth and Reconciliation Commission'. In Jacobsen, R. and Koggel, C. M. (eds.), Our faithfulness to the past: The ethics and politics of memory. Oxford and New York: Oxford University Press, 135-64.

Cavanaugh, W. T. (2009) The myth of religious violence: Secular ideology and the roots of modern conflict. Oxford and New York: Oxford University Press.

Douglas, S. (2018) 'Law's transformative power: Ideology, utopia, and Donald Trump'. In Pavoni, A. et al. (eds.), See. London: University of Westminster Press, 125-58.

Evans, R. (2008) Utopia antiqua: Readings of the Golden Age and decline at Rome. London and New York: Routledge.

Ferguson, J. (1975) Utopias of the classical world. London: Thames and Hudson.

Flisfeder, M. (2018) “"Make America Great Again" and the constitutive loss of nothingness'. Third Text, 32: 5-6, 647-55.

Kumar, K. (1987) Utopia and anti-utopia in modern times. Oxford and New York: Basil Blackwell.

Mayer, W. and de Wet, C. L. (eds.) (2018) Reconceiving religious conflict: New views from the formative centuries of Christianity. London and New York: Routledge.

Nuffelen, P. van (2018) Penser la tolerance durant l'Antiquité tardive. Paris: Les éditions du Cerf. 
Regan, P. (2010) Unsettling the settler within: Indian residential schools, truth telling, and reconciliation in Canada. Vancouver: University of British Columbia Press.

Sacks, J. (2015) Not in God's name: Confronting religious violence. London: Hodder \& Stoughton.

Schweitzer, S. J. (2007) Reading utopia in chronicles. New York and London: T. \& T. Clark.

Sizgorich, T. (2009) Violence and belief in Late Antiquity: Militant devotion in Christianity and Islam. Philadelphia: University of Pennsylvania Press.

Vrzal, M. (2017) 'Pagan terror: The role of pagan ideology in church burnings and the 1990s Norwegian Black Metal subculture'. The Pomegranate, 19/2: 173-204. 


\section{Scripture index}

Old Testament

Gen 1:26 113

Gen 2:7 114

Gen 4:17 96

Gen 12:1 94, 99, 103

Gen 16165

Gen 18:1-15 251

Ex 17:8-16 165

Ex 17:11 165

$1 \mathrm{Chr} 5: 19165$

2 Chr 6:26-27 132

Ps 1:162

Ps 25:4-5 62

Ps 82:7 165

Ps 109:3 159

Ps 131:7 LXX 97

Ps 132:7 96

Wis 1:4 130

Is $11: 1095,103$

Jer 7:4 99

Jer 23:28b 60

Dan 7:27 179

Dan 8:23 178

New Testament

Matt 3:12 61

Matt 5:35 97

Matt 8:23-27 132

Matt 1360

Matt 13:24-30 61
Matt 13:42 185

Matt 13:47-52 61

Matt 23:37-38 94

Matt 26:30 156

Matt 27:52-53 96

Matt 28:19 94

Mark 4:35-41 132

Luke 1:46-55 168

Luke 1:67-79 168

Luke 2:14 168

Luke 2:29-32 168

Luke 17:21 100

Luke 19:41-42 95

John 3:8 99

John 4:24 99

John 11:35-36 95

Acts 1:18 160

Acts 13:46 94

Acts 19:23-20:1 213

Rom 2:22 213

Rom 6:6-8 109, 110

Rom 7:23 110

Rom 7:24 112

Rom 11:33-36 168

1 Cor 3:16 100

1 Cor 6:10 213

1 Cor 9:19-23 65

1 Cor 13168

1 Cor 15116

2 Cor 4:16 110
2 Cor 6:16 104

Gal 4:26 98, 99

Eph 1:3-14 168

Eph 4:17-18 109

Eph 4:22 109

Eph 4:22-24 110

Eph 4:23 110

Eph 5:19 156

Phil 2:6-11 168

Phil 3:20 98

Col 1:15-20 168

Col 3:1-17 109

1 Tim 3:16 168

1 Pet 2:21-25 168

Rev 1:5-6 168

Rev 4:8 168

Rev 4:11 168

Rev 5:9-14 168

Rev 7:10-12 168

Rev 7:15-17 168

Rev 11:1-2 96

Rev 11:896

Rev 11:15-18 168

Rev 12:10-12 168

Rev 15:3-4 168

Rev 16:5-7 168

Rev 19:1-8 168

Rev 21:1 96

Rev 21:16-1896

Rev 22:13 168 


\section{Index}

Abd al-Malik 182, 262

Abitina 39, 44; martyrs of 44, 47, 49

Abthugni 40, 42, 45, 46, 47

acta 38, 40, 41, 46, 47, 49, 50

Africa Proconsularis 39, 40, 42, 57, 67

Agustus 139, 140

Aïn Kebira 43

Alcuin 126, 198, 199, 200, 201

Alexander the Great 184

Alexandria 17, 33, 80, 88, 89, 146, $147,155,157,161,168,212,214$, $215,216,221,222,229,238,246$, 254, 263

Alfred King of Wessex 199, 200

Altava 43

Amalekites 165, 166, 168

Ambrose, bishop of Milan 142, 157, 158, 199

Ammianus Marcellinus 20, 31, 79, 80, 195

Anastasius the Persian 145, 146, 147, 148, 149,150

angels $135,149,178,184$

Anglo-Saxon 10, 14, 199, 201, 202

Antichrist 134, 185

anti-Jewish 81, 82, 87, 162, 163, 167, 172, 179

anti-Muslim 163, 167, 168

Antioch 13, 20, 31, 76, 80, 81, 86, 87, 145, $157,158,254$

apocalyptic 15, 127, 171, 172, 174, 175,

177, 180, 181, 182; Jewish 181; Syriac 184

apostates 183

Apostle Paul 45

apotropaic 235, 236, 245, 254

Arabs 150, 164, 165, 166, 168, 172, 182,

186,261 ; conquest of 185

Arbogast, bishop of Chartres 196

Arbogast, comes 195, 196 architecture 126, 190, 261

Arians 12, 134, 158

Arius 157, 159, 160

art 4, 237, 261; defacing of 12

ascetic(ism) 29, 52, 93, 94, 110, 114, 115, $116,117,118,137,138,146,147,148$, 151

Ashkelon 147, 155

Asklepios 251

Athanagild 138

Athanasius of Alexandria 151, 157

Athena, goddess 15, 232, 233, 234, 235, 236, 237, 238, 240, 241, 242, 243, 244, $245,246,247,248,249,250,254,257$, 258,273

Athens 232, 238, 241, 242, 243; Athenian 80; temples 256; Augustine of Hippo 14, $22,38,40,44,45,46,47,48,51,57,58$, $59,60,61,62,63,64,65,66,67,68,69$, $117,119,142,157,158$

Ausonius, Decimus Magnus 189, 190, 191, 192, 193, 194, 195, 197

autocracy 9

Babylas, martyr 76, 79, 80, 86

baptism 65, 128, 138, 148, 172, 179, 260

Bardaisan 158; Basilica of Messene 258

Basilica Liberiana 261

basilicas 261; Giovanni e Paolo in Laterano 261; Quattro Coronati 261; San Chrysogono 261; San Clemente 261; San Lorenzo in Lucina 261; San Pietro in Vincoli 261; San Sisto Vecchio 261; Santa Maria in Trastevere 261; Santa Sabina 261; Santa Susana 261

Bethlehem 93, 97, 100, 104

bishop(s) 14, 38, 39, 40, 41, 42, 43, 45, 46, $48,57,58,60,62,64,65,67,69,80,94$, $97,101,107,127,128,129,130,131$, 132, 133, 134, 135, 137, 138, 139, 140, 
141, 147, 151, 159, 161, 192, 193, 196, $199,251,253$

body $12,25,51,77,82,83,85,86,107$, $108,109,111,112,113,114,115,116$, 117, 118, 119, 152, 160, 243; of Christ 158; dead 112, 138; of god 76; life of 127; modality of $110,111,112,113,114$, $115,116,118$; mortal 111; problem of $12,107,109,110,111,112,113,115$, 119 ; as slave 119 ; and society 117 ; utopian 12, 107, 109, 112, 114, 115, 116, 117,118

Boethius 200

Bostra 76, 80

burial 260

Byzantine 5, 9, 15, 127, 134, 142, 150, $159,161,162,163,164,165,166,167$, $168,174,232,233,235,246,258,262$; Arab wars 4

Caesarea Palaestina 155

Caesarea Palestine 149

Caesarea Philippi (Paneas) 255

calendars, liturgical 43, 45, 151, 159

Caria 80

Carolingians 126, 201

Carthage 38, 40, 44, 45, 48, 57, 63, 64, 69; Synod of 14, 68

Catholics 12, 51, 57, 134, 135

Cherchell 57, 58, 59, 61, 62, 64, 66, 67, 68,69

children 44, 48, 49, 84, 152, 184, 200; slaves 183

Chosroes II, shah of Persia 148, 150, 155 , 176

Christians 4, 8, 11, 14, 21, 28, 29, 31, 36, $37,38,39,41,43,44,46,49,50,51,58$, $64,75,79,80,81,83,85,86,87,95,97$, $102,134,141,146,149,156,157,163$, $167,168,172,174,177,182,185,236$, $238,242,243,244,251,252,253,254$, 258, 260, 261, 262; anti-Chalcedonian $145,146,147,148,151,152,154$;

Chalcedonian 171; conflict between 8; deliverance of 183; destroying temples 260; of Dura Europos 260

Christological 145

church(es) 11, 14, 29, 36, 39, 40, 41, 42, $44,45,46,49,52,58,59,60,61,62,64$, $65,68,82,83,85,86,93,97,98,101$, $102,103,116,117,129,130,131,132$, $133,134,137,140,141,148,149,151$, $155,156,157,158,159,160,161,162$, $163,167,180,182,192,198,199,246$, $251,253,254,256,259,260,261,262$,
263 ; conversion 11 ; conversion to 255 , 256, 257, 258; of the Dormition 159; episcopal 259; of the Holy Sepulchre 86,97 ; of Peter the Iberian 151; private 260; renewal of 183; Roman 261; of San Clemente 261; of San Lorenzo in Damaso 261; of San Marcello 261; of Santa Maria Maggiore 261; of Santa Pudentiana 261; of St Elias 256, 262; of St Euphemia 149, 155; of St George 251, 256, 262; of St Peter 257; tombs in 137

Cicero 125, 198, 199, 200

Cirta 38, 40, 42, 45, 46, 47, 49

city: utopian 181

Clovis 128, 142, 196, 197

Codex Theodosianus see Theodosian Code commerce 232, 236

Constantine, emperor 30, 38, 40, 42, 45, $51,62,241,251,252$

Constantine, Forum of 232, 241, 242, 243

Constantine III, emperor 196

Constantinople 21, 22, 107, 146, 152, 155, $161,164,168,175,232,235,238,241$, $242,243,244,245,252$; court of 23

contamination $76,77,78,79,85,86$ corpses 75, 76, 77, 78, 79, 86, 180, 198 Council of Chalcedon 145, 146, 147, 148, $149,150,151$

counterpoise see weights

crime 81, 84, 85, 133, 201

Crispina, martyr 39, 44, 48

cross 223

cross the $130,145,147,148,163,164$, $165,166,167,245,257$; sign of 135 cult(s) 9, 13, 21, 25, 43, 45, 86, 105, 136, $144,145,150,151,152,153,163,212$, $213,214,215,216,217,220,221,222$, 226, 229, 232, 238, 242, 260 see saints; African 47; of Anastasius the Persian 152; Graeco-Roman 4, 13, 15, 87, 150, $217,250,251,252,257,262,263$; of martyrs 45, 76, 77; of Peter the Iberian 151; traditional 51

cure 83,85

Cyril of Scythopolis 145

Damascus 255, 261, 262

damnatio memoriae 7, 156, 176, 186, 210 , 217

Daphne 76, 79

Dastagerd 155

deities, pagan 213

Delos 80

Delphi 21, 27, 28, 80 
democracy 9; to come 108; limited 9 demons 13, 135, 148, 149, 183, 211, 212 , 213,231 ; sites of worship 260; spiritual warfare 260

Derrida, Jacques 108

desecration $15,75,78,79,80,86$

Diana, goddess 213

Dio Chrysostom 23, 25, 31

Diodore of Tarsus 157, 158

Diogenes 14, 21, 23, 24, 25, 26, 27, 28, 34, 271; the Cynic 22

Dioscorus 161

Diospolis 155

disgust $13,25,76,77,78,79,80,86,88$, 272

Donatists $12,57,58,59,60,61,62,63,64$, $65,66,67,68,158$

dreams 134

dualism 109, 118

Dura Europos 260

dystopia 5, 13, 16, 107, 109, 110, 116, 128, $133,145,147,151,152,172,173,176$, $177,179,181,185$; apocalyptic 183 ; future 185

\section{Edessa 158}

Egypt 11, 96, 97, 101, 146, 147, 149, 151, $163,242,257$

Elias, saint 256, 262

Emeritus of Caesarea (Cherchell) 57, 58, $59,60,62,63,64,65,66,67,68,69$

Emesa 22, 80

empress 233, 235, 243, 244, 247

Ephrem the Syrian 157, 158

Epictetus 23, 25, 33

epigraphy see inscription(s)

episcopal 40, 45, 52, 57, 58, 64, 65, 126, $128,142,146,151,192,193,203,216$, 259,260

eschatology 8,174

etymology 94

Eulalia, saint 140

Eunapius 127

Eusebius of Caesarea 24, 94, 103, 251, 252

Eutyches 161

excommunication $69,97,101,102$

exegesis $100,101,102$

fear 27, 42, 48, 50, 51, 115, 128, 184, 237

Felix of Thibiuca, martyr 39, 48

Flavian of Antioch 157, 158

Fortunatus of Todi 138

Fortunatus, Venantius 15, 137, 139, 142, 189, 190, 191, 192, 193, 194, 195, 197, 198, 199, 200, 201
Foucault, Michel 12, 17, 109, 119

Fraser, Julius 108, 111, 118

funerals 77, 126, 253

Gaul 13, 15, 126, 131, 133, 189, 195, 197

Gaza 146, 155, 253, 258

Gehenna see hell

geography 97, 102, 103

Georgia 146, 151, 155

Germanos I, Patriarch of Constantinople 164

Gildas 199

gods 228; Graeco-Roman 228; Roman $212,217,219$

Gorgon 237, 238, 241, 242, 245

Gospel of Matthew 60, 96, 132

Goths 203, 258

governor $80,149,156,178$

Gratian, emperor 189, 190

Great Persecution 13, 37, 38, 41, 43, 51

Greece 29, 238, 242, 253, 255, 258;

temples 256

Gregory the Great 13, 126, 133, 134, 136, $137,138,139,141,142$; of Nyssa 98 , 104, 193; of Tours 13, 125, 126, 127, $128,131,132,133,137,139,141,191$, 197,198

Hagar 165, 166

Hagarenes 165, 166

hagiography $8,126,127,141,147,148,150$

healing $13,129,131,137$

heaven $5,26,58,96,99,113,130,133$, $135,136,137,139,140,141,147,180$, 181,185

hell 127, 128, 135, 137, 138, 140, 141; and demons 138

Heraclius, emperor 148, 150, 171, 172 , $175,176,177,178,179,181,182,186$

Hercules (Heracles) 176, 177; trials of 177

Hermon 181, 255

Hierapolis (Mabbug) 148, 150, 155

Hilary of Poitiers 157

Honorius (emperor) 60

Honorius (pope) 161, 257

hymns $15,156,157,158,159,161,162$, $163,164,167,168,256$

Iamblichus 26, 87

Iberia 155

identity $6,9,10,11,12,13,15,60,97,103$, $109,139,171,172,173,174,244,253$;

Jewish 181; and landscape 12

idols/idolatry 11, 12, 180, 252, 256

image(s): of gods 214, 216, 217, 221, 223; imperial 211, 212, 249 
inscription(s) 3, 7, 10, 11, 15, 38, 43, 44, $45,140,159,199,210,223,235,242$, $245,256,257,258,259,264,266$;

Graeco-Roman 257

inter-religious 157,167

intra-Christian 43, 157, 167

Irenaeus of Lyon 156, 157

Isaiah 65, 95, 199

Isis: temple of 257

Islam(ic) 9, 11, 12, 16, 47, 164, 165, 166, $167,168,171,172,174,261,262,263$; conquests 261 ; theocracies 9

Israel 13, 99, 101, 133, 162, 163, 165, 166, $167,168,179,180,271$

Italy 13, 47, 58, 98, 134, 137, 199

Jerome 13, 92, 93, 94, 95, 96, 97, 98, 99, $100,101,102,103,104,142,195$

Jerusalem 86, 92, 93, 94, 95, 96, 97, 98, $99,100,101,102,103,106,146,147$, $148,149,152,153,155,165,169,171$, $173,177,178,179,180,181,184,186$, $188,262,264,265,269,271$; in the Apocalypse 184, 185; heavenly 94, 96, 99, 102, 125; Muslim conquest of 182; temple of see temple; utopian 181

Jew(s) 11, 13, 81, 82, 83, 84, 85, 86, 87, $145,147,148,158,162,163,171,172$, $177,178,179,180,181,182,183,186$, $187,236,251$

John Chrysostom 20, 81, 82, 84, 86, 87, $91,107,110,111,112,113,114,115$, $116,117,118,119,120,121,211,228$, 229, 238, 247, 271; doctrine of mindset 118; view on Manichaeism 119

John Moschus 145, 149

John Rufus 13, 145, 147, 150, 151, 152 judaisers $81,83,85$

Julian, emperor 9, 13, 14, 16, 20, 21, 22, $23,24,25,26,27,28,29,30,31,32$, $33,51,76,77,79,80,81,86,87,88$, 195,242 ; court of 23; persecution of Christians 22

Justin I: emperor 147

Justin Martyr 165

Justinian, emperor 262; closure of schools 22 ; edicts of 22; edicts of 22; edicts of 31 ; edicts of 246; and paganism 22; persecution of pagans 238

Juvenal 210, 229

Ksar Baghai (Bagaï) 67, 68, 69

landscape $12,13,14,15,36,59,75,76$, $80,117,126,133,135,174,178,180$,
$181,189,190,191,192,193,194$, 197, 201, 257; of Jerusalem 180, 181; utopian 182

law 24, 27, 28, 79, 110, 127, 140, 141, 246; Lombard 127, 131, 140; Merovingian 129; Roman 48, 60, 67, 131, 200, 246, 252, 255; Salic 127, 140, 142

Leontius, bishop of Bordeaux 193

Leovigild 138

Lex Salica Karolina see law, Salic

Libanius, orator 20, 31, 80, 211, 212, 214, $228,253,254$

Liuva 138

Lombards 134, 135

Macedonius 161

Magnus Maximus, Augustus of the West 195

Mamre 251, 262

Manichaeism 112, 114, 116, 119, 158

Marcellus of Apamea 215, 253

maritime 232, 233, 242

marketplace 232, 241

martyrs/martyrdom 10, 12, 15, 38, 42, 43, $44,45,46,47,48,50,76,77,79,80$, $86,87,97,117,132,133,134,135,136$, $140,146,148,149,150,151,160,182$, 260, 262; acts of 150

marzban see governor

Mauretania Caesariensis 42

Mauretania Sitifensis 43

Maurice, emperor 175, 177

Maximian of Carthage 62, 66, 67, 68, 69

Maximilian, martyr 44, 47, 48

measures 246

Médiouna 42, 43, 44, 45

Mediterranean (Sea) 10, 16, 36, 43, 45, 47, $78,79,83,88,92,144,152,171,203$, $246,248,251,261,265$

Medusa 233, 237, 238, 241

memory $11,14,16,20,28,36,37,42,43$, $44,49,50,51,58,59,62,63,64,66$, $68,69,80,86,87,107,118,126,137$, $141,158,159,161,167,168,172,173$, $176,177,178,179,181,184,186,194$, $232,235,244,246,252,254,263$; aids to 125 ; art of 125 ; biblical 185 ; boom 6 ; collective $6,11,12,142,201$; communal $38,43,44,49,126$; construction of 7 ; cultural 10, 186, 244; and emotion 126; of Exodus 181; and Gregory of Tours 127 ; history 6 ; individual 10 ; medieval 125, 126; popular 6; social 6; studies 6 merchants 232, 233, 235, 237, 241, 243, 245,246 
Merida 126, 138, 140, 141

Merovingian(s) 126, 127, 128, 129, 131, 141, 191, 193, 197

Mesopotamia: Muslim conquest of 182

Messene 259

Messiah 9, 162, 171, 172, 178, 179, 180, 181

messianic 172, 177, 178, 179

Methodius of Patara 182

Minerva 15, 232, 233, 235, 237, 238, 241, 243, 244, 246, 252

Minucius Felix 213, 228, 229

miracles 125, 127, 129, 134, 137, 138, $139,140,141,146,147,148,151$

mob(s) see riot

monastic(ism) $8,30,92,93,94,97,98$, $101,102,127,129,134,135,138,145$, 146, 147, 150, 151, 152; Chalcedonian 148; Egyptian 147; Palestine 147

Moral Foundations Theory 76, 82, 274

morality 84, 129, 199

Moselle (river) 15, 189, 190, 191, 192, 193, 194, 197

Moses 157, 165, 261

mosque(s) 11, 262, 263; Al-Aqsa mosque, Jerusalem 262; the Great Mosque, Hama 262

Mount of Olives 97, 146, 156, 173, 178, $179,180,181$

Muhammad, prophet 11, 174, 187, 188

Munatius Felix 40, 41, 46, 49

Muslim(s) 4, 11, 15, 163, 164, 165, 166, 167, 168, 174, 182, 236, 251, 261, 262; places of worship 11

Near East 11, 105, 174

Neoplatonic 31

Neoplatonism 21, 25, 26, 30, 32, 76, 242

Nestorius 160, 161

Nicaea, Council of $145,151,152$; antiNicene 12; Nicene 12, 81, 148, 157, 158

Nicetas Choniates 158, 232, 241

Nicetius, bishop of Trier 190, 192, 193

Nichomachus Flavianus: elder 7; junior 7

Nisibis 150, 155, 158

North Africa 36, 41, 43, 47, 48, 49, 59; Muslim conquest of 182

Numidia 38, 39, 45, 60, 66, 67, 69, 70

Optatus 38, 40, 41, 67

Origen of Alexandria 94, 97

Ovid 191, 198, 199

Oxyrhynchus 147
Pactus Lex Salicae see law, Salic

pagans $21,127,158,183,236,243,251$, 252, 255; conversion of 260

Palestine 13, 93, 97, 100, 101, 145, 146, $147,148,150,152,155,164,252,255$, 261

Paradise 5, 200

Parthenon 242

passions 42 , 94, 110, 111, 112, 113, 115, $116,117,119$

pastness $12,107,108,109,111,112,114$, $115,116,117,118$

Paul, apostle $65,109,110,111,112,118$, 152, 156, 213; Epistles of 98, 99, 109, 156

Paula 92, 93, 94

Paulinus of Nola 97, 101

persecution $13,36,37,38,39,40,41,42$, 43, 44, 45, 46, 47, 48, 49, 50, 51, 57, 86, 134; of Christians 76; of Jews 181

Persia(n) 14, 87, 145, 146, 148, 149 , 152, 155, 171, 176, 177, 178, 179; conquest(s) 150,261 ; language 150

personification 235, 236

Peter of Alexandria 160

Peter the Iberian 13, 145, 146, 148, 151, 152, 155

Petilian of Constantina 60, 63, 69

Phocas, emperor 172, 173, 175, 176, 177, 186

pilgrimage $13,44,92,93,94,97,98,99$, 100,101, 102, 103; place of 13,93,98, 99, 101

Plato 22, 82, 112, 113, 114, 119, 254

Pliny the Younger 156

pollution $76,77,78,79,80,81,83,84,85$, 86; ritual 88

Priene 257, 258, 265, 266

Primian of Carthage 67, 69

prison $44,48,115,120,149$

prisoner 149,177

prophecy 22, 174, 184, 185

Psalm(s) 44, 48, 62, 94, 96, 97, 149, 156, 159

Pseudo-Methodius 174, 183, 185; Apocalypse of 172, 173, 182, 184, 185, 186

punishment $83,84,87,116,117,118,129$, $130,133,137,140,141,262$; divine 138 purity $4,22,57,67,75,78,79,80,83,84,85$

Pyrrhus, patriarch of Constantinople 161

Radegund 197, 198, 200

relics $45,76,79,127,128,129,130,132$, $133,136,141,146$ 
religion $11,15,30,75,76,78,79,86,141$, $149,150,254,259,261,263$; GraecoRoman 9; Greek 31, 79, 242; Islamic 164, 165, 166, 168, 171; official 260; Roman 79, 80, 234

Renovatus 140

replacement theology 164, 167, 261, 263

resurrection $96,99,116,132,167,180$

riot $88,211,213,217,220,228,230$

Roma 235, 236, 244

Roman cults: Graeco-Roman 246

Rome 10, 38, 45, 51, 58, 93, 103, 133, 134, 152, 161, 171, 194, 199, 235, 241, $243,244,252,255,257,260$

Rufinus 97

Rufinus of Aquileia 97

Sabellius 161

sailors 243, 246

Saint(s) 7, 13, 15, 44, 45, 48, 96, 98, 117, 126, 127, 129, 130, 131, 132, 133, 134, 135, 140, 141, 157, 164, 253, 260, 262; Anastasia 261; Chrysogono 261; Clement 261; Constantinople 152; cult of 150; Laurence 257, 261; Maria Maggiore 261; Mark 261; Pudentiana 261; Roman 152; Sabina 261; Vitale 261 San Clemente 261

San Sisto Vecchio 261

Saracens 164, 165

Sassanid 171, 178, 182

Scythopolis 149, 255

Sefer Zerubbabel 172, 173, 174, 178, 179, $180,181,182,183,185,186$

Sejanus, emperor 210,211

Seleucia 157, 260

Seleucia-Ctesiphon 148, 155

self $29,108,111,112,113,116,118$; dualism of 118; hierarchy of 112; inner/ outer 110, 111; old/new 109, 110; utopian 118

Serapeum 88

Sergius, patriarch of Constantinople 161, 175

Severus of Antioch 13, 161

shrine(s) 11, 16, 86, 129, 141, 146, 246, $253,257,260,262,263$; destruction of 13, 16; traditional gods 212

Sidonius Apollinaris 193, 196

Silvanus of Cirta, sub-deacon, bp. 46

Sinai 100, 101, 165, 166

slavery/slaves $84,117,130,140,141,176$, 207
Socrates 27

Sodom 96, 97, 201

Sophronius, patriarch of Jerusalem 165

Sotades 157

soul 12, 24, 25, 51, 110, 112, 113, 114, $115,116,118,119,130,135,136,160$; and brain 88 ; and senses 88

Sozomen 30, 80

Spain 13, 47, 93, 134, 138, 140

statues 11, 25, 77, 87, 118, 178, 207, 208, $210,211,212,213,214,215,216,217$, $219,220,221,222,223,225,226,227$, $228,229,231,232,237,238,241,242$, $243,244,245,247,248,249,252,254$, 268, 272, 274; demon-possessed 212; destruction of 9, 16; of gods 212, 213, 219; imperial 211; Roman gods 212 steelweights 15

steelyard weights see weights

stoic(ism) 25, 112, 119

Sufasar 42

Symmachus, Quintus Aurelius 190

synagogues $14,75,85$; destruction of 16

Synesius of Cyrene, orator 31

Syria 11, 12, 115, 148, 253, 255, 260, 261, 262

Tabor mount 100, 101, 181

Tartarus 140

Tébessa 39, 44

Teheran 148, 155

temple $11,14,25,52,75,77,79,86,87$, $99,110,118,177,178,179,180,181$, 215, 242, 246, 251, 252, 253, 254, 255, 256, 257, 259, 260, 262, 263; of Aphrodite 258; of Apollo (Daphne) 76, 79, 86; of Apollo (Didymium) 80; Asklepios 257; Erechtheion 257; Hephaisteion 257; of Jerusalem 86, 94, 177; Jewish 181; of Jupiter 215; Marneion 258; pagan 257; Pantheon 257; Parthenon 257; of Sarpedon 260 temples $89,212,213,214,215,216,217$, $221,222,223,231,248,249,257,265$, 266; destruction of 16; pagan 256 temporality $107,108,111,118$

Tertullian 51, 60, 213, 228, 229, 230

Thekla, saint 260

Themistius 238

Themistius, orator 31

theocracies 9

Theodoret of Cyrrhus 115, 157, 214, 215, 253

Theodoric the Great 196 
Theodosian Code 31, 58, 69, 131, 142, 252, 255

Theodosius I, emperor 211, 214, 215; Augustus of the East 195

Theodosius II, emperor 146, 155, 255

Theuderic 130, 197, 198

theurgy 76

Tiberius Emperor 210

Tipasa $42,43,45$

tomb(s) $43,79,80,86,95,97,101,102$, 130; of martyrs 77

trade: maritime 15

traders 232, 241, 245

tradition 10, 15, 20, 21, 22, 23, 24, 94, 98, 99, 101, 102, 103, 118, 128, 151, $159,161,165,167,196,198,199,232$, $235,237,238,242,244,245,246,251$, 252, 254, 259, 261; Cynic 21, 22, 25 , 26,28 ; of historiography 31 ; North African 49

trauma $36,37,38,50,51,178$

travel 93, 97, 101, 102, 146, 147, 148, 149, 150

Trier 38, 189, 192, 193, 194, 195, 196, 197

Turkey 257

Tyche 235, 241, 244

uchronia 107, 108, 109, 111, 117, 118

Umayyad 167, 261, 262

utopia $3,4,5,8,9,10,11,12,13,14,15$, $16,31,58,59,61,64,68,69,92,102$, $107,109,110,112,114,115,116,117$, $118,128,132,133,139,145,148,151$, $152,173,174,175,177,178,179,180$, $181,182,186,232,236,237,244,246$; artistic 3; biblical 181; definition of 4; eschatological 5, 69, 117, 127, 128, 133,
$136,141,181$; future $59,107,108,116$, $172,173,175,176,180,184$; individual 10 ; modality of 118 ; past $3,12,31,59$, 107, 177; political 3, 69, 176, 180, 183; realistic 9; social 118; spiritual 3, 102, 180

Valentinian I, emperor 189

Venus 251, 257

Veranianus 140

Vergild 140

Victor, grammarian, lector of Cirta 40, 46

Vilicus, bishop of Metz 192

violence $7,11,13,14,17,32,36,37,38$, $43,49,51,71,72,75,76,80,85,89$, $110,116,117,118,119,121,127,128$, $130,131,138,142,183,219,221,222$, $228,231,252,253,267,268,269,272$, $273,274,275,276$

Visigoth(s) 129

Visigothic 127, 128, 138, 140, 141, 142

visions $10,14,15,20,21,22,50,59,94$, $96,115,116,134,136,139,140,149$, $154,160,173,177,178,179,188,189$, 261, 268, 269, 270, 271, 273; dystopian 181; frightening 135 ; prophetic 127 , $134,135,136,137$

weights $15,16,232,233,234,235,236$, $237,238,240,241,243,244,245,246$, 247 ; counterpoise 233 ; steelyard 232 , 233

Zion 100,101

Zorava 255, 256

Zoroastrian(s) 4, 5, 11, 13, 145, 146, 148, 149,150 